
Thomas R. Trielman 



\section{THE TUTORIAL PRAYER BOOK}


First printed, September 1912, 5,000 copies.

Second impression, revised July, 1913, 5,000 copies. 


\title{
THE
}

\section{TUTORIAL PRAYER BOOK}

EOR THE TEACHER, THE STUDENT, AND THE GENERAL READER

\author{
Edited by \\ CHARLES NEIL, M.A. \\ VICAR OF ST. MARY's, STAMFORD BROOK \\ and \\ J. M. W ILLOUGHBY，D.D. \\ VICAR OF ST. LUKE'S, HAMPSTEAD
}

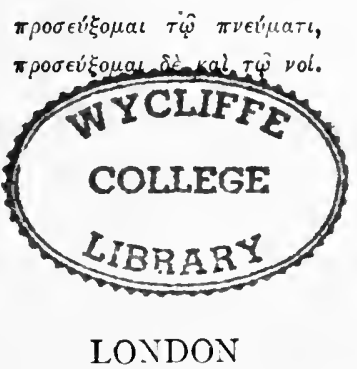

THE HARRISON TRUS'T 57, BERNERS S'TREE'T, W. . 


\section{ANG-0404}

\section{Tn memoriam}

I OANNIS, HARRISON, S.T.P.,

(uDCCOXIV-MDCCCLXXXIII),

PRESBYTERI ECCLESIE ANGLICANR,

QU1,

VERBIS FIDEI ET BONE DOCTRINA ENUTRITUS,

OPERARIUS INCONFUSIBILIS,

VERBUM VERITATIS RECTE TRACTANS,

IDONEUS FACTUS EST MINISTER NOVI TESTAMENTI;
ATQUE PRECIPUE LABORAVIT,

SCRIPTURAS PATRUM ASSIDUE SCRUTATUS,

QUUM ANTIQUORUM, TUM ANGLICANORUM,

ILLORUM DOCTRINAM

DE CENA DOMINI

CUM SCRIPTURIS SANCTIS CONGRUERE,

APERTE ET PERITE DEMONSTRARE;

- ITAQUE ERGO

DEFUNCTUS ADHUC LOQUITUR 


\section{PREFACE}

Since the appearance in 1832 of Palmer's 'Origines Liturgicæ,' an ever-inereasing amount of valuable information has been published respecting the history of the Prayer Book : its relation to Eastern Liturgies, to Latin Scrvice Books, and to the Books of the Continental Reformers : the structure of its Offices: the exposition of its contents : the principles upon which it is composed : and the spirit in which it is to be interpreted. The knowledge thus aceumulated has in great measure to be sought for in separate works, written for specialists, and confined to particular fields of inquiry. In those treatises which attempt to cover the whole ground, the tendency has been to the production of volumies either too bulky and diffuse, or too meagre and superficial. A need exists, therefore, which has found expression in influential quarters, of a comprehensive and yet concise manual harvesting the fruits of previous liturgical research.

The aim of the present undertaking, as the title indicates, is to act in the capacity of a private tutor, whose duty it is to belp the reader over difficult stiles, to furnish him with essentials, to elucidate the subject in a systematic manner, to keep him well abreast of the latest investigations, and throughout to consider lis interests as a student.

The following description of some of the features of this book will serve to show how it is proposed to attain this end.

Tables have been prepared, systematically drawn up to tell their own tale in a simple yet striling manner. Such tabular presentation will prove more helpful than pages of matter, which often tend rather to bewilder than to enlighten. 
Scentifically-constructed Analyses have been introduced wherever scrviceable. By their aid the structure of the various Offices is given in a manner which renders their study easy, and the lines of thought in the Canticles, longer prayers, and other parts calling for such treatment, are clearly exposed to view. Frequently writers fail to furnish analyses, possibly because they do not sufficiently realize their paramount importance for the majority of students. The new feature of inserting brief historical notes in to the analyses, will, it is believed, prove a welcome combination.

The Structural Display of the Text itself, as already used by one of the Editors in clucidating St. Paul's Epistles, has been adopted for those long sentences and intricate paragraphs which require to be so exhibited that their meaning and the relation of their parts may at once be manifest to the eye and readily grasped by the mind. 'The Proface,' for example, seems especially to demand such treatment. Owing to its antiquated style it is far too little read; its structural display, it is hoped, therefore, will induce the reader to make it a matter of carcful study.

Exposition has been carried out as concisely as is consistent with clearness. Care has been taken to avoid being on the one hand Apostles of the obvious, and on the other hand Avoiders of the obscure. When needed, as, for instance, in the case of the Athanasian Creed, a running comment has been introduced, which strikes the happy mean between a paraphrase and a formal exposition.

The difficulty and discouragement experienced in Comparing the Various Editions of the Prayer Book are universally known. For these editions are not readily accessible, and even when they are to hand, it is a very tedious process to mark their differences, though one has the practised eye of a technically trained reader. By the method here adopted all variations of any importance are at once brought to the reader's notice, and he can leisurely examine them. The following example will suffice to show the simplicity and suggestiveness of the method :-

1549. ' An order for Matins daily through the year.'

1552. 'An order for Morning Prayer daily throughout the year.'

1662. 'The Order for Morning Prayer,' etc. 
The General History of the Prayer Book is outlined in a separate section; and to each Office when necessary there is a listorical introduction.

Brief Biographical Sketches are given of those whose writings have been laid under contribution in the compilation of the Book of Common Prayer.

For the usual Glossary have been given Classifled Lists in cases where the tcchnical terms are sufficiently numerous, e.g., in connection with the Trinitarian controversy and the 'Ornaments.'

A consideration of the above features of the Book will show its utility for all classes of readers. The Clergy will have notes suitable for much-needed lectures on the Book of Common Prayer; the Student will have material which will enhance the value of the lectures he attends and the books he consults; the Sunday School Teacher will be able more effectively to impart instruction, having before him a logical and historical presentation of facts; while the intelligent layman will be able to find new beauties in the Services in which he takes part.

The following is a list of the portions assigned, in whole or in part, to other writers by the Editors :-

\section{Act of Uniformity.}

Benjamin Whitehead, B.A., of the Middle Temple, Barristerat-Law. Author of Church Law, etc.

\section{Notes on the Prefaces.}

and

Rules concerning Psalter and Lectionary.

Rev. C. S. Wallis, M.A., Vice-Principal of St. John's Hall, Durham.

Titles and Rules for the Moveable and Immoveable Feasts, etc. Rev. A. W. Greenup, D.D., Litt.D., M.R.A.S., Principal of St. John's Hall, Highbury, Dean of the Faculty of Theology of London University. Co-editor of The Revised Version of the N.T. with Fuller References; Editor of The Yalkut ha-Makiri on the Minor Prophets, etc.

The Collects, Epistles, and Gospels.

Walter A. Limbrick, Diocesan Reader for London, etc. 


\section{A History of Confirmation.}

Rev. Canon Dyson Hague, M.A., Rector of Bishop Cronyn Memorial Church, London, Ontario; Lecturer, WJcliffe College, Toronto, and Examining Chaplain to the Bishop of Huron. Author of The History of Confirmation, etc.

Introduction to the Forms of Prayer to be used at Sea ;

Introduction to the Ordinal ;

Forms of Prayer with Thanksgiving;

and

Introduction to the XXXIX Articles.

Rev. F. S. Guy Warman, D.D., Principal of St. Aidan's College, Birkenhead.

\section{Classified Lists.}

Rev. G. E. Weeks, B.D., LL.D., Vicar of St. John's, Lowestoft.

Exigencies of space compelled a reluctant abandonment of certain work prepared for the Editors, notally a fuller treatment of the Articles from the pen of the Rev. Bernard C. Jáckson, M.A.

The Editors desire to acknowledge the assistance of several others, amongst whom gratitude demands the mention of the Revs. F. J. Hamilton, D.D., F. B. Heiser, M.A., Chas. Werninck, Messrs. F. T. Peachey, Edwin W. Fletcher, and Charles Higham. It is pleasant to record the courteous and readily granted services of Mr. Alfred R. James and the remainder of the Staff in the Office of the Harrison Trust.

It remains to add that the full responsibility for each part of the book must rest upon the Editors, more especially as the desire to preserve uniformity of plan compelled a somewhat free handling of the various contributions.

September 2nd, 1912. 


\section{PREFACE \\ TO THE SECOND IMPRESSION}

The gratifying call for a second impression, within ten months of the issue of the first 5,000 copies, ofiers an opportunity to acknowledge criticisms, public and private. Our critics have been of two kinds.

Many, actuated by sympathy with the work as a whole, have contributed both corrections and suggestions of improvement, which bave been thankfully received and, as far as feasible, adopted. Amongst these criticisms, those of the Rev. Harold Smith and Mr. J. T. Tomlinson deserve a special expression of deep obligation. The Editors are glad to be able to announce that the alterations which they have made, although technically important, do not affect the main teaching of the book.

Others have offered criticism which amounts to a condemnation of the principle upon which the book is produced, i.e. the principle of strict adhesion to the meaning of the Book of Common Prayer as intended by its Compilers and Revisers, and as accepted by the Church of England until the rise of the Tractarian School of interpretation. Such criticism, expressed sometimes in terms of kindly regret, sometimes in tones of cold disapprobation, was not altogether unexpected; and does not call for any lengthy refutation. The Book has been charged with narrowing the wise inclusiveness of the Church of England, a charge which can only justify itself by a fanciful, though common idea as to the extent of that inclusiveness. The liberty granted by the Church of England includes such matters as the following, namely that no more is to be demanded of a layman seeking admission into the Church than belief in the fundamental 
articles of the Christian Faith, as expressed in the $\Lambda_{\text {postles' }}$ Creed: that no private theory of the Inspiration of Holy Scripture and the Second Coming is to be enforced upon any member, clerical or lay: and that the Book of Common Prayer itself allows of latitude (often grievously transgressed) in regard to the saying or singing of portions of the Offices, and the frequency of the administration of the Lord's Supper. Upon these and similar points The Tutorial Prayer Book cannot justly be accused of ignoring the Church's inclusiveness. Unfortunately, since the first appearance of Tract xc., and especially during the last twenty years of reluctance to interfere with the spread of Tractarianism, the idea has become common that the Prayer Book is framed for an inclusiveness which the history of its compilation emphatically and expressly rejects. Hence we find that the Offices, particularly the Communion Office, are interpolated: vesture once discarded, and still illegal, is re-introduced : and those very dogmas, for the denial of which its chief Compilers were burnt at the stake, are boldly assertcd to be the teaching of the Prayer Book.

The welcome extended to the work by Irish Churchmen has led to an additional article in the Appendix, upon the distinctive features of the Irish Book of Common Prayer, from the expert pen of the Rev. T. J. Pulvertaft.

July 2nd, 1913. 


\section{CONTENTS}

Story of the Prayer Book • . . . . . . $\mathrm{x}$ ii

INTRODUCTORY MATTER

Morning and Evening Prayer . . . . . . . . . 76

Athanasian Creed $. \quad . \quad . \quad . \quad .{ }^{\circ} \cdot . \quad . \quad 122$

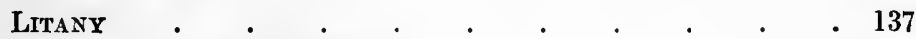

Prayers and Thanksgivings . . . . . . . . 144

Collects, Epistles, and Gospels $\quad . \quad$. . . . $\quad$. 149

Holy Communion - . . . . . . . . . 210

Public Baptism of Infants $\quad . \quad . \quad . \quad . \quad . \quad . \quad . \quad 370$

Private Baptism of Childrey . . . . . . . 393

Baptism of AdUlts . . . . . . . . . . 400

Catechism . . . . . . . . . . . . 403

CONFIRMATION . . . . . . . . . . 426

Matrimony . . . . . . . . . . . . 438

Visitation of the Sick . . . . . . . . . 447

Communion of the Sick . . . . . . . . . . . 458

Burial of the Dead . . . . . . . . . . . 469

Churching of Women . . . . . . . . . 484

Commination . . . . . . . . . . 489

Service at Sea . $. \quad . \quad . \quad . \quad . \quad . \quad . \quad . \quad .494$

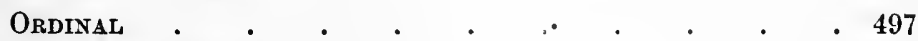

Accession Service . . . . . . . . . . 534

Thirty-Nine Articles. . . . . . . . 536

Table of Kindred and Affinity . . . . . . 574

APPENDices :-

A. Enactments, etc., in Reign of Henry ViIt . . 576

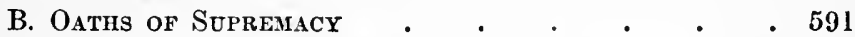

C. Service Books in Reformation Trmes . . . 593

D. Classified Lists of Terms . . . . . 596

E. List of Books for Further Study. . . . . 609

F. Cirronological Table . . . . . . . . 622

G. Distinctive Features of the lrisit Prayer-Book • 639

$\operatorname{INDEX} \quad . \quad . \quad . \quad . \quad . \quad . \quad . \quad . \quad .653$ 


\section{TABLES}

Puritan suggestions of 1603 . . . . . . . . . xxii

Puritan objections at the Savoy Conference . . . . xxvi

Concessions offered at the Savoy Conference . . . xxviii, $n$.

Chief alterations in B.C.P. of 1662 . . . . $\quad$ xxix, $n$.

Prefaces, Calendar, etc. . $\quad . \quad$. $\quad . \quad . \quad . \quad . \quad . \quad 1$

Contents of this Book compared with those of Previous Books . 4,5

Ornaments of the Church . . . . . . 89

Connexion of Morning Pr.lyer with Matins, Lauds, and Prime 90,91

Connexion of Evening Prayer with Vespers and Compline . 115

A Scriptural Account of the Lord's Supper . . . . 212

Ancient Liturgies . . . . . . . . . 230

Communion Service of 1549 and the Sarum Missal . . 256-261

Changes made in the Communion Office of 1552 . . 262, 263

Changes made in the Communion Office of 1662 . . 266-268

Communion Offices of Sarum Missal, 1549, 1552, 1662 . . 281

Changes in the Exhortations in the Communion Office . . 319

Baptismal Offices of 1549 and 1662 (Public) . . . . 378

Baptismal Offices of 1549 and 1662 (Private) . . . 393

Confirmation Offices of 1549 and 1662 . . . . . 430

Burial Services of 1549 and 1662 . . . . . . . . 472

Ordinals of 1552 and 1662 . $\quad . \quad . \quad . \quad . \quad . \quad . \quad 514$

Subjeot-Index to the Articles . . . . . . 536

\section{STRUCTURAL DISPLAYS}

'The Preface' . . . . . . . . 11-16

'Concerning the Service of the Church' . . . 18-22

'Of Ceremonies'. . . . . . . . 27-30

Answer to 'What meanest thou by the word Sacrament?' . 419

Preface to the Order of Confirmation . . . . . 432

Preface to the Ordinal . . . . . . . . 506

Bishop's Address to Candidates for the Priesthood . . 522-524 


\section{THE STORY OF THE PRAYER BOOK \\ IN OUTLINE}

The Book of Commion Prayer cannot be historically separated The Devofrom the Reformation. Every sound investigation into the Embodipreludes, canses, and consequences of the Reformation must ment of preludes, canses, and consequences of the Reformation must the Refor-
illuminate a book which is its devotional and doctrinal exposi- mation. tion. Nevertheless, the Book has a story of its own, the details of which lie ready to the student's use in the treatment of the various documents, services, etc., which forms the bulk of this Manual ; here it is proposed to set forth the ontlines of the story, disregarding as far as possible both the intricacies of historical disputation, and such minutiæ as make it: difficult to 'see the wood for the trees.'

The story has a very early beginning; for, apart from such Its Roots justification of the use of a liturgy as may be derived from Old in.r. and Testament precedents, the Hymnology of the Prayer Book is chiefly drawn from that source, the Decalogue is its standard of piety, and it follows the Lord and His Apostles in honouring the revelation unto the fathers by the prophets. The absence of liturgical regulations in the New Testament-while it justifies the claim of Article XXXIV, that every particular or national Church has the right to make its own arrangements for public worship-must not be understood as excluding the duty of making some provision for such worship under the New Covenant. The old controversy between precomposed forms of prayer and what is called 'extempore prayer' has practically spent itself. The recognition of the necd and utility of both, according to circumstances, has become so prevalent as to cause wonder at the vigour of language once used to defend or attack either practice. All are now ready to see in the Lord's Prayer, and the legitimate deduc. tions from such passages as Acts iv. 24; Eph. v. 14, 19 ; 1 Tim. iii. 16, divine sanction of set forms of prayer and praise as aids to: public worship; while the universal desire to include in prayer the special needs of time and place, has transformed this question from one of controversy to practical attempts to meet those needs. Such attempts are quite in keeping with the records of the e.rrliest 
sub-Apostolic times, as is clear from the Didachè, where forms are provided to protect public worship from ministerial ineffciency, while freedom is given when no such inefficiency is to be suspected.*

Its Dis-

criminating

Conser-

vatism.

Reformation Principles.

1) Liberty. (1) The principle of local independence runs through every age of the English Church, and that without any desire to separate from the Body of Christ. . The Celtic Church was not more keenly resentful of the attempts of Augustine to introduce Roman-customs as law, than was William the Conqueror chary of admitting the growing claims of the Papacy; the Saxon Church was as really opposed to the policy of Wilfrid, as any Norman or Plantagcnet monarch to the ecclesiasticism of an Anselm or a Becket. The succession of Statutes in the fourteenth century, restraining the papal hand in English affairs, was but the concise and concrete expression of a feeling which animated all classes of Englishmen who were not identifying their own advancement with papal aggression. The mean selfishness of a John, or the political exigencies of a Henry IV, might postpone the final repudiation of the Pope's claims to domination, but could not finally overcome a 
purpose which Wyclif had openly shown to be right and proper, and which the instinct of the nation ever held firm. When the breach at last came, whatever the immediate cause might happen to be, even if it were the matrimonial troubles of one man, the real cause was the indefeasible right of England to govern itself in matters of religion as well as of state. The Prayer Book is, therefore, the nation's assertion of its own right to regulate its public worship.

(2) If the first principle was that of religious freedom, the other was an even more sacred one, the principle of the authority of (2) Supreme Holy Scripture. While the arrogant claims of the Popes were Scripture. being undermined by the spiritual bankruptcy of their ecclesiastical system, as well as by resentment against their political demands, while the successive failures of monasticism and of the orders of friars to revive true religion were casting a lurid light upon the spiritual value of the novel dogmas grafted upon Christianity, a force was gradually being called into existence which would complete that disgust with Romanism, already founded upon experience. It would be difficult to exhaust the names of even the known contributors to the revival of learning, commencing really long before the period usually associated with that title. But the name of Wyclif stands out pre-eminently as that of one who began to see that the reform of faith and morals in the Church was only to be achieved by a return to the one authoritative rule of faith, and that the whole Church, ministry and laity alike, must possess that source of light, if anything permanent were to be achieved. In God's providence it was not yet decreed that the Printing Press should be introduced to make copies of His Word an easily acquired possession. Nevertheless, so many copies of Wyclif's Version have survived not only the ravages of time, but the eager and vigorous efforts of more than a hundred years to get rid of them, that one can understand both why the Lollards managed to persist, and why Reformation views spread still more rapidly when the Bible was printed. It was as impossible then, as it is now, to read that Book as the one authoritative revelation of God and His salvation, without at once perceiving the incongruity of the whole papal system, doctrinal and hierarchical, with what is there revealed. The Book of Common Prayer is the direct outiome of the Bible in English; its doctrine, its wording, its very contents, are mainly drawn from that Book; and its place in the hearts of the bulk of those who have ever used it, is assured by its manifest acknowledgment of that only source of authority in matters of faith.

Under these two principles, the right to national and local sicundary freedom, and the sole authority of Holy Seripture, may be grouped 
all the subsidiary events, which, tending to the support of one or other, ushered in the Reformation, and the Prayer Book as its devotional manifesto. It is possible to find fault with one and another of those who figured prominently in the tangled and tortuous policies of the Reformation period: it is often justifiable to criticize the method in which things right in themselves were done. In a word, it is true to say that the giants as well as the pigmies of the Reformation were no more sinless than the participators in the transactions of any other age; but it is not possible, save at the cost of true insight, to attribute the Reformation to the errors of its promoters. He who is able to understand from his own knowledge of Holy Scripture, that the Roman system could not survive the dissemination of Bibletruth, can afford to smile at the attempts to explain away the Reformation-by Henry's efforts to obtain a divorce from Catherine, or to narrow it down to a mere solution of the bonds which bound England to the Vatican. The Prayer Book constitutes a sufficient answer to all such theories, however learnedly advanced; that product of England's freedom from any but God's authority, written in the English tongue for the English people, witnesses to a spiritual movement in which the presence of accidental accompaniments of lower origin only teaches the oft-taught lesson of the over-ruling goodness of God.*

Immediate Precursors of B.C.P.
Direct anticipation of the issue of an English Book of Common Prayer was not wanting in the reign of Henry VIII. Mediæval Primers, containing some devotions in the vernacular, offered both a model and a name to the reformers who desired a means of providing for the spiritual needs of the commonalty. Setting aside those pullished in foreign lands, the first Primer printed in England, Marshall's Primer, dates from 1534, though it is best known from the 1535 Edition. Its attack upon the papacy and upon superstitions inherent in that system, occasioned its partial suppression, and the issue of something more authoritative to take its place, the Bishops' Book of 1537, which represented generally the moderate amount of reform contained in the Ten Articles. of 1536, the first doctrinal symbol of the Church of England. But Hilsey's Primer, arranged under the supervision of Cranmer, 1539, more literally took the place of the earlier Primers, being more suitable for popular use. The reactionary Six Articles of 1530 are somewhat reflected in th King's Book, $\uparrow 1543$, which superseded

* On pp. $576 \mathrm{ff}$. is given a summary of the enactments and publications which contributed to the religious and political breach with Rome.

$\uparrow$ Notwithstanding the rcact o cary tendency observable in the King's Bool, it is well to recollect that it was in 1543 that the English Bible made its way for the first time into public uorship, a chapter being rcad after the Te Deum and Magnificat at Mattins and Evensong. 
the Bishops' Book, but Cranmer had succeeded in preventing publication of the Rationale prepared by the reactionaries in 1540 . Meanwhile, the Sarum Use itself was being submitted to revision. The Breviary had been newly edited in 1516 and in 1531, and the Missal in 1533. In 1542 the Breviary was again issued, in a considerably expurgated form, and was ordered to supersede all others. In 1543 Arch bishop Cranmer told Convocation that it was the King's will that 'all mass-books, antiphoners, portuises, in the Church of England, should be newly examined, reformed, and castigated from all manner of mention of the Bishop of Rome's name, from all apocryphas, feigned legends, superstitious oraisons, collects, versicles, and responses; that the names and memories of all saints which be not mentioned in the Scripture or authentical doctors should be abolished and put out of the same books and calendars; and that the services should be made out of Scripture and other authentic doctors.' The connexion of the work done by the Committee appointed to carry out this command, with the issue of the Prayer Book in 1549, is an abandoned idea. The same year, 1543, saw translations of the Lord's Prayer and the Angelical Salutation laid before the House, and in 1544 the English Litany was ordered for immediate use, and inserted in the new Primer of 1545 , published with the avowed intention of giving ' to our subjects a determinate form of praying in their own mother tongue.'

On the accession of Edward in 1547, the Reformers were in The First the ascendancy, and the first Royal Injunctions * of the reign were Prayer issued, being an advance upon those of 1538. The First Book ${ }_{\mathrm{E}}^{(1) \mathrm{lts}}$ of Homilies, already prepared, was issued at the same time, to explain the doctrinal bearing of the Injunctions, and the Paraphrase of the New Testament by Erasmus was ordered to be procured for the instruction of the clergy. In December, 1547, Parliament decreed Administration in both kinds, but it was not until March, 1548, that any alteration of the Service-Books

* These injunctions ordered :-

1. The clergy to preach fou: ti nes a year against the pretended power of Rome.

2. The remoral of images and the use of only two lights on the altar.

3. A copy of the English Bible of largest size and of Erasmus Paraphrase to be placed within each Parish Church.

4. On every holy day when there was no sermon, the Pater Noster, Creed, and Ten Commandments, be reeited from the pulpit, after the Gospel, in English.

5. One chapter of the New, and one of the Old Testament, to be read at Mattins and Evensong, respectively, on every Sunday and holy day.

6. The Epistle and Gospel at High Mlass to be in English.

7. Processions before High Mass to cease, and the Litany sung in English, kneeling, not chanted in procession. 
appeared, and then only the Order of Communion, to be used with the Missal.* In December, the First Prayer Book was laid before the Commons, passing into Law in January, 1549, just before the completion of the King's second regnal year. The Act enforcing the use of this Book was the first of the four Acts of Uniformity in English History. $t$

(2) Its Character.

'The issue of the First Prayer Book was tentative, and in a sense provisional.' Thus Bishop Boyd Carpenter sums up the Book in his Popular History of the Church of England, p. 191, and some of its Rubrics expressly recognized this tentative and provisional character. Nevertheless, it is easy to note the advance upon anything hitherto known in English public worship. Besides the all-important change from Latin to English, a thorough doctrinal emendation of the portions retained from the old ServiceBooks preceded their incorporation into the Prayer Book, the Lectionary was cleared of Mediæval substitutes for Holy Scripture, and such accompaniments of the Roman Mass as Elevation, Adoration, etc., were either omitted, or definitely forbidden. A Gardiner might taunt Cranmer with the possibility of so interpreting the Book as to bring it into line with the Missal, but in practice the Romanists found it impossible to do so without surreptitiously supplementing it with Romanist " ceremonies not to be found in the Book. The Reformers might be impatient at the caution which the compilers had used, but they could not pretend that its doctrinal features resembled those of the old Breviary, Missal, etc. In fact, although how many and important the subsequent alterations have been a glance at comparative tables in this volume will show, yet the examination of any single portion, a Collect, for example, will also show that the utmost pains had been taken to exclude, speaking generally, all that savoured of scriptural inaccuracy. $\ddagger$

* This Order was an English supplement to the Mass, for the use of the laity, until a complete Service-Book should be provided.

$\dagger$ The introduction of the Book into the House of Lords had been preceded by a Parliamentary Debate in December, designed to facilitate the passing of the Book. The publication in English, in 1532, of Bertram's Treatise on the Lord's Supper, against the teaching of Paschasius, had been the means of weaning Ridley, and through him Cranmer, from both Transubstantiation and from the doctrine of the Real Presence, and the Debate is most important as displaying Cranmer as the champion of the reformed teaching on the Lord's Supper against those who held both those dogmas. That the 1549 B.C.P. in three places contained wording capable of being interpreted in the sense of the 'real Presence,' must not be supposed to imply that Cran. mer altered his views between 1548 and the revision of the 1549 Book, but that the latter was, and was meant to be, a compromise.

$\ddagger$ Even in the Communion Office, where traces of Mediæval doctrine and ceremonial chiefly lingered, the vast gulf between the Sarum Mass and the English Communion Office may be seen in tabular form on pp. 256-261. 
Though the Book scarcely obtained anything like general (3) Its recognition in the three years of its existence as an authorized liturgy, yet it forms the substratum of our present Book, and its sources are of deepest interest. As already noted, every eflort was made to conserve the old Service-Books, where it was possible without doing violence to truth. In this effort the compilers derived great assistance from Quignon's reformed Breviary, prepared at the instigation of one Pope, Clement, and dedicated to his successor, on its publication at Rome in 1535 . We are not left to conjecture as to Cranmer's use of Quignon's reformed Breviary, for the British Museum contains Cranmer's draft of a reformed Latin Breviary much on Quignon's lines, and the 1549 Book exhibits incontestable proofs of its influence,* The second source of many a valuable devotional element was the Consultation of Archbishop Hermann, of Cologne, composed with the assistance of Bucer and Melancthon, and published in German in 1543, with a Latin Edition in 1545, English 1547. It is noteworthy that where there are variations between the German and English, the B.C.P. follows the German more closely. The Church Order of Nuremberg, issued in 1533 by Brentz and Osiander (whose niece Cranmer married, and with whom he was staying in 1532), exercised an influence both direct, through Cranmer, and indirect, through Bucer's use of it in his contribution to the Consultation. By Osiander's use of Luther's liturgical productions, the great Reformer himself is represented in B.C.P. Quite a different source, and one more sparingly used, was the Greek Liturgy of St. Chrysostom, known to have been in Cranmer's hands in 1544; apart from direct contributions from such a source, its serviceableness as a test of the antiquity of the Western Service-Books must have aided the attempt to return to primitive models. More open to doubt is the influence exerted by the Mozarabic Liturgy of Spain, compiled in 1500 by Ximenes ; much formerly attributed to this source has been found to be in the German Church-Orders, which may, it is true, have borrowed from the Mozarabic Liturgy. It has been the custom to dwell upon the supposed foreign influences at work upon the Second Prayer Book, of 1552, with a view of disparaging that Book; Bishop Dowden remarks, however, that 'in truth we have less historical evidence for the influence of external agency on the second book, than we have for such influence on the first.' $\dagger$

The year 1550 was marked by scveral events which bear upon The Second the history of the Prayer Book, directly or indirectly. The order Book.

* For details regarding the cvidences of the influcnce of foreign sources Genc:is. upon the B.C.P., see Dowden's Workmanship of the Prayer Book, cc. 1-3.

† Dowden's Workmanship, p. 16. 
to replace stone altars with wooden tables might seem liturgically unimportant, were it not that in the same year Cranmer's famous Defence of the True and Catholic Doctrine of the Sacrament of the Bcdy and Blood of our Saviour Christ was issued, demolishing the corrupt dogmas which the stone altar tended to illustrate. At or about the same time, a revision of the 1549 Book was commenced, and another object, dear to Cranmer's heart, the preparation of Articles which might refute the decisions of the Council of Trent, was prosecuted with vigour. These two engrossing tasks were pursued in 1551, and both completed in 1552, the revised Prayer Book being accompanied by a revised Ordinal, and published that same year, the Articles in 1553.

(2) Its The general trend of the revision is not disputed. While nothing of the former work was sacrificed, the ambiguities discovered by keen eyes were removed, the practices shown by experience to be inseparable from superstitious abuse were shorn away, and defects remedied. It is unnecessary to do more than utter a direct negative to the extravagant assertions that the 1552 Bool merely, or chiefly, reflected the suggestions of foreign reformers. It is far more true to say that the revision, so far as it owed any doctrinal modifications to external sources, was influenced by a determination to avojd the dangerous ambiguities of the vague teaching of Lutheranism upon the Holy Communion. It is far more important to remember that this Book, though so speedily overthrown by the early death of the King, and the subsequent accession of Mary, is so far in form and substance the Prayer Book of to-day, that the examination of subsequent modifications would be a work of supererogation but for attempts to read into them a mouning expressly denied by their authors.* Restora- in 1559. of Common Prayer, received the royal assent on May 8, 1559 . It

The Elizabethan Act of Uniformity, to-day a part of the Book named the Prayer Book of 1552, with three specified alterations, 'and none other or otherwise,' as the one revived by the Act. But no standard copy of the 1552 Prayer Book was annexed, and amongst some unimportant variations between that Book and the printed copies of 1559 there is one conspicuous change, namely, the alterations in the Rubrics preceding Morning Prayer. $\dagger$ We are not here concerned with the efforts necessary to be made to introduce the Prayer Book into gereral use ; suffice it to say that despite opposition from both sides, Roman and Puritan, the Book steadily made its way. It is liturgically important to note that the same year saw the birth of congregational hymnody in

* For alterations in 1552, see Analyses of separate Offices, and especially tables on pp. 262-3, and 281.

$\dagger$ For comment upon these altered Rubrics, see pp. $76 \mathrm{ff}$. 
En:land, one of the famous Injunctions giving permission for a 'hymn or such like song' at the beginning or end of Common Prayer, a permission eagerly used by the returned exiles of IIary's reign.

Jewel's Apology, published with the permission of the Queen Final and the consent of the Bishops, in 1562 , constituted a semi- Draft of authoritative challenge to the Council of Trent, which was again Articles. sitting. But the revision of the 42 Articles, and their authoritative publication as the 38 Articles, were as definitely and more quthoritatively the Church's reply to the Council. They appeared in 1563, and seeing that they lend their weight to the Second Book of Homilies, these last must have been already composed, though one, the 21st, dates from 1571. Foxe's Acts and Monuments, most unjustly assailed by interested parties in later days, also appeared in 1563, and copies were established in many churches for general reading.* The Puritan difficulty led to the issue of another famous document in 1566, the Advertisements, $\dagger$ declared by the latest legal interpretation to be the present law as to ministerial vesture in the Church of England. The final revision of the Articles in 1571, then made 39, and subscription to them enforced, concluded the Elizabethan enactments touching the liturgical and doctrinal documents of the Prayer Book, though the practical difficulties of regulating obedience thereto continued to the end of the reign.t.

* For a succinct vindication of Foxe, see Hole's Manual of Church History, pp. 246-8.

† See pp. 83, 84.

† Towards the olose of Elizabeth's reign the predominating Calvinism, already becoming marked by certain dogmas with which the name is now associated, found full expression in the Lambeth Articles, a document drawn up under Whitgift, and at his palace, in 1595 . The propositions were :-

1. God from eternity hath predestinated some to life, somo $\mathrm{He}$ hath reprobated to death.

2. The moving or efficient cause of predestination to life is not the prevision of faith, or of perseverance, or of good works, or of anything which may be in the persons predestinated, but only the will of the good pleasure of God.

3. Of the predestinated there is a fore-limited and certain number which can neither be diminished nor increased.

4. They who are not predestinated to salvation will be necessarily con. demned on account of their sins.

5. A true, living and justifying faith, and the Spirit of God sanctifying, is not extinguished, does not fall away, does not vanish in the elect either totally or finally.

6. A truly faithful man, that is one endowed with justifying faith, is certain by the full assurance of faith, of the remission of his sins and his eternal salvation through Christ.

7. Saving grace is not given, is not communicated, is not granted to all men, by which they might be saved if they would.

8. No man can come to Christ execpt it be given to him, and unless the 
ITampton Court Conforence.

The accession of James I found all ecclesiastical parties in a perturbed state. The Romanists even ventured to hope something from the son of the executed Mary Queen of Scots, though their hope was probably greater than their expectation, and disappeared entirely, for the time, with the Gunpowder Plot. The Puritans had better reason to expect consideration at the hands of the Presbyterian Stuart, and their failure is only to be explained on the grounds of (1) the Stuart policy, to retain and even increase the arbitrary power of the throne, for which the support of the Church was of more value than that of the Puritans was likely to be, and (2) the intemperate demands of a section of the Puritans. Nevertheless, the Millenary Petition, signed by 750 Ministers, was far from intemperate in our eyes, however it may have appeared to those with whom feeling ran high in 1603. Indeed, its moderation of tone seems to have frightened the conservatives amo ust Churchmen.* The petitioners sub-

Father draw him. And all men are not drawn by the Father tha they may come unto the Son.

9. It is not placed in the will or power of every man to be saved.

The opposition of Elizabeth and Cecil, and the influence upon Whitgift of Andrewes and Overall, sufficed to prevent these Articles obtaining anything like authority, but they show the doctrinal tendency of the period.

* Perry's Student's English Church History, p. 359 ; the Petition is there given in extenso, Note (A), p. 372. Hole, Manual of English Church History, p. 274, characterizes many of theobjections as a whole as ' of an extremely sensible character,' and such as 'might still interest the serious Church reformer.' 'The following is a complete list of the suggestions of these more moderate Puritans :-

(1) In the Church Service:-

The Cross in Baptism, interrogatories ministered to infants, Baptism by women, Confirmations, enforcement of cap and surplice, to cease.

Examination to precede Communion, and Sermon always to accompany administration.

'Terms, such as 'priest,' 'absolution,' to be corrected.

The ring in marriage to be no longer used.

The longsomeness of the service to be abridged.

Church rongs and music to be moderated to better edification.

The Lord's Day not to be profaned; holidays not to be so strictly urged.

Uniformity of doctrine to be prescribed, and no popish opinion taught.

Bowing at the Name of Jesus not to be taught.

The Canonical Seriptures only to be read in church.

(2) Concerning Church ministers :-

Only ' able and sufficient' men to be ordained, and they to preach ' diligently and specially' on the Lord's Day; those unable to preach either to be removed and charitably provided for, or themselves to provide for the maintenance of preaching.

Non-residency to be forbidden.

King Edward's Statute for the lawfulness of ministers' marriages to be revived.

Ministers not to be urged to subscribe, but according to the law, to the articles of religion and the King's supremacy only. 
scribe themselves as "The ministers of the Gospel that desire not a disorderly innovation, but a due and godly reformation.' The vested interests touched by their suggestions, including the Universities, skilfully opposed the whole movement for reform, by playing upon the foible of the King for absolute monarchy; but returns were made of the number of ecclesiastical irregularities in the matter of livings, pluralities, etc., and the King arranged for the Hampton Court Conference to be held in January, 1604. It is generally admitted that a Conference, in which the King, as moderator, was 'offensively jocular' and unfairly argumentative, and of which the members were nominated by the King in the proportion of 19 on the one side as against 4 on the Puritan side, was little likely to satisfy the latter. The proceedings lasted three days, some few alterations resulting.*

(3) For Church living ard maintenance :-

Livings held by Bishops in commendam to be given up.

Pluralist incumbents to cease.

Impropriations annexed to bishoprics and colleges to be demised to the 'preachers' incumbents, for the old rent.'

Impropriations of laymen's fees to be charged with a sixth or seventh part of their worth, to the maintenance of the preaching minister.

(4) For Church discipline :-

Excommunication to be administered according to Christ's own institu. tion, e.g., not through lay chancellors, etc., not 'for trifles and twelvepenny matters,' not without the pastor's consent.

Unreasonable fees to be forbidden.

Jurisdiction and registers' places not to be farmed.

Popish Canons, as that restraining marriage at certain seasons, to be reversed.

The 'longsomeness' of suits in ecclesiastical courts, ' which vary sometimes two, three, four, five, six, or seven years,' to be restrained.

The oath by which men were forced to accuse themselves to be moro sparingly used-commonly ealled the ex officio oath.

Marriage Licences to be more cautiously granted.

* The alterations were :-

(1) Morning and Evening Prayer:-

1. After 'Absolution' 'or Remission of sins ' added.

2. Prayer for Royal Family added, with corresponding petition in the Litany.

4. Thanksgivings for Rain, Fair Weather, Plenty, Peace and Victory, and Deliverance from the Plague, added to occasional prayers.

(2) Private Baptism :-

1. Restricted to lawful minister.

2. Alteration of Title to suit this requirement.

3. 'That they procure not their children to be baptized' instead of 'that they baptize not their children' in second Rubric.

4. Third and fourth Rubrics altered to suit restriction to "lawful minister.'

5. The inquiry "whether they called upon God for grace and 
Their legality need not concern us, as they were adopted in the legal revision of 1662 . The really substantial results of the Conference were the addition to the Catechism, the diminution of the use of the Apocrypha, and, far the greatest of all, the undertaking of the revision of the English Bible.* 'It is evident,' says Canon Perry, 'from the sort of answers made to the objections that no real trouble was taken to investigate the points which they raised.' Neal complains that ' the Puritan ministers were insulted, ridiculed, and laughed to scorn, without either wit or good manners.' For good or evil, perhaps for both, 'Anglicanism' was coming into being, marking a tendency to separate from foreign reformed bodies, and to force Puritanism into the condition of a sect.

The Canons of 1604, numbering 161, and including several passed in Elizabeth's reign, had considerable permanent effect upon the use of the Prayer Book, though not altering its text. They were subscribed by Convocation, but not ratified by Par liament. They are thus in no sense binding on the laity, and even for clergy they have no validity except when not invalidated by conflict with Statute Law, or by disuse. They endorsed the Advertisements as the standard of ministerial vesture, maintained the Royal Supremacy, introduced a form of Bidding

(3) Confirmation :succour in that necessity' omitted, and caution inserted 'And because some things . . . times of extremity.'

' Or laying on of hands upon children baptized, and able to render an account of their faith, according to the Catechism following' added.

(4) Catechism :-

The concluding portion added on the Sacraments.

(5) Calendar:-

Aug. 26, Prov. xxx. instead of Bel and the Dragon.

Oct. 1, 2, Exod. vi., Josh. xx., xxii. instead of Tobit v., vi., viii.

(6) Gospels :

Second Sunday after Easter, and Twentieth Sunday after Trintiy, the words ' unto His disciples' omitted, and 'Christ said'

'Jesus said' printed in type differing from the actual text.

- The demands of the Puritans at the Conference differed somewhat from those put forward in the Millenary Petition, the more important additions being :-

1. A Protest against the assertion in Art. XVI that 'we may depart from grace given and fall into sin.'

2. A request for the embodiment in the Prayer Book of the Calvinistic Lambeth Articles of 1595.

3. The proposal of an addition to the Articles against the doctrine of Intention.

4. A request for addition to the Catechism (granted).

5. Demand for better observance of the Lord's Day (promised).

6. Proposal for revision of the English Bible (adopted).

7. Objection to Churching of Women. 
Prayer (in which 'Christ's Holy Catholie Church' is defined as 'the whole cougregation of Christian people dispersed throughout the whole world,' and prayer is demanded for the Presbyterian Chureh of Scotland), enforced bowing at the Name of Jesus, defended the cross in Baptism, and inserted restrictions as to marriage.

The outstanding feature of this reign, from the point of view Iaudianism. of the Prayer Book student, is the growth of what is called (1) Its lise: Laudianism, though much besides the personality of Laud is included in what comes under that title. James' undisguised hatred of Puritanism, born of his chafing under Presbyterian restraints when King of Scotland, was nourished by his experience in England of the impossibility of obtaining support in Puritan cireles for his theories of divine right. The too often servile adulation of prominent ecclesiastics would commend itself more to a mind of his type. Moreover, questions of policy moved him to lend a ready ear to anything like a modus vivendi with Roman Catholieism, especially Roman Catholic powers. It is strange to-day to imagine such a dread of world-wide Roman power as was provoked by the Counter-Reformation, and its success in the early part of the seventeenth century, but it is intelligible when the twelve years of Roman. success, 1618-1630, in The Thirty Years' War is borne in mind, with the fearful massacres in the Valteline in 1620, and Magdeburg in 1631. In Holland Romanism was growing, in France Protestantism was decaying. Small wonder that a ruler of James' shiftiness should look about to find security in a policy not too plainly linked with Protestantism. But the great oceasion of Laudianism was neither royal favour, nor personal genius; the rise of Arminianism was the prime factor in altering the Stuart Church from the Elizabethan. Strict Calvinism, that is to say, Augustine's teaching earried to its logical conssquences, leaves no loophole for hierarchical pretensions at any rate, and Laud found in Arminianism a ready-made banner for the party which followed his teaching of Apostolieal Sucession, and the exaltation of the visible Church.

Though not much in favour with James himself, Laud was (2) its supported by Buckingham, and became the dictator of Charles' Results. poliey, and whatever we may think of his intentions, he involved himself, his King, and his Church, in one common ruin. To the majority of English Christians Arminianism logically undermined Justification by Faith, and therewith the Reformation; Laud's attempts to revive Roman eeremonial, when conseerating the chureh of St. Catherine Cree in 1631, threw a sinister light upon his enforcement of the altarwise position of the Holy Table, 
and his inculcation of bowing to that Table on entering and leaving Church : his Scottish Prayer Book, 1637, and his abortive Canons of 1640 , all pointed the same way; add to these things the absurd sermons printed by his authority to exalt the power of the King, even teaching the King's absolute right to legislate and levy taxes: the known leanings of Laud away from the reformed Churches, and towards the unreformed, both manifest in such events as his tyrannous refusal to allow foreign congregations to worship in England save after conforming to episcopacy, and the offer, twice made, of a Cardinal's Hat; and all this at a time when the aggressiveness of Rome by war and by the Jesuits was stirring men as they had not been stirred since the Armada :-surely it is not difficult to account for the deplorable alienation of the nation from the Church of England and from the Book of Common Prayer, as illustrated and interpreted by Laudianism.

savoy con- Unfortunately, that alienation was only partly cured at the terenoe. Restoration. The Savoy Conference, summoned in 1661 to deal with objections to the Prayer Book on-the part of the Puritans, largely consisted, on the Church side, of Bishops too much imbued with Laudian aims. It is easier to understand than to condone the spirit on both sides which made the Conference abortive. The English Church has never recovered from the sectarianism in which Laud involved it, nor can it recover on Laudian principles of Churchmanship. The demands of the Puritans appeared in a long list of suggestions, containing unimportant matters as well as objections worthy of consideration.

The Puritan objections at the Savoy Conference were:-

(1) General :-

1. Nothing doubtful, or questioned by orthodox persons, to be retained.

2. As the first Reformers had retained all they could to win over Romanists, so now the winning over of all Protestants should be the aim.

(2) Divine Service generally :-

1. 'Repetitions and responsals,' and alternate reading in Psalms and Hymns to be omitted.

2. The Litany to be changed to one solemn prayer.

3. The gift of prayer to be allowed in Divine Scrvice.

4. Old and New Testament only to be read as Lessons.

5. Portions of Acts and Old Testament not to be called Epistles.

6. 'To use the 1611 Version only.

7. To substitute 'Minister' for 'Priest,' and 'Lord's Day' for 'Sunday.'

8. One long prayer instead of short Colleets.

9. To abandon the use of the Surplice.

10. 'To cease religious observance of Saints' Days, and the Lenten Fast. 
(3) Morning ard Evening Prayer, ete. :-

1. The Lord's Prayer not to be so often used, and the Doxology always added.

2. Gloria Palri to be used only once Morning and Evening.

3. A Psalm or Seripture Hymn to be substituted for the Bene. dicite.

4. 'Deadly sin,' 'sudden death,' and 'all that travel,' to be altered.

5. 'This day' to be omitted in the Christmas Collect, and Proper Preface for Whitsuntide.

(4) Communion Oflice :-

1. Rubrio respecting notice of communicating to be altered so as to compel longer notice.

2. Minister to have full power to admit or refuse communicants.

3. Kneeling during Commandments, and Kyric, to cease; Minister to conclude the reading with a suitable prayer.

4. Preaching to be more strictly enjoined.

5. 'Homilies hereafter to be set forth' to be omitted.

6. Two Offertory Sentenees from the Apocrypha to be omitted.

7. Collection to be made at or just before the communicants depart.

8. General Confession to be made by the Minister only.

?. Words of the Saviour to be used in administering, as nearly ás possible.

10. Minister not to be required to deliver into each one's hand.

11. Minister not to have to repeat the words to each recipient.

12. Kneeling at reception to be left free, and the Black Rubrio to be restored.

(5) Baptismal Office :-

1. Use of the cross to disappear.

2. Sponsors only to be used if parents desire.

3. Promising in the name of the child deprecated.

4. Private Baptism only to take place with competent minister, and in presence of a sufficient number, with no public reiteration.

(6) Catechism and Confirmation :-

1. Opening questions to be altered, there having been no godparents for several years.

2. "Wherein I was visibly admitted into the number of the members of Christ, the children of God, and the heirs of the kingdom of heaven' to be made the third answer.

3. In the Duty towards God 'particularly on the Lord's Day' to be added at the elose.

4. The former part of the Catechism to be enlarged on the lines of the latter portion on the Saeraments.

5. Faith, Repentance, the two Covenants, Justification, Sanctification, Adoption, and Regeneration, to be particularly treated.

6. The entering of infants into God's Covenant to be more warily expressed, the promise of repentance and faith not being taken for their performance, and infants not being asserted to perform these by their sureties.

7. More requirements to be asked of candidates for Confirmation.

8. Prayer before the Imposition of Hands to be altered.

9. Practice of the Apostles not to be alleged as a ground of Confirmation. 


\section{xxvii THE STORY OF THE PRAYER BOOK}

10. Confirmation not to be nuade a necessary condition of aumis. sion to Holy Communion.

(7) Marriage Service :-

1. The ring to be left indifferent.

2. Other words to be substituted for 'worship' and 'depart " (now 'death us do part').

3. Declaration in the name of the Trinity to be omitted, ax favouring the idea of Matrimony as a Saerament.

4. Change of place and posture to be omitted.

5. 'Consecrated the state of Matrimony to such an excellent mystery' to be omitted, because Matrimony preceded the promise of Christ, and the words savour of the sacramental idea.

6. Direction for Communion on the wedding-day to be omittel.

(8) Visitation of the Sick :-

1. Greater liberty in prayer and exhortation to be permitted.

2. 'I pronounce thee absolved' to be put for 'I absolve thee,' and 'if thou dost truly repent and believe' added.

3. Minister not to be enjoined to administer the Lord's Supper. as desired by the sick, but as thought expedient by the minister.

(9) Burial :-

1. Rubric to be inserted declaring the service to be for the living.

2. Permission to be given to use the whole service in Church.

3. 'In sure and certain hope' to be altered.

Futility of the Confer.nce.
The preparation of this complete list was an error in tactics, adopted by the 12 Puritan Divines at the suggestion of the 12 Episcopal members of the Conference. Baxter is reputed to have swallowed the bait, and he also prepared a Prayer Book of his own at the same time! How their time had been thrown away was brought home to the Puritans when they learned that the other side was intending not to suggest any alterations on their part, but to express full satisfaction with the Book as it stood. The Church party concluded a long general criticism of the Puritan suggestions (containing one important piece of information, viz., that the word 'priest' was retained to distinguish a 'presbyter' from a 'deacon'), with concessions obviously not intended to meet the case. 'The Savoy Conference took the form of a battle between opposing forces. The Puritan party were so unreasonable that agreement was hopeless however conciliatory the Episcopalians might have been; while the Episcopalian party were so unconciliatory that the Puritans could not have been won however reasonable they had been.' So Hole (p. 312) sum up the situation, and the accuracy of his summary is exhibited by the nature of both the Puritan demands and the episcopalian concessions.*

* The concessions offered at the Conference were :-

1. Episties and Gospels to be taken from the 1611 Version.

2. 'For the Epistle' to be used, when taken from O.T. or Acts. 
The abortive Conference, for which four months were ap- The Repointed, came to an end, and Convocation undertook a serious 1601 . Revision, which somewhat discredits the assertion of the 12 Episcopalians at the Conference, that they desired no alterations. However, that must have been known to be nothing but a tactical trick, for there were in existence proposals for altering the Book in the direction of Edward's First Book and the Scottish Book of 1637. Further, Convocation proved much more willing to sec the reasonableness of some of the Puritan suggestions, and sturdily rejected the proposals of divines of the Laudian school.*

3. Psalters to be collated with the former translations.

4. 'This day' to be altered to 'as at this time' save on the actual day.

5. 'At least some time the day before' to be made the requirement for notice of communicating.

6. Rubric concerning not admitting wicked to Holy Communion to be set forth according to Canons 26 and 27.

7. Preface to be prefixed to the Commandments.

8. Second Exhortation to be read some Sunday before Celebration.

9. General Confession in Communion Office to be said by a minister, the people repeating it after him.

10. Manner of consecrating the elements to be made more cxplicit.

11. Font to be placed conveniently for hearing.

12. 'Perform' to be altered to "promise" ("by their surcties') in Catechism.

13. Rubric at close of Baptismal Office to be verbally altered.

14. 'Or be ready and desirous to be confirmed' added to rubric after Confirmation.

15. 'Worship' to be changed to ' honour' in Marriage Service.

16. 'Depart' to be altered to 'do part.'

17. 'Sure and ccrtain' to be omitted in Burial Office.

*The more important alterations were :-

(1) New Material :-

1. The Preface, the former Preface being made a separate chapter

2. 'Pebellion and schism' added in Litany.

3. Seven Occasional Prayers and Thanksgivings.

4. First Anthem on Easter Day.

5. Collect for Easter Even.

6. Clause of thanksgiving for 'saints departed.'

7. Rubrics for presenting Alms, and placing the elements.

8. Rubric for ordering the bread and wine for consecration.

9. Rubric regarding consecration of additional bread or wine.

10. Rubric for covering surplus consecrated elements.

11. Black Rubric.

12. Inquiry of Obedience addressed to sponsors.

13. Reference to Canon 30, explaining the sign of the cross.

14. Ministration of Baptism to such as are of Riper Years.

15. Form for Banns of Marriage.

16. 'If he humbly and heartily desire it' added to rubric on Absolution of the sick.

17. Occasional Prayers added to Visitation Office.

18. Directions for shortened form in Communion of the Sick.

19. First Rubric in Burial Office, regarding unbaptized, etc. 
Its Tendency.

Subsequent Attemptrid Revisions.

Oxford slovement.

Much ill-directed ingenuity has been expended upon attempts to find in these alterations a bias towa: ' 3 a less reforming type of Churchmanship. As the revisers' Preface plainly says, if their words do not redeem them from any such intention, the changes themselves will be sufficient for that purpose to any unbiassed mind. Indeed, without any change of a doctrinal bent, the revision was quite effective enough for the times; more than 2000 ministers were lost to the Church of England when the Book as revised became law in 1662 . It was inevitable; the deprivations of a few years before, when more than 2000 clergy were as unjustly deprived, explain those of 1662 . Nothing could have saved the situation but the presence of a spirit of love sadly absent in either party to the dispute.

The story of the Prayer Book since 1662 includes no further revision save the small alterations caused by the changes of sovereign, but it is not a finished tale even now. In 1668 Tillotson and Stillingfleet entered into negotiations with leading Nonconformists for a method of inclusion, but Parliament stood hopelessly in the way. The temper of the times destroyed a similar effort of Stillingfleet in 1681. In 1689 a powerful Commission actually prepared a revision, meeting the genuine d fficulties of the Puritans, but this time Convocation was an insuperable obstacle, and the effort came to nought.

The Oxford Movement, initiated by the Tracts for the Times, has made the nineteenth century memorable in the story of the Prayer Book, the novel methods of interpretation suggested by that School of Thought called Tractarian, and later, Ritualistic

20. Forms of Prayer for those at Sea.

21. Forms of Prayer for Jan. 30 and May 29.

(2) Re-arrangemont :-

1. Portions used at both Morning and Evening Prayer printed in both.

2. Exhortations in Communion Office.

3. Catechism separated from Confirmation.

4. Rubric on Confirmation made into a Preface to the Office.

5. Psalms and Lesson appointed to be read in $\mathrm{Ch}$ urch at burials.

(3) Changes :-

1. 'Bishops, priests, and deacons' for 'Bishops, pastors, and ministers of the Church.'

2. New Collects for the Third Sunday in Advent, and for St. Stephen's Day; Collect, Epistle, and Gospel, for a Sixth Sunday after Epiphany provided.

3. 'Then shall begin the Communion,' at end of Marriage Service, omitted, and compulsory order for newly-married to receive on the wedding-day altered to a suggestion of its suitableness either on the day, or soon after.

4. The name of the deceased omitted in Prayer at the grave. 
having effected in many cases a revision of the Prayer Book as used in public worship, far more drastic than any actual revision would have been. Appeals to Law have discredited the claims of the Tractarians, so far as their legality is concerned, but they have skilfully cast discredit upon the Courts, as unfit to legislate, and episcopal reluctance to interfere with men of acknowledged zeal, especially with the knowledge that imprisonment is the penalty for breach of the law, has allowed generations to grow up to whom the true meaning of the Book of Common Prayer is utterly unknown. History is repeating itself, and the loss of a large part of the nation suffered by the Church during the Laudian Movement, is being experienced under the episcopal toleration of the Oxford Movement. There is this difference today, that the nation no longer expects to see one school of thought exclusively dominant, and, the day of persecution having ceased, Nonconformity, doctrinal or virtual, is fast alienating the people from the Church and its teaching in the Prayer Book. Yet the true interpretation of that Book would convince the honest student of its truly scriptural basis, and display the latent disregard of its principles and teaching inherent in the new Anglicanism. Such honest study is alone able to preserve both the National Church, and the Book of Common Prayer as its devotional and doctrinal expression.*

* The additions to the Catcchism, passed by Canterbury Convocation Lower House, in 1887, though dealing with a felt need, failed, and happily failed, because their tendency was to disturb the doctrinal balance of the Chureh's formularies. The attempts at revision of the present time are doomed to a similar failure, until it is recognized that the obvious need of revision for adaptation of the Prayer Book to modern needs, must not be made an excuse for doctrinal innovation. 


\section{ABBREVIATIONS}

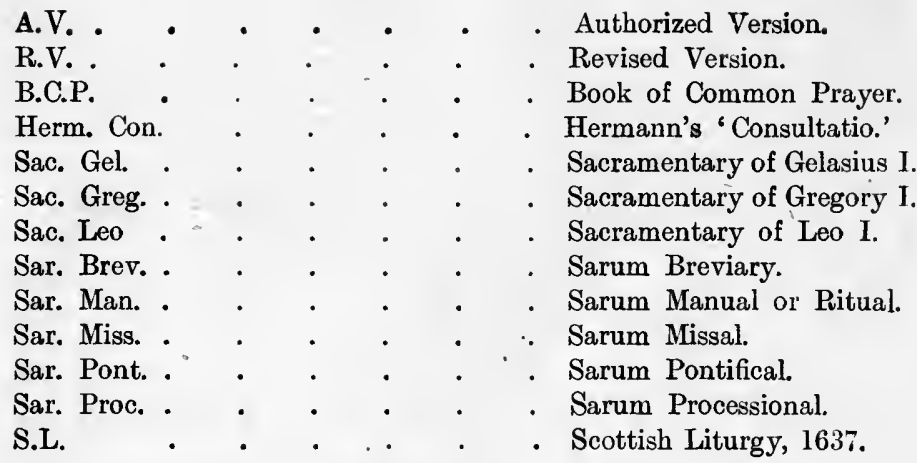

Dates are all A.D. unless stated to be otherwise.

1549 is used for First Prayer Book of Edward VI.

1552 " , Second Prayer Book of Edward VI.

1559 " " The Prayer Book of Elizabeth.

1604 " " The Prayer Book of James I.

1637 " , The Scottish Prayer Book" of Charles I.

1662 " " The Prayer Book of Charles II. 


\title{
INTRODUCTORY MATTER
}

\author{
ANALYTICAL SUMMARY.
}

1. Trthr Pagr

2. Contents of this Book

3. ACT OF UNIFORMTT .

4. Prefaces

i. 'The Preface' . . . . . 11

ii. 'Coneerning the Serviee of the Chureh' . . . . 18

iii. 'Of Ceremonies' . . . . . . . . 27

5. Rules concernniva Psalter and Lectionary

i. 'The Order how the Psalter is appointed to be read' . 32

ii. "The Order how the rest of Holy Scripture is appointed to be read'. . . . . . . . . 35

iii. Tables of Proper Lessons and Psalms

(1) 'Iessons proper for Sundays' • • • . 38

(2) 'Lessons proper for Holy-Days' : : : : $\quad$ : 39

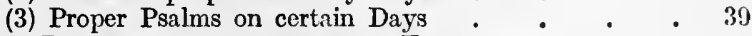

6. Tbales and RUles mainly concerning Feasts

i. 'Rules to know when the Moveablo Feasts and Holy-Days begin'.

ii. 'A Table of all the Feasts that are to be observed in the Church of England throughout the year'.

iii. 'A Table of the Vigils, Fasts, and Days of Abstinence to be observed in the Year'. . . . . . . 49

iv. 'A Solemn Day for which a Particular Service is appointed' 57

v. Tables to find Easter and other Moveable Feasts . $\quad 57$

For Limited Periods.

(a) Two Tables 'to find Easter till the year 2199 inclusive' . $\quad$. 59

(b) 'Tables of the Moveable Feasts'

(a) 'For fifty-one years' . . . . . . 61

(b) 'According to the several days that Easter can possibly fall upon'. . . . . .

(c) Table to find Easter Day from the year 2200 to 2299 inclusive.

For any Period.

-General Tables for finding the Domi nical or Sunday Letter, and the plices of the Golden Number Numbers in

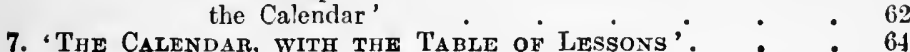




\section{THE TITLE PAGE.}

The Book of Common Prayer and Administration of the Sacraments and other Rites and Ceremonies:-

1549. of the Church : After the use of the Church of England.

1552. in the Church of England.

1604. of the Church of England.

1662. of the Church, according to the use of the Church of England, Together with the Psalter or Psalms of David, Pointed as they are to be sung or said in Churches: and the form or manner of making, ordaining and consecrating of Bishops, Priests, and Deacons.'

$$
\begin{gathered}
\text { (London. } \\
\text { Printed by His Ma.tes Printers. } \\
\text { Cum Privilegio. } \\
\text { M.DC.LXII.) * }
\end{gathered}
$$

From the Title Page we learn that the B.C.P. consists of : (1) Common Prayer; (2) Administration of the Sacraments ; (3) Other Rites and Ceremonies; (4) the Psalter; and (5) the Ordinal.

Common Prayer, i.e. Public Prayers intended for all. A Book of Devotions to be used by Clergy and people, as distinguished from private devotions. The words 'Common Prayer' more particularly refer to the Morning and Evening Service together with the Litany.

This portion of the B.C.P. corresponds to the Breviary.

The Sacraments, i.e. Baptism and Holy Communion.

Baptism formed part of the Manual; Holy Communion with the Collects, Epistles, and Gospels took the place of the Missal.

Other Rites and Ceremonies, i.e. Confirmation (including the Catechism), the Marriage Service, the Burial Service, Churching of Women, etc.

These Offices (with Baptism) formed the Manual.

* The words within the brackets are found in the early editions of the 1662 B.C.P., but they were erased in the Sealed Book, as not being found in the MS. which it represents. 
The word 'Rite,' strictly speaking, refers to the Form of Words used, as, for instance, in the Marriage and Burial Services, etc. 'Ceremonies' are the accompanying actions, as the putting on the ring in Marriage, or the cross in Baptism. Here, however, the two words are used almost synonymously.

\section{According to the Use of the Church of England.}

Prior to 1549 there were several Uses, e.g. Sarum, York, Lincoln, Hereford ; but by the Act of Uniformity of that date it was enacted that the B.C.P. was to be the only one used in Churches. Similarly by the Act of Uniformity of 1662 our present B.C.P. is the only Service Book authorized to be used. Thus since 1549 the B.C.P. has been the national Use.

\section{The Psalter, or Psalms of David.}

This description is used because David is the best known of the Psalmists ; it does not imply that he is the author of all the Psalms. At first the Psalter was not printed in the B.C.P., but, like the old Psalterium, was bound by itself.*

Pointed as they are to be sung or said in churches; i.e. divided by a colon to mark the division of the verse which corresponds to the same in the chant.

Making, Ordaining, and Consecrating of Bishops, Priests, and Deacons ; i.e. The Making of Deacons, the Ordaining of Priests, and the Consecration of Bishops. The word 'making' is used of Deacons to emphasize the difference in status between them as members of the "inferior Order,' and the Presbyterate.

This answers to the Pontifical.

N.B.-The books called 'the Sealed Books' are copies of the original B.C.P., annexed to the Act of Uniformity, 1662. They were printed by the King's Printer, and certified by Royal Commissioners. These 'Sealed Books' were deposited at each of the Law Courts, at Westminster, the Cathedrals, the Tower, and other leading centres.

* As early as 1604, the Psalter was printed in B.C.P., James Parker, First P. B. of Eduard compared, $p$. 408. The book of 1636 used by the 1661 Revisers had bound up with it a psalter, uniform in type with the rest, though of later date, 1639 . 


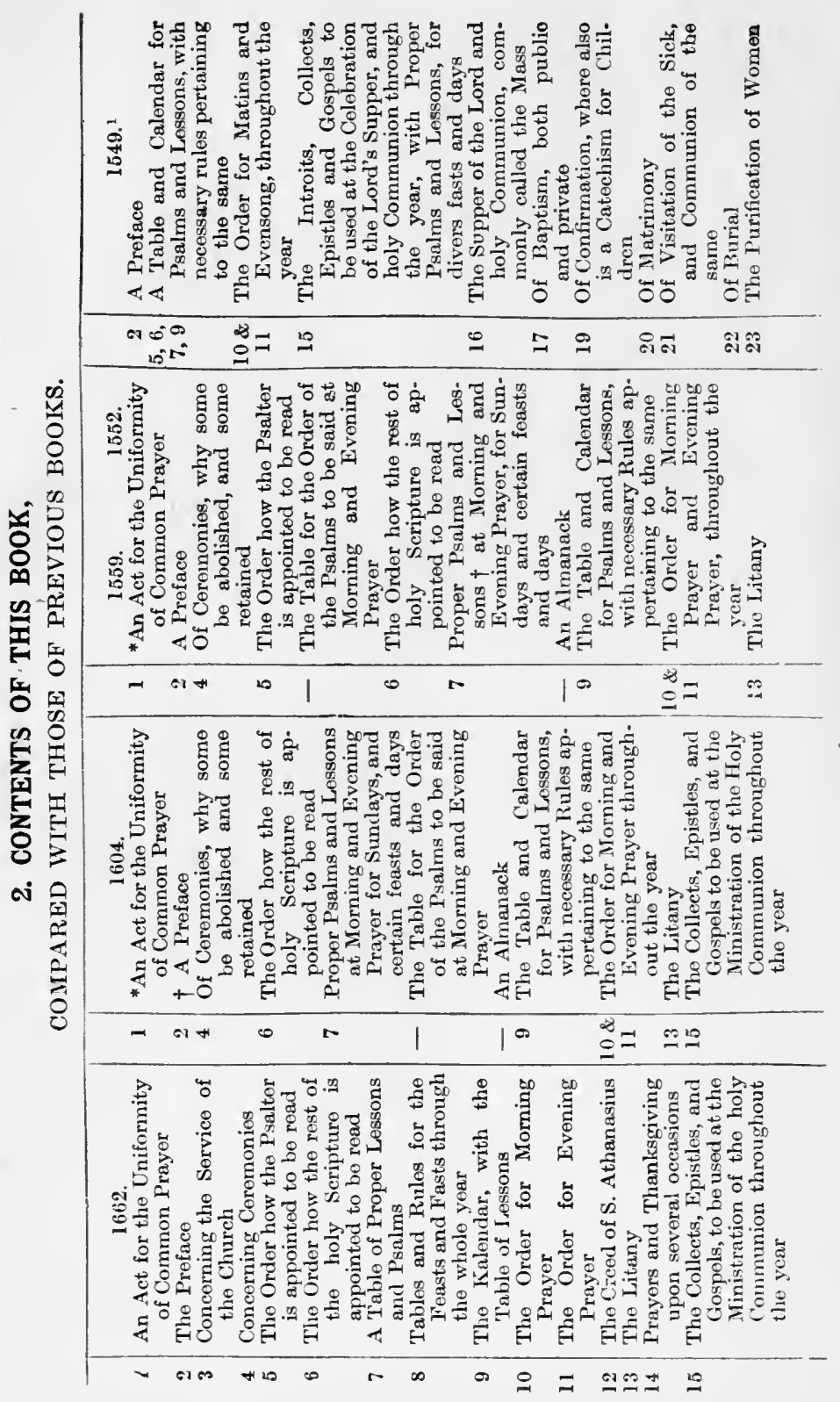




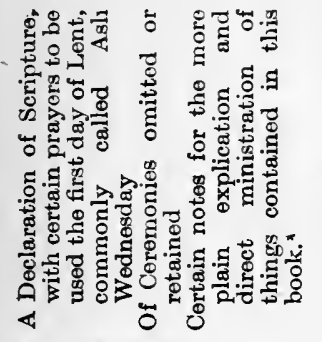

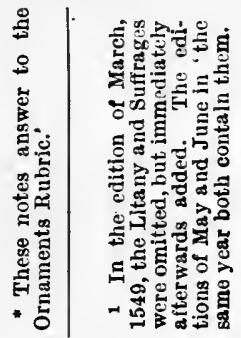

जี

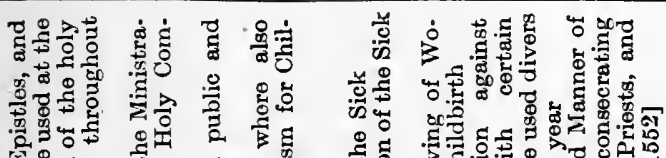

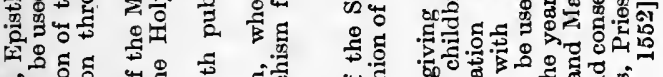

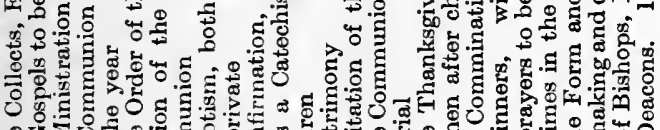

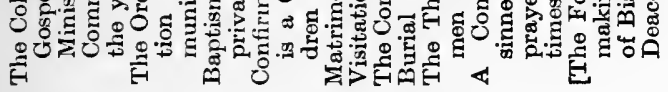

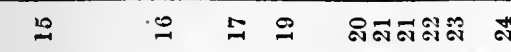

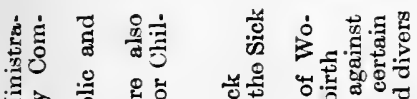

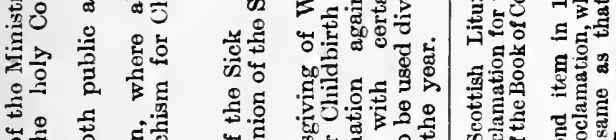

흐을

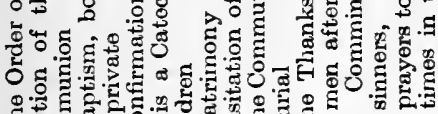

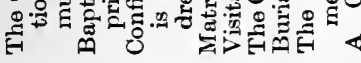

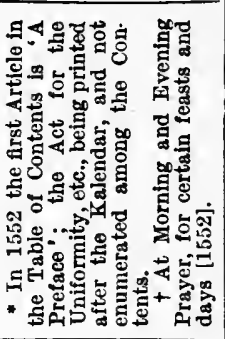

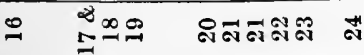

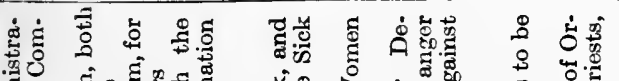

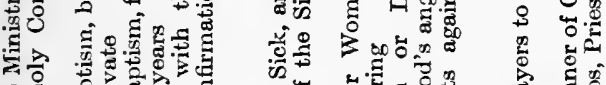

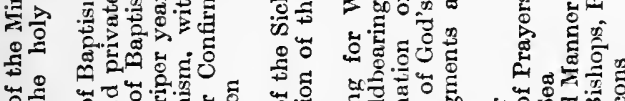

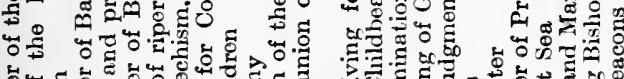

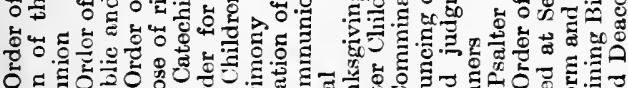

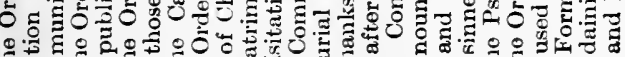

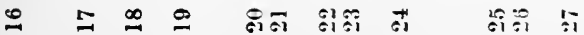




\title{
3. THE ACT OF UNIFORMITY.
}

\author{
AN ACT \\ For the Uniformity of Common Prayer and Service in \\ the Church, and Administration of the Sacraments.
}

\section{PRIMO ELIZABETHÆ.}

Many students will be surprised to find that Queen Elizabetb's Act of Uniformity forms part of our Prayer Book, stands in the forefront of it, and is numbered 1 in the Table of Contents. This surprise is increased by the fact that many persons have never seen a Prayer Book containing this Act, inasmuch as the authorized printers for many years illegally omitted the Act, and altered the numbers of the statutory Table of Contents, making the preface No. 1. Why this was done cannot now be ascertained. It is true that the 'Annexed Book,' that is, the actual book annexed to the Act of Uniformity of 1662, was lost for many years, but copies known as the 'Sealed Books' were accessible all the time, and in all of these the Act of Queen Elizabeth appeared as No. 1 in the Table of Contents. The books issued as Books of Common Prayer must not vary from the statutory Annexed Book except that the spelling may be modernized, and of course subsequent statutory modifications must be incorporated. An exact copy of the Annexed Book as it stands, has been printed, and may be used by students for the purpose of comparison.*

Acts of Uniformity were rendered necessary by the peculiar constitution of the Church of England after the date of the rejection of the authority of the Pope and Church of Rome (see Baker v. Lee). The Church of Rome was and is a free Church, i.e. it makes its own rules, commonly known as the canon law, and with these rules no State or country interferes, unless they

* By the King's Printers. The student should also refer to "The Statutory Prayer Book, as enacted by the Act of Uniformity, and amended by Subsequent Statutes, or by Orders in Council, with a Preface showing the unauthorized changes corrected in this Edition,' by J. T. Tomlinson and Charles H. H. Wright, D.D. 
clash with the temporal laws of the particular country. England was no exception to this. Up to the breach with Rome, the State never interfered with matters purely spiritual.

The canon law having been abrogated, and considerable difference of opinion existing among the principal ministers of religion in England, the most learned of whom, including Archbishop Cranmer, were gradually feeling their way towards the true Protestant faith, there was from the date of the breach with Rome - till the date of the first Act of Uniformity (2 \& 3 Edward VI) no settled authority, and no legal standard of religion. The Lord Protector and the Privy Council of Edward VI had done their best to 'stay innovations or new rites,' but not with much success. The task was the more difficult as there had been in Roman Catholic times in the realm of England and Wales diverse forms of common prayer such as the Uses of Sarum, York, Bangor, and Lincoln. Of course, these involved no differences of doctrine. The doctrine of the Roman Catholic Church was uniform, but the existence of these slightly diverse forms of prayer made it the more easy for much more 'diverse and sundry forms and fashions' to be used in cathedral and parish churches. To remedy this and restore the uniformity which the rejection of the Papal authority had destroyed, it was resolved to have a statutory Prayer Book and enforce it upon the whole nation. The book was naturally in the nature of a compromise. It was (by the King's áppointment) drawn up by the Archbishop of Canterbury and certain bishops and other learned men of diverse views. The framers were directed to have 'eye and respect 'as well to 'the most sincere and pure Christian religion taught by the Scripture,' as to the usage of the primitive Church. It was in itself a 'godly' form, but provided alternatives, so that those attached to Roman Catholic forms of worship should not be too much offended. Hence its failure as a 'Uniform' Book. The alternatives were made the most of and 'coaches and horses' driven through some of its provisions, so that, as the nation was now advancing in Protestantism, it soon became necessary to have a new book. This, the second book of Edward VI (which is practically the Book we now use), was established by authority of Parliament in 1552 (5 \& 6 Edward VI, c. 1). It recites that a godly order had already been set forth, but that there had arisen in the use of it doubts as to the fashion and manner of conducting the services, caused by the ministers and mistakers of the forms; therefore the words of the former book had been "faithfully and godly perused, explained and made fully perfect.' There was added thereto an Ordinal, which in like manner was an explanation and perfeting of the transition Ordinal of $\mathbf{1 5 5 0 .}$

First Act of Unifo'm: ity of $\mathbf{E}$. ward VI 
Third Act of Uniformity,

The Third Act of Uniformity, the statute 1 Eliz. c. 2, forms part of our present Prayer Book, and was passed after the interregnum of Roman Catholicism in the reign of Queen Mary, and its object was to restore the status quo of the 'latter year' of King Edward VI. It repeals Mary's Acts of Parliament which had resulted in great decay of the due honour of God, and (as it is mildly put) in 'discomfort' to the professors of the truth of Christ's religion.

The Act directs the second Prayer Book of Edward VI to be used with one alteration in certain Lesisons, the omission of the reference to the Pope and 'his detestable enormities,' and two sentences only added in the delivery of the Sacrament to the communicants and the alterations were to be 'none other or otherwise.'

The Act then directs with great particularity the various penalties and punishments for non-user of the Book, and for speaking in derogation of it.

Then at the end of the Act comes the well-known proviso containing the reference to the second year of Edward, the meaning of which has been settled by the Privy Council and is referred to later on; and lastly all laws prescribing other services are declared to be utterly void.

Present Act of Uni formity.

The last Act of Uniformity (13 \& 14 Car. II, c. 4) proceeds on much the same lines as the preceding ones, the idea being that all English-people should hold a uniform faith. It recites that a Prayer Book had been ordered by Queen Elizabeth's Act of Uniformity agreeable to the Word of God and usage of the primitive Church; that many persons nevertheless refused to come to their parish church; and that the King had directed the Convocations to revise the Prayer Book, which they had done. This book was annexed to the Statute, which enacts that all ministers must use it, and a form of declaration is given by which they were to declare their unfeigned assent thereto. (This form has since been altered.) Severe punishments were prescribed for such ministers as might refuse.

The Act then proceeds to enact the clause which led to the secession of about 2000 of the clergy, that is : that every incumbent not Episcopally Ordained must procure himself to be ordained deacon according to the form of Episcopal Ordination before St. Bartholomew's Day, 1662 (Black Bartholomew) or be deprived. This new departure was followed up by another clause which provided that no person could be admitted in future to a living or be allowed to consecrate and administer the Lord's Supper unless a priest by Episcopal Ordination under the forms given in the new or old Prayer Books. The penalty for each offence 
was fixed at $£ 100$, a very large sum in those days, but it was not to apply to foreigners or aliens of the foreign Reformed Churches.

The Act further contains regulations as to subscription to Articles, lecturers, licences to preach, the use of the Prayer Book in Welsh and Latin, the alteration of royal names therein, schoolmasters, with very heavy penalties for breaches thereof. Much of this remains law to the present day, but much has been altered, especially by the Acts of Toleration. The Act also confirmed the several good laws and statutes then in force for establishing the Book of Common Prayer, and, as we have seen, the Act of Elizabeth was made part of the annexed Prayer Book.

For 300 years no deviation from the order and form in the Act of UniPrayer Book was allowed, in fact, until about the year 1840, formity when ritualistic non-conformity began. It was, however, con- Act, 1872 . sidered that this ancient form of service, especially at Morning Prayer, was rather too long, so in $\mathbf{1 8 7 2}$ an Act was passed, called the Act of Uniformity Amendment Act, by which a shortened Order of Morning and Evening Prayer was introduced.

' This form may be used on any day except Sunday, Christmas Day, Ash Wednesday, Good Friday, and Ascension Day; if in a cathedral, in addition to, and if in a church, in lieu of, the usual form (sect. 2). This shortened form comprises what is known as the " Order for Morning Prayer," or "Evening Prayer," with the omission, at the minister's discretion, of all or any of the following portions, viz. :-All the appointed Psalms, except one ; one of the Lessons (unless there are two proper Lessons for the day, when both must be read); the Lesser Litany and the Lord's Prayer following the Creed; the prayers for the King's Majesty, the Royal Family, the clergy and people. Each section of the 119th Psalm is deemed to be a separate Psalm. The Act also directs that upon any special occasion there may be used in any cathedral or church a special form of service approved by the ordinary, but there must not be introduced into it anything (except anthems or hymns) which does not form part of the Holy Scriptures or the Book of Common Prayer (sects. 3,4).* The Order for Morning Prayer, the Litany, and the Communion Service may be used as separate services, either together or in varying order, and the Litany may be said after the third collect at Evening Prayer, either in lieu of or in addition to the use of the Li'cany at Morning Prayer, but without prejudice to any legal powers

- 'Form part of' has always been taken to mean 'form part of the text of.' But Archbishop Temple broached the opinion that it excludes only such a service as 'expresses any doctrine which you cannot find the substance of either in the Bible or the Book of Common Prayer.' See Letter of Sir William Harcourt to The Times, ingust 15, 1898. 
vested in the ordinary; and any of the said forms of service may be used with or without a sermon, lecture, or homily (sect. 5). A sermon or lecture may be preached without a previous Prayer Book Service, but, if so, it must be preceded by a service authorized by the Act, or by a bidding prayer (see p. 309), or by a Prayer Book Collect, with or without the Lord's Prayer (sect. 6). An additional form of service varying from any Prayer Book forn may be used at any hour, on any Sunday or Holy Day, in any cathedral or church in which the Morning and Evening Prayer, the Litany, and the ante-Communion Service are duly read at some other hour or hours, so that there be not introduced into such additional service any portion of the Communion Service, or anything (except anthems or hymns) which does not form part of the Holy Scriptures or Prayer Book, and so that such form of service, and the mode in which it is used, is for the time being approved by the ordinary; provided that nothing in this section shall affect the use of any portion of the Prayer Book as otherwise authorized by the Act of Uniformity or this Act (sect. 4).'-Whitehead's 'Church Law,' 3rd edition, pp. 258-259.

Alterations have also been made by Statute in the Calendar and in the Table of Lessons. 

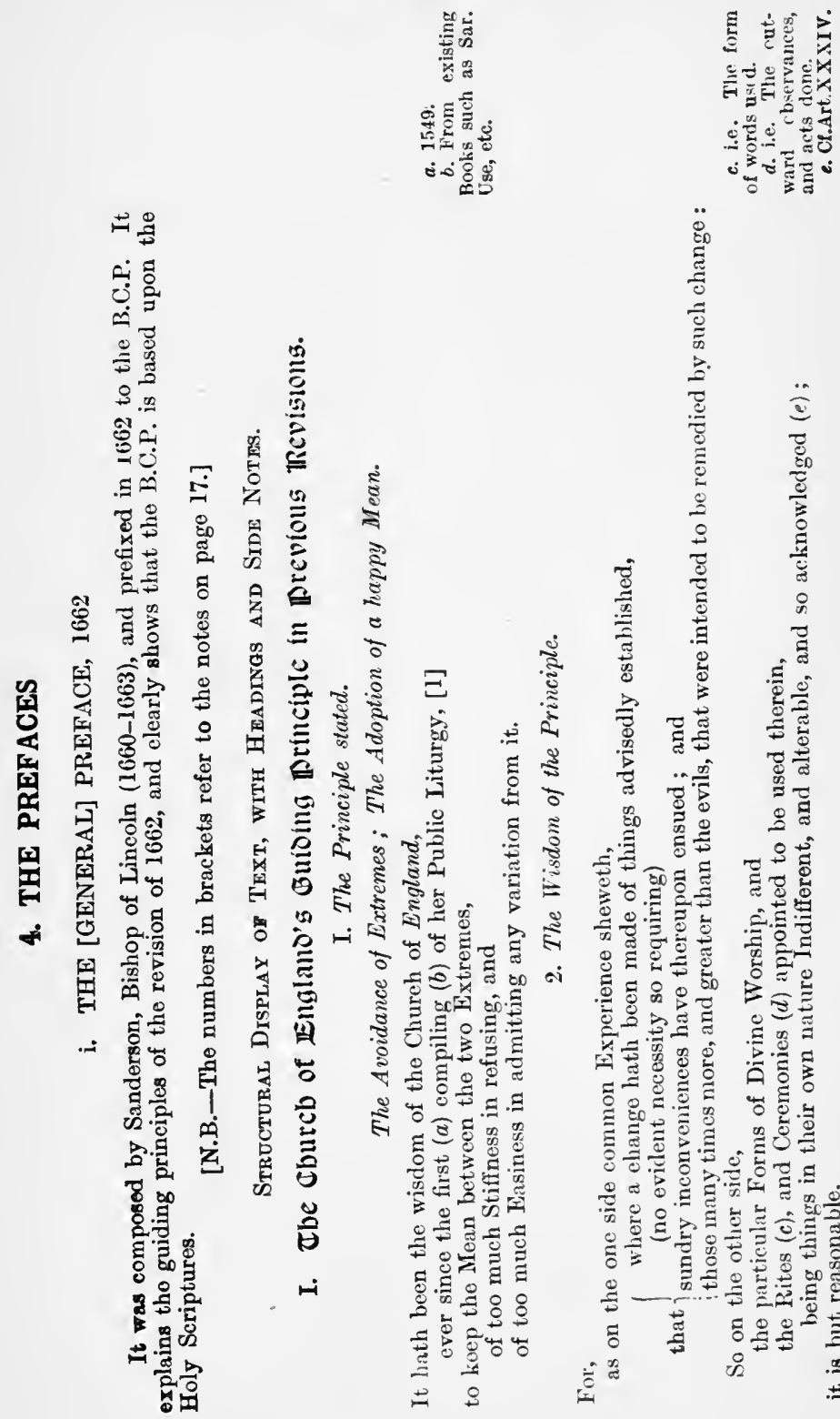

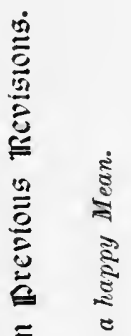

ֻٕ:

$\equiv$

:

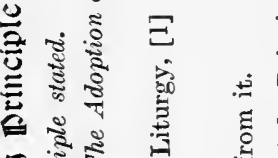

Q चूँ

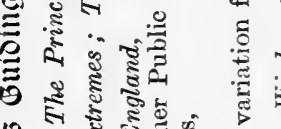

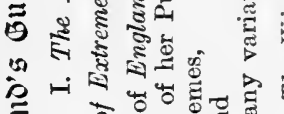

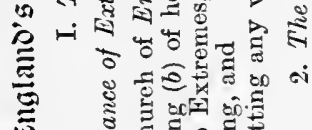

म

\%

०

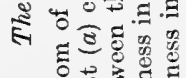

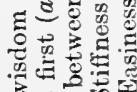

合

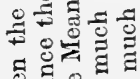

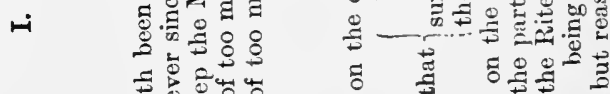

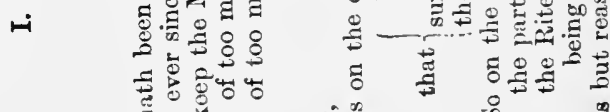

$\pm$

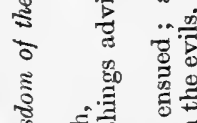

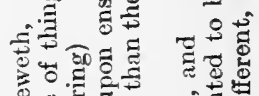

0.

¿ 형유

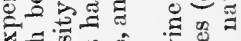

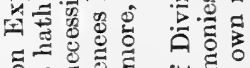

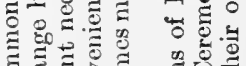

हี

\%

क⿺辶大

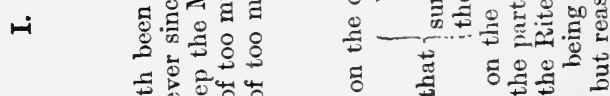

हैं की 

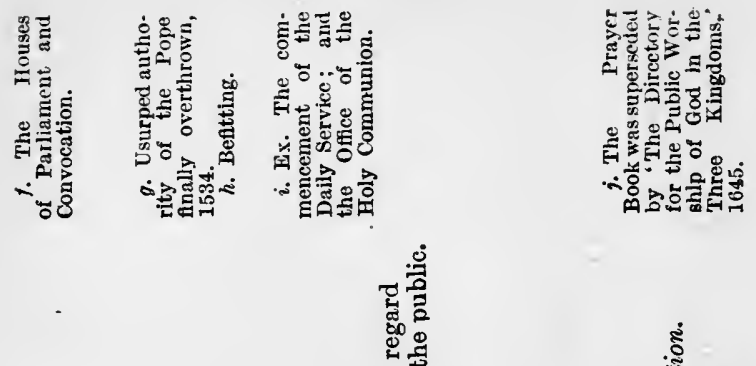

\pm .

要这

है

$=\frac{8}{2} \quad$ कृ

$\stackrel{9}{\circledR}$

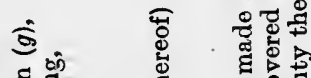

言 离

造

焉点点

总蓎

\&

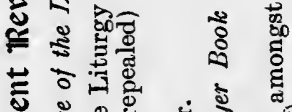

.

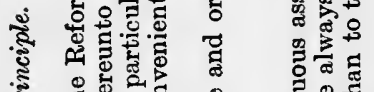

จ

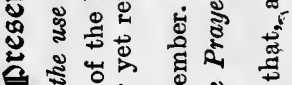

总

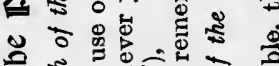

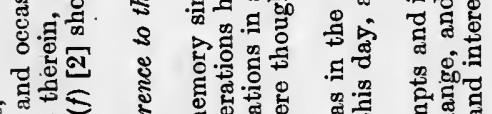

के

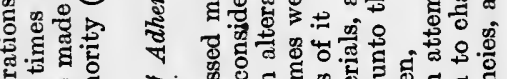

4웡

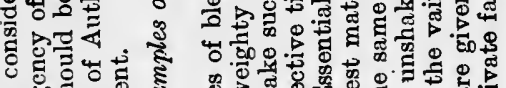

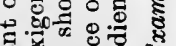

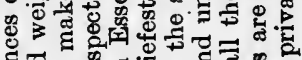

跣

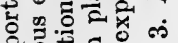

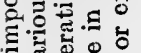

政焉它

है.

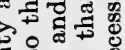

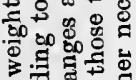

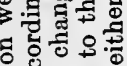

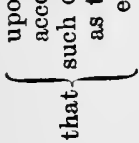

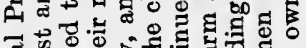

들.

5.

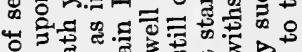

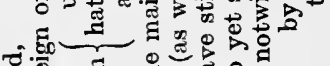

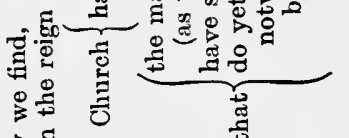

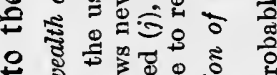

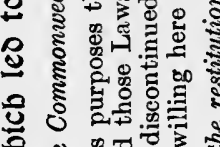

त्ำ

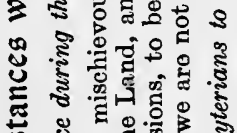

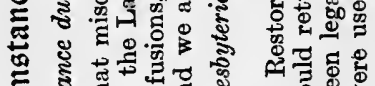

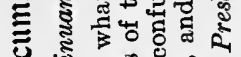

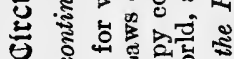

O

ปิ

(口)

获

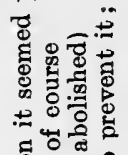

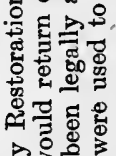

cis

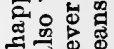

氙

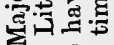

๑. 연 है

를요욜

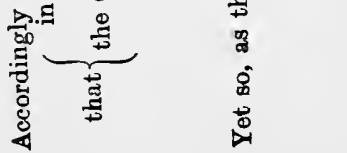

a

政政

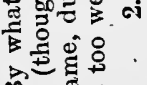

뎡 넝

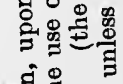

형 


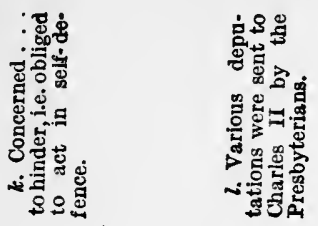

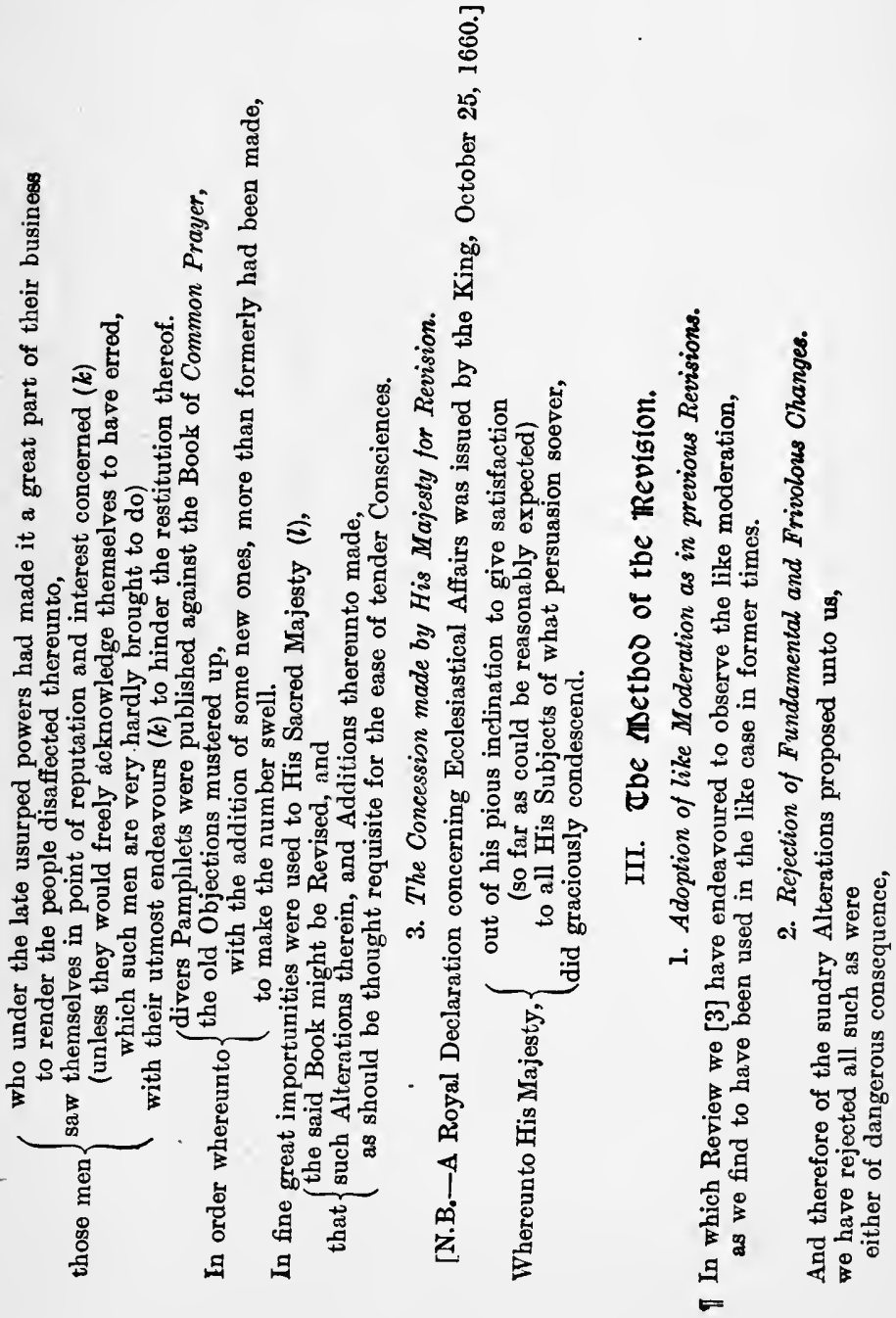




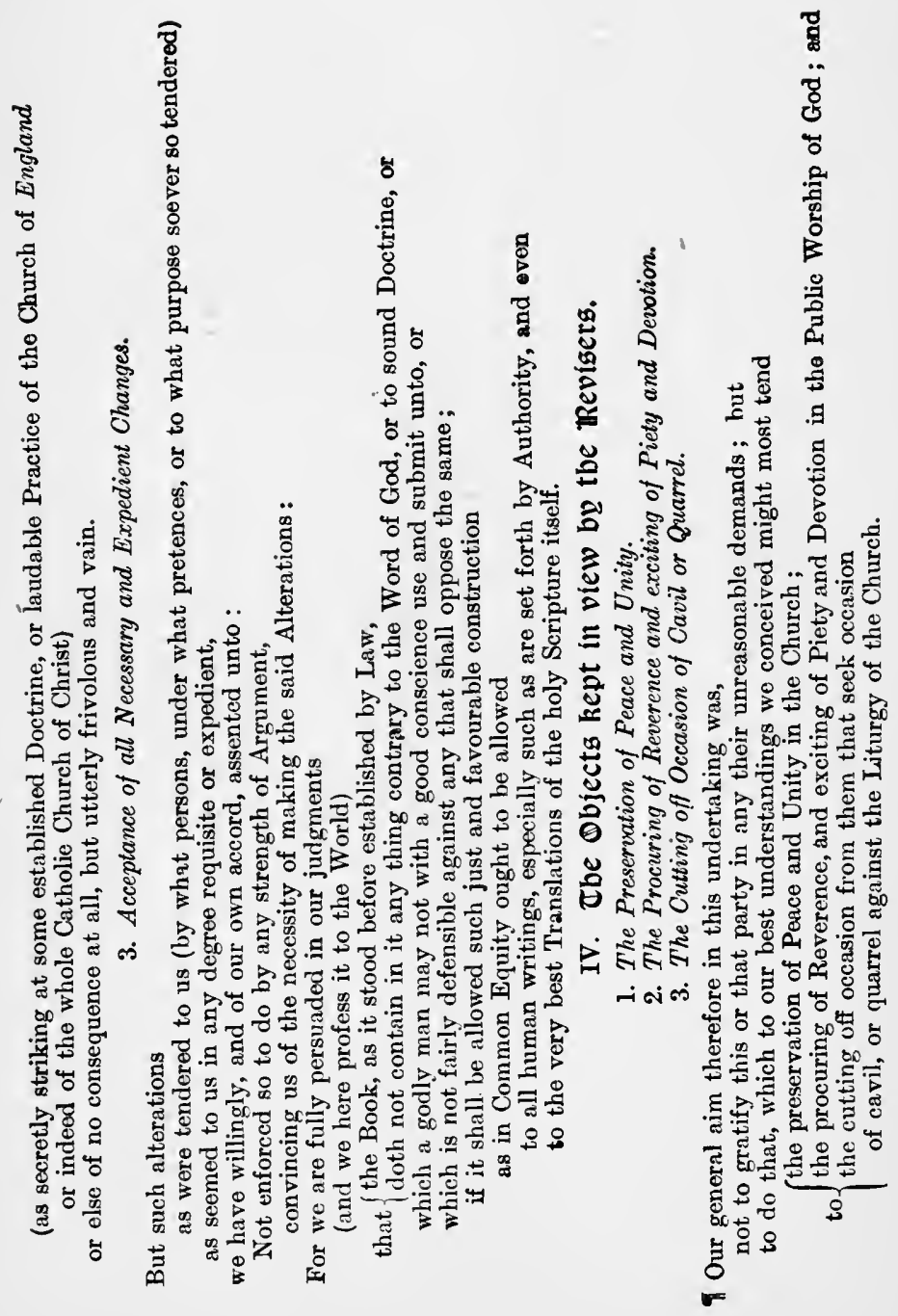




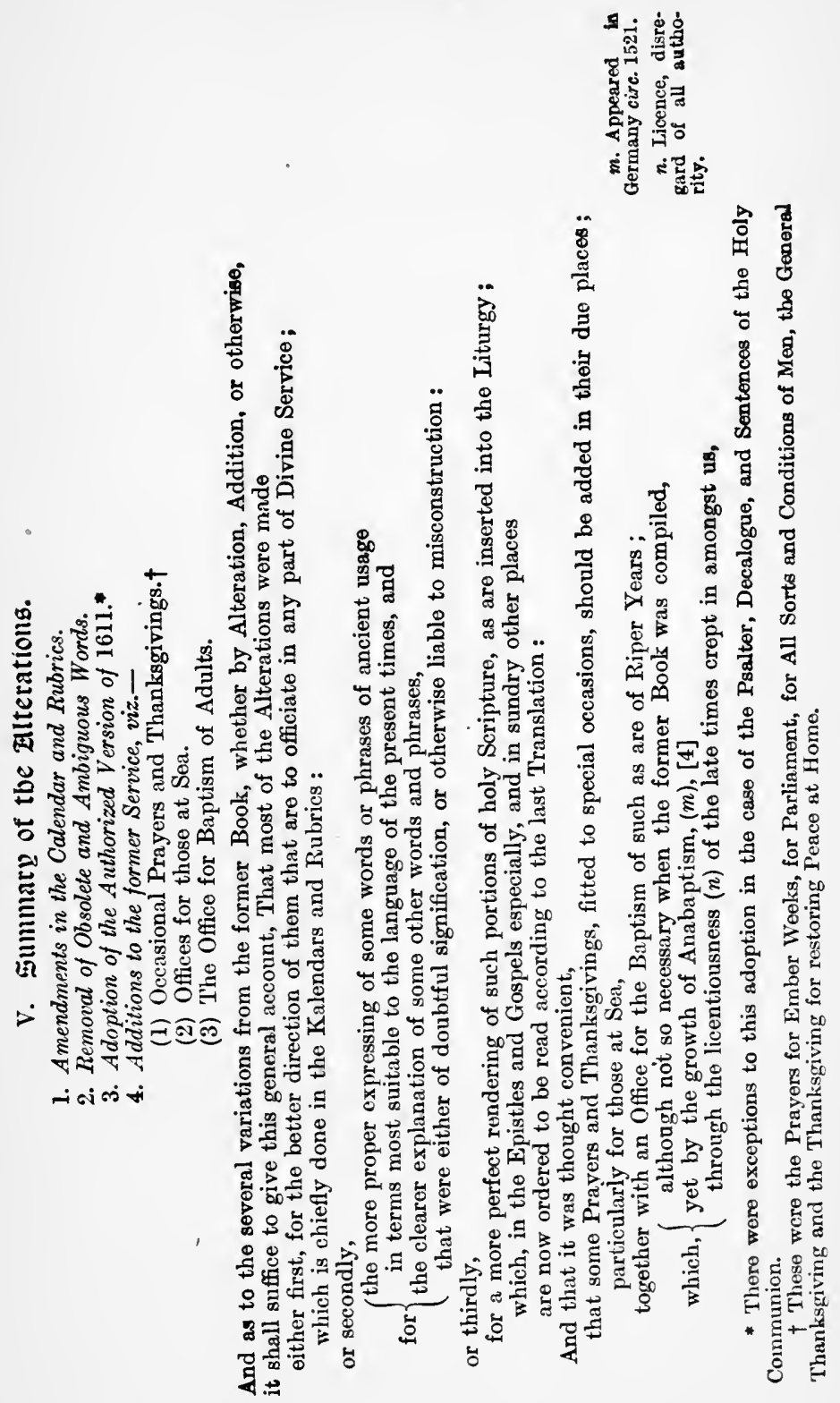




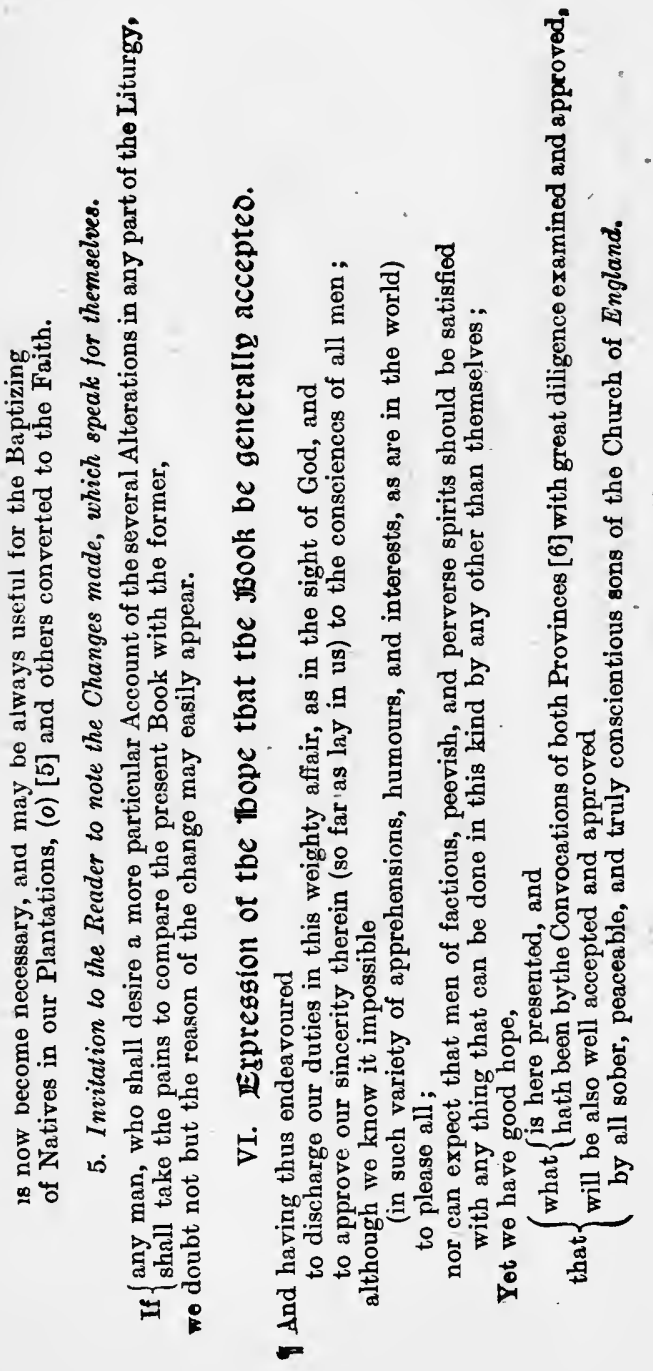


NOTES.

\section{Paragraph 1 .}

The first complling of her publick Liturgy [1]. This refers to the first Prayer Book of Edward VI., 1549. Before this the Church of England as a whole had no public liturgy, for different dioceses had different 'Uses,' e.g., those of Hereford, Bangor, Lincoln, York and Sarum. The word 'Liturgy' is here applied to the whole Prayer Book. It is technically used by ecclesiastical writers for the office of the Holy Communion only.

Those that are in place of Authority [2]. The work of revision was accomplished by a Committee of Members of Convocation, and then the result was submitted to Conrocation. When it was approved, it was submitted to Parliament and the King.

\section{Paragraph III.}

We [3] : i.e., the Committee of eight Bishops appointed by the Upper House of Convocation after the Savoy Conference to revise the Book-Cosin of Durham, Henchman of Salisbury, Morley of Worcester, Nicholson of Gloucester, Sanderson of Lincoln, Skinner of Oxford, Warner of Rochester, and Wren of Ely.

Paragraph IV.

Anabaptism [4]: i.e., the belief of those who deny the validity of Infant Baptism. The sect of Anabaptists originated in Germany and was introduced into England early in the sixteenth century, but their tenets embraced many things besides what is here meant by 'Anabaptism.'

During the period of the Commonwealth there was much neglect of the rite of Baptism and a large number of adults were unbaptized.

In our Plantations [5]: i.e., Colonies. During the latter half of the seventeenth century England's possessions in the Western Hemisphere rapidly increased. Old colonies were developed and new ones established, e.g., Virginia, Jamaica, the Carolinas, etc. This reference is one of the earliest indications of the Church of England realizing her possibilities as a Missionary Church.

\section{Paragraph $V$.}

The Convocations of both Provinces [6]. The Prayer Book of 1662 (which is the only one binding on the Church of England) received the fullest sanction the Church could give. The Book was sub. mitted to the Convocations of both Provinces-representatives of the Convocation of York sitting with the Convocation of Canterbury. 
竞

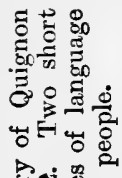

密过

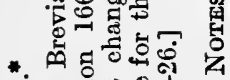

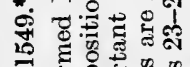

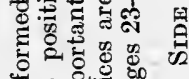

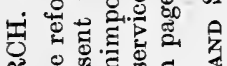

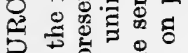

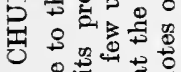

$\rightarrow$ 율열

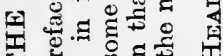

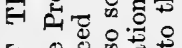

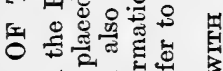

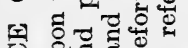

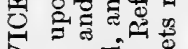

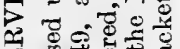

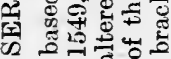

$\rightarrow$ 들눙 늉

ज्ञ

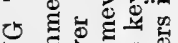

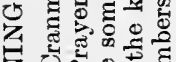

艺出。方苔

ㄱㅇㅇㅇㅇㅛ

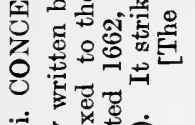

$\therefore$ :
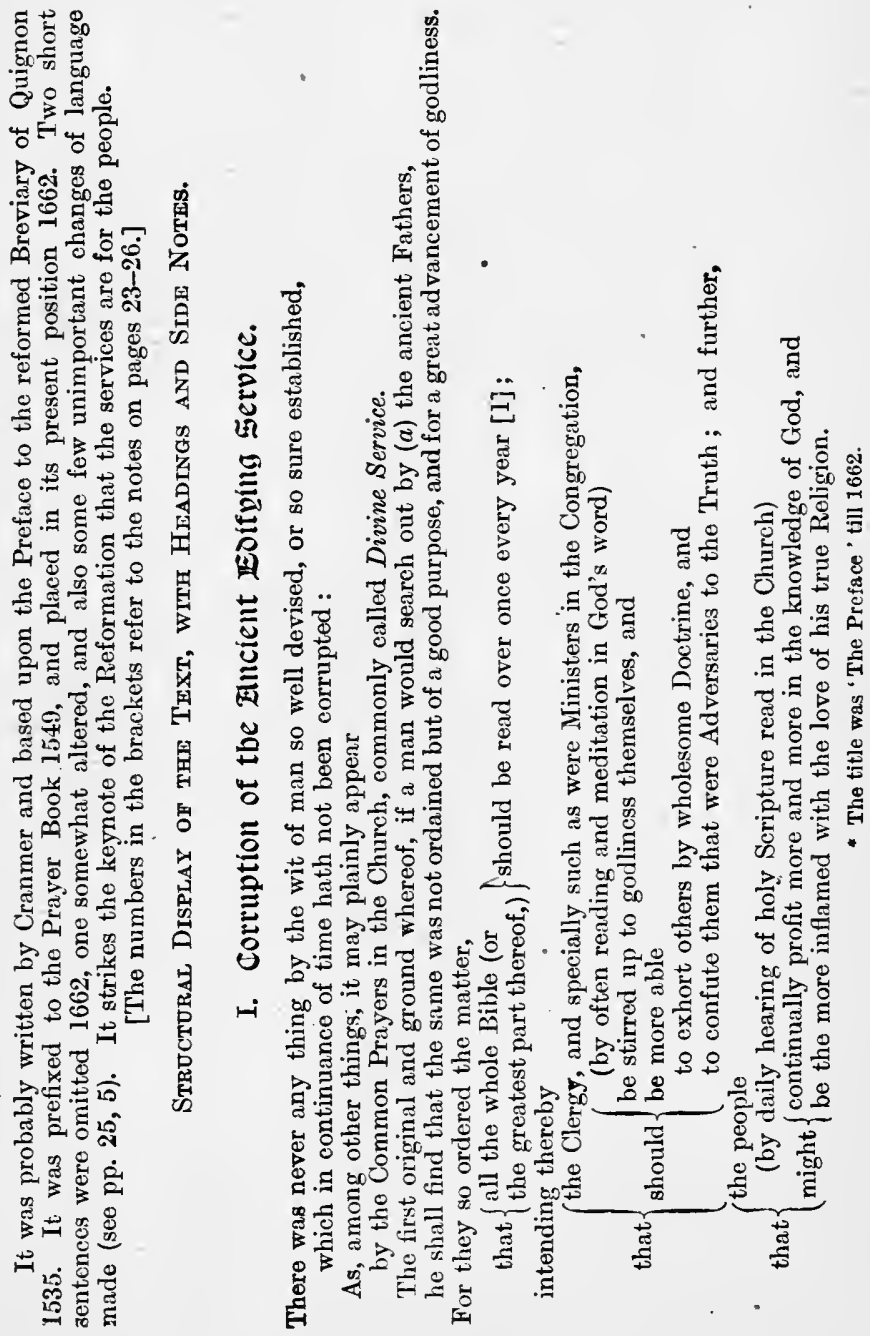

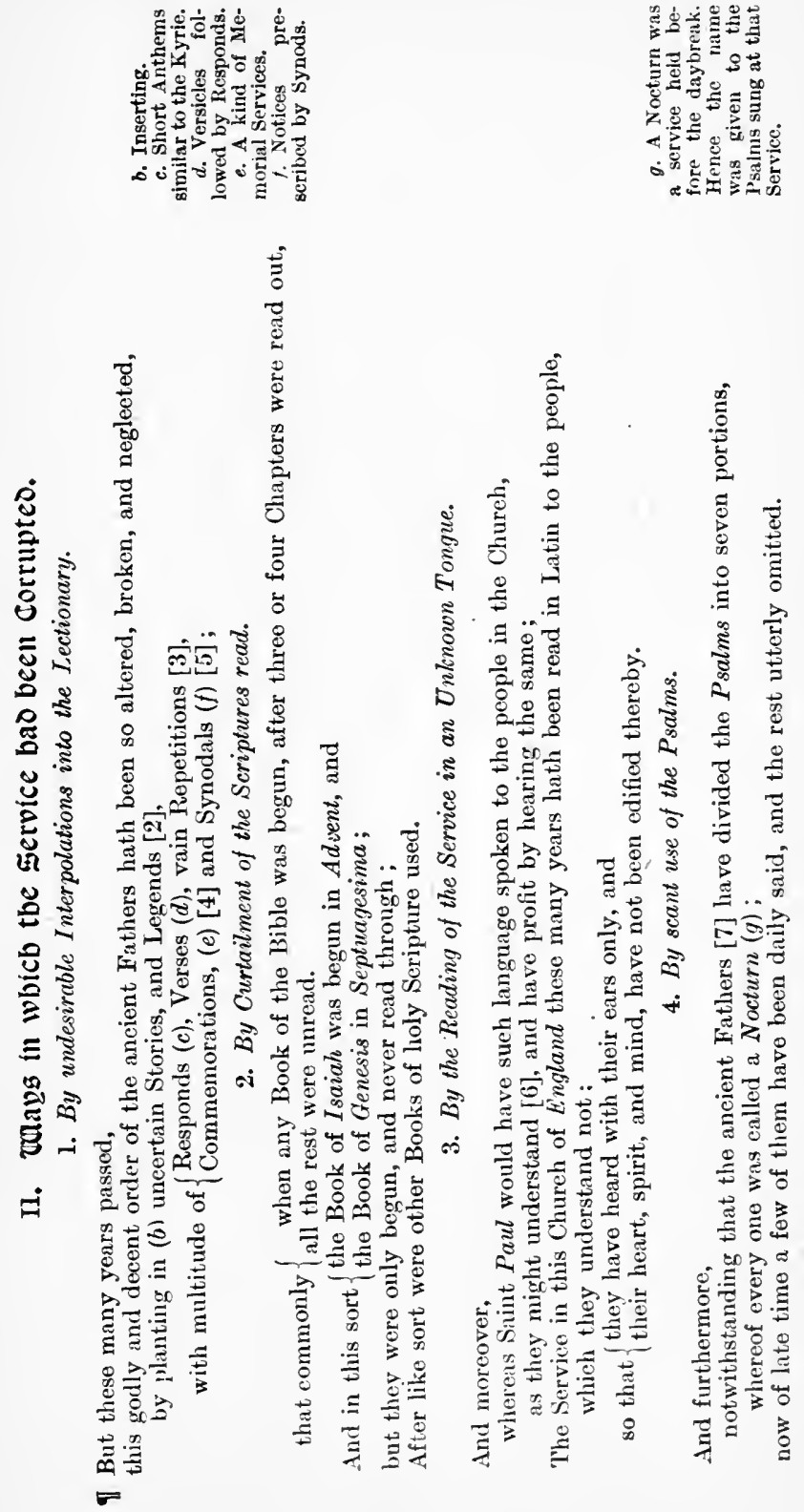


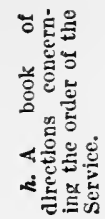

:

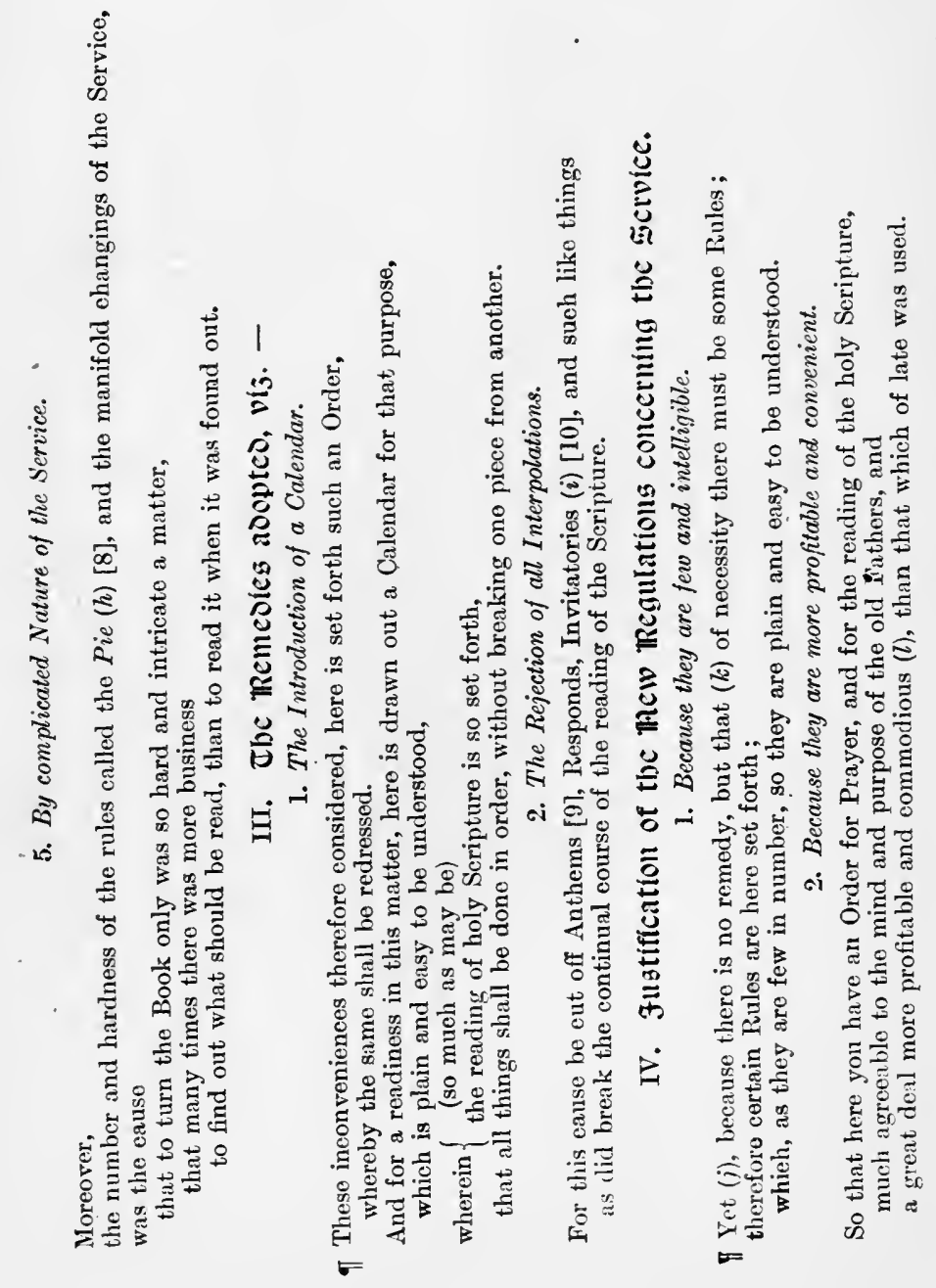

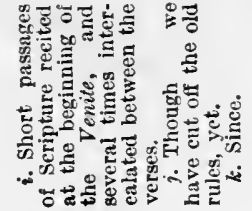

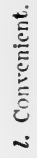




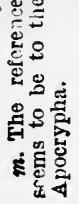

สี

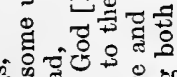
som.

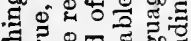

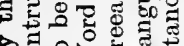

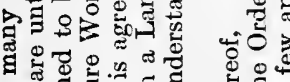

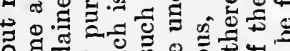

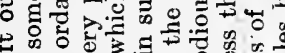

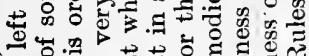

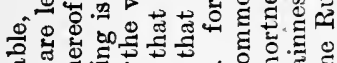

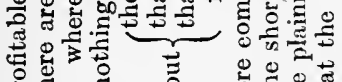

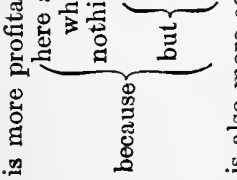

出

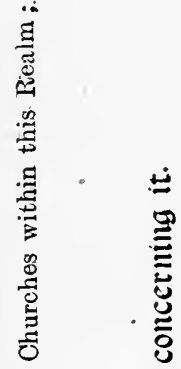

-

잉 훙해

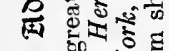

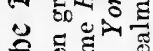

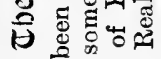

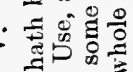
을 (5) sin 응

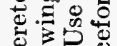

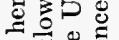

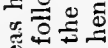

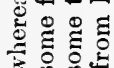
总壳总

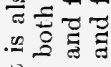
出

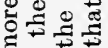
品 竞 葛 言 萨 要 iौ 형 œ 密

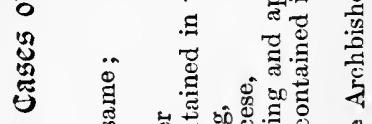
三 范

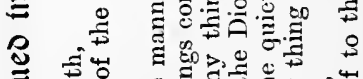

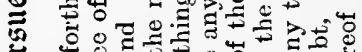
ㄴ. 2.

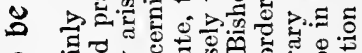

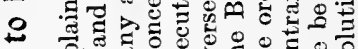

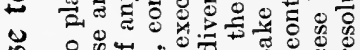
品 可 동.s 日. L o

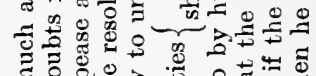

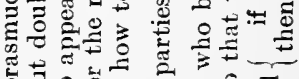

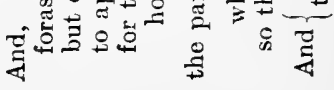




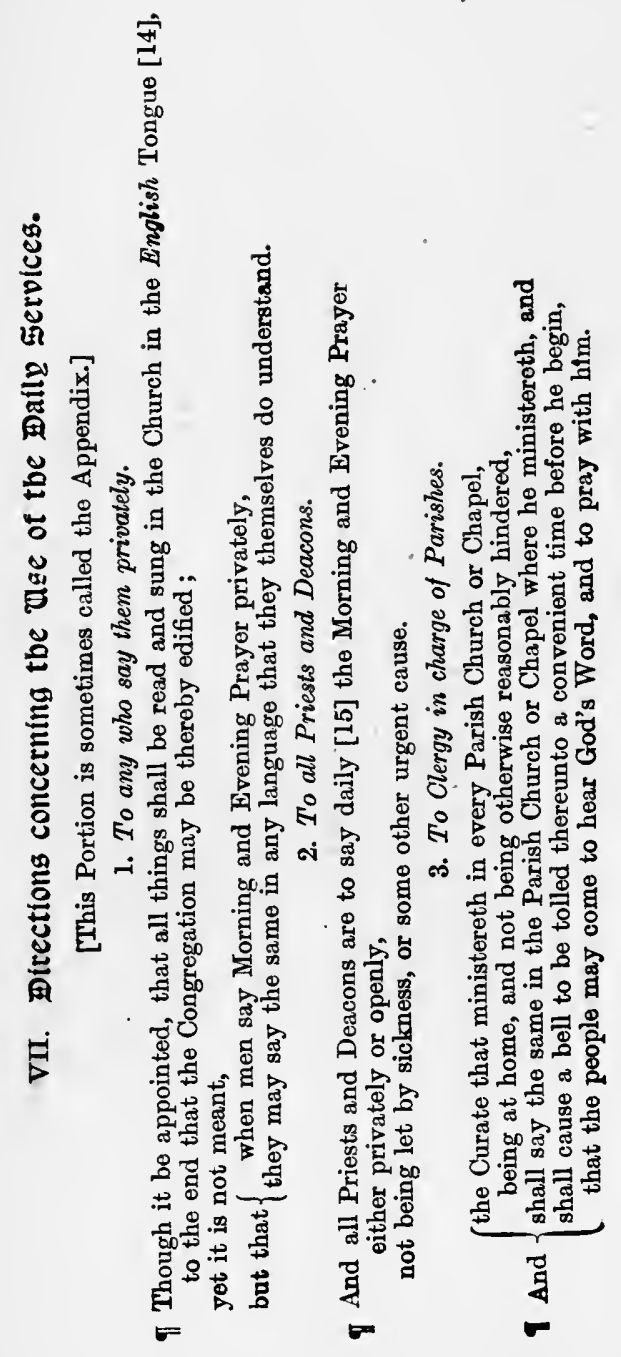




\section{NOTES.}

Paragraph $I$.

They so ordered ... that all the whole Bible (or the greatest part thereof) should be read over once every year [1].

This refers to the primitive arrangement for the reading of the Scriptures. The Lessons were not definitely appointed, but the books to be read were assigned to different parts of the year.

To Cassian, who founded two monasteries in Marseilles (ob. circ. 440 A.D.), the introduction of a regular system of daily Lessons is probably due (cf. Burbidge, 'Liturgies and Offices of the Church,' p. 119).

\section{Paragraph $I I$.}

Planting in uncertain Stories, and Legends [2]: i.e. by reading spurious 'Acts of Saints and Martyrs.' 'Proper Lessons, which were not commonly taken from Holy Scripture, were provided for so many saints' days, that the ordinary course of the Sunday and week-day Lessons must have been continually interrupted' (Burbidge, p. 127, note 2).

Responds, Verses, vain Repetitions [3]. These Responds were complicated repetitions of words which referred to the contents of the Lesson and were supposed to give the keynote of the Lection. Verses were versicles following the Responds; and the "vain Repetitions' refer to the words of the Lesson being repeated again in the Respond and in the Verse. For example, on Advent Sunday the First Lesson was Isa. i. 1, 2; the reader adding, "Thus saith the Lord God, Turn ye unto Me, and ye shall be saved.' 'This was followed by a Respond, ' Looking from afar, bchold I see the power of God coming, and a cloud covering the whole carth. Go to meet Him and say, Tell us if thou art He who shall rule 'Thy people Israel.' Then various verses were said, and parts of the respond were repeated, concluding with the Gloria. Then followed Isa. i. 3, 4, with another respond and verse (cf. Brev. Sar. fol. ii, 'The Matin Offices ').

Commemorations [4]: i.e., the forms of service commemorating the Virgin, or those in honour of local saints, which were introduced into other festal or non-festal services.

Synodals [5] : i.e. Canons of Synods, or notices of special festivals prescribed by a provincial or diocesan synod, read after the Lessons.

The Service in this Church of England these many years hath been read in Latin to the people, which they understand not [6]. The earliest Liturgical Services of the Western Church were in Greek, but as Latin became the common language the Services were translated into it. During the Middle Ages there seems to have been little or no attempt to give the people a service in their own tongue. It was not until the sixtcenth century that the need of the Services in the vernacular was attempted to be met (ef. Hermann's 'Con.' in German, 1543). The phrase 'this Church of England these many years' well proves that the Reformers viewed their work as the reforming of the Old Church of England, and not the founding of a new one. 
The ancient Fathers have divided the Psalms into seven portions, whereof every one was called a Nocturn [7].

'Nocturn' was originally the name of a night service, but it became applied later to the portions of Psalms read at that time. Probably here the word covers the whole of the Psalms for both Mattins and Vespers.

The Psalms were divided among the daily Hour Services. 'Those for Prime, Tierce, Sext, Nones and Compline were all fixed, i.e. the same Psalms were used at these hours. Those for Mattins, Lauds and Vespers were read in course' (E. Daniel).

This system was, however, never adhered to in detail. There were many interruptions through the occurrence of festivals and the general practice (outside Monastic houses) of combining the eight Hour Services into three, completely broke up the order of reading on ordinary days.

\section{The number and hardness of the rules called the Pie [8].}

The Pie (Latin pica, 'a magpie,' and hence applied to the largc black letters at the beginning of a fresh order) was a book which contained the order of the service of the day.

The Responds and Verses varied from day to day, and the service raried according to the relative importance of Saints' Days. Thus it came about 'that to turn the Book only was so hard and intricate a matter, that many times there was more business to find out what should be read, than to read it when it was found out.'

\section{Paragraph III.}

Anthems [9] or Antiphons, were originally Psalms or hymns recited by alternate voiccs. Later they became largcly mutilated by the reduction of the Psalm to a single verse with or without a Gloria or with a refrain. They were sung before and after the Canticles of the Daily Services to emphasize the teaching of the day or season (see Burbidge, 'Liturgies and Offices of tho Church,' p. 130, footnote 4).

Invitatories [10] were verses introduced before the Venite and repeated in whole or part after every few verses.

\section{Paragraph IV.}

Nothing is ordained to be read, but the very pure Word of God, the holy Scriptures, or that which is agreeable to the same [11].

The phrase "that which is agreeable to the same' probably applies to the Apocrypha which was largely read according to the rules of the Calendar of 1549. (For the use of the Apocrypha, cf. Art. VI, and Hooker, 'Eccles. Pol.' Bk. V, ch. 20.)

Few and easy [12]. After these words in the Prayer Book of 1549. the following sentence occurred : "Furthermore, by this order, the Curates shall need none other books for their public service, but this book and the Bible; by the means whereof, the people shall not be at so great charge for books, as in time past they have been:' It was expunged in 1662 .

\section{Paragraph V.}

All the whole Realm shall have but one Use [13].

Prior to the Reformation the Uses were varied. Besides those mentioned in this paragraph there were special Uses at Lichfield, Exeter, Wells, St. Asaph, St. Paul's, etc. 
Attempts were made from time to time to secure greater uniformity, e.g. St. Paul's Use was ordered to be discontinued in 1415, and the Sarum Use replaced those of Exeter and Wells. The introduction of printing tended to produce uniformity, for many editions of the Sarum Breviary and Missal were issued in the early part of the sixteenth century. In 1542 the Convocation of Canterbury ordered the Sarum Use to be employed throughout the whole of the Southern Province.

After the words 'one Use' in the Prayer Book of 1549 there was inserted the following paragraph. "And if any would judge this way more painful, because that all things must be read upon the book, whereas before by the reason of so often repetition, they could say many things by heart; if those men will weigh their labour with the profit and knowledge, which daily they shall obtain by reading upon the book, they will not refuse the pain, in consideration of the great profit that shall ensue thereof.' This was omitted in 1662.

\section{The Appendix.}

1. In the English Tongue [14]. For the edification of the congrega tion the vernacular must be used in public worship. In private devotion men may use any language they understand.

The Act of Uniformity of 1662 allows the use of Latin at colleges of the universities, and those of Westminster, Winchester, and Eton, and in the Convocations of the Clergy. It also orders the Bishops of Hereford, St. David's, St. Asaph, Bangor, and Llandaff, to see that the Book be truly and accurately translated into Welsh.

\section{All Priests and Deacons are to say daily the Morning and Evening Prayer, etc. [15].}

The two concluding paragraphs relating to the daily use of Morning and Evening Prayer take the place of one paragraph in 1549 , which limited rather than enforced that use: "Neither that any man sliall be bound to the saying of them, but such as from time to time, in Cathedral and Collegiate Churches, Parish Churches, and Chapels to the same annexed, shall serve the congregation.' This concession to the predilections of those who re. garded the Prayer Book as new-fangled in 1549 was removed in 1552, the present directions being substituted. All Priests and Deacons, Bishop; being curiously excepted, were now enjoined to say the services daily, either publicly or privately, parish clergy being compelled to their public use. Exception was expressly allowed for 'preaching, studying of divinity, or some other urgent cause,' in the case of clergy generally: while parish clergy were allowed to forego public use if absent from home, 'or otherwise reasonably letted.' In 1662 the mention of 'preaching' and 'studying of divinity' was excluded, 'sickness' being substituted. The quaint direction to the Curate to toll the bell was also altered to "cause a bell to be tolled.'

In regard to the practical interpretaticn of the corditions attached to this regulation, there is some difference of opinion. The substitution of a compulsory cause like 'sickness' for the expedient causes 'prcaching' and 'study,' is thought to point to a greater stringency. On the otlicr hand, the S.L. of 1637, which was before the Revisers in 1662 , mentioned no exceptions at all, and made the Bishop or Archbishop the 'Judge and Allower' if the ' urgent cause' was ' frequently pretended.' This example was not followed in 1662 , and therefore the individual is left to judge for himself, both with regard to the public and private use, whether there is urgent cause to pretermit the daily morning and evening service. To try to define that 
which has been deliberately left undefined, is an unwarrantable intrusion into the domain of private judgment ; it may, however, be pointed out that the changes since the rule was made have contributed ' urgent causes' which are none the less urgent that they could not have been in the minds of the Revisers-(1) the impossibility in many parishes of the people coming to public worship: (2) the provision, through the great development of parochial organizations, of other and more convenient opportunities of zommon prayer: (3) the progress of education which allows of private reading and prayer to an extent undreamed of in 1662 . In regard to the ministerial aspect of the question, moreover, it must be added that the far greater demands made upon the time of the 'Curate,' the result of a far higher conception of the responsibilities of his office, both in regard to mental equipment, and the actual cure of souls, together with the enormously increased range of thought to dictate to him the nature and extent of his private devotions, must tend to multiply the causes which, upon the strongest and most spiritual grounds, should be deemed ' urgent.'

' It is manifest that as the conditions of life to-day are so vastly different from those of the sixteenth century, it is impossible to observe this rule universally, throughout all the parishes of the land. Not only is life infinitely more hurried and fuller of engagements, but Church life is entirely different in its multiplicity of meetings and opportunities for united gatherings for prayer and work. The latter fact should be ever borne in mind. The consequence is, that even where Daily Prayer is the rule there are very few Churches where both Morning and Evening Prayers are said, and even in these, moreover, the relaxation afforded by the Act of Uniformity Amendment Act of 1872 is utilized, whereby the shortened Form is used. The matter is clearly one which will depend entirely on local and congregational circumstances, and the "reasonable hindrance" must be left to the conscience and decision of the clergyman in charge. In a 1 ubric, the obser vance of which is essentially connected with such changes and even trans. formations of conditions as obtain to-day, compared with the sixteenth century, the clergy and people cannot fairly be called disloyal to the Prayer Book, if for any personal or Iocal reasons Daily Prayer in Church is found impracticable. At the same time, it is impossible to ovcr-estimate the spiritual blessing to a parish where minister and people meet day by day for praise and prayer and intercession.'- 'The Catholic Faith,' W. H. Griffith Thomas, pp. 241, 242.

'From the wording of the directions, the order about Daily Prayer in the Church is clearly associated with the gatherirg of a congregation. The idea is not that of solitary prayers by the clergy, but the union of pastor and people in Daily Prayer. He is to "cause a bell to be tolled thereunto a convenient time before: e begin, that the people may come to hear God's Word and to pray with him"'(ibid., p. 241). 


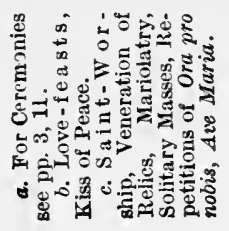

:
$\frac{8}{2}$
$\dot{8}$
$\dot{0}$

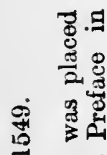

ค. 롫

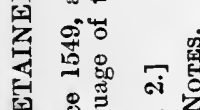

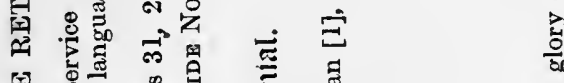

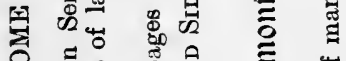

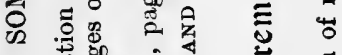

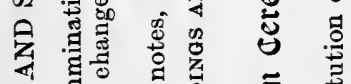

吾 苦营

คิ

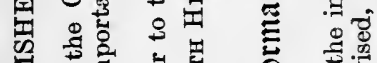

兽.

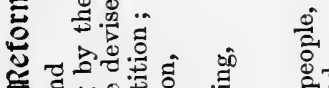

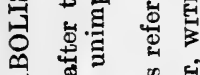

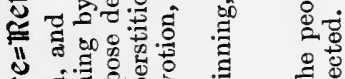

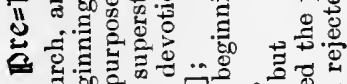

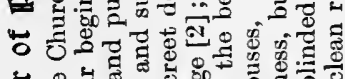

될 吉豆

४

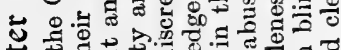

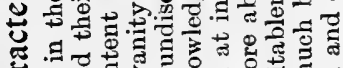

넌 형

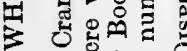

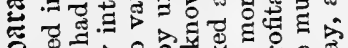

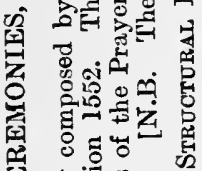

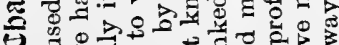

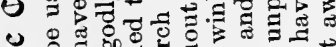

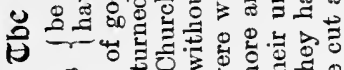

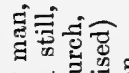

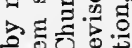

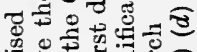

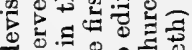

ช

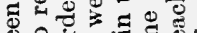

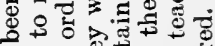

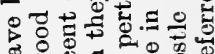

品

क 0 万ठ

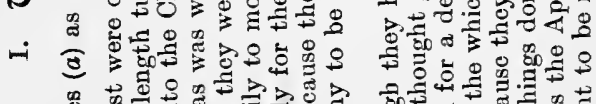

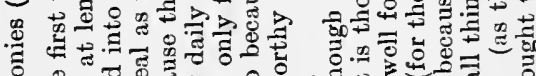

ชิ

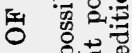

: अ अ के

कै

出驾

모

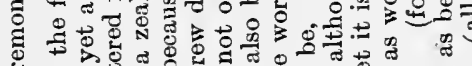

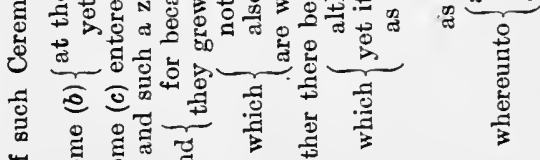


5
मे
$\dot{8}$
$\dot{8}$

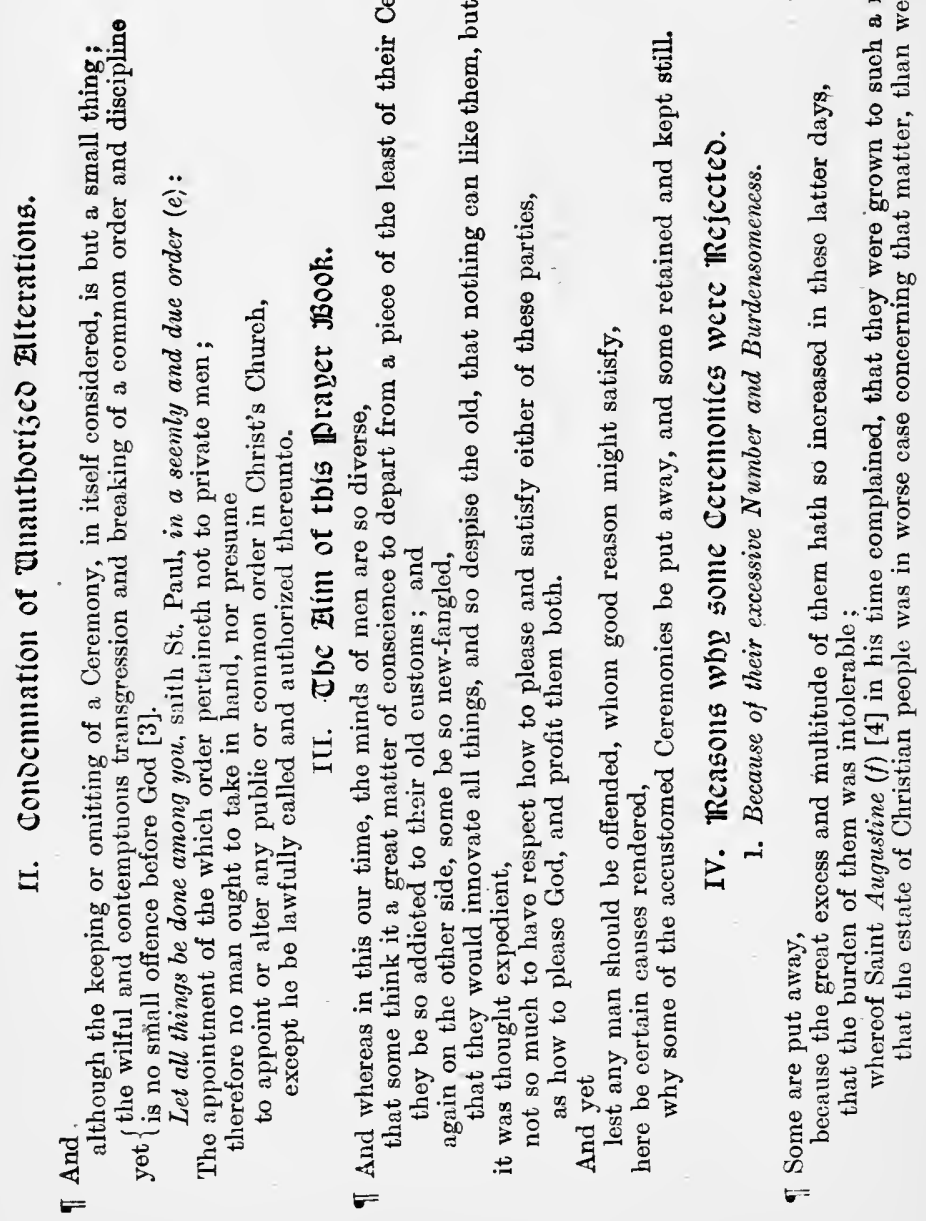


OF CEREMONIES

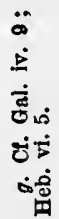

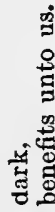

¿ृ

章

苞

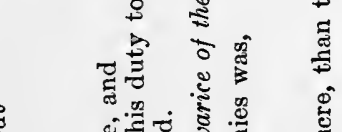

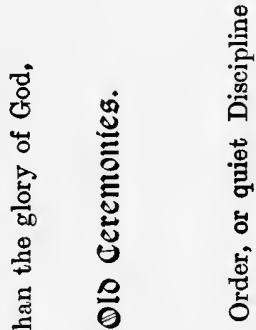

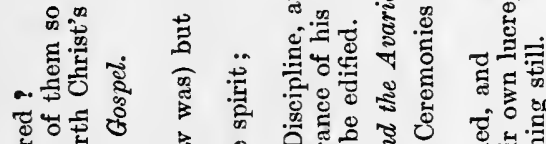

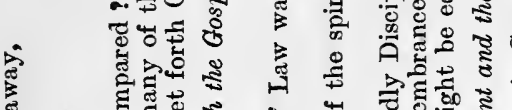

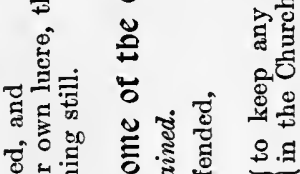

욜 䨠

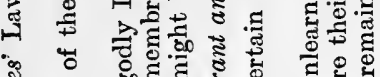

ॐ

$\checkmark$ \&

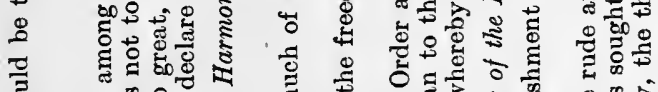

兽

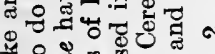

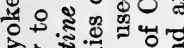

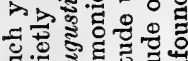
施 돈 ำ

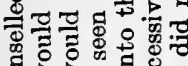
咅 \&. g.

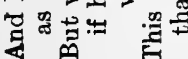

吕吉

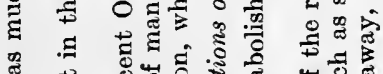

ङ

क्)

उ

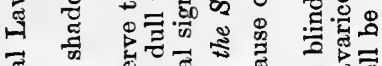

.

घี

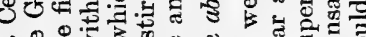

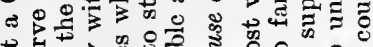

ㄴㅇㅁ

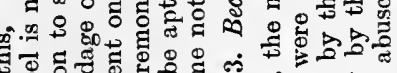

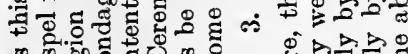

उक क०

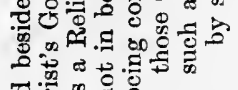

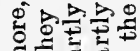

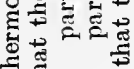

เ

ᄂ

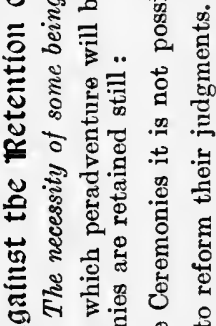

ㄴ.

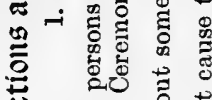

ठ

U

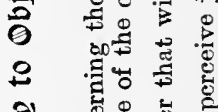

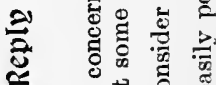

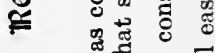

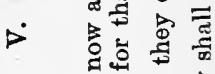

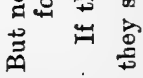




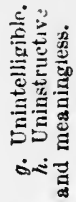
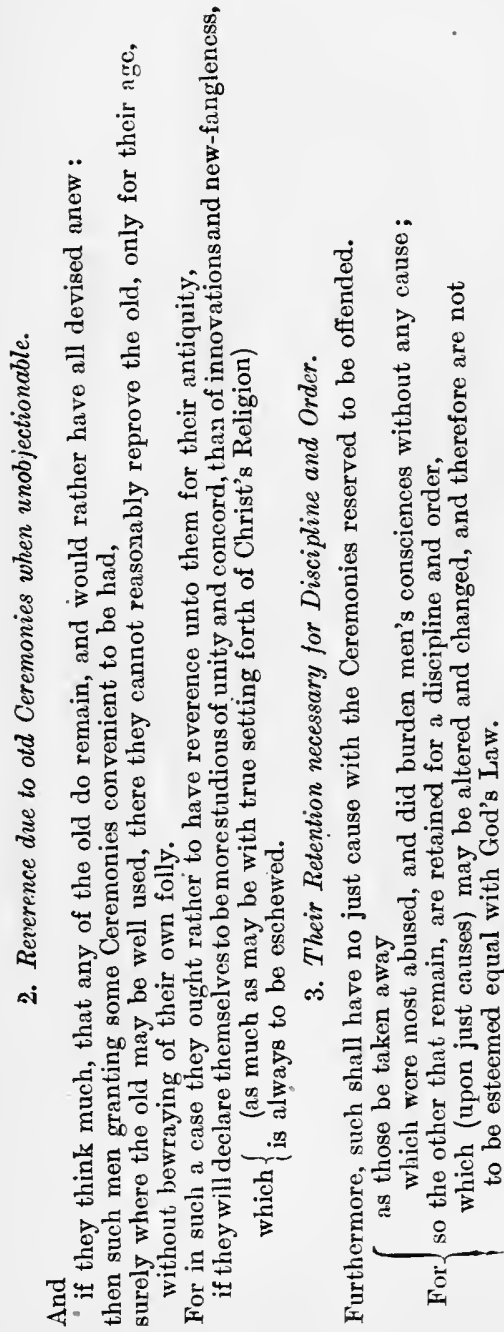

ฐ

ญू =

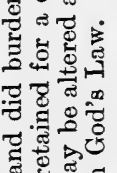

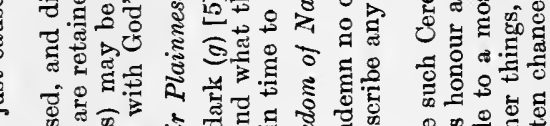

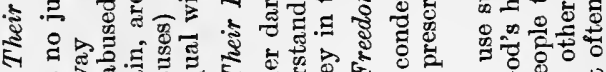
O

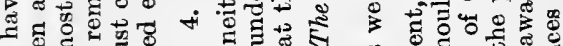

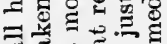

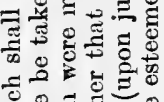

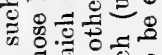
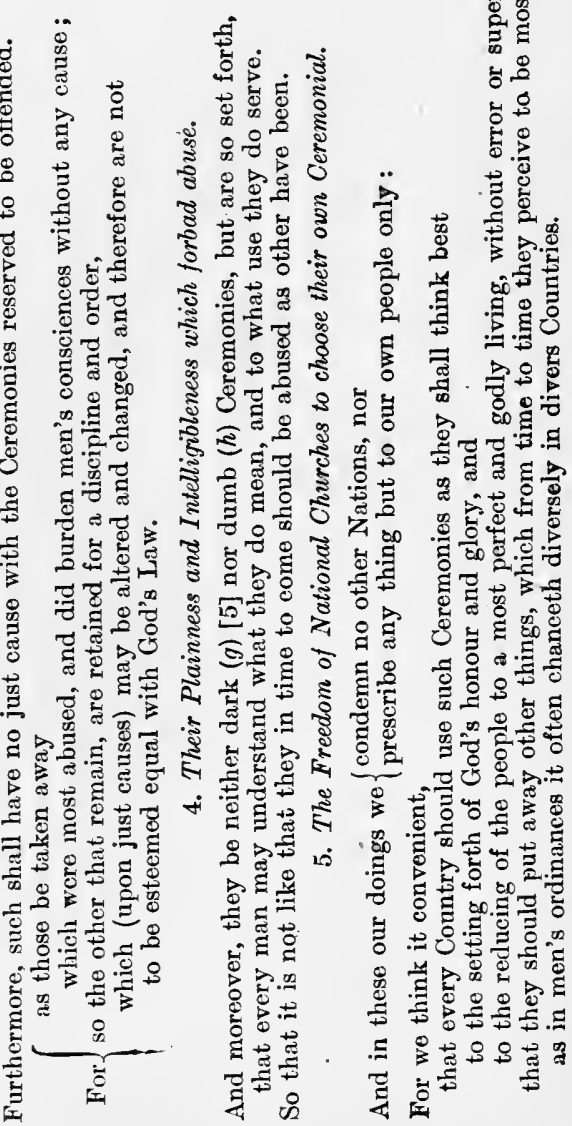


\section{NOTES.}

Paragraph I.

Such Ceremonles as be used in the Church, and have kad their beginning by the institution of man [1].

The Reformers drew a very strong line of distinction between ceremonies derived from the Bible, e.g. use of water in Baptism, and bread and wine in Holy Communion, and those introduced on man's authority, e.g. making the sign of the Cross, and kneeling to receive the elements.

The word 'Ceremony' is here quoted in the same sense as in the Title of the Prayer Book; it includes all the actions used in the different Offices.

In the Mediæval Service Books, and even in the English Prayer Book of 1549 , there were many ceremonies prescribed which were not retained in later revisions, e.g. exorcism and anointing in tho service of Baptism; tokens of spousage, gold or silver, given in Matrimony; a sick person was anointed on forehead or breast and the sign of the Cross made in the Visitation of the Sick; tho Churched woman was to offer her chrisom, etc.

By undiscreet devotion, and such a zeal as was without knowledge [2]. This is well illustrated by the introduction of images, the veneration of relics, and undue honouring of saints.

\section{Paragraph $I I$.}

The wilful and contemptuous transgression ... Is no small offence before God [3].

For the principles on which all Ceremonial ought to bo judged, cf. Hooker's 'Ecclesiastical Polity,' Book V, c. 6-10; and Art. XXXIV.

\section{Paragraph $I V$.}

Saint Augustine in his time complained [4]. The reference is to Augus. tine's 'Epis. 65 ad Januarium,' cap. xix. 35: 'I cannot, however, sanction with my approbation those ceremonies which are departures from the custom of the Church, and are instituted on the pretext of being symbolical of some holy mystery; although, for tho sake of avoiding offence to the piety of some and the pugnacity of others, I do not venture to condemn severely many things of this kind. But this I deplore, and have too much occasion to do so, that comparatively little attention is paid to many of the most wholesome rites which Scripture has enjoined; and that so many false notions everywhere prevail, that more severe rebuke would be ad. ministered to a man who should touch the ground with his feet bare during the octaves (before his baptism) than to one who drowned his intellect in drunkenness. My opinion therefore is that, wherever it is possible, all those things should be abolished without hesitation, which neither have warrant in Holy Scripture nor are found to have been appointed by Councils of bishops, nor arc confirmed by the practice of the universal Church, but aro so infinitely various, according to the different customs of different places, that it is with difficulty, if at all, that the reasons which guided men in appointing them can be discovered. For even although nothing be found, perhaps, in which they are against the true faith, yet the Christian 
religion, which God in His mercy made free, appointing to her Sacraments very few in number, and very easily observed, is by these burdensome ceremonies so oppressed, that the condition of the Jewish Church itself is preferable: for although they have not known the time of their freedom, they are subjected to burdens imposed by the Law of God, not by the vain conceits of men. The Church of God, however, being imeanwhile so constituted as to enclose much chaff and many tares, bears with many things; yet if anything be contrary to the faith or to holy life, she does not approve of it either by silence or by practice.'s

Paragraph $\mathrm{V}$.

Neither dark nor dumb Ceremonies [5]. 'The tenor of the Common Prayer is openness' (Archbishop Benson).

\section{RULES CONCERNING PSALTER AND LECTIONARY.}

\section{i. The Order how the Psalter is appointed to be read.}

Prior to 1662 there was placed above this Order the following Headings :-

1549. The Table and Kalendar, expressing the Order of the Psalms and Lessons to be said at Matins and Evensong [the Morning and Evening prayer, 1552], throughout the year, except certain proper feasts, as the rules following more plainly declare.

Paragraph No. 1 .

1549. The Psalter shall be read through once every Month, and because that some Months be longer than some other be, it is thought good, to make them even by this means.

To every Month, as concerning this purpose, shall be appointed just $\mathrm{xxx}$ days.

And because January and March hath one day above the said number, and February, which is placed between them both, hath only xxxviij days, February shall borrow of either of the Months, (of January and March), one day, and so the Psalter, which shall be sad in February, must begin the last day of January, : 1 end the first day of March.

1662. The Psalter shall be read through onci every Month, as it is there appointed, both for Morning and Evening Prayer. But in February it shall be read only to the twenty-eighth or twenty-ninth day of the Month.

Paragraph No. 2. Prior to 1662 the following clause stood at the end of this Paragraph: 'Now to know what Psalms shall be read every day, look in the Calendar the number 
that is appointed for the Psalms, and then find the same number in this Table, and upon that number shall you see what Psalms shall be said at Matins and Evensong [at Morning and Evening Prayer, 1552].'

Paragraph No. 3. Prior to 1662 the following clause stood at the end of it: 'As you shall perceive to be noted in this Table' ['following' added 1552].

Paragraph No. 4, 5 together with the Doxology added 1662.

Paragraph No. 5.

1549. And here is also to be noted, that in this Table, and in all other parts of the Service, where any Psalms are appointed, the number is expressed after the Great English Bible, which from the ix. Psalm unto the cxlviij. Psalm (following the division of the Hebrews) doth vary in numbers from the common Latin translation.

1662. Note, that the Psalter followeth the division of the Hebrews, and the Translation of the great English Bible, set forth and used in the time of King Henry the Eighth, and Edward the Sixth.

Prior to 1662 there was here added the Table for the Order of the Psalms, to be said at Matins and Evensong [Morning and Evening Prayer, 1552].

In the Mediæval Church there existed elaborate arrangements of the Psalter for Divine Service. It was ordered to be read through once a week, but this was largely disregarded through festivals, etc.; consequently Cranmer devised an entirely new plan, viz. :-

To every month there were appointed thirty days, and the Psalms were divided into sets correspondingly. A clause in the next section provided that in Leap Year the Psalms for the twenty-fifth day were to be repeated on the twenty-sixth.

This, however, proved unworkable and was abandoned by the Revisers of 1662, who adopted the present arrangement, which is peculiar to the English Church.

The Psalter shall be read through once every month.

By the Act for the Amendment of the Act of Uniformity, 1872, it was enacted that-

(i) On all week-days-Christmas Day, Ash Wednesday, Good Friday, and Ascension Day excepted-a shortened form of Morning and Evening Prayer might be used in Parish Churches, and in this only one Psalm or one portion of the 119th Psalm need be read.

(ii) The Ordinary should have power to appoint 'Proper' Psalms to supersede the regular Psalms of the day on 
special occasions, or to be used at a third service on Sundays.

'At the end of every Psalm . . . shall be repeated this Hymn.'

The Gloria Patri is of ancient origin, for forms of it may be traced in the writings of Athanasius and Clement of Alexandria. The words, 'As it was in the beginning,' were added about the sixth century.

The American Prayer Book gives directions that the Gloria may be sung at the end of each Psalm, and shall be sung at the end of the whole portion.

The Psalter followeth the division of the Hebrews, and the Translation of the great English Bible.

The division of the Hebrews is in contradistinction to the division of-

(i) the Septuagint, by which Psalms ix. and x., and cxiv. and cxv. are joined; and Psalms cxvi. and cxlvii. each divided.

(ii) the Vulgate, by which Psalms ix. and $x$. are joined; and Psalm cxlvii. is divided.

The English text follows the numbering of the original Hebrew and so is in advance of the LXX and Vulgate.

The Translation of the great English Bible.

This version was issued in 1539 and was called the Great Bible, or Cranmer's Bible, because the Archbishop wrote a preface to it. It was a new edition of Matthew's Bible, revised, and compared with the Hebrew; by Coverdale and others, and published with the sanction of Cranmer. Copies of it were ordered to be set up in all the churches, and these were chained to a lectern to ensure their safety. (Hence the phrase 'Chained Bibles.')

Owing to the familiarity of the people with it, this translation of the Psalter was retained when the A.V. of 1611 was substituted for the Great Bible translation in the Church Services in 1662. It is much more rhythmical and suitable for singing purposes, although in places it partakes of the nature of a paraphrase rather than of an exact translation.

Westcott says that ' Coverdale, like Luther and the Zurich translators, on whose model his style was formed, allowed himself considerable freedom in dealing with the shape of the original sentences. At one time a word is repeated to bring out the balance of the two clauses; at another time the number is changed; at another time a fuller phrase is supplied for the simple copula, now a word is resolved; and again a particle, or an adverb, or a pronoun, or even an epithet, is introduced 
for the sake of definiteness. . . . The execution of the version undoubtedly falls far below the conception of it: the Authorized Version is in almost every case more correct; but still in idea and tone Coverdale's is as a whole superior, and furnishes a noble type for any future revision.'*

- Attention may here be called to an injustice done to Coverdale's Psalter by the neglect of the printers of the Prayer Book to indicate, as he had done, words and phrases which he embodied in his text, although he regarded them as either not forming part of the original, or as, at least, of doubtful authority. We are familiar with the use of italics in the Authorized Version for a like purpose. In the Psalter as used for purposes of devotion, it is perhaps as well that questions of textual criticism should not be presented; and I do not complain of a usage that has come down to us from the Sealed Books of 1662. $\dagger$ But Coverdale is not to be blamed. As examples of what is referred to we may cite Psalm i. 5, where Coverdale has placed (in 1539) the words "from the face of the earth" within the marks of parenthesis, and Psalm xiii. 6, where the words "yea, I will praise the name of the Lord most Highest" are treated in a similar way.' $\ddagger$

\section{ii. The Order how the rest of Holy Scripture is} APPOINTED TO BE READ.

1549. The Order how the rest of holy Scripture (beside the Psalter) is appointed to be read.

1662. 'Beside the Psalter' omitted.

\section{1 st Paragraph.}

1549. The Old Testament is appointed for the first Lessons, at Matins and Evensong [Morning and Evening Prayer, 1552], and shall be read through every year once, except certain Books and Chapters, which be least edifying, and might best be spared, and therefore are left unread.

1662. The Old Testament ... so as the most part thereof will be read every year once, as in the Calendar is appointed.

\section{3rd Paragraph.}

1662. The words 'Except only the Moveable Feasts, which

*Westcott's 'A General View of the History of the English Bible,' p. 264.

+ Those concerned in the issue and correction of these Books were, as guardians of the legal text, certainly blameworthy in not adhering to the text of the MS. Prayer Book attaehed to the Caroline Aet of Uniformity.

+ Dowden's 'The Workmanship of the Prayer Book' (1902). pp. 179, 180. The whole chapter xvii. pp. 175-191, entitled, 'The English Prayer. Book-Its Literary Style-The Psalter-Coverdale,' is worthy eareful su udy. 
are not in the Calendar, and the Immoveable, where there is a blank left in the Column of Lessons, the Proper Lessons for all which days are to be found in the Table of Proper Lressons' were added.

\section{5th Paragraph.}

1549. Ye must note also, that the Collect, Epistle, and Gospel, appointed for the Sunday, shall serve all the week after, except there fall some feast that hath his proper.

1662. Note also, that the Collect, . . . the week after, where it is not in this Book otherwise ordered.

The following paragraphs were in previous editions, but were omitted in 1662 :-

1549. This is also to be noted, concerning the leap years, that the xxv. day of February, which in Leap year is counted for two days, shall in those two days alter neither Psalm nor Lesson; but the same Psalms and Lessons which be said the first day; shall also serve for the second day.

Also, wheresoever the beginning of any Lesson, Epistle, or Gospel, is not expressed, there ye must begin at the beginning of the Chapter.

1552. The paragraph, 'And wheresoever is not expressed how far shall be read, then shall you read to the end of the Chapter,' was added to those of 1549.

1604. When the years of our Lord may be divided into four even parts, which is every fourth year; then the Sunday letter leapeth, and that year the Psalms and Lessons which serve for the xxiij day of February, shall be read again the day following, except it be Sunday, which hath proper Lessons of the Old Testament, appointed in the Table serving to that purpose.

Also, wheresoever ... of the Chapter.

And wheresoever ... of the Chapter.

Item, so oft as the first Chapter of Saint Matthew is read either for Lesson or Gospel, ye shall begin the same at (The birth of Jesus Christ was on this wise, \&c.).

And the third Chapter of Saint Luke's Gospel shall be read unto (So that he was supposed to be the Son of Joseph, \&c.).

This section was altered to its present form in 1871, when the New Lectionary was issued.

1. The Lessons.

\section{Analysis.}

(a) The First Lessons are so arranged that practically all the Old Testament is read through once a year. 
(b) The Second Lessons ensure that practically all the New Testament is read twice a year.

2. Directions for finding the right portions to read.

Reference is made to the Tables of Proper Lessons for Festivals and to the Calendar for ordinary days.

3. Rules for exceptional cases.

(a) At a second Evening Service a Second Lesson from the Gospels may be chosen at the discretion of the Minister.

(b) The Ordinary may substitute 'Proper' Lessons and Psalms, which shall take the place of those ordinarily appointed.

(c) Proper Lessons for the First Sunday in Advent, Easter Day, Whit-Sunday, and Trinity Sunday precede those of a Holy day. On all other Sundays the Minister las the option of reading either the ordinary Lessons for the day or those specially appointed for the Holy day.

4. The Collect, Epistle, and Gospel appointed for the Sunday shall be used throughout the week, except when otherwise ordered, e.g., The Collect, Epistle and Gospel for 'The Circumcision' are to serve till the Epiphany.

The public reading of the Scriptures is a custom of great antiquity (cf. Justin Martyr's 'Apology '). At first a Lesson seems to have been chosen at will, but by the fifth century four Lessons were read in an appointed order. In the Mediæval period this number was considerably increased-both by portions of Scripture, and by extracts from Homilies of the Fathers or from Lives of the Saints.

In 1549 a Lectionary was inserted in the Prayer Book, which reduced the lessons at each service to two in number, but increased the quantity of Scripture read, and made the reading intelligible by ordering it to be continuous.

In 1871 a revised Lectionary was added. Its chief features are :-

(a) The New Testament is read through twice a year, instead of three times, as before; the Gospels at Morning Prayer for the first half of the year, and at Evening Prayes during the latter half.

(b) The week-day Lessons have been shortened, and the division into chapters were not rigidly observed.

(c) The Proper First Lessons for Sundays were a good deal altered, and alternative lessons appointed for use at a second Evening Service; the Second Lesson for each such service 
may be any chapter from the four Gospels (when an alternative is not provided).

(d) The Ordinary may sanction the use of Proper Lessons on any day.

(c) The amount of the Apocrypha read is much reduced, all Lessons proper for Sundays being taken from the Holy Scriptures.

(f) The list of Lessons for Holy Days is made more complete.

iii. Tables of Proper Lessons and Psalms.

1549. There was no heading.

1552. Proper Psalms and Lessons for divers feasts and days, at Morning and Evening Prayer.

1559. Proper Lessons to be read for the first Lessons, both at Morning Prayer and Evening Prayer, on the Sundays throughout the Year, and for some also the second Lessons. 1662. Proper Lessons to be read at Morming and Evening Prayer, on the Sundays, and other Holy-days throughout the year.

(1) Lessons Proper for Sundays.

1549. There was no separate Table of Proper Lessons, but proper Lessons were attached to the respective Sundays and Holy-days to which they were appropriated, under the head of 'The Introits, Collects, Epistles, and Gospels,' etc.

1552. There was still no separate Table of Proper Lessons, but with the exception of those for certain Feást Days, they were given in the Calendar.

1559. A separate Table of Proper Lessons was appointed.

1871. The New Lectionary made compulsory.

In 1549 there were no Proper Lessons appointed for ordinary Sundays for, with three exceptions-Easter Day, Whit-Sunday, and Trinity Sunday, the continuous daily reading of the Scriptures was unbroken. The table of 'Lessons Proper for Sundays' was first added in 1559, and remained almost untouched by the later revisions. In 1871 a new Table of Lessons was issued, and in it the First Lessons appointed for Sundays form a consecutive yearly course of chapters selected from the Old Testament alone. Its dominant idea is that of Regularity. The course begins in Advent with Isaiah : Genesis is commenced on Septuagesima, and then the selection passes through the Historical and Prophetical Books (with some exceptions) in order.

On all ordinary Sundays the Second Lessons are taken from the continuous order fixed by the Calendar. Proper Second 
Lessons are, however, provided for six occasions-Septuagesima, the Sixth Sunday in Lent, Easter Day, the First Sunday after Easter, Whit-Sunday, and Trinity Sunday, alternatives being provided for all except Septuagesima and the First Sunday after Easter.

\section{(2) Lessons Proper for Holy Days.}

1549. There was no separate Table, but the Lessons were found under the head of 'Introits,' etc.

1552. There was still no separate Table, but with the exception of those for a few certain Holy-days they were given in the Calendar.

1559. A separate Table appointed.

A fairly complete list of Lessons for Holy-days was included in the Prayer Book of 1549 (attached to the Collect, Epistle, and Gospel for each day).

In 1559 this list was inserted separately, and additions were made to it of passages from the Apocrypha. In 1662 it was slightly altered, and in 1871 it underwent a complete revision.

The Lessons now are chosen from passages which are specially appropriate for the Commemoration. "The principle of selection is clearly that of speciality' (Bp. Barry). Among the Apocryphal Books only those of Wisdom, Ecclesiasticus, and Baruch are laid under contribution, and neither of these more than once.

(The American Prayer Book has an enlarged Table of Proper Lessons-including some for the season of Lent, and Rogation and Ember Days.)

\section{(3) Proper Psalms on certain Days.}

1549, 1552. There was no separate Table of Proper Psalms in either of the Prayer Books of these dates. But Proper Psalms for Christmas Day, Easter Day, Ascension Day and Whit-Sunday were appointed in 1549, and placed under the head of 'Introits' and in 1552 placed with the Proper Lessons.

1559. A separate Table appointed.

1662. Proper Psalms provided for Ash Wednesday and Good Friday.

Note.-The morning Psalms for Whit-Sunday have been variously altered in the different Editions. In 1549 they were $48,67,145$. In 1552 the 145 th Psalm was omitted as it already formed one of the evening Psalms. In 1604 they were changed to 45 and 47 , the latter believed to be a mistake for 67 (xivii. for lxvii.). And in 1662 both were replaced by 48 and 68 .

The third Psalm for Ascension Day evening in 1549 was the 
148th; this was in 1552 changed for the 108th, which has remained ever since.

In 1549 Proper Psalms were assigned to Christmas Day, Easter Day, Ascension Day, and Whit-Sunday. Those for Ash Wednesday and Good Friday were added in 1662.

The American Prayer Book contains a much larger selection of Proper Psalms and has also ten 'Selections of Psalms, to be used instead of the Psalms for the day, at the discretion of the Minister'; and 'Portions of Psalms to be sung or said at Morning Prayer, on certain Feasts and Fasts, instead of the Venite exultemus, when any of the foregoing Selections are to follow instead of the Psalms, as in the table.' These 'Portions' are formed of verses culled out of certain named Psalms; and are invitatories for Christmas Day, Ash Wednesday, Good Friday, Ascension Day, and Whit-Sunday.

\section{6. TABLES AND RULES FOR THE MOVEABLE AND IMMOVEABLE FEASTS ; TOGETHER WITH THE DAYS OF FASTING AND ABSTINENCE, THROUGH THE WHOLE YEAR.}

1662 i. Rules to know when the Moveable Feasts and Holy-Days BEgIN. 1662.

1662 Easter-Day (on which the rest depend) is always the first Sunday after the first full moon which happens next after the one and twentieth day of March. And, if the Full moon happens upon a Sunday, Easter-day is the Sunday after.

1604 Advent-Sunday is always the nearest Sunday to the Feast of St. Andrew (November 30) whether before or after.

$\left.1662 \quad \begin{array}{l}\text { Septuagesima } \\ \text { Sexagesima } \\ \text { Quinquagesima } \\ \text { Quadragesima }\end{array}\right\}$ Sunday is $\left\{\begin{array}{l}\text { Nine } \\ \text { Eight } \\ \text { Seven } \\ \text { Six }\end{array}\right\}$ Weeks before Easter.

$\left.\therefore \quad \begin{array}{l}\text { Rogation-Sunday } \\ \text { Ascension Day } \\ \text { Whit Sunday } \\ \text { Trinity Sunday }\end{array}\right\}$ is $\left\{\begin{array}{l}\text { Five weeks } \\ \text { Forty days } \\ \text { Seven weeks } \\ \text { Eight weeks }\end{array}\right\}$ after Easter.

Septuagesima and Ash Wednesday are 63 and 56 days respectively before Easter Day. Rogation Sunday, Ascension Day, Whit-Sunday and Trinity Sunday are 35, 39, 49 and 56 days respectively after Easter. From Septuagesima to Trinity is therefore $63+56=119$ days. 
Easter.-By the early Christians Christ's death and resurrection were celebrated at the time of the Jewish Passover; and the word $\pi \alpha^{\prime} \sigma \chi^{\alpha}$ (from the Aramaic pisch $\bar{a}=\mathrm{Hcb}$. pesach), though a common name for Easter from the second century onwards, was employed, when first used as a Christian term, to denote the celebration of the Fast of Good Friday.* There is no mention of Easter in the writings of the Apostolic Fathers, and the earliest trace of its observance in the West is c. 120, in the time of Pope Xystus. A controversy arose early as to the date of its observance. The Asiatics celebrated the Christian Passover on the 14th of Nisan, the day on which the Lord was believed to have

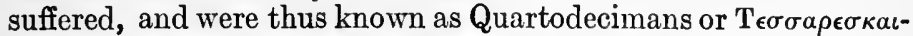

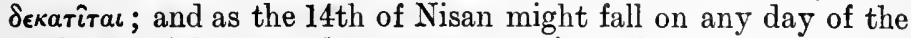
week, so might also the commemoration of the Resurrection. On the other hand, the Roman Church commemorated Friday as the day of the Crucifixion, and the following Sunday as the Feast of the Resurrection. For a history of the controversy the student is referred to works on Church History. $\dagger$ It must suffice here to say that the Roman practice was affirmed at the Council of Nicæa, 325, though Sozomen $\ddagger$ speaks of Quartodeciman practice as still going on in a few communities in 440 .

The fact that the conditions for determining Easter involve both the solar and the lunar year necessitates the employment of cycles for the determination of its date. $\S$ The Metonic cycle (named after Meton, an Athenian astronomer, c. 433 B.c.) of nineteen years was finally adopted, as we learn from a letter of St. Ambrose ('Oper.,' ii., ep. xxiii.) written about sixty years after the Council of Nicæa; and the Paschal Tables of Dionysius Exiguus, a monk at Rome, settled in 525 the question for both Eastern and Western Churches. The determination of Easter was finally settled by these rules:-

(1) Easter to be kept on a Sunday,

(2) which must be the next after the 14th day of the Paschal moon; though should the 14th be a Sunday, Easter to be kept on the following Sunday.

(3) The Paschal moon is the calendar moon whose 14tl day falls on, or follows next after, the day of the vernal equinox.

* See Wordsworth, 'Ministry of Grace,' p. 355.

$\dagger$ The stages are (i) discussion between Anicetus and Polycarp, c. 150; (ii) dispute at Laodicea, between 170 and 177; (iii) Victor and Polycrates, c. 190. See Eusebius, 'H. E.,' iv. 26, v. 23-25.

† Sozomen, 'H. E.,' vii. 19.

$\S$ The student may refer to the well-known work of Seabury, 'Theory and Use of the Church Calendar, etc.' (1872), for an account of the various cycles. Considerations of space prevent any account being given in this handbook. 
(4) The vernal equinox is to be taken invariably as March 21 . The Metonic cycle had defects-it assumed the solar year to consist of $365 \frac{1}{4}$ days, whereas the true solar year is $11^{\prime} 10^{\prime \prime}$ shorter than the tropical year; and also assumed that at the close of the cycle of nineteen years solar and lunar time coincide, which is not the case. The errors which of necessity crept into the calculations were rectified by the adoption of the Gregorian Calendar or 'New Style' in England by Act of Parliament, $1752,{ }^{*}$ and the tables and rules now prefixed to the Prayer Book are those then drawn up by Bradley, the Astronomer Royal. The equation between the Julian solar year and the tropical year is not quite exact, and will necessitate further revision unless it should be determined, before such necessity arises, to keep Easter on a fixed day.

Advent.-This season, commemorating the first coming of Christ, is regarded as preparatory for the Festival of Christmas. The history of its observance is obscure, our first notice of it being in the canons of Saragossa in Spain, c. 380, and it is there mentioned as a preparatory season of church-going before Epiphany. Possibly its institution was due to imitation of Lent as preparatory to Easter. The Ambrosian and Mozarabic rites included six Sundays in it; so too the Council of Macon (581). In Rome there were originally five, but these were reduced to four under Gregory the Great.

The rule for determining Advent does not appear to contemplate the falling of Advent Sunday on St. Andrew's Day. The Scottish Prayer Book of 1637 added to the rule the words, "or that Sunday which falleth upon any day from the twenty-seventh of November to the third of December inclusively.'

Septuagesima, Sexagesima, Quinquagesima, and Quadragesima denote in round numbers, $70,60,50$, and 40 days before Easter. Quadragesima denoted anciently the first Sunday in Lent; the term is used in the Prayer Book only here under the 'Tables and Rules.'

Rogation Sunday.-So called in relation to the Rogation-days. $\dagger$

Ascension Day is also called Holy Thursday in the table of Days of Fasting. We have no mention of its observance till the middle of the fourth century, but Augustine speaks of it

* Though a Bill for its introduction was twice read in the House of Lords, $158 \frac{4}{5}$, but did not go further. By Gregory's time, 1582, there was a discrepancy of ten days. Hence the old English rhyme-

' Barnaby bright,

The longest day

And the shortest night,'

the Feast of St. Barnabas falling on June 11.

+ See below, p. 55. 
as universal and therefore of Apostolic institution ('Ep. ad

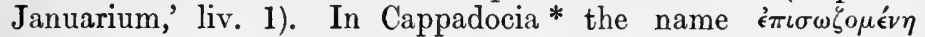
was given to it, indicating that it was a day which marked a festival over and above the already acknowledged great festivals.

Whit-Sunday commemorates the first manifestation of the Holy Ghost to the disciples (Acts ii.). The word means ' White Sunday.' Dr. Skeat ('Etymol. Dict.,' p. 708) says :-

'It is tolerably certain that the English name White Sunday is not older than the Norman Conquest; for, before that time, the name was always Pentecoste. We are, therefore, quite sure that, for some reason or other, the name Pentecost was then changed for that of White Sunday, which came into common use, and was early corrupted into Whit-Sunday, proving that white was soon misunderstood, and was wrongly supposed to refer to the wit or wisdom conferred by the Holy Ghost on the day of Pentecost.'

In confirmation of this we may compare the old lines-

- This day Witsonday is cald,

For wisdom and wit seuene fold

Was given to the apostles at this day.'

The earliest notice of the festival is in Irenæus ; but it is implied in early Christian writings, even if not explicitly mentioned. $\dagger$

Trinity Sunday.-The festival first made its appearance in the tenth century in the Low Countries, and it was not till the time of Pope John XXII (1316-1334) that the Roman Church adopted it and fixed it in its present place.

ii. A Table of all the Feasts that are to be observed in the Church of England through the Year.

1604. The heading stood 'These to be observed for Holy-days and none other.'

1662. St. Barnabas was added to the Table.

Omitting those dealt with above, we may classify thus :-

I. All Sundays in the Year.

II. Commemorations of the Lord :-Circumcision, Epiphany, Christmas.

III. Festivals of the Virgin :-Purification, Annunciation.

IV. Apostles, Evangelists, etc., of the New Testament :-Conversion of St. Paul, St. Matthias, St. Mark, SS. Philip and James, St. Barnabas, Nativity of John the Baptist, St. Peter, St. James, St. Bartholomew, St. Mattliew, St. Michael and All Angels, St. Luke, SS. Simon and Jude, St. Andrew, St. Thomas, St. Stephen, St. John.

- See a Sermon of Gregory of Nyssa in Migne, 'Patrol. Grec.,' xlvi. † Seo Duchesne, 'Christian Worship,' iii. p. 240. 
V. Miscellaneous :-All Saints, Holy Innocents, Mondays and Tuesdays in Easter and Whitsun-weeks.

I. Sunday.-The expression 'Lord's Day' first occurs in Rev.

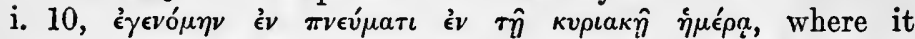
probably means the first day of the week.* The substitution of Sunday for the Sabbath had already taken place in Apostolio times (Acts xx. $7 ; 1$ Cor. xvi. 2), though at first its observance was supplemental to that of the Sabbath. We find early references to the observance of the day in the Didache (xiv.), the Epistle of Barnabas (xiv.), Ignatius ('Ad Magn.,' vii.-x.), Justin Martyr ("Apol.,' i. 67, where the Christians are described as

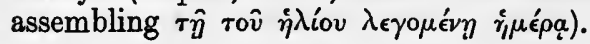

II. Circumcision (January 1).-The Byzantine Calendars give the anniversary of St. Basil also on this day. The festival, as now understood, was not of Roman origin, for in the early calendars its designation is merely the Octave of Christmas (Octava Domini). 'It was a sort of renewal of the solemnity of Christmas, with a special consideration of the Virgin Mother.' $\dagger$ The heathen festivities of the Saturnalia on January 1 caused the day to be observed as a fast day in some places, as e.g. in Spain (Fourth Council of Toledo, canon xi.).

Epiphany (January 6).- In the East the festival marked origin-

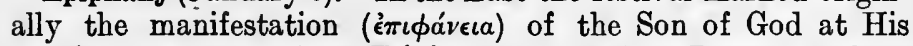
baptism, or rather of the Trinity then; and on January 6 there was a combined celebration of Christ's Nativity and Baptism. The Roman festival marks the visit of the Magi to the infant Christ. The feast found its way into the West through Southern Gaul.f 'It is probable that while on the one hand the Eastern Church, at first commemorating the Nativity and Epiphany as one festival, afterward in compliance with Roman usage fixed the former on a separate day; so too, the Western Church, at first celebrating the Nativity alone, afterwards brought in from the East the further commemoration of the Epiphany, but with the special reference somewhat altered.' $\$$

Christmas.-As said above, Christmas and Epiphany were originally one festival meant to commemorate the Nativity. In the early Church there was some divergence of opinion as to the date of the birth of Christ. In the East the date assigned was January 6, possibly from the Montanists, who celebrated

* For a discussion of other interpretations-Day of Judgment, Easter Day, Sabbath-consult the Commentaries.

† Duchesne, 'Christian Worship,' iii. p. 273.

$\ddagger$ Ibid., pp. 257-260.

$\S$ Sinker in 'Dict. Chr. Antiq.,' i, 618. 
the Passover on April 6 if it fell on a Sunday, otherwise on the following Sunday, and who thought our Lord died on April 6 (Sozomen, 'H. E.,' viii. 18). But in the fourth century the Easterns generally adopted the Western date, December 25, which was fixed by Hippolytus, c. 220.* The earliest mention of December 25 as a festival occurs in the Philocalian Calendar, $\dagger$ transcribed in 354 . The theory that the festival was suggested by the heathen festival of the birth of the sun on that daythe Christians transforming it into a celebration of the birthday of the Sun of Righteousness-has little to commend it. We may note that the Armenians still retain January 6 as the festival of the Nativity.

III. Purification (February 2).-This is dated forty days from Christmas (Luke ii. 22 ; Lev. xii. 2, 4), and is regarded by our Church rather as a festival of our Lord than of the Virgin. It came into the West through Constantinople, and is mentioned as being observed at Jerusalem in the 'Pilgrimage of Silvia', a document of $c .385$, discovered by Dr. Gamurrini in 1884, and published by him in 1887. $\ddagger$ We have no trace of it then till the sixth century, when we meet it under the name ' $Y \pi \alpha \pi \alpha v^{\prime} \dot{y}^{\prime}$ (late form of $\left.i \pi \alpha^{\prime} y \tau \eta \sigma \iota s\right)$ or Meeting, of our Lord and Simeon. The festival is called Candlemas from the blessing and procession of candles which was introduced, either as symbolically setting forth the words of Simeon (Luke ii. 32), or as taking the place of a heathen ceremony of lustration.

Annunciation (March 25).--Its history is obscure. It appears to have been observed in some districts in the East as early as the fifth century, but was not introduced into the West till the seventh. It was instituted, like the Purification, in honour of our Lord, and in the Ethiopian Calendar is called the Conception of Christ.

IV. Conversion of St. Paul (January 25).-A festival of late introduction. There was at an early date in Rome, $\S$ at least in the fourth century, a joint Festival of St. Peter and St. Paul on June 29 ; and the feeling that St. Paul in this way did not receive

* Com. on Daniel (ed. Bonwetsch, p. 244).

+ Known also, from the name of the Pope at the time, as the Liberian Calendar; and, from its first editor (1634), as the Bucherian Calendar.

† See Duchesne, 'Christian Worship,' iii. pp. $547 \mathrm{ff}$.

$\S$ Cf. Hymn of Prudentius :-

- Plus solito coeunt ad gaudia; dic, amice, quid sit; Romam per omnem cursitant ovantque.

Festus apostolici nobis sedit hic dies triumphi Pauli atque Petri nobilis cruore.' 
sufficient recognition led to the commemoration of his conversion on January 25. In the present Roman Calendar there is a commemoration of St. Paul on June 30.

St. Matthias (February 24).-The name does not occur in the Gelasian Sacramentary, and it is uncertain when the festival first came to be celebrated.

St. Mark (April 25).-The day is of late appearance, towards the end of the eighth century. In the Gregorian Sacramentary he is mentioned in the Collect.

St. Philip and St. James (May 1).-The origin of the festival is to be sought in the dedication of a church originally founded by Pope Julius (337-352) in their honour at Rome, 561. No explanation is forthcoming as to the conjunction of the names. In the Greek Church St. Philip is commemorated on November 14.

St. Barnabas (June 11).-Tradition says that he was stoned to death at Salamis in Cyprus, and that his tomb was discovered there about 478.* The festival commemorates this discovery. When it passed into the West is uncertain, probably not before the eighth century. In the Eastern Church the day was kept in honour of Bartholomew as well as Barnabas.

St. John Baptist (June 24).-A festival of early Western origin, $\dagger$ well recognized in Augustine's time (Sermons 196, 287). It is the birth, and not the death, of the Baptist that is commemorated, and so Augustine says, "The Church celebrates two birthdays only, John's and Christ's.' The date is fixed on the inference drawn from the Gospel (Luke i. 36) that John's birth took place six months before that of Christ. Augustine sees in the dates a fulfilment of the words ' He must increase, but I must decrease' (John iii. 30). $\ddagger$

St. Peter (June 29).- - On the joint Festival of St. Peter and St. Paul on this day see above (Conversion of St. Paul). The festival commemorates the day on which the remains of these Apostles were translated, in 258, to the place called ad Catacumbas on the Appian Way, and has no reference to their deaths, which were probably not at the same time. "It is to be regretted that the English Reformers should have altered this feast of the universal Church into one of St. Peter only, perhaps from thinking that St. Paul was represented by the festival of his Conversion" (Sinker).

St. James (July 25).-Obtained general observance quite late,

* See Duchesne, 'Christian Worship,' iii. p. 27.

† Ibid., p. 271, note.

¥ Sermon 287. 'In nativitate Christi dies crescit, in Johannis nativitate decrescit : natus est hodie Johannes, ab hodierno die minuuntur dies; natus Christus viii. Kal. Jan., ab illo die erescunt dies,' 
though in the Carthaginian Calendar (c. 500) * we have under December 27 the entry 'Sanct. Joanis Baptistæ (Evangelistæ should probably be read) et Jacobi Apostoli, quem Herodes occidit.' In the canons of the Council of Oxford, 1222, it is not named amongst the chief festivals to be observed; but we find it established at the Synod of Exeter, 1287. The date, July 25, is a difficulty, as we learn from Acts xii. 2-4 that St. James was put to death shortly before Passover. Possibly there may have been a desire to omit the celebration of a martyrdom in Lent and Eastertide, or the date may have reference to some translation of the saint's remains.

St. Bartholomew (August 24).--Probably to be identified with Nathanael. We have no certain references to the festival till the eighth century, and great diversity existed as to the day of its celebration. It is said to have been a festival of considerable importance in England before the middle of the tenth century.

St. Matthew (September 21).-A festival of late origin, wanting in the Leonine, Gelasian, and Gallican liturgies. In the Greek, Russian and Armenian Churches it is kept on November 16.

St. Michael and All Angels (September 29).- The Sarum Calendar has simply 'Michaelis Archangeli'; the addition 'and All Angels' appearing for the first time in the Prayer Book of 1662. Mr. Staley $\dagger$ thinks it not improbable that the addition is due to the influence of Hooker's 'Ecclesiastical Polity' (1594), much read in the early part of the seventeenth century, which has a fine passage (Book V. ch. iv. $\S \S 1,2$ ) on "The law which angels do work by.' $\ddagger$ St. Michael is the only angel commemorated before the ninth century, and Duchesne says that festivals of this kind can be attributed only to the dedications of churches, -in this case of a church in the suburbs of Rome at the sixth milestone on the Via Salaria.§ It is not likely that the festival of September 29 took its rise in a commemoration of the manifestation in Monte Gargano of Michael to the Bishop of Sipontum, which event was specially connected with the date May 8.|I

St. Luke (October 18).-The earliest mention of the festival is in the Carthaginian Calendar. In the Hieronymian Martyrology it marks a translation of relics in the East.

St. Simon and St. Jude (October 28).- The reason for the association of these names is unknown; probably because of the dedication of some church in their joint names, or from the belief that they were brothers, or from the legend that they

* Wordsworth, 'Ministry of Gr tce' p. 65.

+ 'The Liturgical Year,' p. 125 (London, 1907).

+ See too Hooker, 'Eccles. Pol.,' Book V. ch. Ixx. $\$ 9$.

$\$$ Duchesne, 'Christian Worship,' iii. p. 276.

I| See 'Dict. Christ. Antiq.,' ii. 1176-1181. 
suffered martyrdom at the same time. In the East St. Simon is commemorated on May 10, St. Jude on June 19.

St. Andrew (November 30).-A festival of early date. It is found in the Carthaginian Calendar and the Leonine Sacramentary; also in Boniface's list of festivals, where the only other Apostles named are St. Peter and St. Paul. It is the only festival of an Apostle claiming to commemorate the actual day of his death.

St. Thomas (December 21).--This appears first in the East at Edessa in the fifth century; and was not recognized in the West till a comparatively late date. It is found in the Gelasian Sacramentary, but not in the Carthaginian Calendar, nor in the Leonine Sacramentary. In the Greek Cliurch the commemoration is on October 6.

St. Stephen (December 26). - The Sermons of Gregory of Nyssa show that the festival was kept in the fourth century; ${ }^{*}$ and the discovery of his tomb in $415 \dagger$ gave great impulse to the existing commemoration.

St. John (December 27).-Originally the name of St. James was joined to that of St. John in the festival of December 27, and so we find in the Carthaginian Calendar ; $\ddagger$ but in the Roman service books we have, for some reason unknown, only St. John commemorated on this day.

V. All Saints (November 1) was one of the holy-days ordained by Convocation, 1536, to be kept in term time.§ The Festival originated in the dedication by Boniface IV (608-614) of the old.Roman Pantheon as a Christian church, and its date was at first May 13. It is not in the Gregorian Sacramentary, though we have evidence of its observance in France, Germany, and England in the eighth century. In the Metrical Martyrology of Bede it occurs (? a later addition) on November 1.\|. The old English designation of the day was All Hallows (A.S. halge= saints).

Holy Innocents (December 28).-At first this festival was associated with the Epiphany (Prudentius, Cath. xii. de Epiph.), and is of early date, being found in all Latin Calendars from the sixth century. In the Greek Church it is commemorated on December 29. An old English name for the festival is Childermas,

* Migne, 'Patrol. Grec.,' xlvi. 701, 721.

† For the legend see 'Dict. Chr. Antiq.,' ii. 1929.

$\ddagger$ See above under 'St. James,' p. 46.

$\S$ The others are Ascension Day, the Nativity of the Baptist, and Candlemas.

|| 'Multiplici rutilat gemma ccu in fronte November, Cunctorum fulget Sanctorum laude decoris.' 
and the processions of children-which took place on the day were forbidden by Henry VIII, 1540.: To mark the mournful character of the day muffled peals were rung and black vestments worn.

N.B.-The following information respecting the six Law Terms was given in 1604 :-

In 1604 there was given after the 'Table of all the Feasts' a brief declaration where every Term beginneth and endeth.

Be it known that Easter Term beginneth always the 18th day after Easter, reckoning Easter-day for one; and endeth the Monday next after the Ascension day.

Trinity Term beginneth 12 days after Whitsunday, and continueth 19 days.

Michaelmas Term beginneth the 9th or 10th day of October, and endeth the 28th or 29th day of November.

Hilary Term beginneth the 23rd or 24th day of January, and endeth the 12th or 13th day of February.

In Easter Term, on the Ascension day; in Trinity Term, on the Nativity of S. John. Baptist; in Michaelmas Term, on the feast of All Saints ; in Hilary Term, on the Feast of the Purification of our Lady, the King's Judges of Westminster do not use to sit in Judgment, nor upon any Sundays.

This 'declaration' was omitted in 1662 .

iii. A Table of the Vigils, Fasts, and Days of Abstinence TO BE OBSERVED IN THE YEAR. 1662.

\section{(1) Evens, or Vigils.}

Vigils were originally the nights before the great festivals, and the transition of this observance to the day before the festival is obscure. They were called by the Greeks $\pi a v v v \chi^{\prime} \delta \epsilon s$, by the Latins pernoctationes et pervigitia, ${ }^{*}$ and are of great antiquity, the observance of the Easter Vigil being mentioned by Tertullian (192), though they are of rare occurrence in the oldest Calendars. Early in the history of the Church the Festivals of martyrs had thcir Vigils, and these seem to have been kept in the cemeteries where their remains lay, since we have a canon of the Council of Eliberis (305) forbidding women to spend the night-watches in such places owing to the excesses committed. $\dagger$ No fast was attached to vigils earlier than the ninth century. $\neq$

* Bingham, 'Antiq.,' xiii. 9, 4.

+ 'Placuit prohiberi, ne fæminæ in cemeteris pervigilent, eo quod sæpe sub obtentu orationis latenter scelera committunt.' (Can. 35.)

— Honorius of Autun (1130) connects the chango from night to day, from vigil to fast, with the popular excesses. (Ste Dowden, 'Cliureh Year and Calendar,' p. 74.) 
The Vigils to be observed by our Church in the year are thus sct forth in the table * :-

\begin{tabular}{|c|c|c|c|}
\hline $\begin{array}{l}\text { The } \\
\text { Evens }\end{array}$ & $\begin{array}{l}\text { The Nativity of our } \\
\text { Lord. } \\
\text { The Purification of } \\
\text { the blessed Virgin } \\
\text { Mary. }\end{array}$ & $\begin{array}{l}\text { The } \\
\text { Evens }\end{array}$ & $\begin{array}{l}\text { St. John Baptist. } \\
\text { St. Peter. } \\
\text { St. James. } \\
\text { St. Bartholomew. } \\
\text { St. Matthew. }\end{array}$ \\
\hline $\begin{array}{l}\text { or Vigils } \\
\text { before }\end{array}$ & $\begin{array}{l}\text { The Annunciation of } \\
\text { the blessed Virgin } \\
\text { Easter-day. } \\
\text { Ascension-day. } \\
\text { Pentecost. } \\
\text { St. Matthias. }\end{array}$ & $\begin{array}{l}\text { or Vigils } \\
\text { before }\end{array}$ & $\begin{array}{l}\text { St. Simon and St. } \\
\text { Jude. } \\
\text { St. Andrew. } \\
\text { St. Thomas. } \\
\text { All Saints. }\end{array}$ \\
\hline
\end{tabular}

'The reason,' says Wheatley, 'why the other holy-days have no Vigils before thern, is, because they generally happen either between Christmas and the Purification or between Easter and Whitsuntide; which were always esteemed such seasons of joy, that the Church did not think fit to intermingle them with any days of fasting and humiliation.' This would not account, however, for the omission of Vigils on the Eves of St. Barnabas, St. Michael and All Angels, and St. Luke. In the case of St. Barnabas and St. Luke the reason is probably that these festivals were considered to be of a secondary character, and Bishop Beveridge says, "To distinguish St. Paul and St. Barnabas from the Twelve, the Eves or Vigils of these days are not appointed to be observed as those of the others are.' Wheatley $\dagger^{2}$ suggests as a reason for the omission of a Vigil of St. Luke that the Feast of St. Etheldreda, formerly a celebrated holy-day in the Church of England, fell on October 17. But this explanation is not as reasonable as the former, since in the Sarum Calendar St. Etheldreda is twice commemorated, on October 17 and June 23, the latter of which, the Eve of St. John Baptist, is nevertheless a Vigil. The omission of a Michaelmas Vigil is 'that those ministering spirits, for whose protection and assistance we return God thanks, were at first created in full possession of bliss,' whereas the saints passed from affliction to joy, and this we commemorate in a Vigil.

Ascension Day obviously falls between Easter and Whitsuntide : and the Vigil before it may have some connexion with

* In the P.B. of the American Church this table does not occur. The P.B. of the Church of Ireland adds to the table a note: "The Archbishops and Bishops may appoint Days of Humiliation and Days of Thanksgiving, to be observed by the Church of Ireland; and may prescribe special Services for the same.'

† 'Rational Illustration,' p. 194 (ed. London, 1825). 
the fast of the Rogation-days.* So too with the Vigil of Pentecost. $\dagger$

All Sundays in the year being appointed to be observed as feasts, it is ordered 'that if any of these Feast-days fall upon a Monday, then the Vigil or Fast-day shall be kept upon the Saturday, and not upon the Sunday next before it.'

\section{(2) Days of Fasting, or Abstinence.}

In the Jewish Church there was but one fast day commanded in the Law, the Day of Atonement (Lev. xvi. 29; ef. Acts xxvii.9). After the Captivity four public fasts were introduced (Zech. viii. 19). $\ddagger$ Frequent private fasts were observed by the pious (Luke ii. 37 ; xviii. 12).§ In the New Testament there is no command to fast, Jesus deliberately refusing to enjoin fasting on His disciples (Mark ii. 18-22 and parallels), but teaching that whenever fasting was undertaken it must be with purity of motive and intention (Matt. vi. 16-18).川 We find in the early Church fasting mentioned as taking place before solemn appointments were made (Acts xiii. 2,3 ; xiv. 23 ) : and that an increasing value was set upon it may be gathered from later additions to the true text of the New Testament (e.g. Matt. xvii. 21; Mark ix. 29 ; Acts x. $30 ; 1$ Cor. vii. 5). 1

The purposes of fasting are thus described in the first part of the Homily of Fasting ** :-

(1) To chastise the flesh, that it be not too wanton, but tamed and brought in subjection to the spirit.

(2) That the spirit may be more earnest and fervent to prayer.

(3) That our fast be a testimony and witness with us before God, of our humble submission to his High Majesty, when we confess our sins unto Him, and are inwardly touched with sorrowfulness of heart, bewailing the same in the affliction of our bodies.

The same Homily also guards against the notion of any merit being attached to fasting :-

'Some [good works] are of themselves, and of their own proper nature, always good ... other works there be which,

* Bp. Sparrow says ('Rationale,' p. 148): 'The fast of Rogation week is voluntary; for there is no fast commanded betwixt Easter and WhitSunday.'

† See 'Dict. Christ. Antir.,' ii. p. 1619.

¥ On Purim see Paton, 'Com. on Esther' (1908), pp. 77-94.

$\$$ See Edersheim, 'Life and Times of Jesus,' i. 662; ii. 291.

II A careful study of the passage is given in Lyttelton, "Sermon on the Mount'(1905), pp. 264-274.

If The student should compare the A.V. and R.V. of these passagcs.

** In this connexion Hooker, 'Eccles. Pol.,' Book V, ch. lxxii. should be studied. So too Bingham, 'Antiq.,' xxi. 1, 1.. 
considered in themselves, without further respect, are of their own nature merely indifferent. ... Of this sort of works is fasting; which of itself is a thing merely indifferent, but is made better or worse by the end that it serveth unto. For when it respecteth a good end, it is a good work; but, the end being evil, the work itself is also evil.

'To fast, then, with this persuasion of mind, that our fasting and other good works can make us good, perfect, and just men, and finally bring us to heaven, is a devilish persuasion; and that fast is so far off from pleasing of God, that it refuseth His mercy, and is altogether derogatory to the merits of Christ's death, and His precious blood-shedding.'

The Church of England does not, like the Roman Church,* distinguish fasting and abstinence: for although in the title of the table of Vigils, etc., there is separate mention of 'Fasts, and Days of Abstinence,' yet in the table following the heading is 'Days of Fasting or Abstinence.'

The Prayer Book lays down no rules for fasting, nor indeed is it enjoined as binding on members of our Church. In 1548 "A Proclamation for the abstaining from Flesh in Lent Time' $\dagger$ was issued, the motive of which may be gathered from the intention 'also for worldly and civil policy certain days in the year to spare flesh, and use fish, for the benefit of the commonwealth and profit of his majesty's realm; whereof many be fishers, ... so that hereby both the nourishment of the land might be increased by saving flesh, and specially at the spring time, when Lent doth commonly fall, and when the most common and plenteous breeding of flesh is.' $\ddagger$

The following letter of the late Bishop Perowne of Worcester (1891-1901) to a clergyman who sought from him a dispensation from fasting in Lent on the ground of illness, is of interest as showing the position of our Church in the matter :- As I am not aware that our Church has prescribed a fast during Lent, much less laid down any rules for its observance, I think every individual is free to exercise such abstinence as he may deem best for his own spiritual welfare. A fasting which is profitable to one man would be injurious to another. Common sense, to

- 'In the Church of Rome, Fasting and Abstinence admit of a distinction. On their days of fasting, they are allowed but one meal in four and twenty hours: but on days of abstinence, provided they abstain from flesh, and make but a moderate meal, they are indulged in a collation at night' (Wheatley, 'Rational Illustration,' p. 199).

$\dagger$ Given in Wilkin's ' Concilia,' iv. p. 20.

¥ This proclamation is alluded to in Part II. of the Homily quoted above (ed. of P.B. and Homily Soc., p. 263). (See too Tomlinson, 'The Prayer Book, Articles, and Homilies,' pp. 248, 249.) 
say nothing of right Christian feeling, should lead those who are in a weak state of health to take such food as they require, or as a doctor prescribes. Certainly, I do not see how I am to grant a dispensation (even if $I$ possess the dispensing power) from a law of the very existence of which I am ignorant. In the Homily of Fasting (first part) it is said to be " of itself a thing merely indifferent." I earnestly wish that good people, who are troubled about this matter, would carefully study Isa. lviii. $1-9$.

The 'days of fasting or Abstinence' $\uparrow$ named in the B.C.P. are as follows:-

1. The Forty days of Lent.

2. The Ember-days, at the Four the First Sunday in Lent. Seasons, being the Wednes- the Feast of Pentecost. day, Friday, and Saturday September 14. after $\quad$ December 13.

3. The three Rogation-days, being the Monday, Tuesday, and Wednesday before Holy Thursday, or the Ascension of our Lord.

4. All the Fridays in the Year, except Christmas-day.

I. Lent.-The name is derived from the Anglo-Saxon lencten, 'spring,' and merely indicates the season of the year when the fast oceurs. We have no traces of Lent before the Council of Nicœa (325) $\ddagger$; and it is clear that the fast had its origin in the preparation of candidates for Baptism (which usually took place at Easter). We must distinguish between the Lenten and the Paschal fasts. From the letter of Irenæus to Victor of Rome we gather that a fast preliminary to Easter was observed, but that there was a variety of observance as to its duration, and that this was a matter not only of his own time but of earlier date.§ At Alexandria in the middle of the third century we find it the custom to fast the whole week before Easter.\| In the West the Lenten and Paschal fasts ran coneurrently: but in the East they were conterminous; so we find Chrysostom in

* The Times for Mareh 18, 1892, p. 5, col. 6.

$\dagger$ In the P.B. of the American Church under the table of fasts only Ash Wednesday and Good Friday are included. Then follows a table (identical with our 'Days of Fasting or Abstinence') headed, 'Other Days of Fasting, on which the Chureh requires such a measure of abstinence as is more espccially suited to extraordinary aets and exercises of devotion.'

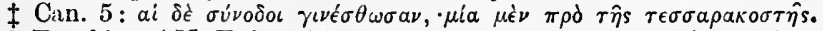

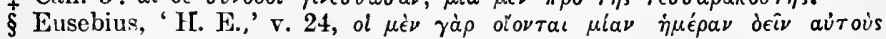

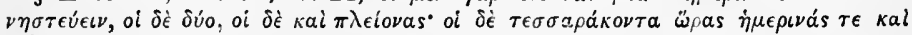

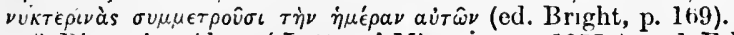

|| Dionysius Alex., 'Letters,' Mligne, x. p. 1277 (or ed. Feltoe, pp. 94 f.). 
one of his sermons saying, "We have at length come to the end of Quadragesima, and we are now about to enter on the great week (Holy Week).' * The historian Socrates (' H. E.,' v. 22) tells us that in his time there was grcat variety in different countries in the length of the fast, that at Rome being for three weeks, $\uparrow$ excepting Saturdays and Sundays. Soon after this we find a lengthening of the fast to thirty-six days, perhaps as forming a perfect number, one-tenth of the whole year; and finally, in the seventh century, four days were added. $\ddagger$

The connexion of the Lenten fast with the forty days of our Lord's fast in the wilderness was an afterthought.

II. Ember Days.-The derivation of the word 'ember' is uncertain. Many take it to be a corruption of the Latin quatuor tempora into quatember and ember (cf. the German Quatember Dutch Quatertemper). Others, with but little reason, connect it with embers in the sense of ashes, formerly used in connexion with mortifications. Others identify it with the Anglo-Saxon $Y m b r e n=a$ round course, a circuit ; $\S$ and this last view is almost certainly the correct one (cf. canon 16 of the English Council of Aenham, 1009-' et jejunia quatuor temporum, quæ Imbren vocant et cætera omnia prout sanctus Gregorius imposuit gent Anglorum conservantur').

The first mention of Ember days in connexion with the four seasons is in he sermons of Leo I (440-461), and we have no trace of their being at this time anything but a local Roman custom. We find them well established in Churches in the West dependent on Rome by the eighth century : and in England their observance, as has been noted from the quotation above, was attributed to Gregory the Great (590-604).\| As to their origin, Duchesne $\nabla$ is of opinion that they are "none other than the weekly fast, as observed at the beginning, but made specially severe, as well by the retention of the Wednesday, which had

* 'Hom. in Gen.,' xxx. 1.

† In the Mozarabic rite preparation for Baptism lasted three weeks.

\$ The addition of four days is frequently attributed to Gregory the Great (Bingham, 'Antiq.,' xxi. 1, 5): but his writings show that he was acquainted with a thirty-six days' fast only (see Gunning, 'The Lent Fast,' pp. $64, f$.$) .$

\$ Our Ember days, the Scandinavian Imbrudagar, appear for the first time [in the Ancren Riwle, c. 1220] in the guise of umbr dei; this and umquhile are the sole survivors in English of the many words formed from our lost preposition umbe, the Greek amphi' (Oliphant, 'Old and Middle English,'p. 278).

II Ember fasts were ordered to be kept by the Council of Cloveshoo (747), can. 18.

I 'Christian Worship,' iii. pp. 233, 285. 
disappeared early from the weekly Roman use, as by the substitution of a real fast for the semi-fast of the ordinary Stations.' * Their purpose, Bingham suggests, may have been 'to beg a blessing of God upon the several seasons of the year, or to return thanks for the benefits received in each of them, or to exercise and purify both body and soul in a more particular manner at the return of these certain terms of stricter discipline and more extraordinary devotion.' $\dagger$ There was much irregularity as to the time of their observance, the present rules being laid down by the Councils of Placentia (can. 14) and Clermont (can. 27) held in 1095, but even as late as the Council of Oxford, 1222, we find a canon (can. 8) ruling on the matter.

Our thirty-first canon wrongly states that the Ember seasons were originally instituted for Ordinations :-

Forasmuch as the ancient Fathers of the Church, led by example of the Apostles, appointed prayers and fasts to be used at the solemn Ordering of Ministers; and to that purpose allotted certain times, in which only sacred orders might be given or conferred; we, following their holy and religious example, do constitute and decree, that no Deacons or Ministers be ordained and made, but only upon the Sundays immediately following Jejunia quatuor temporum, commonly called Ember Weeks, appointed in ancient time for prayer and fastingpurposely for this cause at their first institution-and so continued at this day in the Church of England.

In the early Church there were at first no fixed times for Ordinaton, Gelasius (492-496) being the first to fix definite seasons, these being chosen from the solemnity attaching to them.

III. Rogation Days.-These, on the three days immediately preceding Ascension Day, had their rise in Gaul in the middle of the fifth century, being instituted by Mamertus, bishop of Vienne in Dauphiné, c. 470. The story of their institution, as told by his contemporary Sidonius, is that the city of Vienne was terrified by calamities, and to atone for the sins which were thought to have occasioned them Mamertus ordered a three days' fast with processions and rogations. The example of Mamertus was followed by other bishops, and the practice soon spread throughout Gaul ; and by the Council of Orleans, 511, was enjoined on the whole Gallican Church (canon 27).‡ From

* The term 'Statio' is applied by Tertullian ('De Jejun.,' 14) to the fasts of Wednesday and Friday. See below, p. 56.

$\dagger$ 'Antiq.,' xxi. 2, 1.

† 'Rogationes id est litanias ante ascensionem Domini ab omnibus occlesiis placuit colebrari.' 
Gaul it evidently spread early to England, since at the Council of Cloveshoo, 747, it is ordered that the Litanies, that is Rogations, be kept . . according to the custom of our ancestors, on the three days before our Lord's ascension into heaven.'*

The Rogation Days were not introduced into Rome till the time of Leo III (795-816).

By the Injunctions of Elizabeth, 1559, the Litany was substituted for all processions save at the beating of the bounds $\dagger$; and in the Second Book of Homilies there is a homily by Archbishop Parker for the Days of Rogation Week, $\ddagger$ followed by 'An exhortation to be spoken to such parishes where they use their perambulation in Rogation Week for the oversight of the bounds and limits of their town.'

There is no office for Rogation Days in our Prayer Book. At the revision of 1661 Cosin proposed the following Collect :-

Almighty God, Lord of heaven and earth, in whom we live, move, and have our being, who doest good unto all men, making thy sun to rise on the evil and on the good, and sending rain on the just and on the unjust; favourably behold us thy people, who do call upon thy name, and send us thy blessing from heaven, in giving us fruitful seasons, and filling our hearts with food and gladness; that both our hearts and mouths may be continually filled with thy praises, giving thanks to thee in thy holy Church, through Jesus Christ our Lord. Amen. with James v. 13-18 as Epistle, and Luke xi. 1-10 as Gospel.

IV. The Friday Fast.-Amongst the Jews the special days of the week devoted to fasting were Monday and Thursday (Luke xviii. 12). For these days Christians substituted Wednesday and Friday, and to this practice there is reference in the Didache (viii. 1) - ' Let not your fasts be together with the hypocrites, for they fast on the second and fifth days of the week ; but keep ye your fast on the fourth day, and the preparation (Friday).' In the Pastor of Hermas $\$$ mention is made of fasts under the name of 'stations,' and Tertullian ('De Jejun.,' 14) applies this term to the Wednesday and Friday fasts, which were semi-jejunia, or ' half fasts' lasting till the middle of the afternoon. The term 'stations' may have been taken from military

* Similar Rogations existed in the Mozarabic rite in Sept., Nov., and Jan.

† Gee and Hardy, 'Documents, etc.,' p. 426.

† The homily is divided into three parts, the first of which sets forth ' the goodness of God in the ereation of this world, with all the furniture thereof, for the use and comfort of man.'

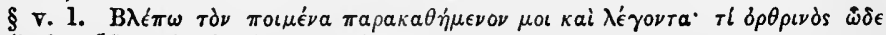

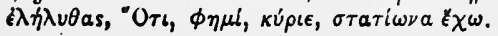


language, St. Ambrose in one of his sermons saying, ' Our fasts are our encampments which protect us from the devil's attack; in short, they are called stationes, because standing (stantes) and staying in them we repel our plotting foes'*; or it may be that the fast was called ' statio' from being kept on stated days (statis diebus). It is said that the Wednesday and Friday fasts were introdüced into the Northumbrian Church by St. Aidan, 635. $\dagger$ We preserve a trace of the Wednesday fast in our P.B. in the recitation of the Litany on Wednesdays.

\section{iv. A Solemn Day for which a Particular Service is APPOINTED.}

The Sixth day of May being the day on which his Majesty began his happy reign.

There is no Act of Parliament enjoining the observance of the Days of Accession ; but they have been observed with special Prayers in every reign since the Reformation. No mention of the observance of such a day was made in the Prayer Book until late in the eighteenth century.

The three Offices given below were in the 1662 P.B. But they were not in the Book when enacted by Parliament, and were annexed only by the sanction of Convocation and the Crown. They were all removed in 1859 by a Royal Warrant, that is to say, by the same authority which originally inserted them.

[Certain Solemn Days, for which Particular Services are APPOINTED.

1. The Fifth day of November, being the day of the Papists' Conspiracy.

2. The Thirtieth day of January, being the day of the Martyrdom of King Charles the First.

3. The Ninth and twentieth day of May, being the day of the Birth and Return of King Charles the Second.]

v. Tables to Find Easter and Other Moveable Feasts.

1549. None were given.

1552. An Almanack for xix years.

1559. An Almanack for $\mathrm{xxx}$ years.

1604. An Almanack for xxxix years.

To find Easter for ever.

1662. A Table of the Moveable Feasts calculated for forty years. To find Easter for ever.

* Serm. 25. See too Tertullian, 'De Corona,' xi.

† Bright, 'Early Eng. Ch. Hist.,' ii. p. 146. 
Since 1751 , by the authority of 24 George II.c. $23,{ }^{*}$ the present eight Tables for finding Easter were substituted for the above-named two Tables of 1662 .

By 'Full Moon' is meant the 14th day of the calendar moon. Here it will be convenient to define certain technical expressions which are necessary for the elucidation of the tables for finding Easter Day.

(i) The Golden Number, so called from the great value attached to them, signifies the year of the Cycle of the Moon. This cycle extends for a period of 19 years, the number of each year being indicated by the Roman numerals I, II, III, $\uparrow$ etc.

(ii) The Sunday or Dominical Letters are the first seven of the alphabet, viz. A, B, C, D, E, F, G, which embrace the space of a week, and they are used in the Calendar for the purpose of determining the Sundays of every year. The Letter for January 1 is always A ; January 2, B ; January $3, \mathrm{C}$, and so on; the seven letters being repeated every week. Therefore, if January 1 be a Sunday, as it was in the year 1911, the Sunday letter is A for the whole year. If January 2 be a Sunday, then B is the Sunday Letter for the year, etc.

N.B.-In leap years there are two Sunday Letters (see below).

(iii) The Epact: the number indicating the excess of the common solar year above the lunar one. The lunar year is shorter than the solar one by eleven days, and this difference runs through every year of the lunar cycle. It follows that if a new moon fall on January 1 in any year, on the first of January in the next year the moon will be eleven days old. The number 11 is therefore the epact of that year; for the following year it would be 22 , and for the succeeding year itwould be 33 if the moon could be so

* The following is the quotation from the Act: ' $\mathrm{Be}$ it therefore further enacted by the authority aforesaid, That the said feast of Easter, or any of the moveable feasts thereon depending, shall, from and after the second day of September [1751], be no longer kept or observed in that part of Great Britain called England, or in any other the dominions or countries subject or belonging to the crown of Great Britain, according to the said method of supputation now used, or the said Table prefixed to the said book of common prayer; and that the said table, and also the column of golden numbers, as they are now prefixed to the respective days of the month in the said calendar, shall be left out of all future editions of the said book of common prayer; and that the said new calendar, tables and rules, hereunto annexed, shall be prefixed to all such future editions of the said book, in the room and stead thereof.'

+ In the Calendar (from March 21 to A pril 18) the notation is Arabic. 
old ; but as it cannot go beyond 30 the epact is $33-30=3$. The epact of the following year is 14 ; and so on till the last year of the cycle, the epact of which is 18. As only 29 days are to be reckoned for the last month of the last year of the cycle, the next cycle begins with 0 as before.

N.B.-This is the general Rule for finding the Epact. But owing to the Solar and Lunar Equations the Epacts are, in the course of centuries, subject to change.

(iv) The Paschal limits are the earliest and latest dates (March 21 and April 18) upon which the Paschal Full Moon occurs : consequently the earliest day on which Easter Day can fall is March 22 and the latest April 25.

\section{FOR LIMITED PERIODS.}

(a) Two Tables to find Easter till the year 2199 inclusive.

A Table to find Easter Day from the Present Time tILl the Year 2199 inclusive ACCORDing to Foregoing Calendar.

This table, as will be seen, is divided into three columns. The first column contains the Golden Numbers; the second, the days of the month from March 21 to April 25 inclusive; the third column contains the Sunday letters. The following is the explanation as to how to use the Table.

\section{1st. Find the Golden Number or Prime.}

\section{Rule-}

Add 1 to the Year of our Lord, and then

Divide by 19 :

The remainder, if any, is the Golden Number;

but if nothing remaineth, then 19 is the Golden Number.

Ex. Find the Golden Number for A.D. 1912.

$$
\frac{1912+1}{19}=100 \text { and } 13 \text { over. }
$$

Therefore 13 is the Golden Number.

\section{2nd. Find the Dominical or Sunday Letter.}

\section{Rule-}

Add to the Year of our Lord its Fourth Part, omitting Fractions, and also the number 6 .

Divide the sum by 7 .

And if there is no Remainder, then A is the Sunday Letter. But if any number remaineth, then the Letter standing against that Number in the annexed Table is the Sunday Letter. 


\begin{tabular}{|l|l|}
\hline 0 & $\mathrm{~A}$ \\
1 & $\mathrm{G}$ \\
2 & $\mathrm{~F}$ \\
3 & $\mathrm{E}$ \\
4 & $\mathrm{D}$ \\
5 & $\mathrm{C}$ \\
6 & $\mathrm{~B}$ \\
\hline
\end{tabular}

Ex. Find the Sunday Letter for A.D. 1912.

$$
\frac{1912+\frac{1912}{4} \text { (omitting fraction) }+6}{7}=\frac{1912+478+6}{7}=\frac{2396}{7}
$$

As in the above Table, 2 is in line with $\mathrm{F}$,

$$
=342 \text { and } 2 \text { over. }
$$

therefore $\mathbf{F}$ is the Sunday Letter.

3rd. Find by the Table the Date of Easter for A.D. 1912. Rule-

Look for the Golden Number of the year in the first column of the Table, against which stands the day of the Paschal Full Moon :

Then look in the third column for the Sunday Letter, next after the day of the Full Moon,

and the day of the Month standing against that Sunday Letter is Easter Day.

If the Full Moon happens on a Sunday, then the Sunday

\begin{tabular}{|c|c|c|}
\hline $\begin{array}{l}\text { Golden } \\
\text { Number. }\end{array}$ & $\begin{array}{l}\text { Day of } \\
\text { the Month. }\end{array}$ & $\begin{array}{l}\text { Sunday } \\
\text { Letter. . }\end{array}$ \\
\hline $\begin{array}{c}\text { XIV } \\
* \\
* \\
\text { XIII }\end{array}$ & $\begin{array}{cc}\text { March } & 21 \\
* & \\
* & \\
\text { April } & 1 \\
& 2 \\
& 3 \\
& 4 \\
& 5 \\
& 6 \\
& 7 \\
* & 8 \\
* & 9\end{array}$ & $\begin{array}{l}\text { G } \\
\text { A } \\
\text { B } \\
\text { C } \\
\mathrm{D} \\
\mathrm{E} \\
\mathbf{F} \\
\mathbf{G} \\
\mathbf{A}\end{array}$ \\
\hline
\end{tabular}
after is Easter Day. 
Ex. The Golden Number for 1912 being 13 (XIII) and the Sunday Letter, $\mathbf{F}$.

Therefore by rule above April 7 is the date of Easter for 1912.

N.B.-Had April 2 been a Sunday then Easter Day would have fallen a week later, namely, April 9.

Note. - That in all Bissextile or.Leap Years the letter found, as above, will be the Sunday Letter from the intercalated day (i.e.the 29th of February) exelusive to the end of the year.

Ex.-The above year 1912 is a leap year. "If it had been an ordinary year the letter would be $\mathrm{G}$, but owing to its being a leap year an extra letter has to be used, and G F are the Sunday letters, G being the letter up to and including February 28 and F from February 29 (the interealated day) to the end of the year.

\section{Anotier Table to find Easter till the Year 2199 INCLUSIVE.}

This Table does not give (like the other one) the date of the Paschal Full Moon, but simply that of Easter Day, and is easily formed from the above Table.

In order to work this Table :-

(1) Find by aid of foregoing Table the Golden Number and the Sunday Letter, and then

(2) Look for the Date of Easter Day, and in doing so be careful to- Note, that the Name of the Month is set on the Left Hand, or just with the Figure, and followeth not, as in other Tables, by Descent. (i.e. vertically), but Collateral (i.e. horizontally).'

Thus if the Golden Number is V, and the Sunday Letter F, then April 7 is Easter Day.

If the Golden Number is XVII; and the Sunday Letter F, then Easter Day is not March 21 but April 21.

(b) Tables of the Moveable Feasts.

(a) A Table of the Moveable Feasts

For Fifty-one Years

According to the Foregoing Calendar.

This Table speaks for itself and saves the reader the trouble of working for himself the dates when the Moveable Feast will fall for a period of fifty years.

(b) A Table of the Moveable Feasts, according to the Several Days that EASTER CAN POSSIBLy FALL UPON.

The Note at foot of the Table is of importance, as the effect produced by the intercalated day (February 29) explains the 
reason of the alterations notified to be made in the Table in Leap Year; for until March 1 each day is one farther removed from Easter than would be the case in the year of 365 days.

(c) Table to find Easter from the year 2200 to 2299 inclusive.

Table to find Easter Day

From

The Year 2200 to the Year 2299 Inclusive.

This Table is worked in the same way as that of "A Table to find EasterDay from the present time till the year 2199 inclusive.'

\section{FOR ANY PERIOD.}

General Tables for Finding the Dominical or Sunday Letter, and Places of the Golden Numbers in the Calendar.

\section{TABLE I.}

By the aid of this Table you can find the Sunday Letter not only as in foregoing tables up to 2199 , but from 1600 for ever.

Rule-

Add to the year

Its Fourth Part, omitting Fractions, and also

The Number which standeth at the Top of the Column, wherein the Number of Hundreds contained in that given Year is found;

Divide the sum by 7 , and

If there is no Remainder then $\mathbf{A}$ is the Sunday Letter, but If any Number remaineth,

Then the Letter, which standeth under that Number at the Top of the Table, is the Sunday Lettor.

(a) Ex. Find the Sunday Letter for A.D. 2300.

$$
\frac{2300+\frac{2300}{4}+3}{7}=\frac{2878}{7}=411 \text { and } 1 \text { over. }
$$

Therefore the Sunday Letter is G.

(b) Ex. Find the Sunday Letter for A.D. 3723.

$$
\frac{3723+\frac{3723}{4} \text { (omitting fraction) }+0}{7}=\frac{4653}{7}
$$

Therefore the Sunday Lettor is C. 
TABLE II.

Tables II. and III. enable one to find the Month and Days of the Month to which the Golden Numbers ought to be prefixed in the Calendar, in any given Year of our Lord.

Rule-

For the given Year consisting of entire Hundreds,

Look in the second Column for the given Year consisting of. entire Hundreds, and

Note the Number or Cypher which stands against it in the third column.

Ex. What is the Adjusting Number for A.D. 3723 ?

3723 comes in the entire hundreds of 3700 , against which 9 stands in the third column. Therefore 9 is the 'adjusting' number, owing to the Solar and Lunar equations, by which with the aid of the next table the date may be found to which the Golden Number is to be prefixed.

\section{TABLE III.}

This table is now easily worked.

Rule-

Look for the 'adjusting number' in the Column under any given (or required) Golden Number, which when you have found,

Guide your eye sideways to the Left Hand, and in the first column you will find the Month and Day to which that Goden Number ought to be prefixed in the Calendar during that period of One Hundred Years.

Ex. Find the Month and Day of the Month to which the Golden Number ought to be prefixed for A.D. 3723 .

First, find the Golden Number.

$$
\frac{3723+1}{19}=196 \text {, and nothing over. }
$$

Therefore 19 is the 'Golden Number.'

And as we found above

$\mathrm{C}$ is the Sunday Letter, and

9 is the 'Adjusting Number'.

We have now to look for the Golden Number 19 in the top line, and run our eye down till we find 9, and guiding our eye sideways we come to April 3.

Therefore April 3 will be the date of the Paschal Full Moon in A.D. 3723, and so this is the date to which the Golden Number XIX must be prefixed. And as C is the Sunday Letter we find by aid of the second vertical column that April 4 will be Easter Day in A.D. 3723. 


\section{THE CALENDAR,}

\section{WITH THE TABLE OF LESSONS.}

The word 'Calendar' is derived from the Latin calendarium, meaning an account book of interest due to a money-lender, and was so called from the interest being due on the calends (calendas) of each month. In ordinary language it means a register of the days of the year by weeks and months showing the various civil and ecclesiastical holidays, festivals, etc.

In early Christian Calendars we find that the saints commemorated were almost entirely those of local martyrs *; and the commemoration was on the date on which they had actually suffered (cf. Cyprian, 'Epp.' xii. 2). Each Church and each district had its own Calendar, and as time went on there were added to the list of local martyrs names of others who, though not belonging to the particular district or Church, had attained pre-eminent distinction. $f$ In this way the Calendars were continually being added to ; in many the same day would often commemorate several saints; and in our own land the number of minor-saints' days before the Reformation had become excessive, interfering with agriculture and trade, and tending to the impoverishment of the labourers. $\neq$

From early times candidates for ordination were required to have a knowledge of the Calendar, and in the Capitulare Interrogationis of Charlemagne (811 A.D.) we find it enjoined, with a view to the due supply of qualified candidates, 'ut scholæ legentium puerorum fiant, psalmos, notas, cantum, computum ... discant.' $\S$

The Roman Calendar was adopted in England by the Council of Cloveshoo, 747 A.D. But the English Church added from time to time the names of her own saints, and at Cloveshoo itself the names of Augustine of Canterbury and Gregory were added. It was not till 1161, when Edward the Confessor was canonised, that the papal authority was exercised when new additions were proposed.

With the exception of two names, $\|$ Evurtius and Bede, our

* From Eusebius, 'H. E.,' iv. 15, we gather that the anniversaries of martyrs were kcpt from the first.

$f \mathrm{Cp}$. e.g. the inclusion of Perpetua and Felicitas in the Liberian Martyrology (the earliest Roman, c. 354 A.D.). In the Carthaginian Calendar (c. 500 A.D.) several Roman martyrs are commemorated.

$\ddagger$ See Tomlinson, 'The Prayer Book, Articles and Homilies,' pp. 1-3.

$\S$ Sce Maskell, 'Monumenta,' i. pp. cxx. cxxi.; also jii. pp. xvi. 224. for examples of rerses on the Calendar meant to assist the memory.

|f See below, p. 66. 
present Calendar is identical with that issued in 1561, the source of which was the Calendars of the Sarum Missal and Breviary; and with three exceptions (Alban, Mary Magdalene, Cyprian of Carthage) the commemorations common to both are identical in date. In the Sarum Calendar we find Roman influence predominant; many additions to be traced to Gallican influence, and many also to English local interest.*

\section{History of the Calendar since the Reformation.}

The main facts are brought together here under their respective dates.

1532. A petition of the Commons, drafted by Cromwell, is presented to the King, complaining of the excessive number of holy-days and praying that they. " might be made fewer in number.' $\dagger$

1536. Convocation declared that the number of holy-dajs was" the occasion of much sloth and idleness ... pernicious to the souls of many men who ... do upon the same commonly use and practice more excess riot and superfluity than upon any other days,' and many were consequently abolished. No feasts were to be kept in harvest time except feasts of the Apostles and Our Lady; and the feast of every church's dedication was to be observed on the first Sunday in October.

1549. In the first Prayer Book of Edward VI. all the blackletter saints were swept away except Magdalen (July 22), which was made a red-letter day with Collect, Epistle and Gospẹl.

1552. In the second Prayer Book of Edward VI. the names of George, Lawrence and Clement are added, together with 'Lammas,' the 'Dog Days' $\ddagger$ and 'Term' days. Mary Magdalene as a red-letter day disappeared.

1559. 'Barnabe Ap.' which had been omitted per incuriam in the Calendar of 1552, though recognized in the body of the Prayer Book, reappears.

1561. Elizabeth directed the Royal Commissioners for Ecclesiastical Causes to draw up a new Calendar. The blackletter days contain all but three (Bede, Alban, Evurtius) of our present list. The Calendar was preceded by a table of feasts, headed 'these to be observed for holy days, and none other.' $\S$

* See Frere, ' Graduale Sarum,'pp. xxii.-xxx.

† See Gee and Hardy, 'Documents illustrative of Eng. Ch. Hist.,' p. 150.

$\ddagger$ i.e. the period during which the dog-star rises and sets with the sun.

$\S$ See 'Liturgical Services (Elizabeth),' Parker Society, pp. 435-455. 
1604. Eunurchus (Evurtius) was added on September 7; taking the place formerly occupied by the birthday of Queen Elizabeth.

1661. Two names were added, Bede (May 27) and Alban (June 17). These came from the Preces Privatæ, a devotional manual issued in $1564 .^{*}$ The fuller descriptions (in some cases erroneous) were taken possibly from Cosin's 'Devotions' (1627).

\section{Saints' Days and Calendar Holidays.}

In the Calendar certain days are marked in red, and these ' red-letter days,' which are dealt with above, $\dagger$ are those which are kept holy by a special service for which Collect, Epistle and Gospel are provided. The principles on which these days are selected seem to have been

(1) the desire to commemorate no person or event unrecorded in Holy Scripture;

(2) the desire to celebrate those festivals only which were of known antiquity.

The tests were not carefully applied, and it is difficult to understand why certain central events of the Gospel-even if their celebration was comparatively late--were not included. $\$$

Other days in the Calendar are marked in black, and are known as 'black-letter days.' They may be grouped thus § :-

\section{A. Biblical :-}

(i) Visitation of the B.V.M. (July 2). Commemorates the visit of Mary to Elizabeth before the birth of the Baptist. Instituted by Urban VI, 1389, and again established by the Council of Basle, 1441. Adopted in England in 1480.

(ii) St. Mary Magdalene (July 22). "The Ointment-Bearer and equal of the Apostles' (Byzant. Cal.). Commemorated by the Greek Church also on this day.

(iii) The Transfiguration (August 6). Was observed locally from an early date, but its general observarce was not enjoined till 1457 by Calixtus III after the victory over the Turks at Belgrade.

* Sec 'Private Prayers (Flizabeth),' Parker Society, pp. 209-428. The Calendar prefixed to these was a very full one, only six days in the year being racant.

$\dagger$ pp. 43 , ff.

I In the Book Annexed of the American Protestant Episcopal Church the Transfiguration of Christ is replaced as a red-letter day (August 6) with Collect, Epistle (2 Pet. i. 13-18), and Gospel (Luke ix. 28-36).

$\$$ For this classification are indebted to a $16 \mathrm{pp}$. pamphlct, 'Minor Holy Days of the Church of England,' without date, name of author or publisher. The latest literature mentioned is dated 1901. 
(iv) Beheading of John the Baptist (August 29). A festival of early date, found in the Gelasian and in some forms of the Gregorian Sacramentaries.*

B. Roman :-

(a) Those belonging to Rome itself:-

(i) Prisca (January 18). Legendary, about the time of Claudius. Said to have been a child martyr; but legend rejected as untrustworthy by Pope Gelasius in 494 . Possibly reminiscent of Priscilla, wife of Aquila (Rom. xvi. 3).

(ii) Fabian (January 20). The well-known Bishop of Rome (236-250), martyred in the Decian Persecution. His epitaph, in Greek, is in the Catacomb of Calixtus. One of the four popes commemorated in our Calendar, the others being Gregory, Clement, and Silvester.

(iii) Agnes (January 21). Martyred 304. Jerome writes of her, "In the writings and tongues of all nations the life of Agnes is praised in the Churches . . . who overcame the tyrant and consecrated her chastity by martyrdom.'

(iv) Gregory (March 12). Known as ' the Great.' 'Apostolus Anglorum.' Pope, 590-604. Added to English Calendar 747 (Council of Cloveshoo).

(v) St. John Ev. ante Port. Lat. (May 6). Commemorates the story, as old as Tertullian ('De Præsc.,' xxxvi), of St. John's having been thrown before the Latin Gate at Rome into a cauldron of boiling oil by order of Domitian, and escaping unhurt. A Church was at a later period erected on the site. In an old English Calendar, printed by Maskell (iii. 188, f.) the entry reads 'St. John at brason gate,' a curious mistranslation of Latina, latten being a soft mixed metal well known in the Middle Ages.

(vi) Nicomedo (June 1). Said to have been martyred under Domitian. The date marks the dedication of a Church to his memory at Rome.

(vii) Laurence (August 10). A Spaniard, archdeacon to Sixtus II and as such gained a great reputation as the administrator of the charities of the Church at Rome. Martyred in 258, three days after Sixtus, by being slowly roasted to death.

(viii) Clement (November 23). The carly Church Father,

* For some intcresting information on the Baptist's place in the Calendare see a letter of Dr. C. I. Feltoe in the Guardian, August 26, 1910. 
author of the letter to the Church at Corinth. 'Greek in speech, Jewish in training and patriotic memories, Roman in world-wide sympathy, in love of law and order, and in tact of ruling." It is doubtful if he is to be numbered among the martyrs.*

(ix) Silvester (December 31). Bishop of Rome, 314-335. His name is inseparably connected with the conversion of Constantine. "Silvester has become a kind of hero of religious fable' (Milman).

(b) Those connected with Italy or provinces adjacent:-

(i) Vincent (January 22). A deacon of Saragossa, martyred at Valentia, 304. Story of his martyrdom much mixed with legend.

(ii) Agatha (February 5). Martyred at Catana in Sicily in the Decian persecution.

(iii) Valentine (February 14). Bishop of Interamnis, where he was martyred c. 273. In the Gregorian Sacramentary there is commemorated on the same day a Valentine, priest and martyr at Rome under Claudius. $\dagger$

(iv) Perpetua (March 7). Martyred with Felicitas under Severus, 202. 'Perpetua and Felicitas' companions in perpetual felicity' (Augustine). The Acts of Perpetua one of the earliest authentic records of martyrdom.

(v) Ambrose (April 4). Bishop of Milan, 374-397. Commemorated on December 7 in the Byzantine Calendar, as also in Quignon's Breviary (1535).

(vi) Augustine (August 28). Bishop of Hippo, died in 430 . The most famous of the Fathers of the West.

(vii) Cyprian (September 26). Archbishop of Carthage, martyred under Valerian, 258. Inserted, or rather the description, on this date by the revisers of 1661 through an error. In the Sarum Calendar the Cyprian commemorated on this day is the converted magjinan of Antioch. The date of the martyrdom of Cyprian of Carthage is September $14, \ddagger$ which in our Calendar is marked off as Holy-Cross Day.

(viii) Lucy (December 13). Said to have been martyred at Syracuse in the Diocletian persecution. Her day regulates the December Ember Days.

* See Lightfoot, 'Clement of Rome,' i. 54.

$\dagger$ Mr. Simpson, in his 'Minor Festivals of the Anglican Calendar,' p. 52, takes this Valentinc to be the one commemorated in our Calendar. But we have no evidence that he was a Bishop.

$\ddagger$ See Wordsworth, 'Ministry of Grace,' pp. 397, 398. 


\section{French.}

The presence of these is explained when we remember that the English Calendar proper came from Rome by way of France.*

(a) Those connected with St. Denys and his time:-

(i) Evurtius (September 7). Appears correctly in the Sarum Calendar as Eunurchus. The present form is the perpetuation of printers' mis-spelling. $\dagger$ Said to have labourtd for twenty years as Bishop of Orleans, where he died c. 340 .

(ii) Faith (October 6). Martyred at Agen in Aquitaine towards the end of the third century. The crypt in St. Paul's Cathedral, London, is dedicated to her.

(iii) Denys (October 9). The patron saint of France, martyred at Paris, c. 286. The legend identifying him with Dionysius the Areopagite was widely accepted and led to the quarrel of Abelard with the monks of the convent of St. Denys in the twelfth century.

(iv) Crispin (October 25). Martyred at Soissons in the Diocletian persecution together with Crispinian. Both were sent from Rome to bring about the conversion of the Gauls, providing for their own necessities by following the trade of shoemakers.

(b) Those connected with the conversion of the Kelts by St. Martin :-

(i) Hilary (January 13). 'Hammer of the Arians.' Bishop of Poitiers, died 367.

(ii) Martin (November 11). Bishop of Tours, died 397. His translation to a Basilica dedicated to his honour (473) is commemorated on July 4.

(iii) Britius (November 13). Succeeded Martin, by whom he had been trained, as Bishop of Tours (397-444).

(c) Those connected with the conversion of the Franks:-

(i) Remigius (October 1). Bishop of Rheims, died c. 530. 'The Apostle of the Franks.' Baptized Clovis, 'the new Constantine' (Gregory Turon, 'H. F.,'ii. 31), who at the time of his conversion was the only Christian King in Europe.

(ii) Leonard (November 6). A disciple of Remigius, and founder of the monastery of Noblat, near Limoges. Died c. 56C.

* Dr. Collins, late Bishop of Gibraltar, advoeated the reform of the Calendar on the ground that as it stands it is too pre-eminently Galliean (Preface to Granger, 'Blaek-letter Saints,' 1910).

† See, however, Staley, 'Liturgieal Studies,' pp. 58-65. 
(d) Those connected with the later evangelization, especially of Eastern France:-

(i) Boniface (June 5). ' The Apostle of Germany.' Archbishop of Mentz. Born at Crediton in Devonshire. Martyred in Friesland, 775.

(ii) Giles (September 1). Abbot in Languedoc, died c. 725 .

(iii) Lambert (September 17). Bishop of Maestricht, martyred at Liège, c. 709.

D. ENGLISH.

(a) British :-

(i) David (March 1). The patron saint of Wales, died 601.

(ii) Alban (June 17). The protomartyr of Britain (303). The date is probably an error for June 22 (see Bede, 'H. E.,' i. 6, 7), which is the date assigned in the Calendars of the Hereford Missal and the York Missal.

(iii) Machutus (November 15). A Welshman who became Bishop of Aleth in Brittany, died c. 630. .

(b) Saxon :-

(i) Chad (March 2). ' The Apostle of the Midlands.' Bishop of Lichfield, died 672. See Bede, 'H. E.,' iv. 3.

(ii) Edward, King of West Saxons (March 18). Murdered at Corfe Castle by order of his step-mother Elfthryth, 978. His translation in 980 from Wareham to Shaftesbury is commemorated on June 20.

(iii) Alphege (April 19). Archbishop of Canterbury, martyred by the Danes, 1012.

(iv) Dunstan (May 19). Archbishop of Canterbury, 960-988.

(v) Bede (May 27). The only festival not in the proper Sarum Calendar. He led 'the scholar's uneventful life, spent ' in a round of religious service and of quiet study.' His 'Ecclesiastical History ' was completed in 731, four years before his death. The title 'Venerable' was given about a hundred years later.

(vi) Swithun (July 15). Bishop of Winchester, 852-862. The date commemorates his translation into the Cathedral, 971.

(vii) Edward the Confessor (October 13). The title 'Confessor' is the general title for an ascetic in the old Roman service-books. He was canonised in 1161. His first translation took place on October 13, 1163 ; the second in 1269.

(viii) Etheldreda (October 17). The first canonised Englishwoman. Founder of the great convent at Ely. Died 679. 
(ix) Edmund (November 20). Last King of East Anglia. Murdered by the Danes, 870, and his body translated in 903 to Berdericswortha (Bury St. Edmund's).

(x) Gregory (March 12).* Bishop of Rome, 590-604. Sent Augustine in 596 to evangelize England. M. after his name $=$ Magnus.

(xi) Augustine (May 26). $\dagger$ Archbishop of Canterbury, 597604.

(c) Mediceval :-

(i) Hugh (November 17). Bishop of Lincoln, 1186-1200. Born in Burgundy, 1140, brought to England in 1182 to take charge of the Carthusian monastery at Witham. Canonised in 1220.

(ii) Richard (April 3). Bishop of Chichester, 1245-1253. The latest saint of our Calendar, canonised in 1260 .

E. EAstern.

Most of these came into the Calendar during the MiddleAges, and probably owed their popularity to the Crusades.

(i) Blasius (February 3). Bishop of Sebaste in Armenia, martyred c. 316. To be identified with the St. Blaise, patron of Pladay, in the Scotch Calendar.

(ii) George (April 23). A native of Cappadocia, martyred in the Diocletian persecution, 303 (?). Traditionally the patron saint of England. In the time of the Crusades Richard I. took him as his patron, but he was not formally adopted as patron saint of England till the time of Edward III., when from 1349 he replaced Edward the Confessor as patron.

(iii) Margaret (July 20). Said to have suffered at Antioch in Pisidia towards the close of the third century. Commemorated by the Greeks under the name of Marina on July 17.

(iv) Anne (July 26). Her name appears as the mother of the Virgin first in the Protevangelium Jacobi. Her festival became popular in England under the influence of Richard II.'s queen, Anne of Bohemia.

(v) Catherine (November 25). Said to have been martyred at Alexandria under Maximin (308-312).

(vi) Nicolas (December 6). Bishop of Myra in Lycia at the time of the Diocletian persecution.

In addition there are some entries in the Calendar which do not admit of classification under any of the above heads:-

- Seo p. $67 . \quad$ T Soo p. 68. 
(i) Invention of the Cross (May 3). An old festival, of Palestinian origin, appearing in the Gelasian Sacramentary on this day.* The word 'invention' means 'finding' (Lat. inventio), and the name describes the tradition of the finding of the Cross by the Empress Helena in 326 (Cyril, 'Ep. ad Const.,' iii.).

(ii) Lammas Day (August 1). The word 'Lammas' is AngloSaxon meaning 'Loaf-mass,' and the day takes its name from the offering on August 1 of loaves made from the new corn. $f$ The festival is also called St. Peter ad Vincula, commemorating the release of the Apostle (Acts xii.), the date August 1 having reference to the dedication of a Roman church in memory of it and where the chains of St. Peter were said to be preserved. $\ddagger$

(iii) Name of Jesus (August 7). Origin of the festival unknown, but it was already in use in England when specially sanctioned by Alexander VI. (1493-1503).

(iv) Nativity of Virgin Mary (September 8). Said to have been established by Sergius I. in 695. It is unknown how the date September 8 was arrived at.

(v) Holy Cross Day (September 14). The dedication festival of the two churches built at Jerusalem by Constantine in 335. The day was believed in Jerusalem to be that of the discovery of the true Cross by Helena. The festival was not introduced into the West till the seventh century, and celebrates the restoration of the relic of the cross by Heraclius in 629. The day regulates the September Ember Days.

(vi) Conception of Virgin Mary (December 8). Seems to have originated in the East. Appears in the West about the beginning of the twelfth century.\$

(vii) 0 Sapientia (December 16). The words represent the opening words of the first of a series of seven antiphons to the Magnificat sung in the West, in connexion with the Spanish Festival of the Annunciation, from this day to Christmas Eve. The antiphons each begin with ' $O$,' and the one under consideration runs, ' $O$ Sapientia quæ ex ore Altissimi prodisti, attingens a fine usque ad finem, fortiter suaviterque disponens omnia ; veni ad docendum nos viam prudentiø.' (Ecclus. xxiv. 3 ; Wísd. viii. 1.)

- Seo Duchesne, 'Christian Worship,' iii. pp. 274, $f$.

+ See Oliphant, "Old and Middle English,' pp. 122, $f$.

I The festival of the pre-Christian martyrs, the Maccabees, was univerally observed about the fifth century on August 1.

I See Dowden, 'Churoh Year and Calendar,' pp. 52-56. 
The Irish Church and the Protestant Church of America* have abolished all black-letter days. The motives which underlay their retention in our Calendar may be gathered from the declaration of the Bishops at the Savoy Conference-' the other names are left in the Calendar, not that they should be so kept as holy days, but they are useful for the preservation of their memories, and for other reasons, as for leases, law days, etc.' + The Church of England does not consider these days as " minor festivals,' for they are deliberately excluded from 'the table of all the feasts to be observed in the Church of England throughout the year,' and there are no special services appointed for them.

The student will have gathered from what he has read above, that the Calendar of the English Church contains the names of many legendary saints, of many who have no particular connexion with the history of our Church, of many who attained no more than local celebrity, and that the omissions of names who have exercised a beneficent influence on English religious life and thought are a serious drawback if we are to continue to commemorate persons and events outside Holy Scripture. Various proposals have been suggested from time to time for the reform of the Calendar, the most important, of recent years, being that of Dr. John Wordsworth, who lays down the following considerations for guidance and has himself drawn up a Calendar in accordance with the suggestions $\ddagger$ :-

(1) 'The desire to bring out any prominent points in the mystery of Redemption that may have been omitted.

(2) To introduce or re-introduce commemorations which may emphasize and foster the sentiment of true Catholicity.

(3) To add what may be necessary to keep in memory the blessings of our own branch of the Church.

(4) To omit commemorations which are of little or no importance or necessity, so as to make what remain of greater interest and to insure that they should be taken seriously.'

- But see note on p. 50.

† Cardwell, 'Conferences,' p. 341. See also Wheatley, 'Rational Illustra. tion,' pp. 55, f. (ed. 1825).

t Wordsworth, 'Ministry of Grace,' pp. 421-438. 
Dates when Names were placed in the Calendar.

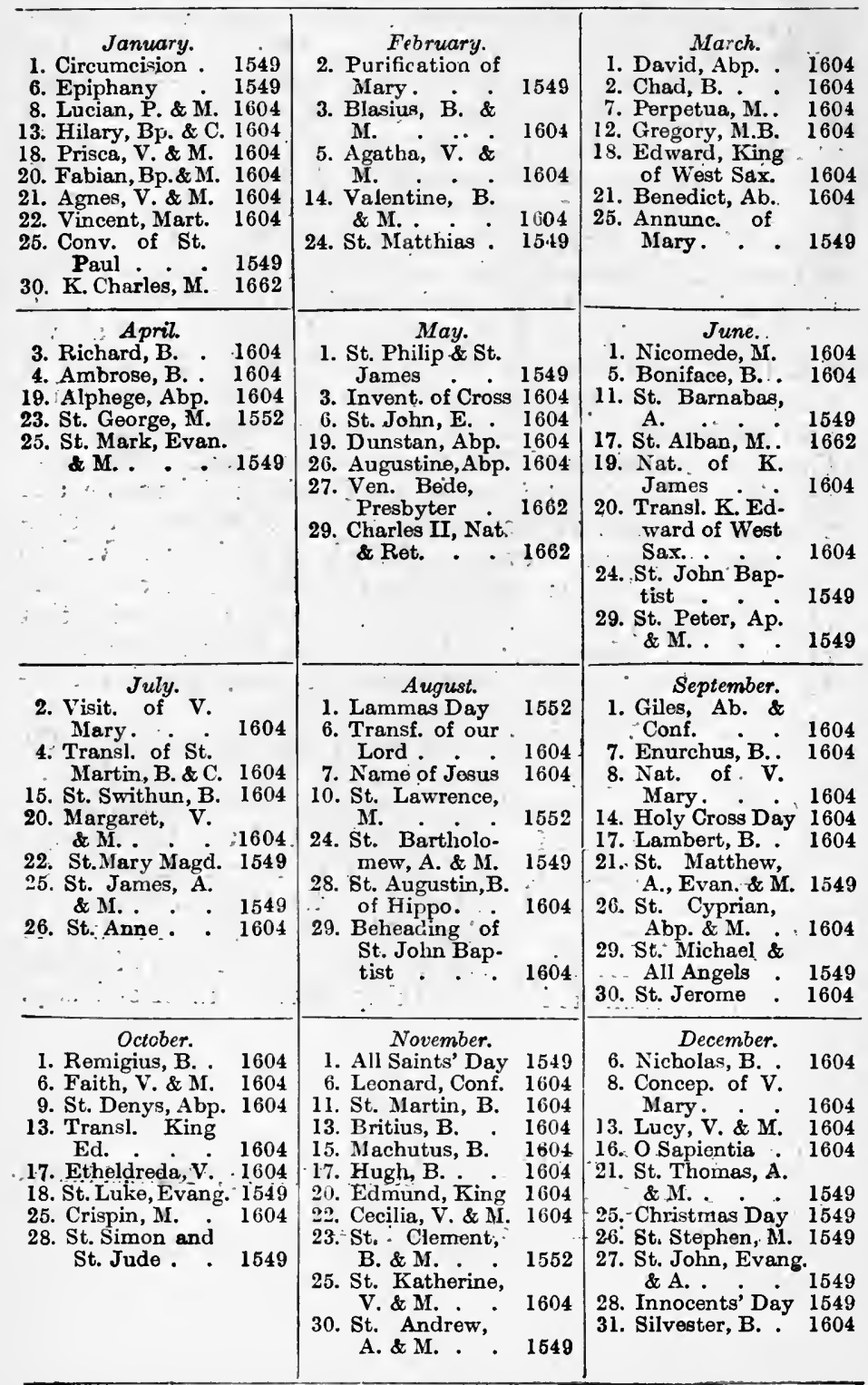


Use of Calendar in finding the Feasts.

In the second column the Calendar (or Sunday) letter is given; and in an outside line to the first column in the Months of March and April the Golden Numbers appear, the positions of which change in the course of centuries. Their present positions will continue until 2199 inclusive. Consequently for this period by the aid of this Calendar both the Paschal Full Moon and Easter Day and all the other Moveable Feasts can readily be fixed. 


\section{THE ORDER FOR MORNING AND EVENING PRAYER}

\section{DAILY TO BE SAID AND USED THROUGH- OUT THE YEAR}

\section{PREFATORY RUBRICAL DIRECTIONS}

These two rubrics, with a special heading, appeared first in 1552 , and present grave problems. They relate to the place where Morning and Evening Prayer are to be read, and to the 'ornaments of the Church, and of the Ministers thereof' to be used at all times of their ministrations, and not only at Morning and Evening Prayer. They were not printed on a separate page in 1552 .

\section{Heading.}

1552. The Order where Morning and Evening Prayer shall be used and said. Scottish Book, 1637: 'where and how': 'said or sung.'

1662. The Order for Morning and Evening Prayer daily to be said and used throughout the Year.

The substitution of 'for' for 'where' makes the heading slightly more general, but the directions in all editions cover other services besides Morning and Evening Prayer. The addition, 'daily ... throughout the Year', refers rather to the services than to the minister, whose duty in respect of their daily use is found in the penultimate clause of the 'Preface concerning the Service of the Church' (see p. 25).

First Rubric, concerning the place where Morning and Evening Prayer are to be read.

[1549. Though there was no corresponding rubric until 1552 the 'priest' is directed at the commencement of 'Matins' to begin that service 'in the quire.'] 
1552. The Morning and Evening Prayer shall be used in such place of the Church [i.e. the body of the Church], chapel, or Chancel, and the Minister shall so turn him, as the people may best hear. And if there be any controversy therein, the matter shall be referred to the ordinary, and he or his Deputy shall appoint the place, and the Chancels shall remain, as they have done in times past.

1559. The Morning and Evening Prayer shall be used in the accustomed place of the church, chapel, or Chancel; except it shall be otherwise determined by the Ordinary of the place; and the chancels shall remain, as they have done in times past.

1662. The last clause, already separated by a colon in 1559 , became completely separate, a full stop being put after 'place,' and ' and ' commencing with a capital, while the statutory comma after ' remain' dropped out, doubtless owing to its unauthorized absence from the printed folio copy of 1636 , employed in the 1662 revision.

This rubric enshrines the history of a division of opinion amongst the Reformers as to the wisdom of retaining the chancels, i.e. the part of the church behind the screen (cancelli). Bucer and Hooper argued strongly for their removal, but Cranmer found them useful as a place where the communicants might gather, to the exclusion of non-communicants. He therefore counselled their retention, explicitly directing their use at Morning and Evening Prayer to be no longer the rule, as in 1549, but contingent upon convenience for hearing.

The omission in 1559 of this regulation as to convenience for hearing is in conflict with 1 Eliz. c. 2 (3), which re-enacted the 1552 Book with three specified exceptions, which included neither this rubric nor the one which follows. The author of the alterations is unknown, but it is conjectured that Elizabeth herself was responsible. The alterations, by whomsoever made, were disregarded, many Episcopal Visitation Articles being extant dating from 1571 to 1622 , in which the question is asked : 'Whether your Minister so turn himself and stand in such place of your church or Chauncell as the people may best hear the same': the very words of the 1552 rubric being used. The substitution of the vague phrase 'the accustomed place' is intelligible as characteristic of Elizabeth's temporizing policy, but its applicability after the suspension of the Prayer Book during the reign of Mary is hard to see. The same criticism applies to its re-enactment in 1662, when the still longer supersession of the Prayer Book had left no 'accustomed place' 
for Moming and Evening Prayer. 'The omission of the 'deputy,' in 1559, is more intelligible ; it was not Elizabeth's way to commit authority to many hands, especially in matters involving ecclesiastical disputes.

The curious separation of the last clause of the rubric, until in $\mathbf{1 6 6 2}$ it became a separate sentence, has led some to suppose that it referred to the condition of the chancels and not to their existence. Apart from the history of the case, which makes such an interpretation impossible, the original comma after 'remain' shows that the emphasis is upon that word, and not upon the 'as' which follows. In 1662 that comma was omitted, but at that time there was no desire that the chancels should remain in the condition in which they had been 'in times past,' when the whole liturgy had been banished.

(See Tomlinson, 'Historical Grounds of the Lambeth Judgment,' 6th Edn., p. 24 : also Tracts on Ritual : No. 192.)

Second Rubric, concerning the 'Ornaments of the Church, and of the Ministers,' i.e. the articles and vesture requisite to the performance of the prescribed Services of the Church.

The prevalence of divergent opinions and practices in the Church, based almost exclusively upon the interpretation of this rubric, necessitates that even a brief comment shall contain some reference to the historical documents concerned, the legal decisions pronounced, and the various views propounded. As being the more prominent part of the subject under discussion, and as involving to a large extent the whole question as to Ornaments, the viesture of the Minister will be first considered, a brief summary of the legal position in regard to the Ornaments of the Church being appended.

\section{Ornaments OF the Minister.}

\section{Historical Documents.}

1549. The directions as to vestments in 1549 B.C.P., put forth 'by the authority of Parliament in the second year of the reign of King Edward the Sixth,' are the earliest of their kind after the repudiation of Papal authority. They are to be found:

(1) At the end of the Book, the first of 'certain notes for the more plain explication and decent ministration of things contained in this book'In the saying or singing of Matins and Evensong, Baptizing and Burying, the Minister, in parish churches and chapels annexed to the same, shall use a Surplice. And in all Cathedral Churches and Colleges, the Archdeacons, Deans, Provosts, Masters, Prebendaries, and Fellows, being Graduates, may use in the quire, beside their Surplices, such hoods as pertaineth to their several degrees, which they have taken in any university within this realm. But in all other places, every Minister shall be at liberty to use 
any Surplice or no. It is also seemly, that Graduates, when they do preach, should use such hoods as pertaineth to their several degrees.

And whensoever the Bishop shall celebrate the holy Communion in the Church, or execute any other public ministration, he shall have upon him, beside his rochette, a Surplice or albe, and a cope or vestment ; and also his pastoral staff in his hand, or else borne or holden by his chaplain.

(2) In the fourth Pubric at the beginning of the Communion Office,Upon the day, and at the time appointed for the ministration of the holy Communion, the Priest that shall execute the holy ministry, shall put upon him the vesture appointed for that ministration, that is to say, a white Albe plain, with a vestment or Cope. And where there be many Priests, or Deacons, there so many shall be ready to help the Priest, in the ministration, as shall be requisite; and shall have upon them likewise the vestures appointed for their ministry, that is to say, Albes, with tunicles.

(3) In the first Rubric at the end of the Communion Office.- Upon Wednesdays and Fridays ... though there be none to communicate with the Priest, yet these days (after the.Litany ended) the Priest shall put upon him a plain Albe or surplice, with a cope, and say all things at the Altar, (appointed to be said at the celebration of the Lord's supper) until after the Offertory. . . .

And the same order shall be used all other days, whensoever the people be customably assembled to pray in the Church, and none disposed to communicate with the Priest.

\section{Explanatory Summary :}

i. Bishops are to wear a 'vestment' (i.e. chasuble) or cope, and an alb or surplice, at all 'public ministrations.'* The sacrificial vestment is thus made permissible and not obligatory; and its special connexion with Holy Communion is no longer regarded so far as Bishops are concerned.

ii. The officiating Priest at Holy Communion is allowed to wear cope or chasuble, but must wear an albe and not a surplice. When there is no celebration, the Priest must wear a cope at Ante-Communion, over either an alb or a surplice. Assistant ministers at Holy Communion are, allowed no alternatives to the alb and tunicle.

iii. At Matins, Evensong, Baptizing and Burying, a surplice must be worn, the same vesture being prescribed for the use of Archdeacons, Deans, etc., 'in the quire' of Cathedral Churches and Colleges, the hood being permitted also, and recommended as 'seemly' for all Graduates when they preach.

iv. The vesture for Holy Communion is distinctive, save for Bishops, but the chasuble ceases to be obligatory.

v. There is no prescribed vesture for any ministers (except the Bishops) at the Litany, Matrimony, Commination, or Churching of Women; unless indeed the statement that 'in all other places (but Cathedral Churches and Colleges) every Minister

* The Ordinal, which followed the 1549 B.C.P., carried the idea of indifference to the chasuble so far as to abandon its use in the ()rdination of Priests. The accipe vestem sacerdotalem of the unreformed ordinal was entirely abandoned. 
shall be at liberty to use any surplice or no,' regulates the vesture at these services.

1552. These directions were superseded in the Second Prayer Book of Edward VI by the following rubric, placed at the head of Morning Prayer*:-

And here is to be noted, that the Minister at the time of the Communion, and at all other times in his Ministration, shall use neither Alb, Vestment, nor Cope ; but being Archbishop or Bishop, he shall have and wear a rochet ; and being a priest or deacon, he shall have and wear a surplice only.

Explanatory Summary :

All distinction between services is removed, and the dress of both Bishops and other clergy simplified by the direction of the use of the rochet, a lawn surplice with sleeves gathered in at the wrist, by the Bishop, and the surplice by a priest or deacon. The 1549 vestments, alb, chasuble and cope, are expressly forbidden.

1559. On the accession of Elizabeth the 1552 B.C.P. was restored by the Act of Uniformity, 1 Eliz. c. 2, which directs :

That all and singular Ministers in any Cathedral, or Parish Church, or other place within this Realm ... be bounden to say and use the Mattins, Evensong, Celebration of the Lord's Supper, and Administration of each of the Sacraments, and all their common and open Prayer, in such order and form as is mentioned in the sald Book, so Authorized by Parliament in the said flith and sixth Years of the Reign of King Edward the Sixth : with one alteration, or addition of certain Lessons to be used on every Sunday In the Year, and the Form of the Litany altered and corrected, and two Sentences only added in the delivery of the Sacrament to the Communicants, and none other, or otherwise.

\section{Explanatory Summary :}

The careful language of the last sentence, not only specifying the three alterations in the 1552 B.C.P., but excluding all other alterations, gives the same authority to the 1552 Ornaments Rubric as to the rest of the 1552 Book. It should be borne in mind that there was no Elizabethan Prayer-Book, strictly speaking; the Act simply re-established the 1552 B.C.P. But, in the same Act are two provisos, $\$ \S 25$ and 26 , the former directly, and the latter indirectly, bearing upon the Ornaments of the Church and its Ministers :

- These two rubrics appear on a separate page for the first time in printed copy of 1636, in which Sancroft notified the alterations in 1661. In his Durham Book, Cosin wrote a direction to the printer: 'Set the first title and ye 2 orders following on the other side, retro, with a fayre compartment before it.' to which is added in Sancroft's writing: ' and in Italic letters.' The appropriateness of this severance from the Orders for Morning and Evening Prayer is obvious, seeing that the same vesture was ordered for 'all times of their ministration' alike. 
$\S$ 25. Provided always, and be it Enacted, That such Ornaments of the Church and of the Ministers thereof, shall be retained, and be in use, as was in this Church of England, by Authority of Parliament, in the second Year of the Reign of King Edward the Sixth, until other Order shall be therein taken by the Authority of the Queen's Majesty, with the Advice of her Commissioners appointed and authorized under the Great Seal of England for Causes Ecclesiastical, or of the Metropolitan of this Realm.

$\S 26$. And also, that if there shall happen any Contempt or Irreverence to be used in the Ceremonies or Rites of the Church, by the misusing of the Orders appointed in this Book, the Queen's Majesty may, by the like advice of the said Commissioners or Metropolitan, ordain and publish such further Ceremonies or Rites as may be most for the advancement of God's Glory, the edifying of his Church, and the due reverence of Christ's holy Mysterles and Sacraments.

\section{Explanatory Summary :}

i. The Authority of Parliament in the second year of Edward VI is contained in the first B.C.P. of Edward, 1549. Either, therefore, this proviso contradicts the earlier provision of the Act, viz. the restoration of the 1552 Book, including its Ornaments Rubric; or the words 'shall be retained, and be in use' do not bear their surface meaning, but merely forbid the destruction or sale of albs, chasubles and copes till authoritative directions shall be forthcoming. This latter was the interpretation of the proviso put forward by Bishop Sandys at the time of the passing of the Act.

ii. Both provisos foreshadow possible changes, made by the specified authority of the Queen acting by advice of her Commissioners or the Metropolitan, the former, $\S 25$, particularly promising 'other order' in regard to vestments ; the latter, $\S 26$, more generally leaving a way open for the addition of 'further ceremonies and rites.'

iii. In the printed B.C.P. of this date, 1559 , the 1552 rubric was altered, without any authority, ostensibly to accommodate the rubric to the proviso :

And here is to be noted, that the Minister at the time of the Communion, and at all other times in his Ministration, shall use such ornaments in the Church, as were in use by authority of Parliament, in the second year of the reign of King Edward the Sixth, according to the Act of Parliament set in the beginning of this book.

Explanatory Summary :

i. The rubric does not profess to possess any authority save as being a digest of the Act. It is omitted in the Latin Prayer Book, published 1560.

ii. As such it is inaccurate, for the Act does not necessarily say that the Ministers shall use such Ornaments, but that they shall 'be retained and be in use,' and the Aet says 'as was in this Chureh,' etc., not 'as were in use.' Moreover, it omits all reference to the promise of 'other order.' 
iii. As a contemporary interpretation of what was understood by 'shall be retained and be in use,' this unauthorized rubric of 1559 might be valuable, were it not that there is no record of any obedience to such a rule, but, on the contrary, abundance of evidence that from 1559 onwards the vesture of the second year of King Edward was forbidden. Indeed, in the very year in which this printed rubric first appeared, the Queen sent Commissioners through the country with certain Injunctions, to which the clergy were compelled to subscribe. Two of these Injunctions relate to Ornaments :

30. Item. Her Majesty being desirous to have the Prelacy and Clergy of this Realm to be had in outward reverence as otherwise regarded for the worthiness of their ministries, and thinking it necessary to have them known to the people in all places and assemblies, both in the Chureh and without, and thereby to receive the honour and estimation due to the special messengers and ministers of Almighty God; willeth and commandeth that all Archbishops and Bishops, and all other that be called or admitted to preaching or ministry of the Sacraments, or that be admitted into vocation ecclesiastical, or into any society of learning in either of the Universities, or elsewhere, shall use and wear such seemly habits, garments, and such square caps as were most commonly and orderly received in the latter year of the reign of King Edward the Sixth, not thereby meaning to attribute any holiness or special worthiness to the said garments, but as St. Paul writeth, Omnia decenter et secundum ordinem flant. 1 Cor. 14 cap.

47. That the churchwardens of every parish shall deliver unto our visitors the inventories of vestments, copes, and other ornaments, plate, books, and specially of grayles, vouchers, legends, processionals, hymnals, manuals, portuasses, and such like appertaining to the Church.

Explanatory Summary :

i. Injunction 30 might seem to refer merely to the outdoor dress of the clergy, if it were not for the words 'both in the Church and without' and 'such seemly habits, garments, and such square caps as were most commonly and orderly received in the latter year of the reign of King Edward the Sixth.'. There was no rule as to ordinary clerical dress in the 'latter year' of Edward VI, but it was in that year that the 1552 B.C.P. became compulsory, with its definite prescription of the rochet and surplice. Moreover, amongst other similar phrases in his visitation articles, Archbishop Parker uses the expression (1563) ' a surplice prescribed by the Queen's Majesty's Injunctions.'

ii. In regard to the inventories demanded by Injunction 47 , it is generally admitted that the Injunction 'clearly indicates that all these things were to be taken away for the use of the Crown' (Perry, 'Student's History,' p. 266). This is in accord with Sandys' famous letter to Parker: 'Our gloss upon this text (i.e. the proviso to retain the ornaments of 1549) is that we shall not be forced to use them, but that others in the meantime shall not convey them away; but that they may remain for 
the Queen.' It is also in accord with what actually happened, as at Grantham, at that time : 'Item, the vestments, copes, albs, tunicles, and all other such baggage was defaced, and openly sold by a general consent of the whole corporation, and the money employed in setting up desks in the Church, and making a decent Communion Table, and the remnant to the poor' (Peacock, 'Church Furniture,' p. 87). This is one of many similar records.

1566. In spite of the Injunctions, much irregularity prevailed, especially due to a widespread unwillingness to wear any ecclesiastical dress at all. The intrusion of the printed rubric, seeming to authorize the vestments of 1549 , disregarded and episcopally banned, could only add to the confusion. The Advertisements of 1566, sometimes dated 1565, the year in which the Queen's mandate for their composition was issued, were intended to cope with this irregularity. The three which relate to the Ornaments of the minister are :

Item.-In ministration of the Holy Communion in the cathedral and collegiate churches the principal minister shall use a cope with gospeller and epistoller agreeably, and at all other prayers to be said at the Communion Table to use no copes but surplices.

Item. - That the Dean and Prebendaries wear a surplice with a silk hood in the quire ; and when they preach to wear their hood.

ftem. - That every minister saying any public prayers, or ministering of the Sacraments or other rites of the Church, shall wear a comely surplice with sleeves, to be provided at the charges of the parish ; and that the parish provide a decent table standing on a frame for the Communion Table.

Explanatory Summary :

i. The surplice is ordered for all ministrations in all churches, with one exception, viz. the three copes for celebrant, gospeller and epistoller at Holy Communion in cathedral and collegiate churches. This novel use of the cope bears some superficial resemblance to the alternative prescription of 1549 , but differs from it in being confined to certain churches, and prescribed for the gospeller and epistoller, as well as for the celebrant.

ii. The direction to dignitaries in the quire and when preaching is identical with the direction of 1549 .

iii. The suppression of the 1552 Rubric, not in set terms remedied by the Injunctions, is atoned for by these direct and explicit regulations. Henceforth the Bishops commonly refer to both the Injunctions and the Advertiscments in their Visitations, the former to dispose of the discarded vestments, the latter to compel the wearing of the surplice. It cannot be said that the order to wear copes was generally obeyed, or ever, so far as is known, enforced; the Bishops really carried out the 
requirements of the 1552 Rubric, appealing to the Injunctions and Advertisements as their authority.

1604. The Canons of 1603-4 were adopted with 'the most formal, solemn, concurrence possible of the Crown and the Convocations.' The Canons relating to vestments are :

24. Copes to be worn in Cathedral Churches by those that administer the Communion.

In all Cathedral and Collegiate Churches the Holy Communion shall be administered upon principal feast-days ... the principal minister using a decent cope, and being assisted with the gospeller and epistoler agreeably, according to the Advertisements published anno 7 Eliz.

25. Surplices and hoods to be worn in Cathedral Churches when there is no Communion.

In the time of Divine service and prayers, in all Cathedral and Collegiate Churches, when there is no Communion, it shall be sufficient to wear surplices, saving that all deans, masters, and heads of collegiate churches, canons, and prebendaries being graduates, shall daily at times both of prayer and preaching wear with their surplices such hoods as are agreeable to their degrees.

58. Ministers reading Divine service and administering the Sacraments, to wear surplices and graduates therewithal hoods.

Every minister saying the public prayers, or ministering the Sacrament or other rites of the Church, shall wear a decent and comely surplice with sleeves, to be provided at the charge of the parish ; and if any question arise touching the matter, decency, or comeliness thereof, the same shall be decided by the discretion of the ordinary. Furthermore, such ministers as are graduates shall wear upon their surplices, at such times, such hoods as by the orders of the Universities are agreeable to their degrees, which no minister shall wear (being no graduate), under pain of suspension. Notwithstanding it shall be lawful for such ministers as are not graduates to wear upon their surplices, instead of hoods, some decent tippet of black, so it be not silk.

\section{Explanatory Summary :}

i. These regulations are merely a recapitulation of those in the Advertisements, save that the 'tippet,' a scarf which is now frequently miscalled a stole, is permitted for non-graduates, and the triple cope wearing in Cathedrals, etc., is limited to principal feast-days.

ii. The Advertisements are cited as the received standard regarding vestments.

iii. Laud's Visitation Articles of 1628 suffice to show the practice of the period: Whether doth your minister wear the surplice while he is saying the public prayers, and administering the Sacrament, and a lood according to his degree of the University: Whether there be in your parish, who are known or suspected, to conceal or keep hid in their homes any Mass books, Breviaries, or other books of Popery or superstition, or any 
chalice, copes, vestments, albs, or other ornaments of superstition, uncancelled, or undefaced, which is to be conjectured they keep for a day as they call it.

1662. At the Restoration the present Ornaments Rubric was substituted for the unauthorized rubric of 1559. It runs :

And here is to be noted that such ornaments of the Church, and of the Ministers thereof, at all times of their Ministration, shall be retained, and be in use, as were in this Church of England by the authority of Parliament, in the second year of the reign of King Edward the Sixth.

\section{Explanatory Summary :}

i. The great and all-important change from the 1559 printed rubric was the substitution of the exact words of the Act of Uniformity, 1 Eliz. c. 2, for the paraphrase of it inserted without authority in 1559 . With the exception of the more grammatical 'were' for 'was,' the rubric is now identical with the proviso.

ii. The introduction of that Act into the Prayer-Book, numbered 1 in the list of Contents of the Prayer-Book,* permitted the omission of the words referring to the Act, it being perfectly obvious that the words of the rubric, being the actual words of the Act, could mean neither more nor less than the Act intended them to mean.

iii. There is abundance of evidence, dating from the time of the last revision, 1662, and furnished by the Visitation Articles of Bishops engaged in that revision, to show that the contemporaneous interpretation of the revised rubric, construed with the Act, was that the surplice was to be worn, and not the vestments of 1549 .

\section{Summary of the above requirements.}

1549. Vestment or Cope, Alb or Surplice at Holy Communion with Albs and Tunicles for the assistant ministers; Surplice only at other services.

1552. Rochet for Bishops, Surplice for other clergy, at all ministrations.

* The omission to print the Act in the ordinary Prayer-Books sold for public use, is much to be regretted. It is strange that with so much depending upon the actual words used, even in the Quarto Editions sold for Churches, the Act is sometimes incorrectly printed, and not divided into sections. For example, the Quarto Editions printed 'cum privilegio' by the Oxford University Press, and published by the S.P.C.K., since the death of Queen Victoria, present both these defects, the error in printing bcing no mere misplacement of a word, but a misrepresentation of the critical words of $\S 25$ of the Act, ' "used ' for 'be in use.' Further, even in so careful a work as that of Keeling, the Act is suppressed, only its opening words being cited, though all other such Acts, some of which have only an antiquarian interest, are given in full. 
1559. By the Act of Uniformity, $\S 3,1552$ Rubric restored. By the same Act, $\S 25,1549$ vesture to 'be retained and be in use.'

By the printed rubric, the minister to use the 1549 vesture.

By the Injunctions, 1552 vesture to be worn, 1549 vesture inventoried for Visitors.

1566. Advertisements: Cope in Cathedrals for Holy Communion, otherwise Surplice and hood at all ministrations.

1604. Canons : repetition (with certain limitations) of Advertisements, with tippet added for non-graduates.

1662. By the Act, as above, under 1559, the Rubric being brought more into verbal agreement with sec. 25 of the Act of Elizabeth.

\section{Legal Decisions.}

The fact that the regulations as to vesture are now confined to an Act of Parliament would seem to suggest that the proper interpreters of those regulations are the King's Judges, however assisted by the historical investigations of others. There is, however, a tendency in some quarters to dispute the jurisdiction of the Church courts, and especially that of the Final Court of Appeal, the Judicial Committee of the Privy Council. Attempts are being made to discover another Court which shall command the approval of all Churchmen; meanwhile there is no other lawful interpretation save that furnished by this Court, whose latest pronouncement upon the Ornaments Rubric was given in the Folkestone Case, 1878. It was then laid down that:

i. The Rubric is subordinate to the Statute 1 Eliz. c. 2, from which it is a quotation, the whole Statute being now part of the B.C.P.

ii. Its application, therefore, turns upon the question as to whether the 'other order' promised in that Statute has ever been taken.

iii. The Advertisements of 1566 were such 'other order.'

In the course of their pronouncement, the judges delivered other important decisions upon details :

i. The printed rubric of 1559 ' was not inserted by any authority of Parliament'; it 'claimed no intrinsic authority for its llf.'

ii. The Injunctions of 1559 are not the 'other order,' as not being proved to refer to the vestments now in controversy, and not issued with the advice required by the Statute. It will be 
noted that the former of these reasons for rejecting the authority of the Injunctions in this connection, is open to correction by historical discovery; the latter is fatal to any idea that the Injunctions are the 'other order' foreshadowed by $\S 25$ of the Act.

iii. The 'authority of Parliament in the second year of King Edward the Sixth' is interpreted as excluding everything prior to the 1549 Book.

iv. It is pointed out that the phrase 'at all times of their ministrations' is incongruous with a return to the 1549 vesture, seeing that no provision was made in 1549 for Matrimony, the Litany, etc.

v. It is also pointed out that the introduction of that phrase into the rubric in 1662 is inappropriate to the reintroduction of vesture which would distinguish the Holy Communion from ' all other times of ministration.'

vi. The suggestion being made that the omission in 1662 of the words ' according to the Act of Parliament set in the beginning of this book,' necessitates the interpretation of the Rubric without reference to that Act, it was replied that the omission could not be so regarded, seeing that the Act was then (for the first time) constituted by the two Convocations part of the B.C.P., and that 'other order' having been already taken (viz. 1566) the words omitted were simply unnecessary.

\section{Other Views.}

i. The contention that the authority of Parliament in the second year of Edward VI refers to the period preceding the issue of the 1549 B.C.P., and therefore legitimizes all pre-Reformation ornaments, still occasionally appears in publications and speeches, but was abandoned by its foremost defenders under examination in the recent Royal Commission upon Ecclesiastical Discipline. Much of the ritual introduced within the last fifty years ultimately depends upon this untenable position; the regulations of the 1549 Book, even if legal to-day, omitted much of the ceremonial in question, and in the 'Notes' at the close of the Book stated why these omissions were made.

ii. The more frequently avowed contention is that "other order' was never taken, and that therefore the requirements of 1549 as to ormaments are still in force.* The Report of Five Bishops of Canterbury Convocation, 1908, practically advances this contention, by its effort to demonstrate that the Advertisements were not the 'other order' required by the Act.

* To eke out those reduced requirements, it is often further eontended that what is not expressly forbidden is enjoined, in spite of the explanation of omissions above noticed. 
iii. That same Report notices another contention, viz. that the Advertisements were a minimum requirement, enacted to combat the Puritan objection to the surplice, and not to exclude the vesture of $1549 . \ldots$ This is a mere conjecture, not only entirely without historical support, but at variance with the strict ' uniformity' demanded at that time and for many years later.

iv. The contention that the Injunctions were themselves the 'other order,' and that the Advertisements were promulgated under $\S 26$ of 1 Eliz. c. 2 , and not $\S 25$, is vitiated by the lack of proof that the Injunctions were issued by the authority required by the Act. Nevertheless, this theory has the merit of calling attention to the weak point in the judgment of the Privy Council, viz. that the Advertisements, issued in 1566, cannot explain the continuous and official enforcement of the surplice from 1559 to 1566 .

v. Another view, recognizing both the untenableness of the theory that the Injunctions were themselves the 'other order,' and also the necessity of accounting for the enforcement of the surplice at Holy Communion, and prohibition of the 1549 vestments before the issue of the Advertisements, is that the reenactment of the 1552 rubric by 1 Eliz. c. 2, sec. 3 is the sole and sufficient explanation of the immediate enforcement of the surplice in 1559, and that 'other order' as regards the 1549 vestments and other ornaments was taken by the Queen's Visitors, who in 1559 went through the country with the Injunctions, disposing of those ornaments. This view alone seems to account for the facts (1) that the 1549 vestments were at once suppressed and the surplice enforced; (2) that the printed rubric was absolutely ignored save by the Puritans, who at a later date used it to attack the Bishops for trying to enforce the surplice, and (3) that the very words of the companion rubric which had also been suppressed in the printed books, were quoted as authoritative in Visitation Articles just as they stood in the 1552 B.C.P. (see p. 77) Bishop Sandys' contemporary explanation of the words ' be retained and be in use,' as referring not to ministerial use of the ornaments but to their retention for the use of the Queen, corroborates this view, which is, however, independent of that explanation, and equally valid if the words of the Proviso contemplated a temporary toleration of those ornaments, a toleration, it is fair to add, of which there is no trace of historical evidence. That the Visitors of 1559 were themselves 'Commissioners under the Great Seal for causes ecclesiastical' who took 'other order' in the Queen's name by destroying, defac:ng or confiscating the ornaments of 1549 is shown in detail in Tomlinson's 
' Royal Visitations of 1547-1559.' The first Prayer Book did. not permit a surplice to be worn at Holy Communion: the Second Book of Edward did not permit the celebrant even to 'have' any other dress than the surplice at Holy Communion. By that simple test the rival theories may.be weighed.*

\section{Ornaments of the Church.}

(1) Articles legally required.

Bible.

Lord's Table with proper coverings, including the fair white linen cloth, plate or paten, cup, fair linen cloth to cover elements. The Table must be of wood and easily movable.

Bread and Wine.

Book of Common Prayer.

Book of Thirty-nine Articles.

Book of Homilies.

Book for Banns.

Pulpit.

Reading Desk.
Font.

Alms chest.

Alms basin.

Bell.

Bier.

Registers.

Tables of Degrees of Kindred and Affinity.

Ten Commandments over Lord's Table.

Sentences of Scripture or Apostles' Creed.

Ordinary furniture of Church and Vestry.

(2) Articles legal, but not compulsory, and in some cases not desirable.

Organs and musical instruments. Clocks.

Credence Table.

Chimes.

Second Lord's Table.

(3) Articles allowable as 'decorations,' but not for use.

Images.

Crosses.

Flowers.

Flower vases.

Royal arms.

Banners.
Regimental colours.

Painted windows.

Holly, etc., at Christmas.

Harvest decorations.

Monuments and brasses.

(See Whitehead's 'Church Law,' tit. 'Ornaments.')

* The so-called 'Interpretations of the Injunctions,' of unknown origin, but apparently dating from about 1560, has been designedly ignored in the above investigation; there is no evidence that they were ever authorized or even published, much less enforced. 
胥

员喿

舟然

슬

运文 कृ

$\rightarrow$ 일

펀

乙

의

$\rightarrow \equiv$

$\geqslant E$

겅

की

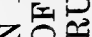

$0_{0}^{1} 0$

$\rightarrow$ 당 $\rightarrow$

$\Leftrightarrow \circlearrowright$

吕四毕

80

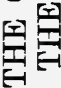

雚

$\frac{1}{4}$

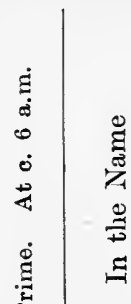

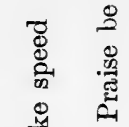

家

离 है की

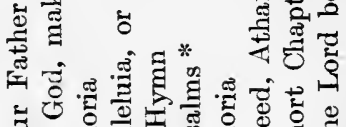

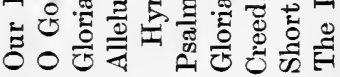

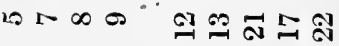

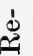

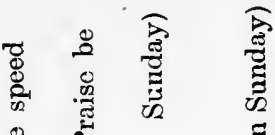

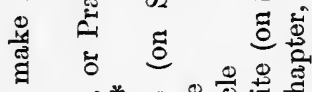

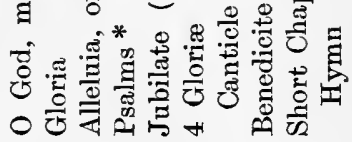

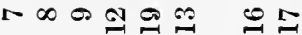

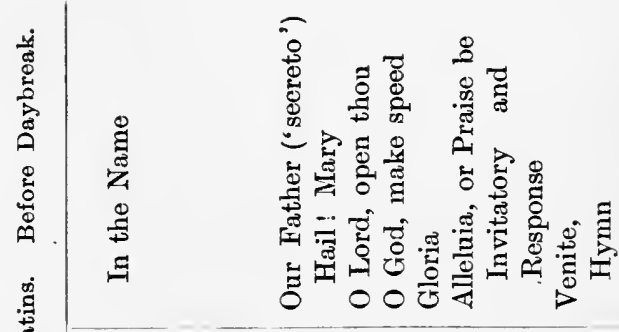

10 $\infty$ - 0 프 


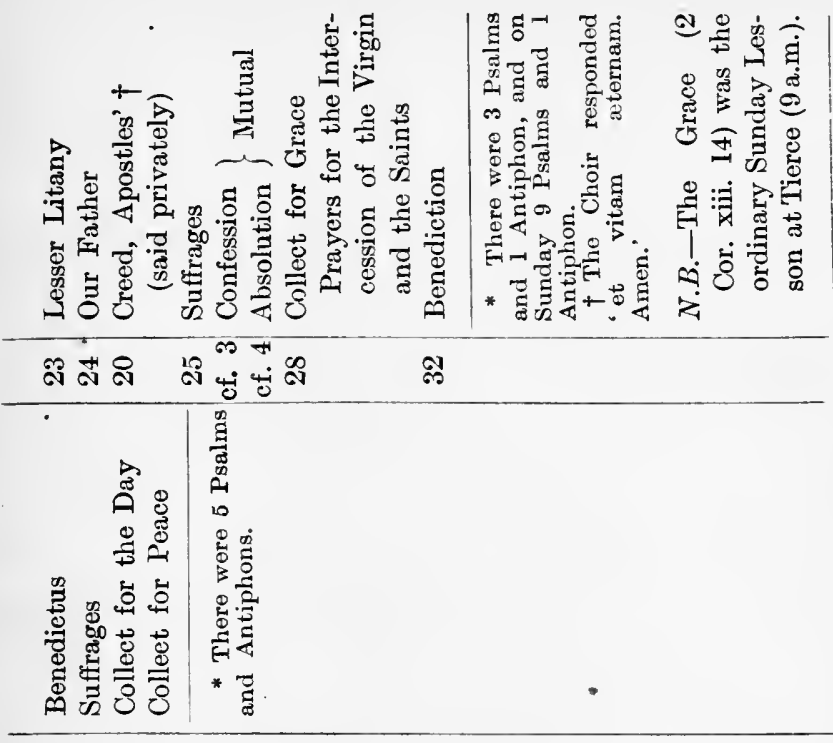

总

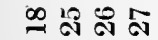

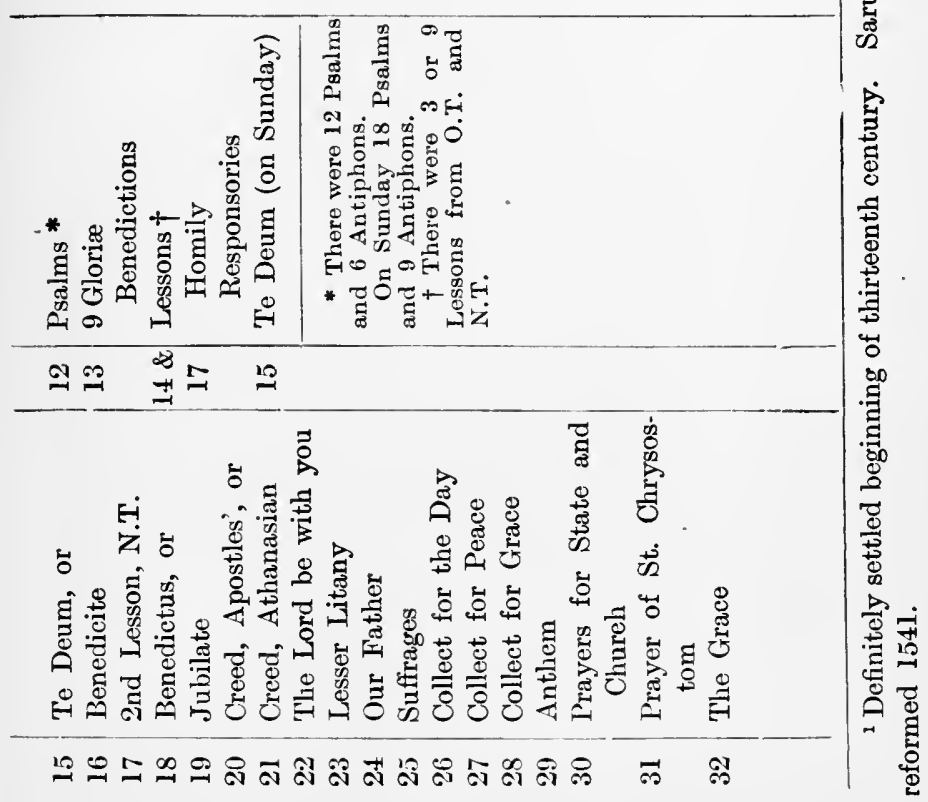




\section{THE ORDER FOR MORNING PRAYER, DAILY THROUGHOUT THE YEAR}

\section{ANALYSIS AND HISTORICAL NOTES.}

\section{Penitential Introduction.* 1552.}

The Sentences, etc., ending with the Absolution.

2. The Lord's Prayer and Versicles. 1549.

[The Doxology to the Lord's Prayer and the Response, 'The Lord's name be praised,' added 1662.]

3. Psalmody, Reading of the Scriptures, and Singing of the Canticles. 1549. Except Jubilate. 1552.

The Venite, etc., ending with the Jubilate.

4. The Confession of Faith. 1549.

The Apostles' Creed, or

The Athanasian Creed on thirteen special occasions.

5. Concluding Prayers and Thanksgiving.

(1) The Suffrages, 'The Lord be with you,' etc., ending with the Collect for Grace. 1549.

(2) Intercession for the State and the Church. Prayer for the King's Majesty. $\dagger 1559$.

Prayer for the Royal Family. $\dagger 1604$.

Prayer for the Clergy and People. $\dagger 1559$.

(3) Prayers and Thanksgivings upon several occasions.

\section{i. Prayers.}

For Rain. 1549. $\ddagger$ For fair Weather. $\ddagger 1549$.

In the time of Dearth and Famine (two forms). 1552.

In the time of War and Tumults. 1552.

In the time of any common Plague or Sickness. 1552. In the Ember Weeks (two forms). 1662.

A Prayer that may be said after any of the former. 1559.

A Prayer for the High Court of Parliament. 1662.

A Collect for all Conditions of men. 1662.

- This section was added by the Reformers and takes the place of Private Confession which still remained in 1549 .

$\dagger$ Printed at the end of the Litany until 1662.

$\ddagger$ Printed at the end of the Communion until 1552. 


\section{ii. Thanksgivings.}

A General Thanksgiving. 1662.

$[1604$.

For Rain. 1604. For fair Weather. 1604. For Plenty.

For Peace and Deliverance from our Enemies. 1604.

For restoring Public Peace at Home. 1662

For Deliverance from the Plague, or other common Sickness (two forms). 1604.

(4) Prayer of St. Chrysostom.* 1549.

(5) The Grace.* 1559.

The Title.

EXPOSITION.

1519. An Order for Matins daily throughout the year.

1552. An Order for Morning Prayer daily throughout the year.

1662. The Order for Morning Prayer, etc.

The Rubric before the Sentences.

1552. At the beginning both of Morning Prayer and likewise of Evening Prayer, the Minister, etc.

1662. At the beginning of Morning Prayer the Minister, etc. The sentences are directed to be read ' with a loud voice.' This was so stated as formerly the priest frequently read in an undertone ('secreto').

The Opening Sentences. 1552. Eleven in number, eight from the Old Testament, three from the New Testament.

The Old Testament sentences (except Dan. ix. 9, 10) were taken from the old Lenten Capitula, and from the penitential Psalms daily read during Lent.

The New Testament sentences, as well as Dan. ix. 9, 10, were selected by the Reformers.

The sentences until 1662 were taken from Cranmer's Bible (1539), commonly called ' The Great Bible.'

Verse 9 of $1 \mathrm{John} \mathrm{i}$. was added to the last sentence in 1662.

The sentences are of a penitential character and designed for different classes. The spiritual counsel they afford may be thus stated $\dagger:-$

(1) Support to the fearful. Ps. vi. 1 ; li. 9 ; cxliii. 2 ; Jer. x. 24.

(2) Comfort to the doubtful. Ps. li. 17 ; Dan. ix. 9, 10 ; Luke xv. 18, 19.

(3) Instruction to the ignorant. Ezek. xviii. 27 ; 1 John i. 8,9 .

(4) Admoni ion to the negligent. Ps. li. 3 ; Matt. iii. 2.

(5) Caution to the formal. Joel ii. 13.

* Printed at end of Litany until 1662 .

+ Comber, Companion to the Temple, in loce. 
The following additional sentences are found in the American B.C.P. of 1792 :

Hab. ii. 20 ; Mal. i. 11 ; Ps. xix. 14, 15 (Psalter).

Others chiefly adapted to special seasons of the Christian Year were added in 1889 .

The earliest daily Service to open with Scripture was the Strasburg Liturgy, which commenced with the Ten Commandments.*

The Exhortation. $\dagger$ 1552. Grounded on the preceding sentences. The idea may liave been suggested :-

(1) By portions of a Homily of Leo read in Lent (Sar. Brev.).

(2) By the Gallic and Spanish Liturgies, in which an address was given after the departure of the Catechumens and before the administration of the Holy Communion.

(3) By the short Exhortations in the Strasburg Liturgy, published by Valerandus Pollanus (Pullain). 1552 (February).

(4) By Hermann's 'Consultatio.'

$$
\text { Analysis. }
$$

I. Address respecting confession of sin.

1. The Source of Authority: the Holy Scriptures.

2. The Spirit: penitential.

3. The Purpose : forgiveness.

4. The Occasion : always, and especiclly at Public Worship, when we meet for :-

(1) Thanksgiving.

(2) Praise.

(3) Hearing God's Word.

(4) Prayer.

II. The Invitation to the performance of this duty.

Rubric before the Confession:-To be said ['made,' 1604]:-

1. By the Minister and the whole congregation.

2. Not with but after the Minister (not necessarily clause by clause).

3. Kneeling, as becometh penitents (cf. Ps. xcv. 6 ; Luke xxii. 41 ; Acts vii. 60 ; ix. 40 ).

* However, according to the rites of many Western Churches, a verse or capitulum was read before the Office of Compline or the latest Evening Service; a custom which is at least as ancient as the time of Amalarius, A.D. 820, for he mentions it (Amalarius 'de Eccl. Offic.', lib. iv. c. 8). The nocturns have for many ages been accounted one office.' (Palmer. 'Origines Liturgicae' vol. i. 210, ed. 1839.)

$\dagger$ Notice the rhetorical reduplication of words, sueh as: 'acknowledge and confess,' 'sins and wickedness,' 'assemble and meet together,' 'not dissemble nor cloke.' 
General Confession. 1552. Based on Rom. vii. 8-25.

It was probably suggested by the Confession in the Strasburg Liturgy; though there is in foreign Service Books nothing which can be fairly regarded as the model of this Confession.

' St. Basil mentions Confession of Sin as coming at the beginning of Divine Service' (Cornford).

It is called 'General' as being suitable for all persons and all occasions.

The Confession in the Mediæval Offices differed much from our form :-

1. It was of the nature of mutual and alternate Confession.

2. It contained Confession to the Virgin and the Saints as well as to God.

N.B.-It was called Confiteor, and, with the Absolution, Misereatur, placed towards the end of Prime and Compline.

\section{Analysis.}

I. An address to God.

II. Confession of Sin.

III. Prayer for Spiritual Blessings, viz. :-

1. For Mercy and Pardon.

2. To live rightly (Godward, manward, selfward).

Amen. When printed in Roman characters to be pronounced :-

(1) By the Minister and people, if both repeat the preceding words.

(2) By the Minister only, if he only repeat the preceding words.

When printed in Italics it is the response of the people.

\section{The Rubric before the Absolution.}

1604. The words in the Rubric, ' or Remission of sins,' were added.

1662. 'Minister' altered to 'Priest,' and the clause 'The people still kneeling' was added.*

The Absolution. 1552. Matt. xvi. 19 ; xviii. 18 ; John xx. 22,23 ; cf. Acts ii. 38 ; 2 Cor. ii. 10 ; v. 18.

It is adapted from 'An order of Service in Latin, and afterwards in French ' (being the version of Calvin's form 1545), used by the Walloons under John a Lasco, a Polish noble who took refuge in England from 1548 to 1550 , and was Minister to the Dutch and German Protestants living in London in the reign of Edward VI.

* In the Scottish Service Book (1637) the rubric is: "The absolution or remission of sins to be pronounced by the Presbyter alone, he standing up and turning himself to the people, but they still remaining humbly upon their knees.' 
The Priest* pronounces the absolution alone, and standing, as God's ambassador. The alteration from 'Minister' to 'Priest' in 1662 , to the exclusion of the Deacon, is due to the tendency to regard the diaconate as rather a probationary office than a distinct order. There is, of course, nothing save ecclesiastical fitness to prevent a Deacon, or a layman, exercising the ministry entailed in the pronouncement of this form of Absolution, which, it is to be noted, still retains the word 'Ministers.'

The former portion of the Absolution is somewhat involved and obscure, and has consequently given rise to interpretations which the words do not warrant. In order to see the meaning of the passage it is necessary to understand the capacity in which the Minister speaks. It is as a Minister of the Gospel he utters the words, and in that capacity he is authorized to make the proclamation that pardon is given to penitent sinners. His words do not convey pardon, but the assurance of pardon to the truly penitent. The following interpolations in the passage will help to elucidate it, ' and hath given power, and commandment, to His Ministers (as preachers of the Gospel and His ambassadors) to declare and pronounce to His people, being penitent, the absolution and remission of their sins; (for in that Gospel it is declared that) $\mathrm{He}+$ (i.e., God) pardoneth and absolveth all them which truly repent, and unfeignedly believe His holy Gospel.'

The warrant for the pronouncing of the Absolution rests upon our Lord's words in which He intrusted the proclamation of pardon to the members of His Church assembled on the evening of the first Easter Day (John xx. 22, 23 ; Luke xxiv. 36). But the words in St. John are to be interpreted by Luke xxiv. 47,48 , and the practice of the Apostles (Acts ii. 38 ; iii. 19 ; x. 43 ; xxvi. 18 ; 1 John ii. 12). They plainly mean, 'Whosesoever $\ddagger$ sins ye (as Ministers of the New Covenant) remit (i.e., declare to be remitted) are remitted, and whose sins ye retain (i.e., declare to be retained) are retained.' $\S$

There are two other forms of Absolution in the B.C.P. :-

(1) In the Communion Office, which is precatory, and expressive of an earnest and assured wish that God ' will

* For explanation of the term 'priest' see pp. 515-20.

$\dagger$ Observe the grammatical construction of the sentence. The pronoun ' $\mathrm{He}$ ' is introduced so as to emphasize the declaratory nature of the Absolution.

¥ In the original Greek 'whosesoever' is plural. The Lord does not guarantee infallibility of judgment as to the applicability of remission or retention of $\sin$ in individual cases.

$\S$ The figure of speech by which what is said to be done is put for what is declared, or permitted, or foretold to be done, is frequently used in the Holy Scriptures. (See Gen. xli. 13; Lev. xiii. 6, 8,11 ; Isa. vi. 10 ; Jcr. i. 10 ; Ezek, xliii. 3 ; cf. Acts x. 15.) 
pardon and deliver' the communicants 'from all their sins.'

(2) In the Visitation of the Sick, where the form is directly personal, although the clause ' by His authority' makes it elear that the authority is ministerial. The retention of this direct form for the sick and dying was a concession to this accustomed mode of consolation in the hour of death.*

If the Service is performed by a Deacon he ought to omit the Absolution and pass on to 'the Lord's Prayer.' There is no Rubrical authority for substituting the prayer for pardon, ' $O$ God, whose nature and property,' etc., as is sometimes done.

\section{A Declaration respecting God, viz. :-}

$$
\text { Analysis. }
$$

1. His desire for the salvation of men.

2. His committal of authority to Ministers to declare and pro. nounce that the truly penitent are pardoned. $\uparrow$

II. A Declaration by the Minister of God's Pardon on the conditions of Repentance and Faith.

III. A Call to Prayer based on the assurance of pardon, for :-

1. Holiness at the present time, and for the rest of our life.

2. Attainment of eternal joy.

\section{Rubric at the end of the Absolution.}

1552. The people shall answer, Amen.

1662. The people shall answer here, and at the end of all other prayers, Amen.

It is worthy of note that the Absolution is here definitely and distinctly described as a Prayer.

\section{The Rubric before the Lord's Prayer.}

1549. The Priest being in the quire shall begin with a loud voice the Lord's Prayer, called the Paternoster.

1552. Then shall the Minister begin the Lord's Prayer with a loud voice.

1662. Then the Minister shall kneel, and say the Lord's Prayer with an audible voice; the people also kneeling, and repeating it with him, both here, and wheresoever else it is used in Divine Service.

Prior to 1549 the Minister was directed to repeat it ' secretly' (' secreto'), or in an undertone, to himself, down to the sixth petition, when the people responded with the seventh petition.

The words ' and wheresoever else,' etc., have caused difference

* For further particulars, see Visitation of the Sick, pp. 453-5.

$\dagger$ The succeeding context shows that this is the extent of the priest's authority. 
of opinion as to whether they govern the case of the opening Lord's Prayer in the Communion Office or not. On the one hand, besides this general direction, the rubric frequently states on its recurrence that both the people and the Minister shall say it, whereas at the beginning of the Communion Service the rubric merely says, 'the Priest standing at the north side of the Table shall say the Lord's Prayer, with the Collect following, the people kneeling.' On the other hand, since the rubric does not state that the Priest alone is to say it, this rubric may hold good, and as such both the Priest and the people should repeat it. (See Dowden, 'Further Studies in the Prayer Book,' pp. 82-88.)

The Lord's Prayer. 1549. Sar. Brev. Taken chiefly from the rendering in the King's Book of 1543, which did not, however, contain the Doxology, but the Ave Maria followed.

It was here that in 1549 the Service commenced, and in 1662 two lines were drawn across the page to mark the point.

The Lord's Prayer, as being the form given for disciples, now furnishes the connecting link between the Penitential Introduction and the offering of praise. The suitability of this arrangement was enhanced by the addition of the Doxology in 1662. This is an ancient Liturgical adjunct, and was adopted by the Greek Church, but omitted by the Latin. In the A.V. it is only found in St. Matthew's Gospel, and in the R.V. it is altogether wanting. It mostly occurs in our Prayer Book where that portion of the Service is associated with praise.

The Lord's Prayer * is given to us as :-

(1) A Form to be used (Luke xi. 2).

(2) A Model by which we are to frame our petitions, as to their order and proportion as well as their substance (Matt. vi. 9):

The Versicles and Responses. 1549. Sar. Brev. Matins. Ps. li. 15 ; lxx. 1.

They are found in the Anglo-Saxon Offices from the sixtb century, and also called ' antiphonal suffrages,' or ' preces.'

1549. My lips, My mouth ; Save me, Help me.

1552. Our lips, Our mouth; Save us, Help us.

The Rubric before the Gloria was added 1662, adapted from the Scotch Service of 1637 .

Gloria Patri. 1549. Sar. Brev. Matins.

This is one of the earliest primitive doxologies and is sometimes called the lesser doxology, as distinguished from the Gloria in excelsis.

- For 'Expository Analysis' see Catechism, p. 413. 
In substance it is as old as the fourth century, the words, 'As it was in the beginning,' etc., having been added in the sixth century. The Arian Version was 'Glory be to the Father, by the Son, and in the Holy Ghost.' There were several doxologies in the Early Church. The form in the Mozarabic Liturgy was, 'Glory and Honour to the Father, and to the Son, and to the Holy Ghost, world without end. Amen.'

The Call to Praise. 1549. Sar. Brev. Matins.

1549. 'Praise ye the Lord' was followed by 'Hallelujah' from Easter to Trinity Sunday.

1552. 'Hallelujah' was omitted.

1662. 'The Lord's Name be praised' (from the Scotch Prayer Book of 1637) was added.

\section{The Rubric before the Venite.}

1549. Then shall be said or sung without any Invitatory, this Psalm, Venite, exultemus, etc., in English, as followeth. Psalm xcv.

1552. Then shall be said or sung, this Psalm following. 1662. The words, "Except on Easter Day, upon which another Anthem is appointed; and on the Nineteenth day of every month it is not to be read here, but in the ordinary Course of the Psalms' were added.

The Venite, exultemus Domino. (Ps. xcv.) 1549. Great Bible. Sar. Brev. Matins.

From very early times it has been usual to intermingle the reading of Scripture in Church with Psalms and Canticles, and this was, indeed, enjoined by the Council of Laodicea, about 360. With the exception of the Te Deum and Benedicite, they are taken from the Holy Scriptures. The Venite was formerly termed ' the Invitatorium,' or the 'Invitatory Psalm.' In the Primer of Henry VIII its title was 'A Song stirring to the Praise of God.' It touches 'the highest and lowest notes of the scale in the spiritual life.'

In the Western Church it was sung from carly times. Anciently it was read while the congregation was assembling. In the Sar. Brev. ' a short versicle, called an ' $\mathrm{I}_{\mathrm{i}}$; itatory' inciting to praise, and suited to the season of the ecclcisstical year, was sung before the Venite' (Evan Daniel).

The pointing of the Psalm was assimilated to the rest of the Psalter, so that it could be sung to the ordinary Psalm tunes, instead of its own peculiar chants.

In the Eastern Church a shortened form of it is used.

In the American Prayer Book the Venice consists of the first seven verses of Ps. xcv., with Ps. xcvi. 9 and 13 
I. A Call to Worship God publicly, viz. :-

\section{Analysis.}

1. To praise and thank the Supreme Sovereign (v. 3) vers. and Upholder (v. 4) and Creator (v. 5) of the Universe 1-5

2. To bend before God's Throne in prayer, because of His own personal relationship to us $\quad \ldots \quad \ldots c 6,7$

II. An Entreaty not to harden our hearts and slight the Word of God lest, like Israel of old, we forfeit the promised rest

\section{B.C.P., Corners of the Earth.}

A.V., Deep places (lit., 'depth of earth').

B.C.P., Strength of the liills.

R.V., Heights of the mountains.

B.C.P., To-day if ye will hear His voice.

R.V., To-day, oh that ye could hear His voice.

R.V. renders second clause of ver. 8 ' as in the provocation, and as in the day of Massah in the wilderness.'

\section{The Rubric concerning the Psalms.}

1549. Then shall follow certain Psalms in order, as they been [' be,' 1552] appointed in a table made for that purpose, except there be proper Psalms appointed for that day.

1662. Then shall follow the Psalms in order as they are appointed.

In accordance with the title page of the B.C.P., the Psalms are to be sung or said. Both practices have the sanction of Scripture (cf. 1 Sam. ii. 1 ; 2 Chron. xxix. 30 ; Ps. cxviii. 2 ; Luke i. 46,67 ; ii. 28 ; Eph. v. 19 ; Rev. vii. 10 ; etc.).

The Psalms. 1549. Sar. Ps. (but sung on a different system). The Prayer Book version is that of Tyndal and Coverdale, 1535, and Rogers, 1537, revised in 'The Great Bible' called Cranmer's, 1539. It is somewhat more rhythmical and suitable for song than that of the A.V. The Prayer Book version, being a translation of a translation, cannot have anything like the claim to accuracy which the A.V. and R.V. possess.

The Psalms are "pointed as they are to be said or sung in Churches,' i.e., they are divided by a colon to mark the break in the chant.

1549. Special Psalms were appointed for the four great festivals (Christmas Day, Easter Day, Ascension Day, and Whit-Sunday).

1662. Special Psalms for Ash Wednesday and Good Friday were added.

The seven penitential Psalms were chosen for Ash Wednesdav, one, the fifty-first, being in the Commination Service. 
The Psalter was in ancient times divided into five books :-

(1) Pss. i.-xli. ; (2) xlii.-lxxii. ; (3) lxxiii.-lxxxix. ;

(4) xc.-cvi. ; (5) crii.-cl.

Some were used by David and Solomon in the Temple Service (1 Chron. xvi. 8; 2 Chron. vi. 41, 42), and in the Synagogue worship after the return from Captivity. Our Lord Himself quoted and referred to some of them (Luke xx. 42,43; xxiv. 44; cf. Acts i. 20). It is generally supposed that Pss. cxiii.-cxviii. formed the great Hallel, which was probably the 'hymn' wlich our Lord sang with His disciples after the Last Supper (Matt. xxvi. 30 ; Mark xiv. 26).

The early Christians used them by selection as we use a hymn book. The continuous use of the Psalms in Public Worship began with the Monastic Orders. In the Sar. Brev. there were fixed Psalms appointed for certain services, the remainder being sung 'in course ' every week. The Antiphonal singing of Psalms, originally an Eastern custom, rapiclly spread in the Western Churches, owing to Gregory the Great setting up the first singing school in Rome.*

There is no Rubrical authority for the Psalms being repeated verse by verse alternately by the minister and people. But this method is plainly alluded to by Tertullian, and it was introduced into the Christian Church by St. Ignatius among the Greeks, and St. Ambrose among the Latins. The practice prevailed in the Jewish Temple.

\section{The Rubric concerning the Doxology.}

And at the end of every Psalm throughout the Year, and likewise at the end of Benedicite, Benedictus, Magnificat, and Nunc dimittis, shall be repeated [Gloria Patri].

\section{The Doxology.}

It was used in the Eastern Church after the last Psalm only, but in most of the Churches of the West after every Psalm. It serves to connect the Unity of the Godhead as known to the Jews with the Trinity as known to Christians.

\section{The Rubric concerning the Lessons.}

1549. Then shall be read two Lessons distinctly with a loud voice, that the people may hear. The first of the Old Testament, the second of the New; like as they be appointed by the Calendar, except there be proper Lessons assigned for that day; the Minister that readeth the Lesson, standing and turning him so as he may best be heard of all such as be present. And before every Lesson, the minister shall say thus: The

- For further cetails about the Psalter, see pp. 32 ff. 
first, second, third or fourth Clapter of Genesis or Exodus, Matthew, Mark, or other like, as is appointed in the Calendar. And in the end of every chapter, he shall say, Here endeth such a Chapter of such a Book.

1604. The following clause was added : 'And to the end the people may the better hear, in such places where they do sing, there shall the Lessons be sung in a plain tune, after the manner of distinct reading; and likewise the Epistle and Gospel.' This clause was omitted in 1662.

1662. Then shall be read distinctly with an audible voice the First Lesson, taken out of the Old Testament as is appointed in the Calendar, (except there be proper Lessons assigned for that day): He that readeth so standing and turning himself, as he may best be heard of all such as are present.

Note, That before every Lesson the Minister shall say, Here beginneth such a Chapter, or Verse of such a Chapter, of such a Book: And after every Lesson, Here endeth the First, or the Second Lesson.

\section{The Lessons.}

The first mention of reading the Scriptures in public is in Neh. viii. 8 ; but cf. 2 Chron. xvii. 7-9. Lessons from the Law and the Prophets were read by the Jews each Sabbath in their synagogues (Luke iv. 17-19 ; Acts xv. 21 ; cf. Col. iv. 16 ; 1 Thess. v. 27). The method was to have two stated lessons, one from the Law and the other from the Prophets. The Lectionary is specially marked in our Hebrew Bibles. Before the settlement of the Canon of Scripture, portions from the Epistles of St. Barnabas and St. Clement were read. Later on, Traditions of the Apostles, Acts of Martyrs and Confessors, etc., took the place of the Holy Scriptures on several occasions. Until the time of St. Augustine of Hippo the Lessons were chosen by the Minister, afterwards Lectionary Books (Lectionaria), containing appropriate Lessons for certain days, began to make their appearance.

The Reformers, following the practice of the early Christians, appointed two Lessons to be read at each Service, one from the old Testament and the other from the New Testament.

N.B.-One of the beauties of the Liturgy is its variety. Thus after the active devotion of Psalmody there comes a refreshing repose in listening to the Lessons. 'He which prays,' as Hooker remarks, 'in due course is thereby made the more attentive to hear; and he which heareth is the more earnest to pray.' 
1549. Daily Lessons were appointed.

1552. Proper Lessons for Holy Days, Christmas Day, Easter Day, Ascension, and Whit-Sunday were added.

1559. Sunday Lessons were added.

1871. A Revised Lectionary was introduced, by which :-

(1) The Old Testament, with certain omissions, is read once during the year, and the New Testament twice. In the first six months the Gospels are read in the Morning Service, and the remaining New Testament Books in the Evening; and vice versa in the last six months.

(2) The Lessons were shortened, and not made coincident with the division of the Bible into chapters (see Isa. lii. and liii.; Acts xxi. and xxii.; Heb. ii. and iii.; iv. and v.).

(3) A second First Lesson provided for Evening Service on Sundays.

(4) Other Lessons upon special occasions to be approved by the Ordinary, may, with his consent, be substituted for those appointed. The following direction respecting the selection of Lessons in cases of Saints' Days when they fall on Sunday is useful :-

If any of the Holy-days for which proper Lessons are appointed in the table fall upon a Sunday which is the first Sunday in Advent, Easter Day, Whit-Sunday, or Trinity Sunday, the Lessons appointed for such Sunday shall be read; but if it fall upon any other Sunday, the Lessons appointed either for the Sunday or for the Holy-day may be read at the discretion of the Minister.

In the old Lectionary, 44 out of the 132 chapters of the Apocrypha were selected to be read. But in the new Lectionary the only books from which selections are taken are Wisdom, Ecclesiasticus, and Baruch. These are read on week-days from October 27 to November 18, and on certain Holy-days, "with a view to instruction in virtue and holiness of life " (see Art. VI).

Before the Reformation in England, several Lessons, sometimes as many as nine, were read in the Services; but as each consisted only of a verse or two, the nine Lessons together were probably shorter than any of ours, and the Lessons were invariable.

The Rubric especially directs that the Lessons 'shall be read distinctly with an audible voice.'*

\section{Rubric concerning the Te Deum. 1549.}

1549. After the first Lesson'shall follow Te Deum laudamus, in English, daily throughout the year, except in Lent, all the

- For fuller particulars, see pp. $35 \mathrm{f}$. 
which time, in place of $T e \dot{D} e u m$ shall be used Benedicite omnia opera Domini Domino, in English as followeth.

1552. After the first Lesson shall follow Te Deum laudamus, in Eng'ish, daily throughout the whole [' whole 'omitted $1604]$ year.

1662. And after that, shall be said or sung, in English, the Hymn, called Te Deum laudamus, daily throughout the Year.

N.B.-From 1552 onward the Benedicite is given as an alternative without restrictions.

Te Deum Laudamus. 1549. Sar. Brev. Matins (Sundays and Festivals).

1545. Called in the Primer of Henry VIII 'The Praise of God the Father, the Son, and the Holy Ghost.'

1549. Prescribed for use 'except in Lent.'

1552. This exception removed.

This Hymn has been called ' a Creed in the form of adoration.' It is included in the Form of Prayer to be used at Sea, after Victory or Deliverance from an Enemy; and also in the Coronation Service.

The history of this famous Hymn is obscure. The earliest mention of it is in the 'Rule of Cæsarius,' Bishop of Arles (470542), while portions of it are to be found in old Greek Liturgies. A well-known tradition, without historical support, makes it the extempore joint production of St. Ambrose and St. Augustine at the baptism of the latter. Conjectures have credited it to Hilary of Poictiers (355) and Hilary of Arles (440). Modern scholarship inclines to the suggestion that the author was either Niceta, Bishop of Remesiana in Dacia $(370-420)$, or Nicetius of Treves (535).

Variations in the MSS. in regard to the eight concluding verses have given rise to the suggestion that they are no part of the original Hymn, but borrowed from the Gloria in excelsis, with the use of which in the West similar verses were associated at the time when the Te Deum took the place of the Gloria as the morning hymn.* Viewed in this light the Te Deum may be analysed as (1) a Hymn to the Holy Trinity, vv. 1-13 ; (2) a hymn to God the Son as Redeemer, vv. 14-21 ; (3) versicles added as a conclusion. The analysis given below is based upon the sense of the Hymn as it stands.

Some instances of departure from the original Latin in the English translation are worthy of note, e.g.-

* See 'The Workmanship of the Prayer-Book,' by Dr. Dowden, pp. 83-94: Church Quarterly Review, October, 1885, p. 20. 
To Deum laudamus: ' we praise Thee as God.'

Laudabilis numerus: 'the praise-worthy number' (of the prophets).

Candidatus exercitus: ' the white-robed army.'

Venerandum : ' adorable,' which is the rendering of the American

P.B. and is perhaps nearer the original than our "honourable.'

Mortis aculeo: 'death's sting' (cf. 1 Cor. xv. 55, 56).

Non confundar in æternum: this can be finely rendered as an indicative, 'I shall never be confounded.'

An important various reading is munerari for numerari : ' make them to be rewarded with Thy saints.' *

I. Praise (vv. 1-9).

$$
\text { Analysis. }
$$

1. From the Assembled Worshippers

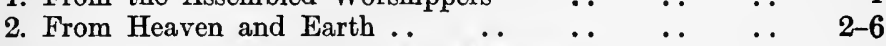

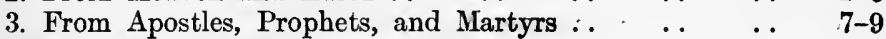

II. Confession of Faith (vv. 10-19).

1. In the Blessed Trinity $\ldots$.

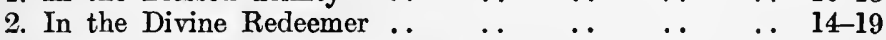

III. Prayer (vv. 20-29).

1. For eternal salvation, eliciting praise $\ldots$. $\quad . \quad$. 20 20-25

2. For present and future preservation from sin .. . 26-29

Benedicite omnia Opera. 1549. Sar. Brev. (sung on Sundays and Festivals at Lauds, among the Psalms).

This Hymn, which is an alternative for the Te Deum, is found in the Septuagint between the 23rd and 24th verses of the 3rd chapter of Daniel, and in the English Apocrypha between the Books of Baruch and Susannah in a much expanded form. Some have thought it to be an expansion or paraphrase of Ps. cxlviii. It is called ' The Song of the Three Holy Children,' Hananiah, Mishael, and Azariah (the Princes of Judah), whom Nebuchadnezzar had taken captive, and to whom had been given the Babylonian names of Shadrach, Meshach, and Abed-nego (Dan. i. 6, 7). In the Hymn itself they are called Ananias, Azarias, and Misael, the Grecized form of their Hebrew names. It was commonly sung among the morning Psalms in the fourth century. In the ancient Offices the Doxology ran thus: " $O$ let us bless the Father, and the Son, and the Holy Ghost; let us praise them, and magnify them for ever. Blessed art Thou, 0 Lord, in the firmament of Heaven; worthy to be praised, and glorious, and to be magnified for ever.' The Reformers (1549) substituted the present Doxology. This Hymn is suitable for Septuagesima

- For further remarks the reader is referred to Dr. Wordsworth's 'Te Deum, Its Structure and Meaning, etc. Revised Edition. S.P.C.K. 
Sunday (First Lesson, Gen. i.-ii. 4) and for the 21st Sunday after Trinity (First Lesson, Dan. iii.).

1549. Ordered to be used in Lent instead of the Te Deum. 1552. This direction removed.

In the Scottish Book Ps. xxiii. takes the place of the Benedicite. The American Book omits the last verse of the Benedicite and the Doxology.

Analysis.

An Appeal to praise the Creator, addressed :- $\quad$ vers.

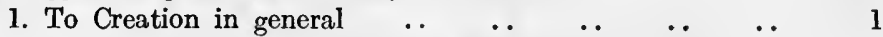

2. To the Angels, the Heavens, and the Heavenly bodies $\quad \begin{array}{lll} & \ldots & 2-7\end{array}$

3. To the great forces and phenomena of Nature.. .. 8-17

4. To the Earth with its vegetable and animal life .. 18-25

5. To our Fellow-men living and dead, and in particular to the Three Children in whose memory the Hymn was

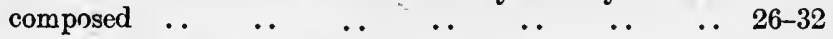

Rubric before the Benedictus.

1549. And after the second Lesson, throughout the whole year, shall be used Benedictus Dominus Deus Israel, \&c. in English as followeth.

1552. The words 'Dominus Deus Israel' and 'throughout the whole year" were omitted ; and after "used" the words 'and said' were added.

1662. Then shall be read in like manner the Second Lesson, taken out of the New Testament; and after that, the Hymn following; except when that shall happen to be read in the Chapter for the Day, or for the Gospel on Saint John Baptist's Day.

Benedictus. (Luke i. 68-79.) 1549. Sar. Brev. Lauds.

This was the Song of Zacharias to which he gave utterance immediately after the circumcision of John the Baptist. It is a summary of the messages of both Testaments. The version differs slightly, both from the 'Great Bible' and from the A.V.

1549. Described, in one edition, as a 'thanksgiving for the performance of God's promises.'

N.B.-The infinitives, "to perform . . to remember . . to to perform' in verses 72,73, are connected with the words ' $\mathrm{He}$ hath raised up a mighty salvation for us' (ver. 69).

Analysis.

I. Thanksgiving for the Advent of the Messiah, in Whom vers. God's promised Redemption was being fulfilled .. $\quad . \quad 68-75$

II. Address to the Infant John, in which Zacharias prophesies the object of his mission as the Forerunner $\quad . \quad$. $\quad 76-79$ 


\section{The Rubric before the Jubilate.}

1552. Or else this Psalm, Jubilate Deo.

1559. Or the C Psalm, Jubilate.

1662. Or this Psalm, Jubilate Deo.

There is, at first sight, some ambiguity in the wording of the Rubric before the Benedictus, and consequently some have thought that the Jubilate should only be sung on the two occasions when the Rubric directs the Benedictus to be omitted. But the meaning is clear if the two Rubrics are read together thus: "And after that, the Hymn following; (except when that shall happen to be read in the Chapter for the Day, or for the Gospel on St. John Baptist's Day),' 'or this Psalm, Jubilate Deo.' The parenthetical marks are inserted for the sake of elucidation. Read in this way, it will be seen that the Jubilate can be sung on any occasion.

Cf. rubrics for use of alternative Prayers for Ember Days, of alternative Thanksgivings in the Post-Communion, and of alternative Psalms in the Office for the Solemnization of Matrimony.

Jubilate Deo. (Psalm c.) 1552. 'Great Bible.' Sar. Brev. Lauds.

In Lauds (Sundays and Festivals) it came before the Lesson.

The joyful character of this Psalm, which was most likely composed for some joyous Festival in the Jewish Temple, makes it specially appropriate after the reading of the glad tidings contained in the New Testament Lesson. Compare its position as the closing Psalm ( $a$ 'doxology') of the series of Psalms xciii.xcix., intended for Temple worship on some joyful occasion. It represents the 'tone' of Morning Prayer, as the Nunc dimittis that of Evening Prayer. In the latter the 'Gospel of Peace' is gratefully accepted, in the former ' grace, mercy, and truth' are made the ground of an appeal for joyous assurance that ' ' the Lord He is God.' The Psalm is written in antiphonal form.

\section{Analysis.}

I. An Appeal to all lands to sing God's Praise, for we are His vers.

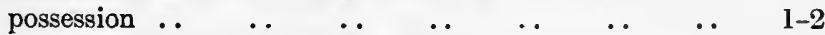

II. An Appeal to thank Him publicly, for His mercy is un-

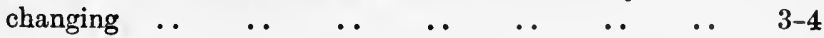

N.B.-R.V. renders 'and not we ourselves,' as 'and we are His.'

The Rubric before the Creed.

1549. Then the Minister shall say the Creed and the Lord's Prayer in English, with a loud voice, \&c. 
1552. Then shall be said the Creed by the Minister and the people, standing.

1662. Then shall be sung or said the Apostles' Creed by the Minister and the people standing : except only on such days as the Creed of St. Athanasius is appointed to be read.

The Apostles' Creed. 1549 (not printed in the Service). 1552 (printed). Sar. Brev. Matins and Prime.

This Creed, 'commonly called the Apostles"' (Art. VIII.), can only claim that designation from its containing Apostolic teaching. Traces of Apostolic formulæ have been thought to be found in Acts xvi. $31 ; 1$ Cor. xv. $3-8 ; 1$ Tim. iii. 16 ; 2 Tim. i. 13,14 ; but none of the various Baptismal Creeds of the primitive Church can boast of direct Apostolic sanction. The Baptismal Formula of Matt. xxviii. 19 is doubtless the germ of both the contents and the structure of the later Creeds, which gradually grew from a simple confession of faith in the Three Persons of the Blessed Trinity to more or less detailed summaries of Scriptural revelation concerning the Father, Son, and Holy Ghost.

The earliest use of a Creed was probably in Baptism, as is suggested by its ancient name Symbolum, i.e. the sign or mark by which a Christian is known. Other old names were Regula fidei, the rule or ' canon' of truth, and ' the standard of truth.' The Apostles' Creed is selected for this purpose in the Church of England, and is used not only in the Baptismal Offices, but also in the Catechism, Daily Services, and Visitation of the Sick.

The Apostles'. Creed attained to its present form about the middle of the eighth century. The following steps are traceable :-

138-161. Aristides' Apology gives 7 of its clauses.

180. Irenæus, Bishop of Lyons, gives a summary of Christian doctrine substantially similar to that of the Apostles' Creed : $A d v$. Haer. I. ii.

341. A Creed in the days of Marcellus shows approximation to the present form.

369-410. The Creed of Rufinus of Aquileia contains further additions towards the completion of the present Creed.

750. In the writings of Firminius the Creed is found in its present form.

About 1000 the Creed, which had already found its way into the Anglo-Saxon Office, was generally adopted by the Western Church. In the pre-Reformation Services it followed the Lord's Prayer amongst the prayers of Prime. Its present position is much more appropriate. It follows upon the reading of Holy Scripture, the foundation of faith, and precedes prayer, which 
both needs and sustains faith. The old practice in the Sar. Brev. was for the Priest alone and inaudibly to recite the Creed till the last clause ("et vitam reternam '), when he raised his voice as a signal to the Choir that they were to join with him in saying it. This inandible recitation of the Creed, as of the Lord's Prayer, has been connected with the early practice of concealing these sacred mysteries from the heathen and unbaptized. The Reformers were anticipated in their improvement upon this somewhat meaningless custom by Cardinal Quignon, who directed in his Breviary, 1536, that the Creed should be said aloud on all days except Sunday. In the Sar. Use the Creed used publicly was the Athanasian, but in Rom. Brev. the Athanasian Creed was used on Sundays only. The rubric directs the people to join the Minister in its recitation, profession of faith being essentially a personal matter ; and to stand, ${ }^{*}$ because that attitude is significant of readiness to defend and suffer for the faith.

There is no authority for the frequent practice of turning to the East in the Creed, nor is there any satisfactory explanation of the origin of the custom. The still more frequent custom of bowing the head at the Name of the Lord Jesus Christ is also without authority and explanation. The 18th Canon of 1604 indeed gives direction for 'due and lowly reverence' whenever in Divine Service the Name 'Jesus' is uttered, but apart from the fact that these Canons are not binding upon the laity, there is no authority here for restricting such observance to the Creed. The practical impossibility as well as the inconvenience attaching to such a direction has from the first prevented the Canon from being generally observed.

It is probable that the great mass of Christians are absolutely at one upon the Apostles' Creed, down to the clause which concluded its earlier forms, 'I believe in the Holy Ghost.' A possible exception is 'He descended into Hell,' omitted in the American Book $\dagger$ and by the Countess of Huntingdon's Connexion, but here the difference is based upon the ambiguity of the word 'hell,' and not upon doctrinal differences. The later clauses were added as the desire became more pronounced to emphasize the Church, and though they contain nothing in their wording to which any Christian would object, they are capable of very divergent interpretation.

It is to be noted that in the B.C.P. the words ' carnis resurrectionem' (Latin Version) are translated 'resurrection of the body,' but in the Baptismal Offices they are rendered 'resurrection of the flesh.'

* In 1549 the Creed was apparently said kneeling.

† Chang d to : 'He was sent to the place of departed spirits.' 
In 1549 the Apostles' Creed came after the Lesser Litany.* The Rubric before the Versicles.

1549. Then shall be said daily through the Year, the Prayers following, as well at Evensong as at Matins, all devoutly kneeling.

1552. And after that, these Prayers following, as well at Evening Prayer as at Morning Prayer, all devoutly kneeling, the Minister first pronouncing with a loud voice.

1662. The words 'as well at Evening Prayer as at Morning Prayer' omitted.

The Versicles before the Lord's Prayer. 1549. See Ruth ii. 4 ; 2 Tim. iv. 22 ; Ps. cxxiii. 3 ; Luke xvii. 13.

These Versicles consist of two parts-

1. The Mutual Salutation. 1552.

2. The Lesser Litany. 1549.

The division is marked by the invitation, ' Let us pray.'

The Rubric before the Lord's Prayer.

1549. Then the Minister shall say the Creed and the Lord's Prayer in English, with a loud voice, \&c.

1552. The words 'Clerks $†$ and People' were added after 'the Minister.'

1662. The words ' in English' were omitted.

It is ordered to be said ' with a loud voice' (cf. Justin Martyr, Apol. i. c. 13), as a corrective, doubtless, to the practice of the Church of Rome, which is to say it mentally.

The Lord's Prayer. 1549. Sar. Brev. Prime, where it preceded the Apostlos' Creed.

This Prayer is a fit introduction to the supplicatory portion of the Service, as a general summary of human need. Objection has been taken to the repetition of the Lord's Prayer, a repetition which in the Irish Book has been obviated by a special rubric. The Lord's warning against mechanical repetitions is interpreted by His own repetitions in Gethsemane (Matt. xxvi. 44). Repetition need not be mechanical, and the best defence of the practice here is that the Prayer is so condensed in its completeness that it is impossible for any worshipper, however devout, to exhaust its meaning in one utterance. The Doxology is omitted here, 'because the characteristic of this part of the Service is Prayer' (Cornford), i.e. as distinct from Praise.

The Rubric before the Versicles after the Lord's Prayer.

1549. Priest.

1552. Then the Minister standing up shall say.

* For the analysis and exposition of the Creed, see Catechism, pp. 406, 7.

† 'Clerks' mean the lay-clerks, i.e. the choir. 
1662. Then the Priest, etc.

The 'standing up' of the Priest is exceptional. The direction was apparently borrowed from the practice in the old Services of his rising up after the 51st Psalm, with the words Exsurgat Deus, and proceeding to the steps of the Altar to say the rest of the prayers, in order to be heard by the people with a view to their responding.

The Versicles or Preces and Responses after the Lord's Prayer. 1549. Sar. Brev. except 5th Versicle, which occurs in Henry VIII's Prymer, 1545.

These Versicles are found in the old Offices for Prime, but not together. Originally they were meant for private preparation for the Service. They are taken from the following texts, viz: Ps. lxxxv. 7 ; 1 Sam. x. 24 ; Ps. xx. 9 ; cxxxii. 9 ; xxviii. 9 ; li. 10, 11. The thoughts contained in them generally correspond with those in the Collects and Prayers which follow-

The 2nd. To the Prayer for the King.

The 3rd and 4th. To the Prayer for Clergy and People.

The 5th. To the Collect for Peace.

The 6th. To the Collect for Grace.

The Rubric before the Three Collects.

1549. The word 'Matins' was used.

1552. The words 'Morning Prayer' were substituted for 'Matins.'

1662. The words " all kneeling' were added.

In 1549 there was the following 2nd Rubric, 'The Priest standing up, and saying, Let us pray. Then the Collect of the Day.'

The Collect for the Day occurred at the end of Lauds.

The Collects with their brief petitions are characteristic of the Western Church; in the East a more exuberant phraseology found favour.

The Reformers recast several of the Collects and carefully rejected whatever was not consistent with the Holy Scriptures. This was especially needful in connection with the Collects for Saints' Days, which frequently contained intercession for or through the saint.*

Collect for Peace. 1549. Sac. Gel. ; Sar. Brev. Lauds. (See 1 Cor. xiv. 33 ; John xvii. 3 ; viii. 31-36 ; Rom. vi. 15-23 ; Ps. xxvii. 1,3.) The terseness of the Latin in the address to God is difficult of reproduction in Englislı: 'Quem nosse vivere, cui servire regnare est.'

Collect for Grace. 1549. Sac. Gel.; Sac. Greg.; Sar. Brev.

* For further details see pp. $149 \mathrm{ff}$. 
The American Book avoids the somewhat difficult grammar of the last clause by rendering it thus-

But that all our doings, being ordered by Thy governance, may be righteous in Thy sight. (Sed semper ad Tuam justitiam faciendam omnis actio Tuo moderamine dirigatur.)

It was here that the Order for Morning Prayer ended before 1662.

\section{The Rubric after the Third Collect.}

1662. In Quires and Places where they sing, here followeth the Anthem.

'Quire' means the choirs of Cathedrals, Royal Chapels, Collegiate Churches and Colleges; and 'Places' refers either to ordinary Parish Churches or to those mentioned in Elizabeth's 49th Injunction. Uuder the word 'Anthem' comes any Hymu or Psalm, rhythmical or metrical. This is the only place in the B.C.P. which authorizes Hymnody; but it has now been formally legalized in the amended Act of Uniformity that Hymns may be sung at other times during Service.

\section{The Rubric before the Five Prayers.}

1662. Then these five Prayers following are to be read here, except when the Litany is read; and then only the two last are to be read, as they are there placed.

Observe that the word 'read' is substituted for 'said,' the term previously used. This shows that the last Revisers were not so regardful as generally supposed of merely ecclesiastical expressions. 'Read' was an expression which came into use in the seventeenth century to distinguish liturgical from extempore prayers.

A Prayer for the King's Majesty. 1559. (1 Tim. ii. 1, 2.)

This Prayer, the authorship of which is unknown, is a good example of the more flowing and rhetorical style of the later Collects, breathing all the fervent loyalty of the Tudor Period. Prayers for Rulers occur in the old Greek and Latin Liturgies. In the Sarum Use they are called 'Memoriæ (Commemorations) pro rege' (Cornford).

The following quotation from Dr. Dowden * is worthy of notice: "This Prayer, "O Lord, our heavenly Father, high and mighty, King of kings," etc., has been much and deservedly admired for the solemn dignity of its opening. Yet there are at least two particulars in which it is capable of improvement. We know from Holy Scripture (Rev. xix. 16 and xvii. 14) that it is He whose "name is called the Word of God" that has on His vesture and on His thigh the name written, "King of kings, and

* See 'The Workmanship of the Prayer Book,' pp. 219, 220. 
Lord of lords." Hence it is "the Lamb" who is the "Lord of lords and King of kings." And in accord with this thought the original of this Prayer was addressed to the Second Person of the Blessed Trinity, and opened in the following sublime language: "O Lord Jesus Christ, mest high, most mighty, King of kings, Lord of lords, the only Ruler of Princes, the very Son of God, on whose right hand sitting dost from Thy throne," etc. The Reformers therefore, by altering the address, injured the thought of the prayer.'

1545. The earliest English form of it is in 'A Prayer for the Kynge' composed in the reign of Henry VIII and occurring in a book entitled 'Psalmes or Prayers taken out of holye Scripture.'

1553. Placed in the reformed Primer, as 'the fourth Collect for the-King' at Morning Prayer; another and shorter 'Prayer for the King' being added to the Collect 'for Peace' and 'for aid against all peril' at Evening Prayer. 1559. Placed in its present form before the Prayer of St. Chrysostom, at the end of the Litany.

1662. Removed to its present position.

A Prayer for the Royal Family. 1604.

This Prayer was approved, if not composed, by Archbishop Whitgift.

1604. Placed among the Collects at the end of the Litany, and entitled 'A Prayer for the Queen, and Prince, and other the King and Queen's children.' It began with the words, 'Almighty God, which has promised to be a Father of thine. elect and of their seed, We humbly beseech Thee to bless our gracious Queen Anne, Prince Henry and all the King and Queen's royal progeny; endue them,' etc.

1625. When Charles the First came to the Throne, having no issue, the words ' the fountain of all goodness' were substituted for the clause "which has promised ... seed.'

1632. After the birth of Prince Charles and the Lady Mary the passage in the 1604 B.C.P. was reintroduced.

1633. The Prayer was finally revised by Laud as we now have it.

1662. Placed in its present position.

A Prayer for the Clergy and People. 1559. Sac. Gel.; Sac. Greg.; Sar. Brev.

1544. Inserted in Cranmer's Litany.

1559. Introduced into Prayer Book, and placed at the end of the Litany. 
1662. Removed to its present position.

'Who alone workest great marvels' (cf. Ps. cxxxvi. 4). These words suggest:-

(1) The Pentecostal outpouring (Acts ii. 2-4).

(2) The Preservation and Triumph of the Church.

'Curates'-i.e. all who have cure of souls, whether they be Incumbents or Assistant Curates.

Other versions of the Prayer are-

Almighty and everlasting God, who alone workest great and marvellous things, send down upon our Bishops, Presbyters, and Curates, etc. (Scottish Liturgy, 1637.) Almighty and everlasting God, from whom cometh every good and perfect gift: send down upon our Bishops and other Clergy, and upon the congregation, etc. (The American Prayer Book.)

Prayer of St. Chrysostom. 1549. (See Matt. xviii. 19, 20.

This Prayer is found in the Liturgy of Constantinople bearing the name of St. Chrysostom, although it is wanting in the most ancient copy of that Liturgy, viz. the Barberini. It is likewise found in the Liturgy of St. Basil (ninth century), and forms part of the Byzantine Liturgy of the same date. The author of it is unkliown. Cranmer ascribed it to St. Chrysostom, probably because he took it from the Liturgy which bears his name. It is addressed to the Second Person of the Holy Trinity.

1544. It was placed at the end of the English Litany which had been set forth by Cranmer and his coadjutors. Before this time it had not been inserted in any of the 'Processions.'

1549. Retained in the same place.

1662. Placed in its present position, in Morning Prayer, but left at end of Litany also.

The Grace. 1559. (2 Cor. xiii. 14 ; cf. Numb. vi. 24-26.)

It is found in Eastern Liturgies. The Latin Hour Services ended with the salutation and the versicle and response-

Let us bless the Lord.

Thanks be to God.

1559. Placed at the end of Litany.

1662. Placed also at end of Morning and Evening Prayer. 
A TABLE SHOWING THE CONNEXION BETWEEN THE ORDER FOR EVENING PRAYER AND THE OFFICES OF VESPERS AND COMPLINE IN THE SARUM USE (BREVIARY).

Prayer Book, 1662.

Evening Prayer.

Sentences

2 Exhortation

3 Confession

4 Absolution

5

Our Father

O Lord, open

7

O God, make speed

Psalms

Gloria

10 Ist Lesson

11 Magnificat, or

12 Cantate

13 2nd Lesson

14 Nunc Dimittis, or

15 Deus Misereatur

16 Apostles' Creed

17 Lesser Iitany

18 Our Father

19 Suffrages

20 Colleet of the Day

21 Collect for Peace

22 Collect for Aid

23 Prayers for State and Chureh

24 St. Chrysostom's Prayer

25
SARUM USE,1 1085.

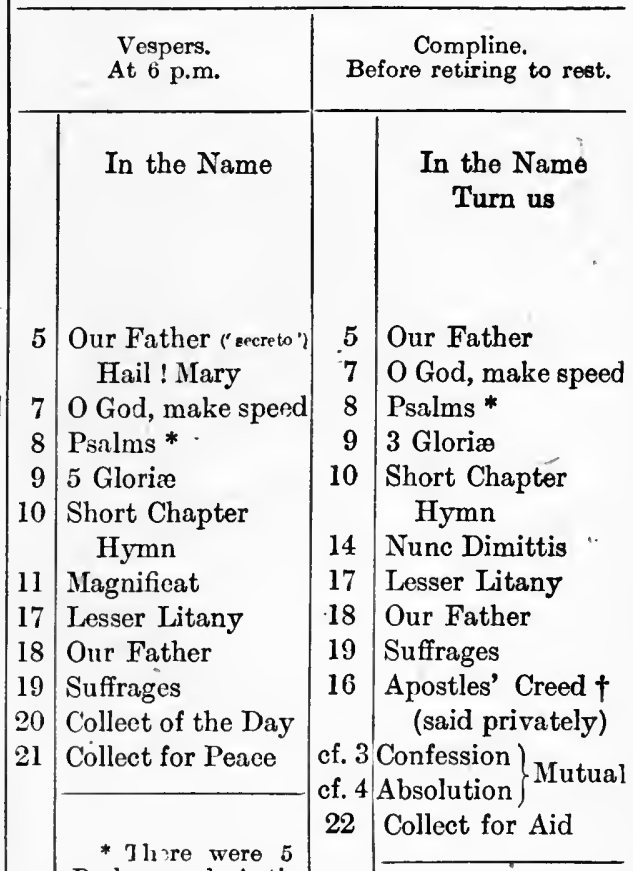

- There were 4 Psalms and Antiphons.

t The Choir re. spondled, 'Et vitam æternam. Amen.'

1 Definitely settled beginning of thirteenth century. Sarum Breviary reformed, 1st ed. 1516, 2nd ed. 1531, further reformed 1541 , 


\section{THE ORDER FOR EVENING PRAYER DAILY THROUGHOUT THE YEAR*}

THE Evening Service of the Book of Common Prayer was compiled partly from materials taken from the ancient Services of Vespers (Evensong) and Compline (the Service before retiring to rest). The general plan of the Order for Morning Prayer was followed, the intention being that both Services should exemplify the same general principles.

A certain difference of tone is traceable between the Order for Morning Prayer and that for Evening Prayer. In the words of Canon Fausset: 'As in the Morning Service intensity and vigour are the characteristics, so throughout the Evening Service there breathes a tranquil spirit, which is well embodied in the aged Simeon's soothing hymn, after his active day was past, and the shades of life's evening cheered by the assurance of Jesus' salvation were gathering round him.' $\dagger$

\section{The Title.}

1549. An Order for Evensong throughout the Year.

1552. An Order for Evening Prayer throughout the Year.

1662. The Order for Evening Prayer daily, etc.

The Sentences, etc.

1552. The Sentences, Exhortation, Confession, and Absolution added, but not printed in the Evening Service. The rubric, however, at the beginning of the Morning Service ran thus: "At the beginning both of Morning Prayer and likewise of Evening Prayer, the Minister shall read with a loud voice some one of these Sentences of the Scriptures that follow. And then he shall say that which is written after the said Sentences.'

1662. The Sentences, etc., up to the Lord's Prayer printed as an integral portion of the Evening Service, i.e. as they now stand.

* Refer to Notes on Morning Service for those parts which are sim lar to the Erening.

† 'A Guide to the Study of the Book of Common Prayer'(1894), p. 105. 
Rubric before the Lord's Prayer.

1549. The Priest shall say.

1662. Then the Minister shall kneel and say the Lord's Prayer ; the people also kneeling, and repeating it with him.

The Lord's Prayer. 1549. Sar. Brev. Vespers. [Not printed in full till 1662.]

In 1549 the service commenced with this Prayer.

The Versicles.

1549. O God, make speed to save me [us, 1552].

O Lord, make haste to help me [us, 1552].

1552. O Lord, open thou our lips

And our mouth shall shew. forth thy praise.

This Versicle and Response were added and placed before the former.

Gloria Patri. 1549. Sar. Brev. Vespers.

The Versicle.

1549. Praise ye the Lord. And from Easter to Trinity Sunday, Hallelujah.

1552. 'Hallelujah,' omitted.

1662. 'The Lord's name be praised' added.

The Rubric concerning the Psalms.

1549. Then Psalms in order as they be appointed in the Table for Psalms, except there be proper Psalms appointed for that day.

1662. Then shall be said or sung the Psalms in order as they be appointed.

\section{The Rubric concerning the First Lesson.}

1549. Then a Lesson of the Old Testament as it is appointed likewise in the Calendar, except there be proper Lessons appointed for that day.

1662. Then a Lesson of the Old Testament, as is appointed.

\section{The First Lesson.}

This occupies the same position in the Service as did the Chapter read at Vespers.

The Rubric before the Magnificat.

1549. After that [i.e. the Lesson] (Magnificat anima mea Dominum) in English, as followeth.

1552. 'Anima mea Dominum' omitted.

1662. And after that [i.e. the Lesson], Magnificat (or the Song of the Blessed Virgin Mary) in English, as followeth.

The Magnificat. (Luke i. 46-55.) Great Bible. 1549. Sar. Brev. Vespers.

This Canticle, which resembles the Song of Hannah (1 Sam. 
ii. 1-10), has been sung at Evening worship from the sixth century, when St. Benedict is said to have assigned it for use at Vespers. In the Eastern Church it is sung in the morning while the Deacon censes the altar. In the King's Primer 1545 it was entitled, "The Song of Mary rejoicing and praising the Goodness of God.' Owing to the high position assigned in the Canticle to the Virgin Mary, and owing to the fact that ornate ritual often accompanied its public use in the Middle Ages, the Puritans tried several times to procure its removal from the Prayer Book. In 1662 the explanatory title was added, "or the Song of the Blessed Virgin.'

I. Outburst of Joy Analysis.
II. Various Notes of Praise for :-
1. The Personal Honour bestowed upon her

The Rubric before the Cantate Domino.

1552. Or else this Psalm.

1559. Or the 98 Psalm. Cantate Domino canticum novum.

1604. Or else this Psalm. Cantate Domino, Psalm 98.

1662. Or else this Psalm; except it be on the Ninetcenth Day of the Month, when it is read in the Ordinary course of the Psalms. Cantate Domino, Psalm : 8

Cantate Domino. (Ps. xcviii.) Great Biblc. 1552. Sar. Brev. Lauds.

The language of this Canticle resembles in several passages that of the Magnificat. The Hymn is a Song of Triumpl for the revelation of Grod to the world as Conqueror, Deliverer, and Judge.

An alternative Canticle was here provided, possibly as a concession to those who were prejudiced against the Magnificat.

In the American Prayer Book a second alternative is provided, consisting of Ps. ciii. 1-4, 20-22.

\section{Analysis.}

\section{A Summons to sing to God, addressed}

2. To all the Nations of the World $\begin{array}{lllll}. . & . . & . & . & 1-4 \\ & & . . & . & 5-7\end{array}$

3. To the World of Nature $\ldots$.

- 'And holy is his name' $(v .49 b)$ is an outburst of adoration called forth by the thought of the personal honour bestowed upon her. 
The arrangement of the verses both in the A.V. and the R.V. somewhat differs from the Prayer Book Version.

The Rubric concerning the Second Lesson.

1549. Then a Lesson of the New Testament.

1662. Then a Lesson of the New Testament, as it is appointed.

\section{The Second Lesson.}

This occupies the place of the Chapter that was read at Compline.

The Rubric before the Nunc dimittis.

1549. And after that [i.e. the Second Lesson], (Nunc dimittis servum tuum) in English, as followeth.

1552. Servum tuum omitted.

1662. And after that, Nunc dimittis (or the Song of Simeon) in English, as followeth.

Nunc dimittis. (St. Luke ii. 29-32.) Great Bible. 1549. ǒar. Brev. Compline.

This is found as a Canticle in the 'Apostolical Constitutions.' * Its use in Compline is ascribed to Gregory the Great (d. 601). Analysis.

I. A thankful readiness to depart, now that Simeon has seen vers.

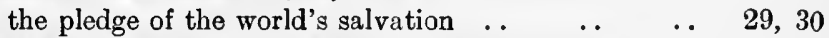

II. Declaration respecting the Saviour's world-wide office as the

Gentiles' Light and Israel's Glory $\quad . \quad \ldots \quad \ldots \quad \ldots \quad$. 31,32

N.B.-In 1549 the Rubric after the Nunc dimittis ran thus: - Then the suffrages before assigned at Matins, the Clerks kneeling likewise, with three Collects,' etc. This was explained by the rubric before the Lesser Litany in the Morning Service which ordered, "Then shall be said daily through the Year, the Prayers following, as well at Evensong as at Matins, all devoutly kneeling.' $\dagger$

The Rubric before the Deus inisereatur.

1552. Or else this Psalm.

1559. Or this Psalm (Deus misereatur nostri) in English.

1604. Or else this Psalm.

1662. Or else this Psalm; except it be on the Twelfth Day of the Month.

Deus misereatur. (Ps. lxvii.) Great Bible. 1552. Sar. Brev. Lauds.

* See 'A post. Const.,' vii. 49.

$\uparrow$ Much difficulty is experienced in ascertaining the rubrical directions in the Prayer Books prior to 1662, and especially those of 1549, as many of those referring to the conduct of the Evening Service are found in the Morning Service, and vice versa. 
The underlying thought of this Psalm is that the acknowledgment of God's blessing leads to further blessings. The keynotes are, 'Prayer,' 'Blessing,' 'Praise,' ' further Blessing.' (John i. 16.)

\section{Analysis.}

I. Prayer for blessing upon Israel, that the nation may fulfil vers.

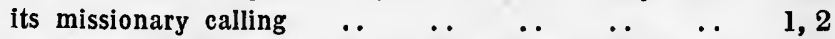

II. Appeal for world-wide praise to God on account of His right-

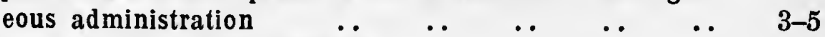

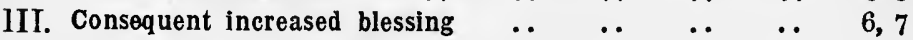

The Rubric before the Creed.

1549. Then the Minister shall say the Creed and the Lord's Prayer in English, with a loud voice, \&s. (See Morning Service in loc.).

1552. Then shall follow the Creed, with other Prayers as is before appointed at Morning Prayer after Benedictus.

1662. Then shall be said or sung the Apostles' Creed by the ' Minister and the people, standing.

The Creed. 1549 (but not printed). Sar. Brev. Compline. The Rubric before the Versicles.

1549. Then the suffrages before assigned at Matins, the Clerks kneeling likewise.

1552. Then shall follow ... other Prayers as is before appointed at Morning Prayer after Benedictus.

1662. And after that, these Prayers following, all devoutly kneeling ; the Minister first pronouncing with a loud voice. Mutual Salutation.

The Versicles before the Lord's Prayer. 1549. Sar. Brev. Vespers and Compline.

The Lord's Prayer. 1549.

The Versicles and Responses after the Lord's Prayer. 1549.

These 'Versicles' are called 'Suffrages' in 1549.

Rubric before the Three Collects.

1549. With three Collects. First of the Day; second of Peace; third for Aid against all Perils, as here followeth: which two last Collects shall be daily said at Evensong without alteration.

1552. And with three Collects ; first of the Day ; the second of Peace; the third for Aid against all Perils, as hereafter followeth: which two last Collects shall be daily said at Evening Prayer without alteration (included in rubric before the Creed).

1662. Then shall follow three Collects; the first of the Day, etc. 
Collect for Peace. 1549. Sac. Gel. ; Sar. Brev., Vespers.

Collect for Aid against all Perils. 1549. Sac. Gel. ; Sac. Greg. ; Sar. Brev. Compline.

Its language echoes noticeably that of the Psalms. "Thou shalt light my candle, the Lord my God shall make my darkness to be light. Yea the darkness is no darkness but the night is as clear as the day : the darkness and light to Thee are both alike. $\mathrm{He}$ will not suffer thy foot to be moved: and $\mathrm{He}$ that keepeth thee will not sleep. Behold He that keepeth Israel shall neither slumber nor sleep' (Ps. xviii. 28; cxxxix. 11; cxxi. 3, 4. Prayer Book Version).

In the first American Prayer Book the Collect reads thus: ' O Lord, our heavenly Father, by whose Almighty Power we have been preserved this day; by Thy great mercy defend us from all perils,' etc., but in the revision of 1886 the English form was adopted.

In the American Book there is a Rubric to the Collect to the following effect : "The Minister may here end the Evening Prayer with such Prayer or Prayers, taken out of this Book, as he shall think fit.'

\section{The Closing Rubric.}

In the 1549 B.C.P. after the Third Collect there was the following rubric: "In the feasts of Christmas, the Epiphany, Easter, the Ascension, Pentecost, and upon Trinity Sunday, shall be sung or said immediately after Benedictus this Confession of our Christian Faith.'* In the B.C.P. of 1552, 1559, and 1604 the rubric directed that it should also be sung or said on the Festivals of Saint John the Baptist and some of the Apostles.

The Court Prayers, the Prayer for the Clergy and People, the Prayer of St. Chrysostom, and the Blessing, were all inserted in 1662 as a result of the Savoy Conference.

The Benediction in the Eastern Vespers was thus worded : - And may the blessing of the Lord come upon us through His grace and lovingkindness continually, now, always and for ever and ever. Amen.'

1549. Thus endeth the Order of Matins and Evensong, through the whole Year.

1552. 'Morning and Evening Prayer' were substituted for 'Matins and Evensong.'

1662. Here endeth the Order of Evening Prayer throughout the Year.

* This was the Athanasian Creed which was printed in 1549 at the end of the Evening Service, i.e. immediately after the Tnird Collect. See notes on 'Athanasian Creed,' pp. 122 ff. 


\section{THE ATHANASIAN CREED}

The Heading. At Morning Prayer. 1662.

The Name of the Creed. This is not given in the heading, but in the opening rubric it is spoken of as "This Confession of our Christian Faith, commonly called the Creed of Saint Athanasius' 1662.

The title in the Utrecht Psalter was 'Hymnus Athanasii de fide Trinitatis'; in many ancient Psalters, 'Fides Catholica sancti Athanasii'; in Sar. Brev. 'Symbolum Athanasii.'

The Creed is called that of St. Athanasius (Bishop of Alexandria, 326-373), because it contains the great doctrine of the Trinity in Unity and the Unity in Trinity, for which he contended against the Arians.

\section{The Rubric.}

1549. In the feasts of Christmas, the Epiphany, Easter, the Asccnsion, Pentecost; and upon Trinity Sunday, shall be sung or said immediately after Benedictus, this Confession of our Christian Faith.

1552. In the feasts of Christmas, the Epiphany, Saint Matthias, Easter, the Ascension, Pentecost, Saint John Baptist, Saint James, Saint Bartholomew, Saint Matthew, Saint Simon and Jude, Saint Andrew, and Trinity Sunday, shall be sung or said, immediately after Benedictus, this Confession of our Christian Faith.

1559. 'Saint' was printed ' $S$ ' (according to Keeling).

1604. 'Saint' was restored for 'S.'

These rubrics and the Creed itself in the above Editions stood at the end of The Order for Evening Prayer.

1662. Upon these Feasts; Christmas Day, etc. . . shall be sung or said at Morning Prayer, instead of the Apostles' Creed, this Confession of our Christian Faith, commonly called the Creed of Saint Athanasius, by the Minister and people standing.

The seven additional days, added in 1552 to the six great Festivals named in $\mathbf{1 5 4 9}$ for its use, were, as will be seen by the 
table below, apparently in order to secure the Creed being said about once a month.

The Six Great Festivals.

1. Christmas Day (Dec. 25).

2. The Epiphany (Jan. 6).

3. Easter Day (March 22 April 25).

4. Ascension Day (April 30June 3).

5. Whit-Sunday (May 10-June 13).

6. Trinity Sunday (May 17June 20).
The Seven other Holy Days.

1 St. Matthias (Feb. 24).

2. St. John the Baptist (June 24).

3. St. James (July 25).

4. St. Bartholomew (Aug. 24).

5. St. Matthew (Sept. 21).

6. St. Simon and St. Jude (Oct. 28).

7. St. Andrew (Nov. 30).

Quicunque Vult was inserted 1549, omitted 1552 and 1559, and re-inserted 1604.

\section{THE SPECIAL CHARACTER OF THE CREED.}

The Creed not only affirms and defines the doctrine of the Trinity and the union of the Divine and human natures in our blessed Lord, but also contradicts and excludes certain heretical opinions of the time when it was composed.

' Every proposition is a record of some battle-field, on which the faith has been assaulted, but finally is maintained, ascertained, and cleared' (Samuel Wilberforce). 'Not a phrase that is used,' writes Dean Armitage Robinson, ' is new : each phrase has been tested in the long fight, and has been found needful to protect some portion of the truth. Almest every section is the tombstone of a buried error.'*

\section{HISTORICAL NOTES.}

o. 420-450. Compiled in Southern Gaul, author unknown.

c. 670. First mentioned in connection with the Gallican Church in a Canon of the Council of Autun.

772. Presented to the Pope by Charlemagne and the Lombards.

c. 900. Introduced into England.

c. 930. Admitted into the Offices of the Church of Rome.

c. 1085. Ordered in Sar. Brev. to be said daily at Prime.

1539. Translated into English in Bishop Hilsey's Primer.

- 'Some Thoughts on the Athanasian Creed,' p. 23. See also pp. 46. 47, 61,62 . 


\section{APPARENT QUOTATIONS FROM THE CREED.*}

798.

By Denebert, Bishop of Worcester, in a Confession of Faith presented to the Archbishop of Canterbury.

633. By the Fathers assembled at the fourth Council of Toledo.

502-542. By Cæsarius, Bishop of Arles.

490-518. By Avitus, Bishop of Vienne.

450. By Vincentius of Lerins.

\section{ITS AUTHORSHIP.}

It was at an early period regarded as the work of Athanasius, and this traditional authorship remained practically unquestioned until the seventeenth century.

The Ten Articles (1536) stated it was 'made by Athanasius.' Richard Hooker follows Baronius in ascribing it to Athanasius, and there is no indication of doubt in formularies until 1662. A Dutch theologian named Gerard Voss in his work on the Three Creeds (De tribus Symbolis), 1642, forcibly and successfully attacked the received opinion.

The arguments against the Athanasian authorship are as follows $\dagger$ :-

(1) It rarely occurs in any MS. of Athanasius, and never with his name affixed.

(2) It is not referred to by Gregory Nazianzen, Basil, Chrysostom, or any other early Fathers.

(3) It is not cited (as it would have been if it had been acknowledged to be the work of St. Athanasius) during the important controversy respecting the Procession of the Holy Spirit, in the eighth century.

(4) It is seldom mentioned up to 1000 A.D.

(5) It is now admitted to be originally a Latin composition.

(6) It is largely dependent on the works of Augustine, who wrote a century later than Athanasius.

(7) It definitely condemns Apollinarianism, which did not become a serious danger till the last years of Athanasius' life, and was not formally condemned till after his death (see Bishop Gibson, 'The Three Creeds,' pp. 183-184).

N.B.-The first four arguments were those used by Voss.

The following have been suggested, but upon inconclusive grounds, as possible authors of the Creed : Hilary, Bishop of Arles (c. 430) ; Cæsarius, Bishop of Arles (470-542); Vincentius of

* See Bishop Gibson, 'The Three Creeds,' p. 191.

$\dagger \cdot$ Critical History of the Athanasian Creed,' 1723 (revised edition by J. R. King, 1870). 
Lerins (450); Honoratus, Bishop of Arles (d. 429). Some have thought it may have been gradually developed by various hands into its present form.

\section{ITS DATE.}

Waterland * tries to fix its date as follows :-

(1) It could not be earlier than 420 , for-

(a) It combats so fully the Arian and Apollinarian heresies.

(b) It depends so largely on the work of St. Augustine on the Trinity (416).

(2) It could not well be later than 430 , for-

It is wanting in those critical terms which were used against the heresies of Nestorius and Eutyches, condemned at the General Councils of Ephesus (431) and Chalcedon (451).

Therefore its date must be between 420 and 430 . $\dagger$

\section{ITS USE IN THE SERVICES OF THE CHURCH.}

There is a very great difference of opinion about this. Against its recital it has been urged that + :-

(1) It is in a high degree ill-suited for use in the large and miscellaneous gatherings that crowd our Churches at the great festivals.

(2) It cannot in its present form be otherwise than misleading.

(3) It is a constant source of irritation and misunderstanding.

(4) It is a composition in the form of a hymn.

(5) Its statements go beyond the teaching of Scripture.

The following several suggestions $\S$ have been offered :-

(1) To make the use optional instead of compulsory, by inserting 'may' in the place of 'shall' in the rubric.

* See Bishop Gibson, 'The Three Creeds,' pp. 181-189.

$\uparrow$ The arguments in support of this conclusion are clearly set out in Harold Browne's 'Exposition of the Articles,' pp. 221-224.

† Seo Ffoulkes, "The Athanasian Creed; by whom written and by whom published,' 1872; Heurtley, 'The Athanasian Creed,' 1872, and 'A Histcry of the Earlier Formularies of Faith,' 1892 ; Lumby, ' History of the Creeds,' 1873; Swainson, 'The Nicene and Apostles' Creeds : their Literary History, together with an Account of the Growth and Reception of the Sermon on the Faith commonly called the Creed of St. Athanasius,' 1875 ; Ommanney, 'A Critical Dissertation on the Athanasian Creed,' 1897 ; A. E. burn, 'An Introduction to the Creeds and to the Te Deum,' 1899.

$\S$ Gibsor deals with these suggestions in his work on 'The Three Creeds,' 1908, pp. 252-258. 
(2) To remove the minatory clauses.

(3) To delete the rubric, as has been done by the Church of Ireland, so that the Creed, while remaining in the Prayer Book, should be no longer used in public worship.

(4) To provide a synodical declaration, or rubrical note, and a new translation.

(5) To print the Creed in its present form, together with a new translation, at the end of the Prayer Book, as an appendix.

The reasons for its retention in its present position are thus stated by Waterland: 'So long as there shall be any men left to oppose the doctrine which this Creed contains, so long will it be expedient, and even necessary, to continue to use it, in order to preserve the rest : and, I suppose, when we have none remaining to find fault with the doctrines, there will be none to object against the use of the Creed, or so much as wish to have it laid aside.'

It is omitted altogether in the American Prayer Book.*

It occupies no authoritative position in the Greek Church. $\dagger$ In the Greek versions the filioque phrase (v. 23) is of course wanting. Since the last quarter of the eighteenth century it has been accorded a place in the Horologion, or Service Book of the Greek Church.

In the Roman Church it is used at Prime, a service when few of the laity are present.

\section{INTRODUCTORY SUMMARY.}

1. The Godhead, the Divinity, the Essential Being of God, that which makes God to be God, is technically called substance. $\neq$

2. In order to describe the individuality of the Father, the Son and the Holy Spirit, the technical term Person $\S$ is used.

3. God the Father begat the Son from all eternity, and He has the same substance with the Father.

* For the discussion as to its retention for public use in the Chureh of England, see Stanley, 'The Athanasian Creed,' 1871 (adverse); Brewer, 'Origin of the Athanasian Creed,' 1872 (defensive); Oxenham, 'The Athanasian Creed: should it be recited ?' 1902 ; J. Armitage Robinson,

'Thoughts on the Athanasian Creed,' 1905.

† See Gibson, 'The 'Three Creeds,' 1909, p. 205.

$\ddagger$ 'Substance' ('sub stare') is that which is supposed to stand under or support attributes.

$\S$ The 'Persons' of the Trinity cannot be contemplated as existing and working in isolation. In all their acts all the Persons of the Trinity cooperate. 
The Arians taught that the Son was of a like but not identical substance. tion.

The Adoptionists taught a Sonship merely by adop-

4. From God the Father and God the Son eternally proceeded the Holy Ghost, and He has the same substance with the Father and the Son. He is not, as the Macedonians taught, a creature.

The words ' begat,' ' proceeding,' are scriptural terms, used as those best able to suggest Divine relationships which are beyond human language to express, and the human mind to grasp.

5. Thus there is a Trinity in Unity and a Unity in Trinity.

6. In regard to the Incarnation of our Lord, the following points need to be firmly held :-

(1) Our Lord had a real human body.

His body was not, as the Docetæ taught, only a seeming body, or a phantom.

(2) In our Lord there is one Person, two Natures.

$\mathrm{He}$ is not, as Nestorianism taught, two distinct persons. He has two natures, not one nature, as the Monophysites affirmed; nor are the two natures fused, as the Eutychians contended.

(3) The human nature of Christ was complete. He had a reasonable or rational soul, and a human will.

The Divine nature of our Lord did not supply or interfere with His rational soul, as the Apollinarians contended; nor did it take the place of His human will, according to the teaching of the Monothelites.

\section{ANALYSIS.}

I. Exposition of the Doctrine of the Trinity (vv. 1-28).

1. Necessity of holding fast the Catholic Faith in its Integrity vers. $\begin{array}{llllllll}\text { and Purity } & \ldots & \ldots & \ldots & \ldots & \ldots & \ldots & 1,2\end{array}$

2 Definition of the Catholic Faith, concerning the Unity in

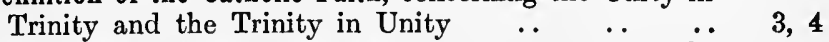

3. Enumeration of the Divine Attributes possessed alike by each Person of the Trinity .. $\quad . . \quad \ldots \quad$..

4. Declaration of the Relations existing between the Divine Persons, viz.-

The Father is made of none;

The Son is of the Father alone ... begotten;

The Holy Ghost is of the Father and the Son ... proceeding

5. Summary of above Statements.

The Three Persons in the Trinity are co-eternal and co-equal 
IJ. Exposition of the Doctrine of the Incarnation (vv. 29- 41)

1. Necessity of a Firm Faith in this Doctrine $\quad . \quad 2 \quad \ldots \quad 29$

2. Statements respecting the Reality of our Lord's Human and Divine Natures, viz.-

The union of the two natures and their distinctness

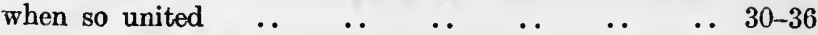

N.B.-Verses 30-33 state the perfection of the two natures in One Person, and vv. 34-36 guard against misunderstandings.

3. Description of the Work of the Incarnate Christ $\quad . \quad 37-41$

Final Re-affirmation of the Necessity of Believing

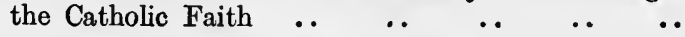

\section{EXPOSITION.*}

\section{The Doctrine of the Trinity.}

1. The Necessity of holding fast the Catholic Faith in its Integrity and Purity (vv. 1, 2).

1. Whosoever $\dagger$ will be saved [would be saved], i.e. desireth to be saved ("Quicunque vult salvus esse') : before all things, i.e. first in importance, it is $\dagger$ necessary [needful] that he hold [fast] ('teneat') the Catholic Faith, i.e. the faith held by the whole Church (Acts xvi. 30, 31 ; Heb. xi. 6) as distinguished from that held by heretical communities.

'Would be saved;' marg. 'desireth to be saved.'

2. Which Faith except $\dagger$ every one [a man] ('quisque '), i.e. one who has been duly instructed in the truth $\dagger$ do keep [have kept] whole and undefiled ("integram inviolatamque servaverit'), i.e. in both its integrity and purity, without omission or corruption: without doubt he $\dagger$ shall [will] perish everlastingly (eternally) (' in æternum peribit').

'Undefiled;' marg. ' uncorrupted.'

The Creed can only be duly appreciated when it is regarded as ' the warning of a loving mother for her children' during the stress of Arian persecutions that severely tried the faith of many. 'The Quicunque' has well been termed by Bishop Dowden 'The mysterious cry, the chant, the inspiring battle-song of the faith, or the hymn of constancy'; and by Dean Armitage Robin-

* The renderings in square brackets [ ] are those of the Committee appointed by the Archbishop to make a new translation of the Athanasian Creed in pursuance of the 29th Resolution of the Lambeth Conference, 1908. These aiternative renderings in the margin are given in small type immediately after the verses. The sign $\uparrow$ immediately precedes the original words which have been differently translated. The marginal alternative renderings of the Committee are given in small type after each verse. 
son 'The great hymn of the Catholic Faith.' The Formal Declaration by the Convocation of Canterbury, 1879, runs, 'Whereupon the warnings in this Confession of Faith are to be understood not otherwise than the like warnings of Holy Scripture ; for we must receive God's threatenings even as His promises, in such wise as they are generally set forth in Holy Writ. Moreover, the Church doth not herein pronounce judgment on any particular person or persons, God alone being the Judge of all.' Bishop Gibson remarks, ' The monitory clauses are simple varnings, not of what we wish to happen to any one, but of what, if God's Word be true, will happen to those who reject or let go the faith' ("The Three Creeds,' p. 243).*

\section{Definition of the Catholic Faith, concerning the Unity in Trinity and the Trinity in Unity (vv. 3,4).}

3. And [now] ('autem') the Catholic Faith is this : That (not only we believe but) we worship ('veneremur') one God $\uparrow$ in [as a] Trinity, and Trinity $\dagger$ in [as an] Unity ('unum Deum in Trinitate, et Trinitatem in Unitate') ;

"The word "worship" marks the attitude of the Church towards the deep mystery of the Faith. It seems to say at the outset: We cannot wholly understand these things, for they are in their nature higher than the sphere in which we live and think as mortal men. We must look up to them : our true attitude is the upraised face of adoring wonder.' $\$$

4. Neither confounding [confusing] by destroying the identity of the Persons (as Sabellius, who considered the Three Persons to be only three different aspects or manifestations of one God, namely, Creator, Redeemer, Inspirer) : nor dividing ('separantes') the Substance (i.e. essential nature of the Godhead) (as Arius, who denied that the Substance of the Son and of the Holy Ghost was the same with the Substance of the Father ; cf. John xiv. 9-11 ; xvii. 11 ; Rom. viii. 9-11).

'The substance' ('sub stare') etymologically the equivalent of the Greek word i $i$ oorárts, hypostasis, which theologically, however, was used sometimes in the sense not of 'substance' but of 'person'. The Greek word generally used for substance was ov́cía, ousia.

* Cf. J. Armitage Robinson, 'Some Thoughts on the Athanasian Creed, pp. 43, 44.

$\ddagger$ J. Armitage Robinson, Ibid., p. 29. 
3. Enumeration of the Divine Attributes possessed alike by each Person of the Trinity (vv. 5-20).

5. For ('enim'), by way of elucidation, there is $\dagger$ one [a] Person ('alia persona') of the Father, another of the Son : and another of the Holy Ghost (cf. Matt. iii. 16, 17 ; John xv. 26).

This verse is directed against the Sabellians, who in their anxiety to preserve the unity of the Godhead, fell into the error of denying such distinctions within the Godhead as are necessary to make the Incarnation and Atonement possible. Hence they were called Patripassians by the orthodox, as implying that God the Father suffered on the Cross.

6. But the Godhead of the Father, of [omit ' of '] the Son, and of [omit ' of '] the Holy Ghost, is all [omit ' all '] one (simply ' una') (John i. 1 ; x. 30) : $\uparrow$ the [their] Glory equal (John i. 14 ; xvii. 5), the [their] Majesty co-eternal (cf. John xvii. 5 ; Heb. i. 3 , R.V.).

This verse is directed against the Arians, who, though they called Jesus the Son of God, yet used the words in an inferior sense, since they denied that $\mathrm{He}$ was of the same eternal and equal Substance with the Father.

7. Such as the Father is, such is the Son : and such is the Holy Ghost.

Verses 7-18 enforce the statements just made (vv. 3-6), by emphasizing the truth that while each of the Divine Persons possesses the Divine properties and attributes, each being uncreated, infinite, eternal, almighty, God and Lord, yet we are not to think of the Persons of the Holy Trinity as being so separate one from another as to be three uncreated infinites, eternals, almighties, or as being three Gods or three Lords (Gibson, 'The Three Creeds,' 1909, pp. 212, 213).

8. The Father $\nmid$ uncreate [uncreated] (cf. Ps. xc. 2 ; Isa. xl. 13, 14 ; xliii. 10 ; John i. 1-3), the Son $\uparrow$ uncreate [uncreated] : and the Holy Ghost $\uparrow$ uncreate [uncreated].

9. The Father $\dagger$ incomprehensible [infinite] ('immensus '), the son $\dagger$ incomprehensible [infinite] : and the Holy Ghost $\dagger$ incomprehensible [infinite] (cf. Job xi. 7-9; Ps. cxxxix. 7 ; 1 Cor. ii. 16).

'Incomprehensible' does not mean here 'not to be comprehended.' This word 'incomprehensible 'in olden days possessed a different meaning from that which it now conveys. As used in this verse it signifies 'infinite,' 'illimitable.' The Latin word in the Creed is 'immen- 
sus.' * Bishop Dowden, however, considers that the word '.incomprehensible' is used to represent not

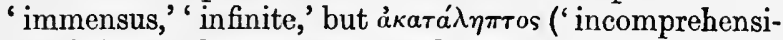
bilis '),' not to be thoroughly understood by the intellect;' and that a Greek text was used for our version. 'The word "immensus," writes Dean Armitage Robinson, "conveys the idea that the Divine nature cannot be measured by any measure that we can apply to it, and cannot be grasped in its completeness by our human faculties.' +

10. The Father eternal, the Son eternal : and [om. ' and '] the Holy Ghost eternal (cf. Ps. xc. 2; Isa. Ixiii. 16 ; Heb. i. 8 ; Rev. xxii. 13).

11. And yet they are not three eternals : but one eternal.

12. As also there are $\nmid$ not three incomprehensibles, nor three uncreated : but one duncreated, and one incomprehensible [not three uncreated, nor three infinites: but one infinite, and one uncreated].

13. So likewise the Father is Almighty, the Son Almighty : and the Holy Ghost Almighty (cf. Gen. xvii. 1 ; Job xxxiii. 4 ; Rev. i. 8 ; xv. 3 ).

14. And yet they are not three Almighties : but one Almighty.

15. So the Father is God, the Son is [omit 'is '] God : and the Holy Ghost is [omit 'is '] God (Acts v. 3, 4 ; Eph. i. 3).

16. And yet they are not three Gods : but one God.

17. So likewise [omit 'likewise '] the Father is Lord, the Son Lord : and [omit 'and'] the Holy Ghost Lord (cf. Matt. xi. 25; Acts x. 36 ; 2 Cor. iii. 17).

18. And yet [they are] not three Lords : but one Lord.

19. For ("quia ' because) like as we are compelled by the Christian verity (i.e. by the truth expressed in the Holy Scriptures) : to acknowledge [confess] $\uparrow$ every Person [each of the Persons] by himself ('singillatim,' singly, severally) to be [both] God and Lord;

By the Christian verity ;' marg. 'by Christian truth.'

'By himself ;' marg. 'severally.'

20. So are we forbidden by the Catholic Religion (see note on v. 1): $\dagger$ to say, There be [to speak of] three Gods, or three Lords.

' We must not view God as we would a material being, as though the Godhead could be divided into three different parts, which three united together made up one whole; and so imagine that the Father alone was not

* Dowden, 'Further Studies in the Prayer Book,' po. 137-162 ; specially p. 145.

¥ 'Some Thoughts on the Athanasian Creed,' p. 69. See also p p. 30-33. 
God, but required to have the Son and Spirit added to Him in order to make up the Godhead. The spiritual unity is far closer, more intimate, and more real than the unity by which parts make up a whole. Each by Himself or considered alone ('severally') must be confessed to be God; and yet all make not up three Gods, but are one in essence, and therefore but one God '. (Bishop Harold Browne, 'Exposition of the ThirtyNine Articles,' 1868, p. 226).

Swainson remarks upon this verse that 'we may speak of a "separate confession" in regard to One or Other (of the Persons of the Trinity); but that it is wrong to speak of One or Other as being " by Himself.",

4. Declaration of the Relations existing between the Divine Persons (vv. 21-23).

21. The Father $\dagger$ is made [omit ' made '] of none ('a nullo '), i.e. $\mathrm{He}$ is self-existent [not made]: $\dagger$ neither [nor] created, nor begotten.

The Father derives His essence from none, being Himself the Fountain and Source of being (cf. John v. 26). He is the essential Godhead with the property ' to be of none,' and is revealed as the first Person in order in the Holy Trinity (cf. Matt. xxviii. 19).

22. The Son is of the Father alone (in contradistinction to the double Procession of the Holy Spirit see v. 23): not made, nor created, but begotten (cf. John v. 26 ; Heb. i. 5).

The very same nature or substance of God which the Father has, is from all etcrnity communicated by Him to the Son.

23. The Holy Ghost is of the Father and of [omit '.of '] the Son ('a Patre et Filio ') (cf. John xiv. 26 ; xv. 26 ; Acts ii. 33) : $\dagger$ neither [not] made, nor created, nor begotten, but proceeding ('procedens').

The famous filioque elause ('and the Son') in the Nicene Creed is rejected by the Eastern Church, as an unauthorized addition to the statement in John xv. 26. The statement in the Creed implies that the very same substance of God is from all eternity communicated to the Holy Ghost from the Father and the Son.*

5. Summary of above Statements (vv. 24-28).

24. So there is [there is therefore] i.c. it follows from what has been stated about the properties of the Godhead (vv. 21-

* See Nicene Crecd, p. 305. 
23) one Father, not three Fathers : one Son, not three Sons : one Holy Ghost, not three Holy Ghosts.

25. And in this Trinity, none is $\dagger$ afore [before], or after other [omit 'other'] as to duration: none is greater, or less than another [omit 'than another'] as to degree, power, and dignity ('Et in hac Trinitate nihil prius aut posterius, nihil majus aut minus');

Bishop Dowden suggests that our English of the second clause of this verse 'is rather a paraphrase of what was supposed to be the true sense of a rather obscure verse, than an attempt to translate it.' $\mathrm{He}$ offers as a free re-translation the following: "And in this Trinity there is nothing afore or after, nothing greater or less.' The idea of the original seems to be, he writes, "that in the conception of the Trinity there is no place for the notions of priority, posteriority, or of greater or less.' *

26. But the whole three Persons are co-eternal $\uparrow$ together [one with another] ('coæternæ sibi') : and co-equal.

27. So that in all $\dagger$ things [ways], as is aloresaid (vv. 3-23); † the Unity in Trinity, and the Trinity in Unity is to be worshipped [both the Trinity is to be worshipped as an Unity, and the Unity as a Trinity] (cf. Rev. vii. 9-12).

28. He therefore that will be saved [Let him therefore that would be saved] (' qui vult ergo salvus esse ') $\uparrow$ : must thus think [think thus] of the Trinity, i.e. 'as consisting of three Persons, coeternal and co-equal, and all one God, distinct enough to be three, united enough to be one; a distinction without division, a union without confusion.'

' That would be saved ;' marg. ' desireth to be saved.'

'Of the Trinity;' marg. 'concerning the Trinity.'

II. The Doctrine of the Incarnation.

1. Necessity of a Firm Faith in this Doctrine (v. 29).

29. Furthermore, it is necessary to everlasting [eternal] salvation : that he also believe $\dagger$ rightly [faithfully] ("fideliter credat ') (cf. 1 John xiv. 3 ; Rom. x. 10) the Incarnation (John i. 14 ; Rom. i. 3, 4) of our Lord Jesus Christ.

2. Statement respecting the Reality of our Lord's Human and Divine Natures (vv. 30-36).

30. † For the right Faith [The right Faith therefore] (' est ergo fides recta') is, that we believe and confess : that our Lord

* Dowden. 'Further Studies in the Prayer Book,' pp. 137-162 ; specially 161,162 
Jesus Christ, the Son of Cod, is [at once both] God and Man (1 John v. 20 ; 1 Tim. iii. 16) ;

In vv. $30-33$ the heresies that are principally alluded to are the Arian, which impugned the truth of our Lord's Godhead; and the Apollinarian, which impugned the perfection of His Humanity.

31. [He is] God, of the Substance of the Father ("ex substantia Patris'), not of a totally different substance, as the Arians contended, nor of a like substance, as the semi-Arians contended, but of the same substance with the Father (cf. Col. ii. 9) begotten before the worlds ('ante sæcula') i.e. before time was (John xvii. 5) : and [He is] Man, of the substance of his Mother (cf. Gal. iv. 4) and not, as Eutyches taught, that the Manhood of Christ was absorbed into His Godhead, born in the world, not, as the Docetæ taught, a phantom ;

'Before the worlds;' marg. ' before all time.'

'In the world ;' marg. 'in time.'

32. Perlect, i.e. completely, God, not, as the Arians taught, that the Son had a beginning, and [omit ' and '] perfect Man (cf. Heb. iv. 15), not, as such Gnostics as the Marcionites taught, that the body of Jesus was not really born of the Virgin Mary, but descended from heaven, and was incapable of suffering and only seemed to suffer: of $\dagger$ a reasonable [reasoning], or rather rational, soul and human flesh $\dagger$ subsisting [consisting], viz. possessed of all the attributes of God and man ; endowed with a rational soul and human flesh in His essential nature, not, as Apollinaris maintained, that the Divine Word supplicd in Him the place of the rational soul ;

'Reasonable ;' marg. ' rational.'

'A reasonable soul' is a soul belonging not to the lower creation, but to man.

33. Fqual (the Arians said 'inferior') to the Father, as touching his Godhead (John xiv. 9, 10; xvii. 11, 22): $\dagger$ and inferlor to [less than] the Father, as touching his Manhood (John xiv. 28 ; Phil. ii. 5, 7).

34. Who although he be God and Man : yet he is not two, but [is] one Christ;

The Apollinarians charged the orthodox with making two Christs, because it seemed to them that the acknowledgment of the existence in the Incarnate Christ of the human spirit in addition to the Divine Logos, involved the recognition of a twofold personality. 
The Nestorians, by their emphatic distinction between the Son of God and the Son of Mary, practically taught that there were two Persons in Christ, viz. the Son of God and a man, into whom the Son of Man descended, and whom the Son left before the Crucifixion.*

35. † One; not by conversion [One, however, not. by change] ('unus autem, non conversione') of the [omit 'the '] Godhead into flesh (i.e. the whole human nature) : but by taking of $\dagger$ the [omit ' the '] Manhood ('assumptio humanitatis ') into God ;

' The Godhead lost nothing by its conjunction with flesh in the Person of Christ, while the manhood, though losing none of its essential propertics, was infinitely exalted by its union with the Divine Nature in the same one Person of Christ.' $\ddagger$

36. One altogether ('unus omnino'), i.e. one wholly, entirely; not by confusion of Substance (the Eutychians taught that after the Incarnation the human nature of Christ was absorbed into the Divine, and thus then ceased to have a distinct existence; the Apollinarians had similarly confounded the Substance) : but by unity of $\uparrow$ Person [person].

'Not by confusion ;' marg. 'One : not by any confusion.'

3. Description of the Work of the Incarnate Christ (vv. 37-41). 37. For ('nam') (by way of analogy) as $\uparrow$ the reasonable ['as reasoning'] soul and flesh is one man (Gen. ii. 7) : so, i.e. just as really and completely, God and Man is one Christ (cf. Matt. xvi. 13-16 ; John vi. 69 ) ;

'Reasonable;' marg. ' rational.'

This does not teach that God and man are united in Christ in the same way in which the soul and flesh are united in man. God and man are two natures, soul and flesh are two parts of one nature.

38. Who suffered (Isa. liii. 4-10) for our salvation : descended $\dagger$ inte hell [to the world below] ('ad inferos') (i.e. Hades, the place of departed spirits), rose again the third day [omit 'the third day'] from the dead (1 Cor. xv. 3, 4).

'Into hell;' marg. 'into Hades.'

'In the text of vv. 38 and 39 two phrases have been interpolated to make the passage correspond more closely with the text of the Apostles' Creed. In v. 38 the words "the third day" should certainly be omitted, and similarly in v. 39 the words "God Almighty." ' §

- Gibson, 'The Three Creeds,' pp. 221, 222.

I Ibid., p. 223. 
39. $\mathrm{He}$ [omit ' $\mathrm{He}$ '] ascended into heaven, ha† [omit ' he '] sitteth [sat down] at the right hand of the Father, God Almighty [omit 'God Almighty'] (Luke xxiv. 51; 1 Pet. iii. 21, 22) : $\dagger$ from whence He shall come [to coms from thence] to Judge (2 Thess. i. 7-10; 2 Tim. iv. 1) the quick and the dead.

40. At whose coming all men shall rise again ('resurgere habent,'* have to rise again) with their bodies : and shall give account $\dagger$ for their own works [for their own deeds] (cf. Isa. xxvi. 19; 2 Cor. v. 10).

'Shall rise again,' alternative rendering in the margin, is 'must rise again.'

41. And they that have done good shall [will] go into life $\dagger$ everlasting [eternal] ('æternam') (Dan. xii. 2): and they that have done evil into $\dagger$ everlasting [eternal] fire (Matt. xxv. 45, 46 ; Heb. x. 26-31).

Observe this emphatic assertion that the rule of judgment on the last day will be in accordance with men's works. The statement stands in striking contrast to the following concluding statement.

Verses 1 and 2 are admonitory, v. 41 is declaratory.

Final Re-affirmation of the Necessity of Believing the Catholic Faith (v. 42).

42. This is the Catholle Faith, i.e. the faith of the whole Church : which except a man $\dagger$ believe faithfully [have faithfully and steadfastly believed] ('Quam nisi quisque fideliter firmiterque crediderit'), ho ernnot be saved ('salvus esse non poterit').

'Believe,' i.e accept as an article of faith, as a Divine revelation of a fact beyond the scope of human reason: but not contrary to it.

'And steadfastly.' The Latin ' firmiterque' is not translated in the Prayer Book version. The translators appear to have followed here a Greek copy of the Creed, where the same omission occurs.

Gloria Patri (vv. 43, 44).

43. Glory be to the Father, and to the Son : and to the Holy Ghost ;

44. As it was in the beginning, is now, and ever shall be : world without end. Amen.

The addition of the Gloria forms a fitting ending to this striking declaration of the Church's Faitl.. It was added about the eighth century, when the Athanasian Creed began to be used in the West as a Canticle at the Hour Services.

* Note the curious phrase, 'resurgere habent' (' are to rise,' 'must rise ') instead of the future tense. 


\section{THE LITANY}

\section{AN HISTORICAL REVIEW OF PRE-REFORMATION LITANIES.}

The first trace of the use of the word 'Litany' occurs in 'The Life of Constantine,' by Eusebius (339), who states that the Emperor ' a little before his death, spent some time in the house of prayer, making supplications and Litanies to God.'*

The word seems to have acquired a liturgical sense about the end of the fourth century. St. Basil the Great (379), for instance, used it as a term for Penitential Services. $\dagger$ The chanting of penitential prayers (Litanies) in Church processions was probably inaugurated about 398 by St. Chrysostom in Constantinople, as a counter attraction to Arian processions. In these processions silver crosses, which had been furnished by the Empress Eudocia, were used.

During the fifth century the custom of reciting or chanting Litanies in public Church processions was adopted by the Western Church, and soon a series of days was fixed and entered in the Calendar.

In Gaul these processional Litanies were called ' Rogations.' Hence, when about the year 467 very dreadful earthquakes were devastating Southern Gaul, Mamertus, Bishop of Vienne, directed that solemn Rogations should be used on the Monday, Tuesday, and Wednesday before Ascension Day. It was in commemoration of these terrible cosmic occurrences that annual Litanies or Rogations were used on these days. Hence, subsequently these days came to be commonly known as Rogation Days.

From the practice of using Litanies in procession through the streets, they were often called 'processions.' Thus in England, during the Anglo-Saxon period, Ascension Week was called Gangwoeca, or Procession Week; and the Rogation Days were called Gang dosgas, or Procession Days.

During the sixth century several Councils, notably those of Orleans (511) and Tours (567), decreed that these Rogation Days

* 'Vit. Const.,' iv. 61.

† Basil, 'Ad Clericos Noocæs.' Epist. ccrii. 
should be observed as Fasting Days, during which Litanies should be chanted.

The Church in Spain, however, deeming it unfitting to have fasting days at Ascension-tide, decreed that fasting days should be observed during Lent, after Whitsuntide, and during the autumn.

About the close of the sixth century a very fatal pestilence appeared in Rome. A Solemn Litany was, therefore, appointed by Gregory the Great to be used on St. Mark's Day. It was called 'Litania Septiformis.' The clergy and laity in Rome formed themselves into seven separate processions, each of which represented a particular ecclesiastical or social status. Each procession assembled at its appointed Church, and marched thence chanting 'Kyrie Eleison' ('Lord, have mercy'), to the Church of Santa Maria Maggiore, where the whole company joined in the special Litany. This great penitential service was repeated each succeeding year, and received the name of "The Great Litany of St. Mark's Day.'

Bede states that it was generally believed in his day that Augustine and his band of missionaries chanted a Litany as they made their first entry into Canterbury in 597.*

In the seventh century the seventeenth Council of Toledo (694) decreed that Litanies, with intercessions for the Church, the King, and the people, should be chanted at least once a month.

In the eighth century the Council of Clovesho (747) decreed that the English Church should observe the three Rogation Days with prayer and fasting; and that Litanies should be repeated by both clergy and people on St. Mark's Day, thus following the precedent that lad been established by Gregory the Great.

In 813 the Council of Mayence ordered that ' all should go barefoot and in sackcloth in the procession of the Great Litany of three days.'

In the old Litany of Gregory the Great, and likewise in others which were in use prior to the eighth century, there were no invocations to angels or saints, but about 800 they seem to have been introduced, and in the following century their number became considerable. Martene quotes one Litany in which 94 occurred : the Litany of the Anglo-Saxon. Church had a long series in this century; one given by Muratori contains the names of 120 saints ; and a Litany used by the Church in Paris contained 102 such invocations.

In the Middle Ages the number of them became still greater. At the time of the Reformation these invocations were addressed to the Virgin Mary, to the Archangels Michael and Gabriel, to 
Angels, and to all the holy orders of blessed spirits, to Patriarchs, to Prophets, to Apostles, to Martyrs, to Evangelists, to the Innocents, to Confessors, to all the Holy Priests, to all Holy Widows and Hermits, etc.

\section{THE FORMATION OF OUR PRESENT LITANY.}

1544. ' Owing to the miserable state of all Christendom,' Cranmer was requested by King Henry 'VIII in 1544 to draw up a Litany. In so doing he drew largely from the Litany of Gregory the Great and from the Sarum and York Uses. He also gathered material from Hermann's 'Consultatio,' which contained a Litany compiled by Melanchthon and Bucer ; and, with much free handling both in arrangement and composition, he produced the litany which is almost identical with the one now in use. Of the sixty-two invocations to Saints and Angels in these Ancient Offices, he retained only three. These were to :-

(1) St. Mary, Mother of God our Saviour ;

(2) The Holy Angels, Arehangels and all Holy Orders of Blessed Spirits ;

(3) The Holy Patriarchs, Prophets, Apostles, Martyrs, Confessors, Virgins and all the Blessed Company of Heaven.

They were placed immediately after the invocations of the Holy Trinity, and ended with the words 'Pray for us.' Other important changes were :-

(1) The omission of the Kyrie Eleison, which had been placed at the beginning of all the earlier Litanies.

(2) The addition of the expression 'miserable sinners' to the invocations addressed to the Three Persons in the Trinity.

(3) The insertion of the words, "proceeding from the Father and the Son,' in the invocation of the Holy Spirit.

(4) The addition of the petition for deliverance 'from the Bishop of Rome and all his detestable enormities.'

(5) ' Remember not, Lord,' substituted for the old suffrage 'Propitius esto ; parce nobis, Domine' ('Be favourable ; spare us, O Lord ').

This Litany was intended to be used as a separate service, and was published in a separate book.

1549. The invocations to the Virgin Mary, Angels and Saints, were now omitted, and, thus amended, it was annexed to the Prayer Book, and placed between the Communion Office and that for Public Baptism, the old title 'The Litany and 
Suffrages,' being retained. This Litany is generally considered to be the first portion of the Prayer Book which appeared in the English language ; but the Creed, the Decalogue and the Lord's Prayer had been issued in English in 1536.

1552. It was removed to its present position.

1558. The words, 'Strengthen in the true worshipping of thee, in righteousness and holiness of life 'were first added in the Queen's Chapel Litany of this date.

1559. The Petition referring to the Pope was omitted.

1662. In the fifth suffrage the words 'rebellion' and 'schism' were added. These additions, said to be due to Bishop Cosin's suggestion, obviously referred to the Great Rebellion, which had recently come to an end, and to the divisions which were then troubling the Church. 'The words 'Bishops, Priests and Deacons' in the fourteenth suffrage were substituted for 'Bishops, Pastors and Ministers.'

The Rubric.

\section{The Litany and Suffrages.}

1549. Upon Wednesdays and Fridays the English Litany shall be said or sung in all places, after such form as is appointed by the King's Majesty's injunctions ; or as is or shall be otherwise appointed by his highness.

1552. Here followeth the Litany, to be used upon Sundays, Wednesdays and Fridays, and at other times, when it shall be commanded by the Ordinary.

1662. Here followeth the Litany, or General Supplication, to be sung or said after Morning Prayer upon Sundays, Wednesdays, and Fridays, and at other times, when it shall be commanded by the Ordinary.

\section{ANALYSIS.}

\section{The Uniform Portion.}

1. Penitential Invocations.

Addressed to the Persons of the Holy Trinity first Vers.

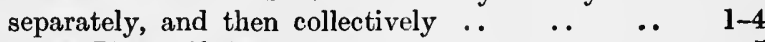

2. Introductory Plea to Christ ..

3. Deprecations, being Prayers :-
(1) For Deliverance from particular forms of evil . . 6-10

(2) For Deliverance generally, making, as the ground of the appeal, the leading facts in connexion with our

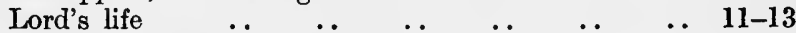

N.B.-These are often called 'Obsecrations.'

4. Intercessions for all sorts and conditions of men .. 14-32

5. Supplications for (1) material, (2) spiritual blessings .. 33,34

6. Versicles and Responses .. 


\section{The Varied Portion.}

1. The Lord's Prayer.

2. Versicles.

3. A Prayer against Persecution, or for Deliverance trom Troubles, and Responsive Supplications.

O God, merciful Father, etc.

4. Commemoration of Mercies and Responsive Supplication.

O God, we have heard with our ears, etc.

5. The Gloria.

6. Preces and Responses.

From our enemies, etc.

7. A Prayer for Trust in Time of Trouble.

We humbly beseech thee, etc.

8. A Prayer of St. Chrysustom.

9. The Grace (2 Cor. xiii. 14).

\section{EXPOSITORY AND CRITICAL NOTES.}

No. 1. Of heaven (Lat. 'de cœlo'). The words signify, "Who looketh down from heaven.' The expression is cquivalent to the words in the Lord's Prayer, 'Which art in heaven' (cf. 2 Chron. vi. 21 ).

No. 1. Miserable sinners. The epithet 'miserable' refers rather to our natural and spiritual condition than to the view we may take of it.

No. 3. Proceeding from. This has reference to the eternal procession of the Holy Spirit.*

No. 5. Remember not ... vengeance of our sins (cf. Second Commandment). We are not, of course, eternally punished for the sins of our progenitors, but temporally we have to bear the ill effects of their transgressions through heredity.

No. 8. Deadly sins, i.e. wilful and presimptuous sin, which debases the whole nature and hardens the heart.

. The phrase 'deadly sin' is not to be regarded as conveying the old scholastic distinction between sins ' venial ' and 'mortal,' a distirction which both implied that there was a difference between sins as to guilt and its removal, and also necessitated confession to an expert casuist to determine to which class sinful actions were to be referred. With the single exception of 'the sin against the Holy Ghost' $\dagger$ (which is rather a state than an isolated act) the Holy Scriptures draw no such distinction between sins (cf. Jas. ii. 10) as the Schoolmen drew. For all sins are venial, if repented of ; all sins, if persevered in to hardening of heart incapable of repentance, are deadly.

At the Savoy Conference an alteration of 'deadly sins' to

* See Athanasian Creed and Nicene Creed, pp. 132, 305.

$\uparrow$ See Matt. xii. 31, 32 ; Mark ii. 28, 29; Luke xii. 10 ; 1 John v. 16, 17. 
' heinous or grievous sins' was suggested; and of 'sudden death ' into ' unprepared death.'

No. 10. Heresy and Schism. Heresy signifies erroneous doctrine, that which is contrary to the teaching of Scripture. Schism refers to the divisions amongst Christian bodies. To express the distinction in another way, Heresy perverts the faith; Schism divides the unity of the Church.

No. 11. By the mystery. 'Mystery' in the New Testament generally denotes something which could not have been made known to man without a supernatural revelation (see Col. i. 26 ; 1 Cor. xv. 51). Here 'mystery' refers to an event which we heartily believe, but which, even with the help of revelation, we cannot fully comprehend. We cannot understand how the Word was made flesh, how He was at once pcrfect God and perfect man, and how the union of these two natures is still maintained. It is in this sense that St. Paul speaks of the Incarnation as a great mystery-"Great is the mystery of godliness : $\mathrm{He}$ who was manifested in the flesh' (1 Tim. iii. 16, R.V.).

No. 13. In all time of our tribulation. This suffrage refers not necessarily to deliverance out of afflictions, but to protection from the special moral dangers which attend them. Suffering does not always fulfil that which God designs it to accomplish ; it sometimes hardens instead of softening the heart, and leads to impatience and murmuring.

No. 15. Righteousness and holiness. The former refers to our duties and dealings with mankind; the latter to our duty towards God (cf. Rom. i. 18).

No. 29. Prisoners and captives. The former signifies criminals, and the latter those who have been taken prisoners in war or specially by pirates. When the Litany was drawn up there were continual cases of piracy in the Mediterranean and the British seas; and hundreds of persons who were taken prisoners by the Algerine pirates were sold as slaves in the African markets.

No. 33. Kindly fruits of the earth; i.e. fruits after their severa] kinds.

\section{The Versicles after the Lord's Prayer.}

After our sins. The use of the word 'after' in the metaphorical sense of ' according to' still lingers in such phrases as 'after the pattern, example,' etc. (comp. Isa. xi. 3 ; Rom. viii. 5).

Prayer for Trust in Time of Trouble. We humbly beseeeh thec, O Father, etc.

1549. Serve thee in pureness of living.

1552. Serve thee in holiness and pureness of living.

Cranmer placed here six collects in the Litany of 1544. In 
1549 the 1st and 5th were combined to form the present collect, the first part of which was adapted from a collect in Sar. Proc., and the second part composed by Cranmer.

A Prayer of St. Chrysostom.

This title dates from 1559.

The Grace (2 Cor. xiii. 14). 1559.

Placed at the end of the Litany in Queen's Chapel Litany.

The Litany of the American Prayer Book.

No. 8. 'From all inordinate and sinful affections' was substituted for 'from fornication.'

No. 13. 'In all time of our prosperity' for 'In all time of our wealth.'

No. 18. 'All Christian rulers and magistrates' for 'Our Gracious King,' etc.'

No. 29. 'All women in the perils of child-birth' for 'All women labouring of child.'

No. 34. The words, "That it may please thee to send forth labourers into thy harvest' were added.

The Minister may at his discretion omit that portion of the Litany which commences after the Supplications and ends after the Collect 'O God merciful Father.' 


\section{PRAYERS AND THANKSGIVINGS UPON SEVERAL OCCASIONS}

\section{PRAYERS.}

In the Mediæval Litanies there were special prayers for several occasions, and collects were introduced into the Mass for fine weather, rain, war, plague, etc. But the Occasional Prayers and Thanksgivings in the B.C.P. were original compositions, with part of the old materials adapted.

Prayer for Rain. 1549.

The Title.

1552. The title was, "For Rain, if the time require."

1662. 'The words 'if the time require' omitted.

1549. This Prayer was inserted at the end of the Communion Office.

1552. Placed at the end of the Litany, before the Prayer of St. Chrysostom.

1662. Removed to its present position.

It slightly resembles an old collect in the Sac. Greg. found in the Sar. Missal. For the phrase "Thy kingdom and the righteousness thereof,' which is due to an inaccurate translation of Matt. vi. 33 in Coverdale's Bible, the Prayer in the Scotch Liturgy of 1637 has 'Thy kingdom and thy righteousness.'

Prayer for Fair Weather. 1549. (Gen. vi. 5-7 ; viii. 21, 22 ; ix. 11.)

1549. Inserted at the end of the Communion Office.

1552. 'Placed at the end of the Litany.

1662. Removed to its present position.

This Prayer likewise slightly resembles an old collect in the Sac. Greg. found in the Sar. Missal. The American Prayer Book omits the allusion to the Deluge. The words 'by the granting of our petitions,' 1549, were changed in 1552, 'for thy clemency.'

Prayers in the Time of Dearth and Famine. (Two forms.) 1552.

The First Form (Gen. i. 22 ; Joel i. 16-20 ; Matt. vi. 11).

1552. Placed at the end of the Litany. 
1662. Removed to its present position.

The Second Form (2 Kings vi. 25 ; vii. $1-16$ ).

1552. Placed at the end of the Litany.

1559. Omitted from the printed Prayer Book.

1662. Restored with alterations, attributed to Bishop Cosin, and placed in its present position.

It is probable that these two Collects are inserted in the Prayer Book in consequence of a dearth which occurred in England in 1551.

Prayer in the Time of War and Tumults. 1552. (1 Chron. xxix. 11 ; Ps. xxii. 28.)

1552. Placed at the end of the Litany.

1662. Removed to its present position.

The words ' and tumults' were added to the title in 1662. This Prayer very slightly resembles a collect on the same subject in the Sar. Missal taken from the Sac. Greg. The American Prayer Book has modified the petition 'Abate their pride and assuage their malice.'

Prayer in the Time of any Common Plague or Sickness. 1552. (Num. xvi. 44-50 ; 2 Sam. xxiv. 15-25.)

1552. Placed at the end of the Litany.

1662. Removed to its present position.

The terrible Sweating. Sickness, which occurred in 1551, was probably the reason for the insertion of this Prayer.

1552. O Almighty God, which in thy wrath in the time of King David, didst slay with the plague of pestilence threescore and ten thousand, and yet remembering thy mercy, didst save the rest; have pity, etc., that like as thou didst then command thine angel to cease from punishing, etc.

1662. O Almighty God, who in thy wrath didst serd a plague upon thine owl people in the wilderness, for their obstinate rebellion against Moses and Aaron; and also in the time of King David . . . that like as thou didst then accept of an atonement, and didst command the destroying Angel, etc.

Collects in the Ember Weeks. (Two forms.) 1662.

The First Form. (Acts vi. 6 ; xiii. 2, 3 ; xx. 28 ; Eph.iv. 7 ;

1 'Tim. v. 22.)

The Second Form. (Jas. i. 17 ; 1 Cor. xii. 8-10 ; John xiv. 16, 17 ; Eph. iv. 11-16.) after-

* The Ember Days are the Wednesday, Friday, and Saturday

* The old English name was ymb-ren-wuce. The prefix ymb means about, round. Rene or ryne means a courso. In Duteh they are called 
(1) The First Sunday in Lent.

(2) Whit-Sunday.

(3) September 14, formerly observed as Holy Cross Day and called (as well as May 3) 'Roodmasday.'

(4) December 13, Feast of St. Lucy, Virgin and Martyr (c. 304).

These days were called Jejunia quatuor temporum, i.e. the fasts of the four seasons. The original intention of the Ember Days, it has been suggested, was to consecrate with fasting and prayer the four seasons of the year. It was at the Council of Placentia, 1095, that Ordinations were ordered to be held on these days. The first Ember Collect was composed by Bishop Cosin, 1662. The second was taken from the Ordination Services, and varied slightly. They had already been inserted in the Scottish Prayer Book, 1637.

Both Collects dwell upon-

(1) The twofold ministry of doctrine and life.

(2) The twofold object, God's glory and man's salvation.

The latter Collect presupposes that the candidates are already chosen.

A Prayer that may be said after any of the Former. 1559. Sac. Greg. ; Sar. Brev. (Ex. xxxiv. 6, 7 ; Rom. vii. 23, 24 ; 1 John ii. 1.)

This Prayer was found in English Primers prior to 1549 at the end of the Litany.

1549. Not inserted.

1559. Placed at the end of the Litany.

1662. Removed to its present position.

Omitted in the American Prayer Book.

'Nature and property' is a translation of the one Latin word Proprium, and mcans 'essential characteristic.'.

A Prayer for the High Court of Parliament. 1662.

1625. First appeared in an 'Order of Fasting.'

1628. Appeared again in a special form of prayer ' necessary to be used in these dangerous times of war.'

1662. Inserted in the Prayer Book.

1801. 'Dominions' was substituted for 'Kingdoms' by an order in Council (Jan. 1).

Its reputed author is Laud.

The words 'Our most religious and gracious' occur in the original form of the Prayer, and were not, as some suppose, a

Quarter temper, and in German Quatember. The Ember Fasts would seem to have been so called, therefore, from their coming round periodically. See also p. 54, 
compliment to Charles II. A similar expression occurs in the Liturgy of St. Basil, viz. 'Our most pious and faithful sovereigns.'

The Collect for all Sorts and Conditions of Men. 1662 .

It has been thought by some that this Prayer was composed by Bishop Sanderson, but its more probable author was Dr. Gunning, Master of St. John's College, Cambridge, and afterwards Bishop of Ely, Coadjutor to the Episcopal divines at the Savoy Conference. It was originally of much greater length, petitions for the King, the Royal Family, Clergy, etc., being included in it. This explains why the word 'finally' is used in so short a prayer. It somewhat resembles the Orationes Generales in the Sarum Missal. The words, "that all who profess and call themselves Christians, may be led into the way of truth,' are thought to be intended to refer to the Puritans, who had increased in such large numbers during the Commonwealth.

The phrase for 'Jesus Christ his sake' is the only trace in our B.C.P. of the theory, once very prevalent, that our possessive case (-'s) is a contraction of the personal possessive pronoun ' his.'

In the American Prayer Book this Prayer is placed in the Order for Morning and Evening Prayer.

In the Irish Prayer Book there are the following special Prayers : 'Prayer for Unity '; 'For a Sick Person' ; 'On Rogation Days' ; 'On New Year's Day'; 'For Christian Missions'; 'A Prayer for the General Synod of the Church of Ireland'; 'A Prayer to be used in Colleges and Schools.'

\section{THANKSGIVINGS.}

General Thanksgiving. 1662.

This was the production of Reynolds, Bishop of Norwich. It is the general thanksgiving as distinguished from the special thanksgivings which follow. There is no authority for its repetition by the congregation, however appropriate the practice. It bears some resemblance to a General Thanksgiving in a Coptic 'Liturgy of St. Basil.'

In the American Prayer Book this Thanksgiving is inserted at the end of the Litany, and also of morning and evening prayer.

Thanksgiving for Rain. 1604. (Acts xiv. 17.)

Title.

1604. A Thanksgiving for Rain.

1662. The words 'A Thanksgiving' omitted.

The titles in the rest of the Thanksgivings were similarly shortened.

For Fair Weather. 1604. 
For Plenty. 160t. (Ps. lxvï. 5, 6.)

For Peace and Deliverance from our Enemies. 1601. (Ps. cxxiv. 1-6.)

For restoring Public Peace at Home. 1662. (Ps. lxv. 7 ; 1 Tim. ii. 1, 2.)

This Thanksgiving is believed to have been composed by Bishop Cosin, and based upon Bishop Wren"s suggestions.

For Deliverance from the Plague, or other Common Sickness. 1604. (Two forms.)

First Form. (Hab. iii. 2 ; Rom. xii. 1.)

Second Form. (Deut. xxvii. 15-30 ; Ps. cxviii. 15.)

These special Thanksgivings, with the exception of that 'For restoring Public Peace at home,' were inserted at the request of the early Puritans.

A Thanksgiving Service for Harvest was prepared by both Houses of Convocation of the Province of Canterbury, February 14,1862 , but still needs the Royal sanction, and approbation of Parliament. The American Liturgy includes forms of Prayer and Thanksgiving for several other occasions, viz. : For a Sick Person'; 'For a Sick Child'; 'For a Person or Persons going to Sea '; 'For a Person under Affliction'; 'For Malefactors after Condemnation'; 'A Prayer to be used at the Meetings of Convention'; 'For Recovery from Sickness'; 'For a Safe Return from Sea '; 'Forms of Prayer to be used in Families' (morning and evening); and a 'Form of Prayer and Thanksgiving to Almighty God for the fruits of the earth, and all the other blessings of his merciful Providence,' to be used yearly on the first Thursday in November, or on such other day as shall be appointed by the civil authority. In the Irish Prayer Book there is a Thanksgiving for Recovery from Sickness. 


\section{THE COLLECTS, EPISTLES, AND GOSPELS}

\section{THE COLLECTS.}

Collects are not peculiar to this portion of the Liturgy; the Epistles and Gospels are appointed for use exclusively in connexion with the Communion Office. Collects, either expressly so called, or prayers similar in structure, appear elsewhere in B.C.P.

The Collects, collecta; either 'a gathering together' or, as has been suggested, a contraction of cum lectione, 'accompanying the reading of Scripture.' If the former derivation be adopted, the word may mean either a summary of the teaching of the Service immediately preceding or following, or a prayer used at the gathering together of the worshippers.

\section{Sources.}

1. The Ancient Collects, which form far the larger number, are, taken from three of the Sacramentaries,* viz. :

(i) . Five from that of Leo I, ' the Great,' the chief ecclesiastical figure of the fifth century. He composed or compiled many prayers.

(ii) Twenty, besides the first part of the Easter Day Collect, from that of Gelasius, Bishop of Rome, 492, a liturgical writer and revisionist.

(iii) Twenty-seven, and the other half of the Easter Day Collect, from that of Gregory the Great, Bishop of Rome, 590 , who condensed, re-arranged, and improved the Sacramentaries of Leo and Gelasius.

(iv) One, for the 22nd Sunday after Trinity, from AngloSaxon sources, though perhaps traceable to Sac. Greg. The authorship of the Sacramentaries is traditional.

* Before 1000 A.D. the Holy Communion Service was in four books. viz. :

1. The Lectionary containing the Epistles.

2. The Evangelistary " " Gospels.

3. The Antiphonary " " Anthems (Introits).

4. The Saeramentary ", ", Collects and Service. 
From these they passed into the Sarum Missal, ascribed to Osmund, Bishop of Sarum, 1073. All the Collects for the Sundays except six, and some of those for Holy Days, were taken from the above sources, with more or less adaptation.

2. The Modern Collects, four Sunday Collects (for the first two in Advent, first after Christmas, and Quinquagesima), besides those for Christmas-Day, Ash-Wednesday, and most of the Holy Days, were composed by the Reformers. The Revisers of 1662 were responsible for four, the 3rd Sunday in Advent, the 6th after Epiphany, St. Stephen's Day, and Easter Eve.

The author of each of the later Collects cannot be named with certainty, but in an Act of Parliament respecting the First Prayer Book, Archbishop Cranmer is named, together with the 'most earned and discreet Bishops, and other learned men of the realm.'

\section{Structure and Style.}

Collects are peculiar to the Western Church; in the Eastern Church prayers are longer and more ornate. Speaking strictly, a Collect consists of :-

1. The Invocation, in which mention is made of the name of God * with one or more of His glorious attributes, and often of some fact connected with redemption.

2. The Doctrine, or ground of the succeeding Petition.

3. The Petition itself.

4. The Aspiration, or object with which the Petition is offered, 'the feather or wings of the Petition.'

5. The Termination, $\dagger$ varying in accordance with the Person of the Holy Trinity involved, but usually a pleading of Chist's merits, sometimes with an ascription of praise and an acknowledgment of the Holy Trinity.

The various Terminations may be thus described:

(i) The General Plea, 'through Jesus Christ our Lord.'

* Only three Collects are addressed to our Lord : 3rd Sunday in Advent, St. Stephen's Day, and 1st Sunday in Lent. None are distinctly addressed to the Holy Spirit. The reason given by some for addressing Collects to the Father, is their special employment at the Communion; but since no special reason can be assigned for addressing the Son on the three Sundays named, this reason has no force. A better would be Christ's own teaching in the opening words of the Lord's Prayer, and His encouragement to offer prayer to the Father in His name.

† In Sar. Miss. the whole termination of a Collect is never given at full length as in our Prayer Book. Rules were given to the officiant: "If you address the Father in your prayer, say "through the Lord." If you make mention of Christ, say " thiough the same," etc."

The doxological ending, e.g. 'through Jesus Christ our Lord; by whom and with whom in the Unity of the Holy Ghost,' etc., does not occur in Sar. Miss. 
(ii) The Specific Plea, 'through the merits,' etc.

(iii) The Extended Plea, which is :-

(a) Doxological, e.g. "to whom with thee and the Holy Ghost be all honour and glory, world witl out end.'

(b) Descriptive, 'who liveth and reigneth with thee and the same Spirit, ever one God, world without end.'

This last is a confession of faith in the Trinity in Unity, and appropriately, although not exclusively, appears in the Collects for the four great Festivals of Christmas, Easter, Whitsun, and Trinity.

The Collects, like other parts of the Prayer Book, have had to run the gauntlet of severe criticism. Some of the early Puritans were by no means satisfied with them, their brevity, in particular, giving great offence. The Puritan objections were met by Hooker, who appealed to St. Augustine, affirming that short prayers express 'the quick and speedy expedition, where with ardent affections, the very wings of prayer, are delighted to present our suits to heaven'; and that long prayers dull the 'vigilant and erect attention of mind, which in prayer is very necessary.'

In the seventeenth century objections were again raised, and in September, 1679, a Royal Commission was held by ten Bishops and twenty other divines to propitiate Dissenters by removing grievances. The Commissioners included Patrick, Stillingfleet, Tillotson, Sharp, Tenison, Burnet, Aldrick, and Jane. They proposed to Patrick that he should 'make the Collects longer by way of makirg them more affecting.'

Their survival, cespite all criticism, proves their excel!ence. All the Collects show that the composers bestowed much study upon the words used, the balancing of clauses, and the unity of the whole composition. They have, as Macaulay writes, 'soothed the griefs of forty generations of Ch istians.' The fact that several of them have been arranged as anthems, to form a part of the worship of other Christian bodies, is no mean proof of their popularity as expres ing devotion.

"While the East soars to God in exclamation of angelic selfforgetfulness, the West comprehends all the spiritual needs of man in Collects of matchless profundity; reminding us of the alleged distinction betwe $\mathrm{n}$ the Seraphim, who love most, and the Cherubim, who know most' (Fr. eman's Principles of Divine Service).

\section{THE EPISTLES AND GOSPELS.}

In the Synagogue worship there were two Lessons, one from the Law and one from the Prophets, and as Early Christian 
worship was modelled largely upon that of the Synagogue, this may have been the origin of the Epistle and Gospel. Justin Martyr (c. 140) notes the reading of the 'Memoirs of the Apostles' at Holy Communion, and Tertullian (c.200) mentions the reading of Evangelical and Apostolic books in Church Services generally.

The passages selected for Holy Communion were very anciently appropriated to the days whereon we now read them, as may be gathered from the fact that early Fathers, preaching on the days to which these portions of Scripture are attached, comment on them.

The adoption of the vernacular constituted a great change in this as in other parts of public worship. From 1549 to 1662 , the translation used was that of the Grcat Bible of 1539-40, but at the Revision of 1662, in accordance with a note in the Black Letter Prayer Book of 1636 (of which a copy was used for suggesting corrections), the Epistles and Gospels were all 'corrected after the last translation,' i.e. the A.V. of 1611.*

The alterations of the Epistles, in 1549 were often trivial, such as dropping one or two words at the beginning which were not in Holy Scripture, and adding a verse or two at the end to finish the passage. But they made the following alterations in the Gospels : they added "The Account of the C'eansing of the Temple' on 1st Sunday in Advent, 'The Healing of the Gadarene Demon'ac' on the 4th Sunday after Epiphany, 'The Raising of Jairus' Daughter' on the 24th Sunday after Trinity; and they omitted 'The Account of the Unbel'ef of Thomas' on the 1st Sunday after Easter. In general, their alterations were in the direction of enla ging the somewhat 'scrappy' lect:ons of the Sarum Missal.

Entirely new were three of the Gospels for Holy Week, added to complete the accounts of the Passion. Matt. i. (including genealogy, omitted 1662) was substituted for St. Luke's account of Simeon, on the Sunday after Christmas.

Matt. zxiv. 23-31 was added in 1662 for the 6th Sunday after Epiphany, then for the first time prov ded for. At this same date the Gospels for Holy Week were conveniently arranged, those for Palm Sunday and Good Friday being reduced from two chapters to one, Tuesday and Thursday before Easter abbreviated, so as not to anticipate Easter events, and the Gospel for the Presentation lengthened to include the account of Anna.

The Principle of Selection, adopted by the compilers in choosing and appointing the Collects, Epistles, and Gospels, is quite ouvious

* For further information upon the several translations adopted for the Epistles and Gospels, see Goulburn, and later pages. 
in the case of the great Festivals, Special Seasons, and Saints' Days. It was to concentrate the mind of the worshipper upon the historical, doctrinal, and practical aspects of the events commemorated. In regard to the Sundays after Epiphany, Trinity, etc., the reason for the selection is not so obvious, and the suggestions usually made are more fanciful than real.*

\section{EXPOSITION.}

\section{The Title.}

1549. The Introits, Collects, Epistles, and Gospels, to be used at the celebration of the Lord's Supper and holy Communion, through the Year; with proper Psalms and Lessons for divers Feasts and Days.

1552. The Collects, Epistles, and Gospels, to be used at the celebration of the Lord's Supper, and holy Communion, through the Year.

1662. The Collects, Epistles, and Gospels, to be used throughout the year.

The omission of the reference to Holy Communion is due to the use of the Collects at Morning and Evening Prayer, and the use of the Epistles and Gospels when only Ante-Communion was read.

The word 'Introits' $\dagger$ was omitted in 1552 ; these were Psalms containing something proper to the day which were sung while the priest made his 'entrance.' The 'proper Psalms and Lessons for divers Feasts and Days' were printed in a separate table in 1552.

\section{Introductory Rubric.}

This was added in 1662, and enjoins the use of the Sunday Collect on the previous Saturday evening, and the Holy Day Collect on its Vigil or Eve, if such there be.

\section{THE FIRST SUNDAY IN ADVENT. $\ddagger$}

The observance of Advent cannot be traced before 300, and the name itself is even later. Advent originally commenced on November 11, St. Martin's Day, on which date it still begins in the Greek Church.

* For such subjects as the 'ritual' prescribed for the reading of the Epistles and Gospels, see Communion Office.

$\dagger$ In the earlier Service Books there were Introits and Graduals, i.e. Psalms sung after the Epistle from the steps (gradus) of the pulpit, and said to date from the time of Jerome (c. 400).

† The Church's year falls into two main divisions: (1) from Advent to Trinity Sunday, in which the work of the Redemption is set forth; (2) from Trinity Sunday to the last Sunday after Trinity, in which Christian duties are enforced. 
The Collect. 1549 ; probably by Cranmer.

Sar. Miss. Collect more resembled present Collect for 4th Sunday in Advent.

The Rubric after the Collect. 1662.

The Epistle. Rom. xiii. 8-14, 1549; Sar. Miss., 11-14.

The Gospel. Matt. xxi. 1-13, 1549 ; Sar. Miss., 1-8.

\section{THE SECOND SUNDAY IN ADVENT.}

The Title, 1662. 'The Second Sunday,' 1549.

\section{The Collect.* 1549.}

The comma after 'patience' is not in A.V. of Rom. xv. 4; nor in the American and some other Prayer Books. This Collect reflects the recent introduction into the public and private life of England of the Holy Scriptures in the vernacular.

The Epistle. Rom. xv. 4-13, Sar. Miss.

The Gospel. Luke xxi. 25-33, Sar. Miss.

\section{THE THIRD SUNDAY IN ADVENT.}

The Title, 1662. ' The 'Third Sunday,' 1549.

The Collect. 1662 : probably by Cosin.

From 1549 to 1662 the old Sar. Miss. Collect was used : 'Lord, we beseech thee, give ear to our prayers, and by thy gracious visitation lighten the darkness of our hearts by our Lord Jesus Christ.'

The third week in Advent being Ember week, this Collect setting forth the right exercise of the Christian ministry is specially appropriate. The word 'Minister' here is the translation not

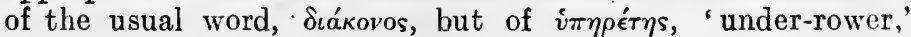
1 Cor. iv. 1, the metaphor being taken from a galley, and emphasizing the relationship of the minister to his Captain, as the other word suggests his duty to the flock.

The Epistle. 1 Cor. iv. 1-5, Sar. Miss.

The Gospel. Matt. xi. 2-10, Sar Miss.

\section{THE FOURTH SUNDAY IN ADVENT.}

The Title, 1662. 'The Fourth Sunday,' 1549.

The Collect. Sac. Gel., Sac. Greg., Sar. Miss., 1549; revised 1662 .

* The old Collects for the 1st, 3rd and 4th Sundays in Advent were addresses to God the Son. This may have suggested the form of in rocation in some of the new Collects, e.g. 'Blessed Lord.' 
The main alteration in 1662 was the addition, after 'hindered,' of the phrase 'in running the race that is set before us'; and of 'help and ' before 'deliver us.'

The Epistle. Phil. iv. 4-7.

The Gospel. John i. 19-28.

\section{THE NATIVITY OF OUR LORD, OR THE BIRTH-DAY OF CHRIST.}

\section{Commonly called CHRISTMAS-DAY.}

Christmas-Day was kept on January 6 by the Eastern Church until $c$. 400, when the Western practice of keeping December 25 began to prevail, though the Armenian Church still observes the January date. The Western Church from an early date separated the Nativity from the Epiphany.*

The observance of Christmas-Day possibly began as a protest against various heretical theories in regard to the Person of Christ, all virtually denying the Incarnation in one way or another.

The Title, 1662 ; 1549, 'Christmas-Day.'

'Commonly' as thus used suggests that the 'title referred to is inaccurate or misleading, cf. "Commonly called the Creed of St. Athanasius,' 'Commonly called the Purification,' etc. In 1549 were provided here two $\dagger$ Introits, Collects, etc., headed 'At the First Communion,' 'At the Second Communion,' respectively. The former Collect, not retained in $1552, \ddagger$ was as follows :

'God,' which makest us glad with the yearly remembrance of the birth of thy only Son Jesus Christ; grant that as we joyfully receive him for our Redeemer, so we may with sure confidence behold him, when he shall come to be our judge, who liveth,' etc.

The Collect. 1549.

This prayer aptly suggests the causal connexion between the Incarnation of our Lord and the regeneration of man; His taking our likeness teaches the possibility of our taking His.

1549. 'This day to be born of a pure Virgin.'

1662. 'As at this time,' as in S.L., 1637, obviously because the Collect is used throughout the week.

The Epistle. Heb. i. 1-12, 1662 ; Sar. Miss., 1549, 1552, 1-13.

* The omission of eleven days in the Western Calendar, not followed by Russia, has resulted in the Eastern Christmas-Day falling so mueh later.

+ In Sar. Miss. there were three.

$\mp$ The American Church has reverted to the earlicr arrangement of pro. viding additional Collects for Christmas and Easter. 
The Gospel. John i. 1-14 ; Sar. Miss. (3rd Mass), 1549; the Gospel for 2nd Mass, Luke ii. 15-20, was appropriated to The Circumcision.

\section{SAINT STEPHEN'S DAY.}

The position of St. Stephen's, St. John the Evangelist's, and Innocents' Days, is stated to be due to the desire to illustrate the triple kind of martyrdom endured: St. Stephen in will and deed; St. John in will; Holy Innocents in deed. Another view is that these days are so placed as to emphasize the honour due to St. Stephen's priority in martyrdom; to St. John's special friendship with our Lord ; and to the connexion of the death of the Innocents with the birth of the Saviour. St. Stephen's Day has been observed from the fourth century.

The Collect. Sar. Miss., Sac. Greg. ; shortened 1549; expanded 1662.

In the Latin original the prayer was addressed to the Father; in 1549 it was more appropriately addressed to Him to whom Stephen prayed at his death : 'Grant us, O Lord, to learn to love our enemies, by the example of thy Martyr Saint Stephen, who prayed to thee for his persecutors; which livest, etc.' The addition in 1662 of the words ' $O$ blessed Jesus,' after the word 'thee' at the close of the Collect, seems to imply the restoration of the address to the Father. The appropriateness of the addition ' to love and bless our persecutors' at the Restoration is obvious ; such a spirit was very necessary.

For the Epistle. Acts vii. 55-60, 1549 ; Sar. Miss., Acts vi. $8-15$.

The Gospel. Matt. xxiii. 34-39, Sar. Miss., 1549.

\section{SAINT JOHN THE EVANGELIST'S DAY.}

The day has been observed from the sixth century. 'The' inserted, 1662.

The Collect.* Sar. Miss. Sac. Gel. ; expanded 1549 and 1662.

1549. 'may attain to thy everlasting gifts,'

1662. 'may so walk in the light of thy truth, that it may attain to the light of everlasting life; '

The figure of light, confined in the old Collect to prayer for illumination by God, and the teaching of His Apostle, is finely developed by the further prayer that the Church may so walk in the "light of God's truth, that it may attain to the light of

* In some old Offices the Collect for St. Stephen's Day was repeated on t. John's Day. 
everlasting life,' the Collect being thus brought more closely into correspondence with the Epistle.

The Epistle. 1 John i. 1-10, 1549 ; Sar. Miss., Ecclus. xv. 1-5.

The Gospel. John xxi. 19-25; Sar. Miss., 19-24.

\section{THE INNOCENTS' DAY.}

Observed from the fourth century ; formerly called ' Childermas Day,' A.-S. Cilda Maesse Daeg. In Mediæval times the mournful character of this day was kept up in England by the use of black vestments and muffled peals.

The Collect. Sar. Miss., Sac. Gel., Sac. Greg., 1549 ; rewritten 1662.

1549. Almighty God, whose praise this day the young Innocents, thy witnesses, hath ['have,' 1559] confessed and shewed forth, not in speaking, but in dying; Mortify and kill all vices in us, that in our conversation, our life may express thy faith, which with our tongue we do confess : through Jesus Christ our Lord.

1662. The introduction was added,justifying the commemoration of unconscious infant sufferers for Christ by the words 'who out of the mouths of babes,' etc., from Ps. viii., part of the Introit of Sar. Miss. The added reference to 'innocency' happily supplies a motive to the remembrance of Herod's victims, thoroughly in accord with our Lord's attitude to children, and His teaching concerning them.

For the Epistle. Rev. xiv. 1-5, Sar. Miss., 1549.

The Gospel. Matt. ii. 13-18, Sar. Miss., 1549.

THE SUNDAY AFTER CHRISTMAS-DAY.

The Collect. As for Christmas-Day.

The Epistle. Gal. iv. 1-7, Sar. Miss. ; 1549.

The Gospel. Matt. i. 18-25, 1662 ; 1549, the whole chapter: Sar. Miss., Gospel for sixth day after Christmas.

\section{THE CIRCUMCISION OF CHRIST.}

\section{The Collect. 1549.}

A 'Benediction on the Octave of the Lord' in Sac. Greg. contains the ideas incorporated in this prayer: 'Omnipotens Deus, Cujus unigenitus hodierna die, ne legem solveret, quam adimplere venerat, corporalem suscepit circumcisionem; spirituali circumcisione mentes vestras ab omnibus vitiorum incentivis expurget; et suam in vos infundet benedictionem. Amen.' 
'Almighty God, whose only-begotten Son on this day underwent bodily circumcision, that he might not break the law which he had come to fulfil, purify your minds from all incentives to vice by spiritual circumcision, and pour into you his own blessing. Amen.'

1549. the true circumcision of thy Spirit.

1552. the true circumcision of the Spirit.

If the alteration was intended, as it seems to have been, to restore the idea preserved in Sac. Greg. of the contrast between circumcision of flesh and spirit, the modern printing of Spirit with a capital initial defeats that object entirely, making it necessary to deduce from 'the Circumcision of (i.e. by) the Holy Spirit' the thought of spiritual circumcision. Col. ii. 11, ' circumcision without hands,' emphasizes the agency; Rom. ii. 29, ' circumcision of heart, in spirit, not letter,' emphasizes the sphere of spiritual circumcision.

The Epistle. Rom. iv. 8-14, 1549.

Col. ii. and Rom. ii. would have offered better Scriptural illustration of the Collect; Rom. iv. 8-14 declares the 'sacramental' meaning of the rite, a sign and seal of faith.

The Gospel. Luke ii. 15-21, Sar. Miss., 1549.

The Rubric, 1552 ; re-written 1662.

1552. If there be a Sunday between the Epiphany and the Circumcision, then shall be used the same Collect, Epistle, and Gospel at the Communion, which was used upon the day of Circumcision.

1662. The same Collect, Epistle, and Gospel shall serve for every day after unto the Epiphany.

The alteration from 'a Sunday' to 'every day' is obviously a provision for other than Sunday Services, whether Morning or Evening Prayer (when the Collect is needed), Ante-Communion or the full Communion Service. The suggestion that the alteration 'seems to contemplate daily Communion'* is negatived by the words of the rubric itself : viz. "shall serve for' instead of 'shall be used,' and by the omission of the words 'at the Communion.'

\section{THE EPIPHANY.}

This season, called in the Greek Church, Theophania, originally commemorated four 'manifestations,' viz. the Nativity, the

* 'The old ideal again came forward and was expressly provided for' (so Frere, in 'Procter and Frere,' p. 530), without any reference to prove daily Communion to be 'the old ideal ' or the contemplation by the Revisers of any such practice. 
Baptism, the first Miracle at Cana, the appearance of the Star. In the Greek Church it is regarded as one of the greatest festivals of the year, and is still one of the three great times of Baptism. That Church also calls it the 'Day of Lights,' from the array of lights with which the ceremony of the Blessing of the Waters is performed. The date was always January 6 , the name ' Twelfth Day' showing its close association with Christmas-tide, of which season it forms the close.

'When in the fourth century the Roman usage as to Christmas prevailed in the East, we find the Epiphany, probably borrowed from the East, observed in the West as a separate Festival' (Barry).

The Sovereigns of England still continue the ancient custom of presenting gifts on this Festival, although these have not, since the time of George III, been offered in person, but through an official of the Royal Household, and the expectation of 'omens' in the gifts has of course ceased.

The Title, 1549. The alternative title, 'Or the Manifestation of Christ to the Gentiles,' 1662.

The Collect. Sar. Miss., Sac. Greg., 1549.

In the Latin, the word perducamur, 'that we may be led on to,' suggests a parallel with the leading of the Wise Men which has not been preserved in the English.

The words 'fruition of thy glorious Godhead,' however, are rather more consonant with reverence and more dignified than contemplandum speciem tuœ celsitudinis: 'beholding the beauty of thy highness.'

The Epistle. Eph. iii. 1-12, 1549 ; Sar. Miss., Isa. ix. 1-6.

The change is justified by the fact that Eph. iii. contains the announcement by St. Paul of his commission to the Gentiles. The Sar. Miss. Epistle is now the First Lesson on Christmas morning.

The Gospel. Matt. ii. 1-12, 1549 ; Sar. Miss., Luke iii. 21iv. 1, made part of the Second Morning Lesson in 1549.

\section{THE FIRST SUNDAY AFTER THE EPIPHANY.}

The Collect. Sar. Miss., Sac. Greg., 1549.

A good illustration of the impossibility of reproducing exactly the terseness of the original : 'Vota, quæsumus, Domine, supplicantis populi cœlesti pietate prosequere; ut et quæ agenda sunt, videant; et ad implenda quæ viderint, convalescant, per,' etc.: ' The prayers, we beg, Lord, of (thy) suppliant people, follow up with heavenly kindness; that they may both see what things are to be done and grow strong to fulfil what they have 
seen,' etc. What the translators necessarily lost in crispness they have atoned for in smoothness.

The Epistle. Rom. xii. 1-5, Sar. Miss., 1549.

The Epistles for the first four Sundays after Epiphany are all taken from the homiletic closing portion of the Epistle to the Romans ; the Gospels deal with self-manifestations of our Lord The 5th and 6th Sundays, which are exceptional in occurrence do not present the same continuity.

The Gospel. Luke ii. 41-52, 1549 ; Sar. Miss., 42-52.

THE SECOND SUNDAY AFTER THE EPIPHANY.

The Title. 'After the Epiphany' added 1552.

The Collect. Sar. Miss., Sac. Greg., 1549.

1604. The word 'peace' altered to 'grace'; restored 1662, and the words 'through Jesus Christ our Lord. Amen,' added from S.L.

The slight variations from the original are obvious improvements, viz. the omission of 'at the same time' (simul), in the reference to the Divine government of heaven and earth, and the substitution of 'all the days of our life' for 'in our times,' which has a selfish sound.

In the versicles of Morning and Evening Prayer the translators have performed the reverse process, translating the original da pacem in diebus nostris, 'give peace in our time.'

The Epistle. Rom. xii. 6-16, Sar. Miss., 1549.

The Gospel. John ii. 1-11, Sar. Miss., 1519.

It is not difficult to understand how great an effect must have been produced upon the minds of the worshippers, when for the first time this Gospel, exhibiting the true relations existing between the Lord and His mother, was read in English instead of Latin.

\section{THE THIRD SUNDAY AFTER THE EPIPHANY.}

The Title. 'After the Epiphany' added 1604.

The Collect. Sar. Miss., Sac. Greg.; modified 1519.

The addition of ' in all our dangers and necessities,' and 'thy right hand ' for 'the right hand of thy majesty' are the chief variations. In the Collect for the Third Sunday in Lcnt, the phrase 'right hand of thy Majesty' is retained.

The prayer to stretch forth the right hand is peculiarly apposite, followed as it is by the account of the Lord's healing toc ch in the case of the leper.

The Epistle. Rom xii. 16 21, Sar. Miss., 1549.

The Gospel. Matt. viii. 1-13, Sar. Miss., 1519. 


\section{THE FOURTH SUNDAY AFTER THE EPIPHANY.}

The Title. 'After the Epiphany' added 1604.

The Col'ect. Sar. Miss., Sac. Greg. ; somewhat varied 1549; much altered 1662 .

1519. 'God, which knowest us to be set in the midst of so many and great dangers, that for man's frailness we cannot always stand uprightly [Lat. subsistere: 'stand out, hold out ;' omit 'always ']; Grant to us the health of body and soul [Lat. 'mind and body'], that all those things which we suffer for sin [Lat. 'for our sins'], by thy help we may well pass and overcome [Lat. 'over. come' only] through Christ our Lord.'

1662. 'That by reason of the frailty of our nature' substituted for 'That for man's frailness.' (Latter part) 'Grant to us such strength and protection as may support us in all dangers, and carry us through all temptations; through,' etc.

The 1549 translation was an improvement upon the original, which asked for merely physical and mental strength; but it retained the ambiguity of the phrase-quce pro peccatis nostris patimur, 'the things which we suffer for our sins,' our English word ' for ' being as ambiguous as the Latin pro, and susceptible of the dangerous idea that our suffering atones for our sins. The use of ' $\sin$ ' for ' sins' did not sufficiently remove the possibility of this misunderstanding, and the prayer was reeast in 1662 accordingly. It is, perhaps, unfortunate that the accuracy of the original was not restored by the omission of 'always.' Man can never 'stand upright' without Divine strength and protection.

The Epistle. Rom. xiii. 1-7, 1519; in Sar. Miss., Rom. xiii. 8-10, part of the Epistle for the First Sunday in Advent.

The Gospel. Matt. viii. 23-34, 1549 ; Sar. Miss., Matt. viii. 23-27.

The 1519 addition to the Gospel makes complete the series of 'Epiphanies of Power' read at this season ; without it, an instance of Christ's authority over the powers of darkness would have been wanting.

\section{THE FIFTH SUNDAY AFTER THE EPIPHANY.}

The Title. 'After tha Epiphany' added 1604.

The Collect. Sar. Miss., Sac. Greg.; very freely translated 1519.

Latin : 'Familiam [1519, 'Church and household,' cf. Collect for 22nd Sunday after Trinity] tuam, quæsumus, Domine, 
continua pietate $[1549$, ' in thy true religion' instead of 'by thy continual goodness'] custodi; ' ut quæ in sola spe gratiæ cœlestis innititur, tua semper protectione [1549, ' mighty power '] muniatur,' etc.

The Epistle. Col. iii. 12-17, Sar. Miss., 1549.

The Gospel. Matt. xiii. 24-30, Sar. Miss., 1549.

\section{THE SIXTH SUNDAY AFTER THE EPIPHANY.}

Prior to 1549 the counting was made from the Octave of the Epiphany, so that six Sundays were provided for, though only five after Epiphany were so named; when in 1549 the counting was made from the Epiphany itself, the following rubric was added: "The Sixth Sunday (if there be so many) shall have the same Psalm, Collect, Epistle, and Gospel, that was upon the fifth.' The Roman Missal, though observing the Octave, provides a Collect, Epistle, and Gospel, for a Sixth Sunday. The present Collect (by Cosin), Epistle, and Gospel were added in 1662 .

The Collects, Epistles, and Gospels for the later Sundays after Epiphany are prescribed for use after the Twenty-fourth Sunday after Trinity, whenever the incidence of Easter shortens the aft 3 -Epiphany season and correspondingly lengthens the period between Trinity and Advent.

The Collect. 1662. It need not fear comparison with the ancient models, being composed of skilfully woven passages from Holy Scripture, including the Epistle for the day.

The Epistle. 1 John iii. 1-8, 1662.

The Gospel. Matt. xxiv. 23-31, 1662.

\section{THE SUNDAY CALLED SEPTUAGESIMA}

or

\section{THE THIRD SUNDAY BEFORE LENT.}

The Title. The sub-title was added 1662 .

This and the two following Sundays form the first stage of the second period of the ecclesiastical year, viz. that which is dependent upon Easter. It is a preparatory stage for Lent, the serond stage closes with Easter Eve, the third stage running from Easter Day to the Sunday after Ascension Day, and the fourth and last being Whitsun-tide.

The names given to these Sundays are peculiar to the Western Church, and are possibly derived from the forty days of Lent, quadraginta. Quinquagesima (sc. dies), fiftieth day, the Sunday before Ash-Wednesday, is fifty days before Easter; the other 
names, sixtieth and seventieth, being given to the two preceding Sundays as convenient, though numerically inexact.

The Collect. Sar. Miss., Sac. Greg., 1549.

'Justly punished'; Lat. Juste affligimur: 'justly afflicted.'

'By thy goodness' added 1549.

The translation expressly recognizes the permissive hand of God in affliction, latent in the 'justly' of the original.

The Epistle. 1 Cor. ix. 24-27, 1549; Sar. Miss., 1 Cor. ix. $24-\mathrm{x} .4$.

The Gospel. Matt. xx. 1-16, Sar. Miss., 1549.

\section{THE SUNDAY CALLED SEXAGESIMA}

\section{or \\ THE SECOND SUNDAY BEFORE LENT.}

The Title. The sub-title added 1662.

The Collect. Sar. Miss., Sac. Greg. ; 1549, with alterations.

The original prayed for defence doctoris gentium protectione, ' by the protection of the teacher of the Gentiles,' i.e. St. Paul. Thi : unscriptural and unnecessary request for protection other than that afforded by God Himself was excised by the Reformers, and prayer for defence by God's power substituted.

The Epistle. 2 Cor. xi. 19-31, 1549 ; Sar. Miss., xi. 19-xii. 9.

The Gospel. Luke viii. 4-15, Sar. Miss., 1549.

\section{THE SUNDAY CALLED QUINQUAGESIMA}

or

THE NEXT SUNDAY BEFORE LENT.

Formerly called Shrove Sunday, from A.-S. Scrifan = 'shriven,' 'absolved.'

The Title. Sub-title added 1662.

The Collect. 1549. In Sar. Miss. it was : Preces nostras, quœsumus, Domine, clementer exiuti, atque a peccatorum vinculis absolutos ab omni nos adversit te cus'odi- ' 0 Lord, we beseech thee favourably to hear our prayers, and defend us, absolved from the bonds of sins, from all adversity.' This prayer, appropriate to the Mediæval custom of using the "Sacrament of Penance' on Shrove Tuesday, was rejected at the Reformation.

The poverty of thought of the old Collect, which only repeats the prayer for protection of Sexagesima, justified the abandonment of any attempt to rewrite it ; the new composition, 'beauti- 
fully formed from the ancient Epistle' (Palmer's 'Orig. Lit.'), justifies itself.

The Evistle. 1 Cor. xiii. 1-13, Sar. Miss., 1549.

The Gospel. Luke xviii. 31-43, Sar. Miss., 1549.

The salutary warning of the Epistle against mere external self-abnegation has not escaped notice.

' It seems clear that this emphasis on the spirit of love which makes and not counts sacrifice, is intended to teach us the true spirit of Lenten self-discipline and self-denial, without which it may be Pharisaic in self-righteousness, or superstitious in selftorment' (Barry).

\section{THE FIRST DAY OF LENT}

\section{commonly called \\ ASH-WEDNESDAY.}

The Title, 1549 : 1552, alternative title omitted; restored 1662 as in S.L.

'Commonly called' here, as elsewhere, casts an imputation of error upon the title introduced. The first day of Lent was formerly called Caput Jejunii, i.e. 'the head or beginning of the Fast'; 'Ash-Wednesday,' Dies Cinerum, is derived from the practice-of doubtful antiquity - of using ashes to signify contrition. There was a Service to bless and apply these ashes, in Sar. Miss. This Service, with the candles of Candlemas, and other like practices was abolished by the Council, 1548.*

The Collect 1549. The introductory sentence is very like the opening of one of the Ash-Wednesday collects in Sar. Miss. : Omnipotens, sempiterne Deus, qui misereris omnium et nihil otisti eorum quas lecisti, dissimulans peccata hominum propter poonitentiam - ${ }^{-}$Almighty and everlasting God, who pitiest ill [men ?] and hatest nothing of the things which thou hast made, treating as non-existent (dissimulans) the sins of men on account of their repentance. . . '

'Who hatest nothing,' etc. Se? Wisd. xi. $24,-$ a rare instance of the use of the devotional Apocrypha in B.C.P.

The Roman Collect is, ' Grant, O Lord, that thy faithful people may enter on this solemn fast with suitable picty, and go through it with unmolested devotion.'

The Rubric after the Collect directing daily use in Lent, 1662.

For the Epistle. Joel ii. 12-17, 1549; Sar. Miss., ii. 12-19.

The Gospel. Matt. vi. 16-21, Sar. Miss., 1549.

* For ths meaning a?d origin of Lent, see p. 53. 
In the Scotch Liturgy a rubric after the Gospel directs the use of the Ash-Wednesday Collect, Epistle, and Gospel until the First Sunday in Lent; this was not incorporated into B.C.P. in 1662 .

\section{THE FIRST SUNDAY IN LENT.}

This is sometimes called 'Quadragesima Sunday.'

The Collect. 1549: probably by Cranmer; Miss. Ambros. contains a Collect distantly resembling Cranmer's.

Sar. Miss.: 'O God, who dost cleanse thy Church by the yearly observance of Lent; Grant to thy Family that what it strives to obtain from thee by fasting, it may carry out by good works.' The mind of the Reformers is clearly indicated by their substitution of the present Collect, basing all abstinence upon the Lord's example, drawing no distinction between fasting and abstinence, severing abstinence from any particular period, limiting its utility to the subordination of the flesh to the spirit, and omitting any claim to Divine sanction for the observance of Lent, and any idea of merit in fasting.

The Epistle. 2 Cor. vi. 1-10, Sar. Miss., 1549.

The Gospel. Matt. iv. 1-11, Sar. Miss., 1549.

\section{THE SECOND SUNDAY IN LENT.}

The Tille. 'In Lent' added 1604.

The Collect. Sar. Miss., Sac. Greg., 1549 (freely translated).

The chief alteration is making the verb 'defend' cover both 'body' and 'soul.' The verbal parallel in the Latin, Muniamur in corpore . . . mundemur in mente: 'defended in body ... cleansed in mind,' does not admit of reproduction in English.

The Epistle. 1 Thess. iv. 1-8, 1549 ; Sar. Miss., iv. 1-7.

The Gospel. Matt. xv. 21-28, Sar. Miss., 1549.

\section{THE THIRD SUNDAY IN LENT.}

The Title. 'In Lent' added 1604.

The Collect. Sar. Miss., Sac. Greg., 1549.

The phrase 'against all our enemies' is not in the original. 'Hearty desires' is the translation of vota, originally 'vows,' but common in later Latin for a 'desire,' or 'prayer.'

The Epistle. Eph. v. 1-14, 1549; Sar. Miss., v. 1-9.

The Gospel. Luke xi. 14-28, Sar. Miss., 1549. 


\section{THE FOURTH SUNDAY IN LENT.}

Mid-Lent Sunday, formerly called Dies (or Dominica) Refectionis: 'the Day (or Lord's Day) of Refreshment,' also 'Mothering Sunday.' The reasons given for these various names are :

(1) The subject of the Gospel: The Feeding of the Five Thousand.

(2) The old practice of feasting or this day midway through the fast: special cakes are still made at this season in parts of Lancashire.

(3) The custom of visiting the Mother Church of the diocese with offerings on this day.

(4) The custom in some parts of England for apprentices and servants living from home to visit their parents on this day and take thom a present, which often took the form of a 'mothering cake.'

The Title. 'In Lent' added 1559.

The Collect. Sar. Miss., Sac. Greg., 1549.

1662. 'Worthily deserve to be punished' instead of 'are worthily punished.' The earlier form was closer to the original, but the alteration renders the prayer more generally applicable to all people at all times.

The Epistle. Gal. iv. 21-31, 1549 ; Sar. Miss., iv. 22-v. 1. The Gospel. John vi. 1-14, Sar. Miss., 1549.

\section{THE FIFTH SUNDAY IN LENT.}

Called formerly ' Passion Sunday,' perhaps from the anticipation of the Passion in the Epistle; but this scarcely explains the name 'Passion Week' applied to the whole week.

The Title. 'In Lent' added 1559.

The Collect. Sar. Miss., Sac. Greg., 1549 (freely translated).

The difficulty recurs here of reproducing the terse and balanced phrasing of the original: Te largiente regatur in corpore, et te servante custodiatur in mente, i.e. literally, "Thee bestowing bountifully it may be ruled in body, and thee preserving it may be guarded in mind.' The rhythm of the English is, however, some compensation, and the fuller significance obtained by substituting 'soul' for ' mind,' together with the use of 'people' and the plural for 'family' and the singular, more than makes up for the loss of verbal nicety.

The Collect much resembles that for the Second Sunday in Lent, and has no obvious connexion with the Passion of our Lord. Bishop Patrick, one of the Commissioners appointed to revise the Prayer Book in 1679, drew up a beautiful Collect, 
which incorporated the language and thought of the Epistle for the day, but the proposals of that Commission were never put into effect.

The Epistle. Heb. ix. 11-15, Sar. Miss., 1549.

The Gospel. John viii. 46-59a, Sar. Miss., 1549.

\section{THE SUNDAY NEXT BEFORE EASTER.}

'Palm Sunday,' 'Holy Week,' 'Great Week,' * 'Indulgence Week,' are terms which are not found in the B.C.P. though 'Palm Sunday' and 'Holy Week' are in popular usage.

On Palm Sunday in comparatively early times there was a ceremony of the blessing and distribution of palms, or small branches of trees, in commemoration of the Triumphal Entry of our Lord into Jerusalem, and the practice is still maintained in the Roman Church. The absence of reference to the triumphal entry, in the Collect or Gospel is explained by the arrangement by which the four accounts of the Passion are read during Holy Week. One of the Second Lessons at Evening Prayer, however (Luke xix. 28-48), recounts the event.

The Collect. Sar. Miss., Sac. Gel., Sac. Greg., 1549.

' Of thy tender love.' Without this phrase, added by the trans. lators, there would be no clear reference to the self-sacrifice of God in this Collect. Bishop Dowden well says that the phrase 'suffuses the whole prayer with its flush of emotion.'

In the original all is based upon the word mereamur: "that we may deserve to have the example of his patience and a share in his resurrection.' The importance of the Reformers' alteration is obvious: 'that we may follow' (not 'deserve to have') 'the example' and 'be made partakers of' (not 'deserve to share in ') ' his resurrection.'

The Epistle. Phil. ii. 5-11, Sar. Miss., 1549.

The Gospel. Matt. xxvii. 1-54, 1662 ; Sar. Miss., xxvi. 2xxvii. $61 ; 1549$, xxvi. 1-xxvii. 56.

Chapter xxvi. was in 1662 appointed for the Second Lesson at Morning Prayer, to make a continuous narrative with the Gospel which follows. The custom of having the Holy Communion Office before Morning Prayer, or apart from it, is a late. introduction of the Victorian period.

\section{MONDAY BEFORE EASTER.}

In the pre-Reformation services, there were special Collects:

* St. Chrysostom (c. 400 ) says that it was called by this name because 'great things were wrought at this time by the Lord,' and he bases an exhortation to acts of Christian devotion and meroy thereupon. 
for each day of the week before Easter; for Monday, Tuesday, and Thursday one each, for Wednesday two, and for Good Friday a large number, as many as eighteen.

The Collects for Monday to Thursday were omitted in 1549, and have never been restored. At the last revision of the American Prayer Book it was proposed to insert a series of Collects, one for each of the four days, but this was not adopted. The subjects of the proposed collects were as follows :-

Monday : Preparation for the right commemoration of the Passion.

Tuesday: Willingness to share in the Sufferings of Christ.

Wednesday: True repentance, after the example of St. Peter.

Thursday: A right reception of the 'Cup of Blessing' in remembrance of the 'cup' drunk by the Saviour in Gethsemane.

For the Epistle. Isa. lxiii. 1-19, 1549; part of Sar. Miss. Lesson for the fourth day in Holy Week.

The Gospel. Mark xiv. 1-72, 1549 ; part of Sar, Miss. Gospel for third day in Holy Week.

\section{TUESDAY BEFORE EASTER.}

For The Epistle. Isa. 1. 5-11, 1549.

The Gospel. Mark xv. 1-39, 1549 ; Sar. Miss., xiv. 1-xv: 46.

\section{WEDNESDAY BEFORE EASTER.}

The Epistle. Heb. ix. 16-28, 1549.

The Gospel. Luke xxii. 1-71, 1549 ; Sar. Miss., xxii. 1-xxiii. 49.

\section{THURSDAY BEFORE EASTER.}

'Next before Easter,' 1559 ; formerly called Dies Ccence Domini, Dies Natalis Eucharistica, Dies Natalis Calicis; known, though not so described in the B.C.P., as 'Maundy-Thursday.' Three derivations of this last name are given :

(1) The most probable-Lat. mando, 'to command' (Dies Mandata), ' the Day of the Commandment,' from the fact that our Lord as on this day gave His disciples commandment: $(a)$ to commemorate His death; $(b)$ to wash one another's feet; $(c)$ to love one another.

(2) Maund, A.-S. mand, 'a basket,' because the royal gifts bestowed on this day were brought and carried away in baskets.

(3) French maundier, 'to beg.'

This day, being the day on which the Lord's Supper was instituted, was formerly observed with greater solemnity than 
the preceding days, and in many English Churches it is now marked by an administration of the Lord's Supper, especially in the evening, as being nearest to the time of its original institution.

For many centuries English Sovereigns, up to James II, following a general practice, washed the feet of a number of poor persons on this day. It was afterwards done by the Archbishop of York as the King's representative, but it is now no longer practised, only the Royal Maundy gifts being continued, with a special service and some of the ancient ceremonial.

Foot-washing is still performed by the Pope, by some high Roman Catholic dignitaries, and by some Sovereigns of Roman Catholic countries, but with ceremonious display, little suggestive of the lowly Redeemer in the 'upper room.'

A number of other practices were associated with this day, such as the repetition of the Creed by catechumens, the public absolution of penitents, and the consecration of the chrism, or baptismal oil.

The Epistle. 1 Cor. xi. 17-34,1549; Sar. Miss., 1 Cor. xi. 20-32.

The Gospel. Luke xxiii. 1-49, 1549; Sar. Miss., with Luke xxii. on another day.

\section{GOOD FRIDAY.}

The Title. 'On Good Friday,' 1549, 1552. This name is peculiar to the Church of England. In the earliest times it was called 'Pascha,' as being associated with, and observed at the time of, the Jewish Passover, but by the second century the name was appropriated to Easter, whence the well-known error of the A.V. in Acts xii. 4, 'intending after Easter [R.V. ' the Passover '] to bring him (Peter) forth to the people.' In another early name for Good Friday the reverse process has obtained, the name 'Day of Preparation' in the Didache, a synonym for Friday, being appropriated to this Friday in particular. Other descriptive phrases and names are : Dies Dominicas Passionis, Dies Absolutionis, Dies Crucis.' There is a peculiar fitness in the English title, both positively, as recognizing the joyous emancipation of the believer through the finished work of the Cross, and negatively as a protest against the superstitious branding of all Fridays, and this one in particular, as 'unlucky'a superstition not yet dead even in England, and traceable without much difficulty to the mistaken ideas which tended to fill the day with an external pomp of funereal gloom. Easter having been in very early times a great day for public baptism, it is not surprising that the solemnity of the events immediately 
preceding Easter should have been seized as an occasion for heart-searching preparations. Such commendable reverence has nothing in common with Mediæval customs, c.g. Creeping to the Cross, The Mass of the Pre-sanctified, Stripping of Altars, Singing of the 'Reproaches.' Apart from the doctrinal errors associated with such practices, there is a danger of obscuring the great lesson which alone justifies the observance of Good Friday, viz. that ' with His stripes we are healed,' not plunged into gloom. The hymnology of Reformed Christendom is not free from the same danger, not infrequently overstepping the bounds of reverential awe, and so tending to reproduce the blindness of those who wept for Christ when their own desperate condition alone called for tears!

The Collects. 1552. 'The Collect,' 1549.

(1) Sar Miss., Sac. Greg., 1549.

(2) Sar. Miss., Sac. Gel., Sac. Greg., 1549.

In the Roman Missal there are eight Collects for Good Friday: for the Church, the Pope, the Monarchy, Catechumens, those in Tribulation, Heretics, the Jews, and Pagans.

(3) 1549 ; ideas found in three Collects in Sar. Miss., Sac. Gel., Sac. Greg.

In 1549 a rubric directs the use of the last two 'at the Communion,' the first one only being 'The Collect.' This rubric was not preserved in 1552 .

The first refers to the Church as the family of the redeemed; the second to the Church as a living organism; while

the last embraces all outside the Church.

It is a strange confusion of thought which imagines that the mention of Jews and Heretics in conjunction with Turks (Mohammedans) and Infidels groups them into one class. Their separate enumeration distinguishes them in all but the one respect of rejection of Jesus Christ as Lord and Saviour. A more valid objection to all the three Collects is their omission on Good Friday of any direct reference to the Redemption. Here, at any rate, the Collects do not summarize the teaching of the Epistle and Gospel for the day.

The Epistle. Heb. x. 1-25, 1549.

The Gospel. John xix. 1-37, 1662; Sar. Miss., xviii. 1-xix. 37 ; 1549, xviii. 1-xix. 42 .

\section{EASTER EVEN.}

The Collect. 1662. A revision of one in the Scotch Liturgy, probably by Laud. It somewhat resembles a Collect for this day in the old Gallican Missal. 
There was no spccial Collect from 1549 to 1662 .

The S.L. Collect was as follows, the chief portions omitted or varied in 1662 being in brackets :

O (most gracious) God, (look upon us in mercy, and) grant that as we are baptized into the death of thy Son our Saviour Jesus Christ; so by (our true and hearty repentance all our sins) may be buried with him, (and we not fear the grave); (that as Christ was raised up from the dead by the glory of thee, 0 Fat er, so we also may walk in newness of life, but our sins never be able to rise in judgment against us) and that, for the merit of Jesus Christ that died, was buried, and rose again for us.

The fanciful idea in the above of ' burial of sins' by repentance is exchanged for the revealed truth of the burial of the believer through death unto sin; and by the words "through the grave and gate of death, we may pass to our joyful resurrection,' the idea of silencing our sins as accusers by holiness of life is excluded.

'As we are baptized.' The reference to Baptism, though directly taken from Holy Scripture, recalls the primitive custom of making Easter Eve one of the pincipal times for that rite. The catechumens were prepared duing Lent, clad in white garments called chrisoms, as a symbol of their having put on Christ.

The Collect in Sar. Miss. is based upon this custom :-

0 God, who dost illuminate this most holy night by the glory of our Lord's resurrection, preserve in the children newly brought into thy family the spirit of adoption which thou hast given, that being renewed both in body and mind, they may render unto thee a pure service, through the same our Lord.

In the opening words there may have been an allusion to the custom of lighting torches and lamps on Easter Eve in churches and private houses, said to have been in vogue early in the fourth century. The lighting of the 'new fire' on this day is still practised in Jerusalem and elsewhere in the East.

The Epistle. 1 Pet. iii. 17-22, 1549 ; Sar. Miss., Col. iii. 1-4.

The Gospel. Matt. xxvii. 57-66, 1549 ; Sar. Miss., xxviii. 1-7.

\section{EASTER DAY.*}

Observed from very early times, but cf. Socrates (fifth century): ' The Apostles had no thought of appointing festival days, but of promoting a life of blamelessness and piety. And it seems

* All other movable Feasts and Holy Days depend upon this date. The rules for finding Easter are fully set out and explained in pp. $57 \mathrm{ff}$. For the controversy respecting the time of ouservance, etc., see pp. 4l, 2. 
to me that the Feast of Easter has been introduced into the Church from some old usage, just as many other customs have been established' ('Eccles. Hist.,' I. xxii. bk. v. : quoted from Blakeney, p. 229).

\section{The Anthems. Rubric, 1552.}

1549. In the morning, afore Matins, the people being assembled in the Church, these Anthems shall be first solemnly sung or said.

The Anthems. 1549; except the first, 1662, when chapter and verse were also added and A.V. used.

The first was in the Anthem Book of Gregory, without the phırase, "Not with the old leaven, nor with the leaven of malice and wickedness.' It came in the Epistle in Sar. Miss.

The second, Antiphonar. Greg., in Communionem; Sar. Brev. ' before Matins'; used a'so in Sar. Miss. In 1549 the two clauses closed with 'Hallelujah' (twice repeated after the first clause), the whole being followed by the following Versicles and Collect :-

The Priest. Shew forth to all nations the glory of God.

The Answer. And among all people his wonderful works.

Let us pray.

0 God, who for our redemption didst give thine only begotten Son to the death of the cross; and by his glorious resurrection hast delivered us from the power of our enemy; Grant us so to die daily from sin, that we may evermore live with him, in the joy of his resurrection; through the same Christ our Lord. Amen.

These, with the Hallelujahs, were om tted in 1552. They were divided according to verses of the Bible, and the Gloria added, in 1662.

The Collect. 1549, Sar. Miss., Sac. Gel., and Sac. Greg.

The provision for Easter-tide has undergone some variations of arrangement :-

1549. Two Collects, Epistles, and Gospels, for first and second Communion.

The first Collect to be repeated on Monday in Easter Week; the second on Tuesday, and on the First Sunday after Easter.

1552. Only the first Collect, Epistle, and Gospel retained for Easter Day.

The first Collect to be used on Monday and the following Sunday; the second to be used on Tuesday only.

1662. The first Collect to be used through the whole of Easter Week; the second Collect to be used on and from the Sunday after Easter. 
The Second Epistle and Gospel of 1549, 1 Cor. v. 6 ff., and Mark xvi. $1 \mathrm{ff}$., have not been used in connexion with Easter since 1552.

The first part of the Collest for Easter Day is by Gelasius, the second by Gregory. Gelasius' Collect simply asked that through the renewing of the Spirit we may rise from the death of the soul. Gregory's revision, with its reference to 'grace preventing us,' was probably made to meet the Pelagian heresy.

The connexion of the petition of this Collect with the opening portion is not obvious. It has the merit of associating a consistent Christian life with the Resurrection, but seems inadequate to the greatest Festival of the Christian year.

The Epistle. Col. iii. 1-7, 1549; Sar. Miss. (Easter Eve), Col. iii. 1-4.

The Gospel. John xx. 1-10, 1549; Sar. Miss. (Saturday after Easter), xx. 1-9.

In the Sar. Miss. the Gospels for Easter-tide seem to have been appointed to secure the reading of all the accounts of the Resurrection, beginning with St. Matthew's on Easter Even.

\section{MONDAY IN EASTER WEEK.}

It is the custom in some quarters to speak of the 'Octave' of certain Festivals, but B.C.P. does not use the term, and makes no provision for the observance of any days in Easter Week save Monday and Tuesday. Augustine and Chrysostom speak of the Octave of Easter, i.e. the observance of the eighth day of the Festival. The Code of Theodosius prescrib d cessation of work for the whole week This is an instance of the practice, which developed so largely in later days, of multiplying holidays until they fostered an indo'ent spirit in the worker by their serious interference in the daily occupations of the people. Under the changed conditions of life prevailing to-day, the provision for three days after Christmas, two days after Easter and Whitsuntide, and the whole of Holy Week, seems more than ample; but at the time when the changes were made they were very sweeping, and were so regarded. The most obvious spiritual calamity attaching to the multiplication of days of observance, is that degradation of the one day in seven which has always accompanied over-strict enforcement of their observance.

The Collect. As on Easter Day, 1549 (the former of the two then appointed).

For the Epistle. Acts x. 34-43, 1549 ; Sar. Miss. ('Tuesday in Easter Week).

The Gospel. Luke xxiv. 13-35, 1549. 


\section{TUESDAY IN EASTER WEEK.}

The Collect. As on Easter Day, 1662. In 1549 and 1552 the second Easter Collect was appointed.

For the Epistle. Acts xiii. 26-41, 1549; Sar. Miss. (Wednesday in Easter Week).

The Gospel. Luke xxiv. 36-48, 1549.

The American Revision Committee suggested a return to the pre-Reformation use of having special Collects for these two days, and Collects were prepared, but the suggestion was not adopted.

\section{THE FIRST SUNDAY AFTER EASTER.}

Other names given to this day are :

(1) Dominica in Albis - 'The Lord's Day in White,' from the newly baptized wearing, for the last time, the white robes, or chrisoms, worn during Easter Week. The robes were then deposited in the Church.

(2) 'Low Sunday.' It was customary to repeat some of the 'Paschal solemnities,' thus making it a special feast, though of a lower degree than Easter Day. Another explanation of the term is that 'Low' is a corruption of Laudes, the Sequence for the day beginning Laudes Salvatori.

(3) The French have a name, 'Paque close'-Pascha clausum, because on this day the Easter celebrations ended.

(4) The Greek Church calls the day 'New Sunday,' the reference being to the new life en'ered upon by the newly baptized.

The Collect. 1549. Origin unknown; based on second Easter Epistle of 1549, with which it was then used. 1 Cor. v. 7, 8; the second Collect for Easter Day in 1549.

1552. Only used on Tuesday in Easter Week.

1662. Restored as Collect for this Sunday.

'Almighty Father.' A form of invocation occurring nowhere else among the Collects.

The Epistle. 1 John v. 4-12, 1549; Sar. Miss., 4-10.

The Gospel. John xx. 19-23, 1549.

The Gospel in Sar. Miss. included vers. 24-31, containing the appearance to Thomas, and the two final verses of the chapter. The compilers in 1549 omitted the last eight verses, the first seven of which now form the Second Lesson at Evening Frayer on this day.

\section{THE SECOND SUNDAY AFTER EASTER.}

\section{The Collect. 1549.}

The old Collect in Sar. Miss. was :-

O God, who by thy Son's humbling himself. hast raised up 
a fallen world; Grant unto thy faithful people perpetual joy, that they whom thou hast snatehed from the dangers of perpetual death, may be brought by thee to the fruition of eternal joys; through the same.

'For it the Reformers substituted one of more solid excellenee. This prayer ... summarizes the whole benefit of the Redemption, as consisting in the provision of a sin offering, and of a perfect example' (Goulburn). One could wish that the framers of such a Collect had forsaken models, however ancient, in providing for Holy Week and Good Friday.

'Thine only Son'; in original draft, and in all editions until 1596, ' thy holy Son'; ' no doubt a printer's error' (Goulburn).

'Daily endeavour ourseives'; a reflexive use of the verb, now no longer in use; cf. Ordination Services: 'I will endeavour myself . . . the Lord being my helper.'

The Epistle. 1 Pet. ii. 19-25, 1549; Sar. Miss., 21-25.

The Gospel. John x. 11-16, Sar. Miss., 1549.

1549, 'Christ said'; 1662, 'Jesus said' prefixed ; Sar. Miss., dixit. Jesus.

In the Black Letter Prayer Book the words 'Christ said' are printed, not in black letter, but in Roman type, in accordance with King James' Letter. in Cardwell's Conf., p. 218 : 'These words (Christe seyde) to be printed in letters differing from the text.' Compare the use of italics in A.V. for a similar reluctance to place human additions, however needed for sense, on a level with the actual words of Holy Writ.

\section{THE THIRD SUNDAY AFTER EASTER.}

The Collect. Sar. Miss., Sac. Leo, Sac. Gel., 1549.

'The Way' stood alone in Sac. Leo; 'of righteousness' was added by Gregory.

'May return'; Lat. possint redire: ' may be able to return.'

'Admitted into the fellows'ip of Christ's religion': Lat. qui Christiana professione censentur: "who are rated, estimated, according to their Christian profession.'

'Esche $v^{\prime}$; Lat. respuere: 'to eject from the mouth'; cf. Rev. ii . 16.

The Epistle. 1 Pet. ii. 11-17, 1549 ; Sar. Miss., 11-19.

The Gospel. John xvi. 16-22, Sar. Miss., 1549.

THE FOURTH SUNDAY AFTER EASTER.

The Collect. Sar. Miss., Sac. Gel., Sac. Greg., 1549.

1662. "Which dost make the minds of all faithful men to be of one will,' as in the original Latin, altered to ' who 
alone canst order the unruly wills and affections of sinful men.' This more sad opening may be an intentional reflection of the divided state of English Christianity at the time.

The Epistle. Jas. i. 17-21, Sar. Miss., 1549.

The Gospel. John xvi. 5-14, Sar. Miss., 1549.

\section{THE FIFTH SUNDAY AFTER EASTER.}

Also called, though not in B.C.P., ' Rogation Sunday,' because the three Rogation Days, 'Days of Asking,' immediately follow it (see p. 55).

There is some appropriateness to the idea of Rogation-tide in the opening words of the Collect, and in the Gospel. The Gospel also announces the Ascension, commemorated on the following Thursday.

The Collect. Sar. Miss., Sac. Gel., Sac. Greg., 1549.

The only deviation of any importance from the original is the substitution of the more inclusive word 'good' for 'right': 'think those things that be good.'

The Epistle. Jas. i. 22-27, Sar. Miss. 1549.

The Gospel. John xvi. 23-33, 1549; Sar. Miss., 23-30.

\section{THE ASCENSION-DAY.}

The Title. 'The' omitted 1559 , restored 1662.

This Festival was observed from earliest times, according to St. Augustine, who reckons it with Good Friday, Easter, and Whitsuntide. In modern times Christmas would be acknowledged to be of more general and more definite observance, partly, at any rate, because of the exigencies of daly life, which permit of a public holiday at Christmas tide more easily than in the days before the Whitsun tide holiday. On the Continent Ascension Day is still a public holiday, especially in France. The Ascension of our Lord is hardly sufficiently emphasized, and, so far as a more strict observance of Ascension Day is calculated to remedy that defect, such fuller observance is desirable.

The Collect. Sar. Miss., Sàc. Gel., Sac. Greg., 1549.

The Sarum Collect varies considerably from the Gelasian, to which the 1549 Collect is a return, laying stress, as they both do, upon the effort to attain to dwelling in heaven, as well as upon the spiritual ascension of believers.

For the Episte. Acts i. 1-11, Sar. Miss., 1549.

The Gospel. Mark xvi. 14-20, Sar. Miss., 1549. 


\section{SUNDAY AFTER ASCENSION-DAY.}

The Title. 1604; 1549, 'The Sunday after the AscensionDay'; formerly called Dominica Expectationis: 'Waiting Sunday,' as coming within the ten days of waiting between Ascension-Day and Whit-Sunday.

The Collect. 1549.

The Sarum Collect made no allusion to the Ascension : 'Almighty and everlasting God, make us always to have a will devoted unto thee, and to serve thy majesty with sincerity of heart; through the Lord.'

The compilers worked into the present Collect part of a beautiful antiphon which formed a part of the ancient Vespers for Ascension-' Day, and which was used by Bede on his death-bed : ' $O$ Lord, Kiug of glory, Lord of virtues, who to-day didst ascend in triumph above all heavens, do not leave us orphans, but send upon us the promise of the Father, even the Spirit of Truth.' The Greek o $\rho$ фavoús in John xiv. 18, is translated 'comfortless' in A.V., as in this Collect; R.V. 'desolate'; 'orphans ' in margin A.V. and R.V. This antiphon is addressed to God the Son; the Collect, to God the Father.

The Epistle. 1 Pet. iv. 7-11, Sar. Miss., 1549.

The Gospei. John xv. 26-xvi. 4a, Sar. Miss., 1549.

\section{WHIT-SUNDAY.}

The name 'Whit-Sunday' is variously explained :-

(1) White Sunday, from the chrisom, or white baptismal garment, assumed by English baptismal candidates on that day in preference to Easter Day. Evan Daniel argues strongly for this explanation, appealing to $(a)$ the history of the word as it is used in Medirval documents and Service books; $(b)$ the Icelandic and Welsh names for the day, which both mean 'White Sunday'; and (c) the analogy of Saxon words and proper names, e.g. Whitlow, Whitchurch, all meaning 'White.' Referring to the mode of printing the word Evan Daniel says: "The facsimile of the House of Lords' MS. of the Prayer Book of 1662 has "Whit-Sunday" in all five places where the word occurs. Modern Prayer Books vary greatly. The division of the word by a hyphen after Whitsun should be abandoned, in spite of the term "WhitsunWeek" in B.C.P., where, however, the hyphen is wanting in correctly printed books. By analogy, the term "Whitsun tide" has come into popular use, but its cognates "Whitsun-Monday" and "Whitsun-Tuesday" are happily dead or dying.'

The objection to this derivation, viz. that the real White 
Sunday (Dominica in Albis) is the First Sunday after Easter, is met by the argument that the Northern Churches preferred the later date of Pentecost for their great Baptismal Sundays from considerations of climate.

(2) The day was called Whit-Sunday because ' wit,' i.e. understanding and wisdom, was given to the Apostles at Pentecost. This derivation is only a plausible conjecture, unsupported by any reliable evidence.

(3) 'Whitsun' is said by Neale and other liturgiologists to be derived from the German Pfingsten, in itself a corrupt form of 'Pentecost,' i.e. Fiftieth Day.

The original name, 'Pentecost,' fiftieth, from the N.T. name of the Jewish Festival, is still largely used for Whit-Sunday. The Jews were bidden to keep the feast on the fiftieth day from the morrow of the sabbath after the Passover, to commemorate the ingathering of the first-fruits of the harvest, two loaves from the new harvest being ceremonially offered at this feast (Lev. xxiii. 15-22).*

The Collect. Sar. Miss., Sac. Greg., 1549.

'To have a right judgment in all things'; Lat. recta sapere. The word sapere = first, ' taste,' cf. 'savour'; then, ' to have good taste, discernment,' finally, 'to be wise.' The address to God without an interjection, and the ending, are peculiar to this Collect.

The Epistle. Acts ii. 1-11, Sar. Miss., 1549.

The Gospel. John xiv. 15-31, 1549; Sar. Miss., 23-31.

\section{MONDAY IN WHITSUN-WEEK.}

The Collect. As for Whit-Sunday.

In Sar. Miss. there were special Collects for Monday and Tuesday; it was proposed to have such in the American B.C.P. (1883), but the proposal was not adopted.

The Epistle. Acts x. 34-48, 1549 ; Sar. Miss., for Tuesday.

For The Gospel. John iii. 16-21, Sar. Miss., 1549.

\section{TUESDAY IN WHITSUN-WEEK.}

The Collect. As for Whit-Sunday.

For the Epistle. Acts viii. 14-17, 1549; Sar. Miss., for Wednesday.

The Gospel. John x. 1-10, Sar. Miss., 1549.

* It has been roughly calculated from Exod. xix. 1 that the giving of the Law took place fifty days after the original Passover, and later rabbinical writers enlarge upon the point. There is no trace of the idea in Holy Seripture or in Josephus. 


\section{TRINITY SUNDAY.}

The Church of England seems to have led the way in the observance of this Festival, but the fact that the Collect is the one appointed for the Sunday after Whitsunday in Sac. Greg. indicates that the idea of specially considering the subject of the Blessed Trinity on this day was early introduced into the Western Church. The word 'Trinity' dates from 180 A.D. Durandus gives 834 as the date of the institution of the Festival, when Gregory IV was Pope. Pope Alexander II (1061-1073) discouraged its observance as unnecessary, seeing that in every day's worship the Trinity was recognized, and Alexander III (1179) said there was no day in the Roman Calendar set apart for this commemoration. Other authorities state that Thomas à Becket, who was consecrated on this day in 1162, first ordained its observance in honour of the Holy Trinity. Its general observance was certainly enjoined by the Synod of Arles (1260), and its observance was formally ordered by Pope John XXII (1324). The Church of England follows the Sarum Use in reckoning the succeeding Sundays from Trinity Sunday; in the Greek and Roman Churches they are called 'Sundays after Pentecost.'

. In the Eastern Church this Sunday is kept as the Festival of All Martyrs.

The Collect. Sar. Miss., Sac. Greg., 1549; slightly altered 1662.

1549. That through the stedfastness of this faith, we may evermore be defended, etc.

1662. That thou wouldest keep us stedfast in this faith, and evermore defend us, etc.

'By the confession of a true faith ... in the power of the Divine Majesty'; Lat. in confessione verce fidei . . . in potentia Majestat - -the prepositions being the same in both clauses. The balance of the Collect is lost by the translation 'by' and 'in,' and the latter is ambiguous. ' $\mathrm{By}$ ' is certainly right; it alone gives a clear meaning. We acknowledge the Blessed Trinity by our faithful confession; we adore the One God by the prompting of His infinite power.

The Epistle. Rev. iv. 1-11, Sar. Miss., 1549.

The Gospel. John iii. 1-15, Sar. Miss., 1549.

THE FIRST SUNDAY AFTER TRINITY.

The Title. In 1549, 1552, 'The First Sunday after Trinity Sunday.' The full title of the First Sunday after Trinity in the Roman Church is "The Sunday after the Octave of the Holy Sacrament, or the Second Sunday after Pentecost.' 
The Collect. Sar. Miss., Sac. Gel., Sac. Greg., 1519; slightly altered 1662 .

The labours of Gelasius to extirpate the Pelagian heresy lend peculiar emphasis to the words 'through the weakness of our mortal nature.'

The Epistle. 1 John iv. 7-21, 1549; Sar. Miss., 9-21.

The Gospel. Luke xvi. 19-31, Sar. Miss., 1549.

\section{THE SECOND SUNDAY AFTER TRINITY.}

The Title. 1549, 1552, the words 'after Trinity' omitted from the Second Sunday after Trinity onwards.

The Collect. Sar. Miss., Sac. Gel., Sac. Greg., 1549 ; transposed in 1662 to make it uniform with other Collects ; the original began with the petition, and closed with the ground of appeal.

Considerable freedom was used in rendering the original Collect. into English : 'Sancti nominis tui, Domine, timorem pariter et amorem fac nos habere perpetuum; quia nunquam tua gubernatiore destituis quos in soliditate tuæ dilectionis instituis. Per Dom:num.' 'Stedfast fear and love' can only mean man's love to God; the original speaks of man's being established 'in the firmness of God's love for man.'

The Epistle. 1 John iii. 13-24, 1549 ; Sar. Miss., 13-18.

The Gospel. Luke xiv. 16-24, Sar. Miss., 1549.

\section{THE THIRD SUNDAY AFTER TRINITY.}

The Collect. Sar. Miss., Sac. Greg.; altered 1662.

1662. 'And comforted in all dangers and adversities' added.

The Epistle. 1 Pet. v. 5-11, 1549; Sar. Miss., 6-11.

The Gospel. Luke xv. 1-10, Sar. Miss., 1549.

\section{THE FOURTH SUNDAY AFTER TRINITY.}

The Collect. Sar. Miss., Sac. Greg., 1549.

'Things temporal '; bona temporalia, 'temporal good things.' The contrast between 'temporal good things' and 'eternal good things' is lost by the translation, which contrasts temporal things, good and bad, with eternal good things. The clear warning of the original against contentment with, and misuse of, the good things of time is sacrificed to the definite warning against misuse of this life generally.

The Epistle. Rom. viii. 18-23, Sar. Miss., 1549.

The Gospel. Luke vi. 36-42, Sar. Miss. 1549. 


\section{THE FIFTH SUNDAY AFTER TRINITY.}

The Collect. Sar. Miss., Sac. Leo, Sac. Greg., 1549.

In the original : "Grant to us, Lord, we besecch thee, that both the course of this world may be directed (dirigatur) peaceably for us by thy ordinance, and that thy Church (ecclesia) may rejoice with tranquil devoutness (tranquilla devotione).' The Reformers have escaped the somewhat selfish suggestion by omitting 'for us,' and have made clear the latent idea of the original, that peace on earth enhances the Church's opportunities of service, by fusing the iwo co-ordinate sentences of the original into one compound sentence, 'so ... that ....' Ecclesia was translated 'congregation' in 1549, 'people' in S.L., 'Church' in 1662.

The Epistle. 1 Pet. iii. 8-15, Sar. Miss., 1549.

The Gospel. Luke v. 1-11, Sar. Miss.; 1549.

\section{THE SIXTH SUNDAY AFTER TRINITY.}

The Collect. Sar. Miss., Sac. Gel., Sac. Greg., 1549.

'Such good things as pass man's understanding'; Lat. bona invisibilia ; cf. 'Eye hath not seen,' etc. (1 Cor. ii. 9). The translation, by borrowing the phrase from Phil. iv. 7, 'which passeth all understanding,' avoided the mistake, still commonly made in using the former passage, of ignoring the fact that these 'good things' have been revealed to us by the Spirit. The connexion with Phil. iv. 7 has been obscured by the omission of 'all' before 'man's understanding,' in 1662.

'Above all things'; Lat. in omnibus et super omnia: 'in all things and above all things'; 1549, 'in all things.' The combination, agreeable enough in the Latin, is overweighted in English. It is difficult to decide between the two selections of 1549 and 1662 : the latter is more smooth to our ears, but the former displays deeper insight into the difficulties of the spiritual life. Difficult as it is to put God first, it is even more subtly difficult to love Him unfalteringly in all circumstances of joy or sorrow.

'That love thee... love towards thee ... loving thee'; Lat. diligentibus te . . . affectum tui amoris . . . diligentes. The poverty of the English tongue is here painfully apparent. The love owned of God is set forth in the original as active (cf. 'diligent'), all idea of passion being absent; cf. Greek, (far more

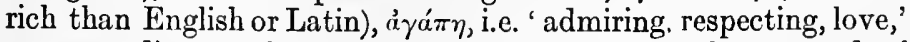
corresponding to the love here mentioned, and always used of

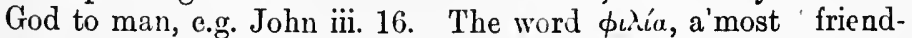
ship,' the love of communion, is the love three times claimed by 
Peter in John xxi., where, as is well known, the translation of the two words by the one English word seriously affects the meaning of the whole passage; ‘ै $\rho \omega s$, love between the sexes, is never used in Holy Scripture. Amor, like 'love,' suffers from its use for all affection, highest and lowest.

Affectum tui amoris is ambiguous, tui being either an adjective or a pronoun, it may mean ' love of thy love,' i.e. the disposition of heart which allows God's love to be reflected in man's heart: 'We love Him because He first loved us' ; or, 'the mood (almost "will ") of love of thee '- the mood to love thee,' an equally needful petition.

The Epistle. Rom. vi. 3-11, Sar. Miss., 1549.

This is the first of a long series of nineteen Epistles taken from St. Paul, in Biblical order save on the Eighteenth after Trinity, when the order is broken.

The Gospel. Matt. v. 20-26, 1549 ; Sar. Miss., 20-24.

\section{THE SEVENTH SUNDAY AFTER TRINITY.}

The Collect. Sar. Miss., Sac. Gel., Sac. Greg.; 1549, very freely translated.

This Collect is worth detailed investigation as an examp'e of the Reformers' enrichment of prayers already rich.

'Deus virtutum, cujus est totum quod est optimum, insere pectoribus nostris amorem tui nominis, et præsta in nobis religionis augmentum, ut quæ sunt bona nutrias, ac pietatis studio quæ sunt nutrita custodias' - 'God of virtues, to whom belongeth all that is best, plant in our breasts love of thy name, and furnish in us increase of religion, that thou mayest nourish what things are good, and with the zeal of fatherly love guard what things are nourished.'

The flow of the English Collect best justifies the freedom of the translation as a whole; the changed times account for the insertion of 'true' before 'religion'; 'author and giver of' for 'to whom belongeth' is more direct and more close to Scripture (Jas. i. 17); ' nourish us ' and 'keep us ' are preferable to ' nourish and guard'impersonal qualities; it is more lowly to appeal to God's 'great mercy' than to His 'zeal of fatherly love.'

The Epistle. Rom. vi. 19-23, Sar. Miss., 1549.

The Gospel. Mark viii. 1-9, Sar. Miss., 1549.

THE EIGHTH SUNDAY AFTER TRINITY.

The Collect. Sar. Miss., Sac. Gel., Sac. Greg,, 1549.

Lat. Deus, cujus providentia in sui disposition non lallitur: 
lit. 'God, whose providence is not deceived in the management of its own.'

1549. God, whose providence is never deceived.

1662. O God, whose never-failing providence ordereth all things both in heaven and earth.

The Epistle. Rom. viii. 12-17, Sar. Miss., 1549.

The Gospel. Matt. vii. 15-21, Sar. Miss., 1549.

\section{THE NINTH SUNDAY AFTER TRINITY.}

The Collect. Sar. Miss., Sac. Leo, Sac. Gel., Sac. Greg., 1549.

Lat. ut qui sine te esse non possumus, secundum te vivere valeamus: 'that we who without thee cannot be, may be strong to live in accordance with thee.'

1549. That we which cannot be without thee may by thee be able to live according to thy will.

1662. That we who cannot do anything that is good without thee, may by thee be enabled to live according to thy will.

The Epistle. 1 Cor. х. 1-13, 1549; Sar. Miss., 6-14.

The Gospel. Luke xvi. 1-9, Sar. Miss., 1549.

THE TENTH SUNDAY AFTER TRINITY.

The Collect. Sar.'Miss., Sac. Leo, Sac. Gel., 1549.

The English Collect followed Gelasius in the beginning, then the earlier prayer of Leo.

Sar. Miss. ut petentibus desiderata concedas : "that thou mayest grant thy petitioners their desires.' The change in the English Collect, 'that they may obtain their petitions,' is in every way preferable. It is not God's willingness to bestow, but man's capacity to receive, which undergoes change.

The Epistle. 1 Cor. xii. 1-11, 1549 ; Sar. Miss., 2-12.

The Gospel. Luke xix. 41-47a, Sar. Miss., 1549.

THE ELEVENTH SUNDAY AFTER TRINITY.

The Collect. Sar. Miss., Sac. Gel., Sac. Greg., 1549.

'God,which declarest thy almighty power most chiefly in shewing mercy and pity; give unto us abundantly thy grace, that we running to thy promises, may be made partakers of thy heavenly treasure.' This is much closer to the original than the present Collect, the only marked variation being 'give unto us abundantly' for ' multiply upon us.' It is at least open to question whether 'mercifully grant unto us such a measure of thy grace,' 1662 , is an improvement. 'Running to thy promises,' ad tua 
promissa currentes, is only allied in sound to the 'running the way of thy commandments' of 1662 ; the change quite obscures the important teaching that God's promises themselves need grace for their attainment, and that man derives from promises, and not from obedience to commandments, the assurance of heaven.

The Epistle. 1 Cor. xv. 1-11, 1549 ; Sar. Miss., 1-10.

The Go:pel. Luke xviii. 9-14, Sar. Miss., 1549.

Vers. 9, 10 of the Epistle, and the whole Gospel, fit in admirably with the original Collect, recognizing that the ground of acceptance with God is our acceptance of His grace, rather than conformity with ordinances.

\section{THE TWELFTH SUNDAY AFTER TRINITY.}

The Collect. Sar. Miss., Sac. Leo, Sac. Gel., Sac. Greg., 1549.

The original has been enriched, greatly in 1549, somewhat also in 1662. Lat. qui abundantia pietatis tuce et merita supplicum excedis et vota ... ut dimittas qua conscientia metuit, et adjicias qua oratio non prcesumit- who in the abundance of thy fatherly love exceedest both the merits and the desires of thy suppliants .... that thou mayest banish the things which conscience fears, and confer the things which prayer does not presume (to ask).'

1549. Which art always more ready to hear than we to pray, and art wont to give more than either we desire or deserve ... forgiving us those things whereof our conscience is afraid, and giving us that, that our prayer care not presume to ask.

1662. The last clause was skilfully rnunded off, and the pleading of Jesus Christ our Lord woven into it: "And giving us those good things which we are not worthy to ask, but through,' etc.

The Epistle. 2 Cor. iii. 4-9, Sar. Miss., 1549.

The Gospel. Mark vii. 31-37, Sar. Miss., 1549.

\section{THE THIRTEENTH SUNDAY AFTER TRINITY.}

The Collect. Sar. Miss., Sac. Leo, Sac. Gel., 1549.

'Of whose only gift'; Lat. de cujus munere. 'Only,' i.e. ' alone,' is a suggestive addition by the Reformers.

'True and laudable service'; Lat. digne et laudabiliter serviatur. The change of 'worthy' to 'true' is a distinct gain; our best service may by God's grace be true, i.e. genuine; it can never be worthy, in this life.

'That we may so faithfully serve thee in this life. that we fail 
-ot finally to attain thy heavenly promises.' As in the Collect for the Eleventh Sunday after Tr.nity, this 1662 alteration is certainly justifiable. The original is "that we may run to thy promises without stumbling': ut ad promissiones tuas sine offensione curramus ; 1549 , 'that we may so run to thy heavenly promises, that we fail not finally to obtain the same.' It is more scripturally accurate to speak of advancing towards promises so as to attain them, than to suggest their attainment by any service, however faithful.

The Epistle. Gal. iii. 16-22, Sar. Miss., 1549.

The Gospel. Luke x. 23-37, Sar. Miss., 1549.

\section{THE FOURTEENTH SUNDAY AFTER TRINITY.}

The Collect. Sar. Miss., Sac. Leo, Sac. Greg., Sac. Gel., 1549.

'That we may obtain'; Lat. ut mereamur ad sequi: 'that we may deserve to obtain.' The omission of 'deserve to' in 1549 is significant; the Roman Use still retains the word. The history of the Reformation is wrapped up in this seemingly minute alteration.

The Epist'e. Gal. v. 16-24, Sar. Miss., 1549.

The Gospel. Luke xvii. 11-19, Sar. Miss., 1549.

\section{THE FIFTEENTH SUNDAY AFTER TRINITY.}

The Collect. Sar. Miss., Sac. Gel., Sac. Greg., 1549.

'From all things hurtful ' inserted in 1662 after ' keep us,' from the original a noxiis, omitted in 1549 .

'By thy perpetual mercy,' 1549. The original has 'by thy perpetual propitiation (atonement),'-propitiatione perpetua. In early days this may only have meant 'by thy propitiation whose effects are perpetual'; yet even so, the Church is not kept by the atonement, but by the intercession of the risen Saviour, and by His Holy Spirit, sent in virtue of the Saviour's cxaltation to power. In later times the possibility of serious error scarcely needs more than mention; 'perpetual propitiation' would suggest one thing in particular, viz. the sacrifice of the Mass. It may be added that, apart from that error, there is a dangerous ambiguity in using the adjective 'perpetual' with the atonement: the 'blood-shedding' is not perpetual, but a finished work, though the application of the blood shed to the individual, cleansing from all unrighteousness, is continuous till this dispensation closes.

'The frailty of man without thee cannot but fall'; Lat. sine te labitur humana mortalitas: "without thee human mortality slips.' 
'Profitable to our salvation'; Lat. saiutaria. It is unfortunate that the word 'salutary' to-day suggests little or no connexion with salvation.

The Epistle. Gal. vi. 11-18, 1549; Sar. Miss., Gal. v. 25vi. 10.

This is the only Epistle for the Trinity season not taken, in whole or in part, from the earlier Service Books. In view of the alteration of 'perpetual propitiation' to 'perpetual mercy,' the reason for the change is not far to seek. St. Paul's directions to mutual service are exchanged for his vigorous assertion of the only motive for such service, the new creation in Christ Jesus, fulfilling and superseding the external rites which foreshadowed it.

The Gospel. Matt. vi. 24-34, 1549 ; Sar. Miss., 24-33.

\section{THE SIXTEENTH SUNDAY AFTER TRINITY.}

The Collect. Sar. Miss., Sac. Gel., Sac. Greg., 1549.

1662, 'Church'; 1549, 'congregation,' Lat. Ecclesia. The word 'congregation,' common in Scripture for the O.T. Church as a whole, has become appropriated to local assemblies of Christians.

'Continue in safety'; Lat. salva consistere: 'stand safe.' The change to 'continue' after the adjective 'continual' is an intentional violation of the English idiom, in order to emphasize the concurrent continuity of God's pity and the Church's well-being.

The change to 'preserve,' from 'governed,' Lat. gubernetur, conserves the unity of thought lost in the original.

The Epistle. Eph. iii. 13-21, Sar. Miss., 1549.

The early selection of this Epistle to follow the above Collect, would seem to suggest that the connexion between the Collects and Epistles generally is not intended to be a close one. Eph. ii., which would have emphasized the Scriptural idea of "the Church,' is passed over for the present passage from Eph. iii., in which the Church receives only incidental mention in the closing verse.

The Gospel. Luke vii. 11-17, 1549 ; Sar. Miss., 11-16.

\section{THE SEVENTEENTH SUNDAY AFTER TRINITY.}

The Collect. Sar. Miss., Sac. Greg., 1549.

'Prevent'; Lat. preveniat. The etymological meaning intended here (and elsewhere in B.C.P.) has only survived in the technical theological phrase : 'prevenient grace.' The idea of 'coming before' to belp, has given place to the idea of coming before to binder-' prevent,' in our modern sense-a sad comment upon 
human experience. The Collect for Easter Day contains a similar reference to prevenient grace, but here the idea is completed by the addition of grace which follows as well as precedes.

'Continually'; Lat. jugiter, ' perennially,' especially of the flowing of a stream; the root seems to be that of jungere, 'to join.'

'Given to'; Lat. intentos, a slightly different idea.

The Epistle. Eph. iv. 1-6, Sar. Miss., 1549.

The Gospel. Luke xiv. 1-11, Sar. Miss., 1549.

\section{THE EIGHTEENTH SUNDAY AFTER TRINITY.}

The Collect. Sar. Miss., Sac. Gel., Sac. Greg., 1549.

'To withstand the temptations of the world, the flesh, and the devil,' 1662, for ' to avoid the infections of the devil,' 1549, Lat. diabolica vitare contagia, 'to avoid diabolical intercourse (contact) with the devil.' The substitution of 'temptations of the world, the flesh, and the devil,' a phrase peculiar to English Reformed Offices (cl. Dowden's Further Studies, pp. 254 ff.), compelled the change from 'avoid' to 'withstand'; though contact, i.e. vicious intercourse, with the devil, can and must be avoided, temptations cannot be avoided, but must be withstood.

'With pure hearts and minds,' 1662 ; ' heart and mind,' 1549, combines Gregory's pura mente with puro corde of Gelasius.

'Follow'; Lat. sectari, 'to pursue eagerly,' commonly used of hunting.

The Epistle. 1 Cor. i. 4-8, Sar. Miss., 1549

Wheatley thinks that the selection of this Epistle, an exception to the rule that the Epistles of this season are selected in Biblical order, is due to there having been at first no Epistle and Gospel appointed for this Sunday; the ceremonies and devotions of the Ordination of clergy, which took place on the Saturday evening, keing prolonged over this day, such Sunday being styled Dominica vacans. The statement is not convincing, and cannot te accepted as proved, although it is true, as Wheatley says, that ver. 5 of the passage selected may be appropriately applied to newly ordained ministers (Wheatley, sect. xxvi. pp. 239, 240, 1863).

The Gospel. Matt. xxii. 34-46. 1549 ; Sar. Miss., 35-46.

\section{THE NINETEENTH SUNDAY AFTER TRINITY.}

The Collect. Sar. Miss., Sac. Gel., Sac. Greg., 1549.

The Latin Collect commenced with the petition, and concluded with its reason; this order was reversed in 1519. A greater improvement was made in 1662 : 'the working of thy mercy,' 
Lat. operatio tuæ miserationis, being happily dropped for 'thy Holy Spirit,' the notion of 'mercy' being retained by inserting the adverb 'mercifully' before 'grant.'

'Direct and rule' 1549 ; Lat. dirigat, only. The double noticn of guidance by ruling is already in the one Latin verb.

The Epistle. Eph. iv. 17-32, 1549 ; Sar. Miss., 23-23.

The Gospel. Matt. ix. 1-8, Sar. Miss., 1549.

\section{THE TWENTIETH SUNDAY AFTER TRINITY.}

The Collect. Sar. Miss., Sac. Gel., Sac. Greg., 1519.

The variations from the original are numerous.

'Most merciful God'; Lat. Misericors Deus: 'pitiful God'; 1549, 'merciful God'; 1662, 'most merciful God'; both in sense and sound a helpful emendation.

'Uf thy bountiful goodness'; Lat. propitiatus: 'baving been made favourable,' a somewhat harsh phrase, yet undoultedly true.

'Keep us . . . from all things that may hurt us'; Lat. unversn nobis adversantia exclude: 'shut out all things adverse to us.' There is a subtle touch of tenderness in the alteration of the petition from one merely to get rid of our difficulties to one for our personal protection; there is also a valuable lesson in the change from 'things adverse' to 'things that may hurt,' for things adverse may be the very opposite of things hurtful.

'Ready'; Lat. expeditus: 'unimpeded,' commonly used as a noun for a soldier lightly equipped for forced marches.

'Body and soul'; Lat. mente et corpore: 'mind and body.'

'Chcerfully,' 1662 ; 'with free hearts,' 1549; Lat. liberis montibus. In spite of long association with the 1662 alteration, regret must be felt for the loss of the phrase of 1549 and the orioinal. Cheerfulness is not the full equivalent of that spiritual freedom which makes spiritual service possible.

The Epistle. Eph. v. 15-21, Sar. Miss. 1549.

The Gospel. Matt. xxii. 1-14, Sar. Miss., 1549.

\section{THE TWENTY-FIRST SUNDAY AFTER TRINITY.}

The Collect. Sar. Miss., Sac. Gel., Sac. Greg., 1549.

'Pardon'; Lat. indulgentiam placatus : i.e. 'grant indulgence on the ground of satis'action having been made to thee.' 'The word 'pardon,' though dependent upon that same satisfaction, does not need it to be so plainly expressed as the word 'indulgence' does.

'Qu et mind'; Lat. secura mente, a mind devoid of anxious care, sine cura. 
'Serve'; Lat. deserviant, a rare but classical compound of servio. The preposition denotes a devotion of service, which might well have found place in the translation, suggesting, as it does, the eagerness of service consequent upon realized forgiveness and cleansing.

The Epistle. Eph. vi. 10-20, 1549; Sar. Miss., 10-17.

The Gospel. John iv. 46-54, 1549; Sar. Miss., 46-53.

\section{THE TWENTY-SECOND SUNDAY AFTER TRINITY.}

\section{The Collect. Sar. Miss., 1549; Sac. Greg. (? See p. 149).}

This Collect is found in the Anglo-Saxon Missal of Leofric, Bishop of Exeter c. 1050. hold.'

'Thy household the Church'; Lat. familiam tuam: ' thy house-

'Devoutly given to serve thee in good works, to the glory of tliy name'; Lat. in bonis actibus tuo nomini sit devota: 'be deroted to thy name in good works.'

'In continual godliness'; Lat. continua pietate: ' with thy continual fatherly goodness.' It has been rendered here, as in the Collect for the Fifth Sunday after the Epiphany, ' in thy true religion,' in a way which is either an intentional departure from the original or a mistranslation. Pietas is very remote from the English word 'piety'; it originally denoted a sense of duty towards heavenly beings, parents, children, country, etc., and was therefore predicable of God as well as man. The English use of the word sufficiently explains the translators' abandonment of any attempt to retain it.

The Epistle. Phil. i. 3-11, 1549; Sar. Miss., 6-12.

Tho Gospel. Matt. xviii. 21-35, 1549 ; Sar. Miss., 23-35.

\section{THE TWENTY-THIRD SUNDAY AFTER TRINITY.}

The Collect. Sar. Miss., Sac. Greg., 1549.

'Strength '; Lat. virtus, originally ' manliness,' etymologically therefore most inapplicable to God.

'The author of all godliness, be ready to hear the devout prayers of thy Church'; Lat. adesto piis Ecclesice tuce precibus, auctor ipse pietatis: 'Be present to the dutiful prayers of thy Church, thyself the author of dutifulness.' From this literal translation it will be seen that the emphasis upon piis and pietatis in the original could hardly be retained. Goulburn's suggestions, ' godly' and 'godliness,' 'devout' and 'devotion,' scarcely mect the case ; 'godly prayers' is meaningiess : 'devout' and 'divotion' are only alike in their derivation, not in their modern 
use. 'Loving' and 'love' would be correct, though, of course, more wide than the original.

The Epistle. Phil. iii. 17-21, Sar. Miss., 1549.

The Gospel. Matt. xxii. 15-22, 1549 ; Sar. Miss., 15-21.

\section{THE TWENTY-FOURTH SUNDAY AFTER TRINITY.}

The Collect. Sar. Miss., Sac. Greg., 1549.

'Absolve,' 1662 ; 'assoil,' 1549; Lat. absolvere. 'Assoil' is the old English form of 'absolve'; 'assoilzie' is still a Scots law term for 'acquit.' The idea of the original might have been preserved by translating ' loosen,' appropriate to the 'bonds,' (1549 'bands': Lat. nexibus) which follows. Ovid's u e of nexus for the 'coils' of a serpent, and the later 'legal obligation,' are both suggestive in this connexion.

'Sins which by our frailty we have committed'; Lat. peccatorum . . . qua pro nostra fragilitate contraximus: 'sins which, such is our frailty, we have contracted.' The use of this last word is doubtless suggested by the word nexibus, which actually divides the relative quce from its antecedent, peccatorum.

The Epistle. Col. i. 3-12, 1549 ; Sar. Miss., 9-11.

The Gospel. Matt. ix. 18-26, 1549; Sar. Miss., 18-22.

\section{THE TWENTY-FIFTH SUNDAY AFTER TRINITY.}

The Collect. Sar. Miss., Sac. Greg., 1549.

Lat. ' Excita, quæsumus Domine, tuorum fideliunı voluntates ; ut divini operis fructum propensius exsequentes, pietatis tuæ remedia major apercipiant ' -'Arouse, we beseech thee, O Lord, the wills of thy faithful [people], that they, more readily pursuing the fruit of thy Divine work, may get possession of greater helps of thy fatherly goodness.'

The English Collect is scarcely a translation; except in the opening petition it is only by the similarity of the words used that any connexion with the Latin is recognizable.

For the Epistle. Jer. xxiii. 5-8, Sar. Miss., 1549.

The Gospel. John vi. 5-14, Sar. Miss., 1549.

Almost the same passage (John vi. 1-14) is appointed for the Fourth Sunday in Lent, the only instance of such a repetition. It has been suggested that the choice of this miracle was due to its containing the words ' gather up the fragments,' applicable to the gathering up of all the teaching of the past year.

1552. Rubric providing for ' more Sundays before Advent' by the use of omitted Services between the Epiphany and Septuagesima. 
1662. Instruction to omit services when fewer than twentyfive Sundays between Trinity and Advent, and to use Collect, Epistle and Gospel for the Twenty-fifth Sunday on the Sunday before Advent. This last regulation was contained in Sar. Miss.

\section{SAINTS' DAYS.}

The word translated 'saints' in A.V. is applied to all believers, even though, as in the case of Corinth, the standard of holiness was far from 'saintly' in modern parlance. The singular, 'saint,' one of the commonest words in the N.T., is curiously subjected to restrictions which are not observed in the use of the plural, nor of the singular as applied to things, e.g. 'holy city,' 'holy kiss.' The restrictions are, that if used of any person save the Persons of the Blessed Trinity, the adjectival use, as contrasted with the title, must be unmistakable. Even so, the word is applied to another person but four times: ' holy angel' (Acts x. 22); ' greet every saint' (Phil. iv. 21); 'Blessed and holy is he that hath part in the first resurrection' (Rev. xx. 6); ' he that is holy' (Rev. xxii. 11). Besides being adjectival, it will be observed that these last three uses of the singular in connexion with man are not so used of individuals; the plural would give the same sense. The use of the singular for the Three in One, especially for the Holy Spirit, and in the Trisagion, ' Holy, Holy, Holy,' would sufficiently account, on grounds of reverence alone, for the reluctance in Apostolic and sub-Apostolic times, to apply this word as a title to any created being. The later use of 'saint' as a technical term, no longer suggestive of this careful Scriptural practice, renders tolerable what would otherwise be grossly irreverent.

The technical use grew out of the early and not unnatural practice of commemorating the dead, especially martyrs.* However, four centuries passed before the word became a title, implying recognition of special 'sanctity' in certain individuals, and still later came formal beatification and canonization by the Church-'a judging of men before the Lord's judgment' (Latimer). The Reformers found it one of their chief tasks to expunge

* This word has become teehnically restricted to those who have borne witness to Christ by dying for their faith. The injustice of the restriction is well exemplified in the cases of the two sons of Zebedee. It would be difficult for any one to imagine that James was a more faithful witness than John. The frequent reference by the latter, in the Apocalypse, to all believers as dying for their witness to Christ, e.g. vi. 9-11, has been misunderstood from very early times, and that misunderstanding easily explains the traditions which attach a violent death to practically every early 'saint.' 
the multitude of Saints' Days, the observance of which had not only obscured the Divine institution of one day in seven, but also deposed the Word of God from its place in public worship, in favour of memorials of saints, legends-at first so called because ' to be read' but worthily described by that word in it; later significance, conferred upon it by the legendary and puerile nature of the 'legends.' They retained twenty-on', including the Presentation in the Temple (not a Saint's Day under this, its official title), All Saints' Day, and Innocents' Day (without the word 'holy' prefixed).* The request for the intercession of saints, a characteristic of the Collects in Sar. Miss., compelled the abandonment of many of the Latin Collects, nine being retained with more or less alteration, eleven new ones composed in 1549, and one in 1552. Four of the older ones and two of the new ones underwent further revision in $\mathbf{1 6 6 2}$.

\section{SAINT ANDREW'S DAY}

The placing of St. Andrew's Day first in the Church Calendar is attributed either to St. Andrew's having been the first called (but St. John was called at the same time, whereas St. Thomas is the next Apostle in the Calendar), or to Gregory's personal predilections, he having dedicated his monastery at Rome to St. Andrew. $\mathrm{As}$, however, it is asserted that this 'is perhaps the only . Festival of an Apostle claiming to be really on the ann versary of his death' (Wordsworth's Ministry of Grace, ap. Reynolds) it would seem that the exigencies of date decided the matter, and that the above given theories are post factum explanations. Of St. Andrew we know his call (John i. 35-40); his leading his brother to Christ (41) ; his city, Bethsaida (44); his second call when fishing (Matt. iv. 19 and parallels); his place in the twelve, always next after the first three. Twice he fulfils a useful function (John vi. 8 and xii. 22 ); but after the dispersion of the Twelve from Jerusalem nothing is recorded of him. Tradition has it that he visited Scythia, Epirus, and Achaia ; that he was crucified at an advanced age at Patras in the Morea, on a 'St. Andrew's Cross,' $\dagger$ decussate, preaching to 20,000 spectators at his martyrdom, which lasted two whole days; and that his bones were removed from Patras io Rome in 359.

The Festival of St. Andrew is one of the nine found in St. Jerome's Lectionary. This Apostle's memory is held in high esteem in the Greek Church as the traditional evangelist of South Russia (Scythia ; cf. Stanley's Eastern Church, p. 293), and in the

* For further particulars upon the Calendar, see p. 64.

$\dagger$ St. Andrew being the national saint of Scotland, the St. Andrew's Cross finds a place in the 'Union Jack.' 
Greek Vesper Services he is addressed, together with St. Peter, thus : 'Hail, Andrew, first called example of manliness. Hail, chosen and noble pair of brethren before Christ our God, who -followed the example of crucified suffering. Fail not to ask him continually that our souls may be saved.'

The Collect. 1552. The only Collect of that date. No parallel has been found in ancient Liturgies. *

1549. Almighty God, which hast given such grace to thy Apostle Saint Andrew, that he counted the sharp and painful death of the cross to be an high honour, and a great glory : Grant us to take and esteem all troubles and adversities which shall come unto us for thy sake, as things profitable for us toward the obtaining of everlasting life ; through Jesus Christ our Lord.

The grave uncertainty of the martyrdom of St. Andrew rendered the alteration imperative in a prayer to Omniscience. The Collect is otherwise unexceptional, the reference to troubles as 'profitable' and not 'meritorious,' being perfectly consonant with Holy Scripture. The Collect in Sar. Miss. will serve to illustrate the change. $\uparrow$ "We humbly beg thy Majesty, O Lord, that as the blessed Apostle Andrew lived as preacher and ruler of thy Church, so in thy presence (apud te) he may be a perpetual intercessor on our behalf.'

The Epistle. Rom. x. 9-21, 1549; Sar. Miss., 9-18.

The Gospel. Matt. iv. 18-22, Sar. Miss., 1549.

This is Andrew's second call; the na? rative of his first call was used in Sar. Miss. on the vigil, John i. 35-41.

\section{SAINT THOMAS THE APOSTLE.}

Thomas, Heb.; Didymus, Gr., 'a twin,' presumably therefore not the $\Lambda$ postle's real name.

Apart from the lists of the Apostles (where, from the conjunction of his name with that of St. Matthew, ground has been found for the suggestion that they were brothers), there are but four references to him in Holy Scripture: John xi. 16 ; xiv. 5 ; $\mathrm{xx}$. 28 (all suggestive of that character which is associated with blunt honesty, genuine loyalty, and common sense, even at the expense of real 'common sense'); and xxi. 2, where he is one of

* Palmer cites, 'Per Christum nostrum qui beato Andreæ in prima vocatione dedit fidem, et in passione dedit victoriam ' from a prayer in the old Gallican Liturgy. He says, it 'somewhat resembles our Collect,' but, sa re the mention of Andrew and his call, searcely suggestive of any necessary connexion, they have nothing in common.

Tr. from Dickinson, Missale ad Usum Sarum, 657, 660. 
the seven present at the second miraculous draught of fishes. 'I'radition names the East, Mesopotamia, Persia, and India, as the scene of his Apostolic labours; at Malabar a Church still survives called 'The Christians of St. Thomas.' Martyrdom is ascribed to him also, in the shape of death by a spear-thrust, at Taprobane (Ceylon).*

\section{The Collect. 1549.}

Sar. Miss. : 'Grant us, Lord, we beseech thee, so to rejoice in the festival (solemnitatibus) of thy blessed Apostle Thomas, that we may be supported by his patronage (patrociniis) and pursue his faith with corresponding (congrua) devotion.' The wording of our Collect is not quite free from perilous ambiguity. It is not true that Thomas was allowed to doubt merely for our benefit, which is attributing to God ' the doing of evil that good may come.' God suffered Thomas to doubt, primarily because our creation in His image, with wills to choose or reject, renders compulsory faith as impossible as it would be unacceptable to One who is calling not slaves but sons.

The Epistle. Eph. ii. 19-22, Sar. Miss., 1549.

The Gospel. John xx. 24-31, Sar. Miss., 1549.

\section{THE CONVERSION OF ST. PAUL.}

The unreformed Calendar commemorated St. Paul thrice, viz. his conversion, January 25 ; with St. Peter, June 29 ; and his Martyrdom, June 30 . The day retained is associated with the event three times detailed in Holy Scripture; the day usually retained for a saint is the traditional date of martyrdom, St. Paul's, St. John Baptist's, and the Virgin Mary's days being exceptions. This Festival is of comparatively late introduction (ninth century), and is peculiar to the Western Church.

The Collect. Sar. Miss., Sac. Greg., Miss. Ambros., 1549.

The changes are as follows:-

Sar. Miss. : 'Deus, qui universum mundum beati Pauli apostoli tui prædicatione docuisti ; da nobis, quæsumus, ut qui ejus hodie conversionem colimus, per ejus ad te exempla gradiamur'- ' God, who hast taught the whole world by the preaching of thy blessed apostle, Paul, grant us, we beseech (thee), that we who observe to-day his conversion, may walk to thee through his example.' The Collect in Sac. Greg. contained a prayer for St. Paul's advocacy.

* The very common use of the name Thomas for the dedicntion of old Churches in England is largely derived from the mediæval reverence for Thomas à Becket. 
1549. God, which hast taught all the world, through the preaching of thy blessed Apostle Saint Paul : Grant we beseech thee, that we which have his wonderful conversion in remembrance, may follow and fulfil thy holy doctrine which he taught; through Jesus Christ our Lord. Amen.

1662. O God, who through the preaching .... hast caused the light of the Gospel to shine throughout the world; Grant, we beseech thee, that we, having his wonderful conversion in remembrance, may shew forth our thankfulness unto thee for the same, by following the holy doctrine which he taught; through Jesus Christ our Lord. Amen.

The inaccurate statement of the original, that God had taught the whole world ' by' St. Paul's preaching, is amended by the use of the word 'through' in 1549, and the enlargement of the passage in 1662, by substituting 'taught' for 'caused the light of the Gospel to shine,' makes it still more accurate.

All reference to mere observance of the day disappears in 1549 , when the memory of St. Paul's wonderful conversion becomes the ground for any such observance. The additional mention of thankfulness, in 1662, happily marks the difference between true and false commemoration.*

For the Epistle. Acts ix. 1-22, Sar. Miss., 1549.

The Gospel. Matt. xix. 27-30, 1549; Sar. Miss., 26-29

\section{THE PRESENTATION OF CHRIST IN THE TEMPLE, commonly called}

\section{THE PURIFICATION OF SAINT MARY THE VIRGIN.}

The Title: originally, at its institution, probably by Justinian (c. 541), Hypapante, 'Meeting,' from the meeting of our Lord with Simeon. This name still survives in the Greek Church, but in the West, pari passu with the growing cult of the Virgin Mary, the name 'Purification' gained ground from the ninth century onwards, the commemoration of Mary displacing that of the Lord. Curiously enough, the Roman Church has stereotyped this name, which goes far to stultify the later Roman dogma of the Immaculate Conception. In 1549 the Roman name was preserved, but the revision of

In Sar. Miss. is a second Collect, relating to a St. Præjectus, commemorated on the same day: "Let the glorious intervention of St. Præjectus thy martyr commend us, O Lord; that what we do not deserve by our deeds, we may obtain by his prayers.' 
1662 restored the true title, relegating the familiar 'Purification' to the position of a mistaken sub-title: 'commonly called The Purification of Saint Mary the Virgin.' Sar. Miss. contains a special Service for the Blessing of Candles on this day, which was popularly known as 'Candlemas' in Mediæval times. It is strange that the name 'Purification' should have obtained such permanence, seeing that the Collect, and also the Candlemas prayers, refer to the Presentation in the Temple and the meeting with Simeon, and not to the Purification, unless, indeed, the word 'pure' in the Collect is a distant allusion thereto.

The Collect. Sar. Miss., Sac. Greg.; Sac. Gel. (altered by Gregory), 1549.

'Eve living,' 1662 ; 'everlasting,' 1549; Lat. sempiterne.

'In the substance of our flesh,' 1662 ; ' in the substance,' etc., 1549 : Lat. cum nostro carnis substantia: ' with the substance.' The Latin is more strictly accurate.

'So we may be presented,' 1662 ; 'so grant that we may be presented,' 1549 ; Lat. ita nos facias prasentari.

'Pure and clean hearts,' 1662 ; 'pure and clean minds,' 1549 ; Lat. purificatis mentibus.

'By the same thy Son Jesus Christ our Lord,' 1662; 'by Jesus Christ our Lord,' 1549; Lat. per eundem. The use of 'by' at the close of this Collect is unique; it greatly enriches the Collect here; Christ was presented that we may be presented by Him, such presentation being a not infrequent figure in N.T.: Eph. v. 27 ; Col. i. 22 ; Jude 24.

For the Epistle. Mal. iii. 1-5, 1662 ; Sar. Miss., 1-4; 1549, Epistle for preceding Sunday.

The Gospel. Luke ii. 22-40, 1549; Sar. Miss., 22-32.

Both purposes of the visit to the Temple are here noted-the presentation of the first-born male (Exod. xiii. 2), and the purification of the mother (Lev. xii. 1-8). Reynolds, Book of Common Prayer, strangely states that 'except to fulfil the letter of the law, no purification was needed after such a birth, evidently missing the point of the whole rite. Strictly speaking the purification was the waiting period (Lev. xii. 6), 'when the days of her purifying are fulfilled'; the sacrificial offering obtained the ceremonial cleansing which officially recognized the purification as complete. The fact that Christ was the child in this case docs not affect the matter at all : 'The Levitical law ascribed impurity exclusively to the mother, in no degree to the child' (Spexker's Commentary, on Lev. xii. 4). Incidentally, the only direct evidence of the poverty of our T.ord's earthly circumstances is given by Mary's offering the sacrifice prescribed for those unable to bring a lamb 
and a pigeon-the Purification no doubt taking place long before the visit of the Magi, with-their offerings.

\section{SAINT MATTHIAS' DAY.*}

Holy Scripture is silent concerning this Apostle after his selection to fill the place of Judas. It is an old conjecture that this choice was premature, and that St. Paul was our Lord's selection for the vacancy. There is no Scriptural support for the idea, for the absence of further mention would be fatal to the Apostleship of most of the Twelve. Tradition even is unusually vague and uncertain, stating both that he died a natural death in Judæa, and that he was crucified in Cappadocia or Ethiopia. It is illustrative of this uncertainty that the Greek Church observes this Festival on August 9. Its nearness to Ember-tide lends an appropriateness to the Western date, at any rate with its present Collect.

The Collect. 1549.

Sar. Miss.: 'Grod who didst join Matthias to the band (collegio sociasti) of thy Apostles; Grant, we beseech thee, that by his intervention we may always feel the heart (viscera) of thy surrounding fatherly goodness (tuce circa nos pietatis).' This prayer, besides that it does not lend itself to translation, has no point as regards Matthias, the false assumption of his power to 'intervene' implying the still more erroneous idea that God needs such intervention, and the unreasonable one that, needing such intervention, $\mathrm{He}$ is to be asked to procure it.

For the Epistle. Acts i. 15-26, Sar. Miss., 1549.

The Gospel. Matt. xi. 25-30, Sar. Miss.; 1549.

\section{THE ANNUNCIATION OF THE BLESSED VIRGIN MARY.}

The Title. 1662. 'Blessed' inserted, a literal application of Luke i. 48 : 'all generations shall call me blessed,' not without value as a reply to the Roman accusation, still made, of Protestant irreverence towards the 'Mother of our Lord' (Luke i. 43). 'Blessed Mary' would be the most literally Scriptural title, 'Virgin Mary' being linked to the superstitious and degrading idea, often expressed by the phrase, "Mary Ever-Virgin," that sanctity attaches to the unreality of her marriage with Joseph, though the genealogy of our Lord is traced by that marriage, certainly in Matt. i., possibly in Luke iii., an though that mar-

* Before 1662, the extra day in 'eap year was added after February 23. instead of after February 28 , making each day from February 24 to 28 a day late. St. Matthias' Day bcing normally the 24 th, it became in leap vear the 25th. 
riage is implied in Matt. i.25. This is irrespective of the parenttage of the 'brethren of the Lord'; though, apart from a false idea of the degradation incurred by marriage, it is doubtful if any would ever have sought to disprove their relationship to Christ, after the flesh, through Mary.

The still familiar name for this day is ' Lady Day,' perpetuating both the speeial cult of St. Mary on this day, and also the high attributes eonferred upon her, 'The Lady' par excellence, Domina. The 'Sequence' in Sa". Miss. for this day suggests the lengths to which the Roman Church had gone in Cranmer's time: "Mundi spes, Jesse virgula, cœli luminarium, per quam porta coli aperitur.' This extravaganee is even surpassed to-day.

'It is beyond all dispute that Holy Scripture and primitive antiquity, while they bring out her blessedness and dignity, give no vestige of authority for all that has gone beyoud this both in the Eastern and in the Western Chureh' (Barry).

The Collect. Sar. Miss. (Post-Communion Colleet), Sae. Greg., 1549 .

Sar. Miss.: 'God, who didst will thy Word to undertake flesh from the womb of the blessed Mary always virgin, at the announcement of an angel; Grant to thy suppliants, that we who believe her truly the Mother (genetricem) of God, may be helped with thee by her intercessions.' The 'always' (semper) before 'virgin' is a various reading, the idea of perpetual virginity not having become firmly rooted till after the original date of the Colleet. The word genetricem, instead of matrem is noteworthy. As early as Nestorius a protest was made against the Greek

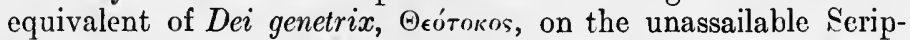
tural ground that St. Mary is ealled $\mu \eta \dot{\tau} \tau \rho$ rov Kvpívv, 'Mother of the Lord' (Luke i. 43), never 'Mother of God,' ' produeer of God.' Unhappily Nestorianism went to the opposite extreme, and divided the Personality of Christ in a vain attempt to define Mary's relationship to the 'God-Man.' Looking at the dire results of such very unnecessary epithets as Dei genetrix

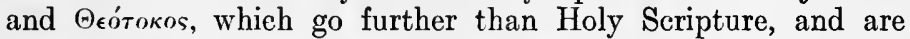
therefore solely due to human reasoning, good or bad, it is fair to state that had the Greek Fathers foreseen whither things would tend, they would have been content with the ipsissima verba, as in the Creeds of undivided Christendom. Nestorianism was rightly condemned as destructive of our Lord's Godhead; the Mediæval and modern exaltation of Mary has tended to the same effect, by another route. Truth is perhaps more easily hidden by unwarrantable additions than by direet opposition. 
The Collect is an exact translation of the Sar. Miss. PostCommunion Collect, whe:e the Annunciation is mentioned, but not the Virgin Mary. It is strikingly incongruous with the later importations into the Missal, e.g. 'Pour thy grace,' instead of attributing to Mary the power of communicating grace.*

For the Epistle. Isa. vii. 10-15, Sar. Miss., 1549.

The Gospel. Luke i. 26-38, Sar. Miss., 1549.

\section{SAINT MARK'S DAY.}

In addition to the comparatively full knowledge of the Evangelist to be gleaned from Holy Scripture, universal tradition connects him with Alexandria, where he is said to have been martyred for opposing the worship of Serapis. By reason of the alleged removal of his body to Venice in 465 , he is claimed as the patron saint of that city. His name has been given to the Alexandrine Liturgy, and to Gregory's Litany.

The Collect. 1549, re-arranged 1662.

'That, being not like children . . . we may be established,' 1662 , ' so to be established . . . that we be not, like children,' 1549 . The alteration is unnecessary or worse, for the 1549 version gives the true sequence of cause and effect. 'In the truth of thy Holy Gospel,' 1662 ; ' by thy Holy Gospel,' 1549. The allusion to children is borrowed, but inaccurately, from Eph. iv. 14, ' Be no more children, tossed to and fro, and carried about by every wind of doctrine.' St. Paul emphasizes the weakness of children in a storm, not any disposition to fickleness of belief, which would be impossible in infants, as the 'children' are in the original, v'ris a comma before and after 'like children.' It is perhaps unfortunate that this expression should have found its way into a Collect for St. Mark's Day, suggestıng a reminder of his defection on St. Paul's first Missionary Jonrney (Acts xii. 25 ; xiii. 13 ; xv. $37,38)$.

Sar. Miss.: 'God, who hast elevated thy blessed Evangelist Mark by the grace of gospel preaching; Grant, we pray, that we may always profit by his instruction, and be defended by his praying.'

The Epistle. Eph. iv. 7-16, 1549 ; Sar. Miss., 7-13.

The Gospel. John xv. 1-11, 1549; Sar. Miss., 1-7.

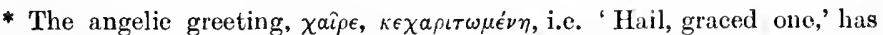
been ambiguously rendered into Latin: Ave, Maric, plena gratia, i.e. cither 'filled with grace' (not doetrinally remote from the original), or 'full of grace,' as a fountain. 


\section{SAINT PHILIP AND SAINT JAMES' DAY.}

The Title, 1662. 1549, 'Saint Philip and James.' The omission of the 'Saint' before the second name is due to the Latin mode of combining the titles: SS. Philippus et Jacobus.* Even in 1662 the possessive case was not used for Philip, a trifling but real error of grammar.

Philip is fairly well known in the Gospel story: found by the Lord (John i. 43) ; belonging to Bethsaida (44); the 'missionary' to Nathanael (45), with whom, if this latter be identical with Bartholomew, he is coupled in the Gospel lists of the Apostles (with Thomas in the Acts); questioned as to supplying bread for the five thousand (vi. 5, 6); following Thomas in questioning the Lord (xiv. 8). In the Acts another Philip is prominent, and the Apostle's subsequent life is unknown. Even traditions are 'more than usually contradictory' (Reynolds), one, however, ascribing to him a martyr's death in Phrygia.

Which James is here referred to is uncertain, all depending upon the vexed question of the identity of the son of Alphæus with the Lord's brother. The Epistle intends the latter to be commemorated. Of the other, if he be another, nothing is known. Of this James, claimed as a son of Joseph by another marriage, on no other grounds save the reluctance to admit any children of Joseph and Mary, something is known. St. Paul credits him with high authority at Jerusalem (Gal. i. 19; ii. 9, 12), and Acts xv. 13 ff. accords with the Epistle on this point. The common custom of calling him Bishop of Jerusalem, however, is a misleading anachronism; he owed his authority to his special call, 1 Cor. xv. 7, and his high character, recognized by Josephus. He met his death not long before the destruction of Jerusalem, at the hands of his fellow-countrymen.

There is no explanation forthcoming of the commemoration of two 'Saints' together, nor of the conjunction of this particular pair. The idea that the 'two and two' of the Lord's appointment has anything to do with it is both baseless in itself and overturned by the fact that only two pairs are thus conjoined.

The Collect. 1549 ; expanded 1662.

1549. As thou hast taught Saint Philip, and other the Apostles, etc.

1662. That, following the steps of thy holy Apostles, Saint Philip and Saint James, we may stedfastly walk in the way that leadeth to eternal life, etc.

- The persistence of the Anglicized Latin title is paralleled by the name of the old Parish Church of East Bristol, St. Philip and Jacob, where probably few associate the second name with any one but the Patriarch. 
The expansion carries out the thought of the 1549 petition, to know Christ as 'the Way' and to walk therein. It is somewhat strange that the Lord's answer to St. Thomas's question should form the basis of the petition, when St. Philip's question and His answer, forming part of the Gospel, are so near at hand and so suggestive. The uncertainty with regard to James accounts for the absenre of his name from the 1519 Collect.

Sar. Miss.: "God who delightest us with the annual festival of thy Apostles, Philip and James: Grant that as we rejoice by their merits, we may be instructed by their examples.'

The Epistle. Jas. i. 1-12, 1549 ; Sar. Miss., Wisd. v. 1-5.

The Gospel. John xiv. 1-14, 1549; Sar. Miss., 1-13.

\section{SAINT BARNABAS THE APOSTLE.}

The Title. 1662. 1549, 'Saint Barnabe Apostle.' This addition of the words 'the Apostle' is unusual, and doubtless was intended to mark the fact that Holy Scripture thus designates Barnabas (Acts xiv. 14), though he was not one of the Twelve.

Barnabas is well known in Holy Scripture, but outside that source no definite knowledge is available. His name is attached to the spuirious 'Epistle of Barnabas,' he is one of the conjectured authors of the Epistle to the Hebrews, and tradition credits him with both the foundation of the Church at Milan, and martyrdom by stoning at Salamis, in Cyprus, where he landed with St. Paul on the first Missionary Journey. The observance of St. Barna. bas' Day cannot be traced beyond the seventh century.

The Collect. 1549.

'Singular gifts of the Holy Ghost' ; cf. Acts xi. 24, 'a good man, and full of the Holy Ghost, and of faith.'

Sar. Miss.: "We beseech thee, O Lord, let the praying of thy blessed Apostle Barnabas commend thy Church, and let him stand as mediator (interventor) for it, as he illuminates it by his teaching and suffering.'

For the Epistle. Acts xi. 22-30, 1549.

The Gospel. John xv. 12-16, Sar. Miss., 1549.

\section{SAINT JOHN BAPTIST.}

The birth and not the death is commemorated; the latter is a 'black letter' day in the Calendar, viz. August 29. The association of the day with Midsummer has connected his words with the observance: 'He must increase, but I must decrease,' June 24 and December 25 roughly marking the commencement of shortening and lengthening days. The commemoration is mentioned as early as the time of Augustine. 
The Collect. 1549 .

'Repentance,' 1662; ' penance,' 1549. The technical meaning of the latter was sufficient reason for its excision, while the use of 'repentance' in A.V. doubtless accelerated the change.

Sar. Miss. : 'God, who hast made this present day honourable for us by the nativity of blessed John: Give to thy people the grace of spiritual joys, and direct the minds of all the faithful into the way of eternal life.'

The abandonment of this Collect, in spite of its freedom from doctrinal error, excellently betrays the attitude of the Reformers towards Saints' Days. They had no desire to forfeit any means of spiritual prayers, but saw no value in such emphasis as this prayer lays upon the mere day of commemoration.

For the Epistle. Isa. xl. 1-11, 1549 ; Sar. Miss., Isa. xlix. 1-7.

The Gospel. Luke i. 57-80, 1549; Sar. Miss., 57-68.

\section{SAINT PETER'S DAY.}

The Title. 1549. Sar. Miss. : 'Dies Apostolorum Petri et Pauli,' from the legend that both suffered martyrdom at Rome on the same day. The observance of a commemoration of St. Peter is traceable back to the fourth century. In Sar. Miss. provision is made for the Vigil and Octave, as well as for the day itself.

The Collect. 1549. The use of the word 'Pastor,' intended to have special reference to the command to Peter, unintentionally provides opportunity for remembrance in prayer of ministries not technically episcopal, an opportunity rare in B.C.P., from absence of the need in 1549 , and absence of realization of the need in 1662. This Collect is adapted for use in the Consecration of Bishops.

Sar. Miss.: 'God, who hast consecrated this day by the martyrdom of thy Apostles Peter and Paul; Grant to thy Church to follow in all things the teaching of those by whom it took the beginning of religion.'

The incorporation of doubtful legend, coupled with the general baldness of the Collect, justified its abandonment ; the Reformers, moreover, were careful to pray that the Church should follow, not the teaching of even a Peter or a Paul, but that of God: 'thy Holy Word, and the people obediently to follow the same.'

For the Epistle. Acts xii. 1-11, Sar. Miss., 1549.

The Gospel. Matt. xvi. 13-19, Sar. Miss., 1549.

The entire absence of reference to St. Paul in the Epistle, though the selection is as old as Leofric's MS., points to the lateness of his inclusion in the observance of this day 
[SAINT MARY MAGDALENE.

In 1549 provision was made for this day as follows:-

The Collect. Merciful Father, give us grace that we never presume to sin through the example of any creature; but if it shall chance us at any time to offend thy divine majesty, that then we may truly repent, and lament the same, after the example of Mary Magdalene, and by lively faith obtain remission of all our sins; through the only merits of thy Son our Saviour Christ.

Sar. Miss.: 'Grant us, most merciful Father, that like as the blessed Mary Magdalene, by loving thy Son above all things, obtained forgiveness of her sins, so she may obtain eternal blessedness for us from (apud) thy pitifulness.'

Regret has been expressed (Reynolds's The Book of Common Prayer, p. 240) at the abandonment of this Sarum Collect, ' which was singularly beautiful, and might with slight change have been adopted.' But the latter part credits Mary Magdalene with powers on our behalf for which there is no warrant in Holy Scripture, and, which is worse, thereby discredits the Father, as needing intervention to obtain the mercy which $\mathrm{He}$ has promised without any mediation save that of God the Son and God the Holy Ghost; while the former part, besides assuming the identity of Mary Magdalene with ' the woman which was a sinner' (see below), dangerously misinterprets the Lord's words in Luke xii. 47, 'Her sins which are many, are forgiven; for she loved much, but to whom little is forgiven, the same loveth little.' The ambiguity of the English conjunction 'for,' used to express both the cause and also the evidential result, is doubtless responsible for a misinterpretation still common. The context, however, even in the verse itself, without the parable to Simon, demonstrates clearly that love is the result and proof of forgiveness, not its cause. The Reformers carefully excised this error: 'truly repent, and lament the same (i.e. sin), after the example of Mary Magdalene, and by lively faith obtain remission of all our sins; through the only merits of thy Son our Saviour Christ.' The 'only merits' designedly excludes both our own and any other merits, whether of love or service. Thus the whole of the Sarum Collect stands Scripturally condemned.

The Epistle. Prov. xxxi. 10-31, Sar. Miss., 1549.

Until 1662, no distinction was made betwcen 'Epistles' drawn from Epistles proper, and those taken from other parts of Holy Scripture. In this case, the observance having been abandoned in 1552, the word 'For' was never used. It was customary 
in Sar. Miss. to denominate such portions as are used 'for the Epistle,' Lectio.

The Gospel. Luke vii. 36-50, Sar. Miss., 1549.

This day was reduced to a Black-Letter Day in 1552 ; possibly its proximity, July 22, to St. James' Day, July 25, had some weight in deciding the matter. At any rate, a complete revision would have been necessary, for the identification of Mary Magdalene with the woman 'which was a notorious sinner'

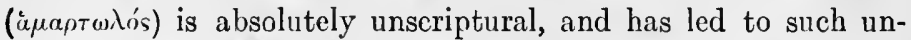
worthy ideas of Mary Magdalene as are suggested by the word ' maudlin,' a corruption of Magdalen.]

\section{SAINT JAMES THE APOSTLE.}

Saint James the Great (or Greater), probably so styled from his pre-eminence with Peter and John amongst the Twelve, is the only Apostle whose death is recorded in Holy Scripture. The date of his death being just before the Passover (Acts xii. 3 ), his day, July 25, is plainly wrong, which fact renders doubtful the listoricity of other Calendar dates. Tradition has been busy with St. James, connecting him with Spain, both in the brief period of his ministry and after his death. Absolutely untrustworthy as it is, the tradition is noteworthy from the prominence given to the Apostle in that country under the name Iago.

The Collect. 1549 .

'Thy holy commandments'; 'holy' added 1662.

There is no real parallel between what James abandoned at his call, and what we are to forsake according to this Collect.

Sar. Miss. : 'Be to thy people, O Lord, Sanctifier and Guardian ; that fortified by the succours of thy Apostle James, it may both please thee by its conversation, and serve thee in safety.'

For the Epistle. Acts xi. 27-xii. 3a, 1549 ; Sar. Miss., Eph. ii. $19-22$.

The Gospel. Matt. xx. 20-28, 1549 ; Sar. Miss., 20-23.

\section{[THE TRANSFIGURATION.}

The Reformers dropped the observance of this day, August 6 ; the American B.C.P. has restored it. The event is certainly worthy of commemoration.

The American Collect, Epistle (2 Pet. i. 13-18), and Gospel (Luke ix. 28-36) are all new, or altered from Sar. Miss.

The Collect. God, who on this day hast revealed to the fathers of either Covenant (Testamenti) thine only begotten 
(Son) wonderfully transfigured (transformatum) in a heavenly manner ; Grant us, we beseech thee, by deeds well pleasing to thee, to attain to the continual contemplation of his glory, in whom thou hast testified that thy Fatherhood is well (optime) pleased.

The Epistle. 2 Pet. i. 16-19.

The Gospel. Matt. xvii. 1-9.]

\section{SAINT BARTHOLOMEW THE APOSTLE.}

The Title. 'The Apostle' added 1662, from S.L.

The identity of Bartholomew and Nathanael is a moot point, supported by Eastern, denied by Western, tradition-the latter on the insufficient ground that Nathanael was of too ligh a position in life to be chosen a disciple of our Lord! The name is no difficulty, Bartholomew, like Barnabas, being a patronymic, and not a personal name. Nathanael was brought to Jesus by Philip, and in three of the lists of the Apostles Philip and Bartholomew are coupled together, as though they were connected by some close bond. Moreover, Nathanael was present with other Apostles when our Lord appeared at the Sea of Tiberias after His resurrection; and the Evangelists who mention Bartholomew do not mention Nathanael, while St. John, who mentions Nathanael, does not mention Bartholomew. The new Lectionary of 1871 gives a semi-endorsement to the identification, by appointing as First Lessons, M., Gen. xxviii. 10-18, to which our Lord alludes in speaking to Nathanael (John i.51); and E., Deut. xviii. 15, containing Moses' prophecy of the Messiah, alluded to by Philip in his endeavour to persuade Nathanael to come to Christ (John i. 45). However, this selection is noncommittal, for the Second Lessons are not 'proper' to the day, and the use of John i. $43 \mathrm{ff}$. was advisedly not prescribed (Humphrey, one of the Revisionists 1871, ap. Reynolds, p. 243). Tradition makes Bartholomew a martyr in India.

The Collect. Sar. Mliss., Sac. Greg., 1549 (much altered).

'Who didst give to thine Apostle Bartholomew grace truly to believe and to preach thy word,' 1662; Sar. Miss. : 'Who hast allowed the venerable (venerandam) and holy joy of this day for (in) the festivity of thy blessed Apostle Bartholomew.'

'To love that Word which he believed,' 1662; Lat. amare quod credidit: ' to love what he believed.' 'Both to preach and receive the same (that Word)'; Lat. prcedicare quod docuit: 'to preach what he taught.'

For the Epistle. Acts v. 12-16, Sar. Miss., 1549.

The Gospel. Luke zxii. 24-30, Sar. Miss., 1549. 


\section{SAINT MATTHEW THE APOSTLE.}

The Title. 'The Apostle' added 1662, as in S.L.

St. Matthew is unknown outside the New Testanient, even tradition only credits him with martyrdom, specifying no circumstances of place or time. The Greek Church observes November 16. His call and his Gospel are his sufficient memorial.

The Collect. 1549.

Sar. Miss.: " May we be helped, O Lord, by the prayer of thy Apostle and Evangelist blessed Matthew, that what our possibilities [sing. in Lat.] do not compass, may be given us by his intercession.'

The Epistle. 2 Cor. iv. 1-6, 1549 ; Sar. Miss., Eph. ii. 19-22.

The change introduced a Lesson on worldliness, specifically appropriate to the call of Levi the publican.

The Gospel. Matt. ix. 9-13, Sar. Miss., 1549.

\section{SAINT MICHAEL AND ALL ANGELS.}

The reprobation of the cult of angels in Apostolic times (Col. ii. 18 ; cf. Rev. xix. 10 ; xxii. 8,9 ) would lead to the conclusion that this commemoration is not of early date. Traces are supposed to be found in the fifth century. Michael is the only archangel of whom Scripture speaks (the use of the plural in the Communion Office being a doubtful inference), Jude 9 . He is called 'prince ' in Daniel: ' your prince' ( $\mathrm{x} .21)$; 'the great prince' (xii. 1); 'one of the chief princes' (x.13). In Rev. xii. 7 he is simply named 'Michael and his angels.' Some think Michael (='who is like God?') is Christ Himself ; Dan. x. 13 is the chief passage against this supposition, and the only Scriptural ground for believing there is more than one archangel.

The Roman Calendar contains two Festivals of St. Michael, the Appearing of St. Michael, May 8, the Dedication of St. Michael the Archangel, September 29. 'All Angels' are not commemorated, but 'Guardian Angels' have a day of their own, Oct. 2.

The Collect. Sar. Miss., Sac. Greg., 1549.

'Hast ordained and constituted ' ; Lat. dispensas: ' dost manage.'

'By thy appointment,' added in 1549 , to avoid even the semblance of needing their help save as 'ministesing spirits sent forth' (Heb. i. 14).

'Succour and defend us'; Lat. vita nostra muniatur: 'our life may be fortified.'

For the Epistle. Rev. xii. 7-12, 1549 ; Sar. Miss., i. 1-5.

Rev. xii. $7-12 a$ is the Epistle in Sar. Miss. for the feast Sancti Michaelis in Monte Tumba. The only other angel mentioned by 
name in the Scriptures is Gabriel. Raphael and Uriel arc mentioned in the Apocrypha.

The Gospel. Matt. xviii. 1-10, Sar. Miss., 1549.

\section{SAINT LUKE THE EVANGELIST.}

The Title. 'The' added 1552.

The 'beloved physician' is unknown outside Holy Scripture ; the traditions that he was a painter, and that he was martyred, are unhistorical. He is conjectured to have been one of the seventy, a native of Antioch, and the unnamed companion of Cleopas on Easter Day. The Festival has been suggested to have commenced with the removal of his body to Constantinople in 484 .

The Collect. 1549.

'Whose praise,' etc.; cf. 2 Cor. viii. 18.

' Evangelist,' added 1662.

'The doctrine delivered by him,' 1662 , altered from ' his doctrine,' 1549.

'The merits of' added 1662 .

Sar. Miss.: 'O Lord, we beseech thee, let holy Luke the Evangelist intervene on our behalf; who continually bore in his own body the mortification of the cross for the honour of thy name.'

The Epistle. 2 Tim. iv. 5-15, 1549.

The Gospel. Luke x. 1-7, Sar. Miss., 1549.

This selection perpetuates the supposition that Luke was one of the seventy.

\section{SAINT SIMON AND SAINT JUDE, APOSTLES.}

The Title. 1662. 'Simon and Jude Apostles,' 1549.

Simon is unknown outside the list of the Apostles, where he is called 'the Zealot,' or 'the Canaanite,' both of which refer to the sect of the Jews whose impatience led them beyond the policy of the ordinary Phariscan party. According to an untrustworthy tradition, he was sawn asunder in Persia.

Jude, the 'Judas, not Iscariot' of John xiv. '22, was not one of the Lord's brethren, for both the Simon and Jude thus related to the Lord were unbelievers after the Apostles were chosen. The Epistle was presumably not written by the Apostle (Jude 17). He was generally identified with Lebbæus and Thaddæus. Tradition has asserted his working with Simon, and si:flering martyrdom with him in Persia, but as the Greek Church does not commemorate the two together, it is probable that the tradition arose to account for their being so coupled, and not vice versâ. The association is more probably due to the confusion of the 
Apostles with the Lord's brethren. The commemoration is not traceable further back than the eleventh century.

The Collect. 1549.

'Church,' 1662, for ' congregation,' 1549.

The English Collect is entirely based upon Eph. ii. 20-22. The omission of the names of the Apostles is unique ; it may well be due to the prevailing uncertainty as to the identity of Simon and Jude, which made it impossible to associate their names with the word 'Apostles' in prayer.

Sar. Miss.: "God, who hast granted us to come to the knowledge of thy name through the blessed Apostles Simon and Jude; Grant to us both to celebrate their eternal glory by profiting (by it), and to profit by celebrating it (proficiendo celebrare et celebrando proficere).'

Here, as so often, the Reformers have departed from any such emphasis upon the benefits to be derived from merely observing festivals, even though the Sarum Collect does recognize that 'profiting' is the only true 'celebration.'

The Epistle. Jude 1-8, 1549 ; Sar. Miss., Rom. viii. 28-39.

The Reformers have followed the Eastern Church in selecting this Epistle ; the choice is a tacit support of the Apostolic authorship of Jude, a theory which is not tenable.

The Gospel. John xv. 17-27, 1549; Sar. Miss., 17-25.

The Gospel in the Eastern Church, John xiv. 21-24, contains the only recorded saying of Jude.

\section{ALL SAINTS' DAY.}

The Title. 1662. 'All Saints,' 1549.

This Festival is a.continuation of the early commemoration of martyrs, too numerous for individual commemoration; later, all dead Christians were included. The invention and development of the doctrine of Purgatory led to a separation between those technically endowed with the name of 'Saints,' and the souls in purgatory, the latter being remembered on the following day, All Souls' Day. With the escape from the tyranny of purgatorial inventions, the English Church abandoned 'All Souls' Day,' and 'All Saints' now includes all ' the faithful departed.'

The Collect. 1549.

'Blessed Saints,' 1662, for ' holy saints,' 1549.

'Mystical body.' 'Mystical' is the adjective formed from 'mystery,' the word used by St. Paul to describe the 'secret' concerning our relation to Christ, typified by the institution of marriage, revealed in Christ Jesus (Eph. v. 29-32). 
The Collect carefully ignores any human distinction between the elect, as do also the Epistle and Gospel. Sar. Miss.: 'Almighty everlasting God, who hast granted us to venerate the merits of all Saints on one day (sub una); We beseech thee to bestow upon us the longed-for abundance of thy propitiation, our intercessors having been multiplied.'

For the Epistle. Rev. vii. 2-12, Sar. Miss., 1549.

The Gospel. Matt. v. 1-12, 1549; Sar. Miss., 5-12a. 


\section{THE ORDER OF THE}

\section{ADMINISTRATION OF THE LORD'S SUPPER OR HOLY COMMUNION}

\section{HISTORICAL INTRODUCTION.}

As an aid to devotion the English Communion Office is its own recommendation, needing no other support than that of the New Testament with which it claims to be in absolute accord in all things essential. Nevertheless, as an historical document it has points of contact with primitive precedents and teaching, and points of contrast with medirval doctrine and practice, the knowledge of which is as helpful in the appreciation of its incomparable beauty, as. it is essential to the interpretation of its form and substance. Further, its very arrangement and wording enshrine the progress of the English Reformation, and illustrate the religious differences of the period of the Restoration. Finally, it has been for many years the battlefield of conflicting schools of thought in the English Church, the story of which is not yet concluded.

This introduction must therefore include a summary, however concise, of the doctrinal and liturgical history of the Lord's Supper itself. That history is, in brief, the account of the gradual loss of scriptural simplicity, of its costly recovery at the Reformation, and of the struggle to preserve it in succeeding centuries. Two distinct yet closely related questions determine the main course of historical inquiry: (1) Are the Body and Blood of the Lord literally present in, under, or with, the consecrated elements? (2) Is the Lord's Supper the commemoration of a finished sacrifice, or is it itself a sacrifice? In the search for such an answer to these questions as will adequately explain the Communion Office, the following sources of information will be successively laid under contribution :- 
1. Scriptural references to the Lord's Supper. . . . 211

2. Sub-Apostolic writings. . . . . . . . . . 222

3. Early Liturgies and Patristic Literature. . . . 228

4. Mediæval doctrinal pronouncements. . . . . 238

5. Liturgical products of the English Reformation :- 251

(1) The Order of Communion, 1548. . . . . 252

(2) The Communion Office of 1549 . . . . . 255

(3) The Communion Office of 1552 . . . . . 261

6. Liturgical changes at the Restoration. . . . . 264

7. Interpretative principles of the Tractarian Movement 269

\section{Scriptural References to the Lord's Supper.}

If, as some have thought, there are traces of early hymns in the N.T. which may have been used liturgically, these are the only traces of anything like a 'liturgy,' in either its general sense of 'a form of worship,' or its later restricted one of 'an office for Holy Communion.'* The command 'This do in remembrance of Me' was given to the Church to obey, without the inculcation of any manner or method of ritual observance, beyond what obedience to the command necessarily implies. This divinely permitted freedom is of primary importance in estimating what is obligatory in this service, and in opposing the rigid system of uniformity which was increasingly enforeed as the rite became more and more unlike the original institution. The suggestion that ritual and liturgical details constituted part of 'the things pertaining to the kingdom of God,' which the Risen Lord made known to His disciples (Acts i. 3), is sufficiently met by the fact that the N.T. writers appeal to no such 'traditions,' even when, as in 1 Cor. $x$., xi., the subject was to the fore. The existence of any divinely ordered liturgical requirements is contradicted by the great variety of use in early centuries.

The N.T. passages referring to Holy Communion are :-

* The word 'liturgy' is found in LXX. and N.T., where. it signifies 'ministry.' It originally meant a public or state duty, from $\lambda \in \hat{\epsilon}$ ros and "zprov. "In later ecclesiastical use it has been sometimes attempted to limit its use to those prayers and offices which stand in more immediate relation to the Holy Eucharist; but there is no warrant in the best ages of the Church for any such limitation.' 'Trench, Synonyms,

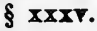




\section{$a$. The Four Accounts of tile Institution.}

MATT. xxvi. 2629.

And as they were eating

Jesus having taken a loaf

and having blessed

brake

and having given to the disciples, said :

Take ye, eat ye, This is my body.

And having taken a $\mathrm{cup}$

and having given thanks

he gave to them

saying

Drink all ye of it for this is $\mathrm{my}$ blood, that of the covenant,

which is being poured out concerning ( $\pi \in \rho i)$ many

unto remission of sins

But I say unto you that I will not henceforth drink of this fruit of the vine, until that day when I clrink it with you new in the kingtom of my Father.
MARK xiv. 22-25.

And as they were eating

having taken a loaf

having blessed

he brake

and gave to them, and said:

Take ye :

This is my body.

And having taken a cup

having given thanks

he gave to them. and they all drank of it

and he said unto them

This is my b'ood of the covenant

which is being poured out on behalf of (iviép) many

Verily I say unto you that I will never any more drink of the fruit of the vine, until that day when I drink it new in tho king dom of Gou.
LUKe xxii. 19, 20.
And heving taken
a loaf
having given
thanks
he brake

and gave to them, saying :

This is my body which is given on your behalf ; This do in remom. brance of me.

And the cup like. wiso

after supper

snying

This eup (is) the new covenant in my blood

which is being poured out on your behalf.

(vv. 15-18 in St. Luke's account contain a simi. lar reference, but before the Lor/s Supper, and ex. pressly referring to the Passover.)
I Cor. xi. 23b-26.

The Lord Jesus, in the night in which he was botrayed, took a loaf

and having given thanks

he brake,

and said :

This is my body which (is) on your behalf ;

This do in remem. brence of me.

Likewise also the cup

after supper

saying

This eup is tho new covenant in iny blood:

this do, as oft as ye drin's, in re. memibrance of no.

(in v. 26 the rite is linked to the Lord * Second Coming, some think in the Lord's own uords) For as oft as ve eat this loaf, and drink the cup, ye proclaim the Lord's veath till he come.

The following liturgical and doctrinal points emerge from the above :- 


\section{(1) The Materials employed.}

A loaf of bread and a cup of wine are alone mentioned. The 'bread' was more accurately a 'loaf,' somewhat of the shape of an English 'tea-cake,' and unleavened at the original institution, but not necessarily afterwards. The wine may very possibly have been diluted with water, as such dilution was frequent; it is, however, no ritual requirement, such dilution not being expressed.

(2) The Words used.

None are strictly requisite, however naturally used to express the meaning of the rite. The variations in the records of the Lord's words sufficiently prove them to be of secondary import, as words, to the institution. The differences existing from the first centuries to the present day, as to the use of the words of institution, and as to the stress to be laid upon them, corroborate this conclusion.

They are of three kinds :-

(a) Devotional.

The. words used by the Lord over the loaf and the cup are not recorded; we are simply told that $\mathrm{He}$ 'gave thanks,' or 'blessed.' The identity in meaning of the:e two expressions is clear from their being used to describe the same action in the different accounts. Precisely the same words are used, with similar indiscriminateness, to express the Lord's 'saying grace" over the five loaves and two fishes, the seven loaves and the few small fishes, and the bread broken at Emmaus.

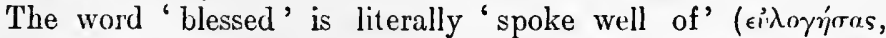
cf. English ' eulogy'). Strictly speaking, the bread and wine cannot be 'blessed,' any more than they can be 'thanked,' though the figure is well enough ur derstood, and common to-day in the phrase 'asking a blessing' upon our food. There is no word governed by the verb 'blessed' in Matthew and Mark, the A.V. has introduced the word 'it.' St. Paul, in 1 Cor. x. 16, mentions 'The cup of blessing, which we bless,' where the accusative is probably an accusative of respect: 'the cup of blessing in respect of which we bless God.' But, if the elements are to be considered as direct objects of the verb, the blessing here is precisely identical with the blessing of the five loaves in Luke

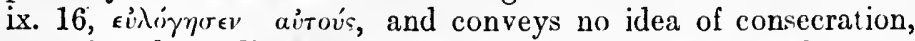
save for the ordinary purpose of consumption as food.

(b) Descriptive.

'This is my body which is being given on your behalf.' 'This cup is (the new covenant in) my blood, which is being poured out on your behalf.'

The interpretation of the recorded ward of our Lord is of the 
utmost importance as determining the meaning of the whole rite, for it is universally acknowledged that the Lord's Supper must mean now what it meant at its original institution. The meaning of the word ' $i s$ ' in the words 'This is my boty' may be said to lie at the root of all the divergent views of the Holy Communion. It is, however, agreed that the verb 'to be' is used to denote symbolical as well as literal identity ; e.g. 'this Agar is mount Sinai' (Gal. iv. 25) : and in the accounts of the Lord's Supper probably no theologian, at any rate, now desires to press the literal identity of the 'this' which the Lord distributed to His disciples, with the body which was being given on their behalf. Those who believe that the bread and wine are the body and blood of Christ after consecration, do not believe that the body of the Speaker was transmuted into that ' loaf' before the disciples' eyes ; and strict identity of the 'This' with 'My Body which is being given for you' demands no less. It is thereiore a question as to what kind of limitation is to be assigned to the word ' is.' Had the Lord meant to teach that the bread and wine were miraculously changed in any way, there was a word used in the Gospol for such a miracle of change, a word which would have made ambiguity impossible, viz., the word 'become,' employed to describe the miracle at Cana of Galilee, John ii. 9. The following considerations should be carefully noted :-

i. The Lord refers to His natural body and blood, 'given and 'poured out,' for the remission of sins.

ii. The bread and wine are, therefore, given separately, with a considerable time intervening, the separation of the body and blood constituting the essence of sacrificial death.

iii. The Aramaic words used by our Lord are unknown, but, as interpreted by St. Luke and St. Paul, the identity of the wine with His blood is not stated or intended: "This cup is the new covenant in my blood.'

iv. The words are spoken at a Passover Feast, with which the whole rite is so closely associated that the words used by St. Matthew, (xxvi. 29), and St. Mark, (xiv. 25), of the wine, are by St. Luke spoken of the Passover as such (xxii. 15-18). At the Passover Supper, the Lord, as President (cf. Justin Martyr's account of Holy Com-

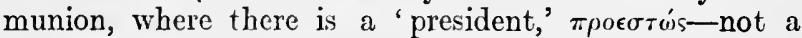
ministerial designation), would take an unleavened loaf, and distribute it, saying: "This is the bread of affliction which our fathers ate when they came out of 
Egypt,' where identity could be neither intended nor understood.

v. The disciples had already been familiarized with the phraseology, ' eating His flesh, drinking His blood,' and its explanation, viz., 'believing on Him,' John vi., esp. vv. 47,54 .

vi. The words 'this do in remembrance of me' identify the original institution with every succeeding observance, so that what it meant then it means now, and what it means now it meant then. Now the institution preceded the Crucifixion, so that had the bread and wine become in any sense the body and blood of Christ, separated in Sacrifice and offered for the remission of sins, both the Sacrifice of Calvary and its redemptive effect were anticipated, and rendered unnecessary, the night before!*

\section{(c) Preceptive.}

There are two preceptive utterances, one that all should partake, the other that the rite was to be repeated. The importance of the first command is intensified by the strange disregard paid to it both in 'non-communicating attendance,' and in withholding from the laity the cup, in connexion with. which the word 'all' was used.

The other direction demands special attention for two widely different reasons, its bearing upon frequency of observance, and its interpretation by some as stamping the rite with sacrificial meaning.

\section{i. Frequency of Observarce.}

There is here no strict regulation, but the words 'as oft' in St. Paul's account, seem at least to contemplate some amount of frequency. With this agrees the N.T. practice so far as it can be traced, cf. Acts ii. 42. There is no Scriptural justification for daily observance, the reference of Acts ii. 46 to the Lord's Supper being more than doubtful: 'And they continued daily with one accord in the temple, and breaking bread at home (R.V.), did eat their meat with gladness and singleness of heart.' The proximity of $v$. 42, where 'breaking of bread' comes between 'Apostles' doctrine and fellowship" and 'prayers,' might seem to suggest that in $v .46$, too, a religious 'breaking of bread' is implied; but the reference to taking their food with cheerful content removes that implication; and the word 'daily' (R.V. 'day by day') is not necessarily con-

* For the importance of this point at the Council of Trent, see below, p. 250 . 
nected with anything but their gathering in the Temple. It is remarkable that the N.T. is so silent in regard to the frequency of observance of the Lord's Supper. Acts xx. 7 : 'Upon the first day of the week, when the disciples came together to break bread,' suggests definitely that the observance was on Sunday, and, possibly, that it was a weekly occurrence.

\section{ii. Sacrificial Meaning.}

The attempt to fasten the idea of Sacrifice upon these words would seem to be sufficiently answered by the identity of the original institution with every subsequent observance of it, for if 'do this 'means, as is alleged, 'make this sacrifice,' the original institution must have been a sacrifice, and that expressly for the remission of sins, in which case Crucifixion was unnecessary.

However, as the idea still holds in some quarters, the following notes are necessary :-

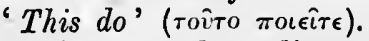

(a) 'Do' is the ordinary meaning of the word.

$(\beta)$ All the Greek Fathers so understood it.

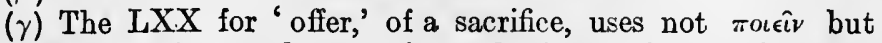

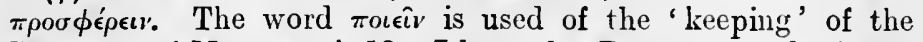
Passover, of Matt. xxvi. 18, 'I keep the Passover at thy house with my disciples.'

$(\delta)$ Modern Commentators tind no support for the notion of Sacrifice in the word; Bishop Gore, Body of Christ, p. 318, abandons the idea.

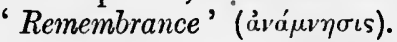

The contention to be met is that "the primary thought sug-

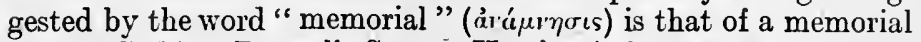
before God'; Darwell Stone, Hastings' Dictionary of Christ and the Gospels, Art. 'Lord's Supper.' The following is the reply :-

(a) The word for ' emorial before God ' in LXX is $\mu v \eta \mu$ ó $\sigma v v o v$ not å $v \dot{\alpha} \mu \nu \eta \sigma \iota s$.

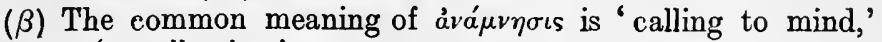
'recollection.'

$(\gamma)$ That is its meaning in the only other place in which it is used in N.T., Heb. x. 3, ' remembrance of sins.'

(j) All the Greek and Latin Liturgies support the translation '. 'remembrance.'

(є) The four passages in LXX, cited by Darwell Stone as conveying the sense of 'memorial.' are all capable of the idea of 'remembrance'; cf. T. K. Abbott, Reply to Criticisms, p. 41 : 'Most certainly árá $\alpha \nu \eta \sigma \iota s$ is not 
a sacrificial term ; it never means or can mean " memorial offering." '

The all-important idea connected with such an interpretation could scarcely have been hidden away in words usually bearing another meaning, and not to be found at all in two of the four accounts of the institution.* If Papias be correct, and St. Mark's Gospel is St. Peter's teaching, both he and those who depended upon his teaching were ignorant of these words altogether.

(3) The Manual Acts performed.

\section{i. Breaking the bread.}

The early introduction of the word 'broken' into MSS. of the N.T. in 1 Cor. xi. 24, was doubtless due to the idea that the breaking of the bread was intended to symbolize in some sort the death of the Lord. No such dramatic action accompanied the use of the wine; it was not "poured out at the institution. The discovery that the word 'broken' is an interpolation is therefore of great importance in assisting the recovery of the true symbolism of the 'breaking.' + The division of the 'loaf' into pieces for the disciples to eat, conveyed precisely the same idea as the 'loving cup' of which all were to drink, viz., communion, fellow-partaking. St. Paul, in 1 Cor. x. 16, calling attention to this 'fellow-partaking,' refers to 'the cup of blessing which we bless,' and 'the bread which wo brcak'; it is noteworthy that he does not say of the bread 'which we bless,' 'breaking' being more important for his purpose, viz. to show that $(v .17)$ 'we being many are one loaf, and one body ; for we are all partakers of that one loaf.' The recognition of this idea of 'communion' as underlying the 'breaking' from the earliest days, is plainly visible in the phrase 'breaking of bread,' which, though not exclusively used of the Lord's Supper, is apparently employed in that sense in Acts ii. 42, and with rou'wrio, the word translated 'communion' in 1 Cor. x. 16: 'and they continued stedfastly in the Apostles' teaching and the fellowship (Kou'w'ía), the breaking of bread, and the prayers.' There is no conjunction between 'the fellowship' and 'the breaking of bread' in the best MSS., this omission suggesting that the 'breaking of bread' describes the 'fellowship.' In the Didachè, directions are given concerning 'the cup' and 'the

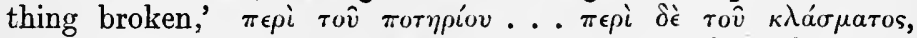
tho 'breaking' being so important as to displace the word 'bread ' $\ddagger$ altogether.

* This interpretation, be it understood, is quite late it arose long after the practices for which it is supposed to find sanction.

$\dagger$ St. John lays stress upon the prophetic promise that brëaking should not accompany tho Lord's death; (xix. 36); His body was given for us, not brokon. 
ii. Distribution.

This needs no explanation, but only emphasis, in view of the maiming of the rite in later ages.

(4) The Circumstances accompanying the Institution.

The fact that the Lord's Supper was instituted in the midst of a Passover meal, besides declaring the Lord's intention in calling the bread His body, also condenıns superstitious regard to fasting in connexion with the rite. The Lord's Supper was instituted ' as they were eating,' and St. Paul refers to the 'cup of blessing,' the name commonly given to the third cup at the Passover feast (1 Cor. $x$. 16). That the accompaniment of a common meal is not indeed obligatory, is clear from the advice to the Corinthians to satisfy hunger at horne (1 Cor. xi. 22, 34) ; but this very command would lend weight to the Lord's example (if weight could be lent to teaching so directly divine), for St. Paul does not bid the Corinthians sup after the Lord's Supper. Whatever the N.T. teaching in regard to fasting may beand it is notorious that the MSS. have been tampered with in several places to enforce the practice-there is not only no association of it with this rite, but the very reverse. The investigation of this question is indissolubly bound up with another much debated matter, the time of observance, with regard to which the original institution is equally clearly a sanction of the evening hour. Both at Corinth, and at Troas (Acts xx. 7), N.T. practice still further sanctions the evening hour, though it has been, and is, seriously contended that the irregularities at Corinth put an end to the custom, and that at Troas St. Paul purposely preached until midnight, that in regard to both the hour of communion and the fasting condition of the communicants, the supposed apostolic rule might be observed. The great name of Augustine, who claims apostolic authority for 'fasting communion' ( $E p$. ii. liv. § 8 : Edn. 1679), has doubtless been instrumental in perpetuating what is now known to be historically erroneous. He argues that so general a custom as fasting reception had by his time become, could not have arisen without divine authority; and that St. Paul's words 'the rest will I set in order when I come' (1 Cor. xi. 34 ) are to be taken as referring to this matter amongst others. In addition to the negative evidence afforded by the absence of any reference to any such apostolic tradition, there is positive evidence that the theory is untenable :-

(a) St. Augustine himself, strangely enough, permits a late reception on Maundy Thursday, in the very Epistle cited above.

(b) Socrates, Hist. Eccles., v. 22, states that evening communion, after supper, was the practice in the Thebaid. He mentions it 
as a peculiarity, but without any suggestion of blameworthiness. The well-known asceticism of the Thebaid, which would have sufficiently explained fasting communion, renders the prevalence of the contrary practice an all the more forcible argument against the existence of any apostolic order to fast.

(c) Chrysostom, though acquainted with the custom of fasting, blames abstention from the Lord's Table on the part of those who were not in a fasting condition.*

(d) Cyprian, finding fault with the Aquarians for using water only at their morning Communion, acknowledges that they used wine in their evening observance. He has no fault to find with the hour, but rather regards the general abandonment of that hour as needing explanation (see Bingham, Ant. xv. vii. § 8).

(e) The 3rd Council of Carthage, 397, which ordered a fasting celebrant, is cited in support of Fasting Communion; why an ecclesiastical regulation if already apostolic ?

$(f)$ The Didachè, whether its date be as early as 90 , or as late as 200, knows no separation of the 'Agapè ' $\dagger$ and the Lord's Supper. The attempt to refer $\S \S 9,10$ of that work to the 'Agapè' only, would, if successful, bring about the strange result that the Didachè knows nothing of the Lord's Supper at all, or does not think it worth even a mention. It expressly enforces fasting before Baptism, but not before the Lord's Supper.

(g) Ignatius, c. 110, calls the Lord's Supper by the name 'Agapè': 'it is not lawful apart from the Bishop either to baptize or to hold an Agapè.' This can only be denied by conceding that Ignatius attached more importance to the "Agapè" than to the Lord's Supper.

The question remains: How did the practically universal custom arise? $\ddagger$ The records of the sub-apostolic age are exceedginly scanty, but they afford an intelligible explanation :-

(a) Trajan had a jealous fear of clubs of every kind, as probable hot-beds of sedition; this is well known, cf. his letter to the

* Dimock, Hour of Holy Communion, p. 7.

† The 'Agapè' is mentioned in two N.T. passages, showing con. siderable verbal resemblance, 2 Pet. ii. 13 ; Jude 12. There are MS.

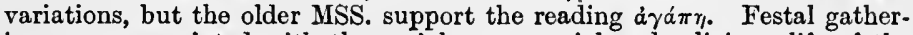
ings were associated with the social, commercial and religious life of the age, and Christians, being debarred from heathen feasts, would make all the more of their own. The feast outlived its separation from the Lord's Supper, though more and more restricted to commemorative festivals of the dead. Its observance in Churches was forbidden in the East by Conc. Laodic., Canon 28, 361 ; but the prohibition needed renewal in the Council of Trullo, so late as the seventh century.

$\mp$ It should be borne in mind that the burden of proof rests upon those who claim authority for Early and Fasting Communion, not upon those who claim liberty in that regard. 
younger Pliny granting an exemption in the matter of clubgatherings to the city of Amisa, concluding: ' in all the other cities which are subject to our laws: anything of the kind must be prohibited.'

(b) Christians were accused in Trajan's time of horrible crimes at banquets, the charge being doubtless due to misunderstood or misrepresented references to the body and blood of Christ.

(c) St. Paul's directions to the Corinthian Church made it clear that the association of a banquet with the Lord's Supper was not essential.

(d) The regular teaching of the N.T. in regard to loyal citizenship on the part of Christians would inculcate readiness to forego what was not essential.

(e) Pliny's letter to Trajan (110), concerning the Bithynian Christians, expressly states that the evening meeting for a meal had been abandoned in response to Pliny's edict carrying out Trajan's commands.

$(f)$ The reasons which compelled the abandonment of the Agapè, also interfered with freedom for any kind of evening gathering, so that the Lord's Supper was more conveniently held at the morning gathering.

$(g)$ The rapid growth of asceticism, exemplified by the early regulation for fasting before Adult Baptism, helped to attach a religious significance to what arose purely from considerations of expediency.

(h) These considerations are not affected by the fact that the Agapè is mentioned by Ignatius as still practised c. 110. Imperial Edicts were not enforced with the same rigour in every part of the Empire; and, in fact, the Agapè survived not only Trajan's commands, but the condemnation of councils.

\section{b. The N.T. References to the Lord's Supper.*}

(1) Acts ii. 42 ; xx. 7, 11 :-' the breaking of bread,' see above, p. 217. This phrase does not always refer to the Lord's Supper, e.g. Acts xxvii. 35.

(2) 1 Cor. x. 14-22:-' a joint-partaking of the blood ... the body of Christ.' $\dagger$ St. Paul's point is the double fellowship of believers with one another, symbolized in their joint-partaking of the one loaf (see above, p. 217), and of believers with Christ.

* The Lord's address at Capernaum, in John vi., is not directly connected with the Lord's Supper; the institution docs, indeed, embody the same teaching, but the address explains the rite, the rite does not explain the address. Cf. Westeott, Commentary, in loc.

$t$ The cup precedes the bread in the Didachè also. Compare the indecisiveness in the Gospel accounts in regard to the cup of which our Lord will not partake 'till He come.' 
Such fellowship must not be defiled by similar fellowship with demons. The impossibility of deducing from these words any idea of literal partaking of the body and blood of Christ is most clearly seen by the context, where the noun and adjective are used as follows :-

$v .16$, joint-partaking of the blood . . . the body.

$v .18$, joint-partakers of the altar (spoken of "Israel after the flesh').

$v .20$, joint-partakers of demons.

If $v .16$ must mean that the literal body and blood are partaken of, then the altar in $v .18$, and demons in $v .20$ must be literally devoured. In truth the only possible point to be drawn from St. Paul's parallel, is that participation in a religious feast implies fellowship with the object of worship in that feast, Christ or demons.

The avoidance of the word 'altar' in this passage is notable. Used for Israel's religious feasts in $v .18$, it is carefully suppressed for the Christian feast in $v .21$, where 'table' is substituted. For convenience, Heb. xiii. 10 may here be mentioned: 'we have an altar': a passage often misquoted in support of a sacrificial idea of the Lord's Supper. Even Thomas Aquinas interprets that 'altar' of the Cross ; it would be strange indeed if that.Epistle, written to prove the supersession of all altars by the Cross, should conclude by re-establishing them.

(3) 1 Cor. xi. 20-34. This passage has been largely dealt with already (for the designation, 'the Lord's Supper,' see p. 287) ; there only remains to note the Apostle's commentary upon the institution :-

(a) v. $26:-$ 'shew the Lord's death': this emphasis upon preaching the death of Christ in the rite has been grievously overlaid by an unwarrantable misinterpretation of the word 'shew,' $\kappa a \tau \alpha \gamma \gamma \epsilon \hat{\epsilon} \lambda \epsilon \tau \epsilon$. It can only mean that by partaking of the bread and wine, the symbols of the body and blood separated in sacri. ficial death, that sacrificial death is preached to the world ; there is absolutely no idea of presentation before God. Nor is there any need to find in the words a custom of describing the death in words (Godet, Commentary, in loc., arguing from the IIaggadah, or historical explanation, given at the Passover); the partaking is the preaching. The later, though still early, custom of treating the rite as a mystery to be hidden from unbelievers, finds no countenance here, but rather the reverse.*

* Perhaps it should be said that such preaching to unbelievers by the rite is quite another and different thing from the fancy that benefits attach to the non-communicating attendance of believers. 
(b) v. 26 :- ' till He come.' These words echo the Lord's own statement that He would not partake of the fruit of the vine till the Kingdom comes. Their bearing upon the 'bodily absence' of Christ in the rite is obvious.

(c) $v v .27-34$. Here the bread and wine are expressly distinguished from the body and blood; careless misuse of the former is guilt in regard to the latter, visited in this life with condign punishment. In $v_{.} 29$ ' not discerning the body,' (not 'the Lord's body '), where the 'blood' is not mentioned, refers to the mystical body of Christ, the communion or fellowship of the faithful.* The guilt of the Corinthians was precisely failure to recognize that organic oneness of the mystical body, cf. $v v$. $21,22$.

(4) 1 Cor. v. 7, 8 is a possible reference, the mention of the Passover sacrifice and the Feast together"suggesting the true relation of the Cross and Holy Communion; but, like John vi., it covers more than the rite-all the faithful life of a believer is a feasting upon Christ.

Summary of N.T. requirements.

i. A loaf of bread and a cup of wine.

ii. Thanksgiving for the gift of bread and wine.

iii. Breaking of the loaf.

iv. Distribution and partaking of the bread and wine.

Summary of N.T. teaching.

i. Remembrance of the death of Christ.

ii. Partaking of the Body given and tho Blood shed.

iii. Fellowship in that partaking.

iv. Preaching the death 'till He come.'

The attempt to find more than these in Holy Scripture, especially to find a teaching of identity of Christ's body and blood with the bread and wine, and a propitiatory sacrifice in the Sacrament, is rendered vain both by the absence of any such estimate of the Sacrament in the time of the Apostles, and by the fact that those dogmas preceded the search for Scriptural support, and did not arise from the plain interpretation of the words.

\section{Sub-Apostolic Writings.}

Although the Reformers expressly asserted the unique and paramount authority of Holy Scripture, they were by no means blind to the interpretative value of genuine records of the Early

* The usual explanation of $v .29$ is that the Corinthians failed to discriminate between the sacred symbols of the Lord's Body and Blood and the ordinary food provided at the Love-Feast. 
Church. For examiple, Jewel's famous Apology, a more than semi-authoritative document, was based upon the incompatibility of certain rejected tenets of the unreformed Church with the teaching of the first six centuries. Unhappily falsifications, both by interpolation and by excision, together with the too common attempt on the part of later writers to enhance the authority of their books by attaching to them earlier and more authoritative names, complicate the question; but nevertheless it is possible to see the comparative simplicity and purity of the first centuries, and to detect the first beginnings of tendencies which foreshadowed later corruptions.

The earliest patristic documents are largely silent in regard to the Lord's Supper, Clement (Rom.) (96),* Hermas (140 (?), Polycarp (d. 157), and the writer of the Epistle to Diognetus (c. 150), make no allusion thereto;-a significant comment upon the disproportionate attention it has received in ages more remote from the Apostles.

Ignatius mentions Holy Communion at least four times, (if the 'middle recension,' the seven letters, be authentic) :-

(a) Ad Smyrn. vii. : "They abstain from Eucharist and prayer, because they do not confess that the Eucharist is flesh of our Saviour Jesus Christ, which ( $\tau \eta^{\prime}{ }^{\prime}$, flesh) suffered for our sins, and which the Father of His goodness raised.'

The Docetæ, who denied the reality of the Lord's body, naturally found a serious difficulty in the Lord's Supper; how could there be a figurative representation of something which had no real existence? At a later date this passage was quoted by Theodoret against the Eutychians, whose belief involved them in a similar difficulty. Theodoret either made or preserved

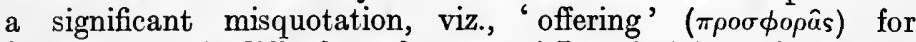
'prayer.' It is difficult to be sure of Ignatius' intention in the first use of the word 'Eucharist,' for it has there no article, and is conjoined with 'prayer.' In the following words the meaning must be 'the Eucharist.'

This pascage has been often cited in support of the dogma of a 'Corporal Presence,' but the words need not mean more than the Lord's own utterance at the institution, they carefully retain the Lord's reference to His body which suffered, they even exclude the idea of any kind of identification by the mention of the Resurrection. Moreover, they are explained by the figurative

* It is unfortunately still necessary to protest against the citation of Clement as supporting the 'sacrificial' idea of Holy Communion. His reference to the O.T. priesthood, as illustrating God's provision of decency and order, is not obscure enough to justify the continuance of a long-exploded misuse of his words. 
use in Ad Trall. : viii. ' be ye renewed in faith, that is the flesh of the Lord, and in love, that is the blood of Jesus Christ.'

(b) Ibid. viii. : 'Let that be considered a valid Eucharist which is under the bishop or him to whom he entrusts it . . . it is not allowable without the bishop either to baptize or to

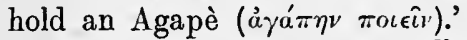

The Lord's Supper, now called 'Eucharist,' is still one with the Agapè (see above, p. 219).

(c) Ad Philadelph. iv. : 'Be zealous then to use one Eucharist; for one is the flesh of our Lord Jesus Christ, and one cup for the oneness of his blood, one altar, as one bishop, together with the presbytery and deacons, my fellowservants, in order that whatever you do you may do it in accordance with God.'

The word 'altar' here, though in such close proximity to the words describing the Eucharist, has no ritual connexion therewith. It is used figuratively of the Christian faith, as in $A d$ Trall. vii. : "He who is within the altar is clean, but he who is outside is not clean.' Again, in Ad Magnes. vii., the word is figuratively used: "Do ye all therefore come together (agree) as to one altar, as to one Jesus Christ.' Polycarp, in Ad Philip. iv. adds yet another figurative use,-widows are the 'altars of God.'

(d) Ad Eph. xx. " . . breaking one loaf, which is the medicine of immortality.' This new idea, probably drawn from John vi. 53,58 , became enshrined in liturgical use.

(2) One document, of unknown authorship and disputed date, is probably to be ascribed to early days :- the recently discovered Teaching of the Twelve Apostles, commonly known as the 'Didachè.' Some date it as early as 90, others as late as 120, 200, and even later. Its references to Holy Communion are :-

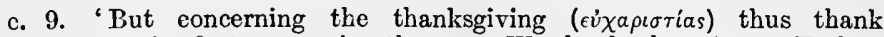
( $\epsilon \dot{v} \chi \alpha \rho \iota \sigma \tau \eta \dot{\eta} \sigma \alpha \tau)$; first concerning the cup : We thank thee, $O$ our Father, for the holy vine of David thy servant (raiobs), which thou hast made known to us by Jesus thy servant (maıjis); to thee (be) the glory for ever. And eoncerning the fragment ( $\kappa \lambda \dot{\alpha} \sigma \mu a r o s)$ : We thank thee, $O$ our Father, for the life and the knowledge whieh thou hast made known to us by Jesus thy servant; to thee be the glory for ever. As was this fragment once scattered over the mountains and beeame gathered into one, so may thy chureh be gathered from the ends of the earth into thy Kingdom; for thine is the glory and power by Jesus Christ for ever. And let no one eat or drink from your Eueharist, but those who have been baptized into the name of the Lord; for eoncerning this the Lord has said: Give not that which is holy to the dogs.'

c. 10. 'And after being filled ( $\mu \epsilon \tau \grave{a} \delta \hat{\epsilon} \tau \dot{d} \dot{\epsilon} \mu \pi \lambda \eta \sigma \theta \hat{\eta} \nu a \iota$ ) thus give thanks: We thank thee, $O$ holy Father, for thy holy name, ... thou hast given both food and drink to men for enjoyment, that they may thank thee, but to us thou hast given spiritual food and drink and life eternal 
through thy Son. For all things we thank thee. . . If any one is holy, let him come; if any one is not, let him repent; Maranatha. Amen. But suffer the prophets to give thanks as they will.'

c. 14. 'And on cach Lord's Day when assembled together break bread and give thanks, after you have confessed your transgressions in order that your sacrifice may be pure. But let none that hath strife with his comrade come together with you until they be reconciled, that your sacrifice be not defilcd. For this is that which was spoken by the Lord : In evcry place and time-bring me a clean sacrifice; because I am a great King, saith the Lord, and my name is wonderful among the nations.'

Forms of thanksgiving are here provided, for the cup and the bread (in that order, as in 1 Cor. x.), and also for use after partaking, but with express latitude in regard to their use ; if a 'prophet,' anyone able to conduct worship, is present, he is not to be tied to forms. The word 'sacrifice' is also introduced, though without any closer association with the Lord's Supper than with the rest of public worship. Regulations are given to warn unfit communicants, and general confession of sins is inculcated to prevent unworthy communicating. The Lord's Day is the only day for such worship. The 'breaking' is so essential that the bread is called 'the fragment,' or 'thing broken,' and the Eucharistic prayer in regard to it dwells solely upon the communion of believers.*

(3) Some light is thrown upon early Christian worship by a writing whose heathen authorship lends peculiar value to its witness, Pliny's letter to Trajan ( $E p$. x. 96) :-

'They protested that this was the sum of their fault or error, that they were wont on a fixcd day to meet before daylight, and to sing (dicere) together in turn a hymn to Christ as God, and to bind themselves by an oath (sacramento), not to any crime, but that thcy would commit no thefts, robbcries, adulteries, would not break their faith, would not deny a trust when challenged (ne depositum appellati abnegarent): which things complcted it was their eustom to disperse, and come together again to take food, common however and harmless: and that they had ceased to do cven that after my edict by which, following your orders, I had forbidden elub-meetings (hetarias) to be held.'

If any allusion to Holy Communion is to be found here (as every one is ready to admit), it is only on the assumption that the 'food' mentioned relates to it or includes it. For the impossibility of the reference of the word sacramento to the rite see p. 289, and for the importance of this passage in accounting for the general abandonment of Evening Communion see p. 220.

* The connexion of these passages with the Lord's Supper is denied by some. Frere, History of B.C.P. (1910), is euriously unccrtain. On pp. 506,7 , he gives the passage as the first of "Thrce carly aecounts of the Holy Eucharist' ; on p. 432, note 1, he says the Lord's Supper is called Eucharist 'probably in the Didachè'; note 2, "the forms very possibly refer only to the Agapè.' 
The information is otherwise of a very negative character, giving no hint of any 'liturgy' in connexion with the Lord's Supper. One positive element is important; the Lord's Supper becoming compulsorily connected with the morning meeting, the antiphonal hymn and mutual pledge thus became accidentally associated with the Sacrament.

(4) One other author of the early period deserves special notice, Justin Martyr, c. 140. His accounts of services are-very full, the most important being :-

(a) Apology i. 65, 66: 'Having eeased from the prayers (for a newly baptized convert) we greet one another with a kiss; then is brought

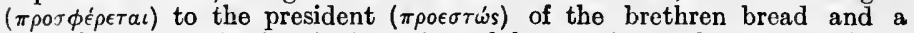
cup of water and wine (кра́ $\mu \alpha \tau o s)$, and he, reeeiving them, sendeth up praise and glory to the Father of all, through the name of the Son and

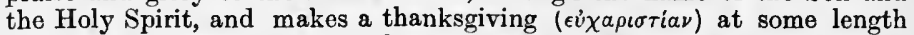
for that He has granted us these blessings. When he hath ended the prayers and thanksgiving, the whole people present join in with one voice saying Amen. And after the president has given thanks and the people have assented, those ealled among us deacons give to each of them present to partake of the bread and wine and water, over which thanksgiving has been made, and carry it to those not present.

- And this meal is called with us Eucharistie, of which none is permitted to partake except one who believes that the things taught by us are true, and who has passed through the washing for remission of sins, and new birth, and so lives as Christ commanded. For we receive these not as common bread or as common drink, but, just as Jesus Christ our Saviour, being incarnate through the word of God, possessed both flesh and blood for our salvation, so also we were taught that the food over which thanksgiving has been made by the (utterance in) prayer of the word which is

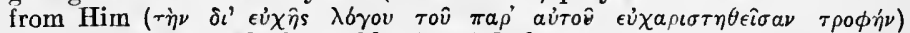
- that food from which our blood and flesh are by assimilation nourished -is the flesh and blood of Him, the Incarnate Jesus. For the Apostles, in the memoirs which they wrote whieh are called Gospels, transmitted to us that Jesus Christ thus charged them, that after taking bread and giving thanks $\mathrm{He}$ said : Do this in remembrance of $\mathrm{Me}$; this is $\mathrm{My}$ body : and that likewise having taken the eup and given thanks, He said: This is my blood, and gave to partake to them alone ...'

(b) Ibid. c. 67, the same aecount is given in an abbreviated form: ' On the day called that of the Sun there is a congregation of all who dwell in town or country into one place, and the reminiscences of the Apostles or the writings of the prophets are read so far as time permits; then, the reader ceasing, the president by an address admonishes and exhorts to the imitation of these noble deeds (men ?); afterwards we all stand up together and offer prayers; and, as we said before, when we ccase from prayer, bread (a loaf) is brought and wine and water; and the president sends up prayers likewise and thanksgivings to the best of his ability, and the people assent saying the Amen. And the distribution of and participation in the things which have been nade objects of thanksgiving $\left(\tau \hat{\omega} \nu \in \dot{\nu} \chi \alpha \rho \iota \sigma \tau \eta \theta^{\dot{\epsilon}} \nu \tau \omega \nu\right)$ takes place for each, and to those not present they are sent by means of the deacons. And the prosperous and willing each according to his own previous purpose, contribute each what they will; and that which is colleeted is laid by with the president, and he helps orphans.' ete. 
(c) Dial. cum Trypho, c! 70 : 'In this prophecy allusion is made to

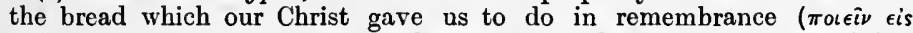
$\dot{\alpha} \nu \alpha \dot{\alpha} \nu \eta \sigma \iota \nu)$ of His being made flesh in behalf of those who believe in Him, for whom also $\mathrm{He}$ became subject to suffering; and to the cup which $\mathrm{He}$ gave us to drink in remembrance of His own blood, with giving of thanks.'

(d) Ibid. cc. 116, 117. 'Now God receives sacrifices from no one, except through His priests. Therefore God anticipating all the sacrifices which we do through His name, and which Jesus the Christ enjoined us to do, i.e., in the Encharist of the bread and of the cup, and which are done by Christians in all places throughout the world, bears witness that they are well-pleasing to Him. ... You assert that God .... is pleased with the prayers of the individuals of that nation then dispersed, and calls

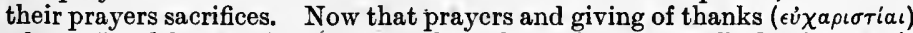
when offered by worthy men, are the only perfect and well-pleasing sacrifices to God, I also admit. For such alone Christians have undertaken to do, and in the remembrance made by their food, both solid and liquid, in which the suffering of the Son of God which $\mathrm{He}$ endured is brought to remembrance.'

Summary of Justin's liturgical teaching :-

(1) Worship, including Holy Communion, is on Sunday.

(2) The kiss of peace.

(3) A president, ministerial qualification unspecified.*

(4) Reading of O.T. and N.T. Scriptures.

(5) A Sermon.

(6) Prayers, by the congregation.

(7) The bringing to the president of bread and mixed wine and water. $\dagger$

(8) A long prayer of thanksgiving.

(9) The response of the people, Amen. $\ddagger$

(10) Administration.

(11) Distribution to the Sick.

(12) Almsgiving, according to the regulation of 1 Cor. xvi. 2. Doctrinal references :-

(1) Sacrifices are prayers and thanksgivings, the latter including those offered at the Lord's Supper. In describing the rite the

* It deserves a passing protest that Blunt, Annotated Prayer Book, should have rendered the colourless word $\pi \rho 0 \epsilon \sigma \tau \omega$ 's by the highly eoloured word sacerdos.

$\dagger$ Frere, History of B.C.P., p. 433, denominates this 'the oblation,' trading on the double meaning of the verb $\pi \rho \sigma \sigma \phi \epsilon^{\prime} \epsilon \tau a$, which can only mean 'is brought' herc, seeing that 'to the president' immediately follows. It is unfortunate that in his quotation from Justin, p. 507, he omits the passage containing this addition, and only preserves the more brief repetition of these words: ' as we have said, when we ccase from prayer bread is brought,' etc. The 'as we have said ' refers to the context, where the words 'to the president' are expressed. The vcrb eannot mean both 'bring' and 'offer' in one passage.

$\ddagger$ For the attempt to derive from this that St. Paul called the Lord's Supper 'Eucharist.' see p. 288. 
word 'sacrifice' $\left(\theta v \sigma^{\prime}{ }^{\prime} \alpha\right)$ is not used.* 'Other sacrificial terms are absent.

(2) Bread and wine are still called bread and wine when distributed, though Justin is not afraid of sacramental identification with the body and blood of Christ.

(3) Justin's parallel between the Incarnation and the figurative body and blood in Holy Communion, innocently enough used by him, is nevertheless one of those vague and unscriptural analogies peculiarly liable to be superstitiously misused.

\section{Early Liturgies and Patristic Literature.}

\section{Liturgies.}

The efforts to obtain satisfactory historical evidence by comparisons of ancient liturgies and sacramentaries, and the liturgical hints to be found in patristic writings, have been notoriously unproductive of trustworthy positive results. The negative teaching, however, is of great importance as furnishing indisputable evidence that some particular development was not in vogue when and where the particular liturgy was in use ; it is possible on such grounds alone to disprove the claims to catholicity of most medirval doctrine and ritual. But to establish positive teaching as to the age or prevalence of any rite contained in these documents is not possible. When undisputed facts and statements of patristic writers are so continually tortured into giving evidence to suit the biassed inquisitor, it is not to be expected that in this region, where the difference between early and late is a matter of delicate weighing of probabilities and possibilities, the results obtained by liturgiology will do much more than reflect the predilections of the liturgiologist. Moreover, even were a greater measure of success obtainable, the earliness or lateness of the introduction of any doctrinally important liturgical novelty is a matter of no practical importance, save as teaching a melancholy lesson upon the rapidity with which purity of doctrine is lost as the stream becomes remote from its scriptural source. Carelessness in the use of unscriptural phraseology, largely borrowed from Jewish and Pagan religion : the proneness of human nature to find substitutes for the exacting demands of spiritual devotion in the fatally easy refuge of an æsthetic cult : the well-meant but ill-starred efforts to embrace hordes of heathen within the Christian fold by accommodating Christianity to their superstitious ideas of religion: the combined tendencies of priestly ambition on one side, and ignorant

* Yet Frere (p. 432) c.tes Justin, Dial. c. 41, 117, as the authority for $\theta$ ivia as one of 'the principal early titles of the service,' with how much (or how little) justice, can be seen from the quotations above given. 
indifference on the other, to evolve a hierarchical and sacrificial system for which there were parallelis on every side : these, and such like reasons, writ large in the experience of all ages, sufficiently explain the comparatively early transmutation of the simple worship of the New Testament into the superstitious, more than semi-heathen, displays of later times.

One further precaution should precede any consideration of the liturgies. They are not doctrinal treatises, though they involve doctrine. This needs emphasizing in view of the too common practice of treating the rhetorical expressions of devotion as though they were found in a volume of dogmatic theology. Such procedure is as unwise and as unfair as would be an attempt to trace the course of Anglican theological belief by means of a popular hymn-book. At the close of the following outline of the comparatively reliable data of liturgical research, will be found some typical quotations from doctrinal writings of the periods to which the earliest liturgical relics can be ascribed; those quotations will serve to refute hasty doctrinal deductions often made from the fervid language of public worship.

In the Table on p. 230 an attempt has been made to indicate the most probable relations of the more important liturgical compilations to one another and to modern uses, with brief notes of the dates of their earliest extant MSS., etc. Free use has been made of the Articlc 'Liturgies' in Encyclop. Britann., 11th Edn., where may be found justification of the arrangement, and reference to sources of fuller information.

\section{i. The Clementine Liturgy.}

There is a long gap between the simplicity and freedom of the service described by Justin, and the earliest known liturgy, which is probably that in the eighth book of the so-called 'Apostolical Constitutions,' a work emanating from the neighbourhood of Antioch, in the fourth century or later. From its claim to be the ipsissima verba of the Apostles, written down by Clement, the account of the Lord's Supper therein is called the 'Clementine Liturgy,'* which enshrines the following important changes introduced in the two centuries or more since 150 A.D. :-

(1) A sharp division of the service into two parts, one for catcchumens, etc., the other for the faithful.

(2) Prayer for the Church, including the faithful departed.

(3) Gifts are now brought to the 'Altar.'

(4) The sign of the Cross is introduced.

* For some account of this work sce Protestant Dictionary, Art. 'Apost) lical Constitutions,' where it is proved to be tinged with Arianism and full of absurd anachronisms. 


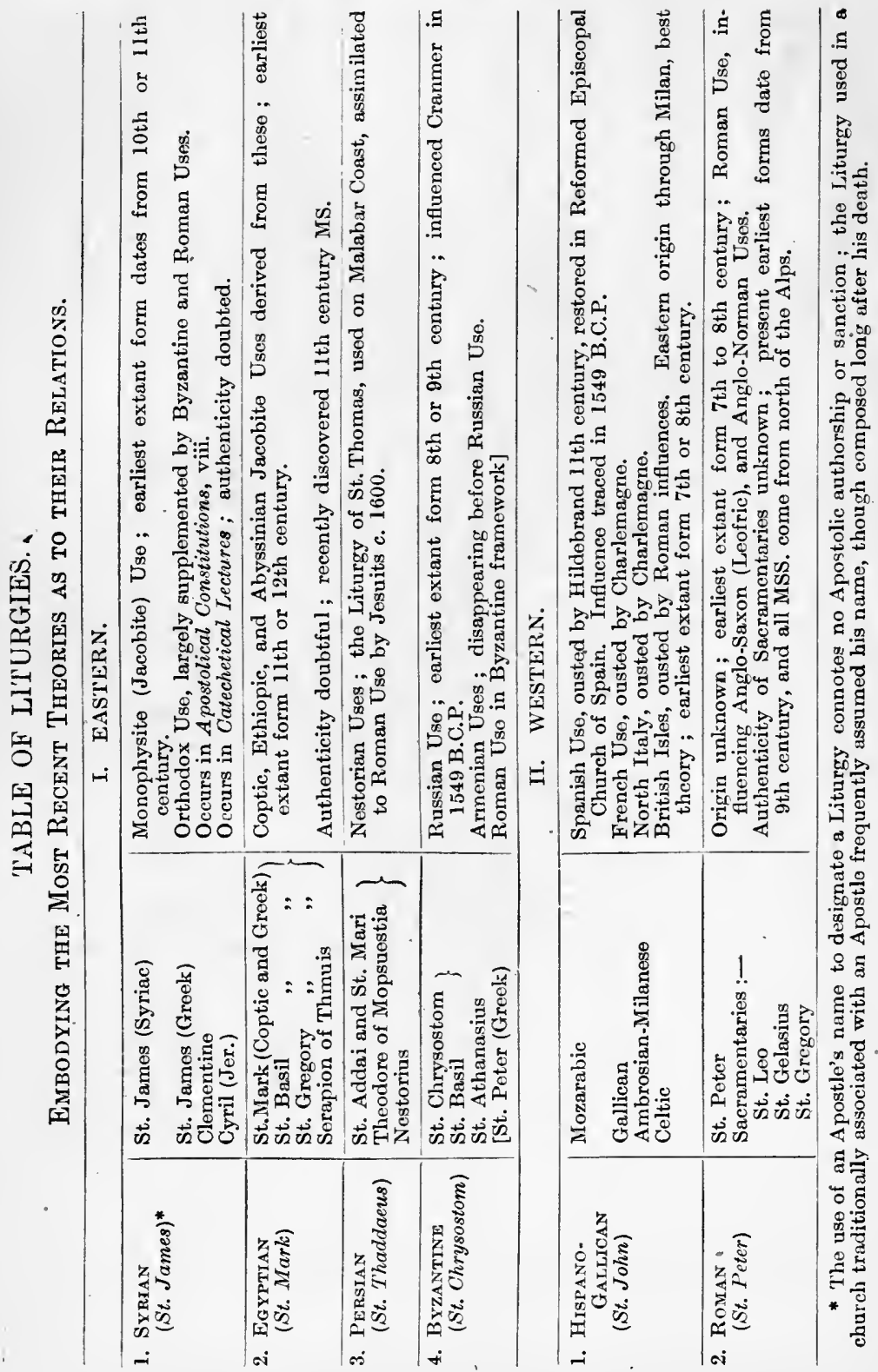


(5) The Sursum Corda, and Ter Sanctus.

(6) Prayer, including :-

(a) Account of the Institution (inexcusably travestied).

(b) Oblation of the Bread and Wine.

(c) Invocation of the Holy Spirit upon 'this sacrifice,' that He may 'show forth this bread the body of thy Christ, and this cup the blood of thy Christ.'

(d) 'Offering on behalf of' the faithful dead.

(7) Words of Administration, 'The Body of Christ'; ' the Blood of Christ, the cup of life '; 'Amen' being the recipients' answer to both.

ii. Cyril of Jerusalem.

Side by side with the Clementine Liturgy should be set the Liturgical hints to be deduced from the Calechetical Lectures of Cyril of Jerusalem (348).* The following are the notable innovations :-

1. Ceremonial hand-washing before Kiss of Peace.

2. Invocation of the Holy Spirit that He may be sent forth on these (things) lying before Him, that $\mathrm{He}$ may make the kread the body of Christ, and the wine the blood of Christ.

3. Sacrificial terms used of the bread and wine: 'the spiritual sacrifice,' ' that sacrifice of propitiation.' $\dagger$

4. Offering for the departed.

5. Prayers and intercession of the Saints mentioned.

6. The Lord's Prayer mentioned.

7. The Choir sings before Communion, 'Taste and see that the Lord is gracious.'

8. 'Altar' is frequently used. $\ddagger$

iii. Serapion.

In an eleventh century MS., discovered in the last decade of the nineteenth century, is contained what would be called in the West a Sacramentary. The name of Serapion, Bishop of Thmuis, and friend of Athanasius, is prefixed to part of the liturgy which it contains, but it offers no resemblance to his current works. It is conjectured to date from $c .350$, and the Delta is the apparent place of its origin. The most important point to be noted here is its invocation of the Word upon the bread and wine: ' 0 God of truth, let thy holy Word settle upon this bread that the bread may become body of the Word, and on this cup that the

* In fairness to Cyril it should be observed that his authorship of these Lectures is doubted by Bishop Andrewes and Dean Goode.

$\dagger$ Similar language is found in Irenæus, but not in a liturgy.

$\ddagger$ For the well-known direction to the communicants in the matter of reception, see p. 237 , and p. 341 . 
cup may become blood of the truth. And cause all who communicate to receive a drug of life for healing of every disease and empowering of all moral advance and virtue.' * The elements are called a 'living sacrifice, a bloodless offering'; the bread and wine are called 'likeness of his body and blood' before consecration. It is some indication of early date, that, though the invocation is capable of a meaning akin to later doctrines of a literal transformation of the elements, 'sacrifice' is used of the unconsecrated bread and wine, which are called 'likeness of his body and blood' before consecration.

iv. Chrysostom.

His writings contain outlines of the use at Antioch, in which the following words occur, paving the way for enhanced doctrine and ritual :-

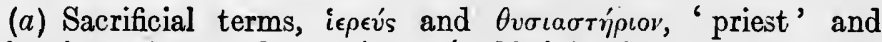
'altar,' are in use, but $\tau \rho a ́ \pi \epsilon \zeta a$, 'table,' is also used.

(b) The Holy. Spirit is invoked to "come and touch the gifts lying before Him, that grace may fall on the sacrifice, and through it kindle the souls of all.'

v. Syrian practices. $\dagger$

From the fifth to the eighth century the following liturgical changes came into use :-

(a) Lessons confined to Epistle and Gospel.

(b) Creed recited.

(c) In narrative of institution, ' and confess His resurrection' added to 'show His death.'

(d) Invocation of the Holy Spirit to come 'on us and on the gifts' to 'hallow and make this bread the holy body of Christ and this cup the precious blood of Christ,-that they may become to those who worthily partake by faith, for remission of sins, for life eternal, and for a guard of soul and body.'

(e) 'Unbloody Sacrifice '-

(f) Elevation of the bread.

(g) Burning of unconsumed bread and wine.

* As translated in Encyclop. Britann. The writer of the Article affords an instructive illustration of the way in which inference; can be drawn from such devotional passages, which would be repudiated by their Authors : 'Here the bread and wine become by consecration Tenements in which the Word is reincarnated as he aforetime dwelled in flesh. They cease to be now likeness of the body and blood, and are changed into receptacles of divine power and intimaey, by swallowing which wo are benefitted in soul and body.' Proof will be forthcoming from the Fathers of later centuries than the fourth that such ideas as ' reincarnation,' 'tenements,' and 'receptaeles,' and 'ceasing to be bread and wine' would have been quite unintelligible in the reputed period of this work.

$\dagger$ Extracted from various writings by Brightman, Liturgies Eastern and Western. 


\section{vi. Byzantine practices.}

The following are stated to be earlier than 600 :-

(a) Incense is used, possibly only as a fumigatory.

(b) Ritual bringing of bread and wine 'to the holy altar' (' table,' however, still used).

(c) The words 'showing to God' introduced.

(d) Eating and drinking the unconsumed bread and wine.

The justifiable conclusions to be drawn from the contents of these 'Early Liturgies' are that :-

(a) The earliest are the simplest, both in ritual and devotional language.

(b) Remembrance, Spiritual Feeding, Thanksgiving, and Fellowship, are still the explicit teaching of the rite.

(c) Faith is still the means of receiving: Baptism, Holiness, Charity, the qualifications for being present.

(d) The connexion of forgiveness of sins with the rite is becoming obscured, the rite itself being treated as a cause of forgiveness, instead of a thanksgiving for forgiveness.

(e) Sacrificial terms are assimilating the simple commemorative Feast of 'the Upper Room' to the Jewish and Pagan Sacrifices around, a process hastened by the influx of nominal Christians after the outward adhesion of the Emperor Constantine to Christianity.

$(f)$ Mystery, in the modern sense of the word, is becoming attached to the bread and winc after consecration, and the practice of hedging the rite around is cultivated.*

(g) To justify the mystery, the Lord's simple thanksgiving for God's gift of food is dropped for invocations, varying in form and wording, but all asking for some effect upon the elements themselves. $\dagger$ The effect of this change is various: the Holy Spirit displays, shows, the bread to be the body (Clementine): makes the bread the body (Cyril ?) : touches the gifts that grace may fall on them (Chrysostom-Antioch): hallows and makes the brcad body (Syrian) : while, in Egypt, the holy Word is the agent by Whom the bread becomes the body of the Word (Serapion).

(h) Such language, apart from the unscriptural invocation and its implications, docs not necessarily convey any change in the elements save for use; there is, as yet, neither a reasoncd literal identification of the brcad and wine consumed with the

* Even so early as Tertullian the idea had ariscn of comparing the Lord's Supper to the Eleusinian mysteries, but it is perhaps unfair to him to press his comparison far.

$\dagger$ It will be remembered that the 1549 B.C.P. contained an invocation of the Holy Spirit and the Word, which was expunged in 1552. 
body and blood of Christ, nor a sacrifice by the priest for the remission of sins apart from communicating, save that in the latter case, the idea of offering for the dead, who could not partake, logically leads to the idea of benefits obtainable by the living, through non-communicating attendance at a sacrifice.

\section{Patristic Literature.}

It remains to quote typical passages from the early Fathers containing their reasoned teaching upon the Lord's Supper. Here two all-important preliminary observations must be made :-

(1) The language of devotion is to be interpreted by that of doctrinal statement, and not vice versâ; cf. for example, the relation of the B.C.P. Baptismal Service to the Catechism and Articles.

(2) One indisputable passage by an author declaring certain language to be figurative, stamps as figurative any number of uses of such language by that same author, unless he himself states that he has altered his mind; e.g. an astronomer's book on the Solar system is not to be explained away by his use of the words 'Sunrise' and 'Sunset,' however often used and used without explanation, once he has committed himself to the Earth's motion as the cause of Sunrise and Sunset.

The following passages will suffice :-

(1) Tertullian (early in third century): 'The bread, taken and distributed to the disciples, He made it His own body, by saying, This is my body, that is the figure of my body' (Adv. Marc. iv. 40).

The stock reply to such passages as this, in Origen as well as in Tertullian, is that these teachers were heretics, though Muratori tries to get rid of the obvious force of the above-quoted passagc by interpreting it as meaning that bread was a figure of Christ's body in the Old Testament! This exegesis needs no answer ; the question of heresy opens a very wide field. There were heretics, there were also refutations of heresy, in very early days, but neither Tertullian nor Origen was charged with heresy on the point in question. On the contrary, Tertullian and others refuted such heretics as the Docetæ, and that by citing figurative representation of the Lord's body in the Lord's Supper: 'There could not however be a figure, unless there were a body of truth ; nay, an empty thing, a phantasm, cannot take a figure,' see, for other examples, Dimock, Eucharistic Worship, pp. 61, 62.

(2) Augustine (354-430): " for the Lord did not hesitate to say, This is my body; when he was giving a sign (signum) of his body' (Contra Adimant., xii. § 3). This passage occurs in a 
proof that the word ' is ' in "The blood is the life" does not convey literal but figurative identity, 'that Rock was Christ' being quoted as illustrative, and reference being also made to Christ's mercy in inviting Judas 'to the banquet, in which He commended and delivered to the disciples the figure of His body and blood.' *

In view of the frequent teaching that "the Word was made flesh' is to be understood as parallel to 'This is my body,' Dr. Harrison's words (Answer to Pusey, pp. 398, 399) should be weighed: "No orthodox Father ever said of the phrase "The Word was made flesh," "that is, a figure of the flesh" . . . No orthodox Father ever affirmed that "St. John did not hesitate to say, The Word was made flesh, when he meant a sign of his flesh." " There is a true parallel to 'This is my blood' in 'I am the true vine,' and numerous parallels can be cited, from Clement of Alexandria to Ambrose, and from later writers still, where the Lord's words in regard to the wine, and of Himself as the vine, are brought into closest juxtaposition as explaining one another (Harrison, ibid. pp. 395-8). $\dagger$

(3) Augustine, De Doctrina Christiana, iii. 16, commenting on the words, 'Except ye eat the flesh of the Son of Man, and drink His blood, ye have no life in you' : 'It seems to order a crime or an outrage : it is therefore a figure, commanding us to share in the Lord's Passion, and to store in our memory sweetly and usefully, that for us His flesh was crucified and wounded.'

Though the words of Scripture commented upon are not regarded, even by many Roman writers, as directly bearing upon the Lord's Supper, yet these latter admit that Augustine's comment makes their view of the identity of the consecrated elements with the body and blood of Christ " a crime or an outrage' (facinus vel flagitium). The argument is precisely the same for the words 'This is my body,' 'this is my blood,' if they be interpreted of any presence of Christ's body given for us and His blood shed for us, in, under, or with the consecrated elements. The straits to which these words of Augustine have reduced adherents of a 'Real Corporal Presence' may be gathered from the following facts :-

i. Paschasius, whose name marks an epoch in the development

* For similar tcaching in Ephrem, Procopius, Jerome, see Dimock, ibid. pp. $70 \mathrm{ff}$.

$\dagger$ Yet Frere writes (New History of B.C.P., p. 431): 'the Church at once ... gave a quite different interpretation to the statement "This is my body,' from that which it gave to such parallel statements as "I am the vine," 'etc. 'This statement is made without any allusion to the more than twenty quotations from Patristic literature to be found in IIarrison, Dimock, etc., where the latter phrase is quoted to illustrate the former. 
of mediæval doctrine, could only say, in reply to Frudegard's citation of this passage, that if any one believed it (the Lord's saying) to be so a crime as they then believed it to whom $\mathrm{He}$ said (the words) ... says that this flesh and this blood are themselves so to be taken without mystery and sacrament, not partly in figure, ... being carnally understood carnally destroys the whole, and so therefore perhaps the blessed Augustine says that so to understand this is a great crime. This halting attempt at explanation, with its admission of 'partly in figure,' and its consciousness of insufficiency, ' has probably,' to quote [Harrison, 'never been repeated, and is beneath notice.'

ii. De Villiers published in $\mathbf{1 6 0 8}$ an edition of the works of Fulbert of Chartres, who quoted with approval the words of Augustine. Confronted with the problem of dealing with so unequivocal a condemnation of the then received doctrine, de Villiers adopted a solution which sufficiently shows what he thought Augustine's words to mean. He interpolated dicet horeticus, 'a heretic will say,' thus making Fulbert put St. Augustine's words into the mouth of a heretic! The interpolated words were certainly not in Petavius' MS. of Fulbert, which de Villiers was using, and their insertion is certainly not excusable as a 'typographical' error. The day of such interpolating without risk of detection having passed, in the list of Errata at the end of the book, amongst genuine errors which are one and all of the usual kind found in printed books, comes the statement that the interpolated words are not in Petavius, while to save the situation is added 'the interpretation is mysterious,' interpretatio est mystica. Nor is this all ; subsequent reprints of Fulbert's Works, right down to Migne's Patrology, reproduce the interpolated words, with de Villiers' note from the Errata; this suggestio falsi being the only way of getting rid of Augustine's * plain condemnation of the Corporal Presence.

iii. Pusey, in 400 pages of quotations from the Fathers, containing one from the same little treatise of Augustine, omits all reference to this passage, one of the best known, and quoted in Eucharistic controversy from the days of Bertram and Paschasius. Perhaps this omission is more significant than any comment.

(4) Cyril of Jerusalem, if the Catechetical Lectures be his, may supply another illustration, different in kind, of the absence in the early Church of later mediæval ideas of the meaning of the

- For a full account of this strange procedure, see Dimock, Ritual, 1910, Edn., pp. 69-80, and for similar treatment of Chrysostom, Eucharistic Worship, pp. 105-112, of Elfric (c. 1000), Ibid. pp. 122-129. 
Lord's Supper. In Catech. Myst., v. 21, 22, occurs the following instruction: "When you draw near do not come with your palms wide open or your fingers apart, but making your left hand a throne for the right, as about to receive a king, and making your palm hollow, receive the body of Christ, saying Amen ; and when you have with care sanctified your eyes with the touch of the sacred Body, receive.' The directions for the wine are even more elaborately superstitious, viz. to apply the hands to the moisture on the lips, and with the mojsture to sanctify eyes, forehead, and 'the rest of the organs of sense.'* Dimock, Eucharistic Worship, p. 53, records similar practices, e.g., wearing of the sacrament as a preservative against perils by land and sea, giving the consecrated bread to the dead, using it as a plaster or poultice, St. Basil's desire that a part of the sacrament, which he had waved over the altar, should be buried with him, use of the consecrated wine mixed with ink for solemn documents, etc. Roman divines recognize that such practices, though significant of a growing superstitious regard for the consecrated elements, are quite incongruous with any belief in their identification with the body and blood of our Lord ; Muratori says they are 'too little in conformity with the institution and majesty of the Eucharist.'

(5) Cyril also supplies a valuable commentary upon the language of his time in regard to the invocation of the Holy Spirit, Catech. Myst., iii. 3: 'for as the bread of the Eucharist, after the invocation of the Holy Spirit, is no longer simple bread, but body of Christ, so also this holy oil is no longer bare, (i.e. mere oil), nor as one might say, common, after invocation, but grace of Christ and of the Holy Ghost, becoming full of power by the Presence of His Deity.' The use of such language for the Chrism, or oil for anointing in baptism, is illustrative of the universal custom of applying the same dignity to the things connected with Baptism as to those connected with the Lord's Supper. Indeed frequently they are identified : ' each one of the faithful is then made a partaker of the body and blood of Christ, when in baptism he is made a member of the body of Christ': so Fulgentius, referring for his authority to Augustine's words: 'If therefore ye are the body of Christ and His members, the mystery of yourselves is placed upon the Lord's Table; ye

* Dowden, Further Studies, p. 230, whose translation is used above, adds a not unmerited rebuke of the widely prevalent attempt in the Chureh of England to ereate a rule out of part of Cyril's directions : ' we are only too familiar with the practice of eiting from the Fathers only the si.ippets which make for one's own notions.' Cf. also Dimock, The Doctrine of the Lord's Supper, p. 12. 
receive the mystery of yourselves.'* Such passages could not occur in writers who held the bread and wine to be literally the Lord's Body and Blood.

The force of these five quotations, which could be multiplied indefinitely, is nevertheless absolutely independent of their number. Though, it is not contested that extravagant language and unscriptural terms were freely employed at an early date to describe the Lord's Supper, yet it is contended that its very extravagances were inconsistent with the doctrines the rise of which will occupy the following section.

\section{Mediæval Doctrinal Pronouncements.}

' The very body of the tree-or rather the roots of the weeds -is the popish doctrine of transubstantiation, of the real presence of Christ's flesh and blood in the sacrament of the altar (as they call it), and of the sacrifice and oblation of Christ made by the priest, for the salvation of the quick and the dead; which roots, if they be suffered to grow in the Lord's vineyard, they will overspread all the ground again with the old errors and super stitions.'

These oft-quoted words of Cranmer (True and Catholic Doctrine and Use of the Sacrament of the Lord's Supper) serve not only to indicate the exact task set him at the Reformation, but also to summarize the teaching whose development is now to be traced. It is unnecessary to recapitulate the tendencies which, appearing at a comparatively early period, enable the modern student of Church History to see the germs of the later completed sacerdotal system. $\dagger$ Suffice it to remark that there is no difficulty in understanding the process ; the difficulty is to trace it accurately. Judging by the experience of later centuries, it is most certain that popular extravagance of language and practice would precede anything like authoritative embodiment of such thing in doctrinal formularies, even as to-day the established doctrines of the Roman Church owe their origin to unauthoritative and unauthorized impulses on the part of individuals and communities. The popular cult unchecked, a time arrives when to check it effectually is only possible with a disturbance of the body ecelesiastic which those in authority seldom care to encourage; the alternative course is followed, viz., to adopt the cult and its implications, and to force it into some kind of apparent conformity with existing institutions.

* Harrison, Vol. ii. pp. 175, 176 ; cf. Vol. i. pp. 161 ff. for other refer. ences.

$\dagger$ For words as early as Justin, Tertullian and Origen, capable of being usel to support later theories, besides those given above, see Dimock, Doctrine of the Lord's Supper, pp. 49, 50. 
A superstitious regard for the elements began at an early date; under its influence they gradually ceased to be symbols and signs by the faithful reception of which "they be certain sure witnesses, and effectual signs of grace'; the invocations of the Holy Spirit upon them naturally paved the way for conceptions of some miracle wrought in them whereby the benefits attaching to their reception were obtained. The region of surmise is left for that of definite fact at four chief periods, two marked by the names of John Damascene and Paschasius, two by those of Fopes Hildebrand and Innocent III.

\section{(1) John Damascene and the Augmentation Theory.}

John Damascene entered history as the champion of images against the Byzantine Emperor Leo, c. 730, whose attempts to stem the advancing tide of revolting image-worship were opposed by Patriarch, priests, monks, and people, together with the Popes, Gregory II and III. Leo's son, in 754, summoned an Ecumenical Council at Constantinople, at which the 350 bishops present, (Rome sending no legates), sweepingly condemned image-worship, whereupon Pope Stephen III, in 769, retorted with 'a dreadful anathema' against all opponents of images.* In the Council's desire to attack images, it refers to the Lord's Supper, stating that Christ 'ordered the substance of bread to be offered, which does not resemble the form of man, lest idolatry might be dragged in, no other form or type being chosen by Him, as able to represent His incarnation": this alone is "the God-given image of his flesh .... the true image of the incarnate dispensation of Christ our God.'

In 787, under an Empress favouring image-worship, another louncil was called, which ranks as the Ecumenical Second Council of Nicæa, the Pope being represented. It included some bishops who were present at the now disowned Council of 751 , but they all denounced as unscriptural the idea of the bread being an image of Christ's Body : 'it is manifestly evident, as regards the unbloody sacrifice offered by the priest, that nowhere is it called an image or type, by the Lord, or by the Apostles, or by the Fathers, but the Body itself, and the Blood itself.' They adopted the teaching of John Damascene, (who appears to have died between the time of the two Councils), that when the word ' antitype' $\dagger$ was used of the elements by the Fathers, it referred to the unconsecrated elements. The falsity of this

* For fuller details see Dimock, Ritual, 1910 Edn., pp. 81 ff.

$\dagger$ The word 'antitype' has changed its meaning. In IHeb. ix. 24, 1 Pet. iii. 21, tr. A.V. 'figure,' the old meaning remains, viz. the earthly counterpart of a heavenly reality. Such is the meaning here. 
idea is now universally admitted; the Fathers did frequently call the consecrated elements antitypes. The Council further declared, by the way, that 'if it is an image of the body, it cannot be the Divine body itself,'-a declaration the truth of which condemns all the rest of their Eucharistic pronouncements.

The doctrines enunciated by these two Councils exemplify two separate stages of advance in sacerdotal ideas since Augustine's time. According to the former, the elements themselves, apart from their use, though called an image or 'icon,' represent the Incarnation in some sort, and some kind of divine wonderworking produces the representation,-it is no mere choice of a figure: "the Master Christ, as $\mathrm{He}$ deified the flesh, which $\mathrm{He}$ took, by His own natural sanctification and by the union itself, so $\mathrm{He}$ was well-pleased that the bread of the Eucharist, as a true image of the natural flesh sanctified through the visitation of the Holy Spirit, should become divine body.' The second Council did not find fault with these words, but exchanged their comparative indefiniteness, and susceptibility of interpretation in a figurative manner, for an argument which left no room for misapprehension; the 'unbloody sacrifice' is no image but 'the body and blood of Christ': figurative explanation is expressly excluded.

But this did not mean any theory of transubstantiation; the language is explained by the teaching of John Damascene in his De Fide Orthodoxa, IV. xiii. Again the caution must be added that this is but a formal enunciation of ideas suggested by very early language, and anticipated by John's predecessors in 'doctrinal theology.* Anastasius of Mt. Sinai, a century earlier, was, according to Waterland, 'the first, or among the first, that threw off the old distinction between the symbolical and true body, thereby destroying in a great measure the very idea of a sacrament.' Anastasius said : 'So we believe, and so we confess, according to the voice of Christ Himself-this is my body-He

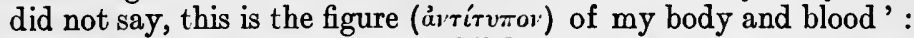
anticipating the very language of John, and of the Second Council of Nicæa. John's words are also those of the Council : 'God forbid' (that any one should think bread and wine to be types) they are 'the very deified body of the Lord.'

The history of Eucharistic doctrine from this period onwards is really a history of the modes of interpretation of the supposed miracle wrought by consecration. The Second Council had established the doctrine as an article of the faith, subsequent.

* For a catena of passages see Dimock's Doctrine of the Lord's Supper: Appendix on the Augmentation Theory. 
theological speculation could only supply theories to obscure the contradiction between what the bread and wine obviously are, and what this dogma asserts them to be. In this enterprise, which might seem to be an impossible one, they were greatly aided by the apparently pious conception that the greater the impossibility to be believed, the more meritorious the credulity which accepted it, -credo quia impossibile-an idea not without meaning, indeed, as affirming the reasonableness of what transcends human experience, if there is reasonable ground for trusting the Revealer, but an idea fatal to purity of faith, if applied to any revelation less than infallible, that is, Divine.

Waterland reduces the theories roughly to five :-

1. The elements literally become the same personal body.

2. The elements contain the same body.

3. The elements become another personal body.

4. The elements contain another personal body.

5. The elements are or contain a true and proper body of Christ, distinct and different from a personal body.

The enumeration of these shades of distinction clearly demonstrates the difficulty immediately felt when the typical interpretation of Holy Scripture is abandoned ; for these theories antedated the enunciation of transubstantiation.

In John Damascene's teaching, often called the Augmentation Theory, the following points are noteworthy (the translations are strictly literal) :-

1. 'The bread and wine are changed into body and blood of God.'

2. 'The Holy Spirit visits, and does these things which are above reason and thought.'

3. 'But the mode is unsearchable,' yet as a parallel is cited the process by which food becomes man's body and blood, not another different body from that before possessed ; so "by the invocation and visitation of the Holy Spirit' the bread and wine 'are marvellously changed' into Christ's body and blood-' and are not two, but one and the same.'

The difference between this and the later extravagances of Eucharistic theory is plain; there is here no teaching of the same body being on ten thousand altars at once; the bread becomes body, indeed, but by being incorporated into Christ's body through the operation of the Holy Ghost. In the Augmentation Theory the word ' body' in Christ's words is adjectival : 'This is my body, but not all of it': it was left for later teaching to make the words an outrage upon common reverence and common sense by asserting that whole Christ, and the same 
Christ who is in Heaven, is in every particle of the bread, and every drop of the wine. Nevertheless the language of the Augmentation Theory is often scarcely distinguishable from that of Transubstantiation; in the West, where not the invocation of the Holy Ghost, but the priest's recital of the words of institution, was the míracle-working agency, and there was therefore even greater room for superstitious development, that theory soon paved the way for further grievous error.

In Waterland's words * : 'Before the end of the ninth century the Eastern innovations, introduced by Anastasius and Damascene, and established by the Nicene Council, spread far and wide, both among Greeks and Latins. ... The old notion of - a sacrament, as importing a sign and a thing signified, wore off apace, and now all the care was how to make out that very body and blood, by some subtile evasions, or newly devised theories.' Such a departure was bound to end in 'blasphemous fables and dangerous deceits,' both in East and West, $\dagger$ and the first fatal step was taken in attaching to the elements what Holy Scripture only promises to the faithful recipient. It is not necessary, it is not any use, that the bread should become the Lord's body in order that the partakers may partake of the Lord's body; the incorporation of a fragment of miraculously changed bread into the physical. system can only be deemed of any worth whatever, by those who are sadly ignorant of the meaning of partaking of Christ's slain body and shed blood. Such literature is indeed 'a crime and an outrage' in Augustine's words already quoted.

(2) Paschasius.

That advances in the direction of further corruption were generally slow, and not by leaps and bounds, is excellently shown by the very tardy growth of anything like direct worship of the consecrated elements. Adoration of the Host, for example, was still unknown in the early part of the ninth century, $\ddagger$ though it seems one of the first natural deductions from the Augmentation Theory. However, with the appearance of Paschasius' work, De Corpore et Sanguine Domini, written 831, but published

* Works, Vol. v. p. 204.

† In the regular Syriac Liturgy, whether older or more recent than the official promulgation of the Augmentation Theory, occur these words amongst the private prayers of the priest before reception: 'Grant me, 0 Lord, to eat thee holily,' 'I hold Thee, who containest the ends of the world; I have Thee in my hands, who rulest the deep; Thee, God, I place in my mouth.' (From Freeman's Principles of Divine Service, Vol. ii. part i., p. 182, where something similar, though not so terrible as the last, is stated to exist in the anolont Fnglish User.)

\$ See Dimock on Agobard, in Eucharistic Worship. pp. 219-224. 
some years later, a change began which marks a new epoch. The teaching of Paschasius, though not without its antecedent causes and subsequent modifications, is substantially the teaching of the Church of Rome to-day. It has been often noted that the development of the Roman doctrine of the Real- Presence runs more than parallel with the development of the Papal system, and that in both the three stages of development coincide. The notorious False Decretals, a product of this period, embodied Paschasian doctrine, and the two works have been described as twin births of the same conception of the Ecclesiastical mind.* The next stage was that of Gregory VII (Hildebrand), 10731085, who also appealed to a forged document to establish his power, and in whose pontificate the condemnation of Berengarius established the Paschasian doctrine. The third stage saw Transubstantiation promulgated at the Fourth Council of Lateran, (1215), by Innocent III, whose aims at aggrandizement were furthered by the shame'essly interpolated Decretum of Gratian. $\dagger$ This very noteworthy concomitance is not produced to foreclose inquiry, but to suggest an explanation of the way in which Paschasian and ultra-Paschasian dogmas triumphed over the opposition of the most learned theologians of the time, and over the common sense of the very Popes themselves.

Paschasius' doctrine differs from that of John Damascene in substituting for the latter's augmentation theory unmistakable teaching of the change of the bread and wine into the very flesh and blood which were born of Mary and hanged upon the Cross. Comparing the miracles of feeding, he says : 'for from the very blessing of Christ such great abundance remains, and what was eaten and what laid aside was not anything else than the five or seven loaves themselves. How much more therefore (for the Word was made flesh) the flesh of the Word produces, and the abundance of Christ and His blood flow in the Sacrament. And there is no other than flesh of Christ, and yet Christ remains whole.' $\ddagger$ Such passages are frequent. Paschasius bolsters up his theory by the citation of miracles, such as the appearance of the consecrated bread in the form of a lamb. One pious priest prayed that he might see what was the appearance (species) hid under the form of bread and wine, and was rewarded with the vision of the Child Christ on the altar, afterwards partaking

* Greenwood, Cathedra Petri.

+ For details see Dimock, Romish Mass and English Church, pp. 63 ff.

\pm Tr. in Harrison, Dr. Pusey's Challenge, ii. p. 314; here and in Vol. i. Chaps. viii., ix., will be found full details of Paschasius' teaching, with its curious anticipation of some modern equivocations in the use of the words 'spiritual,' ' sacramental,' ' mystical,' etc. 
of the Sacrament, but ' not before it returned into the outward appearance of its prior form.'

More : wonderful than the compiling of such a farrago is its triumphant spread against all the learning of the day. Rabanni Maurus and Bertram were amongst the more famous opponents, the latter writing specifically to oppose Paschasius' teaching. Odo, Archbishop of Canterbury, is said to be the only tenth century author who publicly declared himself on the Paschasian side. It is now the fashion to maintain that Bertram did not really differ from Paschasius; this opinion was not held when Bertram's work was prohibited by Clement VIII, placed in the first class of heretical writings in 1559, denounced as a forgery of Ecolampadius by Poissevin the Jesuit, and stated by Bellarmine to be the work of the chief opponent of Paschasius. Referring to the ominous inactivity of Popes Nicholas I and Adrian II in regard to the controversy, L'Aroque says they saw 'that the belief of the enemies of Paschas was a belief publicly received by all the world-in France, in Germany, in England, and elsewhere; and, moreover, approved by the most learned men of the age, publicly vindicated by writings, supported by the authority of the most eminent princes and prelates ... it cannot be said but these Popes had credit and power enough to have opposed themselves.' Is this tacit papal support a partial solution of the mystery of this triumph of error over truth?

\section{(3) Hildebrand, Gregory VII.}

Two centuries later than Paschasius, the dogmas associated with his name were almost, but not quite, triumphant. Berengarius of Tours, the friend of Hildebrand (afterwards Pope Gregory VII), wrote a famous letter to Lanfranc in 1049, reproaching him for maintaining Paschasian doctrine, and appealing to Scotus and the Doctors of the Church. This letter was read in a Synod at Rome in 1050, and Berengarius was excommunicated and summoned to appear at a Synod. Being at the time in prison he could not appear, but was condemned in his absence. Two more condemnations followed in 1051 ; in 1054 a Council was arranged to be held at Tours under Hildebrand as Papal Legate, but the illness of the Pope, Leo IX, and Hildebrand's consequent departure for Rome, saved Berengarius for the time. In 1059, under Pope Nicholas II, he appeared and had to give way, signing the famous Ego Berengarius declaration. How far Western Christendom had travelled in the direction of Paschasian materialistic doctrine regarding the Lord's Supper, could hardly be better illustrated than by this repeated condemnation of the 
'apostle' of the patristic teaching, culminating in his being forced to sign the following declaration :-

' I, Berengarius .... with mouth and heart profess myself to hold ... that the bread and wine which are placed on the altar are after consecration not only a Sacrament but also true body and blood of Our Lord Jesus Christ : and sensibly (sensualiker), not only sacramentally but really, are handled and broken by the hands of the priest, and ground by the teeth of the faithful. ....'*

Berengarius had yielded to force, but had not altered his mind. Returning to Tours, he answered a treatise by Lanfranc with another still extant. Pope Alexander II was content to give him a friendly warning, but at the Council of Poictiers, 1075, he hardly escaped with his life. At last, at Rome in 1078, Hildebrand, now Pope Gregory VII, and personally averse from the Berengarian controversy, in which his personal beliefs must have been on the 'heretic's' side, as certainly his policy of personal aggrandizement was on the other, instead of reinforcing his predecessor's condemnation of Berengarius, addressed the following words to him : 'I certainly do not doubt thou dost think well concerning the Sacrifice of Christ according to the Scriptures; however, because it is my custom to have recourse to the Blessed Mary concerning those things which move me, I directed a certain " religious" friend to pay attention to fastings and prayers some days beforehand, and so to obtain from Blessed Mary, that through him she would not be silent to me, as to whither I should betake myself concerning the business which I had on my hands concerning the Sacrifice of Christ, (for a position) in which I might remain unmoved. The "religious man" heard from B. Mary, that nothing was to be thought concerning the Sacrifice of Christ, nothing was to be held save what the authentic Scriptures contained, against which Berengarius was holding nothing.' It may well be imagined that this extraordinary action on the part of the Pope gave no satisfaction, except to Berengarius, whom he sent back to Tours with great honour. Cardinal Benno's comment is : 'He commanded a fast to the Cardinals, that God might show who was right in his opinion concerning the body of the Lord, the Roman Church or Berengarius ;-(he who is) dubious in faith is unfaithful.' Egilbert's is: 'Behold a true pontiff and a true priest who doubts if that which is taken on the Lord's Table be true

* To ebviate any ambiguity, the statement is repeated twice in the declaration, once as opposed to Berengarius' teaching, onee as above translated. For the whole story see Harrison, ibid. i. 219 ff. Dimock, Ritual, pp. 98 ff. 
body and blood of Christ': that of the Council of 30 Bishops at Brixen is (1070): "putting in question the Catholic and Apostolic faith concerning the body and blood of the Lord, an old disciple of the heretic Berengarius.' This last comment was directed against Gregory's contentment with the very hazy declaration now signed by Berengarius, of which it has been said that "The doctrinal exposition of Pope Gregory and the Roman Council would have satisfied any of the reformed denominations.' * This was in 1078 ; in 1079 Berengarius had to sign another confession, acknowledging that the elements are substantially changed into the Real Body and Blood of Christ, a confession which he speedily rejected.

The opinions of Berengarius lived on, though in influential quarters they were either abandoned or concealed. The Council of Plaisance, 1095, had to condemn them; Abelard, in the twelfth century, still regarded the question as under discussion; St. Bernard's views are doubtful, but even after the Fourth Lateran Council the University of Paris had to defend itself from a charge of similar heresy. In fact it is impossible to believe that learned students of Holy Scripture and the early Fathers could fail to hold such opinions, however reluctant they might be to take the stand of a Wycliffe. Nevertheless there is no question as to what was the 'orthodox' opinion of the time; the teaching of Paschasius had ripened to that extent that the formation of some doctrine of Transubstantiation could not be long withheld.

(4) Innocent III.

The Fourth Lateran Council, 1215, which decreed the death of heretics, the suspension of allegiance to princes who would not punish heretics, and compulsory confession to a priest, also declared Transubstantiation to be an Article of the Faith. Transubstantiation is the climax of the attempts to explain the obvious contradiction involved in any theory of a change in the consecrated elements; they are not changed-the bread remains bread, and the wine remains wine. Physical explanation being, therefore, impossible, recourse was had to metaphysics, and the Realistic philosophy of the Schoolmen supplied what was wanted. By that philosophy material things were supposed to consist of 'substance' and 'accidents,' the 'substance' being the thing itself, the 'accidents' the qualities of the thing, supposed to inhere in the substance. Bread, for example, would consist of a substratum which may be called 'breadness'; its colour, size, weight, and everything knowable about bread being 'accidents' inherent in the subs'ance. In consecration

* Edgar, Variations of Popery, p. 7. 
the substance of 'breadness' disappeared, being exchanged for 'fleshness,' * the 'substance' of Christ's body; while the accidents remained unchanged. The philosophy is now obsolete, but it served its turn, and just as the papal system survives the discovery that its historic bases were forged and false, so the Roman Eucharistic doctrine survives the exposure of its false philosophy.

It should be at once stated that there is a considerable doubt as to whether Transubstantiation was the work of the Council at all. Innocent III, in whom the papacy attained to its greatest height of absolute power, was not much concerned about the views of those whom he called to his Councils. Bishop Cosin says the Canons of the Fourth Lateran Council are simply the Pope's Decrees, "written by him, and read in the Council, and disliked by many, and afterwards set down in the Book of Decretals, under certain titles, by his nephew Gregory IX.' Dimock says: 'Transubstantiation was hardly regarded as an Article of the Faith before the Council of Trent. How else is it to be accounted for, that Peter d'Alliaco speaks of it as the general opinion of the Doctors (which he therefore embraces), but as no necessary inference either from Scripture, or, as it seems to him, from the determination of the Church ?' +

An instructive indication that 'Transubstantiation was known at the time to be an advance upon previous teaching, and dangerously out of keeping with much of it, is afforded by the Decretum in Gratian, in its record of the 'Ego Berengarius,' already quoted above. There the following gloss appears, from the hand of John Semeca, of Halberstadt, written about 1215: 'Unless thou wisely understandest the words of Berengarius, thou wilt fall into a greater heresy than he himself was (in). And therefore thou shouldst refer all things to the species themselves.' In other words, the doctrine of Transubstantiation, with its separation of substance and accidents, was formulated largely to disprove literal grinding with the teeth of the very flesh of Christ, which Berengarius was forced to approve! The Schoolmen could admit the teaching that Christ's human body was at the same time on earth in many places and in heaven-with the adverb 'sacramentally' thrown in as a salve to their outraged intellects, + -but they could not allow the idea that that human

* This word is used as a pis aller ; in fact the Roman teaching is that not only 'body,' but also 'soul ' and 'divinity' are in the transubsta ntiated bread. It is impossible really to reconcile this oven with the exploded philosophy on which it is based.

† Cosin, Works, Vol. iv. p. 222; Dimock, Romish Mass, p. 71.

\$ So Aquinas : but Bellarmino confutes it. Jeremy Taylor, Real Pre- 
body of Christ is continually being wounded and torn by the teeth of the faithful. How could the invisible, intangible, imperceptible 'substance' be seen or touched? In fact they agree :so far with Berengarius' real belief, and not with what the Council compelled him to say.

It is not possible here to enter into the many contradictions involved in the new doctrine of Transubstantiation, nor is it necessary, for the story of their confutation is the story of the English Reformation. Yet it is worth while to conclude this section with a brief notice of some of the more fundamental absurdities of the doctrine.

(1) The manifest absurdity of the separation of 'substance' and 'accidents' led to the practical test-question: are the ' accidents' of bread and wine able to nourish the body, though no 'bread-ness' and no ' wine-ness' remain after consecration? Some early Schoolmen, logically enough if transubstantiation were true, denied the nourishing power of the 'accidents,' but logic had to yield to facts, and the later teaching admits the nourishing. Various have been the attempts to define what does the nourishing, for certainly shape, colour, etc., are not articles of food. The futility of all such attempts is clear; unless the 'accidents' are stretched to include all that makes bread ' bread,' unless in fact the distinction between 'substance' and 'accidents' is abandoned, the nourishment is an insoluble problem.

(2) What really happens to the accidents? The Catechism of Trent teaches that: "Since those " accidents " cannot inhere in the body and blood of Christ, it remains that they sustain themselves resting on no other thing, above all the order of nature ... this was the perpetual and constant teaching of the Catholic Church.' Yet the Fathers not only asserted that accidents could not exist without their substance, but confuted heretics on the strength of that argument.* The statement of the doctrine is its best refutation, cf. Cranmer : "although all the accidents, both of the bread and wine, remain still, yet, say they, the same accidents be in no manner of thing, but hang alone in the air, without anything to stay them upon .... in the bread and wine, say they, these accidents cannot be, for

sence, xi. $\S 21$, is worth quoting on this point: ' $I$ might make advantage of this contestation between two so great patrons of transubstantiation if $I$ did need it, for AqL as says that a body cannot be in two places at once locally, Bellarmine says then neither can it be sacramentally; it were easy then, to infer that therefore it is in two places no way in the world.'

* Stillingfleet, Doctrine of the Trinity and Transubstantiation compared, pp. 23-27. 
the substance of bread and wine, as they affirm, be clean gone. And so there remains whiteness, but nothing is white; there remaineth colours, but nothing is coloured therewith; there remaineth roundness, but nothing is round ; and there is bigness, and yet nothing is big; there is sweetness without any sweet thing; softness without any soft thing; breaking without anything broken; division without anything divided.'*

(3) Where is now the literal interpretation of the words 'This is my body'? To Transubstantiation it means : 'What you take and eat is my body in 'substance,' but all that you touch, see, handle, taste, etc., is 'accidents' of bread. You take and swallow substance of body, but you press accidents of bread with your teeth.' Surely, this congeries of absurdities reduces the so-called literal acceptance of Christ's words to a literal rejection of them, and to trace even briefly the steps by which such caricatures of the Lord's ordinance came into being, is to understand that the moving spirit of the Reformation was something quite other than a desire for political or intellectual freedom, namely a protest against the degradation of God and Man. $\dagger$

This section will fittingly conclude with some reference to the question of Sacrifice. The term had been applied to the Lord's Supper figuratively for many centuries; with the development of the Real Corporal Presence, a sister-dogma appeared, which changed its significance altogether. The sacrificial idea in some sort preceded any idea of transformation of the elements in consecration, as witness the remembrance of the dead, as benefitted by the sacrament in some undefined way; but the conception of a propitiatory offering for sin was not attached thereto. Justin Martyr, Tertullian, and Minucius Felix defended themselves against the charge of being atheists as having no sacrifices, by saying they had no need of any but spiritual sacrifices; Julian the Apostate (d. 363) found fault with the Christians because they had no sacrifices and no altars. Long after the importation of the idea of 'oblation' of the elements, there was still no real sacrifice pretended, though a perilous step had been taken. Eusebius, Jerome, and Augustine, are quoted by Jewel to repudiate the idea of any real sacrifice in the Early Church, save the 'spiritual sacrifices' offered by the whole body of the redeemed. $f$ Indeed, there could be no thought of the real

* Cranmer, Lord's Supper.

$\dagger$ As an illustration of the protest of the English people as a whole against the doctrine of Transubstantiation, may be cited the phrase 'Hocus-pocus,' used to describe juggling quackery of any kind, yet-sad to contemplate -drawn from the Latin of our Lord's words of institution! So low did Transubstantiation bring His Name.

‡ See Harrison, Vol. i. o. xii. $\S \S 133 \mathrm{ff}$. for abundance of proofs from lator authors. 
propitiatory sacrifice in the Holy Communion, until the dogma of a Real Corporal Presence had taken shape. The Conception of a sort of dramatic representation of Calvary, due to a misunderstanding of Holy Scripture, (a misunderstanding which still finds place in the hymnology of the Reformed Churches) is quite confessedly remote from a real sacrifice, which could only follow the acceptance of Paschasian teaching concerning the effect of consecration. When that teaching became prevalent, all was changed. Such additions as those to the Ordinal: 'Receive the power to offer sacrifice,' with the formal handing to the ordinand of paten and chalice : indicate the greatness of the change. Compelled to deliberate upon the matter at the Council of Trent, the Church of Rome set its seal to the dogma of Mass-Sacrifice, which for several centuries had dominated the popular mind to the virtual exclusion of 'Communion' in the Lord's Supper, by decreeing that there is a true and proper and propitiatory sacrifice in the Mass ; that they are anathema who say that the sacrifice is a sacrifice of praise and thanksgiving, a commemoration only of the Sacrifice of the Cross ; that in His Last Supper, Christ, showing Himself a Priest for ever after the Order of Melchizedek, offered His Body and Blood to God the Father under the species of Bread and Wine. Cranmer had been dead some years when this decree was issued, in 1562, but this authoritative statement sums up the sacrificial doctrine with which he and the Reformers had to contend, and against which the B.C.P., both in 1549 and 1552, was directed.

The decree demands a brief examination :-

(1) It enshrines a curious reminiscence of a serious division in the Council. The question arose: Did Christ offer Himself as a propitiatory Sacrifice to God in the Supper? If so, then why the Death upon the Cross? * If not, then how could any repetition of the Lord's Supper be a propitiatory sacrifice? The Council was very evenly divided, and every argument that could be brought to bear against the novelty of declaring that Christ offered Himself was brought by the one side, especially by the Bishop of Veglia, who almost won his case, according to Sarpi. However, the party which saw that to maintain the Mass-Sacrifice was essential to the preservation of the papacy, prevailed, and it was decreed that the Lord did offer Himself. Note, however, a most significant omission in the decree; the Lord's offering of His Body and Blood is not stated to be "propitiatory,' and the omission was designed. $\dagger$ Could there be a

* See Dimock, Romish Mass, passim, esp. pp. 5 ff. for fuller detail.

† See Dimock, ibid., p. 7, note 
clearer admission of the impossibility of reconciling the MassSacrifice with the Lord's Institution?

(2) The relation of the Mass-Sacrifice to the one Sacrifice once offered upon the Cross is another dilemma. The theory that the latter propitiates for original sin, the former for later sins, was repudiated by Rome itself with indignation. * It is impossible to attribute propitiatory efficacy to the Mass without detracting from the sufficiency of the Death upon the Cross, which Rome dare not do as yet, at least in so many words. 'Commemorative sacrifice,' 'Applicatory sacrifice,' and other such phrases, apart from their doctrinal inaccuracy, will not consist with the categorical wording of the Tridentine decree: 'true and proper and propitiatory.'

(3) The tangle in which the mind is involved becomes confusion worse confounded when such questions are asked as : What is sacrificed, and how is it sacrificed ? According to Bellarmine these questions can only be answered by assuming that Christ sacrificed Himself by first transubstantiating the bread into His very Body, and then by eating and so destroying His own Body.

(4) One last dilemma shall be noted. The Mass-Sacrifice is stated to be the one means by which the Sacrifice of the Cross is made available for the living and the dead. If so, what need of repeated masses, for the dead, at any rate? The soul is presumably made partaker of that perfect Redemption, yet it needs further applications! Well might the Reformers use the famous words of the Homily: 'We must take heed lest of the memory the Holy Supper be made a sacrifice.'

\section{Liturgical Products of the English Reformation.}

Though the appeal to Holy Scripture, and the recovery of the great doctrine of Justification by Faith, were as much the lever of the Reformation in England as elsewlfre, the specifis point chosen by Cranmer's unerring instinct for bringing Reforming principles to bear upon religious thought and life was the doctrine of Holy Communion. In his oft-quoted words denominating the dogmas of the Real Presence and Mass-Sacrifice as the roots of all Roman heresy, is enshrined the specific characteristic of the English Reformation. The displacement of the Sacrifice by the Communion, of the Corporal Presence on the Altar by the Spiritual Presence in the heart of the believer, governed the compilation of the B.C.P., and procured the death

* 'The attempt to interpret Art. XXXI as framed only against this theory of Mass Sacrifice is well-known; see Dimock, Blasphemous Fables and Dangerous Deceits. 
of the martyrs in Mary's reign. The martyrdom of John Frith in 1533, on account of his denial of the Corporal Presence, was the first indication of this becoming the crucial test of reforming tendencies. The enactment in 1539 of the Six Articles, upholding with terrible penalties Transubstantiation, Communion in one kind, and Private Masses, (in half the Articles,* therefore, opposing the Reformation in this specific doctrine), served both to prove the existence of opposition to Mass dogmas, and to identify reform with that opposition. Not only did Bishops Latimer and Shaxton resign their sees, but so many were those who refused to obey, that the penalties had to be modified. Henry's idea of reformation, i.e., merely independence of the Pope, was plain in the English Litany of 1544, where one of the petitions was for deliverance from the Bishop of Rome and all his detestable enormities, but the opposition to the Six Articles Act manifested the impossibility of stopping there.

With Ec'ward's accession, on January 28, 1547, things rapidly altered. On July 31 the first Book of Homilies appeared, and also Edward's first Royal Injunctions were issued, on December 20 the first Act of Edward's first Parliament ordered the priest to communicate with the laity, not by himself, and to administer to the laity in both kinds, while on December 24 a repealing Act got rid of the Six Articles Act. Yet the doctrine of the Holy Communion was not clear; a Royal Proclamation enjoined men to 'devoutly and reverently affirm that holy bread to be Christ's body, and that cup to be the cup of His holy blood, according to the purport and effect of the Holy Scripture'-words which might mean anything, according to the beliefs of those who interpreted them. The purpose of the Proclamation was to check irreverence due to rejection of the Mass-doctrines with no clear teaching to replace them, and for that purpose it would suffice. Images had largely disappeared by May, 1548. The order for communion in both kinds had been accompanied by the appointment of a committee to deal with the liturgical alterations needful, and the history of the doctrine of the Lord's Supper becomes one with the history of the liturgy, in which three dates are marked by liturgical productions :-1548, the Order of Communion ; 1549, Edward's First Prayer Book; 1552, Edward's Second Prayer Book.

(I) The Order of Communion, 1548.

This was an interim production, to be used at first with the

* Of the other three, Vows of Celibacy, Celibacy of Priests, and Auricular Confession, the last was closely eonnected with the Mass, and the othey two did not touch the life of the layman. 
Latin Missal, but afterwards incorporated in the 1549 B.C.P.* The contents were as follows :-

1. Exhortation - the first in 1662 B.C.P.

2. Rubric: "The time of the Communion shall be immediately after that the Priest himself hath received the Sacrament, without the varying of any other rite or ceremony in the Mass (until other order shall be provided), but as heretofore usually the Priest hath done with the sacrament of the body, to prepare, bless, and consccrate so much as will serve the people; so it shall continue still after the same manner and form, save that he shall bless and consecrate the biggest chalice, or some fair and convenient cup or cups full of wine with some water put unto it ; and that day, not drink it up all himself, but taking one only sup or draught, leave the rest upon the altar covered, and turn to them that are disposed to be partakers of the communion, and shall thus exhort them as followeth':

3. Second Exhortation-the third in 1662.

4. Warning to Communicants-made one clause of the first in 1662, ('If any man 'here be an open blasphemer,' etc.).

5. Rubric: 'Here the Priest shall pause a while, to see if any man will withdraw himself : and if he perceive any to do so, then let him commune with him privily at convenient leisure, and see whether he can with good exhortation bring him to grace : and after a little pause, the Priest shall say':-

6. 'You that do truly,' etc.

7. Rubric: "Then shall a general confession be made in the name of all those that are minded to receive the Holy Communion, either by one of them, or else by one of the ministers, or by the Priest himself, all kneeling humbly upon their knees':

8. The Confession-as in 1662.

9. The Absolution-as in 1662, save that it commenced: 'Our blessed Lord, who hath left power to His Church, to absolve penitent sinners from their sins, and to restore to the grace of the heavenly Father such as truly believe in Christ, have mercy upon you,' etc.

10. The Comfortable Words.

11. Prayer of Humble Access - as in 1662, with the addition of 'in these holy mysteries,' after 'drink his blood.'

12. Administration, first to Ministers, then to people, with the first part of the present words, save that instead of " body and soul,' 'body' was used alone in administering the bread, 'soul' alone in adminstering the wine.

* The important doctrinal and other differences from the present B.C.P. are noted later under the 1549 .B.C.P., in which the Order was inserted almost bodily. 
13. Rubric: "If there be a Deacon or other Priest, then shall he follow with the chalice, and as the Priest ministereth the bread, so shall he for more expedition minister the wine.' The bread is to be 'such as heretofore hath been accustomed; and every of the said consecrated breads shall be broken in two pieces at the least. ... A And men must not think less to be received in part, than in the whole, but in each of them the whole body of our Saviour Jesus Christ.' If the wine 'hallowed' is not enough, more is to be consecrated, the words of institution (in Latin) being used, " and without any levation or lifting up.'

This first instalment of reform, * avowedly temporary, exhibits the transitional nature of the doctrine held at the time. On the one hand, Gardiner expressed approbation of it, which he well might do, being able to interpret it by the Missal, still retained and used with it : on the other hand, the use of the English tongue, administration to the laity, and that in both kinds, with the order to break the bread for distribution, and the calling the consecrated elements 'bread' and 'wine' in the closing Rubric, marked a distinct advance, and promised still greater alterations. Cranmer's own position on the Lord's Supper was that of one groping towards fuller light. So far back as 1532 he had been lodging at Nuremberg with Osiander, whose niece he married, and whose Church Order was then being completed. The indebtedness of the B.C.P. to this work, in several particulars supposed to prove dependence upon Mozarabic and other Ancient Liturgies, suggests at least some influence on Cranmer. However, it was through Ridley that Cranmer's final doctrine of the Lord's Supper took shape, and, therefore, through the publication in 1532 of Bertram's Treatise against Paschasius. That work, unable to overthrow heresy at the time, bore fruit in later days, in a way of which Bertram could not have dreamed.

In May of 1548, the whole service was used in English, and, in the words of Dr. Gasquet: "It is clear that before September, 1548, services were already drawn up and in use, the main parts of which corresponded with those subsequently enforced in the Book of Common Prayer.' $\dagger$ This proof of the industry of the Committee appointed to provide the 'other order' of the Rubric quoted above from the Order of Communion, is supplemented

* Ordered to be used on Easter Day, April 1, 1548.

$\dagger$ Gasquet, 147 ; from Tomlinson's Great Parliamentary Debate, p. 7, a document of the utmost importance for the story of 1548 . 
by the report of the Great Parliamentary Debate no the Lord's Supper on December 15, 17, 18, 1548. From that report the following, amongst many, important conclusions must be drawn :-

(1) Cranmer and his fellow reformers distinguished between Transubstantiation and the Real (Corporal) Presence, and rejected both.

(2) The other side recognized that omission was prohibition, and deplored the abandonment of Adoration, Elevation, and the Oblation of the Host, Tonstal also protesting against the discredit thrown upon the word 'Mass.'

(3) The unreliability of the 'Ancient Liturgies' as standards of historical or doctrinal accuracy was clearly felt and expressed.

\section{(I) The Communion Office of 1549.}

Within a month of the Great Debate, Parliament passed the new book, and by March it was published, coming into general use on Whit-Sunday, June 9. The relation of its Communion Office to the Sarum Missal is exhibited in the following description of their respective contents * in parallel columns, in which parts largely identical in both Offices are in Clarendon type; parts used by the Reformers, but with alterations of doctrinal significance, are in Italics; the many important changes of order will be seen directly from the Table; rubrics are indented, only the more important of those in the Missal being noted, their length being greater than the remainder of the service. $\dagger$ The comparison must compel agreement with the following estimate : "The Eucharistic Service of the Church of England is substantially a new service. If we take even the Communion Service of 1549 and compare it with the Canon according to the Use of Sarum, we find that by far the greater part of it is new. ... The Office of 1549 occupies twenty-three closely-printed pages at the end of Mr. Maskell's Ancient Liturgies of the Church of England, and of these not above two pages are to be found in the Sarum Missal' (Prebendary Sadler, The Church and the Age, p. 305).

* The full text of the Office of 1549 , side by side with that of the Sarum Use in English, may be seen in Canon Estcourt's Dogmatic Teaching of the Book of Common Prayer on the Eucharist. The 'Canon' is similarly displayed in Tomlinson, Tracts on Ritual, Vol. i, No. 113.

$\dagger$ The divisions of the Mass are borrowed from Frere, pp. $282 \mathrm{ff}$. 
1549 B.C.P.

The Supper of the Lord and Holy Communion commonly called The Mass.

Notice to be given by intending Communicants. Evil-livers and those at variance to be kept away.

Vesture (vestment or Cope).

Psalm in English (Introit).

Priest to stand afore the midst of the Altar.

Lord's Prayer.

Collect for Purity.

Psalm.

Lesser Litany.

The Gloria in Excelsis.

The Lord be with you, etc.

The Collect.

Alternative Collects for the King. The Epistle.

The Gospel.

Announced by the reader, with response, "Glory be to thee, 0 Lord.'

\section{Sarum Ugs. \\ Ordinarium Missæ.}

1. Preparation.

Vesting hymn.

Versicle and Response.

Collect for Purlty.

Psalm.

2. Psalm, etc.

Lesser Litany.

\section{Lord's Prayer.}

Hail Mary.

3. Approach to Altar, eto.

Versicles and Responses.

Confession of Priest.

Absolution of Priest by the Minister. Confession of Ministers.

Absolution of Ministers.

Kiss of Peace.

Lights, kissing altar, etc.

Priest to begin at South corner of Altar.

Silent Prayers.

4. Censing.

Lesser Litany.

Many regulations for censing; for procession to altar; for dress of deacon, sub-deacon, light-bearers, etc., for colours.

5. Gloria.

The Gloria in Exceisis (ten variations) : regulations as to priest's sitting or standing.

6. Collects and Memorials.

The Lord be with you, etc.

The Collects (seven the maximum).

Many regulations as to posture, signing the cross, bringing bread, wine and water, bringing basin and water for washing, etc.

7. Epistle.

8. Gradual.

Rubric concerning gradual, etc.

9. Alleluia, Sequence, and Tract.

10. Censing.

11. Gospel.

Many regulations as to procession, posture, blessing, censing, etc. 
1549 B.C.P.

The Creed.

Sermon and Homily.

Exhortation to worthy receiving the Sacrament.

Exhortation to the negligent.

Offertory, by tho people' "to the poor men's box.'

Sentences inciting to generous giving.

Singing the Sentences.

Nature of the offertory.

Non-communicants to. leave the Quire.

Brearl and wine (with water) to be set upon the Altar, after the offertory.

The Lord be with you.

Sursum Corda.

It is very meet, right, etc. (somewhat altered).

Proper Prefaces, reduced to five, and two entirely new.

Holy, Holy, Holy.

Prayer for the whole state of Christ's Church.

To be said "plainly and dis. tinctly.'

Intercession (wording entirely new).

For acceptance of 'these our prayers.'

For the truth and unity of Church.

For the King and Council, etc.

For Bishops and Clergy.

For all God's people.

Praising God for Saints, Maryalone mentioned by name.

For God's servants departed (before the Consecration, to avoid the idca of offering for the dead).

(ii) Consecration.

Reference to the one oblation once offered.

Prayer for sanctification of the brcad and wine by the holy Spirit and word (two crossings).

Recital of institution with two single directions for manual acts.

Elcvation and shewing sacrament forbidden.

\section{SaRUM Ustr.}

12. The Creed.

13. Versicles, etc.

The Lord be with you.

14. Offertory, i.e. by the

Priest of bread and wine.

Crossings, kissings, censings, washings, etc.

15. Its Prayers.

Prayer for acceptance of Sacrifice for sins and Offences, on behalf of living and dead.

16. The Secret.

- Secret Prayers, ete.

17. The Salutation.

The Lord be with you.

Sursum Corda.

18. The Preface.

It is very meet, right, etc.

Proper Prefaces.

19. The Sanctus.

Holy, Holy, Holy.

20. The Canon.

Rubrical regulations for hands, eyes, signing cross, etc.

(i) Intercession.

For acceptance of these 'holy sacrifices.'

For the Church.

For the Pope and King.

For special individuals.

Corrmemorating Saints (25 by name), and seeking thcir merits and prayers.

- Hcre to regard the host with great veneration-

For acceptance of this oblation

Again to look at host-

For its becoming the Body and Blood of Christ.

(ii) Consecration.

Wash fingers and elevate host.

Recital of institution, not in the words of the Bible, and multitudinous accom. panying regulations. 
1549 B.C.P.

(iii) Ob'ation.

Celebrating before God 'the memorial which (His) Son hath willed us to make.'

Sacrifice of Praise and thanksgiving.

Our Souls and bodies offered as a reasonable Sacrifice.

Prayer that these prayers may be taken to God's holy Tabernacle in Heaven by the Ministry of His holy Angels.

(iv) Lord's Prayer (without regulations).

The Peace of the Lord, etc.

Substituted for Agnus Dei :

Christ our Paschal Lamb is offered up for us, once for all, when he bare our sins on his body upon the cross; for he is the very lamb of God, that taketh away the sins of the world; wherefore let us keep a joyful and holy feast with the Lord.

N.B.-Agnus Dei transferred to 'the Communion time.'

Invitation to Confession.

Confession by all, Priest and people.

General Confession.

Absolution. [cf. Absolution of Priest by the Minister (p. 256), Division 3.]

Comfortable Words.

Prayer of Humble Access.

Rubric for Reception.

Words of Administration.

Sentences.

Twenty-two from Holy Scripture,

\section{Sardm Use.}

(iii) Oblation.

Offering Victim to God, cf. Abel, Abraham, and Melchizedek.

Prayer for Angels to take the host to God's Altar in heaven.

Prayer for the dead.

Prayer for the living to have their part with the Saints (15 named).

Aseription, with five signings of the Cross.

(iv) Paternoster, with minute regulations as to Elevation of Paten and hands.

Prayer with more regulations, for peace, etc., by intercession of Saints.

Breaking the Host in the Chalice.

Peace, with signing the Cross.

21. Agnus Dei.

22. Commixture and Pax.

Prayer, placing third part of the .Host in "the Sacrament of the blood.'

Prayer for the priest's worthy reception.

Kissing corporal and the deacon.

Minute regulations for the Pax.

23. Prayers at reception.

Prayer to God "Who willed thy only begotten to take flesh .... which $\mathrm{I}$, unworthy, here hold in my hands.'

Adoration of the Host.

Address to the Body, and reception. Address to the Blood, and reception. Thanksgiving prayer.

(No Communion of the Pcople in the Missal.)

24. Prayers at Ablutions.

Three prayers with elaborate rubrics.

25. Anthem 'Communio.' 
1549 B.C.P.

not including the ambiguous

'Taste and see.'

The Lord be with you, ete.

Colleet, "We most heartily thank thee.'

The Blessing.

\section{Sarum Use.}

'Taste and see,' etc.

26. Post-Communion.

Dominus vobiscum, with ritual regu. lations.

Collects, replete with invocations and memorials of Saints.

Dominus vobiscum.

Let us give thanks unto the Lord. 27. Dismissal.

Ite, Missa est.

28. Closing Prayer.

Private Prayer for acceptability of the Sacrifice.

In the name of the Father, etc. Regulations for procession.

Post-Communion Gospel (John i. 1-14).

It is scarcely credible that any one would find the outstanding point of this comparison to be 'the close similarity' between the 1549 B.C.P. and the Sarum Use * ; their fundamental difference is even more apparent, if possible, in the following list of the chief omissions, alterations, additions, and transpositions :-

a. Omissions.

The ' Hail Mary.'

The ritual approach to the Altar.

Mutual Confession and Absolution of Clergy.

Kiss of peace.

Censing (passim).

Collects ealled 'Momorials.'

Gradual, etc., with ritual aceessories.

Ritual production of the Book of the Gospels, with Kissing the Book, etc.

Ritual placing of the elements, with kissing, censing, and hand-washing.

Prayer of oblation of elements, offered in honour of 'saints,' and for salvation of living and dead.

Kissing Altar, crossings, etc.

Secret prayers, involving intercession of Saints.

Offering of the elements, as 'their holy undefiled sacrifices,' in the 'Canon.'

Reference to merits and prayers of the Saints.

Elevation of the consecrated Elements, and accompanying posturings.

Reference to the 'pure victim,' 'holy victim,' etc., with erossings.

Refcrence to Abel's, Abraham's; and Melchizedek's sacrifices.

Prayer that Angels should earry the elements to the 'Altar on high.'

Prayer to 'sanetify and to give life to' the Elements.

Using the Host to make 5 signs of the Cross.

Prayer for intercession of Mary, etc., and all the Saints.

Ritual kissings, touching eyes with tho paten, etc.

Threefold breaking of the Host, ete.

'Commixture' of the Bread and Wine.

Tho Pax, kissing of 'corporal,' and of tho deaeon. 
Private prayer before priest's communicating, referring to the Lord's taking 'flesh, the which I, unworthy, here hold in my hands.'

Address ' to the Body' before reception : 'Hail for evermore, Most Holy Flesh of Christ,' etc.

Address 'to the blood.'

Rinsing of hands and chalice, with prayers, including "we adore the sign of the Cross.'

'Taste and see that the Lord is sweet,' ctc.

Post-Communion, Procession, and Gospel.

\section{b. Alterations.}

The Title 'Mass' relegated to position of no repute.

Use of the English tongue.

Chasuble made of no account by alternative use of Cope.

Collect for purity said publicly.

'God's board ' used sometimes instead of 'altar.'

Sentences exhorting to eharitable giving during the Offertory, instead of a devotional anthem from the Psalms.

Prayer to 'receive these our prayers, which we offer,' etc., instead of 'accept and bless these gifts, these presents, those holy undefiled sacrifices,' etc.

Praising God for virtue of Saints, instead of 'Communicating with and venerating the memory,' and pleading the merits and prayer's of the Saints.

Christ's 'one oblation, once offered,' etc., for ' this oblation-we beseech thee to accept.'

- Bless and sanctifythese thy gifts of bread and wine that they may be unto us the body and blood' instead of 'which oblation make blessed, admitted, ratified, reasonable, and acceptable, that it may be made to us the Body and Blood.'

Words of Scripture used in the Consecration.

'Celebrate the memorial which thy Son hath willed us to makc' instcad of 'offer a pure victim,' etc.

'Our sacrifice of praise and thanksgiving' for 'a holy sacríice, an immaculate victim.'

Partakers of this Holy Communion,' for 'this participation of the altar.'

General confession to God alone, for the Confitior addressed to Saints, etc.

Unambiguous sentences of scripture, for 'Taste and see,' ctc.

'Almighty and ever-loving God, we most heartily thank thee,' etc., for the five Post-Communion Collects including reference to sacrifice, intereession of Saints, etc.

'The Peace of God,' etc., instead of the priest's private prayer for the acceptance of the sacritice he has offered.

\section{c. Additions.}

Collect for the King.

Sermon, and exhortation 'to the worthy receiving.'

Exhortation to communicate more diligently.

Gathering the communicants together, and excluding others from the quire.

Offering oneself to be a 'reasonable holy and lively sacrifice.'

'Christ our Paschal lamb is offered up for us, once for all, when he bare our sins, on his body upon the cross; wherefore let us kecp a joyful and holy feast with the Lord.'

' Ye that do truly and earnestly,' etc.

Comfortable words. 
Prayer of humble access.

Words of administration "The body which was given: ... The

d. Transpositions.*

Commemoration of the dead placed bcfore the consecration to avoid suggestion of offering Christ for the quick and the dead.

'Agnus Dei' transferred to ' the communion time, beginning so soon as the priest doth receive,' etc.

Confession and absolution, (the latter prefaced by reference to God's promises of forgiveness to the repentant), made 'general' instead of for celebrant only, and transferred to a suitable position.

The Act which established the 1549 B.C.P. is the "Authority of Parliament, in the Sccond Year of the Reign of King Edward the Sixth,' words of importance for the understanding of the 'Ornaments 'Rubric,' in which they are still to be found. That even these great changes were only of the nature of a compromise is sufficiently attested by the extant correspondence of the day; not, however, a compromise between Rome and the Reformers, but between Lutheran views of the Sacramental Presence and those of Cranmer and the English Reformers generally. $\dagger$ The genuine opposition of the great body of those who rebelled in various parts of the country is evidence of the departure from the Sarum Mass, not to be weakened by Gardiner's claim that he could find the Mass in the book. Such emphasis upon ambiguous words and phrases, scattered here and there, to the exclusion of the general and obvious trend of the whole book, is an unworthy policy unhappily not unknown in England at a later date, and in a less ambiguous B.C.P. The new Ordinal, published March, 1550, was far more free from ambiguity (see p. 498), and, with the abolition of altars at the same period, and the calling in of old Service-Books, paver the way for the inevitable revision of 1552 .

\section{(III) The Comulnion Office of 1552.}

It is remarkable that this Prayer Book, which had scarcely time to come into use before Edward's death caused the suspension of all reform for five years, is nevertheless essentially the B.C.P. of 1912. It was passed on April 14, printed in August, and prescribed for use from November 1, 1552 ; the 42 Articles, substantially our 39 Articles, received the King's Mandate on

* The Injunctions of 1548 , No. 19, mention 'transposed' as a contemplated process in reforming the Mass; such transposition was made more offective still as a reforming instrument in 1552 .

$\uparrow$ For the true relation of the 1549 B.C.P. to Lutheranism see Dimock, II istory of B.C.P., 1910 Edn., pp. 7 ff.; for evidence that it was regarded as transitional see Tomlinson, Great Purliamentary Debate, pp. 19, 20; and First Prayer Book of Eduard VI, pp. 4 ff. 
June 9, 1553, the King's death occurring on July 6 . The nature of the Book is clear from the statement of the Act which enjoined its use, it is the former book 'explained and made fully perfect ... more earnest and fit to stir Christian people to the true honouring of Almighty God.' This estimate of their work by those who compiled both books might suffice to silence for ever the Cosin-Heylin theory, popularized by Wheatley, that the second book was virtually the work of foreigners, even if that theory were not otherwise untenable. It is now disclaimed, but it has done its evil work in casting a slur upon the revision of 1552.

The importance of the changes will be seen from the following lists of omissions, alterations, etc. :-

a. Omissions.

'Commonly called the Mass,' in the Title.

All special Vesture : the surplice being ordered for all scrvices.

Introit sung by clerks.

Introit said by priest.

Lesser Litany.

Dominus Vobiscum.

'Glory be to thee, 0 Lord' before Gospes.

Direction to add to the wine ' a little pure and clean water.'

Prayer for dead.

-Doth vouchsafe, in a Sacrament and Mystery, to give us his said body and blood to feed upon spiritually.'

'Blessed is he that cometh in the name of the Lord ' in the Ter Sanctus.

'In these holy mysteries,' after 'so to drink his blood.'

Indented Rubrics and sign of the cross in prayer of consecration.

'We ... do celebrate and make here before thy divine Majesty, with these thy holy gifts, the memorial which thy Son hath willed us to make.'

Agnus Dei during communion.

Post-communion sentences.

Petition for prayers to be carried by the Angels to heaven.

The declaration that in each part is received the whole body of Christ.

\section{b. Alterations.}

'North side of the Table,' for ' afore the midst of the Altar,' this last word being everywhere changed.

' He hath instituted and ordained holy mysteries, as pledges of his love,' etc., for : ' he hath left in those holy mysteries, as a pledge of his love, and a continual remembrance of the same, his own blessed body, and precious blood,' etc.

'Discreet and learned Minister of God's word, and open his grief, that by the ministry of God's holy word,' etc., for 'discreet and learned priest, taught in the law of God, and confess and open his sin and grief secretly ... requiring such as shall be satisfied with a general confession, not to be offended with them that do use, to their satisfying, the auricular and secret confession to the Priest,' otc.

The exhortations of 1549 completely rearranged.

'That we receiving these thy crcatures of bread and wine ... may be partakers of,' for 'with thy Holy Spirit and word vouchsafe 
to $\mathrm{bl}+$ ess and sanc + tify these thy gifts and creatures of bread and wine, that they may be unto us the body and blood,' etc.

'Delivereth the bread ... the cup' for 'delivereth the sacrament of the body of Christ . . . of the blood of Christ.'

'Into their hands' for 'in their mouths at the Priest's hand.'

Second part of present words of administration instead of the first.

'Vouchsafe to feed us, who have duly received these holy mysteries,' for 'vouchsafed to feed us in these holy mysteries.'

'A good number,' instead of ' some' necessary to communicate with the priest, the 'good number' being given as 'four or three at the least,' even in a parish with not more than twenty communicants.

Bread ' usual to be eaten,' instead of 'unleavened and round '; 'threc times in the year,' instead of 'once.'

\section{c. Additions.}

Ten Commandments.

'Militant here in earth' added.

Rubric concerning notices.

Delivery 'into the hands' of the people 'kneeling.'

Rubric regulating disposal of surplus bread and wine.

The Black Rubric.

d. Transpositions.

Gloria from beginning to end of Service.

Prayer for Christ's Church, entirely broken up and rearranged.

Confession, etc., before consecration.

Lord's Prayer after communicating.

First Thanksgiving taken out of Prayer at Consecration, and made an alternative after communicating.

The following alterations outside the Communion Office also bear upon it :-

Provision for Double Communion for Christmas and Easter omitted.

Communion Table allowed to stand in the middle of the Church.

Reservation for the Sick omitted.

Celebration at burial omitted.

The relation between the two Edwardian books is plain enough from these lists of changes; the second is the first with the removal of whatever had been proved by experience to be ambiguous. It is significant that every detail fastened upon by Gardiner as a loop-hole for the Mass, was altered. Nor was any room left for any Lutheran idea of a Corporal Presence, a matter of grave importance in view of current controversy, seeing that the work of 1552 is the B.C.P. of to-day. The proof of this last statement will now appear.*

On the accession of Queen Elizabeth the 1552 B.C.P. was expressly restored, with three alterations, 'and none other or otherwise.' The three specified alterations were (1) the omission of the petition against the Bishop of Rome in the Litany, (2) new Tables of Lessons, and (3) the addition of the words of administration in 1549 to those prescribed in 1552, making our

* The holes and corners in which the Real Corporal Presence and Mass. Sacrifice are still pretended to be found, will be noted in the last section of this Introduction, pp. 269 ff. 
present compound sentences. The too common phrase 'PrayerBook of Queen Elizabeth' is, therefore, a misnomer, and actually misleading as liable to convey the impression that revision of any kind took place. The one alteration in the Communion Service, above-described, simply restored words of administration with some claim to scriptural accuracy and doctrinal safety ; the words ' which was given,' ' which was shed,' especially with the words of 1552 retained : 'Take and eat this,' 'Drink this in remembrance:' effectually safeguarded the change from misinterpretation. However, two other changes appeared in the printed B.C.P. which have been cited as evidence of a retrogression in doctrine :-(1) the unauthorized Rubrics prefacing Morning Prayer, (2) the omission of the 'Black Rubric.' The former of these matters is dealt with elsewhere (pp. 76 ff.). The Black Rubric will also receive attention elsewhere, but the simple fact that it was not part of the 1552 B.C.P., but a Royal Proclamation appended thereto, divests its omission of any siguificance whatever.*

The final form taken by the XXXIX Articles, and the addition of that portion of the Catechism which deals with the Sacraments, are the two important additions to the B.C.P. between 1552 and 1662. This last addition was made in 1604, and sundry occasional prayers and thanksgivings were added, the B.C.P. thus enlarged being often called the Prayer Book of James I.

\section{Liturgical Changes at the Restoration.}

In estimating the intention and effect of the last revision of the B.C.P., preponderating attention should be paid to the Revisers' own Preface. They state, by the pen of Bishop Sanderson, that in spite of various alterations 'the main body and essentials of it (as well in the chiefest materials, as in the frame and order thereof) have still continued the same unto this day, and do yet stand firm and unshaken'; they are 'fully persuaded in (their) judgments, and here profess it to the world that the book as it stood before, is free from error'; and that with no desire 'to gratify this or that party in any way' they set about revising the book with practical aims, the general account of their alterations being that they were made to :-

1. Guide the clergyman in Divine Service.

2. Alter archaic and ambiguous language.

3. Embody the improved English Version of Holy Scripture.

4. Add special services for special occasions.

Despite this straightforward declaration of policy, concluding

- For further information see pp. $273 \mathrm{ff} ; 365 \mathrm{ff}$. 
with an appeal for comparison of the old and new, when they 'doubt not but the reason of the change may easily appear,' there is a tendency to attribute to the revision an effect which credits the Revisers with a deep dark plot to undermine the doctrine, (especially the doctrine of the Lord's Supper), of the Church of England. This charge has been often and openly brought: "The Revisers seized the opportunity (contrary to what the public was reckoning upon) to make our formularies not more Puritanic, but more Catholic. They effected this, without doubt, stealthily, and, to appearance, by the minutest alteration; but to compare the Communion Service as it now stands, especially in its rubrics, with the form in which we find it previously to that transaction, will be to discover that, without any change of features which could cause alarm, a new spirit was then breathed into our Communion Service.'* On the same page is added 'It has actually escaped general observation. Wheatley on the Liturgy notices the changes ; but though himself a High Churchman, overlooks their import. Nicholls, if I remember right, scarcely adverts to the fact; and Shepherd, who meant to take pains, seems not to have known anything of the matter.'

What then are these changes, designed to effect so much, yet recognized not even by their authors nor by any one else for two centuries? The Laudian movement, with all its tendencies to exclusive episcopalianism, Arminianism, and the revival of discarded outward forms, did not seriously touch the doctrine of Holy Communion. In the temper of the Protestant world over the Thirty Years' War, and active papal propagandism by the Jesuits, that high-handed disregard of the rubrics which ordered the altar-wise position of the Lord's Table and the railing it in, loomed large enough to help to embitter the nation against Laud, but it would hardly bear to be construed as a doctrinal innovation, save by implication. Treatises on the Lord's Supper might defend the Church of England from imputations of Zwinglianism, by asserting that the Presence to the hearts of the faithful was a 'Real' Presence, and even (less wisely) by using the word 'oblation' in a sense which the B.C.P. had carefully avoided, but the doctrine of the Church of England was untouched.

The failure of the Savoy Conference in 1661 was perhaps to be expected, with both parties in the land indisposed to concession ; but when the revision was handed over to Convocation, there was at any rate some sign of a willingness to meet the desires of the Puritans, and, as will shortly be seen, some of the

* Alexander Knox, Remains, Vol. i. p. 60: from Dimock, History of 6he Prayer Book, p. 68. 
changes recently attributed to an imaginary longing for the B.C.P. of 1549, were actually changes granted at the request of the Puritans. There certainly was a party anxious to introduce such changes as are to be seen in the ill-fated Scottish Liturgy of 1637 , but that party met with no success ; the famous note in Sancroft's handwriting runs : 'My Lords the Bishops at Ely House ordered all in the old method': the changes proposed were not adopted. Mention of some of these rejected proposals will indicate the true nature of the revision :-

1. To substitute 'Catholic Church' for 'Church Militant here in earth,' so as to include the dead in the prayer by the words' we, and all they which are of the mystical body of Thy Son, may be set at His right hand.'

2. To prefix ' priest the 'to ' minister of God's Word.'

3. To provide ' another method of the Consecration, Oblation, Adßress, and Distribution,' including :-

$a$. Invocation of the Holy Spirit and the Word on the bread and wine.

b. After Consecration a rubric: 'Immediately after shall follow this Memorial or Prayer of Oblation.'

c. 'We Thy humble servants do celebrate and make here before Thy Divine Majesty, with these Thy holy gifts, the Memorial which Thy Son hath willed and commanded us to make... death of Thy Son Jesus Christ, now represented unto Thee.'

d. 'That whosoever shall be partakers of this Holy Communion, may worthily receive the most precious body and blood of Thy Son Jesus.'

e. Agnus Dei to be sung during administration.

4. The Table always to stand in the East.

5. The Priest to 'offer up and place' the elements on the Table.

6. Wafer bread to be allowed.

The rejection of these proposals, to be seen inserted in the 'Durham' or 'Bodleian' Books or Laud's B.C.P. of 1637, used by the Revisers, is most significant, and corroborates the evidence of the Preface. The mistake, often made, is due to the failure to distinguish between the temper of the Commission, which made no alterations, and the Convocation which did make concessions to the Puritans. The spirit of the latter, and not of the former, is to be regarded as the motive of the revision of 1662.

The changes actually made may be seen in the following list :- 
Notice required some time the day before.

Ordinary to be informed of any refusal to admit to the Lord's Table.

Direction to people to kneel at commencement of the office.

Enlargement of rubric explaining the Kyrie.

'The Priest standing as before,' for 'standing up,' before Collect for the King.

Creed 'sung or said ' for 'said.'

Notices put before the Sermon; enlarged list of notices, with restriction of notice-giving to the Minister, who must announce only what is prescribed in the B.C.P., or by the King or the Ordinary.

'Then shall the Priest return to the Lord's Table and begin the Offertory' added; ' earnestly exhort them to remember the poor' omitted.

Alms 'and other devotions' to be gathered into 'a decent basin' which must be reverently brought to the Priest " who shall humbly present and place it upon the Holy 'Table.'

'Deacons' added to Churchwardens, etc., as Collectors.

Rubric to 'place upon the Table' the bread and wine, added.

'And oblations' added to Prayer for Church Militant; 'or oblations' to indented rubric.

Clause beginning 'And we also bless thy holy name' added.

Exhortation of 1552, to be 'sometime' said at the discretion of the Curate, adapted for use as a regular exhortation for announcing Holy Communion.

In exhortation to the negligent 'in the remembrance of the sacrifice of his death' for 'in the remembrance of his death.'

In same exhortation paragraph omitted expressly condemning ' gazers and lookers on them that do communicate.'

Reference to confession 'before this congregation' omitted.

Leading in the confession restricted to 'one of the Ministers.'

'Pronounce this Absolution' instead of 'says thus.'

'Holy Father' to be omitted from 'It is very meet, right,' etc., on Trinity Sunday.

'As at this time' for 'as this day' in Christmas Preface, and for 'this day' in Whit-Sunday Preface.

'Be sung or said' for 'follow' in Rubric before 'Therefore with Angels,' etc.

'The Lord's Table' for 'God's board ' in Rubric before Prayer of humble access.

'When the Priest, standing before the Table, hath so ordered the Bread and Wine, that he may with the more readiness and decency break the Bread before the people, and take the cup into bis hands ' added to Rubric before the 'Prayer of Consecration,' this name being then first given.

Five indented Rubrics in Prayer of Consecration, and 'Amen' at close of Prayer, added.

Rubric for consecrating additional bread and wine added.

Rubric for replacing and covering surplus consecrated bread and wine added.

'The mystical body of thy Son' for 'thy mystical body' in 2nd PostCommunion Prayer.

'One or more' for 'one' in rubric directing use of collects when there is no Communion.

'Sundays and other Holy-days' for 'Holy-days' in rubrio directing method of closing service when no communion on such days.

'Closing with the Blessing,' added to that rubric.

'Convenient number' for ' good number,' in rubric forbidding celebration without sufficient communicants. 
Omission of 'at the table with other meats' after 'Bread be such as is usual to be eaten.'

Curate to have bread and wine remaining, only if unconsccrated, the consecrated not to be carried out of the Church, but reverently eaten and drunk immediately after the Blessing, by the Priest and such other of the communicants as he shall then call unto him.

Omission, in the Rubric relating to provision of bread and wine, of the words: " and the Parish shall be discharged of such sums of money, or other duties, which hitherto they have paid for the same, by order of their houses every Sunday.'

Rubric added, concerning disposal of offertory.

'Black Rubric' re-introduced, being the Royal Proclamation of 1552, altered by the re-arrangement of one clause, the addition of the word 'therein' before 'given to all worthy receivers,' and the sub. stitution of 'corporal' for 'real and essential' before 'presence,' beside verbal changes of no significance whatever.

N.B. -The alteration of compulsory to suggested Communion in Marriage Service.

Of these changes the following, amongst others, were directly due to the Puritan objections at the Savoy Conference :-

1. Notice required some time the day before.

2. Leading in the confession restricted to ' one of the ministers.'

3. 'As at this time' for 'as this day.'

4. Indented Rubrics in Prayer of Consecration, which name is practically that used in the Puritan request: "Prayer at the Consecration.'

5. The Black Rubric was restored at their request, covering all alterations with regard to kneeling.

The following are the alterations most generally supposed to mark a retrograde movement :-

1. Addition of remembrance of the faithful dead in the Prayer for Church Militant.

2. Alteration of rubrics regarding presentation of alms, and placing of bread and wine on the Table.

3. 'Remembrance of the Sacrifice of his death' for ' remembrance of his death.'

4. 'Pronounce this absolution' instead of 'say this.'

5. Rubric before Prayer of Consecration, directing the ordering of bread and wine.

6. 'Prayer of Consecration.'

7. 'Paten' and 'Chalice.'

8. 'Amen' at end of Consecration.

9. Rubric commanding surplus bread and wine to be covered.

10. Alteration in wording of Black Rubric.

The separate doctrinal effect (if any) of these alterations will be noted either in the following section, or in their place in the Exposition. Their general effect, as indicative of the tendency of the last revision, can be summed up in a very few words :- 
1. The Preface disclaims ' to the world' any doctrinal tendency at all.

2. The known proposals containing a doctrinal tendency towards higher sacramental doctrine were ignored.

3. The alterations supposed to embody higher sacramental doctrine were largely due to Puritan suggestion.

4. Such aiterations as the relaxation of the rule requiring the Communion after matrimony, and others outside the Communion Service, pointed the other way.*

If, therefore, it is still held that the $1662 \dagger$ B.C.P. represents a retrograde step doctrinally, it is held at the cost of the honesty of the Revisers, the facts of historical research, and the plain meaning of the alterations themselves, which are, on this theory, to be interpreted by the use of the words 'Paten' and 'Chalice,' 'Amen' at the end of a Prayer, 'Absolution' in the rubric preceding a prayer (inserted in Morning and Evening Prayer in 1552), thankful remembrance of the faithful dead, as desired by Bucer, and as safeguarded from Prayer for the Dead by the retention of the Title 'Church Militant here in earth,' and the injunction to cover the unconsumed bread and wine after administration. $\ddagger$

\section{Interpretative Principles of the Tractarian Movement.}

No changes have taken place in the Communion Office since 1662 , save the necessary alterations of royal names. Such doctrinal variations, however, as the use of the word 'altar' in Coronation Services, and the introduction of prayer for the dead into occasional special offices, illustrate the new method of affecting the doctrinal standards of the Church of England, viz. by the imposition of a new meaning upon her unaltered formularies. This new method is due to a school of thought originating in the 'Tracts for the Times,' and well known as 'The Oxford Movement.' In spite of the Prefaces to the B.C.P., and to the Articles, claiming that 'any man' can understand all changes; that all ceremonies ' are set forth that every man may understand what they do mean, and to what use they do serve, so that it is not like that they in time to come should be abused'; and that 'no man hereafter shall either print,

* The regulation for consecrating more bread or wine separately is definitely opposed to Roman directions : Canon Estcourt, (R.C.), terms it the revival of 'the sacrilegious rubric of 1548,' because it allows a second consecration in one kind, destructive of any sacrifieial idea in consecration.

$\dagger$ Convocation completed its work on December 20, 1661, but the revised book only became law on May 19, 1662.

$\ddagger$ The inclusion of the words 'the sacrifice of ' (No. 3 in list) suggests no alteration of doctrine. 
or preach, to draw the Article aside any way, but shall submit to it in the plain and full meaning thereof, and . . . shall take it in the literal and grammatical sense,' yet a microscopical search has been made by the new school for words and phrases, rubrical and devotional, which may serve to establish an interpretation of the B.C.P. unknown to its authors, and to three centuries of Christian life and thought.

Though no part of the B.C.P. has been neglected in this search, those parts which deal with the doctrine of the Lord's Supper have naturally been most in the minds of those whose position depends upon the mediæval ideas of a Corporal Presence and priestly Sacrifice.

To assist the student by gathering into one place the items chiefly relied upon by the new school, they are here submitted to brief discussion. Two of these may be dealt with summarily. (1) The 'Ornaments Rubric' has been dealt with in its place on pp. $76 \mathrm{ff}$. ; here it needs only to repeat that according to some modern interpretations, it teaches doctrine as well as ritual, the assumption being that the 'ornaments' prescribed therein carry with them the doctrines connoted by their use. (2) The retention of such words as 'Mass,' 'Canon,' and 'Altar,' in 1549, are often used as a justification for their re-introduction; it would seem, however, that the use of such words in 1549, with their subsequent rejection, tells in precisely the opposite direction.

In regard to the other items, consisting of minute details of phraseology in the present B.C.P., it is necessary to remark that they must be interpreted not by their possible meaning in another connexion, or in no connexion at all, but by their relation to their context, to any alterations in that context which have taken place, and to the professed interpretation of them by those who introduced them. It is justifiable to scrutinize with care a method of interpretation which depends upon minute and scattered phrases: which demands their consideration in isolation from their surroundings and history: which claims an equivocal passage as necessarily supporting only one of two possible views: which, finally, supersedes the general witn'ss of the whole B.C.P. and its history.

(1) In the First Exhortation in the Communion Office :- 'God hath given His Son, our Saviour Jesus Christ . . . to be our spiritual food and sustenance in that holy Sacrament. Which, being so divine and comfortable a thing to them who receive it worthily, and so dangerous to them that presume to receive it unworthily,' etc.

It is contended that, ' holy sacrament' being the antecedent 
to 'which,' and Jesus Christ being ' in that holy sacrament,' and 'it' being capable of unworthy reception, Jesus Christ is present independently of the worthiness of the recipient. If it should be replied that 'sacrament' means only the externals, the bread and wine, then, it is argued, Christ must be in the bread and wine. It is claimed that whichever meaning of Sacrament be chosen, a Real Objective Presence is taught by these words.

The answer is:-

(a) Apart from any flaw in the argument, the explicit statement of the title of Article XXIX : ' Of the wicked which eat not the Body of Christ in the use of the Lord's Supper': must govern the interpretation of this hortative language, and not vice versâ.

(b) The Exhortation states that God has given His Son, not to be in that holy Sacrament, but to be our spiritual food therein. It is for us by worthy reception of the Sacrament, to accept or reject God's gift of His Son.

(c) The two-fold use of the word 'Sacrament,' first as both outward and inward, then as outward only, is too common to justify any deduction from such double use here.

(2) 1st and 3rd Exhortations, etc. : ' Mystery, mysteries.'

The suggestion is that such a term could not be applied to the bread and wine, without there being some change in them deserving such a title, and though the whole rite may be intended elsewhere, the plain meaning of the words in the second PostCommunion Collect: 'duly received these holy mysteries': forbids its application to aught but the consecrated elements.

The point of this argument turns on the meaning of the word ' mystery,' the signification of which had originally nothing to do with 'mystification,' the literal translation of the Greek word being 'secret,' either from Greek $\mu$ '́w, 'shut,' or Heb. mistar, 'secret place.' It is, therefore, only properly applicable to bread and wine as such, and not at all to bread and wine which have ceased to be figurative ; as Bertram says : " If there be no figure in that mystery, it is not properly called a mystery.' St. Paul uses the word many times, of the Gospel, of faith, etc., where the application of the modern meaning of the word makes either a wrong sense or no sense at all. The literal application of the four words 'This is my body' to bread destroys its ' mystery,' as a secret: cf. Art. XXVIII, 'overthroweth the nature of a Sacrament,' i.e. confounds the figure with that which is figured, so that there is no 'mystery'-no ' secret'-left.

(3) Prayer of Humble Access: "Grant us ... so to eat the flesh ... and to drink his blood. that our sinful bodies may 
be made clean by his body,' etc. The inference is that it is possible so to partake of Christ's flesh and blood as not to be made clean, etc., i.e. that the wicked can partake of that flesh and blood, which are therefore not dependent upon the faith of the recipient.

Here is to be observed a curious ignorance of the English idiom of the B.C.P. The word 'so' may be used before 'that' to signify 'in such a manner' or ' with such a result.' To-day the separation of 'so' from 'that' implies the meaning 'in such a manner,' three centuries ago it did not: ef. 'so assist us with thy grace, that we may continue in that holy fellowship.' This does not leave any room for God's so assisting us with His grace that we may not continue in that holy fellowship.*

(4) The Words of Administration. The argument is that the former part of the words declare the bread and wine then given to be the Lord's Body and Blood, and that the 'this' of the second clauses refers to the 'Body' and 'Blood' of the preceding clauses. The history of the words is sufficient answer to all argument; the first sentence of 1549 is an old form with the significant addition of 'which was given (u'as shed) for thee'; the second, in 1552 , took the place of the first to silence misinterpretation; the two were combined in 1559 , in order to preserve the ancient form and yet safeguard it from misuse. The 'this,' of the 1552 clauses, could only mean the elements then given to the recipient; this is all it means now.

(5) The First Post-Communion Collect: 'this our sacrifice of praise and thanksgiving.' 'This,' it is said, refers to the Communion just administered, which is called a sacrifice. To most readers of the Bible, however, the form of the words is enough to solve all doubts, 'sacrifice of praise' being the very language of Heb. xiii. 15, and 'thanksgiving' being the summary of the latter part of that verse, which cautiously explains the ambiguous word 'sacrifice' - 'that is the fruit of our lips giving thanks to His Name.' Thus is precluded any meaning in the phrase save 'sacrifice which consists of praise and thanksgiving.' $\dagger$ But historically the words 'sacrifice of praise' had been used in a sense which took 'sacrifice' literally and not figuratively, the words ' of praise' being descriptive, and not a definition of the thing offered in sacrifice. It is therefore to be granted that the phrase alone is ambiguous, but the following facts will remove

* Several other examples from B.C.P. may be found in Dimock, Eucharistic Presence, p. 438.

f It has been suggested that the word 'this' may refer here, not to the praise and thanksgiving of the rite as a whole, but to the saerifice mentioned in the remainder of the prayer. 
the ambiguity. In 1549 the same words formed part of the long Consecration Prayer, where, immediately after Consecraticn, came: "Wherefore ... wc ... do celebrate and make here before thy divine Majesty, with these thy holy gifts, the memorial which thy Son hath willed us to make ... entirely desiring thy fatherly goodness mercifully to accept this our sacrifice of praise and thanksgiving.' The following words of Cranmer show what he meant by the phrase: 'His (Christ's) Sacrifice ... was the taking away the Sins of the world; ours is a praising and thanking for the same ... this is the priest's and people's sacrifice.' However, ' mis-taking' compelled the re-arrangement of the whole service in 1552 ; these words were taken from before administration, and placed after it, where their application to the completed rite is unmistakable; the words about making a memorial before God were omitted as unscriptural; and the newly-made Post-Communion Collect became an alternative to the already existing one, so that the phrase was deprived of any important doctrinal teaching by its us̉e being not obligatory.*

The expressed desire to make this prayer obligatory in any new revision is evidence that those who would press the literal sacrificial meaning, recognize the hopelessness of so doing with the B.C.P. as it stands. $\dagger$

(6) The 'Black Rubric.' Nothing is more confidently affirmed than that the alteration of the original wording of this note in 1552 on its reintroduction in 1662, has restored the doctrine of the Real Presence to the Church of England, for the original had 'Real and Essential' where the revisers put 'Corporal,' thereby implicitly allowing the Real Presence of Christ's natural Flesh and Blood.

The answer is plain :-

(a) The "Rubric' was reintroduced at the request of the Puritans, to explain that kneeling at reception should not be misconstrued into adoration $\ddagger$ of any Presence in the Elements.

(b) It expressly states this to be the purpose of its reintro-

* That the 'this' was not meant to refer to any of the bread and wine left after distribution, is proved by the words of Bishop Cosin, pointing out that if, as the Scottish Book of 1637 directs, proper care is used in consecrating, it is easy to avoid having any consecrated bread left.

$\dagger$ For the attempts to use the Greck of the words ' Do this' and 'Remembrance' to establish the idea of literal sacrifice see pp. 216,7 above. The direction to the Celebrant to use the Roman Missal in his private prayers immediately after the B.C.P. form of Consecration, so as to intrude the sacrificial idca, is, apart from its questionableness on moral grounds, a confession of the non-sacrificial form of our Liturgy.

$\ddagger$ For the practice of Adoration, see p. 366 . 
duction : "lest the same kneeling should . . . out of ignorance and infirmity, or out of malice and obstinacy, be misconstrued and depraved.'

(c) It declares kneeling to be for the spiritual reason of humble and grateful acknowledgment of the benefits of Christ therein given to all worthy Receivers, and for the practical reason of avoiding possible profanation and disorder.

(d) It forbids adoration of either 'the sacramental Bread or Wine there bodily received,' or ' any Corporal Presence of Christ's natural flesh and blood,' exchanging the ambiguous words, 'real and essential,' for the unequivocal word 'corporal.' 'Real,' etymologically derived from res, 'the thing,' and 'essential,' etymologically derived from esse, 'being,' had come to mean, since Cranmer's time, what they now mean. Every Christian believes in the 'reality' of Christ's Presence to all worthy receivers at Holy Communion in that later sense ; what Cranmer meant by 'Real Presence' is just what advocates of a Real Presence in the elements mean by it to-day, and is excluded by the word 'Corporal.'

(e) It gives as the reason for forbidding adoration, that 'the sacramental bread and wine remain still in their very natural substances,' so that to adore them is to be abhorred as idolatry ; that the natural Body and Blood of Christ are in Heaven and not here; and that it destroys the truth of His Natural Body to imagine it to be in more places than one. In any sense, therefore, in which Christ's Body can be the Body which was given for us, it is never on earth, according to this Rubric, so that any kind of Real Presence (in the old sense of the word 'real') is expressly denied.

(f) To fancy some Presence of a 'Spiritual Body' as taught or even justified by the omission of the words 'Real Presence' (nowhere to be found in B.C.P.) is to attribute to the Revisers something of which they are known to have been innocent; the Bishops' reply at the Savoy Conference was: 'The posture of kneeling best suits at the Communion, as the most convenient, and so most decent for us, when we are to receive, as it were from God's hand, the greatest of seals of the Kingdom of heaven.' Convocation, more desirous of placating the Puritans, certainly did not mean more than the Bishops at the Conference, unless their honesty is to be impugned.

(g) What Presence is possible, which leaves the Sacramental bread and wine still in their very natural substance, and leaves Christ's Body, given for us, in Heaven? Attempts have been made to avoid this dilemma by boldly claiming that the 'rubric' is not binding-a suggestive cutting of the Gordian knot-and 
by claiming that the ' rubric' excludes a carnal, physical, Presence, but not a 'Spiritual Presence,' this last trading on an ambiguity in the use of the word 'Spiritual.' St. Paul uses the word ( 1 Cor. $\mathrm{xv}$.) as meaning ' belonging to the spirit,' contrasting the 'spiritual body' with that 'belonging to the soul' (A.V. ' natural body'). In that sense the Lord's body is now a ' spiritual body,' and is 'in heaven, and not here.' Upholders of a Real Presence in, with, or under the forms of bread and wine, intend to convey by ' Spiritual Presence,' the Presence of some imaginary 'budy' made of 'spirit,' a meaningless self-contradictory suggestion, which cannot bear for one moment the investigation of the word 'spiritual.' The true spiritual Presence of Christ is His Presence by His Spirit, to our spirits, and no other Presence is thinkable without violence to the truth of His Incarnation and perfect manhood.

(7) The First Book of Homilies,* notice at its close : "Hereafter shall follow sermons... of the due receiving of His blessed Body and Blood, under the form of bread and wine.' The first 160 pages of Pusey's work, The Real Presence the Doctrine of the English Church, are devoted to this. $\dagger$

The following considerations will show the futility of any arguments based upon the words of this notice :-

(a) This argument for building a doctrine upon a notice proceeds from those who reject the binding authority of the titles of the Articles; see below, p. 277.

(b) The notice was issued in July, 1547, when, as Pusey admitted, Cranmer's belief as to the Real Presence was not what it was afterwards; when not even the Order of Communion had been issued ; and when it was penal to doubt Transubstantiation, the Six Articles Act being still unrepealed until December 24. One of the Homilies was from the pen of Bonner.

(c) When the Second Book of Homilies appeared, in Elizabeth's reign, the title of this Homily was changed, though most of the others retained the titles given in the notice appended to the First Book.

(d) The Article authorizing the Homilies mentions the titles of the Second Book, sanctioning thereby not the 1547 title of the promised Homily, but 'Of the worthy receiving of the Sacrament of the Body and Blood of Christ.'

(e) Cranmer replied to Gardiner's claim that in the 1549 B.C.P. 'it is there said, the body and blood of Christ to be under the

* This and the three following passages are not in the Communion Office itself, but so immediately bear upon it, as to demand treatment in this place.

† See Goode, On the Eucharist, Supplement, pp. 20-22. 
form of bread and wine':- 'When you shall show the place where this form of words is expressed, then shall you purge yourself of that, which in the meantime I take to be a plain untruth.'*

(f) The teaching of the Homily, as is well known, directly opposes the doctrinal accompaniments of the Real Presence.

(8) The Catechism : ' $Q$. What is the inward part, or thing signified ? A. The Body and Blood of Christ, which are verily and indeed taken and received by the faithful in the Lord's Supper.'

The argument for the teaching of a Real Objective Presence in this passage is largely dependent upon an exploded idea of the opinions of Overall, the Author of this part of the Catechism, $†$ whose opinions, moreover, orthodox or unorthodox, could in no case bind the Catechism, which was, as Wheatley says, 'allowed by the bishops' at the Hampton Court Conference, including Whitgift. It was made to meet the view of the Puritans of 1604, and definitely approved by the Puritans of 1661 at the Savoy Conference.

To put the matter briefly, the language is scriptural, both in what it includes, and in what it excludes. Christ is received 'by the faithful' in the Lord's Supper ; such oneness with Christ, in His own ordinance, on the part of those who are His own, is not denied ; in fact, it is greatly due to a belittling of the sacramental belief of the reformed churches, by those who seek to establish a doctrine of a Corporal Presence of some kind, that any idea has arisen that there is anything in these words needing explanation by those who reject that Corporal Presence: Christ is not received by the faithless, nor by the faithful in virtue of the physical reception of bread and wine-except, of course, that that reception is part of the obedience of faith. $\$$

The attempt has been made to interpret 'faithful' as here used in a loose theological sense, somewhat resembling 'Christian,' as applied to a country. This interpretation, however, is expressly excluded elsewhere. Cf. Art. XXVIII, XXIX.

(9) Article XXIX. ' Of the wicked which eat not,' etc. Here has to be met an attempt to explain away a serious indictment against any 'Presence' (independent of the faith of the recipient),

* Dimock, Eucharistic Presence, pp. 230 ff., shows by quotations that the Real Objective Presence is not necessarily taught by the words in question, even were they authoritative.

† Dimock, Euch. Pr., pp. 295 ff.

† The Irish B.C.P. has added a Q. and A. to the Catechism here, explaining the reception to be after a heavenly and spiritual manner, by faith, using the actual language of the second paragraph of Art. XXVIII. 
rather than to enlist language on behalf of that position. The argument is that in correct theological language " partakers of Christ' does not mean what it appears to mean, but 'partakers of the benefits of Christ's Presence,' which benefits of course the wicked do not enjoy.

It is, perhaps, useless to urge that the Royal Declaration prefixed to the Articles speaks of 'the plain and full meaning,' and 'the literal and grammatical sense,' but the complete absence of any such 'theological' sense of 'partakers of Christ,' in any writings of the Reformers in the period when the Articles were drawn up, demands an answer. The 'theological' sense appears in the pleadings of those who, both in Cranmer's time and now, are called upon to reconcile their belief that the wicked can partake of Christ with the plain statements of Holy Scripture attaching everlasting life to any feeding on Christ. Bradford and Jewel both had to meet this imaginary distinction between real receiving and effectual receiving of Christ.

The refusal to regard the title as authoritative has been already alluded to above (p. 275), in connexion with the argument drawn from the notice closing the First Book of Homilies, of 1547. But, whether authoritative or not, this title was set in its place by those who passed the Article, and is thereforc authoritatively interpretative of the meaning of the Article in the eyes of those who thus passed it.

Again, this Article was kept out of the printed copies, though it passed Convocation in 1562 , because it too plainly shut out all believers in a Real Corporal Presence, including Lutherans. Why should this have been, if in the theological language of the time it did no such thing? Bradford was put to death for 'the denial of wicked men to receive the Lord's Body'; other Reformers used the same language. Rogers' Exposition of the Articles, 1585, 'perused and by the lawful authority of the Church of England, allowed to be public,' speaks of the ' ubiquitaries, both Lutheran and Popish . . . saying the very body of Christ, at the Lord's Supper, is eaten as well of the wicked as of the godly,' as ' adversaries of this doctrine,' i.e. that of the Article. To the indefensible argument, that the Article cannot mean what it says because certain bishops responsible for it were opposed, viz., Parker, Cheney and Geste, see the full answer in Dimock, Euchar. Pres., pp. 629 ff. Archbishop Parker visited C'heney with ecclesiastical penalties for his Lutheran tendencies; Geste's and Cheney's opposition proves the Article to mean what it says. In the same place will be found full reply to the further allegation that as Augustine is mentioned in the Artiele, and he believed the wicked to take Christ's body (?), therefore the 
Article cannot mean what it says; -as though the teaching of the English Church depended upon either the doctrine of St. Augustine, or the authenticity of certain words quoted from him, instead of upon the obvious purpose and meaning of their quotation by the framers of the Article.

(10) Article XXXI, 'the sacrifices of Masses.' Again the difficulty created is an argument not so much to establish any dogma, as to get rid of the plain force of language subversive of a dogma.

It is asserted :-

(a) That the phrase 'the sacrifices of Masses' is not 'the sacrifice of the Mass.'

To this contention, not generally held now, it is enough to reply that the plural term is used as equivalent to the singular in many authoritative documents.*

(b) That the words ' commouly. said' could not be used of an authoritaicive doctrine, so the Article must be directed against some popular misconception, and not against the Roman doctrine of Mass-Sacrifice.

But there was no authoritative doctrine of the Mass-Sacrifice in 1553 when the Article was written, so that the framers of the Article could only say ' commonly said.' The Missal itself contains no verbal oblation of Christ, as the Reformers often pointed out in appealing to the Missal against the Roman Mass.

(c) That the rejected doctrine is one inconsistent with the onc offering of Christ once made, with which the Roman Mass claims not to be inconsistent.

But the Reformers thought and taught that the Roman Mass is inconsistent with, and derogates from, the complcteness of the finished work of Christ, disputing the Roman claims.

(d) That the strong language used, 'blasphemous fables and dangerous deceits,' must point to something more grossly corrupt than Mass-Sacrifice.

But the Reformers believed that nothing could be more gross than to put a limitation to the redemption wrought once for all on the Cross, and believed that limitation essentially to attach to the received Roman teaching of Mass-Sacrifice.

(e) That the special error denounced in the Article is that Christ's Death took away original sin, the Mass being used for actual sins of baptized Christians-a dogma taught by some eminent Romans, and credited to Roman Catholicisin generally by the Lutherans, but repudiated authoritatively.

But the language in which Rome repudiates this special error emphatically teaches for truth the very thing condemned in the Article, namely that the Mass does benefit the quick and

* Sec Dinock, Danger us Deccily, p. 10, and Appendix, Noto A. 
the dead, py the offering of Christ therein.* Rome has never repudiated the language attributed to the doctrine of the Mass in that Article; nor were the Martyrs put to death for disbelieving what Rome hersclf repudiated. The Homily clearly teaches what the Reformers believed and what they disbelieved : 'Christ commanded to His Church a Sacrament of His Body, and Blood : they have changed it into a sacrifice for the quick and the dead.'

It is worth noting, in conclusion, that when, in 1562 , the Council of Trent anathematised those who said that the MassSacrifice was 'blasphemous' as detracting from the sacrifice of Christ on the Cross, in the revision of the Articles which took place immediately afterwards, the Reformers added 'blasphemous' to the word 'fables' in the Latin copy, the English version being similarly altered in 1571, ' forged fables' (figmenta) becoming 'blasphemous fables' (blasphema figmenta).

\section{Omission and Prohibition.}

Against such unsuccessful efforts to read into the B.C.P. a doctrine already acquired outside it, must be set the designed excision therein of both the idea of a Presence of Christ in the elements, and also that of a sacrifice of any kind save the scriptural ones of thanksgiving, self-sacrifice, and self-surrender. The effect of the contrast is felt even by those who persevere in grafting upon the Church of England the doctrines rejected by her, and justification is now sought in the new-fangled principle that omission is not prohibition, i.e. that unless a doctrine is expressly repudiated, no amount of evidence of its removal from the B.C.P. will avail to prove it to be inconsistent with loyalty to the Church of England. A telling illustration of the effects of such a principle is to be seen in the following commentary upon the Praycr of Consecration, successively altered in 1549 and 1552 to get rid of the Corporal Presence and Mass-Sacrifice.

' The Prayer (of Consecration) avoids at this point any express mention of the consecration of the creatures of bread and wine, and of the work of the Holy Spirit in consecration : it is carefully worded so as not to express any special theory of consecration while consecrating the sacrament: the prayer has already been offered that we may duly eat the flesh of Christ and drink his blood, and it is enough now to pray that we, receiving those creatures of God, may partake of that Body and Blood, truly and really, in a sacramental manner, according to the full meaning of Christ's Ordinance, whatsoever that may be, without specifying the hidden way in which the earthly elements are made conductors of the heavenly grace.' $\dagger$

* Dimock, ibid. pp. 27-30.

† Frere, in Procter \& Frere, last Edition, p. 492. 
Note :-

(1) 'At this point.' There is no mention, save in the 1662 Title, of any consecration at any point, and "the work of the Holy Spirit in conseeration,' is not only wanting at any 'point,' but has been expunged from this point since 1552, the work of the Holy Spirit being to consecrate $u s$, not the bread and wine-we consecrate the elements in the secondary sense of setting them apart for saered use.

(2) 'Express mention.' The phrase suggests that somewhere there is unexpressed mention 'at this point'; but where? 'Avoided' is hardly a fair equivalent for 'excised " (see p. 336).

(3) 'Any special theory'-implies that any theory may be held, including Transubstantiation; the omission of the words 'that they may be to us the Body,' ete., in 1549, is, then, to be reckoned as of no doetrinal importance. Hence the prayer excludes, and does not merely fail to include ' any special theory of consecration.'

(4) 'Consecrating the Sacrament.' The word 'sacrament' is used for the bread and wine alone, i.e. not including the whole of the outward part (e.g. the breaking and the reception), and excluding all the inward part of the Sacrament. This use of the word allows the suggestion that both the outward and inward are in the bread and wine, antecedently to and apart from faithful reception.*

(5) 'Those creatures of God.' This variation of the B.C.P. words, 'these thy creatures of bread and wine,' is capable of a meaning foreign to the Prayer-Book words, which expressly exclude any idea of any change through consecration.

(6) 'Truly and really, in a saeramental manner.' Why qualify 'truly and really' with 'in a sacramental manner'? 'Sacrament' above meant bread and wine: does 'sacramental' here mean the same?

(7) 'Whatsoever that may be.' These words ignore the omission in B.C.P. of all ways of receiving Christ involving a Presence in the elements.

(8) 'Hidden way.' What is hidden, and from whom ? Neither the B.C.P., nor Holy Scripture, has any idea of any 'hidden way,' save as all revelations, ' mysteries,' are hidden from unbelief.

(9) 'Made conductors.' The elements do not 'conduct' grace, which is only conferred upon faithful recipients of the elements. The word 'made' is, therefore, meaningless, or worse, as suggesting some miraculous change in the clements.

* Tho word 'Sacrament' is used in B.C.P. of the elements alone, e.g. Art. XXIX; but the phraso 'consecrating tho Sacrament' is not to be found thero. 


\section{COMPARATIVE TABLE OF COMMUNION OFFICES.}

\author{
Saruar Use. \\ Private prepn. \\ with
}

2. Collect

Antiphons, etc.

1. Lord's Prayer

Hail Mary, ctc.

Introit

Clergy Confessn.

Censing, Kyric, etc.

30. Gloria

5. Collect, etc.

6. Epistle, etc.

Gradual, censing

7. Gospel, etc.

8. Creed

Oblation of elements

Censing ditto

Handwashing

Secret prayers

21. Lift up your hearts

22. Preface

23. Holy, Holy, Holy

13. Prayer for Church

25. Consccration

27. Lord's Prayer, etc.

Agnus Dei

Commixture

The Pax

Priest's reception

Ablutions

Collects

Dismissal

Private Prayer

Last Gospel
1549.

Introit

1. Lord's Prayer

2. Collect Kyrie

30. Gloria

4. Collects for King

5. Collect for day

6. Epistlo

7. Gospel

8. Creed

10. Sermon

16. Exh. to eommunicants

14. Exh. to negligent

11. Offertory Sentences

12. Providing elements

21. Lift up your hearts

22. Prefaces

23. Holy, Holy, Holy

13. Prayer

$$
\text { Church }
$$

25. Consecration

28. Thanksgiving

27. Lord's Prayer

Versicles

Agnus Dei

17. Invitation

18. Confession

19. Absolution

20. Comfortable

$$
\text { Words }
$$

24. Humble Access

26. Administration words

Agnus Dei

Sentences

Versicles

29. Thanksgiving

31. Blessing

\begin{tabular}{r|l} 
1552. & \multicolumn{1}{|c}{1662.} \\
1. & 1. Lord's Prayer \\
2. & 2. Collect \\
3. & 3. Commandments \\
4. & 4. Collects for King \\
5. & 5. Collect for day \\
6. & 9. Epistlo \\
7. & 7. Gospel \\
8. & 8. Creed \\
10. & 9. Notices \\
9. & 10. Sermon \\
11. & 11. Offertory Sen- \\
& \multicolumn{1}{|c|}{ tences }
\end{tabular}

12. Placing elements

13. 13. Prayer for Church

15. 14. 1st Exhortation

14. 15. 2nd to negligent

16. 16. 3rd to Communicants

17. 17. Invitation

18. 18. Confession

19. 19. Absolution

20. 20. Comfortable Words

21. 21. Lift up your hearts

22. 22. Prefaces

23. 23. Holy, Holy, Holy

24. 24. Humble Access

25. 25. Consecration

26. 26. Administration words

27. 27. Lord's Prayer

25. 28. Thanksgiving

29. 29. Altcrnative ditto

30. 30. Gloria

31. 31. Blessing

32. Surplus consumed

Sarum Use is much shortened to bring it within limits for comparison (for closer comparison see pp. $256 \mathrm{ff}$.); portions of 1549 in Italies were in 1548 Order of Communion, used with the Missal: Words of Administration of 1549 and 1552 were combined in 1559 as in 1662 ; Exhortations were much changed in arrangement (see p. 319). 


\section{ANALYSIS AND HISTORICAL NOTES}

Title, 1552 (1549).* . . . . . . . . . 286

\section{ANTE-COMMUNION.}

fGiving notice of intention to communicate, 1549 ;

altered $1662 . \quad . \quad . \quad 290$

Warning notorious evil-livers, 1549 . $\quad . \quad$. $\quad .291$

Warning those at variance, 1549 ; order to report to

Ordinary added 1662 . . . . . . 291

Defining place of Table, and position of Priest, 1552 ;

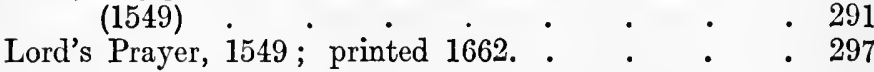

Collect for purity, 1549 . $\quad . \quad$ • . . . . 297

(Here in 1549 followed :-

Introit.

Lesser Litany.

Gloria in excelsis.

The Lord be with you, etc.)

Concerning the Commandments, 1552 ; enlarged 1662. . 298

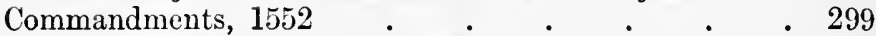

Concerning Collects for the King, 1549 . $\quad$. $\quad$. 299

Collects for the King, 1549 . . . . . 300

Concerning Collect, Epistle and Gospel, 1549 ; altered

1552 and 1662.0 .500

Creed, 1549 . . . . . . . . . 304

Respecting Notices, 1552 ; enlarged and placed before

Sermon, 1662 . . . . . . 306

Prescribing Sermon or Homily, 1549 ; altered 1552 and

1662

(Here in 1549 followed :-

$\ddagger$ Exhortation to communicants.

Exhortation to negligent.)

* Dates are put into brackets when subsequent changes of position, wording, or both, are important.

+ Rubrics are in italies and indented.

$\ddagger$ For the intricate changes of arrangement of Exhortations see Table on p. 319. 
Regurding the Offertory Sentences, 1549 ; altercd 1552, made separate Rubric 1662 . . . . . 310

Offertory Sentences, 1549 . . . . . . 310

Regarding the collection of the offerings, 1549; altered 1552 ard 1662

311

Ordiring the placing of the bread and the wine, 1662 (1549) ; no directions, 1552 . . . . (Hare in 1549 followed:-

The Lord be with you, etc., second time.

Lift up your hearts, etc.

Proper Prefaces.

Ter Sanctus.

Prayer for Church, including Consecration.)

Prayer for Chu ch Militant, 1552, (1549); last sentence added 1662

Indented Rubric, 1552 ; 'oblations' added 1662 .

Ordering Announcement of Holy Communion, 1548, (1549) ; 1662

First Exhortation, 1548; e.larged for the negligent, 1549; some time said also, 1552; adapted for announcing, and clause added from another Exhortation, 1662 .

Providing for the negligent, $154 \dot{9}$; placed before Second Exhortation. 1552

Second Exho:tation, 1552 ; one clause omitted 1662. .

313

318

318

318

322

323

\section{COMMUNION.}

Directing that communicants be conveniently placed, 1662 ; (1549) .

Third Exhortation, 1548 ; placed here 1549 ; one clause transferred to First Exhol tation, 1662

323

Preceding the Invitation, 1549, (1548); placed here 1552.

Fourth Exhortation (Invitation), 1548; placed here 1552.

Regulating the Confession, 1548

Confession, 1548

Confession, 1548 . . $\cdot 326$

324

325

326

326

Regarding the Absolution, 1548 ; called 'Absolution' 1662

321

Absolution, 1548; altered 1549

Comfortable Worus, 1548 .

Lift up your hearts, etc., 1549 ; placed here $15 \dot{2} \div 328$

Directing turning to the Lord's Table, 1662 . . 328

It is very meet, right, etc., 1549; placed he1e 1552 . 328

Indcnted Rubric, 1662 . $\quad$. $\quad$. $\quad$. $\quad .328$

Respecting Proper Prefaces, $1549 \quad$. $\quad$. $\quad$. 328 
Ter Sanctus, 1559 ; printed 1662 . $\quad$. $\quad$. 329

Proper Prefaces, 1549 :-

(1) Christmas, 1549; seven days after, 1552 . 329

(2) Easter, 1549 ; seven days after, 1552 • $\quad$ • 329

(3) Ascension, 1549; seven days after, 1552 . . 329

(4) Whitsunday, 1549; six days after, 1552 . . 330

(5) Trinity, 1549 ; in 1549, 1552, 'It is very meet,' etc., repeated with this Preface, 'holy Father' excepted 330

*Ter Sanctus, 1549; altered 1552 . . . . 331

(Here in 1549 followed :-

Long Prayer (the Canon), $\dagger$ including :-

Petitions for living and dead.

Consecration.

Oblation.

Thanksgiving.

Lord's Prayer.

Agnus Dei.

Fourth Exhortation.

Confession.

Absolution.

Comfortable Words.)

Preceding Prayer of Humble Access, 1548 . $\quad$. 331

Prayer of Humble Access, 1548; placed here 1552 . 332

Providing for arranging the bread and the wine, 1662. 333

Prayer of Consecration, 1552; (1549) . . . . 334

Indented Rubrics, 1662 ; (1549) . . . . . 339

Prescribing the order of reception, 1549, (1548); altered

1552 and $1662 . .340$

Regarding the administration of the bread, 1548 ; altcred

1552 and 1662 . . . . . 342

Words of administration of the bread, 1559 ; first part

1548,1549 ; second 1552 . . . . . 342

Regarding the administration of the wine, 1548 ; altered

1552 and 1662 . . . . . 343

Words of administration of the wine, 1559 ; first part

1548, 1549 ; second 1552 . . . 345

Dirccting Consecration of more brcad or wine, 1548 ; wanting in 1549, 1552 ; altered and placcd here $1662 \quad 345$

Directing to cover with a fair lincn cloth, 1662 . . 346

(In 1549 Agnus Dei sung during administration.)

* The Ter Sanctus was originally printed here only.

† The term 'Canon' is used in 1549 Communion of the Sick : it disappearcd in 1552. 


\section{POST-COMIMUNION.}

PAGE

(In 1549 Post-Communion Sentences and Versicle.

Respecting the saying of the Lord's Prayer, 1552 . 348

Lord's Prayer, 1549; placed here 1552; printed 1662 . 348

First alternative Thanksgiving, $1552 ;(1549)$. . 349

Second alternative Thanksgiving, 1549; altered 1552 . 352

Glo: ia in excelsis, 1549 ; placed here with one sentence

repeated 1552 . . . . . . 353

Regarding the method of dismissal, $1548 \quad$. $\quad$. $\quad$. 354

Blessing, 1549; (1548) . . . . . . 351

\section{APPENDIX.}

Concerning the use of Collccts when no Communion, 1549 ; enlarged 1552 , altered 1662 .
Collects, 1549 ; two for Rain and Fair Weather placed elsewhere 1552 . . . $\dot{C}$. . .

Concerning Sundays, etc., when no Communion, 1552 ;

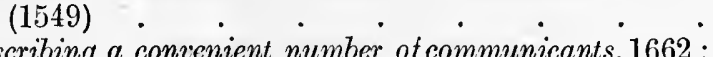

Prescribing a convenient number of communicants, 1662 ;

some, 1549 ; good number, 1552 . . . . . 356

Fixing the minimum, 3 out of 20,$1552 ;(1549) \quad$. $\quad$. 356

Ordering Clergy to communicate weekly in Cathedrals,

etc., 1552 . . . . . . . 357

Prescribing the use of purest Wheat Bread, $1552 ;(1549) \quad 357$

Dirccting the disposal of the bread and wine remaining,

Directing the provision of the bread and wine, 1549 ; altcred 1552 and 1662 . . . . . 362

Ordering a minimum attendance of three times a year,

$1552 ;(1549)$. . . . . . . 362

Regarding Easter Dues, 1552; (1549) . . . 364

Regulating the disposal of the offerings, 1662 . $\quad 365$

'Black Rubric,' 1552 ; omitted 1559 ; restored with verbal alterations, 1662 • $\quad$ • $\quad$ • . 


\section{EXPOSITION}

'We are thus taught by the Saviour, and also by the Apostle Paul, that this bread and this wine, which is placed upon the altar, are placed for a figure or memorial of the Lord's Death, so that it may recall to present memory that which was done in the past, and that we may be reminded of His Passion; by it also are we made partakers of the Divine gift by which we are freed from death. Knowing that when we shall come to the vision of Christ we shall no more have need of such outward means, by which we may be reminded of that which divine goodness endured for us. For beholding Him face to face we shall not be influenced by the outward admonition of temporal things, but by the contemplation of the thing itself (ipsius veritatis) we shall perceive in what way we ought to give thanks to the Author of our salvation.'-The Book of Bertram, Monk of Corbie, A.D. 840, on The Body and Blood of the Lord (De Corpore et Sanguine Domini), c. 100, translated by Archdeacon Taylor.

He who would know the principle upon which the Communion Office of the Church of England was built up by Cranmer can see it 'writ large' in this extract from the work whose reproduction at the period of the Reformation led Ridley, and through him Cranmer, back to Scriptural truth.

Title.

1549. The Supper of the Lord, and the Holy Communion, commonly called The Mass.

1552. The Order for the Administration of the Lord's Supper, or Holy Communion.

Commonly called The Mass : cf. 'Commonly called the Creed of St. Athanasius,' 'Those five commonly called Sacraments' (Art. XXV), 'the Sacrifices of Masses, in the which it was commonly said,' etc. (Art. XXI). The adverb ' commonly' stamps the usage as popular but inaccurate and undesirable; cf. "The Presentation of Christ in the Temple, commonly called The Purifcation of Saint Mary the Virgin,' a new title given in 1662 to justify the special observance of the Day, consonant with the Collect, Epistle, and Gospel. 
The name "Mass' is generally derived from the words of dismissal: Ite, missa est." It had been retained in the " $O$ de" of Communion' of 1548, and 'time of High Mass' is found in the Royal Preface to the Homilies in 1547 and 1548 , but it was changed to 'the Celebration of the Holy Communion' in the 1549 Edn. It appears only here in the 1549 B.C.P., and was finally discarded in 1552.

Bishop Tonstal at the great Parliamentary Debate on the Lord's Supper in December, 1548, began the disputation by objecting to the abandonment of the term 'Mass,' see Tomlinson's Tract, containing a verbatim reprint, Tracts on Ritual, vol. ii.

The Lord's Supper is a name derived from 1 Cor. xi. 20. The title prevailed in very early days, e.g., Hippolytus, 220 ; Dionysius the Great, 254 ; cf. Scudamore, Not. Euch., p. 5. $\dagger$ Though a very common name in the Middle Ages (Frere, $l . c$.), its manifest incongruity with the practice of non-communicating presence at a sacrifice, and that early in the day, had practically abolished its use in the West. $\$$ "I chanced in our communication to name the -Lord's Supper. 'Tush,' saith the bishop, 'What do ye call the Lord's Supper? What new term is that?" (Latimer's Sermons, p. 121, P.S.). Following a Jesuit of the close of the fifteenth century, Roman divines and others now try to dissociate the term as used by St. Paul from the Holy Communion; but no answer is or can be given to the fact that St. Paul goes on immediately to describe t' e Holy Communion, and has not a word to say about the Agapè : this latter may certainly have accompanied the Holy Communion at Corinth-probably did do so-but it is not the matter concerning which St. Paul writes. Nor is it easy to see on what ground any feast save the Holy Communion could be called 'the Lord's Supper.'

Holy Communion is taken from 1 Cor. x. 16, 17, which teaches the common partaking of Christ, and therefore fellowship with one another. This is the distinctive Reformation title, bringing out, by its implication of fellow-partaking, the contrast between the original rite, now restored, and the Mass-Sacrifice.

Other names have been and are in '1se ; 'Breaking of bread' Acts ii. 42 ; xx. 7 ; 'Eucharisti," an early and appropriate title, though not Scriptural. It is a strange irony that this title should

* I.e. : 'Go, the (congregation) is dismissed.' Others suppose that missa is a late corruption of missio, 'dismissal.'

$\dagger$ Frere says (New History of the B.C.P., Edn. 1910, p. 438, ft. nt.) that "it does not appear that 1 Cor. xi. 20 was interpreted absolutely of the Eucharist before the end of the fourth century.' This seems to be wrong.

$\ddagger$ In Hermann's Deliberatio (1535) the name was restored; see Dowden, Further Studies, p. 56. 
have become chiefly, though not exclusively, the property of those whose tendency is to subordinate the sacrifice of praise and thanksgiving to the idea of a sin-offering. The words of 1 Cor. xiv. 16 :-Else when thou shalt bless with the spirit, how shall he that occupieth the room of the unlearned say Amen at thy 'giving of thanks,' seeing he understandeth not what thou sayest? - have been cited as Scriptural authority for applying the name 'Eucharist' to the Holy Communion.* But there is not one word to indicate that St. Paul refers here to Holy Communion; the two preceding verses refer to prayer and praise, this to blessing and thanksgiving, the latter as general as the former in application; and the whole chapter deals with mysterious utterances, which, far from being necessary parts of worship, were ordered to be controlled as liable to disturb public worship. The nemesis of this kind of exegesis, which attempts to attach a later technical meaning to a word originally as general as our 'thanksgiving,' is its being carried to such an extremity as the limitation of the word in 1 Tim. ii. 1 :-' I exhort, therefore, that, first of all, supplications, prayors, intercessions, and Eucharists, be made for all men.' At the original institution our Lord 'said grace' over the bread and wine,

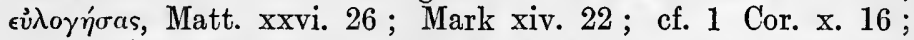

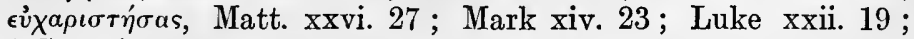
1 Cor. xi. 24 ; this use of the word, apart from the indiscriminate use of two Greek words, is decisive against its technical association with the whole rite. The early transition from the general meaning of thanksgiving to the special application of the word to the Holy Communion may be seen in the Didachè, $\S 9$; Ignat. ad Smyrn., 7, 8. Justin's Apology (i. 67), however, conclusively proves that the word was not thus restricted generally in 140 .

Sacrament is not, strictly speaking, a name of Holy Communion, though often used as such. It meant in classical Latin (1) the sum of money deposited by the parties to a suit, called 'a sacred thing,' either because a pledge against perjury and injustice, or because deposited in a temple, and to be used, if forfeited, for sacred things: (2) the suit itself : (3) the military recruit's preliminary pledge: (4) the military oath generally. In postAugustan Latin it had already become common for any solemn oath or obligation, in which sense it is used in Pliny's famous letter to 'Trajan, containing the Bithynian Christians' description of their public worship :

* Palmer, Orig. Lit., vol. ii. pp. $114 \mathrm{ff}$ : Frere, p. 30, ft. nt. (2), p. 432, ft. nt. (1), 'probably not in the technical sense,' and p. 435 , without any such qualification. This curious inconsistency of the latter writer is itself suffi. cient answer. 
'They asserted that this was the sum-total of their fault or error, that they were wont, on a fixed day, to assemble before daylight, and sing (dicere) a hymn in turn to Christ as God; and to bind themselves by an oath.(sacramento), not to a erime of any sort, but not to commit thefts or adulteries, not to deny their faith, not to repudiate a trust : these things completed, it was their custom to disperse, and to reassemble to take food, in common, however; and innocently : and even that they had abandoned sinee my ediet forbidding elubs by your mandate.'

Here the word has obviously its ordinary meaning of a sacred pledge.* Another meaning was conferred upon the word in ecclesiastical Latin, some idea of which may be gained by its use in the Vulgate to translate the Greek $\mu \nu \sigma \tau$ 'p (not 'an intellectual puzzle,' as the modern use of the word 'mystery' suggests) ; cf. Tobit, xii. 7, ' it is good to keep a king's secret (LXX $\mu v \sigma \tau$ ' clearly the works of God' $:$ Eph. v. 32, of the symbolic meaning of marriage : 1 Tim. iii. 16, 'great is the mystery of godliness (Vulg. sacramentum pietatis), God was manifest in the flesh,' êc. : Rev. i. 20: 'the mystery of the seven stars.' $\dagger$ From such passages as this last it is easy to see how the modern idea of 'transcending intelligence' attached to the word 'mystery,' a fruitful cause of mischief. in interpreting Patristic references to Holy Communion, as well as Holy Scripture. However, it is quite another error which has accompanied the use of the word 'Sacrament,' due to its ambiguity. Anciently used, like its

* Bishop Beveridge's suggestion, that the word is here used of the Holy Communion, though " the following words seem to show that the Eucharistie Service was in the evening ' (Robertson, History, i. 18, Note a), might pass unnoticed were it not that Harold Browne (Art. XXV) claims that 'it is generally supposed that its applicalion in this passage was to the Supper of the.Lord,' and refers 'to Waterland's Eucharist e. i. Frere (Procter and Frere, 432, n. 1) makes the same elaim, saying " the word was probably misunderstood by Pliny, and may have been teehnieally employed. It is probable enough that he [Pliny] used the very word whieh he had heard from them [the Bithynian Christians], and that they used it in the Christian and technieal sense, howsoever Pliny may have understood it.' Pliny's conjectural use of the actual word used by the Christians, and his conjectural misunderstanding, and eonsequent eonjectural mistranslation of their word-for presumably the Bithynians did not use Latin terms in A.D. 112-constitute slender support for a claim styled 'probable.' It is more truly probable that the desire to find earlier evidenee of the separation of the Holy Communion from the Evening Agapè, and another reason for it than that expressly contained in the letter itself, viz., Trajan's mandate against clubs, is responsible for the perpetuation of this suggestion. It is unfortunate that Harold Browne's quotation stops short of the referenee to the re-assembling for food. Robertson $(l . c$.$) supposes that the baptismal$ vow may probably be intended; Tertullian ( $A$ pol.2) gives it no sacramental signification of any kind.

$\dagger$ Mysterium is also sometimes employed in the Vulgate; ef. Eph. vi.

19 ; ' mystery of the Gospel,' mysterium evangelii. 
Greek theologieal equivalent, for anything connected with revelation (e.g. Cyprian's reference to many saeraments in the Lord's Prayer), it very gradually acquired a teehnical meaning in Augustine's time: signa, cum ad res divinas pertinent, sacramenta appellantur, Ep. 138. He applies the word to O.T. symbols, e.g., manna, as well as to Baptism and Holy Communion, but regards these two as the N.T. sacraments, $D e$ doctrina Christiana, iii. 9 : ef. Epistle 54, where, however, is added et si quid aliud in Scripturis Canonicis commendatur: ' and anything else, if any, which is commended in the Canonieal Scriptures.' Lombard fixed upon the symbolical number seven, in the twelfth century; the Reformers returned from this arbitrary use of the word to the more reasonable one suggested by Augustine, limiting it more definitely, however, to the two rites instituted by Christ. A further ambiguity, produetive of many misconceptions, is the double use of the word, both to signify the rite $\mathrm{cs}$ a whole, including the outward visible sign and the inward invisible grace, and also for the former alone. Sometimes even the outward visible sign is not wholly included in the word, the consecrated bread and wine, to the exclusion of the distribution and partaking thereof, being called 'the Sacrament.' Many a reference to the whole rite, in the Fathers, in the Reformers' writings, and in B.C.P., is reasonable and intelligible as applied to the Sacrament as a whole, which would be unjustifiable if used of the outward alone. It is interesting to note that in the expression 'pledges of his love,' there is a return to the classical meaning of the word 'Sacrament,' a pledge given by God to us, however, not by us to Him.*

\section{ANTE-COMMUNION.}

Rubric giving notice of intention to communicate, 1549 .

1549. Overnight, or else in the morning afore the beginning of Matins, or immediately after.

* Other expressions, as 'offering' ( $\pi \rho \circ \sigma \phi o \rho d)$ ), 'sacrifice' $(\theta v \sigma i a ́)$, are given as early names of the rite in Frere $(l . c$.$) ; but, if accurately, their technical$ meaning is abandoned for a spiritual one. For example the passage cited but not quoted by him for the use of 'Sacrifice,' and 'Commemoration, Memorial,' Justin, Dial. 117, is : 'Now that prayers and giving of thanks, when offered by worthy men, are the only perfect and well-pleasing sacrifices to God, I also admit. For such alone Christians have undertaken to do, and in the remembrance made by their food, both solid and liquid, in which the suffering of the Son of God which he endured is brought to

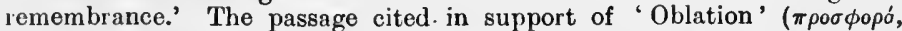
a word frequent in the N.T for a sacrificial offering, but never used of Holy Communion) is Clem., Ep. Cor., 40, where, far from being a 'name' for Holy Communion, the word is not used in the singular at all; and the whole passage refers expressly to Jewish sacrifices, ' high-priest,' 'Levites,' and 'Jerusalem' being named to define the reference. 
1552. 'Matins ' altered to 'Morning Prayer.'

1662. At least sometime the day before.

This alteration was a concession to the request of the Pres byterians at the Savoy Conference.

Rubric warning notorious evil-livers, 1549 ; unimportant verbal changes 1552 and 1662 .

Rubric warning those at variance, 1549 ; order to report to Ordinary added 1662 .

The Ordinary is the judge authorized to take cognisance of causes, i.e.-in this case the Bishop of the Diocese, from whom appeal lies to the Archbishop, and from him to the King in Council. Seeing that Canon Law is abrogated by desuetude, and that this form of exercising 'the Canon' has certainly not been used for some time, the Ordinary cannot fulfil this rubric. The abandonment of attempts to enforce uniformity has made it unlikely that an open or notorious evil-liver would come to the Lord's Table, though it is to be feared that those at variance may do so, in spite of warnings. A recent attempt to interpret 'evil-liver' in a sense not recognized by Statute Law, and to refuse the bread and wine to one who had married his deceased wife's sister, was condemned on appeal to Law by the rejected communicant.

Rubric defining place of Table and position of Priest, 1552.

1549. A rubric stood here, regulating the vesture of the officiant, and of his assistants, if any (see p. 79), concluding, "Then shall the Clerks sing in English for the Office, or Introit* (as they call it), a Psalm appointed for that day. The Priest standing humbly afore the midst of the Altar, shall say the Lord's Prayer, with this Collect.'

1552. The Table, having at the Communion-time a fair white linen cloth upon it, shall stand in the body of the Church, or in the Chancel, where Morning Prayer and Evening Prayer be appointed to be said. And the Priest standing at the North side of the Table, shall say the Lord's Prayer with this Collect following.

S.L. The Holy Table having at the Communion-time a Carpet, and a fair white linen cloth upon it, with other decent furniture, meet for the high mysteries there to be celebrated, shall stand at the uppermost part of the Chancel

* The 'Introit as they call it' was a reminiscence of the mediæval 'approach to the Altar,' and was removed in 1552. It has been of late re-introduced under cover of the growth of the use of hymns. 
or Church, where the Presbyter standing at the North side or end thereof, etc.

1662. As in 1552, with 'the people kneeling' added.

\section{(1) The Meaning of 'Table.'}

In 1549 the word 'table' was introduced three times, 'God's Board' twice, ' altar' being also retained. But though the word was retained, the altars themselves began to disappear as early as February of that same year, and an Order in Council, dated November 23, 1550, bade every bishop 'pluck down the altars,' and prescribed a 'table' instead, stating that 'the form of a table shall more move the simple from the superstitious opinions of the popish Mass, unto the right use of the Lord's Supper. For the use of an altar is to make sacrifice upon it; the use of a table is for men to eat upon.' Accordingly, in 1552, the word 'altar' disappeared from the B.C.P., and was not restored at the revision of 1662, though the abortive Canon of 1640 , attempting to enforce the altar-wise position of the Table, claimed a legitimate use of the word as applied to the Lord's Table: "We declare that this situation of the Holy Table doth not imply that it is, or ought to be esteemed a true and proper Altar, whereon Christ is again really sacrificed, but it is and may be called an Altar by us, in that sense in which the Prinitive Church called it an Altar, and no other.' The word bas persisted in popular language, especially in regard to the Marriage Service, where a sense of humour might have killed theinaccuracy; and the occasional Coronation Offices, which cannot be taken to govern the doctrine and usage of the Church of England, have been used for an introduction of the word. The word is unseriptural, unhistorical, and misleading :-

(a) In the 0.T. the prescribed altars were two, the brazen altar of sacrifice, and the golden altar of incense. Earth and unhewn stone were the only materials permitted, though the casings were directed to be of brass and gold for the two altars of the Tabernacle. To carve the stone was to pollute the altar, and to add steps was an insult to God (Exod. xx. 24-26). An altar may be sometimes called a table, cf. Ezek, xli. 22, and Mal. i. 7 ; but a table cannot conversely be called an altar.

In the N.T. the altar of sacrifice finds its typical significance fulfilled in the Cross, the golden altar has its counterpart in the Presence of God where our High-Priest ever liveth to make intercession for us. The two altars are both mentioned in Revelation, where they are in heaven, save indeed that the measured temple, altar, and them that worship therein (xi. 1), are once figuratively applicd to the Church Militant. In all 
the word is used twenty-three times, and always of the two O.T. altars, save once of Abraham's altar, and once of the Cross perhaps. This last reference, Heb. xiii. 10, 'we have an altar,' may very well refer to the Israelitish Altar of Sacrifice, for the ' we,' which is unemphatic, would mean Israelites in a letter written by a Jew to Jews. If the 'we' means 'we Christians,' even so the writer does not say that we have 'altars' in our churches, much less that the Table of the Lord is an altar. As a matter of fact the typical altar was outside the building, symbolizing by its position that not until sacrifice had been offered could any one venture to enter the Tabernacle or Temple. In one place (1 Cor. x. 18-21), St. Paul uses the word 'altar' of the Jewish sacrifices, in connexion with the Lord's Supper, and carefully avoids using the word of the Christian rite, substituting for it the word 'table.'

(b) In the primitive church Ignatius and Polycarp use the word fancifully enough (see p. 224), but most early writers avoided the dangerous word, Minucius Felix stating roundly that Christians have no altars. So late as Ambrose, the figurative use of the word is clear : 'our altar is not visible but invisible' (Ep. ad $H e b$. viii). It was not until the eleventh century that the wooden tables were replaced in England by stone altars, though the growth of the idea of a sacrifice for sin in the Lord's Supper had long tended to make the table an altar. The brief account of the Reformers' action already given demonstrates the importance which they attached to the avoidance of both the word and the thing.

(c) The re-introduction of the word is to be deprecated as inevitably leading to unscriptural ideas of the Holy Communion, with which, indeed, the word is associated by the majority of those who use it with any meaning atall. The highest Court of Appeal stated in 1857 that 'the Reformers considered the Holy Communion not as a Sacrifice but as a feast to be celebrated at the Lord's Table,' and declared stone structures to be illegal.

The use of the singular, 'the Table' in B.C.P. sufficiently. shows that side-tables, 'Credence-Tables,' were not contemplated by the compilers or revisers, but the use of such was not condemned when the case was brought into court. The meaning of the term 'credence' is not known, but the tables are used for the elements before they are placed on the Lord's Table. Such side-tables seem to have been unknown before the seventeenth century (see Micklethwaite, Ornaments of the Rubric, p. 40.

(2) Place of Table.

1549. No order was made, the :Itar-wise position being 
retained (though some altars disappeared that same year), and the Communicants being gathered in the 'Quire,' from which non-communicants were excluded.

1552. The Table was to be placed in the Nave or the Chancel, for the convenience of worshippers, that the Priest's words might be audible and his actions visible.

1559. Elizabeth's injunction ordered the Table to be placed 'where the Altar stood,' except at Communion, when it was to be "so placed in good sort within the Chancel, as whereby the minister may be more conveniently heard ... and the communicants also more conveniently, and in more number communicate'; the Table was afterwards 'to be placed where it stood before.'

An old synopsis of 'Varieties in the service,' of 1565, describes the absence of a uniform placing of the Table in those days :-

- The Table standeth in the body of the Church in some places, in others it standeth in the Chancel. In some places the Table standeth Altarlike distant from the wall a yard, in some other in the midst of the chancel north and south.'

1566. The Advertisements in one place specified 'the East wall over the said Table,' but did not deal directly with these varieties.

1640. A Canon, framed to enforce the altar-like position, spoke of it as adopted 'in most Cathedrals, and some Parochial Churches,' and as not being any longer under 'just suspicion of Popish superstition or innovation.' It also ordered the railing in of the Table, to prevent the irreverent way in which it had been misused, namely for hats, and even as a seat.

1662. Attempts to enforce this Canon on the lines of the Scottish B.C.P. of 1637 were frustrated, the liberty of the 1552 Rubric being still retained.

Within a short time from the Restoration the moving of the Table for the Communion seems to have died away; the custom of erecting pews in Churches had already made the placing of the Table in the body of the Church difficult, if not impossible, while the almost invariable addition of rails made any moving of the Table a practice scarcely to be carried out with the quiet reverence desirable at the Lord's Supper. The absence of screens, too, made moving unnecessary.*

* For very full details, with illustrations, see Tomlinson, Tracts on Ritual, Nos. $88,164,180$ and 203 , from which the above notes have been freely borrowed 
(3) Position of Priest.

1549. Standing humbly afore the midst of the Altar.

1552. Standing at the North side of the Table.

S.L. Standing at the North side or end thereof.

1662. Standing at the North side of the Table ; and (in the Rubric before the Consecration) 'when the Priest, standing before the Table, hath so ordered the Bread and Wine, that he may with the more readiness and decency break the Bread before the people, and take the Cup into his hands,' etc.

The position 'afore the midst of the Altar' represented the medieval position of a sacrificing priest; in earlier days the officiant had often stood behind the Table, facing the people. Before 1552, the Eastward Position (as it is called) had been very generally abandoned, and the North side position was apparently chosen to obtain uniformity wherever the Table stood, against the East Wall or in the body of the Church. Of course it had no meaning in itself, save as a visible protest against the Mass position, which commenced at the South and ended 'afore the midst of the Altar.'

The 1552 ordinance was unchanged in 1662, the new rubric before Consecration providing for such cases as that of Bishop Wren, who defended himself from the accusation of having once adopted the sacrificer's position by alleging that his littleness of stature made it impossible for him readily and decently to reach the bread and wine from the North side.

In spite of the plain facts of history, and the obvious concurrence with these facts of the 'North side or end' of S.L., cfforts to recover the sacrificial position of the Priest at Holy Communion were crowned with considerable success in 1890 , when the then Archbishop of Canterbury decided that the Eastward Position is legal, so that the 'afore the midst' of 1549, and the 'North side' of 1552, are to be considered synonymous. Yet the highest Court of Appeal had stated in the Purchas Judgment: "North side means that side which looks towards the north'; and, in the Ridsdale Judgment: 'It is the duty of the minister to stand at the side of the Table which, supposing the church to be built in the ordinary westward position, would be next the north, whether the side be a longer or shorter side of the table ... it is accurate, both in scientific and in ordinary language, to say that a quadrilateral table has four sides.'

The history of the theory which seems to have determined the Lambeth Judgment of 1890 is important as showing that that theory is novel. 
(a) The North side is the North-West Corner; sug. gested in a journal called The Ecclesiastic.

(b) The whole front is divided into five sections, viz. N. and S: Corners, the Midst, and, between the Corners and the Midst, the N. and S. sides ; theory of F. G. Lee, Directorium Anglicanum, 1865.

(c) The front is divided into three sections, North side Middle, and South side; theory of Blunt and Freeman:

(d) The front is divided into two sides, North and South, by an imaginary line ; theory of Littledale.

(e) There is now no 'North side,' the rubric only referring to the Table as placed East and West in the Body of the Church, so that, being oblong, its North side was identical with its front when placed Altar-wise. This is the theory of Walton and Scudamore, who, so early as 1866 , pointed out the absurdity of their predecessors' attempts to reconcile the Eastward Position with the words 'North side.'

Is their own any better?

(i) It assumes a distinction between 'side' and ' end?' which was unknown to Laud and Wren when the S. L. was drawn up, in 1637 , with the words 'side or end.'

(ii) It assumes that all Tables were oblong, which they certainly were not.

(iii) It assumes that when moved from the East End to the Chancel or body of the Church, the Tables were always placed East and West, of which assumption there is no proof.

(iv) It assumes either that all Tables were always moved for the Communion in 1662-an obvious contradiction of facts-or that the rubrical direction for the priest was of only partial application, viz., to those in Churches. where the Tables were so moved-an assumption of which there is no evidence.*

In conclusion, it should be noted that the Eastward Position should be avoided on the following grounds :-

(1) Now, as at the Reformation, its significance is the sacrificial idea conveyed thereby.

- For tho whole subject, including full historical investigation of the Lambeth Judgment, see Tomlinson, Tracts on Ritual, $l$. c., also 195, and Lambeth Judgment Examined, in vol. ii. 
(2) The Lambeth Judgment itself recognizes the necessity of the manual acts being visible; a practical impossibility with the Eastward Position.

(3) The posture is inconsistent with the whole genius of the B.C.P. which sets the ministry forth as ministering to a congregation, not as acting for them in any sacerdotal capacity.

Lord's Prayer, 1549 ; printed here 1662, cf. S.L.; Sar. Miss. in Priest's Preparation.

The omission of any direction to the people to join in the Lord's Prayer is probably the reason for the prevalence of the custom of the Priest's saying it alone, though it may also be that its having formed part of the private preparation of the Priest in the Missal aided the practice. Whatever the cause, the custom is inconsistent with the 1662 Rubric before the Lord's Prayer in Morning Prayer directing the people to repeat it with the Priest, " both here, and wheresoever else it is used in Divine Service.' Some have imagincd that 'Divine Service' applies only to Morning and Evening Prayer, with, perhaps, the Litany ; but this theory will not hold with the use of the phrase in two 1662 Rubrics in the Communion Service, that for giving notices, and that directing the disposal of the collection. Others (e.g. Blunt) suggest that the wording of the Morning Prayer Rubric (Cosin's) was an oversight, which is hardly serious. Strictly the Lord's Prayer should be repeated by the people, and the 'Amen' is so printed that unless they do so, they take no audible part in the Prayer.*

Collect for Purity, 1549 ; Sar. Miss. in Priest's Preparation; Leofric; Alcuin.

The Latin has been partly improved by the English Translation, but partly impaired: Deus, cui omne cor patet, et omnis voluntas loquitur et quem nullum latet secretum; purifica per infusionem Sancti Spiritus cogitationes cordis nostri; it te perfecte ditigere et digne laudare mercamur. Per Christum Dominum nostrum. Amen.

Literally translated: 'God, to whom every heart is open and every. wish speaks, and from whom no secret lies hid ; purify by the inpouring of the Holy Spirit the thoughts of our heart; that we may deserve to perfectly love and worthily praise thee. Through Christ our Lord, Amen.' 'All desires known' is a

* See Dowden, Further Studies, pp. 82-88.

$\dagger$ The verb mereor had bccome very general in its significance, often moaning little more than 'obtain.' But its very frequent use in Latin Collects is at Icast ambiguous, especially when the tendency of human nature to substitute mcrit for grace is talien into consideration. 
somewhat poor equivalent for the original, lit. 'to whom every wish speaks'; on the other hand, the idea of 'merit,' in the word mereamur, is gladly missed.*

Rubric concerning the Commandments, 1552; enlarged 1662. 1552. Then shall the Priest rehearse distinctly all the $X$. Commandments, and the people kneeling shall, after every Commandment, ask God's mercy for their transgressions of the same, after this sort.

1662. Then shall the Priest, turning to the people, rehearse distinctly all the Ten Commandments; and the people, still kneeling, shall, after every Commandment, ask Godt mercy for their transgression there of for the time past, and grace to keep the same for the time to come, as followeth.

The addition, 'turning to the people', was a partial concession to the Puritans' demand at the Savoy Conference.

In 1549 Auricular Confession $\uparrow$ was still recognized (though not enforced) with its examination of the sinner. In 1552 for this method of examination, liable to so many and grievous corruptions, was substituted the reading of the Decalogue, with a special petition after the reading of each Commandment. Palmer finds some precedent for both the reading and the petition in the custom of reading the last Six Commandments in Lent, with a prayer at the close : "Pity me, 0 Lord, since I am weak, heal me, O Lord.' But the petition is obviously formed by adding to the familiar words of the Lesser Litany, used in the Communion Office here in 1549, a special request for power to keep each Commandment. Cranmer had many precedents for this departure. The Frankfort Church Order of 1530 introduced the Decalogue just before the Exhortation warning against unworthy reception; the Christly Order for Bremen (1534) directed an exposition of the Ten Commandments after the Sermon in the Mass ; Bugenhagen's Church Order for Pomerania (1535) prescribed them to be sung as an alternative use in the Mass; the Northeim Church Order (1539) contained the Decalogue; the Order for Calenberg and Göttingen introduced it just before Confession in the Mass. Moreover Luther's metrical version (1524), each verse being followed by 'Lord have mercy,' was translated into English by Coverdale, with the response. These possible sources render it quite needless to trace Cranmer's work to Pullain's service for refugees at Glastonbury (with Frere and Daniel), in which the Decalogue was sung

* For the variation of the Service here in 1549, which more uearly followed the order in Sar. Miss., see analysis, p. 282.

$\dagger$ See p. 321. 
at Morning Prayer, in two separated parts, especially as this service only appeared in 1551, barely, if at all, in time to suggest anything to the Revisers of the 1552 B.C.P. The prayer in Pullain's Service : 'deign to write (thy law) in our hearts by thy Spirit': is similar to the response to the tenth Commandment, and may possibly have suggested it, but so scriptural a figure need not be traced to anything but knowledge of the Bible.*

The present Scottish B.C.P. allows the use of the Lord's summary of the Commandments (Matt. xxii. 37-39), with a petition similar to that after the tenth; the American B.C.P. gives a similar relaxation when the Commandments have been read in full once in a day. The Non-Jurors' B.C.P. of 1718 was the first to substitute this summary.

S.L. (1637) added after 'transgression': 'either according to the letter, or to the mystical importance of the said Commandment,' a valuable distinction taught by the Sermon on the Mount, but capable of clearer expression. It did not make any reference to 'the time to come,' cf. 1552 B.C.P., possibly because that is plainly included in the petitions themselves. Frere states that the word 'mystical' has special reference to the Fourth Commandment, a statement which agrees with the autboritative desecration of the Lord's Day at that period; but 'mystical' is rather too euphemistic a description of the Laudian practice.

Commandments, 1552.

The version of the Great Bible was not changed for A.V. in 1662 , as in most other cases ; the same version is used in the Catechism, where, however in 1549, the Commandments were abbreviated.

Rubric concerning Collects for the King, 1549.

1549. Then shall follow the Collect of the day, with one of these two Collects following, for the King.

1552 added :- the Priest standing up, and saying: Let us Pray.

1662. Then shall follow one of these two Collects for the King, the Priest standing as before, and saying : Let us pray.

The mention of the Collect for the Day first, in 1549 and 1552 , is a reminiscence of the Missal, where ' memorials,' i.e. various Collects, were read after the Collect for the Day, and before the Epistle. The Rubric regulating the use of the six collects at the end of the Communion Office was altered in 1552 to permit of their being used not only when there was no Com-

* See Dowden, Further Studies, pp. 167 ff. 
munion, as in 1549 , but also at the Communion, and other Services. It has been suggested that the intention was that they should be used here (Palmer), but without any evidence in support of a theory which conflicts with the next Rubric : 'immediately after the Collect the Priest shall read the Epistle.'

Collects for the King, 1549.

1662. 'Church' for 'congregation' in the first Collect.

St. Paul's injunction (1 Tim. ii. 1,2) to remember Kings and all that are in authority first in our prayers, was very literally carried out in the Middle Ages, Kings sometimes bargaining for Masses to be said in return for benefits.* The changes in regard to the authority exercised by Kings seem to call for some recognition in B.C.P., which still retains the language suitable to the times of Absolute Monarchy. However, these Collects are more free from such unsuitable phrases than some others, though the second is markedly preferable to the first, as not pronouncing the King to be God's chosen servant (which reads queerly of a Charles II or James II), and as praying more definitely for grace for the King to fulfil his high office, instead of, as in the former of the two, for grace for his subjects to obey him. Yet the turbulence of 1548, under a boy-king, may well have made the latter a more pressing need than the former. As Bishop Dowden points out, the successive changes in political life call for suitable petitions, and rebuke that strange spirit of worship of the antique which opposes such improvements on the ground that the present forms are old.

Rubric concerning Collect, Epistle and Gospel, 1549 ; altered 1552 and 1662.

1549. The Collects ended, the Priest, or he that is appointed, shall read the Epistle in a place assigned for the purpose, saying. The Epistle of Saint Paul written in the - chapter of - to the -. The Minister then shall read the Epistle. Immediately after the Epistle ended, the Priest, or one appointed to read the Gospel, shall say, The holy Gospel written in the - chapter of - . The Clerks and people shall answer, Glory be to Thee, 0 Lord. The Priest or Deacon then shall read the Gospel. After the Gospel ended, the Priest shall begin.

1552. Immediately after the Collects, the Priest shall read the Epistle beginning thus: The Epistle written in the - chapter of -. And the Epistle ended, he shall say the Gospel beginning thus: The Gospel written in

* See Dowden, Workmanship of the Praycr Book, 2nd Edn., p. xxii. 
the - chapter of - . And the Epistle and Gospel being ended, shall be said the Creed.

S.L. Immediately after the Collects, the Presbyter shall read the Epistle, saying thus: The Epistle written in the - Chapter of - at the - verse. And when he hath done, he shall say : Here endeth the Epistle. And the Epistle ended, the Gospel shall be read, the Presbyter saying : The holy Gospel is written in the - Chapter of - at the - Verse. And then the people all standing up shall say : Glory be to theo, 0 Lord. At the end of the Gospel, the Presbyter shall say: So endeth the holy Gospel. And the people shall answer: Thanks be to thee, 0 Lord. And the Epistle and Gospel being ended, shall be said or sung this Creed, all still reverently standing up.

1662. Then shall be said the Collect of the Day. And immediately after the Collect the Priest shall read the 'Epistle', saying, The Epistle [or, The portion of Scripture appointed for the Epistle] is written in the - chapter of - beginning at the - verse. And the Epistle ended, he shall say, Here endeth the Epistle. Then shall he read the Gospel (the people all standing up) saying, The holy Gospel is written in the - chapter of - beginning at the - verse. And the Gospel ended, shall be sung or said the Creed following, the people still standing, as before.

With the excision, in 1549 (note the words : 'immediately after the Epistle ended'), of much ceremonial in introducing the Gospel, there also took place the custom of naming the places from which the Epistle and Gospel are taken. After the division of the Bible into verses, which first appeared in the Genevan Version (1557-60), the exact verse was also announced, both in S. L. and in 1662. According to Frere (Sarum Customs) the practice of making some such announcement, of course in Latin, obtained in the Middle Ages. The German Church Orders, e.g. Brunswick, 1528, prescribed this practice; cf. also Brandenburg-Nuremberg Order, 1533.

In the Missal, the Epistles taken from most of St. Paul's writings commenced with the word Fratres; from his Pastoral Epistles with Charissime; from the other Epistles with Charissimi. The Gospel began with in-illo tempore, as also did 'Epistles' taken from the Acts and historical books of the O.T. ; selections from the Prophets had Haec dicit Dominus prefixed.

The direction to the people to say: 'Glory be to thee, 0 Lord': after the announcement of the Gospel, was omitted in 1552, and not re-inserted in 1662, though the S.L. had 
restored it, and added: 'Thanks be to thee, $O$ God': after the reading. Either the 1549 or the S.L. practice is very general now, but neither has sanction in B.C.P.

In 1662 the incongruity of saying: 'The Epistle written in the-Chapter' of a book which is not an Epistle was removed.*

Incense. In 1549 the words 'immediately after the Epistle ended,' prefacing the announcement of the Gospel, marked an important divergence from Sar. Miss., which introduced the Gospel with elaborate ceremonial, including profuse employment of incense. In view of the re-introduction of the use of Incense, the following conclusive proofs of its unscriptural, unprimitive and unreformed nature are valuable.

(a) In the O.T. incense was used under stringent regulations as to material, method, and place, Aaron's sons suffering death for disregard of those laws. The offering of incense was confined to the priesthood, the type of Christ's priesthood, and took place out of sight of the worshippers.

In the N.T. Zacharias was offering incense in his turn as priest, when the birth of John was foretold to him. There is no other mention of incense in the N.T. except in Revelation, where it is always used of a heavenly ritual. In regard to the words of Mal. i. 11, 'in every place incense shall be offered unto my name' (A.V.), it is to be borne in mind that the words 'shall be' are not in the original, and that R.V. substitutes' is,' which makes a literal interpretation impossible. The N.T. writers know nothing of any literal fulfilment of this passage. Indeed, the ingredients of the incense so carefully prescribed in the Pentateuch are no longer known, their place being taken by a mixture of spices, pitch, and burnt sugar, in the Church of Rome.

(b) The early church knew nothing of incense as an accessory to public worship. Its use is disclaimed by all who mention it from Justin Martyr to St. Augustine. Scudamore holds its ritual use to have commenced somewhere in the sixth century, or possibly in the fifth. The meaning of it was plainly prayer in Holy Scripture; its early use in churches seems to have been quite different, namely, as a fumigatory, under the impression

- The arrangement of the Gospels on Palm Sunday and Good Friday, so as to follow the Second Lessons at Morning Prayer on those days, indicates the intention that Holy Communion should follow Morning Prayer. The B.C.P. lays no stress upon the hour of Holy Communion, which, as in the early Church, must be dictated by convenience (see p. 218 and p. 225) God's own example in subordinating times and seasons to weightier matters in regard to the Passover, should here be the communicant's guide; the ministerial obligation is to provide for the spiritual needs of all believers. 
prevailing to a very late date, that to disguise the odour of anything unhealthy was to cure it. This notion lingers in the Roman explanation of the use : "that all spirits of diseases, and all spirits of infirmity, and the ensnaring emissaries of the enemy smelling its odour may flee away' (Pontif. Rom. Part II). It is now variously interpreted as symbolical of zeal, virtue, and prayer.

(c) Nothing was more strongly repudiated at the Reformation than the use of incense, which, even before the Reformation, was far from general. Grindal ordered the destruction of censers as 'relics and monuments of superstition and idolatry'; the Homily On Peril of Idolatry is very strong : 'Let us honour . . . none but Him, not in lighting of candles, burning of incense, etc., for all these be abominations before God.' The Ecclesiastical Courts, as well as the Archbishops of Canterbury and York, have pronounced the ritual use of Incense in the Church of England to be illegal.

Lights. Edward VI's Injunction of 1547, ordering ' no offering or setting of lights or candles, tapers or images of wax to be set afore any image or picture, but only two lights upon the high altar, before the sacrament,' has become famous as the historical ground for the re-introduction of lights at Holy Communion. Edward's order was only a repetition of that of Henry VIII, in 1541, and at the date of the re-enactment, July 31, 1547, no change of doctrine had been attempted. With the 'enactment of the 1549 B.C.P. these Injunctions were ordered to be no longer read, Ridley and Hooper expressly forbidding the lights to be placed upon the Lord's Table. Queen Elizabeth, apparently for state purposes, had two candles burning before a crucifix in her own chapel, but the crucifix was broken and the candles were no longer lighted when they had served their turn in mystifying the foreign ambassadors. Moreover, they were not lights before the Sacrament. Bishops Grindal and Horn, in 1567, stated that "the Church of England has entirely given up the use of a foreign tongue, breathings, exorcisms, oil, spittle, clay, lighted tapers, and other things of that kind which by prescription of the laws are never to be restored.'

The general history of the use of lights in Christian service may be summarized as follows :-

(a) In the N.T. lights are once mentioned, when they were used to give light (Acts $\mathrm{xx} .7,8$ ). It could never occur to a Christian Jew to attempt to copy the seven-branched candlestick (lampstand) of the Temple, the Light of which was fulfilled in the Person of Christ, the Light of the World, the oil supply in the gift of the Holy Spirit, and the sevenfold candlestick 
itself in the various light-bearing branches of the one Church (Rev. i.).

(b) Tertullian (192), Lactantius (303), and others derided the heathen custom of using lights in the daytime; and Jerome only furnished a half-hearted defence of the practice, adopted by some in his day, of lighting tapers by day in honour of martyrs, crediting them with ' a zeal of God, but not according to knowledge.' Such careless toleration of customs admittedly heathen in origin has been a fruitful cause of doctrinal perversion in every age of the Church's history. Jerome also reports that at the reading of the Gospel lights were lit at noon in the East to signify the light-giving of the Word. This practice spread to Spain by the seventh century, the lights, after use, being set at first on the floor, later upon the Altar. This seems to have been the origin of altar-lights as distinct from the two lights before the Sacrament.

(c) In 787, the second Council of Nicæa decreed that incense and lights might be offered to images of Christ and the Saints, to the Cross, to the Book of the Gospel, etc., defending themselves on the perilous ground that 'the honour which is paid to the image passes on to that which the image represents.'

(d) By 1215, when at the Fourth Lateran Council Pope Innocent III decreed the doctrine of Transubstantiation, the "Host"' had become the chief representation of Christ. Accordingly, then, for the first time, the two lights were ordered to be set burning upon the altar. Cardinal Langton, in 1222, promulgated the order in England, directing that "two candles, or at least one together with the lamp' (i.e. the lamp before the reserved host), should be burning at Mass, and that the laity must kneel to the Body of the Lord as to their ' Creator and Redeemer.'

The two lights on the Lord's Table are therefore historically inseparable from the mediæval doctrines which were repudiated at the Reformation.

Creed, 1549, Sar. Miss.

Before the Reformation the laity, who did not know the Nicene Creed, were bidden to say the Apostles' Creed to themselves, while the priests recited the Nicene.

Since Hort's Dissertation, in 1876, it has been generally admitted that this Creed, commonly called the Nicene Creed, or. more fully Niceno-Constantinopolitan, from the theory that the additions therein to the Nicene Creed of 325 were made at the Council of Constantinople in 381, appears in Epiphanius about seven years before that Council. Epiphanius came from the neighbourhood of Jerusalem, and the Catechetical Lectures of 
Cyril of Jerusalem contain material which, put together, composes the Creed practically as it is now known. The Acts of the Council of Constantinople are not extant, but, from the Creed being called Constantinopolitanum, it is conjectured that it was there propounded by Cyril and received as orthodox. In 451, the Council of Chalcedon recited it as the Creed of the 150 Fathers at Constantinople.*

The qualitative difference between the Nicene and Apostles' Creeds is that the latter is the development of a formula for baptism, the former is a document primarily drawn up, at Nicea, as a test of episcopal orthodoxy, and provided with an Anathema, the first to appear in the history of the Church. But the form of both Creeds is identical, emphasizing in turn the three Persons of the Trinity.

Strangely enough, the use of this (or any) Creed at Holy Communion originated in the protest of the Monophysite Patriarch of Antioch, Peter the Fuller (476-488), against the Chalcedonian definition of the faith. The custom spread rapidly in the East, and by 600 it was adopted in Spain, by 800 in Gaul. It was in Spain, at the Council of Toledo, 589, that the famous clause ' and the Son' was first added to ' proceedeth from the Father,' a clause which still divides the Eastern and Western Churches. $\dagger$ Only in 1014, under Pope Benedict VIII, was the Creed introduced into the Roman use.

A literal translation of the Greek Creed is appended, the portions not in the original Nicene Creed, of 325 , being bracketed :-

1 We believe in one God Father Almighty. Maker of heaven and earth, of all things both visible and invisible:

And in one Lord Jesus Christ, the Son of God the only-begotten,

* See Turner, History and Use of Creeds, etc., pp. $41 \mathrm{ff}$.

$\uparrow$ The Westerns were certainly in the wrong in making the unauthorized addition, as the Pope very plainly showed by refusing, in 809 , to sanction the Gallic form with the added words. He had two silver shields made and inscribed with the original Greek and the Latin Version, excluding that addition. Not till 1054 did the final rupture between the Eastern and Western Churches take place, and then through resentment against papal aggrandizement rather than from any doctrinal differences. As regards the clause in dispute, in the words of Holy Scripture only 'Procession from the Father' is mentioned (John $x \mathbf{v}$. 26), the Lord referring to Himself in the same verse as 'sending' the Holy Spirit, Who, however, is called the Spirit of Christ Jesus elsewhere in N.T. Doubtless a fear of derogating from the perfect equality of the Son with the Father dictated the desire to add 'and the Son': but taking into nccount the Son's own words, and our profound ignoranee of what heavenly reality 'proceding from' connotes, the addition may be regretted on every ground. 
(Who was ${ }^{2}$ begotten of ${ }^{3}$ the Father before all the ages),

- Light ${ }^{5}$ out of Light,

${ }_{6}$ Very God out of Very God,

Begotten not made,

Of one substance with the Father,

Through ${ }^{7}$ Whom all things were made;

Who for us men and for our Salration came down out of heaven And was made flesh (of the Holy Spirit and Mary the Virgin)

And was made man,

(And was crucified on our behalf under Pontius Pilate) and suffered and was buried,

And rose up on the third day according to the Scriptures,

And went up into heaven,

(And is sitting on the right hand of the Father,)

And is to come again with glory to judge living and dead,

${ }^{8}$ (Of Whose kingdom there shall be no end:)

And in the Holy Spirit (the Lord the ${ }^{\circ}$ Life-maker,)

(Who proceedeth from the Father, ${ }^{10}$ )

(Who with Father and Son is together worshipped and together glorified,)

('Vho spake through the prophets;)

(11 In one ${ }^{12}$ holy Catholic and Apostolie Chureh :)

(We acknowledge one baptism unto the remission of sins :)

(We look for uprising of dead,)

(And life of the coming age.) Amen.

1 The Greek is plural throughout, the Latin singular.

2 The Latin has natum, 'born'; the English here follows the Greek.

3 'His' in the English Version is not an improvement.

4 'God of God 'is a later addition to the original Creed; it is sufficiently expressed in the next clause but one.

- 'Out of,' Greek $\epsilon^{\prime} \kappa$, Latin de, is given instead of the ambiguous ' of ' of the English Version. A comma at 'God,' 'Light,' 'Very God,' would remove the ambiguity :- ' God, of God ; Light, of Light,' etc.

- 'Very,' i.e. genuine.

7 'Whom,' i.e. the Son.

8 This Clause was omitted in 1549; Dowden sces here, and in Note 2, proof that Cranmer used more than the Latin form, seo Workmanship, pp. 104-108.

- 'The Lord and Giver of Life' is ambiguous in an English Version; the omission of 'and' as in the original, and a comma at 'Lord' would be an improvement: 'the Lord, the Giver of life.'

10 Here came the Spanish addition: 'and the Son.'

11 The omission of ' in ' before 'Church' in the English Version is due directly to Cranmer, indireetly to the authority of Augustine, who laid it down that 'to believe in' is only properly applieable to the three Persons of the Holy Trinity. Cranmer's own translation of the Apostles' Creed, of 1538 or 1542, has: 'I believe in the Holy Ghost; And that there is an holy Catholic Church.'

12 ' Holy' is omitted in the English Version, according to the critical opinions of the Reformation period. Later investigation has shown that 'holy' was in the original.

Rubric respecting Notices, 1552 ; cnlarged and placed before Sermon, 1662.

1552. After such Sermon, Homily, or Exhortation, the Curate 
shall declare unto the people whether there be any holy days or fasting days the week following: (the remainder of the Rubric deals with the Offertory, which immediately followed the Notices in 1552).

1662. Then the Curate shall declare unto the people what Holy-days, or Fasting days, are in the week following to be observed. And then also (if occasion be) shall notice be given of the Communion; the banns of Matrimony published, and Briefs, Citations and Excommunications read And nothing shall be proclaimed or published in the Chureh, during the time of Divine Service, but by the Minister : nor by him any thing, but what is presoribed in the Rules of this Book, or enjoined by the King, or by the Ordinary of the place.

Though the Rubrie demands notice of communion to be given before the Sermon, the Exhortation to be used in giving such notice is printed after the Prayer for the Church Militant.

The order to publish banns of Matrimony in this place does not appear in modern books, being revoked by the Act 4 George IV, c. 76, specifying the time as immediately after the Second Lesson, at which place an earlier Act, 26 George II, c. 33, had already ordered their publication at Evening Prayer, when there was no. Morning Service. This point, otherwise of no importance whatever, has been raised frequently since a custom las arisen of relegating Morning Prayer to such insignificance that practically banns cannot be 'published,' though they may be 'read,' in that Service, there being no 'public' to hear them.*

Briefs are letters authorizing the collection of money; Citations are summons to appear before any authority; Excommunications are public expulsions from the Church, or suspensions from its privileges.

In regard to the final sentence, defining Notices, a wise latitude of interpretation is allowed, in accordance with the wide development of modern Church life ; yet it may fairly be questioned whether the multiplication of such announcements does not defeat the object by exceeding the number which the worshippers can remember. Abuse of the latitude allowed, by announcements being made little in accord with Church work, deserves no defence.

Rubric prescribing Sermon or Homily, 1549; altered 1552 and 1662 .

* Frere, ignoring the sccond Act altogether, maintains that the 1662 position is the only 'proper place' for the publication of Banns (p. 479). 
1549. After the Creed ended, shall follow the Sermon or Homily, or some portion of one of the Homilies, as they shall be hereafter divided : (the remainder of the Rubric deals with the First Exhortation).

1552. After the Creed, if there be no Sermon, shall follow one of the Homilies already set forth, or hereafter to be set fo, th by common Authority.

1662. Then (i.e. after the Notices) shall follow the Sermon, or one of the Homilies already set forth, or hereafter to be set forth, by Authority.

Next to the use of the English language in Divine Service, the enforcement of preaching was the greatest practical-as distinct from doctrinal-mark of the Reformation. Sermons had been preached before, but they had no place in the Missal, the drama of the Mass being sufficient preaching from the point of view of the Roman Church.

Unfortunately, the number of clergy capable of preaching was ludicrously small, and Homilies were published to remedy the lack due to their ignorance and inexperience of public proclamation of the Gospel. The first book, the only one referred to in the 1549 Rubric, consisted of 12 sermons, by various hands, partly, but probably not wholly, compiled in 1543, their publication being delayed, by the reaction of the last years of Henry VIII, until 1547, at which date some seem to have been written. The notice forecasting further similar sermons has been dealt with above (p. 275). The Second Book, with 21 Homilies, the titles of which are enumerated in Article XXXV (see p. 569), was published in 1563, with the exception of the last, on Rebellion, which was incorporated in the Second Book in 1571 .

The Authority of the Homilies is described in Art. XXXV : they ' contain a godly and wholesome doctrine, and necessary for these times.' Their chief, or only, use of late has been to illustrate the Reformers' doctrine, an use expressly authorized in the case of the Homily of Justification, the third of the first Book, in Art. XI.*

The promise to subdivide the Homilies, in 1549, was fulfilled, in Grafton's edition, 1549 ; in 1552 no provision for reading portions was made. The retention of the phrase, sug-

* Some interesting and important ehanges have taken place in the Homilies, of which a good account is given in Tomlinson's Prayer Book, Articles, and Homilies, ce. ix., x. The alteration of 'High Mass' to 'the Holy Communion' in the 1549 Preface to the first book, is instruetive, as are also Queen Elizabetli's alterations made in the teeth of Convocation, whereon arguments have been founded by that school of thought to whom lay efforts to expound doctrine are peculiarly abhorrent. 
gesting the possible publication of more Homilies, has borne no fruit.

With the revival of preaching, the provision for the Sermou in B.C.P., viz. only in the Communion Service, (save for such special services as Matrimony), had long been insufficient, when the Act of Uniformity Amendment Act, of 1872, permitted sermons to be preached after any authorized Service, or without any service at all if preceded by a Collect or the Bidding Prayer, with or without the Lord's Prayer. The 'Bidding Prayer' is, according to Frere, p. 255, connected with an authorized preReformation custom of interpolating in the Mass a form of vernacular prayer called the Bidding of the Bedes, a recital of the subjects of prayer. Under Henry VIII and Edward VI amended forms were issued, also under Elizabeth, when praise, instead of prayer, for the dead was inculcated. The form now in use at the Universities, Inns of Court, etc., is practically that of the Canons of 1604, and is generally employed before sermons when there is no other form of Service. The custom of prefacing the sermon with a prayer is derived from this source, even extempore prayer being in some sort countenanced by the variableness of the Bidding Prayer. There is no warrant beyond that of undisturbed custom for prefacing the sermon with the Invocation: 'In the Name of the Father,' etc. : or for closing with the familiar ascription, the formality of which not infrequently grates upon the spiritual sensibilities of both preacher and congregation.

The direction to the Sponsors, in the Baptismal Office, to 'call upon them (the children) to hear Sermons,' coupled with the fact that there is no other provision for a Sermon save in this place, has been claimed as sanction or even direction for 'Children's Eucharists,' on the ground that the presence of children is commanded at this point in the Service, and that there is no direction at any place to withdraw. This contention ignores the fact that when the direction in the Baptismal Office was inserted, there was also a clause in the Exhortation to the Negligent, strongly condemning non-communicating atterdance, and demanding the withdrawal of those who did not intend to communicate. The absence of any express Rubric directing the withdrawal of non-communicants, both before and after the 1662 revision, is atoned for by the exclusive references to communicants in the Rubric preceding the Third Exhortation, added in 1662, when the clause in the Exhortation to the Negligent was omitted as unnecessary, no non-communicants remaining. The real reason for Children's Eucharists, as for all other non-communicating attendance, is that benefits are supposed to accrue from 
participation in a sacrifice, at which Christ is present in, with, or under, the bread and wine. Neither the dogmas, nor the practices founded on them, are supported by the B.C.P.

Rubric regarding the Offertory Sentences, 1549 ; altered 1552. made separate Rubric 1662 .

1549. Then shall follow for the Offertory one or more of these Sentences of holy scripture, to be sung while the people do offer; or else one of them to be said by the minister, immediately afore the offering.

1552. (Part of Notices Rubric) . . . and earnestly exhort them to remember the poor, saying one or more of these sentences following, as he thinketh most convenient by his discretion.

1662. Then shall the Priest return to the Lord's Table, and begin the Offertory, saying one or more ... etc., as in $155 \%$.

The prominent place given to a collection of money for the poor in the service for the Holy Communion was a novelty in England in 1549. In the mediæval Church 'oblations' indeed were often made at Mass by pious persons to the Priest, and on 'offering days' (generally four times a year) the Masspenny had to be paid, but that the ordinary rule should be that a collection for the poor was to form the normal order on every Sunday and holy day was quite a new thing. It had, however, been adopted some years earlier in Germany, as we see from many of the German Church Orders.*

From these words will be seen the great difference between the word Offertorium, as used in the Missal, and 'Offertory,' as used in the B.C.P. The latter word was dropped in 1552, but restored in 1662, when it could no longer be confounded with the offering of the bread and wine. $t$ The elements, in B.C.P., are not 'offered,' but 'set' (1549) or 'placed' (1662) on the Table (see p. 313). The omission, in 1662, of the words ' earnestly exhort them to remember the poor' was partly, at least, sug gested by the objection of the Puritans to the fact that four of the sentences refer to offerings to the ministry and not to the poor.

\section{Offertory Sentences, 1549 .}

There has been no change here since 1549, even the version

* Dowden, Further Studies, p. 175.

$t$ The refusal to recognize this distinction is common in a certain class of B.C.P. Manuals, and invalidates all their tables of comparison of the Mass and English Service Books. For example, Frere, p. 469, uses the one word to deseribe the Offertory of the Sal um Use, and those of 1549 and 1552, in which latter the very word is wanting. 
of the Great Bible being retained. The Puritans at the Savoy Conference objected to them, on the grounds that two were apocryphal, and (as already noted) that four were calculated to excite generosity rather to the ministry than to the poor. They also desired the offertory to be wholly removed to the close, or near the close, of the service. However, they remain untouched, constituting a clear testimony to the greatness of the change of the Offertory from the days when, instead of incitements to charitable self-denial, was sung (in Latin): "To thee, O Lord, have I lifted up my soul, my God, in thee do I trust, let me not be put to shame,' etc. In no case is the return to primitive precedents more marked.

In S.L. considerable changes were made, five new sentences being introduced, having no direct bearing upon charitable gifts, one of them expressly dealing with sacrificial oblations; these had to be taken from 0.T. There were several omissions, and one addition from N.T.

Rubric regarding the Collection of the Offerings, 1549 ; altered 1552 and 1662.

1549. Where there be Clerks, they shall sing one or many of the sentences above written, according to the length and shortness of the time that the people be offering.

In the meantime, while the Clerks do sing the Offertory, so many as are disposed shall 'offer to the poor men's box every one according to his ability and charitable mind. And at the offering days appointed, every man and woman shall pay to the Curate the due and accustomed offerings.

In another Rubric at the end of the 1549 Office will be found: "the Parishioners of every Parish shall offer every Sunday, at the time of the Offertory, the just value and price of the holy loaf (with all such money and other things as were wont to be offered with the same), to the use of their Pastors and Curates.'

1552. Then shall the Churchwardens, or some other by them appointed, gather the devotion of the people, and put the same into the poor men's box : and upon the offering days appointed, etc. . . . after which done, the Priest shall say, (Let us pray for the whole estate of Christ's Church Militant here in Earth).

S.L. While the Presbyter distinctly pronounceth some or all of these sentences for the offertory, the Deacon or (if no such be present) one of the Churchwardens shall receive the devotions of the people there present in a bason provided for that purpose. And when all have 
offered, he shall reverently bring the said bason with the oblations therein, and deliver it to the Presbyter, who shall humbly present it before the Lord, and set it upon the holy Table.

1662. Whilst these sentences are in reading, the Deacons, Churchwardens, or other fit person appointed for that purpose, shall receive the Alms for the poor, and other devotions of the people, in a decent basin, to be provided by the Parish for that purpose; and reverently bring it to the Priest, who shall humbly present and place it upon the holy Table.

The following changes are noteworthy :-

1549. Alms are put into the poor men's box ; dues, including the 'price of the holy loaf' are paid to the Curate.

1552. Alms ('devotion') are collected and put into the poor men's box; dues ('price of the holy loaf' omitted) are paid to the Curate.

S.L. 'Devotions' (also called 'oblations') are collected in a provided ' bason,' humbly presented 'before the Lord,' and 'set' upon the holy Table.

1662. Alms for the poor, and other devotions, are collected in a provided 'basin,' humbly presented, and placed upon the holy Table.

The omission, in 1662, of the payment of 'dues' at this place was urged by Cosin. The distinction between offerings for the Poor and offcrings for the maintenance of the Ministry, though rightly enough made, especially after the Puritans had pointed out the recognition of both in the Offertory Sentences, was not one which demanded separate treatment in their reception; as the 1662 Rubric puts it, all are 'devotions' and as such, offerings to God. For the bearing of these alterations upon the word 'oblations' in the Prayer for the Church Militant, see notes ad loc. below.

Rubric ordering the placing of the bread and wine, 1662 (1549); no directions 1552.

1549. Then so many as shall be partakers of the holy Communion, shall tarry still in the quire, or in some convenient place nigh the quire, the men on the one side and the women on the other side. All other (that mind not to receive the said holy Communion) shall depart out of the quire, except the Ministers and Clerks. Then shall the Minister take so much Bread and Wine as shall suffice for the persons appointed to receive the holy Communion, laying the bread upon the corporas, or else in the paten, 
or in some other comely thing, prepared for that purpose; And putting the wine into the Chalice, or else in some fair or convenient cup, prepared for that use, (if the Chalice will not serve) putting thereto a little pure and clean water: And setting both the bread and wine upon the Altar: Then the Priest shall say.

1552. No regulations.

S.L. And the Presbyter shall then offer up and place the bread and wine prepared for the Sacrament upon the Lord's Table, that it may be ready for that service. And then he shall say.

1662. And when there is a Communion, the Priest shall then place upon the Table so much Bread and Wine, as he shall think sufficient. After which done, the Priest shall say. In the new Rubric of 1662 the following omissions are important :-

(a) The mixture of water with the wine.

In the Lambeth Judgment permission is given to use wine mixed with water, but not to $\mathrm{mix}$ them during the Service. So early as 1523 Luther had shown the inaccuracy of associating the 'mixed chalice' with the unmixed water and blood which flowed from Christ's side, and the German Orders contained no directions for mixing wine and water. Andrewes held it 'a matter not worth the standing on'; the Roman Church regards it as merely an ecclesiastical ordinance, neither essential nor divinely ordered.

(b) The words 'offer up and 'before 'place.'

These words were definitely before the Revisers, both in S.L., and in the Durham Book, and were refused admission. However primitive it may be, the idea of offering the elements to God is not scriptural, and the use of a sacrificial term, besides the peril which experience both before and since 1662 has been shown to lurk therein, is far from reasonable in the case of bread and wine, all of which the 'offerers' will consume themselves, and where, therefore, neither death of a victim nor participation by God suggests 'sacrifice.' Our Lord thanked God for the loaf and the cup, and His example can be followed without using any such termis.

The 1549 direction for placing the people is dropped, another being added in 1662 before the Third Exhortation (see p. 323). The practice of dividing the sexes was not again ordered, being curiously subversive of the scriptural principle that 'in Christ Jesus there is neither male nor female.'

Prayer for Church Militant, 1552 (1549); last sentence added 1662. 
The 1549 B.C.P., following more closely the arrangement of Sar. Miss., made the Prayer for the Church part of the Consecration Prayer (see Analysis, p. 283). In 1552 the long Prayer of 1549 was broken up, and the first part of it placed here, before the departure of the non-communicants.* The chief changes in the wording are :-

1549. Let us pray for tle whole state of Christ's Church.

1552, 'Militant here in earth': added.

1549. To receive these our prayers.

1552. To accept our alms and to receive, etc.

1662. To accept our alms and oblations and to receive, etc.

1549. 'And especially we commend unto thy merciful goodness this congregation, which is here assembled in thy name, to celebrate the commemoration of the most glorious deat's of thy Son : And here we do give unto thee most high praise, and hearty thanks, for the wonderful grace and virtue, declared in all thy saints, from the beginning of the world : And chiefly in the glorious and most blessed virgin Mary, Mother of thy Son Jesu Christ our Lord and God, and in the holy Patriarchs, Prophets, Apostles, and Martyrs, whose examples (O Lord) and stedfastness in thy faith, and keeping thy holy commandments, grant us to follow. We commend unto thy mercy (O Lord) all other thy servants, which are departed hence from us, with the sign of faith, and now do rest in the sleep of peace : Grant unto them, we beseech thee, thy mercy and icierlasting peace, and that at the day of the general resurrection, we and all they which be of the mystical body of thy Son, may altogether be set on his right hand,' etc. (as at close of last Burial Collect).

1552. All the foregoing omitted.

S.L. And we commend especially unto thy merciful goodness, the congregation which is here assembled in thy name to celebrate the commemoration of the most precious death and sacrifice of thy Son and our Saviour.Jesus

* The 1549 Prayer, called the Canon in the Communion of the Sick, consisted of :-

(1) The Prayer for the Church, corresponding to the present Prayer for the Church. Militant, placed immediately after the Offertory in 1552. 1552.

2) The Prayer of Consecration, immediatcly preceding reception in

(3) The Prayer of Oblation, transferred, with the omission of reference to Oblation, to immediately after the Lord's Prayer in 1552, and made an alternative Prayer of Thanksgiving. The Lord's Prayer followed in 1549; in 1552 it was placed before the Thanksgiving, immediately after reception. 
Christ. And we most humbly ... adversity (as in 1552). And we also bless thy holy name for all those thy servants, who having finished their course in faith, do now rest from their labours. And we yield unto thee most high praise, and hearty thanks for the wonderful grace and virtue declared in all thy saints, who have been the choice vessels of thy grace, and the lights of the world in their several generations; most humbly beseeching thee, that we may have grace to follow the example of their stedfastness in thy faith, and obedience to thy holy commandments, that at the day of the general resurrection, we, and all they which are of the mystical body of thy Son, may be set on his right hand,' etc., as in 1549 . 1662. Foregoing omitted, and praise in place of prayer, for the faithful departed, added: "And we also bless thy holy Name for all thy servants departed this life in thy faith and fear: beseeching thee to give us grace so to follow their good examples, that with them we may be partakers of thy heavenly kingdom.'

In Sar. Miss. the prayer for the dead was separated from the prayers for Church, Pope, Bishop, King, and the living, by the Consecrating and Offering of the elements. Where not entirely original, the B.C.P. Prayer owes more to Hermann than to Sar. Miss. (Dowden, Workmanship, p. 28).

The above alterations speak for themselves, but two of the additions of 1662 demand special notice, viz., 'oblations,' and the commemoration of the faithful departed.

\section{(1) Oblatlons.}

The attempt to find in this word a re-introduction of the early but not scriptural practice of 'offering' the bread and wine to God, has received recent treatment at the hands of the late Bishop Dowden, from whose exhaustive examination of tle subject (in Further Studies in the Prayer Book, pp. 176 ff.) the ollowing decisive points are extracted-

(a) The word is to be used whether there is a Communion or not; this conclusively proves it did not mean the elements exclusively.

(b) There were those who desired to make an 'oblation' of the elements, and Cosin's suggestion for the rubric before this Prayer contained the words 'offer up and place,' as in S.L. ; the words ' offer up and 'were designedly rejected.

(c) The collection is to be 'reverently' 'orought to the Priest, and he is to 'humbly present and place' it; the bread and wine he is simply to "place' upon the Table. 
(d) In S.L. 'the said bason with the oblations therein' is the collection, 'oblations' being used as a more general term to describe money which, by a later rubric in S.L., was to be given half to the poor or for Church furniture, half to the Minister for his library.

(e) 'Oblations' meant money in the middle ages;* cases occurred where the priests refused to administer the 'host' till they were paid their 'oblation' by the communicant.

(f) Hooker, V. lxxiv. 4: 'Nothing therefore is more proper than to give the name of oblations to such payrnents [to the clergy] in token that we offer unto Him whatsoever His Ministers receive.'

( $g$ ) Edward's Injunctions of 1547 order 'a strong chest with a hole' for the parishioners' 'oblation and alms.'

(h) The omission of the mention of payment of dues in 1662 was made up for by mentioning not only 'alms' but also 'other devotions.' The "other devotions' of the rubric are the 'oblations' of the prayer. Hence also the omission of the direction : "and earnestly exhort them to remember the poor,' etc. Notice also the omission of 'given unto the poor' in the indented Rubric of 1662 .

(i) The first mention of oblations coincided with the first mention of a ceremonial presentation of the collection.

(j) A special service of 1635 , which does speak of offering the bread and wine, expressly uses the word 'oblations' of the money received at the reading of such sentences as are not chosen for alms. Bishop Andrewes had two basins, one for alms and another for offerings.

(k) Wren, one of the Revisers, used the words 'oblation' and 'prosphora' of the collection.

(l) Cosin in 1668 twice used the actual phrase 'alms and oblations' of money; so Sancroft, 1686.

The source of the mistake in regard to the word is a popular writing of Bishop Patrick, so early as 1667, in which, in dcfiance of the above-given facts, he states that the oblations 'can signify nothing else 'but the elements, 'an illustration' (says Dowden) ' of the caution with which even almost contemporary glosses are to be viewed.' The Non-jurors readily adopted the mistake, and Wheatley assisted in making it wide-spread. It still lives on as part of the attempt to read into the B.C.P. the very things carefully excluded at the various revisions: "The interpretation of the additional word is somewhat doubtful, but it seems legitimate to refer it either to the elemen:s, just set upon the altar, or else from a more strictly antiquarian 
point of view, to the dues and offerings paid by the people to the clergy' (Frere, p. 482). This is characterized by Dowden as 'rather a lame conclusion.'

\section{(2) Commemoration of the faithful departed.}

In spite of Bucer's desire to retain some such remembrance, the Revisers of 1552 thought it safer to exclude anything which might be perverted into prayer for the dead. The danger in 1662 was not so pressing, and it was thought fit to add a carefully-worded clause to this Prayer. The 1549 B.C.P.retained both the distinction between 'Saints' and 'all other thy servants, which are departed hence from us, with the sign of faith? -a distinction which, if it existed in any sense, no human power could apply to individual cases;-and also the se'f-contradictory prayer for ' peace' for those who 'now do rest in peace,' a stultification which must accompany any attempt to make a definite, i.e. a real prayer, for those of whom it has been revealed that they are ' with Christ, which is far better.'

S.L. restored the distinction between 'sain ts' and other servants of God, but avoided the other pit-fall, only praying that we may so follow the stedfastness of the 'saints' that 'we and all they which are of the mystical body of thy Son, may be set on his right hand,' etc. This prayer is susceptible of a quite reasonable interpretation, but taking the words literally, it is a prayer for the dead, that they may be set on Christ's right hand.

In 1662 great care was taken to eradicate every possible mistake :-

(1) The prayer for peace was not restored.

(2) No distinction was made between 'saints' and the other faithful dead.

(3) Instead of 'we and they,' 'we with them' was made the subject of the sentence, just as in the 1552 revision of the 1549 Burial Service.*

(4) The Title 'Church Militant here in earth' was retajned, after deliberation, effectually condemning attempts to find prayer for the faithful departed here, though such are still made. $\dagger$ The only scriptural prayer we can offer affecting the condition of the faithful dead is 'Thy Kingdom come,' and

* It is ominous that the Revision Committee of Canterbury Convocation Lower House has proposed altering the Burial Prayer by using 'and' instead of 'with.'

$\dagger$ Cf. Frere, p. 482: "the thanksgiving and prayer for the faithful departed was added at this time (1661).' 
that prayer must not be supposed to imply that their present condition is not one of happiness (Rev. vi. 10, 11).

Indented Rubric, 1552; enlarged 1662.

1552. If there be no alms given unto the poor, then shall the words of accepting our alms be left out unsaid.

1662. If there be no alms or oblations, then shall the words (of accepting our alms and oblations) be left out unsaid.

The meaning of 'oblations' has been given above (p. 315). The wording of the Rubric is obscure; the use of 'or' suggests that the whole phrase 'alms and oblations' is to be used, whether the collection be exclusively for the poor or for any other object. It will be noted how absolutely this wording conflicts with any idea of making the bread and wine an oblation.

\section{Rubric ordering Announcement of Holy Communion, 1548 (1549); 1662.}

An announcement is implied (though no directions are given) twice in the 1549 B.C.P. : once in the Exhortation to the negligent, adapted for ordinary announcement in 1662 ; and once in one of the concluding Rubrics, where arrangements for the provision of bread and wine are made according to houses, "the which may be the better done, for that they know before when their course cometh, and may therefore dispose themselves to the worthy receiving of the Sacrament.' In 1552 there were no similar implicit regulations:

In the Order of Communion, 1548, a Rubric ordered announcement on "the next Sunday or holy day, or at the least, one day before,' with the Exhortation (' or such like '), which was restored to the purpose of making announcement in 1662, but prescribed for 'negligent' in 1549. This Rubric is rarely obeyed now, though there is a custom in some churches of using the first sentence in announcing Holy Communion.

First Exhortation, 1548; enlarged for the negligent 1549; ' sometime said also,' 1552 ; adapted for announcing, and clause added from Exhortation to Communicants, 1662 (see pp. 270, 1).

$\left.\begin{array}{l}1548 \\ 1549\end{array}\right\}$ 'On - next, I intend ...'

1552. This opening sentence wanting.

1662. Opening sentence restored, but shortened.

1548. 'Doth vouchsafe, in a Sacrament and Mystery, to give us his said body and blood spiritually : to feed and drink upon. 
Table of Changes of Arrangement of Exhortations.

\begin{tabular}{|c|c|c|c|}
\hline 1548 & 1549 & 1552 & 1662 \\
\hline \multirow[t]{2}{*}{$\begin{array}{l}\text { 1. To give notice } \\
\text { place in Ser- } \\
\text { vice not } \\
\text { specified. }\end{array}$} & $\begin{array}{l}\text { 1. To negligent } \\
\text { after Ser- } \\
\text { mon. }\end{array}$ & $\begin{array}{l}\text { 2. To negligent } \\
\text { after Prayer } \\
\text { for Church } \\
\text { Militant } \\
\text { (B) included. }\end{array}$ & $\begin{array}{l}\text { 1. To give notice } \\
\text { after Sermon } \\
\text { (A) inserted. } \\
\text {.. }\end{array}$ \\
\hline & 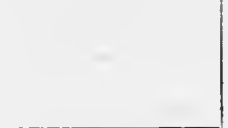 & $\begin{array}{l}\text { 1. 'Sometim: } \\
\text { also at dis- } \\
\text { cretion.' }\end{array}$ & $\begin{array}{l}\text { 2. To negligent } \\
\text { after Sermon } \\
\text { (B) omitted. }\end{array}$ \\
\hline $\begin{array}{l}\text { 3. To communi- } \\
\text { cants after } \\
\text { Priest's re- } \\
\text { reception } \\
\text { (A) at end. }\end{array}$ & $\begin{array}{l}\text { 3o communi- } \\
\text { cants at cele- } \\
\text { bration } \\
\text { (A) inserted. }\end{array}$ & $\begin{array}{l}\text { 3o communi- } \\
\text { cants at cele- } \\
\text { bration } \\
\text { (A) inserted. }\end{array}$ & $\begin{array}{l}\text { 3. To communi- } \\
\text { cants at cele- } \\
\text { bration } \\
\text { (A) trans- } \\
\text { ferred to } 1 .\end{array}$ \\
\hline $\begin{array}{l}\text { 4. Invitation } \\
\text { after } 3 \text {. }\end{array}$ & $\begin{array}{l}\text { 4. Invitation } \\
\text { after conse- } \\
\text { cration. }\end{array}$ & $\begin{array}{l}\text { 4. Invitation } \\
\text { after } 3 .\end{array}$ & $\begin{array}{l}\text { 4. Invitation } \\
\text { after } 3 .\end{array}$ \\
\hline
\end{tabular}

$(\Delta)=$ paragraph ' Therefore if any of you be a blasphemer . . . body and soul.'

(B) = paragraph condemning non-communicating attendance.

The Exhortations are all printed after Prayer for Church Militant in 1662 , as in 1552, but the 1st and 2nd are ordered to be used after Sermon.

1549. 'Doth vouchsafe, in a Sacrament and Mystery, to give us his sald body and blood to feed upon spiritually.'

1552. 'Hath given . . . to be our spiritual food and sustenance, as it is declared unto us, as well by God's Word, as by the holy sacraments of his blessed body and blood.'

1662. 'Hath given ... to be our spiritual food and sustenance in that holy sacrament.'

1548. 'And if any man have done wrong,' etc. ; this sentence wanting.

1549. 'For neither the absolution of the priest can any thing avail them, nor the receiving,' etc.

1552. 'For otherwise the receiving,' ete.

1662. 'For otherwise the receiving,' etc. (The next sentence of 1662 is taken from Exhortation to Communicants of 1548, 1549 and 1552.) 
1548. ' discreet and learned priest, taught in the law of God, 1549. and confess and open his sin and grief secretly, that of us (as of the Ministers of God and of the Church) he may receive comfort and absolution ...'

1552. 'discreet and learned Minister of God's word, and open his griel ... that by the ministry of God's word he may receive comfort and the benefit of absolution ....'

1662. As in 1552, with 'holy' before 'word,' ' comfort' omitted.

In 1549 a concluding sentence tolerated ' auricular and secret confession'; this toleration was omitted in 1552 , and not restored in S.L. or in 1662.

\section{Analysis.}

I. The meaning of the Sacrament :-

1. Remembrance of the death of Christ.

2. Thanksgiving for :

(1) The death of Christ.

(2) Sustenance in the Sacrament.

II. Precaution against unworthy reception :- Which being so divine.'

Consideration of the dignity of the rite.

III. Ways and means of preparation :-

1. Self-examination by the Commandments.

2. Confession of sins to God.

3. Determination to amend.

4. Restitution to the wronged.

5. Forgiveness of offenders.

IV. Warning against unworthy reception :- 'Therefore if any.'

V. Provision for extraordinary cases of disturbed consciences :

- And because it is requisite.'

1. Opening of grief to a minister of God's Word.

2. Absolution and spiritual advice by ministry of the Word.

Judas. The Reformers have followed St. Luke in giving Judas a place not only in the last Passover, but in the Lord's Supper itself. St. Matthew and St. Mark do not suggest Judas' presence, but their narrative does not absolutely exclude it. Edersheim (Life and Times of Jesus the Messiah), with many other commentators, believes Judas to have departed before the institution ; Godet (Commentary on St. Luke's Gospel) represents another school of interpretation taking the opposite view. Tradition, as embodied in Leonardo da Vinci's picture, and in the superstition in regard to sitting 13 at table, is inconclusive, since all are agreed that Judas was present at part of the meal. 
open his grief. This direction has been made the ground of a re-introduction of that 'auricular' and secret' confession which forms part of the Roman Sacrament of Penance, and was still tolerated in 1549 , but rejected in $\mathbf{1 5 5 2}$.

The New Testament only attaches efficacy to confession of sins before men in the case of sickness, James v. 14-16. There Christians are bidden to confess sins * to other Christians, in order that they may pray for the sinner's health. The ministry is not empowered to receive such confessions, and that though the 'elders' are mentioned (14) as those authorized to pray over the sick man and anoint him. Such confession, therefore, is not to a priest, not to obtain absolution, not to comprise an exhaustive enumeration of sins, and not to be generally practised ; it was, moreover, voluntary, and not necessarily private.

Public voluntary confession was common in the early Church, but not as a necessary part of confession to God, much less as a substitute for it. Chrysostom deprecates confession to man : 'I entreat and beseech you to confess continually to God. For I do not bring thee unto the theatre of thy fellow-servants, nor do I compel thee to uncover thy sins to men.' $\dagger$ So Augustine : 'To what purpose do I confess my sins to men, as if they themselves could heal my distresses ?- to a set of men inquisitive in inquiring. into the lives of others, but indolent in amending their own. And how shall they, who know nothing of my heart but by my confession, know whether I say true or not?'

The following are the steps by which voluntary public confession became compulsory secret confession to a priest :-

1. By 400 it had become the rule that those guilty of notorious sins should confess publicly before admission to the Lord's Supper.

2. Between 440 and 461 Leo I. wrote to the Bishops of Campania directing such confessions to be made to the priest instead of before the congregation. This became universal by 600 , fostered by the growing belief that the priest was the representative, not of the scandalized congregation, but of the injured God, and therefore empowered to bestow absolution.

3. In 763 this kind of confession of greater offences was made compulsory.

4. In 1215 the Lateran Council ordered private confession of all sins to a priest at least once a year.

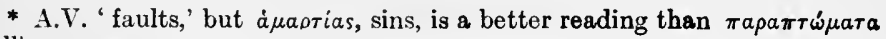
f:llings away.

$\dagger$ De incarnatione Dei: Hom. v. 57.

† Confessions: x. 3. Yet Vernon Staley, Cathulic Religion, p. 214, cites Augustine as saying that sins are forgiven by baptiam, prayer, and penance. 
5. In the sixteenth century the Council of Trent, Canon 6, anathematized those who denied the divine institution of sacramental confession, or its necessity for salvation, although Bellarmine, Maldonatus, and other Roman authorities declarc that it was unknown to the early Church.*

The Reformers tried, in 1549, to retain the practice of secret confession as a voluntary aid to distressed sinners, but abandoned it altogether in 1552. The evils inseparable from the practice, acknowledged in Papal Bulls and Roman writers generally, are summed up in the words of Archbishop Magee: "I denounce the system as an outrage on decency and common sense, as well as on God's Word. ... I maintain that taking God's place without God's attributes, it is impossible, however prudent the priest may be, to avoid instilling vice by the Confessional.' $\dagger$ The revision of 1552 safeguarded the permission to receive any confession by the following provisions :-

1. It is only to be received in special cases of spiritual distress. This provision is carefully made both here and in the Visitation of the Sick.

2. It is to be entirely voluntary.

3. It is not ordered to be secret, the word 'secretly' was expunged in 1552 .

4. It is not to be an exhaustive enumeration of sins, but the opening of grief.

5. It is to be made, not to a priest, but to a minister, whose qualifications are knowledge of God's Word, and discretion.

6. The relief, both of absolution and spiritual counsel, is to be found in God's Word and not in any ministerial function save the unfolding of the Word. No form of absolution is provided in this place, and that in the Office for the Visitation of the Sick is only to be used at the request of the sick man (since 1662: see p. 454). $\ddagger$

Rubric providing for the Negligent, 1549; placed before Second Exhortation 1552.

1549. First Exhortation, 'or like words,' to be used for the negligent.

* Vernon Staley, Catholic Religion, p. 214, says that the Sacrament of Penance was instituted by Christ, relying upon the commission given by Christ in John $x x$. 23. That the authority then given to remit and retain sins was not given to the ministry as such, but to the witnessing Chureh as a whole, and that it was not associatcd with any secret confession, is sufficient reply.

$\dagger$ Auricular Confession in the Church of England, quoted from AntiRitualism, p. 25.

‡ For 'Confession' see p. 95. 
1552. ' at certain times,' Second to be used.

1662. Second to be used 'instead of the former,' when negligence seen.

Second Exhortation, 1552 ; one clause omitted 1662.

This Exhortation is possibly due to Bucer.

The two alterations in 1662 were :-

(1) 1552. 'In the remembrance of his death.'

1662. 'In remembrance of the Sacrifice of his death.'

S.L. 'In the remembrance of his death and sacrifice.'

(2) The long clause condemning 'gazers and lookers on' was omitted in 1662, because, as Wren records, the custom of non-communicating attendance was quite unknown. It were to be wished that the Revisers had retained a sentence so valuable to check a possible recurrence of the evil.

\section{Analysis.}

I. Invitation in God's Name.

II. Examination of Refusals :- ' Ye know how grievous.'

1. Heedlessness.

2. Business.

3. Personal unfitness.

III. Scriptural condemnation of all excuses :- They that refused.'

IV. Official exhortation of the

1. Minister, ready to do his part.

2. Ambassador, inviting in Christ's name.

V. Explanation of the rite and its implications:-' And as the Son of Grod.'

1. The remembrance of the sacrifice of Christ.

2. Neglect of such remembrance an injury* to

(1) God.

(2) Oneself.

(3) Brethren.

VI. Remedy of neglect :-

1. Thoughtful consideration by the negligent.

2. Instant prayer by the minister.

\section{COMMUNION.}

Rubric directing that communicants be conveniently placed, 1662, (1549).

* The word 'injury' here, used in reference to God, retains something of the meaning of the Latin word, injuria, 'insult.' 
1549. The 'quire' was prescribed as the place for the communicants, the sexes being separated, as in some of the German Orders.

1552. The moving of the Table rendered explicit directions unnecessary, but the words of the Fourth Exhortation 'draw near' ("with faith' was added in 1662) were often interpreted literally by the communicants, a custom which still linge: $s$ in some churc'ies.

1662. The latter custom was regulated by the direction to conveniently place the Communicants, the duty of the Churchwardens.

Third Exhortation, 1548 ; ${ }^{*}$ placed here 1549 ; clause tiansferred to First Exhortation 1662. (See p. 271.)

Important differences :-

1548. Because we make no difference of the Lord's body.

1549. INot considering the Lord's body.

1548. 'Judge therefore,' as in 1662, with clause 'If any man here' at the close.

1549. Before 'Judge therefore' the clause at end of 1548 inserted.

1552. As in 1549.

1662. The clause transferred to First Exhortation.

1549. He hath left in those (the e, 1548) holy Mysteries, as a pledge of his love, and a continual remembrance of the same, his own blessed body, and precious (om. 1548) blood, for us to feed upon spiritually to our endless comfort and consolation.

1552. He hath instituted and ordained holy mysteries, as 1662. pledges of his love, and for a continual remembrance of his death, to our great and endless comfort.

\section{Analysis.}

I. The necessity of examination for worthy participation :-

1. Great benefit.

2. Great danger.

- In 1548, the Order of Communion followed the Priest's Communion : it consisted of the Third and Fourth Fxhortations, the Confession, Absolution, Comfortable Words, Prayer of Humble Access, Administration and Blessing.

In 1549, being no longer used with the Latin Mass, it was incorporated . into the English Communion Service, the First Exhortation following the Sermon and preceding the Offertory, the remainder, except the Blcssing, following the Consecration, and the Blessing concluding the Service.

In 1552 , it was rearranged as in 1662 B.C.P., save for variations in regard to use of the Third Exhortation, for which see special Table on p. 319. 
II. The conditions of worthy participation :- 'Judge therefore yourselves.'

1. Repentance.

2. Faith.

3. Amendment.

4. Love.

5. Thankful remembrance of Christ's death shown in :-

a. Subm ission.

b. Service.

'We eat and drink our own damnation.' This passage occurs in the same words in the 1548 Order of Communion, taken from 1 Cor. xi. 29, where A.V. uses also the word 'damnation,' R.V. 'judgment.' The later association of the word 'damnation' with final prunishment has lent the word a severity which St. Paul did not intend, and which has accordingly acted as a deterrent in the case of many who would otherwise communicate. The American B.C.P. has cut the Gordian Knot by omitting the whole sentence containing the word: the Irish B.C.P., more wisely, has altered the word to 'judgment' (as the R.V. has done), and omitted the remainder of the sentence associating disease and death with God's wrath upon unworthy communicants. St. Paul definitely attributes sickness and death amongst the Corinthians to this cause $(v .30)$, so that the association is thoroughly scriptural. The sin of the Corinthians was that of selfish disregard of one another in the common meal, which proved their disregard of the solemnity attaching to the Sacrament of Unity. To partake of the sacred symbols of Christ's Body and Blood in such a spirit, was to display a carelessness amounting to contempt, in regard to the Body and Blood of Christ, given and shed for their redemption. Moreover, they . failed to discern the 'Body,' the oneness of believers in Christ. St. Paul warned them (v. 31) that if they did not 'discern' themselves, the would be judged of God, the play upon the two Greek words, diakrino and krino, being impossible to reproduce in English. 'The substitution of 'judgment' for 'damnation,' without any other alteration or omission, would sufficiently meet any difficulty. It may be that now as of old God does visit those who belittle His Sacrament of Redemption with temporal afflictions.

Rubric preceding the Invitation, 1549 (1548); placed here 1552.

1549. Here the Priest shall turn him toward those that come to the holy Communion, and shall say. 
1552. Then shall the Priest say to them that come to receive the holy Communion.

The Eastward Position was abandoned in 1552, so that the direction to 'turn' became unnecessary.

The 'Here' of 1549 was at the close of the long prayer including Consecration; the 'Then' of 1552 was at the close of the Third Exhortation, as in 1662.

In 1548 a Rubric here bade the Priest pause to see if any would withdraw in response to the Exhortation to selfexamination.

Fourth Exhortation (Invitation), 1548; placed here 1552.

Two alterations were made in 1662 : 'Draw near with faith' for 'Draw near,' which had been literally interpreted by many; and the omission of the words 'before this congregation here gathered together in his holy name,' after ' make your humble confession to Almighty God.' In 1548 and 1549, 'and to his holy Church' was read for 'before this congregation.' This latter change is easily understood, but the omission in 1662 is not so clear. Frere (p. 485) attributes it to the fact that non. communicants were now absent, but the remainder might be more accurately called a ' congregation gathered in God's Name' than the mixed congregation.*

Rubric regulating the Confession, 1548 .

$1548,1549,1552$. 'Either by one of them, or else by one of the Ministers, or by the Priest himself.'

S.L. 'by the Presbyter himself, or the Deacon.'

1662. 'by one of the Ministers.'

This alteration was a concession to the Presbyterian request at the Savoy Conference.

Confession, 1548 ; Herm. Con.

This Prayer has no counterpart in Sar. Miss., with which indeed it was ordered to be used in 1548. The single phrase 'thought, word, and deed,' occurs in the Mutual Confession of the Priest and his assistants early in the Mass Service, in which the Confession was to 'God, blessed Mary, all the saints and you,' and the prayer was not directly addres ed to God, but to

* Frere, $\boldsymbol{l}$. c., states that 'the rubrics which precede and follow still contemplate the presence of others not communicating,' because both rubrics mention those 'that come to receive the holy Communion.' If this precarious reasoning be adopted, the further conclusion is emphatically to be drawn, viz., that the others present have no part or lot in the matter. But the Rubric before the Absolution simply says ' the people,' so also in the Administration and Lord's Prayer Rubrics, while the 'Humble Access" Rubric repeats the phrase used here. No distinctive stress, thercfoi $\theta$, must be laid upon tliat phrase. 
'holy Mary, all the Saints and you, to pray for me.' The whole prayer has many correspondences with the form in Herm. Con., in which much of this part of the 1548 Order is to be found.

Rubric regarding the Absolution, 1548 ; called 'Absolution' 1662.

' Or the Bishop (being present)' added 1552.

Absolution, 1548 ; altered 1549 ; (Sar. Miss.).

1548. 'Our blessed Lord, who hath left power to his Church to absolve penitent sinners from their sins, and to restore to the grace of the heavenly Father such as truly believe in Christ ....'

1549. As in 1662 .

The latter part of this Absolution is derived from the Absolution of the Priest by the Ministers in Sar. Miss. : Misereatur vestri omnipotens Deus, et dimittat vobis omnia peccata vestra; liberet vos ab omni malo, conservet et confirmet in bono, et ad vitam perducet aternam : literally, 'Almighty God have mercy upon you, and put away from you all your sins: free you from all evil, keep and strengthen (you) in good, and lead you unto life eternal.'

In Herm. Con. the Absolution is declaratory, not, as here, precatory; the Reformers omitted all reference to the powerto absolve, which is retained in Herm. Con.

Comfortable Words, 1548.

In Herm. Con. five such passages, including the four of B.C.P. save the first, Matt. xi. 28, which is found 'in the preliminary discourse on the Lord's supper in Hermann's work,' with John iii. 35, Acts x. 43, were placed between the Confession and Absolution, one of them only to be read, with the preface, 'Hear the Gospel.' This position was valuable as leading the penitent to expect absolution; the B.C.P. position confirms faith by justifying the precatory absolution just offered. The German Editions of Herm. Con., slightly earlier than the Latin, had: ' Hear the Gospel-comfort,' obviously the source of the phrase ' Comfortable words.'

The 1548 version of the passages has been slightly altered :1662. 'Are' for 'be heavyladen': ' will' for 'shall refresh:' ' everlasting life' for 'life everlasting.'

1548. 'Worthy . . . to be embraced and received'; 'embraced and ' omitted 1549 .

1548. ' He it is that obtained grace for our sins,' altered to ' and he is the propitiation for our sins' in 1549 .

S.L. adopted the A.V. The Revisers retained the independent translation of 1548 . 
Lift up your hearts, etc., 1549 ; placed here 1552.

In 1549 these words immediately followed the Offertory, and began with 'The Lord be with you,' 'And with thy Spirit,' as in Sar. Miss. where the priest is bidden to lift up his hands in saying :

Sursum corda $=$ learts upwards :

Habemus ad Dominum = we hold them (up) to the Lord.

Gratias agamus Domino Deo nostro = let us give thanks to our Lord God.

Dignum et justum est $=$ it is worthy and right.

This part of the Service is probably the oldest invariable portion of the Office, Cyprian in the third century quoting the first versicle and response. It will be noted that the second, 'Let us give thanks,' indicates the true Eucharistic purpose of the rite, and is, like other portions preserved in the Missal, contradictory of later sacrificial ideas.

\section{Rubric directing turning to the Lord's Table, 1662.}

This addition of 1662 is partly consonant with the Bishops' reply to the Puritans' desire, expressed at the Savoy Conference of 1661, that the Minister should turn to the people all the time : 'Not so ; when he speaks to them it is convenient that he turn to them: when he speaks for them.to God, it is fit that they should all turn another way, as the ancient church ever did.'* The Revisers, however, did not bid the Priest turn right around, but 'to the Lord's Table.'

It is very meet, right, etc., 1549 ; placed here 1552 ; Sar. Miss.

In the original Latin : Vere dignum et justum est, coquum et salutare, nos tibi semper et ubique gratias agere, Domine Sancte, Pater Omnipotens, Eterne Deus : 'It is truly worthy and right: fair and wholesome, that we should always and everywhere give thanks to thee, Holy Lord, Almighty Father, Eternal God.'

Indented Rubric, $16 \overline{6} 2$.

Prior to 1662 the purpose of this Rubric was achieved by repeating, before the 'Trinity Preface, 'It is very meet, right,' etc., with the omission of the words 'holy Father.'

Rubric respecting Proper Prefaces, 1549.

The ten surviving Proper Prefaces of Sar. Miss. were reduced to five in 1549, and those only to be used on the actual days. In 1552 the extension was made to eight days for the first three, and to seven days for the Whit-Sunday Preface.

The Saxon Order, largely the work of Justus Jonas, Cranmer's intimate friend, reduced the Prefaces to six, in 1539. The sixth.

* Frere, p. 178. 
that for the Epiphany, contained nothing doctrinal in its Sar. Miss. form to offend: Quia cum Unigenitus tuus in substantia nostros carnis apparuit, in novam nos immortalitatis sucs lucem reparavit: "Because when thy Only-begotten appeared in substance of our flesh, he restored us to the new light of his own immortality.' Perhaps the vagueness of it, coupled with anxiety to simplify the service, caused the omission of any Epiphany Preface.

Ter Sanctus, 1559 ; printed in full 1662.

In 1549 and 1552 the words 'Therefore with Angels,' etc., were in the Rubric. For notes see below, p. 331.

Proper Prefaces, 1549 :-

(1) Christmas, 1549.

In Sar. Miss. : Quia per incarnati Verbi mysterium nova mentis nostra oculis lux tuce claritatis infulsit: ut dum visibiliter Deum cognoscimus, per hunc in invisibilium amorem rapiamur: 'Because by the mystery of the in: carnate word the new light of thy brightness has shone in upon the eyes of our mind: so that while we know God visibly, by Him we are carried away to a love of things invisible.'

It is not surprising that the Reformers abandoned this very misty composition, for something emphasizing the redeeming work entered upon at the Incarnation.

1662. 'As at this time 'for 'as this day,' in deference to the request of the Puritans at the Savoy Conference.

(2) Easter, 1549 ; Sac. Greg., Sar. Miss.

In Sar. Miss. : Et te quidem omni tempore, sed in hac potissimum die gloriosius prodicare, cum pascha nostrum immolatus est Christus. I pse enim vere cst agnus, qui abstulit peccata mundi: qui mortem nostram moriendo destruxit, et vitam resurgendo reparavit: "And to extol thee indeed at all times, but more exultantly on this day especially, when Christ our Passover was sacrificed. For he is truly the Lamb, who took away the sins of the world : who by dying destroyed our death, and by rising again restored life.'

The Reformers were justified in dealing very freely with this original, suggesting, as it does, that Christ was crucified on Easter Day.

(3) Ascension, 1549 ; Sac. Greg., Sar. Miss.

In Sar. Miss. : Per Christum Dominum nastrum. Qui post resurrectionem suam omnibus discipulis suis manifestus apparuit, et ipsis cernentibus est elevatus in colum, ut nos 
divinitatis suce tribueret esse participes: 'Through Christ our Lord. Who after $\mathrm{h}$ is Resurrection manifestly appeared to all his disciples, and, with them discerning, was raised up into heaven, that he might grant us to be partakers in his divinity.'

1552. 'Apostles ' for 'disciples,' more accurately.

The Reformers exchanged the vagueness of the closing clause of the original for the concrete Scriptural promise.

(4) Whit-Sunday, 1549.

In Sar. Miss.: Per Christum Dominum nostrum. Qui ascendens super omnes colos sedensque ad dexteram tuam, promissum Spiritum Sanctum hodierna die in filios adoptionis effudit. Quapropter profusis gaudiis totus in orbe terrarum mundus exultat. Sed et supernce virtutes atque angelica potestates hymnum glorics tuæ concinnunt, sine fine dicentes: "Through Christ our Lord. Who ascending above all heavens, and sitting at thy right hand, poured out the promised Holy Spirit on this day upon the sons of adoption. Wherefore with abundance of joy all mankind throughout the world exults. Yea, even the heavenly virtues and angelic powers join in the hymn of thy glory, saying without cessation.' Here, as elsewhere, the Reformers supplied the facts of divine revelation instead of the fancies of human imagination.

(5) Trinity, 1549 ; shortened from Sac. Gel., Sac. Greg., Sar. Miss.

In Sar. Miss.: Qui cum unigenito Filio tuo, et Spiritu Sancto, unus es Deus, unus es Dominus, non in unius singularitate personce, sed in unius trinitate substantia. Quod enim de tua gloria revelante te credimus, hoc de Filio tuo, hoc de Spiritu Sancto, sine differentia discretionis sentimus. Ut in confessione verco sempiternoque deitatis, et in personis proprietas, et in essentia unitas, et in majestate adoretur cequalitas: "Who with thy only-begotten Son, and the Holy Spirit, art one God, art one Lord, not in the singularness of one person, but in the threefoldness of one substance. For what we believe of thy glory through thy revelation, this we hold concerning thy Son, this concerning the Holy Spirit, without the difference of distinction. So that in the confession of the true and eternal Godhead, both peculiarity in the persons, and unity in essence, also equality in majesty, are adored.'

Those who use the B.C.P. in worship will be grateful for the wise freedom with which the Reformers have used this com- 
plex credal statement of Sar. Miss. ; indeed, they might have departed from it altogether to advantage, and followed the other Prefaces by giving some indication of what the import of the Revelation of the Blessed Trinity is to man. The American Prayer Book gives an alternative: For the precious death and merits of Thy Son Jesus Christ our Lord and for the sending to us the Holy Ghost the Comforter; who are one with Thee in Thy Eternal Godhead.

In 1549, instead of closing with 'Therefore,' etc., this Preface closed with 'whom the Angels,' etc., the first words of the Latin exceptional ending: "Whom the angels and archangels praise, the Cherubim also and Seraphim, who do not cease with one voice to cry, saying.' This was altered in 1552.

Ter Sanctus, 1549 ; altered 1552 ; Sac. Greg., Sar. Miss.

This hymn is called Ter Sancius or Trisagion from its use of the threefold address to God, 'Holy, Holy, Holy,' found in Isa. vi. 3 , Rev. iv. 8.

1549. Hosannah in the highest, Blessed is he that cometh in the name of the Lord. Glory to thee, O Lord, in the highest.

1552. Glory be to thee, O Lord, most high.

The omission of the 'Hosannah ... Blessed is he that cometh' was due to the more than possible mistaking the words as a reference to the effect of the forthcoming Consecration.

The Sar. Miss. version was (translated) : "And therefore with Angels and Archangels with Thrones and Dominations, and with all the soldiery of the heavenly army we sing the hymn of thy glory, endlessly saying Holy, Holy, Holy, Lord God of hosts (Sabaoth). The heavens and the earth are full of thy glory: Hosanna in the highest. Blessed is he who comes in the name of the Lord: Hosanna in the highest.'

There has never been any rubrical direction as to whether all or part of this should be joined in by the congre gation, since 1549, when the Rubric followed: 'This the clerks shall also sing': and a mark before 'Holy, Holy, Holy,' indicated that as the part to be sung. In 1552 the words 'shall follow,' without the 1549 direction, did not clearly direct saying or singing, but the alternative was expressly given in 1662 , by the use of the words 'sung or said.'

At this point, in 1549, followed the long Prayer roughly corresponding to the Canon of the Mass in Sar. Miss. ; see Analysis, p. 284.

Rubric preceding Prayer of Humble Access, 1548. (See p. 271.) 1549. 'Turning him to God's board,' added before 'kneel down.'

1552. Kneeling down at God's board. 
1662. Kneeling down at the Lord's Table.

Prayer of Humble Access, 1548; placed here 1552.

In 1549 this Prayer followed Consecration : since 1552 it has preceded it. The change of position is significant, being designed to answer one of Gardiner's 'mis-takings,' and pointedly forbidding the application of any phrase in it to the consecrated elements. The most equivocal words, 'in these holy mysteries', were also removed, as follows :-

1548 and 1549. . . . and to drink his blood, in these holy Mysteries, that we may continually dwell in him, and he in us, that our sinful bodies ... blood.

1552 and 1662. . . . and to drink his blood, that our sinful bodies ... blood, and that we may evermore dwell in him, and he in us. For the force of the idiom: 'so to eat ... that,' sae Introduction, p. 272.*

The doctrinal importance of the omission of 'in these holy Mysteries' needs no comment; the re-arrangement of the clauses, and their connexion by the conjunction 'and,' not only make them run more smoothly, but avoid the suggestion that union with Christ is in order to cleanse, when in truth the cleansing is with a view to union. $\dagger$

The idea of the body being cleansed by the body of Christ, and the soul by His blood, is even more definite in the 1548 words of administration: "The body of our Lord Jesus Christ, which was given for thee, preserve thy body unto everlasting life': 'The blood ... preserve thy soul,' etc. In 1549 these words 'were altered, 'body and soul' being united in the words of administration both of bread and wine, as now. The Prayer, however, remained unaltered in 1549, and in 1552 and 1662, too, this idea was left unchanged. There seems to be no exact parallel, but the mention of the soul and body in connexion with the body of Christ, the soul alone with the blood, occurs in a Missal of Subiaco, 1075, and in an old missal found near Rheims ; $\ddagger$ the York and Mozarabic Missals have these words for the Priest when communicating: "May the body and blood of our Lord Jesus Christ keep my body and soul unto life eternal, Amen': while a prayer in the Hereford and Westminster Missals refers to the flesh cleansing, the blood washing, from which may come the verbs 'cleansed' and 'washed' in the Prayer. The famous gloss upon Gelasius' condemnation of communion in one kind is quoted by Becon,

* This idiom is explained and illustrated an Dowden's Further Studies, pp. 339-343, as well as in Dimock, quoted in Introduction.

$\dagger$ See Dowden, Further Studies, p. 335.

† See Dowden, ibid. pp. 319 tf. 
Cranmer's Chaplain: 'The sacrament is not superfluously received under both kinds. For the kind of bread is referred unto the flesh, and the kind of wine unto the soul.' Becon also quotes the Pseudo-Ambrose and Aquinas to the same effect. Anselm expressly taught the idea, going on to warn against the thought that the whole Christ is not received under either kind, being reputed the first to enunciate elearly the dogma of concomitance, though the name was given by Aquinas: "in either kind the whole Christ is taken.' It is possible that the words in the Prayer were written by Cranmer to accompany and to justify the restoration of the cup to the laity. However, it would seem from the Act of Parliament of 1547 and the Royal Proclamation affixed to the Order of Communion of 1548, ordering administration in both kinds 'except necessity otherwise require it,' that the dogma of concomitance was hardly yet abandoned. Indeed, the fluid state of Cranmer's doctrine of the Lord's Supper in 1547 is a well-known bar to basing definite conclusions upon his words at that period.

The Puritans contended, not unreasonably, that these words seem to attach greater efficacy to the blood than to the body of Christ, and asked for a readjustment of the words. In view of the alteration in the words of Administration in 1549, a similar alteration might have been made in 1662 if the spirit on both sides had been a less contentious one. The Bishops' reply that the words of the Lord associated forgiveness of sins with the blood-shedding and not with the body, was an evasion; if strict regard for the Lord's words counted for so much, they should at least have omitted any reference to our sinful bodies being cleansed by His body. The separation of the efficacy of the body and of the blood is meaningless.

Rubric providing for arranging the Bread and the Wine, 1662.

1552. Then the Priest standing up, shall say as followeth:

S.L. Then the Presbyter standing up, shall say the Prayer of consecration, as followeth, but then during the time of consecration, he shall stand at such a part of the holy Table, where he may with the more ease and decency use both his hands.

1662. When the Priest, standing before the Table, hath so ordered the Bread and Wine, that he may with the more readiness and decency break the Bread before the people, and take the Cup with his hands; he shall say the Prayer of Conseeration, as followeth :

The Puritans, in 1661, asked that the directions accompanying the 'Prayer at the Consecration' might be more explicit. The 
indented rubrics were restored to meet their demands, and the above Rubric was added.

Comparison with S.L., which prescribes the special position of the Presbyter during the time of consecration, demonstrates that the 1662 Rubric was carefully worded to proscribe that position except for the few moments required for arranging the bread and wine. The words 'standing before the Table" are within the clause 'when the Priest hath so ordered,' and grammar forbids any interpretation of them as relating to the position in which consecration should be performed. Yet, without any explanation, it is stated : "The insertion of the Rubric authorized the Eastward position at consecration.'*

The important words 'before the people' constitute a reductio ad absurdum of the theory that the Rubric commands Eastward Position at this point; and, in fact, this undisputed direction is infringed continually by the adoption of the Eastward Position. The Cope, commanded to be worn at Holy Communion in Cathedrals and Collegiate Churches, is only a somewhat more complete obscuration than the surplice, of everything that is done by the hands of the celebrant who ministers with his back to the people.

It is not without bearing upon this matter that in 1549, at the close of the Prayer of Consecration, is a Rubric saying: 'These words before rehearsed are to be said, turning still to the Altar, without any elevation, or shewing the Sacrament to the people.' If the Revisers meant more than they said in commanding the position before the Table for ordering the Bread and Wine, here was a clear precedent for their saying it ; if they meant less than they said in prescribing the manual acts being done 'before the people,' again there was precedent for saying it clearly.

It is to be remembered that S.L. reverted to the 1549 arrangement to a large extent, which the Revisers in 1662, with S.L. before them, refused to do.

After 'Holy, Holy, Holy,' in S.L. came :

Prayer of Consecration, wording assimilated to 1549.

Memorial, or Prayer of Oblation, as in 1549.

Lord's Prayer.

Prayer of Humble Access.

Administration.

Prayer of Consecration, $1552 ;(1549)$.

The prayer falls into three parts :-

* Frere, p. 491, quoting Talbot, Ritual, p. 132. For the Eastward Position generally, see p. 295. The MSS. annexed to the Act of Uniformity has a semirolon, not a comma, after 'hands.' 
(1) A declaration of the true relation of the Sacrament to the Sacrifice ('Almighty God,' etc.).

(2) A petition that partakers of the elements may be partakers of Christ ('Hear us,' etc.).

(3) A recital of the scriptural account of the original institution ('Who, in the same night,' etc.).

\section{(1) Declaration.}

The first part of the prayer was composed in 1549, and strikingly exhibits the mind of the Reformers, with its reference to the one oblation, once offered upon the Cross : its multiplication of definite terms :- ' full, perfect and sufficient sacrifice, oblation and satisfaction': and its explanation of the ordinance as 'a perpetual memory of that his precious death.' However, the 'mis-takers' laid hold of the ambiguities retained, rather than of the clear teaching provided, and in 1552 the second part of the prayer was carefully re-written, while in this part the word ' continue 'was substituted for ' celebrate,' and 'of himself' added after ' oblation.' In Sar. Miss. there is nothing corresponding, the words in the parallel position being: "This oblation therefore of our service, as also of thy whole household, we beseech Thee favourably to accept,' etc., preceded by the direction: 'Here let the priest gaze upon the host with great reverence, saying.'

\section{(2) Pertition.}

Sar. Miss. Here again let him gaze upon the host saying: "which oblation do thou, God Almighty, we beseech thee, deem worthy to make in all things bless + ed, ap + proved rati + fied, reasonable, acceptable, that for us it may be made the $\mathrm{Bo}+\mathrm{dy}$ and $\mathrm{Bl}+$ ood of thy most beloved Son our Lord Jesus Christ.

1549. Hear us ( $O$ merciful Father) we beseech thee; and with thy holy Spirit and word vouchsafe to bl + ess and sanc + tify these thy gifts and creatures of bread and wine, that they may be unto us the body and blood of thy most dearly beloved Son Jesus Christ. Who, etc.

\section{S.L. As in 1549.}

1552. Hear us, O merciful Father, we (most humbly, 1662) 1662. S beseech thee, and grant that we, receiving these thy creatures of bread and wine, according to thy Son our Saviour Jesus Christ's holy institution, in remembrance of his death and passion, may be partakers of his most blessed body and blood: Who, etc.

With thy holy Spirit and word. The invocation of the Holy 
Spirit, not in Sar. Miss., and omitted from B.C.P. in 1552, is a special feature of the Eastern liturgies, where doubtless it was found by Cranmer, though a similar prayer, without mention of the Holy Spirit, in a German Book of 1543, largely by Osiander, the uncle of Cranmer's wife, suggests the possibility of that source (cf. Dowden, Further Studies, etc., $66 \mathrm{ff}$.). This invocation, 'epiklesis,' is extant in the Apos'olical Constitutions, compiled by the Pseudo-Ignatius (c. 350?), and containing the so-called 'Clementine Liturgy,' where the Holy Spirit is invoked upon" this sacrifice ("voíar), the witness ( $\mu$ áprvpa) of the suffering of our Lord Jesus, that He may display this bread as

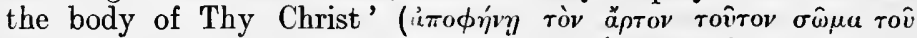
$X \mu \iota \tau \tau o \hat{v} \sigma o \hat{v})$, etc. The use of the verb 'display' here is not obviously consistent with an entirely spiritual presentation. 'The Liturgy of Palestine, 348 (?), has moเ' $\sigma \eta$, 'make,' not 'display.' The excision of a reference which is in any case unscriptural, and in application to the bread and wine misleading, is cause for congratulation.* The addition of "and word' to 'holy Spirit' reminds us of the liturgical MS. recently discovered at Mount Athos, purporting to be by Serapion, of the fourth century, where the "Holy Word' is invoked. S.L. restored this invocation, in the words of 1549. The American B.C.P. has the same invocation, but prays, not "that they may be unto us' but 'that we, receiving them,' etc., as in 1552. The Scottish B.C.P. has ' that they may become.'

That we . . may be partakers; 'that they may be unto us,' 1549 ; ' that it (the oblation) may be made unto us,' Sar. Miss. Cranmer explains the 1549 change thus: 'we do not pray absolutely that the bread and wine may be made the body and blood of Christ, but that unto us in that holy mystery they may be so ; that is to say, that we may so worthily receive the same, that we may be partakers of Christ's body and blood, and that therewith in spirit and in truth we may be spiritually nourished' (On the Lord's Supper, p. 79, P.S. Edn.). However, the sweeping change of 1552 removed all ambiguity. The 1549 change excluded transubstantiation; the 1552 change closed the door to Lutheranism. $\dagger$ The turn of the words by which the worshipper is prayed for instead of a request being made for a blessing upon the bread and wine (which could only have a figurative meaning) is quite in accordance with Holy Scripture (sec Introduction, p. 213). The interchangeable use

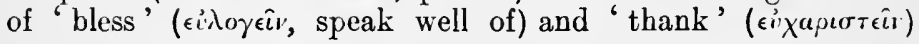

* For the history, see Dimock, Eucharistic Presence, pp. 559-561.

$\dagger$ See Dimock, History of the B.C.P., passim. 
in the several accounts of the institution, makes it unreasonable to attribute the blessing to the elements. We thank God for the cup, in Matthew and Mark; we cannot give another object to the 'bless,' used in connexion with the 'bread' in those two Gospels, especially as in Luke, and in 1 Cor. xi., the word 'thank' is used instead of 'bless,' in connexion with the bread. The use of the word 'bless' with an inanimate object can only be supported by two passages (in the accounts of the Institution there is no object after 'bless' though A.V. has supplied 'it') :-1 Cor. x. 16, where 'the cup which we bless' is equally grammatically rendered 'the cup as to which we bless (God), and Mark viil. 7, of the seven loaves, where the same grammatical rendering can be applied (if indeed it be necessary, for the readings vary). This transference of thought from the inanimate elements to the relation of God to the recipient, symbolized by them, is the English Reformation in brief.*

\section{(3) Recital.}

The third part, the consecration proper, $\dagger$ is a recital of the Gospel record of the institution, with certain actions ; - an old, but by no means invariable, practice. The famous words of Gregory the Great, that the Lord's Prayer only was the original method of consecrating, will readily occur to the mind. For the manual acts, see below. The differences in this portion of the Prayer will be seen from the following :-

Sar. Miss.: "Who on the day before He suffered, took bread into his boly and venerable hands, and with eyes raised to heaven (Here let him-the priest--raise his eyes) to Thee God, His Father Almighty, (Here let him bend limself, and afterwards rise a little saying :) paying thanks to Thee, He bles + sed, broke, (Here let him touch the host, saying :) and gave to his disciples, saying, Take and eat of this, all : for this is my body. (And those words must be put forth in one "rreath and one utterance, with no pause interposed. After these words let the priest bend himself towards the host, and afterwards raise it on his forehead, that it may be seen by the people ; and let him reverently replace it before the cup making with it the sign of the cross. And then let him uncover the chalice'... saying:) In like manner, after supper,

* For modern evasions of the force of the ehanges of 1552, carefully retained in 1662, see Introduction, p. 279.

$\dagger$ Even in 1548 this part is alone commanded to be used in the consecration of more wine. 
taking also this noble cup into his holy and venerable hands, also to Thee (Here let him bow, saying :) giving thanks, He bles + sed, and gave to his disciples, saying : Take and drink of it, all : (Here let the priest elevate the cup a little, thus saying :) For this is the eup of my blood, of the new and eternal testament, the mystery of faith, which for you and for many shall be shed for the remission of sins: (Here let him elevate the cup up to the breast, even over the head, saying :) As often as you shall do these things, you shall do them in remembrance of me.* (The host having been then offered as 'a holy sacrifice, an immaculate victim,' this prayer followed: Command these things to be carried by the hands of thy holy Angel to thy altar on high, in sight of thy Divine Majesty.)

1549. Who, in the same night that he was betrayed : took bread, and when he had blessed, and given thanks: ho brake it, and gave it to his disciples, saying : Take, eat, this is my body which is given for you : do this in remembrance of me: Likewise after supper he took the cup, and when he had given thanks, he gave it to them, saying: drink ye all of this, for this is my blood of the new Testament, which is shed for you and for many, for remission of sins : do this, as oft as you shall drink it, in remembrance of me. $\dagger$

1552. But one alteration was made, the omission of 'blessed

* It is noteworthy that the Missal interprets the Lord's words "do and not 'sacrifice,' 'remembrance' and not 'memorial.'

+ The B.C.P. account is a perfect blend of the Scriptural accounts :-

Who in the (same) night... brake it

Gave ... disciples

Saying

Take, eat,

This is my body

which is for you

given

Do this, etc.

Likewise after Supper

took

Cup

And when ... to them

Saying

Drink ye all

For this ... covenant

New

Shed for you

for many

for remission of sins

1 Corinthians.

Matthew.

Luke.

Matthew.

All.

Do this, etc.

Luke, 1 Cor.

Luke.

Luke, 1 Cor.

Luke, 1 Cor.

Matt., Mark.

All.

Mark.

Luke, 1 Cor.

Matthew.

Matt., Mark.

Luke, 1 Cor.

Luke.

Matt., Mark.

Matthew.

1 Corinthians. 
and,' a patent recognition of the scriptural identity of the words 'bless' and 'thank.' The unauthorized additions to the Gospel which disfigured Sar. Miss. were excised in 1549.

The 'Amen' was added in 1662 ; there was none here in 1549,1552 , or S.L.*

Indented Rubrics, 1662, (1549).

In Sar. Miss. the great multiplicity of directions included none corresponding to those in B.C.P. A triple fracture later in the Service might indeed be reminiscent of the original institution, but it did not mean a breaking for distribution. One of the fragments was uced for the 'commixture,' made by dropping one part into the wine, a mediæval feature wholly discarded in 1549 .

1549. There were but two : Here the Friest must take the bread (shall take the cup) into his hands.

15526. There were no directions $\dagger$; the Puritans complained in 1661 that the matter was not explicit enough, and that the minister's breaking of the bread was not so much as mentioned.'

S.L. Added to the 1549 directions the order to lay the hand on the cup, (not on the bread).

1662. Five directions were given :-

Here to take the Paten,

Here to break the bread,

Here to lay his hand upon all the bread,

Here to take the Cup,

Here to lay his hand upon every vessel, etc.

The history of the 'Manual Acts' shows their non-essential nature, but the clearness of the directions since 1662 is matter for congratulation, and cause of gratitude to the Revisers, who were not so deaf to Puritan suggestions as were the Bishops at the Conference of 1661 . Moreover, the restoration of the direction to break the bread, at this the proper place, was a distinct return to scriptural accuracy in administration, especially as those for whose reception it is broken immediately partake.

* Frere writes, p. 492, 'At this point the prayer comes to an abrupt end,' thus deploring the absence of any oblation of the consecrated elements. But it is at any rate just as abrupt, or not abrupt, as the original institution, which interposed nothing between these words and communion.

$\dagger$ They werc 'designedly' omitted, the 'manual acts' being used by some as a method of reintroducing elevation, etc. See Bp. Middleton's Visitation Articles. 
Rubric prescribing the order of Reception, 1549, (1548); altered 1552 and 1662 .

1548. The Priest [who had already communicated some time before, in accordance with the Latin Office] shall deliver the Communion, first to the Ministers, if any be there present, that they may be ready to help the Priest, and after to the other.

1549. Then shall the Priest first receive the Communion in both kinds himself, and next deliver it to other Ministers, if any be there present (that they may be ready to help the chief Minister) and after to the people.

1552. Then shall the Minister ... (that they may help the chief Minister) and after to the people in their hands kneeling.

1662. Then shall the Minister . . . himself, and then proceed to cieliver the same to the Bishops, Priests, and Deacons in like manner, (if any be present) and after that to the people also in order, into their hands, all meekly kneeling.

\section{(1) To the Clergy First.}

The reason for administering to the Clergy first, though not expressed in 1662, is obvious enough. The recent practice of having clergy present who do not communicate, whether they have already communicated at some earlier service or not, is not countenanced by the Rubric. The 'drink ye all' is so explicit, and the meaning of communion, 'fellow-partaking,' is so clear, that this practice can only be described as a maiming of the Lord's institution. The unfortunate idea of some necessity of fasting for the reception of the elements, apart from any custom of preparation of soul for the whole solemn rite, is responsible for this transgression of Holy Scripture and the B.C.P.

\section{(2) Into their hands.}

The 1552 order to deliver the elements into the hands of the communicants superseded the direction of 1549 contained in the last Rubric at the end of the Communiou Office: "And although it be read in ancient writers, that the people many years past received at the priest's hands the Sacrament of the body of Christ in their own hands, and no commandment of Christ to the contrary; Yet forasmuch as they many times conveyed the same secretly away, kept it with them, and diversely abused it to superstition and wickedness ; lest any such thin' hereafter should be attempted, and that an uniformity might be used throurhout the whole Realm, it is thou'tht 
convenient the people commonly receive the Sacrament of Christ's body in their mouths, at the Priest's hand.'

The danger of a superstitious regard for the bread, if that mode of administration were preserved, soon outweighed the dangers mentioned in 1549 , and the simpler custom, admittedly scriptural, was adopted in 1552, the only alteration in 1662 being from " in' to the more precise 'into' (their hands). S.L. contained no direction at all, an omission to which the Puritans took grave exception, as indicating a retrogression to the 1549 rule.*

The mention of the plual, ' hands,' has led to a curious error, now enshrined in a quite frequent custom, namely the use of both hands for receiving. Obviously, 'their hands' in 1552 means no more than 'their mouths' in 1549 , when it is hardly pretended that the plural applies to the individual. This custom is not infrequently backed by the direction of Cyril of Jerusalem : -When you draw near do not come with your palms wide open or your fingers apart; but making your left hand a throne for the right, as about to receive a King, and making your palm hollow, receive the Body of Christ.' The remainder of Cyril's directions are not quoted, ordering the eyes to be touched with the body, and, with the moisture of the wine from the lips, not only the eyes but ' the rest of the organs of sense.'

Careless reasoning has led to another mistake. The use of the word ' hands' to take the place of 'mouths' plainly does not distinguish the palm from the fingers, which are quite as much part of the hand as anything below the wrist. Dowden $\dagger$ quotes Gibbon's story concerning a 'very holy lady,' Sylvia (c. 392) who rebuked a deacon for indulging in the luxury of washing, boasting that, though in her sixtieth year, none of her limbs had touched water save the tips of her fingers, and that for the sake of communion. This story, if true, gives an early authority for the fingers, however that authority may be viewed in regard to the luxury of washing! The use of the palm or the fingers is quite a matter of convenience; the palm is perhaps easier for the Minister, the finger and thumb easier and more reverent for the recipient to carry the bread to his mouth.

\section{(3) Kneeling.}

This was introduced in 1552, with the 'Black Rubric' to guard against the superstitious idea of a Real Presence to be

* Scudamore, Not. Euch., attributes the change from 'mouths' to ' hands' to I662, an unusual inaccuracy.

$\dagger$ Further Studies, p. 232. 
adored. The 'Black Rubric,' which was not strictly part of the B.C.P., had disappeared since 1559. It was restored in 1662 in deference to Puritan objections to kneeling, and made part of the B.C.P.

Rubric regarling the administration of the bread, 1548; altered 1552 and 1662 .

1548. And when he doth deliver (delivereth, 1549) the sacrament of the body of Christ, he shall say to every one these words following.

1552. And when he delivereth the bread, he shall say.

1662. And when he delivereth the bread to any one, he shall say.

The misuse of the word ' sacrament' by its application to the elements was remedied here in 1552. The absence of the words 'to every one' in 1552, restored in 1662 ('to any one '), did not imply any change from the custom of saying the words to cach recipient; the Puritans, in 1661, desired that the requirement to distribute the elements and to address the words to each communicant might be done away. Their quite correct plea that this change would be scriptural was of no avail, the Bishops replying that 'it is the propriety of Sacraments to make particular obsignation to each believer,' a slur upon the 'propriety' of our Lord's institution, which betrays the unconciliatory temper of the Savoy Conference. However, Convocation was no more compliant on this point, but expressly ordered individual administration, thereby laying a burden upon the Church which has sanction neither in Holy Scripture nor in common sense:

Recent proposals to relieve the Church in a matter involving no doctrinal question, and, indeed, to sanction a breach of the strict letter of the law which is very common, have tended to accentuate rather than remove the evil. The Lower House of Canterbury Convocation has suggested the saying of the second part of the words of administration, commencing: "Take and eat this': 'Drink this' : once, with the repetition of the first part to each communicant. If any such compromise were at all wise, it might be thought that the latter part, with its plain direction nearly in our Lord's words, is more worthy of repetition; unfortunately, a section of the Church has suppressed that part altogether in administration, and the relief is rather calculated to suit their doctrinal irregularities than to meet the practical needs of the Church generally.

Words of Administration of the bread, 1559 ; first part 1548 , 1549 ; second 1552. (See.p. 272.) 
1548. The body of our Lord Jesus Christ, which was given for thee, preserve thy body unto everlasting life.

1549. The body . . . preserve thy body and soul . . .

1552. Take, and eat this, in remembrance that Christ died for thee, feed on him in thine heart by faith with thanksgiving.

1559. The words of 1549 and 1552 joined by ' and.'

S.L. The words of 1549 , with 'Amen.'

1662. The words of 1559 , with the ' and 'omitted, but another added before 'feed on him.'

In Sar. Miss., as in other mediæval Missals, there were no words of administration; but the Sarum and York Manuals for administering the bread to the sick had (in Latin): 'The Body of the Lord Jesus Christ keep thy body and thy soul unto everlasting life. Amen.' This was doubtless the basis of the B.C.P. words of administration, qualified by the addition of the important words ' which was given (shed) for thee,' which make it impossible reasonably to interpret the words 'Body' and 'Blood' of the elements. This addition was drawn from German sources, Hermann's Bedencken, and Nuremberg Ordcr.* The combination of the words of 1549 and 1552 was one of the three specified alterations, ' and none other or otherwise,' of $1559 . \dagger$

For the 1549 alteration : 'body and soul' for 'body': see above on the Prayer of Humble Access, p. 332.

The value of the 1662 retention of the 1552 words, in spite of their omission in S.L., is abundantly shown by such misunderstandings as the following: "If then the bread is not the Blessed Body ... I am guilty of a falsehood every time I use those words, and knowingly deceive the hearts of the Faithful by declaring It to be what It is not.' $\ddagger$ With such possible ' mis-taking,' it is clear that the Reformers of 1552 were justified in abandoning the ancient form, though capable, as it certainly is, of a most scriptural interpretation, and safeguarded by the words 'which was given,' etc.

Rubric regarding the administration of the wine, 1548; altered 1552 and 1662. (See p. 271.)

1548. And the Priest delivering the Sacrament of the blood, and giving every one to drink once and no more, shall say.

1519. 'Minister' for 'Priest.'

1552. And the Minister that delivereth the cup, shall say.

* See Dowden, Further Studies, pp. 234-237.

t 'The other two related to the Lessons and the Litany.

$\ddagger$ Husband, quoted from Dimock, Eucharistic Presence, p. 434. 
1662. And the Minister that delivereth the cup to any one shall say.

The practice of withholding the cup from the laity, 'Communion in one kind,' was abolished in the Order of Communion, 1548, and forbidden in Art. XXX. It took its rise from the twofold source of fear lest the transmuted elements should suffer from lack of care, and the reasoning that both kinds were unnecessary seeing that 'whole Christ,' His 'Body, Soul, and Divinity,' were inseparably in either kind. It might rather be concluded from our Lord's institution of both kinds that the doctrine is erroneous. This doctrine is called the Doctrine of Coneomitance, and originated in the Middle Ages. The withholding of the cup not only began the protests which culminated in the Reformation; it also formed the actual cause of the Taborite rebellion in the Empire, which was successful against all the forces of Pope and Emperor for many years. The Council of Constance, 1415, at which it was hoped that the cup would be restored to the laity, decreed precisely the reverse; and the Council of Trent included amongst its many anathemas one against those who objected to communion in one kind.

The defence of the practice is as follows :-

i. The Lord's words in John vi. 51, 58, where what is elsewhere attributed to eating His flesh and drinking His blood, is spoken of eating 'bread' alone. But if the Lord had meant that communion in one kind would suffice, He would not have instituted communion in both kinds. Moreover, the argument proves too much, for it declares that the wine is as unnecessary for the celebrating priest as for the communicant. The true interpretation of these passages is discovered by recognizing that the word ' bread 'is equivalent to both 'flesh and blood,' the former being a figurative presentation of the latter.

ii. St. Paul's words in 1 Cor. xi. 27 : 'Eat this bread or drink the cup unworthily ... guilty of the body and blood. . . ' This reading of the true text, it is urged, affirms grammatically that guilt in regard to either kind is guilt in regard to both.

But, apart from the fact that St Paul here unmistakably affirms reception in both kinds, it is obvious that unworthiness in the reception of either kind involves unworthiness in regard to receiving both. It is impossible to discriminate between the kinds in regard to worthiness, and to use the word ' or' of body and blood would have introduced an absurdity. If it were possible to deduce any such sufficiency of either kind alone from this passage, it would justify the withholding of the bread as much as of the cup. 
iii. The practice of the Early Church is adduced as supporting the doctrine. The confutation is easy :-

(a) The Lord distributed in both kinds to all, and they were not celebrating priests on that occasion: 'Drink ye of it, all,' ' and they all drank of it.'

(b) The Early Church did not withhold the cup from any one save in illness, and then, if the present practice in the East is any guide, the bread was soaked in the wine, so that there was no real withholding of either kind. Illness would usually render the swallowirg of bread the more difficult process.

(c) So late as the Council of Clermont, 1095, and the letter of Paschal II, 1118, communicating in both kinds is enforced, Paschal excluding only infants and the infirm "who cannot swallow bread.' Of earlier Popes, Leo styled the abstinence from the cup a Manichæan heresy, and Gelasius ordered those who did not receive the cup to be kept away altogether, on the ground that division of the ordinance involved great sacrilege.

iv. Refuge is often taken in the right of the Church to decide its own customs.

But the respective spheres of custom and obedience to divine commands are not difficult to decide ; cf. Cyprian, Ep. lxxiv. : 'Custom without truth is only antiquity of error': Augustine, Contra Donat. vi. 71 : 'When the truth is made plain custom must give way to truth.'

Words of administration of the wine, 1559 ; first part 1548 , 1549 ; second 1552 .

1548. The blood of our Lord Jesus Christ, which was shed for thee, preserve thy soul to everlasting life.

1549. As in 1548, save 'body and soul unto' for 'soul to.'

1552. Drink this in remembrance that Christ's blood was shed for thee, and be thankful.

1559. As in 1549 and 1552 , joined by 'and.'

1662. As in 1549 and 1552 , 'and' of 1559 omitted.

In 1548,1549 , a Rubric followed directing a Deacon or other Priest, if present, to follow with the Chalice, 'as the Priest ministereth the bread (1549, Sacrament of the body) for more expedition.' This was omitted in 1552, but the reference to assistance in the earlier Rubric concerning administration to the Ministers first, made this rubric superfluous. The omission of such reference in the 1662 Rubric is remarkable ; the custom is, at any rate, for a Deacon to assist with the cup only.

Rubric directing consecration of more bread or wine, 1548 ; wanting in 1549, 1552; altered and placed liere 1662 . In 1548, the last Rubric, after the Blessing was: 'Note, that 
if it doth so chance, that the wine hallowed and consecrated doth not suffice or be enough for them that do take the Communion, the Priest, after the first Cup or Chalice be emptied, may go again to the altar, and reverently, and devoutly, prepare, and consecrate another, and so the third or more, likewise beginning at these words, Simili modo postquam conatum est, and ending at these words, qui pro vobis et pro multis effundetur in remissionem peccatorum, and without any elevation or lifting up.'

The last few words of this Rubric were incorporated into the Rubric following, and regulating, the Prayer of Consecration in 1549 , but the remainder had no counterpart in 1549 or 1552 , though the nced of such a regulation is proved by the prosecution of a clergyman in 1574 for administering unconsecrated bread and wine when more were needed. This prosecution was successful, and it is therefore presumed that a repetition of some part of the service was generally understood to be requisite. In 1548 it was evidently thought that there should be no difficulty in estimating the amount of bread required.

In S.L. a closing Rubric directed the Presbyter to recite the whole of the words of institution, whether for more bread or more wine. The Revisers of 1662 took their own more reasonable line, directing only the appropriate part of the words to be used for either.

The Rubric is important as denoting what constituted in the Reformers' opinion the actual consecration, namely the recital of the words of institution, so early as 1548. Even in S.L., which restored the invocation of 1549 , it was not regarded as of sufficient importance to be repeated. According to Scudamore, in the period immediately before the withdrawal of the cup from the laity, contact with consecrated wine was deemed sufficient to consecrate any added to it-an opinion not. held by the Reformers.

Rubric directing to cover with a fair linen cloth, 1662.

No directions for dealing with any surplus had been given in 1548,1549 , or 1552 ; the simple and reverent regulation here provided is in every way satisfactory.

\section{Agnus Dei.}

In 1549 a Rubric after administration ordered :-

In the Communion time the Clerks shall sing,

O Lamb of God, etc. : have mercy upon us.

0 Lamb of God, etc. : grant us thy peace.

This was excluded in 1552, and not restored in S.L. or 1662 . In spite of the absence of address to the consecrated clements, so marked in Sar. Miss., it was rightly felt that the words "ere 
capable of misrepresentation and misuse. Such misuse accompanying the unauthorized re-introduction of the practice of singing Agnus Dei at this point, makes the decision of the Lambeth Judgment to permit this use surprising :-

(1) In the Roman Use Agnus Dei at this point is recognized as a prayer to the Son of God, 'under the forms of bread and wine.'

(2) Becon, Cranmer's Chaplain, commenting on the practice, calls its users ' abominable idolaters,' and the practice 'intolerable blasphemy.'

(3) Ridley, in May 1550, when the hymn was authorized to be sung during the Communion, forbade, in his Visitation Articles, 'counterfeiting the Popish Mass in saying the Agnus before the Communion.'

(4) Modern Roman critics characterize the omission in 1552 as significant: 'this omission of the Agnus cannot be considered accidental . .. the scruples felt at the sirained interpretation put by Gardiner on the 'Prayer of Humble Access' as opening the door for adoration, would have a greater effect in determining the Revisers to this change.'*

(5) The attempt made to treat the restoration of the practice as not significant does violence to the fact that its use is desired as significant.

(6) The argument that the omission in 1552 was simply due to its transference to the Gloria in Excelsis, where in 1552 it was repeated three times, as against twice in 1549 , is discounted by Frere (p. 496) who points out that some MS. settings of the 1549 B.C.P. have the triple repetition.

(7) In 1662 the proposal to reinstate the use was formally considered, and rejected; Sancroft records the rejection.

(8) The suggestion that Baxter's formula: 'The body of Christ which was broken for us, and offered once for all,' affords any parallel to "Who takest-art taking-away the sins of the world,' illustrates the untenableness of the whole position.

(9) The use of the Gloria in Excelsis in 1552 in the Post-Communion, after that the elements have been consumed, is too significant to be overlooked. Cosin's words show the eagerness of the 'High Churchman' of that time to avoid the danger disregarded by the Lambeth Judgment: "If he be careful as he ought to be, to consecrate no more than will suffice to be distributed to the communicants, none will remain.' The care of S.L. to avoid any surplus is expressed in a Rubric, urging error

* Gisquet, Ed. VI and the First Prayer Book, p. 294; quoted from Ton:li ason, Lambeth Judgment Examined, p. 70, which see for full treatment cf the subject. 
on the other side, which could be remedied by further consecration, rather than to have any left over.

\section{POST-COMMUNION.*}

Rubric respecting the saying of the Lord's Prayer, 1552.

' The people repeating after him every petition:'-These words call attention to the mediæval-practice of the Priest's saying all alone down to 'But deliver us from evil.' In 1549, when the Lord's Prayer still remained part of the long prayer before Administration, this mediæval custom was retained here ; indeed, it endured in other Offices, the Litany, Matrimony, Visitation of the Sick, Burial of the Dead, Churching of Women, and Commination, until 1662.

The words 'after him,' contrasted with the 'with him' of the Morning Prayer General Rubric, have been sometimes thought to require a literal repetition of each clause by the people after the minister here. But the "with him' is certainly used to put an end to the Minister's saying the prayer alone, not to the mode of their saying it together ; and Cosin, who was responsible for this general Rubric, uses ' with him ' and ' after him 'interchangeably. $\dagger$ After all, the supposed distinction would be thoroughly pointless.

In 1549, the Post-Communion, which immediately followed reception, consisted of a sentence of Holy Scripture, sung by ' the Clerks,' ' every day one,' out of a selection of twenty-two, nearly all from the Gospels, and inciting to obedience, assurance, and love. The Post-Communion in Sar. Miss. was a variable Collect, quite different, therefore, from that of 1549. The re-arrangement of the Service in 1552 provided an admirable close to the Office, rendering the 1549 provision unnecessary.

Lord's Prayer, 1549 (Sar. Miss.); placed here 1552; printed 1662.

The addition of the Doxology here is in keeping with the generally received theory that it is used when praise and thanksgiving are markedly associated with the use of the Lord's Prayer ; but the Doxology is not used after Baptism.

Printed books vary the punctuation curiously in one petition, some putting the comma 'after 'Thy will be done,' others after ' in earth.' If Keeling is accurate, the second is the correct method in B.C.P., though there is something to be said for a punctuation which brings this clause into line with the preceding

* This name was applied in 1549 to the Sentenees, one of which was sung after Cominunion.

† See Dowden, Further Studies, pp. 88 ff. 
ones, and treats ' in earth as it is in heaven' as a 'modifying' clause, and not part of the petition proper.

First Alternative Thanksgiving, 1552, (1549).

This Prayer formed part of the Canon in 1549, and opened with a sentence stating that" we ... do celebrate and make here ... the memoria!,' the word 'oblation' being carefully avoided, as applicable only to the' one oblation once offered.' In 1552 this whole sentence was omitted, the remainder of the Prayer being made the first alternative Thanksgiving. S.L. restored the 1549 wording and position, calling the Prayer in a Rubric 'this memorial or prayer of oblation,' but the example was not followed in 1662 .

1549. Wherefore, $\mathrm{O}$ Lord and heavenly father, according to the Institution of thy dearly beloved Son, our Saviour Jesu Christ, we thy humble servants do celebrate and make here before thy divine Majesty, with these thy holy gifts, the memorial which thy Son hath willed us to make : having in remembrance his blessed passion, mighty resurrection, and glorious ascension ; rendering unto thee most hearty than'is, for the innumerable benefits, procured unto us by the same ; entirely desiring thy fatherly goodness, mercifully to accept this our Sacrifice of praise and thanksgiving most humbly beseeching thee... that whosocver shall be partakers of this holy Communion, may worthily receive the most precious body and blood of thy Son Jesus Christ ; and be fulfilled with thy grace and heavenly benediction, and made one body with thy Son Jesu Christ, that he may dwell in them, and they in him. And although we be unworthy .... and service, and command these our prayers and supplication, by the Ministry of thy holy Angels, to be brought up Into thy holy Tabernacle, before the sight of thy divine majesty ; not weighing our merits, etc. The striking omissions of 1552 combine with the significant change of position to display what Frere terms 'the revolutionary revision' of that date :-

(1) Memorial may be a harmless word, signifying merely ' remembrance,' but coupled with 'make here before thy divine Majesty,' i.e. apart from the whole rite, including partaking, it is ne dlessly ambiguous.

(2) This our sacriflce (see Introduction, p. 272) on the lips of the Priest turned towarls the Altar, immediately after consecration, might be, and was, misinterpreted. The same words after reception, when there ought to he nothing remaining, according to Cosin, cannot refer to the elements. To call this 
now a 'Prayer of Oblation' * is not ' rnis-taking' but ' misrepresenting,' and casts an sinister light upon the proposal of the Revision Committee of Canterbury Lower House of Convocation to permit the use of both Prayers. The absurdity of attributing any 'Prayer of Oblation' to the Revisers of 1552 is shown by the fact that they excised the sentence of 1549 suggesting 'Oblation,' transferred the prayer from before to after administration, and made it an alternative to the old prayer of Thanksgiving. It is scarcely conceivable that a doctrinal detail of such importance should be taught by a prayer whose use was left to the discretion of the individual minister. In 1662 the disastrous precedent of S.L. in reproducing the 1549 Prayer, in the 1549 position, was happily rejected. The whole sentence suggesting Oblation has been excised.

(3) May worthily receive the most precious body and blood of thy Son Jesus Christ. The omission of these words is doubly important in view of the retention of the words: 'So to eat the flesh,' etc. : in the Prayer of Humble Access. In the latter, the words are those of John vi. 53, etc., where no reference is made to the Holy Communion, $f$ which was not instituted till a year later ; the ambiguous word 'receive,' in the former, is happily gone. Moreover, those who have found it possible to discover the teaching of an unworthy reception of Christ in the latter phrase (see Introduction, p. 271) would more reasonably claim support of their fancy in "worthily receive the most precious body,' certainly capable of implying (what it was equally certainly not meant to imply) the possibility of the wicked receiving the Lord's Body and Blood.

(4) Made one body with thy Son Jesu Christ is another passage which is well omitted. The whole Sacrament is a symbol of oneness with Christ, because the common-partaking figures that Mystical Body, of which He is the Head, as excellently expressed in the alternative Prayer. The use of these words, before reception, is capable of suggesting a mere physical identification of Christ's Body with the bodies of the recipients of the consecrated elements, as alien to Holy Scripture as it is devoid of any value.

(5) Prayers ... to be brought into God's holy Tabernacle; this petition was scriptural (Rev. viii. 3,4), and constituted a clear condemnation of the petition in Sar. Miss. that the elements should be taken to heaven, etc. Nevertheless, not only in 1552 and 1662, but even in S.L., where the rest of the prayer of

- See Frere, pp 492, 496.

† See Westcott, Commen'ary, in loc. 
1549 was restored, this petition was omitted as perilous in this connexion.

These changes were made in spite of the fact that the safeguarding words : "by the merits and death ... . and through faith in his blood': would seem to preserve the other expressions from any reasonable misuse. However, when even Cosin could interpret: 'we and all thy whole Church' : as including and sanctioning prayer for the dead, it is plain that no expression is safe from the imputation of a meaning foreign to the mind of those who uttered it.

It is to be noted that 'faith in his blood,' though in accordance with A.V. in Rom. iii. 25, and a possible interpretation of the Greek original, is not the probably correct idea; Propitiation, (1) through faith, (2) by his blood, (R.V., which puts 'through faith in his blood' in the margin), is more consonant with the scriptural use of the word 'faith.'

The present Prayer combines the two kinds of spiritual sacrifice open to the Church of the Redeemed: "Praise and Thanksgiving,' Heb. xiii. 15, 1 Pet. ii. 5, 9 ; 'Ourselves,'* Rom. xii. 1; the latter includes the other two senses in which Holy Scripture connects sacrifice with the Christian life : generous self-denial, Heb. xiii. 16, and publishing the Gospel, Rom. xv. 16. Such sacrifices are not specially connected with the Lord's Supper, save that in that reminder of the Lord's finished work of redemption, the redeemed will renew their recognition of His claims upon them.

In 1549 the Prayer was preceded by a Rubric : "These words before rehearsed (the consecration) are to be said, turning still to the Altar, without any elevation, or showing the Sacrament to the people.' This regulation had been anticipated in the Order of Communion, where the rules for consecrating additional wine directed it to be done ' without any elevation or lifting up,' and that although the rest of the Mass Service, including the original consecration, was unaltered. S.L. did not restore this Rubric, the practice having entirely disappeared from the Reformed Churches for more than a century. Art. XXVIII expressly condemns it as unscriptural.

The first historical note upon the custom is contained in some Constitutions issued by Odo, Bishop of Paris, 1197, ordering the presbyter not to elevate the Host until the words 'This is My Body' had been spoken. The practice is therefore plainly due to the dogma of Transubstantiation, then coming into vogue.

* For parallels to offering of 'ourselves' in Hermann, see Dowden, Further Studies, p. 238 ff. 
Another Bishop of Paris, in 1228, ordered a bell to be rung at the elevation. With the rejection by the Church of England of any idea of an Objective Presence, as it is sometimes called, the custom of elevating the consecrated elements came to an end.

Second Alternative Thanksgiving, 1549; altered 1552.

This, the only Prayer in 1549, has no parallel in Sar. Miss., where the Priest alone offers a thanksgiving, after reception: 'I pay thanks to thee, Holy Lord, Almighty Father, Eternal God, who hast refreshed (refecisti) me with the most sacred Body and Blood of thy Son our Lord Jesus Christ : and I pray, that this sacrament of our salvation, which I, an unworthy sinner, have taken, may not come to me to judgment nor to condemnation according to my deserts, but for the advancement (profectum) of body and soul unto life eternal.'

The alterations in 1552 are again significant :-

1549. Hast vouchsafed to feed us in these holy Mysteries, with the spiritual food, etc.

1552. Dost vouchsafe to feed us, which have duly received these holy mysteries; etc.

1549. And hast assured us (duly receiving the same) of thy favour, etc.

1552. And dost assure us thereby of thy favour, etc.

In the double alteration of 'hast' to 'dost,' as well as the change from 'in these holy Mysteries' to 'which have duly received,' etc., and from 'duly receiving the same' to 'the:eby,' the determination to dissociate the 'feeding upon spiritual food' from the mere reception of the symbols, even 'duly,' is most marked. The physical feeding only symbolizes a feeding which is the continual reward of faith, and carries an 'assuring' which is likewise the perpetual posse ssion of the faithful.

In 1662, 'thy mystical body,' inappropriate in a prayer addressed to the Father, was altered to 'the mystical body of thy Son.' The definition of that 'mystical body' as 'the blessed company of all faithful people' dates from 1549, and is notably in contrast with later exclusiveness. The most reasonable meaning of 'the body' in 1 Cor. xi. 29 (R.V. ' if he discern not the body') is not that body of Christ symbolized by the Bread, but the 'mystical body' of the faithful; for in v. 27, where dishonour to the symbolized body is intended, there the blood is mentioned too, while here only the body is named. Moreover, in the preceding chapter, x.16, 17, emphasis is laid upon the breaking and distributing, as symbolizing the oneness of the mystical body, upon which stress was laid by the Early Church (see Introduction, p. 217). The Corinthians' 
offence was a double one; they were 'guilty of the body and blood of the Lord,' by partaking of the symbols in a wrong spirit, and of offending against His mystical body, by the form that wrong spirit took with them, namely, making distinctions between the members of that body.

Gloria in Excelsis, 1549 ; placed here with one sentence repeated 1552 ; Sar. Miss.

This hymn is amongst the very earliest liturgical relics outside the Bible.* It is to be found in Codex Alexandrinus, the great Bible MS. of the British Museum, known to Bible-students as 'A.' It is there placed "at the end of the Psalter, a position which bears witness to the early regard paid to it, for that MS. is certainly little later than 400 A.D., and possibly earlier. First used as a Morning Hymn, as it still is in the region of its origin, the East, it became incorporated into the Mass in the West, but long after its first introduction into Western services. In 1552 it was moved from the beginning of the Communion Office to the end ; in 1549 it stood where it had been in Sar. Miss. Of this change, Dowden says $\dagger^{\prime}$ it seems to me that there is a peculiar fitness in its bringing to a close the great Christian Sacrifice of praise and thanksgiving. Even the supplications for mercy, which are so marked a feature of the latter part of this great hymn, are not unsuited to the devout heart which is conscious of the unworthiness of the miserable imperfections of its best devotions.' This sufficiently accounts for and justifies the change.

It is, perhaps, a matter for regret that no simple musical setting of this hymn has been composed, at the same time worthy of the hymn and not needing a choir to render it, so that the rubrical permission to sing the hymn might be taken advantage of without the accessories of 'Choral Communion.'

The changes in the translation are verbal, and unimportant save in two cases :-

(1) 'In earth peace, good will towards men,' for ' in earth peace to men of good will' (hominibus bonce voluntatis), in accordance with the critical Greek text of Luke ii. 14, at the time. In R.V., as a result of increased critical apparatus, 'peace among men in whom he is well pleased,' has been adopted, the older translation being relegated to the margin, as the reading of 'many ancient authorities.' Several Greek Service Books have the A.V. and B.C.P. form, which depends upon the omission

* For a somewhat varied form of the hymn in the Apostolical Constitution see Burbidge, Liturgies and Offices of the Church, pp. 36, 37.

† Workmanship, pp. 77, 78. 
of a single letter. In either case the meaning is the same, for it is not men of good will towards one another, but men who enjoy God's good will, or good pleasure, who are the promised recipients of peace.

(2) In 1552, "Thou that takest away the sins of the world, have mercy upon us,' was added between the two appeals,* an addition attributed by Scudamore, but not with conclusive proof, to a reminiscence of the similar threefold appeal in Agnus Dei. It may be added that 'God on high,' A.V. 'God 'in the highest,' is the Great Bible rendering in Luke ii. 14, which explains its adoption in 1549 .

Rubric regarding the method of dismissal, 1548.

1549. Then (shall 1548) the Priest, turning him to the people, shall let them (the people 1548) depart with this blessing.

1552. Then the Priest, or the Bishop, if he be present, shall, etc.

The omission of 'turning him to the people,' marks the abandonment of the Eastward Position ever since 1552.

In Sar. Miss., the only words to be said facing the people were 'Go, you are dismissed' (Ite, missa est) ; any words of blessing were to be said facing the altar.

Blessing, 1549, (1548).

1548. The peace of God ... and in his Son Jesus Christ our Lord. To the which the people shall answer, Amen. 1549. The peace of God .... and of his Son Jesus Christ our Lord : And the blessing ... alway. Then the people shall answer, Amen.

1552. As in 1549, but always, and ' Amen' printed immediately after the blessing, in the same type, as if to be said by the Minister.only.

1662. As in 1552, but 'Amen' printed in Italics, to be said by the people.

The 1548 portion is from Phil. iv. 7 ; the 1549 addition is stated to have been the usual episcopal Benediction in the Mass. $\dagger$

In 1549 two Rubrics followed, one ordering the Priest to 'say,' when no Clerks were present to 'sing'; the other permitting the omission of Gloria, Creed, Homily and long Exhortation, on week-days and in private houses.

\section{APPENDIX.}

Rubric concerning the use of Collects when no Cormunion, 1549 ; enlarged 1552, altered 1662.

* See above, p. 346.

$\dagger$ Frere, notes at foot of p. 497. 
1549. Collects to be said after the Offertory, when there is no Communion, every such day one.

1552. Permission added to use them after the Collects of Morning or Evening Prayer, Communion or Litany, at the Minister's discretion.

1662. As in 1552, save for the addition 'or more' : 'Every such day one or more.'

The name- 'Table Prayers' was given to this Ante-Communion Service; they were customary in the German Orders, which prescribed, not a chasuble, but a cope, as in 1549.*

Collects, 1549 ; two for Rain and Fair Weather placed elsewhere, 1552.

(1) Assist us mercifully, etc., Sac. Gel., Sar. Miss.

A beautiful adaptation of the Sarum Collect in the Mass for those going on a journey : Jit., 'Assist, O Lord, our prayers and dispose the way of thy servants in the prosperity of thy salvation: that amongst all the vicissitudes of this way and life (vice et vita) they may always be protected by thy help.' The translators could not preserve the alliteration of vice et vitce, but restored it-in 'changes and chances.'

(2) O Almighty Lord, etc., Sac. Greg., Sar. Brev.

This prayer was used after Prime, not in public service. The translation gets rid of some doctrinal error, as will be seen from this literal rendering of the original : 'Deign, we beseech thee, O Lord God, to direet and sanctify and rule our hearts and bodies in thy law, and in the works of thy commandments ; that here and for ever by thy help we may deserve to be healthy and saved (sani et salvi), etc.

(3) Grant, we beseech thee, etc., 1549.

As would be presumed from the subject-matter, the request for fruitful results upon hearing the word, this Collect was a composition of 1549 .

(4) Prevent us, O Lord, ete., Sac. Greg.

The original contains a thought which it were to be wished had been more plainly preserved in the translation: 'We beseech thee $O$ Lord to prevent [help] our actions by favouring them [lit. breathing upon them, i.e. providing a 'fair wind,' aspirando], and to follow them up by assisting : that all our working may always both begin from thee, and, being begun through thee, may be completed.'

(5) Almighty God, the fountain, etc., 1549.

(6) Almighty God, which hast promised, etc., 1549.

These two Collects are particularly suitable to supplement the necessary imperfection of the best human prayers.

$$
\text { * See Dowden, Further Studies, pp. 244. } 247 .
$$


Rubric concerning Sundays, etc., when no Communion, 1552 ; (1549).

1549. The Ante-Communion, "until after the Offertory,'* with one or two of the above Collects and the Blessing, was to be said ' at the Altar' on Wednesdays and Fridays after the Litany, and on other occasions when there were 'none disposed to communicate.' $\dagger$

1552. The Ante-Communion, 'until the end of the Homily,' concluding with the Prayer for the Church Militant, and one or more of the Collects, to be said upon the holydays (if there be no Communion).

1662. As in 1552, save that the Homily is omitted, and the Blessing expressly enjoined as in 1549 .

Rubric prescribing a convenient number, 1662 ; some, 1549 ; good number, 1552.

1549. Likewise in Chapels annexed, and all other places, there shall be no celebration of the Lord's Supper, except there be some to communicate with the Priest.

1552. And there shall be no celebration ... except there be a good number ... the Priest, according to his discretion.

1662. As in 1552, except 'convenient' for 'good,' (S.L. 'sufficient').

The words 'some,' ' good number,' ' convenient number' (i.e. suitable to Christ's Institution of Communion, not to the convenience of anybody), all teach the eagerness, at every stage of the history of B.C.P., to get rid of the solitary 'sacrifice' of the Mass, and to set in its place the scriptural fellowship of believers.

Rubric fixing the minimum, 3 out of 20,1552 ; (1549).

1549. No rubric stating numbers, but the third Rubric from the end of the Office ran : Also, that the receiving of the Sacrament of the blessed body and blood of Christ may be most agreeable to the institution thereof, and to the usage of the primitive Church; In all Cathedral and Collegiate Churches there shall always some Communicate with the Priest that Ministereth. And that the same may be also observed every where abroad in the country ... (regulations following, regarding houses providing bread and wine in turn in each parish) ... and by this

* It is instructive that in 1549 ' the Offertory' did not include the bread and wine, being used when there was no Communion.

† The same Rubric preseribed 'Alb or Surplice, with a cope' for this service, sce p. 79. 
means the Minister, having always some to communicate with him, may accordingly solemnize so high and holy mysteries with all the suffrages and due order appointed for the same. And the Priest on the weekday shall forbear to celebrate the Communion, except he have some that will communicate with him.

1552. And if there be not above twenty persons in the Parish, of discretion to receive the Communion; yet there shall be no Communion, except four, or three at the least, communicate with the Priest.

By this Rubric, which was left unaltered in 1662, it will be seen that three is an extreme minimum not counting the officiant, and that its application is only to the least populous parishes; in the larger parishes of to-day, to celebrate with four, or three, cornmunicants is virtually to strain this regulation.

The words 'of discretion to receive' explain and are explained by the words in the Preface to Confirmation, 'years of discretion.'

Rubric ordering clergy to communicate weekly in Cathedrals, etc., 1552.

In 1662, 'Colleges' was added to 'Cathedral and Collegiato Churches,' and 'Priest' was used, instead of 'Minister,' to describe the officiant. In all these directions, urging frequent communion, it is noteworthy that 'daily celebration' is never mentioned. The weakness of the position of those who strive to find some excuse for that unscriptural and inprimitive practice, is well shown by their appeal to the regulation prefixed to the Table of Proper Lessous, prescribing the use of the Collect, Epistle and Gospel ' all the week after,' where it is not otherwise ordered ; it would be strange indeed, if ' all the week' were an abrogation of the express refusal to permit celebrations without a 'convenient number,' and if it could not mean quite as well ' whenever necessary' as 'once a day,' the latter mcaning being not the one taught by contemporary use, but by recent efforts to reinstate 'daily sacrifice with intention.'

\section{Rubric prescribing the use of purest wheat bread, 1552;} (1549).

1549. For avoiding of all matters and occasion of dissension, it is meet that the bread prepared for the Communion be made through all this realm after one sort and fashion; that is to say, unleavened and round, as it was afore, but without all manner of print, and something more larger and thicker than it was, so that it may be aptly 
divided in divers pieces, and every one shall be divided in two pieces at least, or more, by the discretion of the Minister, and so distributed. And men must not think less to be received in part, than in the whole, but in each of them the whole body of our Saviour Jesu Christ.

1552. And to take away the superstition which any person hath, or might have, in the brear and wine, it shall suffice that the bread be such as is usual to be eaten at the table with other meats, but the best and purest wheat bread that conveniently may be gotten.

S.L. And to take away... Bread and Wine, (though it be lawful to have wafer bread) it shall suffice that the Bread be such as is usual : yet the best ...

1662. And to take away all occasion of dissension and superstition .... (as in 1552, but 'at the table with other meats' omitted).

The hope of the Revisers, that 'all occasion of dissension' might be taken away, was fulfilled for nearly two centuries, after which the 'wafer' was reintroduced. The history of the. 'Wafer' may be summarized thus :-

i. At the original Institution an unleavened loaf, or cake, was. used, and broken into several portions.

ii. The bread at the ordinary Communions, save when Jewish Christians were debarred from the use of leavened bread, was taken from the ordinary food brought for the Agapè.

iii. The growth of the idea that the bread must be identified with the Body of Christ made the thought of crumbs through breaking intolerable, and small pieces, made of flour and water only, took the place of the loaf in the West about 1000 A.D. The Eastern Church still uses leavened bread.

iv. At the Reformation, in 1549, unleavened bread was still ordered, to avoid 'dissension,' round in shape, but made larger and thicker than the Roman Wafer, so that the symbolic breaking and distribution of the loaf might be to some extent restored; all printing the bread was strictly forbidden. For those who were accustomed to the entire wafer to themselves, comfort was provided by the assurance that they were not to think that less was received 'in part, than in the whole, but in each of them the whole body of our Saviour Jesu Christ.'

v: In 1552, 'superstition' was feared rather than 'dissension,' and the 1549 directions were entirely omitted, including the clause seeming to teach that the whole body of Christ resides in a fragment of the broken bread. Ordinary bread, but 'the best and purest wheat bread' obtainable, should 'suffice.' The use of the word 'suffice,' on which much stress has since 
been laid, is obviously used here to denote a direction, not to allow an alternative to the wafer, which certainly would not ' take away the superstition which any person hath, or might have.' The phrase 'it shall suffice' well calls attention to the comparative unimportance of the material of the bread, provided only it be consistent with the carrying out of the Lord's command to break and distribute it. If, as is claimed, this Rubric is only a toleration of the use of ordinary bread instead of the wafer, why does it not say so? "What is substantially different will not "suffice" ' (Privy Council Judgment, Ridsdale $v$. Clifton, 1877).

vi. An Injunction of Queen Elizabeth, in 1559, directed the 'sacramental bread' to be 'made and formed plain, without any figure thereupon, and of the same fineness and fashion round' as the old wafer, but 'somewhat bigger in compass and thickness.' The Privy Council held that this Injunction could not have over-ridden the Rubric of 1552 , then again made legal ; but some dissension arose over the matter, and practice was very varied.

vii. In S.L. 1637, 'Wafer bread' was expressly stated to be legal, but the 1552 regulation as to bread was laid down, putting ' wheat bread,' 'such as is usual,' in the foremost place, 'wafer bread' in a secondary position, though the old words 'it shall suffice' introduced the sentence recommending the former.

viii. In 1662, not only 'superstition' but also 'dissension" (as in 1549) was provided against, and the S.L. words asserting. the legality of wafer bread were not adopted,* the 1552 rubrio being retained. 'Best and purest wheat bread,' 'such as is usual to be eaten' is not 'a composition of flour and water rolled very thin and unleavened'; nor does the latter 'take. away all occasion of dissension and superstition'; it cannot be said of it, therefore, that 'it will suffice.' The Rubric demanding provision of the bread by the Curate and the Churchwardens 'seems to contemplate ordinary bread as the only material to be used, and the 20th Canon is still more precise in the same direction.' + From the passing of that Canon, in 1603-4, the episcopal Visitation Articles required 'fine white bread,' and the same requirement was made after the revision of 1662.

* Cosin proposed to add after 'gotten': 'though Wafer-bread pure, and without any figure set upon it, shall not be forbidden, espccially in such Churches where it hath bcen accustomed. The Wino also shall be of the best and purest that may bo had' (Works, v. 618). Convocation rejected this proposal to re-introduce wafer-bread.

$\dagger$ Ridsdalo Judgment, 18i 7 . 
The use of the wafer, therefore, is not scriptural, not primitive, not legal, and, though otherwise a matter of indifference, substitutes for the Lord's teaching of the oneness of believers in Him, the associations of a physical reception of His Body and Blood.

Rubric directing the disposal of the bread and wine remaining, 1662 ; (1552).

1552. And if any of the bread or wine remain, the Curate shall have it to his own use.

1662. And if any ... remain uneonsecrated, etc.; but if any remain of that which was consecrated, it shall not be carried out of the Church, but the Priest and such other of the Communicants as he shall then call unto him, shall, immediately after the Blessing, reverently eat and drink the same.

S.L. Generally as in 1662 , with requirement added that the Officiating Presbyter shall take care to 'consecrate with the least,' repeating the words of consecration ' if there be want.'

The absence of any distinction between consecrated and unconsecrated surplus bread and wine in 1552 is sufficiently explained by these words of Cosin*: "Yet if for lack of care they consecrate more than they distribute, why may not the Curates have it to their own use ... for though the bread and wine remain, yet the consecration, the sacrament of the body and blood of Christ, do not remain longer than the holy action itself remains for which the bread and wine were hallowed; and which being ended, return to their former use again ?' Cosin elsewhere says: 'We also deny the elements still retain the nature of sacraments when not used according to Divine institution, that is, given by Christ's ministers, and received by His people, so that Christ in the consecrated bread ought not, cannot be kept and preserved to be carried about, because $\mathrm{He}$ is present only to the Communicants.' $\dagger$

The feeling that such minute quantities as would remain after administration deserve reverent treatment, and could be of no use to the Curate, is a natural one, and Cosin himself, who justified the giving up even of the consecrated relics to the Curate, yet urged that ' the priest may be enjoined to consider the number of them which are to receive the sacrament, and to consecrate the bread and wine in such near proportion as shall

* Works, v. 43 ; taken from Tomlinson, Tracts on Ritual, cxii. ; which see for fuil treatment of the question of Rescrvation and B.C.P.

$\uparrow$ History of Transubstantiation, p. 61. 
be sufficient for them : but if any of the consecrated elements be left, that he and some others with him shall decently eat and drink them in the Church before all the people depart from it.'* This course was adopted in 1662, much as in S.L., save that in the latter the order was given to take care that none was left over. Also in 1662 was added the Rubric ordering the reverent, covering of any surplus with a fair linen cloth.

The bearing of these regulations upon the now vexed question of Reservation would seem to be obvious, but it is said freely that 'the rubric was not intended to touch upon the ques-. tion of the Reservation of the Sacrament for the Communion of the Sick.' $\dagger$ This sentence is cleverly worded: perhaps the Rubric was not 'intended to touch upon' Reservation. But it was most certainly so framed as to render any reservation, for any purpose, a flagrant breach of its directions. . It was issued, moreover, in full consciousness that the 1549 B.C.P. had ordered Reservation of consecrated bread and wine for the Sick, in its 'Communion of the Sick,' 'if the same day there be a celebration of the holy Communion in the Church,' and that this direction had been expunged in 1552, and not restored. 'It is forbidden by our Church, as you may see by the rubric at the end of the Communion Service, beginning: " and if any of the bread and wine remain unconsecrated"-so expressly forbidden that no evasion is possible.' $\ddagger$

The direction to 'reverently eat and drink the same' is accompanied by the order to call certain of the communicants to join in this task, a regulation not always observed, nor always easy to observe.

It is more important to note that the command to let none remain over is in keeping with the scriptural order concerning the Passover, and carries out the same idea, namely, that all the sacred food should be consumed by all who take part therein, the family alone having any right to that food, and that food having meaning only for the family.

The statement that this Rubric 'authorizes the ablutions by which this consumption is reverently and adequately carried out,' $\S$ not only contradicts the fact that the elaborate requirements of the Sar. Miss. were ignored from the first by the Reformers, but also the fact that even the Lambeth Judgment forbade the drinking of the ablutions during divine service. The suggestion that after the Blessing, when the Rubric orders

* Works, $\nabla .431$. $\dagger$ Frere, p. 502.

$\ddagger$ Bishop Durnford, in 1878. For 'Reservation' see Communion of the Sick, p. 459 .

₹ Frere, p. 502. 
the consumption of what remains, is not part of the service, and therefore ablutions of the Cup, Paten, and Priest's fingers may then be drunk, is not worthy of argument. It is plainly reasonable that those who believe that the Body, Soul, and Divinity of the Lord Jesus are in any way in, under, or with, the minutest particle of either bread or wine, should be scrupulously careful to rinse the vessels, and drink the rinsings; but the Church of England has rejected that doctrine, and with it such necessary accompaniments.

Rubric directing the provision of the bread and wine, 1549 ; altered 1552 and 1662 .

1549. A rubric demanded the special contribution at the Offertory, with other offerings, of money to pay for the "holy loaf.' Another rubric made regulations for 'Chapcls annexed,' bidding the people either pay the expense or else resort to their parish Church for Holy Communion. A third Rubric directed that in every parish 'abroad in the country,' one house 'by course' should ' offer for the charges of the Communion.'

1552. The bread and wine for the Communion shall be provided by the Curate and the Churchwardens, at the charges of the Parish ; and the Parish shall be discharged of such sums of money, or other duties, which hitherto they have paid for the same, by order of their houses every Sunday.

1662. The last clause of 1552 omitted, (as in S.L.).

Rubric orderng a minimum attendance of three times a year, 1552 ; (1549).

1549. 'To communicate once in the year at the least' is ordered in the last Rubric but one, amongst general commands to be present at divine service, to pay their duties, to receive and take all other Sacraments and rites in this book appointed, on pain of excommunication, or other punishment inflicted by the Ecclesiastical judge.

1552. And note, that every Parishioner shall communicate at the least three times in the Year; of which Easter to be one; and shall also receive the Sacraments, and other rites, according to the order in this book appointed.

1662. Omitted 'and shall also receive .. . book appointed,' the rest bcing only trivially altered.

The omission in 1662 of the word 'Sacraments,' i.e. more than one besides Holy Communion, is an important testimony to the exclusive use of that word in the Church of England for 
Baptism and the Lord's Supper, according to the teaching of the Catechism and Articles.

The question as to how often the believer should communicate is plainly to be distinguished from that of frequency of celebrations, as the latter must provide not for the one communicant, but for the varying needs of many. If the Passover could be reneated, under Hezekiah, care should be taken in a populous parish at any rate, to provide for the very varied circumstances of the population. Nothing can be more deplorable than the regulation of the hours and days of administration by a human rule, such as fasting, so as virtually to excommunicate a section of the Church of Christ. On the other hand, with the frequency of opportunity, it should be clearly taught that not little sections of the local body of Christians, but the whole body, so far as is practicable, should communicate together, if the Lord's ordinance is to be followed.

The absence of any regulation by the Lord and His Apostles as to the frequency which the individual should observe constitutes a liberty in the matter which forbids any more definite regulation than that of this Rubric. In 1549 the Roman obligatory rule of once a year was followed, which sufficed for a system in which Communion had sunk to a very secondary place, and sacrifice for sins had taken its place. In 1552 the minimum was increased from once to three times a year, but as a minimum, while clergy attached to Cathedral bodies were bidden to communicate once a week as a rule. Once a week is suggested by the Apostolic record, for the whole church, but no evidence is extant to show that any obligation was enforced upon the individual communicant. The separation of Holy Communion from the Agapè, however effected, must have done much to alter any habit of regular weekly attendance, as is suggested by the practice of reserving for the absent.

Advocates of daily administration are forced to rely upon a comment of Cyprian, c. 250, upon the Lord's Prayer, in which he identifies 'daily bread' with the Eucharist: "This Bread we pray that it be given us day by day, lest we who are in Christ and who daily receive the Eucharist for food of . salvation, should . . . be separated from the body of Christ.' It is by no means certain that Cyprian is not using the word 'Eucharist' in as vague and figurative a way as that in which he uses the phrase 'daily bread.' This is corroborated by Augustine, who, a century and a half later, commenting on the same passage,* and interpreting 'daily bread' of 'spiritual

* In Sermone Domini in Monte, ii. 7 : Frere cites Cyprian, but does not refer to Augustine. 
bread,' sets aside the idea of sacramental bread, saying: 'they who are very numerous in the Eastern parts, do not agitate the question concerning the sacrament of the Lord's body, nor do they communicate daily in the Lord's Supper, although this has been called daily bread. . . . For we cannot now say "Give us this day," what we have now received; or can any one compel us to celebrate that sacrament at the close of the day ?' But, even if Cyprian be taken literally, the feebleness of its justification sufficiently condemns the practice, especially as Cyprian was the first and only ante-Nicene Father of repute to promulgate sacrificial notions of the Holy Communion, with the Bishop as a High-Priest, and the presbyters as his attendant Levites ! *

The rule of three times a year is prescribed, according to Frere, in Canon 18 of the Council of Agde (506), Christmas, Easter, and Whitsuntide, being specified-a regulation incorporated afterwards into the Decretum. He does not state whether this was a minimum, and Bede in 734 condemned the practice of being content with that standard. The Reformers were guided by no such regulation, but steered between the two dangers of sanctioning neglect on the one hand, and of restricting Christian liberty on the other. Such wise precaution should still be followed, encouraging frequent remembrance of the Lord's Death in His own appointed way, and warning against degrading the remembrance to a magical rite, by which it ceases to be a means of grace.

The specification of Easter-Day as one of the three obligatory days scarcely needs explanation, for the preaching of 'Jesus and the Resurrection' stamps that day as the Christian Anniversary. Indeed, that day's importance has sanctioned the observance of the First Day of the Week, 'the Lord's Day,' instead of the seventh.

Rubric regarding Easter Dues, 1552 ; (1549).

1549. 'To pay their duties' is one of the regulations of the last Rubric but one, Easter not being specified, either for communicating or for paying 'duties.'

1552. And yearly at Easter every Parishioner shall reckon 1662. with his ('the' in 1662) Parson, Vicar, or Curate; or his or their deputy, or deputies, and pay to them or him all ecclesiastical duties, accustomably due, then and at that time to be paid.

- See Gwatkin, Early Church History, II. p. 278. In a footnoto aro the words: 'Cyprian would have been as shocked as any Quaker at the idea of turning a presbyter into a priest. 
'Parson' is a corruption of Persona, the leading personage of the Parish. It is thus a wide term, as indeed is 'Curate,' which includes any one having a 'cure' of souls. The three terms more strictly apply to Rectors, Vicars, and Perpetual Curates; the first being those in possession of the rectorial tithe; the second those who act under, or instead of, some person or persons holding the rectory, but not discharging the ministerial functions; - the last strictly covering all others in charge of ecclesiastical districts, now generally called 'Vicars' by title.

Lapse of time has both abolished 'many 'duties' and also rendered it difficult to trace what they may have included. The modern methods of business in regard to 'tithes' have also tended to make this Rubric meaningless in all parishes, but the custom of voluntary Easter Offerings, growing more and more widespread, is an indirect perpetuation of the regulation.

Rubric regulating the disposal of the offerings, 1662 .

In 1549 and 1552 the offerings were placed in the " poor men's box,' and no provision was made for other gifts save their direct payment to the clergy, though this last kind of gift was certainly contemplated by those who chose the Offertory Sentences.

In S.L. a rubric immediately following the Blessing prescribed the division of 'that which was offered,' in the presence of the Presbyter and the Churchwardens; 'one half shall be to the use of the Presbyter to provide him books of holy divinity'; the other half was to be devoted to 'some pious or charitable use, for the decent furnishing' of the Church, or the poor, at the discretion of the Presbyter and Churchwardens.

The Revisers borrowed the adjectives 'pious and charitable,' but left the whole of the offerings to be disposed of by the 'Minister and Churchwardens,' with the 'Ordinary' as a court of appeal in case of difference.

'Black Rubric,' 1552 ; omitted 1559 ; restored with verbal alterations, 1662. (See p. 473.)

The Black Rubric was not strictly part of the B.C.P. in 1552, and therefore did not come under the Law of 1559 restoring that book.

1552. Although no order can be so perfectly devised, but may be of some, either for their ignorance and infirmity, or else of malice and obstinacy, misconstrued, depraved, and interpreted in a wrong part; And yet because brotherly charity willeth, that so much as conveniently may be, offences should be taken away; thercfore we willing to do the same, Whereas it is ordained. . . .

1662. Whereas it is ordained. . . . (The references to misunder- 
standing, expressed in the same words, are made further on in 1662.)

1552. Ordained in the book of common prayer, in the Administration....

1662. Urdained in this office for the Administration. . . .

The change of wording here illustrates the fact that the original was not part of the B.C.P. in 1552, but became part of the Communion Office in 1662.

1552. Any real and essential presence there being of Christ's natural flesh and blood.

1662. Any Corporal Presence of Christ's natural Flesh and Blood.

This alteration has been alrcady considered in the Introduction, pp. $273 \mathrm{ff}$.

1552. Against the truth of Christ's true natural body. . . .

1662. Against the truth of Christ's Natural Body. . .

The omission of the word 'true' is an emendation; the word 'true' is redundant, and can only weaken the force of the teaching that Christ's Natural Body, in any sense of the words, is in heaven and not here.

\section{Analysis.}

1. Purpose of the order to kneel :-

i. To signify humble gratitude.

ii. To avoid profanation and disorder.

2. Sources of possible misconstruction :-

i. Ignorance and weakness.

ii. Malice and obstinacy.

3. Declaration against Adoration :-

i. Not intended by this regulation.

ii. Not right in itself; - whether paid to-

(a) The Sacramental bread and wine.

(b) Any Corporal Presence of Christ's Natural Flesh and Blood.

\section{Ground of the Declaration :-}

i. The bread and wine remain unchanged, so that to worship them is idolatry.

ii. The Natural body and blood of Christ are in Heaven, and not here, so that to worship a fancied Corporal Presence is to deny the truth of Christ's humanity.

Adoration.

This whole declaration, by its definition of the purpose of kneeling, as well as by its doctrinal condemnation of adoration, might seem to suffice to put an end to 'Adoration' in the Church 
of England. The substitution, in 1662, of ' corporal' for ' real and essential,' means no more than the recognition of a change of meaning in the words ' real,' ' essential.' Bishop Jewel could write 'real or corporal' a hundred years earlier, the terms being synonymous. The alteration avoided seeming to deny any Presence of Christ, as taught in Holy Scripture, viz. through the Holy Spirit, and as Head of His mystical Body, the Church. In the modern meaning of "real and essential" such a Presence deserves the use of such terms ; the word 'corporal' excludes any 'bodily' Presence, not only in the Holy Communion, but everywhere and always.

However, the Presence of 'whole Christ, Body, Soul, and Divinity,' 'in, under or with, the elements,' is still taught, and with it the duty of adoring that Presence. To avoid the condemnation in this Rubric of any localizing of the Presence, various expodients have been used:-

i. It is said to be not local, but supra-local, which, if possessing any meaning at all, does not excuse the direction of adoration to the localized elements.

ii. It is said to be not a Presence by location; but by ' extension,' which also fails to get rid of the fact that adoration is directed to the elements which have 'location.'

iii. It is said that 'real and essential' are not 'corporal,' which is untrue if the Presence be that of the Body of Christ, whether the Body 'given for us,' or the unscriptural 'Body, Soul, and Divinity' of the theory in question.

iv. It is said that the Presence is 'Spiritual,' meaning thereby, not the Spiritual Presence which all believe, but the Presence of a 'Spiritual Body.' * Such an evasion-for it is nothing more -ignores the fact that a Spiritual Body is still a Body.

Adoration can be justified only by the localized Presence of the Lord's Person, and that so inseparably united to the elements that there is no possibility of idolatry through adoring the elements alone. Transubstantiation indeed claims that the elements themselves are changed into the Body, Soul, and Divinity of Christ. Those who recognize that Transubstantiation is untenable within the Church of England, claim nevertheless that there is such a union of Christ with the consecrated elements as to justify and compel adoration :-

"The Eucharist is frequently called "The Extension of the Incarnation " ; and the expression is significant and appropriate, not simply because the Fucharist is the means of extending the benefits of the Incarnation to all time, but because there is in both cases a real union between the earthly and the heavenly: 
in the Incarnation between the Eternal Word and man's nature, in the Eucharist between the Person of Christ and the elements of bread and wine : so that it may be said without a metaphor, that there is a renewal or continuation of the Incarnation. What was done in the Incarnation is renewed in the Sacrament; not. in the same manner, but in a certain resemblance and proportion. . . . In order to this union of the flesh of Christ with ours, He first Incarnates Himself in the hands of the priest; that is, at the moment of Consecration, Christ unites Himself, Body, Soul, and Divinity, in an ineffable manner, with the elements of bread and wine. ... As the Divine and Human Nature in the Incarnate are called, and are, one Christ; so in the Eucharist the heavenly and the earthly substances, remaining each in its own nature, when united by Consecration are called, and are the Body of Christ.'*

Apart from the demerits of a theory which can only be sustained in the Church of England by doing violence to her formularies, it is reasonable to ask what is gained by this theory? What spiritual gain attaches to it? Is it the communication of the benefits of Christ's sacrificial death to the soul ? But that needs no such theory. Is it a Presence of Christ to worship? Yet surely that is the privilege of every believer, independently of any such localized Presence, painfully suggestive of possible degradation. Is it the continual evidence of a miracle to strengthen faith? But there is no evidence of any miracle ; instead of helping faith, it makes demands upon it which to many are impossible of fulfilment. The true miracle, capable like the New Testament miracles of evidential testing, is the power of the blessing attaching to faithful obedience to Christ's command. If gain and loss are any criterion of the truth or falsehood of a dogma, this dogma stands hopelessly condemned.

The weakness of the argument from the Incarnation is felt by the author above quoted : ' a certain resemblance and proportion,' 'in an ineffable manner,' are phrases betraying a sense of weakness not to be satisfied by the brave words 'it may be said without a metaphor.' On an examination that weakness is everywhere apparent:-

i. The Incarnation was the union of the Nature (if the word may be used of God) of God with the nature of man made in His own image, after His likeness; in the supposed extension of the Incarnation, the Nature of God is united with the nature of a vegetable product.

ii. In the Incarnation the union was with a view to the exalta-

* Pusey, Tracts for the Day, pp. 232, 233. 
tion of humanity : there is no idea of exalting the nature of bread and wine in the supposed 'cxtension.'

iii. That union was once for all, and for ever, this union is repeated daily a thousand times, to cease with the consumption of the bread and wine.

iv. The Incarnation was effected by the descent of the Son of Man from Heaven; this Presence of the very Divine Person and Human Body of Christ leaves Christ at the Right Hand of God the Father.

v. Finally, the Lord did not say that the bread and wine which He gave to His disciples were His Body, Soul, and Divinity, but His Body given in death, and His Blood shed in death, i.e. that Body and Blood separated from the Soul and Divinity in death, and therefore not the objects of worship, even if they could be reproduced upon an Altar.

The Lutheran doctrine, Consubstantiation, is a compromise, as its name would suggest. Transubstantiation is denied, but a corporal presence of Christ's Body and Blood is asserted, 'in, under, and with the bread and wine.' This presence is so objectively real, that the wicked are able to receive the actual Body and Blood of Christ. Our Article XXIX was directed rather against Lutheranism than Romanism, though it necessarily conflicts with both. Lutheranism safeguards itself against the logical consequences of its doctrine, by the precaution that the Body and Blood are not present by any priestly act of consecration, but only by and at the faithful reception of the bread and wine. There is, therefore, in Lutheranism no Mass Sacrifice, no Oblation, no Reservation, no Eucharistic Adoration. The Council of Trent, at its thirteenth session, passed a Canon expressly condemning the doctrine that Christ's Body is only present in the use of the sacramental bread, and not present before or after such use (extra usum).

With many shades of opinion on the subject of the Lord's Supper, there is one broad line of demarcation which divides them into two irreconcilable classes. On one side must be placed all theories which assume any change in the elements of bread and wine, on the other all opinions which recognize that the bread and wine remain still in their very natural substances, and that the Body given for us and the shed Blood are no longer separated in death, but raised from the dead and 'in heaven and not here.' This latter alone is consistent with Holy Scripture, the belief of the primitive Church, and the tenets of the Reformed Faith; the former can only be held in spite of such testimony, and must ever carry with it the dead weight of the multitudinous superstitions with which it has obscured the Gospel. 


\section{THE MINISTRATION OF PUBLICK BAPTISM OF INFANTS, TO BE USED IN THE CHURCH}

\section{INTRODUCTION.}

There are eight Occasional Offices of the English Church, namely, Baptism, Confirmation (preceded by the Catechism), Matrimony, Visitation of the Sick, the Communion of the Sick, the Burial of the Dead, the Churching of Women, and the Commination Service. These Services find their justification not only in the human desire to recognize the hand of God in the outstanding experiences of life, but in the duty of imitating the example of the Saviour who ' embraced' children 'in His arms,' ' adorned and beautified with His presence' the marriage in Cana of Galilee, visited the sick, comforted the afflicted, wept at the grave of Lazarus, and was ever ready to receive the penitent.

\section{The Matter of Baptism.}

The washing of the body with water, as a symbol that the soul requires to be cleansed, is a rite of great antiquity, and not peculiar to Christianity. The Greeks adopted the almost universal custom of lustration for the purpose of moral cleansing. The rite of Baptism was employed by the Jews in admitting proselytes to their religion. Our Lord, therefore, in appointing this to be the rite of entering His Church (Matt. xxviii. 19) did not "introduce a new ceremony or a new symbol, but rather invested an old oue with greater sanctity and deeper significance.'

In the Eastern Church Baptism has always been by immersion, except in the case of Clinic Baptism, i.e. Baptism on a sick bed which was performed by affusion.

The question of the necessity of immersion has been largely canvassed within the Reformed Churches up to recent years; it is, however, beginning to be generally admitted that the word ' baptize,' as used in the original of the N.T., cannot always, and need not ever, mean 'immerse.' Doubtless a larger quantity 
of water was understood to be used than is provided usually at a font (cf. John iii. 23), and accordingly the B.C.P. requirement is immersion, unless the sponsors state the child to be physically unfit for it. The almost universal custom now is to use affusion only.

\section{The Place of Baptism.}

(1) At first in private houses, or by the water side.

(2) Later in Baptisteries adjoining places of public worship.

(3) Still later in the Church-porch.

(4) At last at the Font, placed within the Church, but near the door.

\section{The Time of Baptism.}

(1) Anciently between Eastcr and Whitsuntide, except in cases of imminent danger.

(2) In 1549,1552 , and 1559 only on Sundays or Holy Days.

(3) In 1662 any other day, if necessity so require.

\section{Infant Baptism.}

The careful language of the first of the two Rubrics at the end of the Office for the Public Baptism of Infants; certifying the salvation of the baptized who die in infancy, without presuming to predict anything of the infants dying unbaptized, and still more the careful language of Article XXVII, claiming that Infant Baptism is to be retained ' as most agreeable with the institution of Christ,' would seem to be designed to avoid ' unchurching' those who find a difficulty in Infant Baptism.

The ground upon which is made the claim for Infant Baptism in the Rubrics, positive enough in spite of its careful wording, is not directly Scriptural, the baptism of ' households' being only of conjectural value, and, consequently, of value only as confirmatory of other valid arguments. On the other hand, the absence of an express Scriptural command to baptize infants admits of easy explanation. The absence of the mention of infant baptism is what we should expect in the records of a 'Missionary' Church, as the Church was during the period covered by the N.T. As regards the want of an express command, the argumentum a silentio is never conclusive by itself, though of great weight if it fits in with positi ve arguments. In the case of Infant Baptism, this argument has been used on both sides; if we are not told in so many words to baptize infants, neither are we told to exclude them from the rite. But the arguments for this practice are stronger than those against it. The rite of circumcision having accustomed Israel to the entry of unconscious infants into convenant relationship, it may well be 
claimed that in the case of baptism, brought into direct contrast and comparison with circumcision (Col. ii. 11-13), the absence of an explicit exclusion of infants from the N.T. rite, is the valid form of argumentum a silentio, being based on positive teaching as regards circumcision.

Add that Baptism was no new rite in the time of Christ, but the familiar preliminary rite in the admission of proselytes to Judaism, and as such administered to infants, ${ }^{*}$ and the weight lent by this positive basis to the absence of an order excluding infants, becomes considerable. The historical practice of the Church in this rite, as in the matter of Sunday observance, tends still further to throw the burden of proof upon those who term the practice unscriptural. $\dagger$

The exceptions to this rule of the early church prove its general observance, for in such cases Baptism was postponed not to adolescence but to the death-bed, under the notion that all sin after baptism is unpardonable, or at any rate not so visibly and plainly removed as in the baptismal rite.

The positive objection to Infant Baptism is the connexion of faith and baptism in Holy Scripture, a connexion acknowledged by the Church in the Catechism, in the promises exacted from the sponsors, and in Arts. XXV, XXVI, and XXVII.

Through the rejection of Acts viii. 37, and the semi-rejection of the last verses of St. Mark's Gospel as in the R.V., it is sometimes asserted that baptism is not conneoted with a profession of faith. But the possession of faith (which is surely something far more than the profession) is, at any rate, essential to rightly (recte) receiving Baptism (see Art. XXVII). The Scriptural association of that Sacrament with regeneration, i.e. new birth, the one human condition in the bestowal of which is repentant faith, utterly repudiates attempts at solution of the difficulty by dissociating faith from Baptism. The right direction in which to seek the justification of Infant Baptism is the one suggested by the Office itself, namely the capacity of a child for the reception of Divine grace, and for entering into Covenant relationship. The expression, 'Believers' Baptism,' which seems to enshrine incontestably Scriptural truth, is really only a half-truth; for though true as excluding adult unbelievers, it makes no provision for infants. Yet the Bible is clear as to the capacity of children to receive blessing, privilege and sanctification. For example, 'of such is the Kingdom of Heaven'; 'He blessed them'; 'Else were your children unclean, but now are they holy' (åyıa, saints'). The

* Sce Wall, Infant Baptism. Istroduction.

† Origen (c. 250 A.D.); Liclesia ab apostolis traditionem suscepit parvulis baptismum dari. 
rite of circumcision already noted; the case of John Baptist, filled with the Holy Ghost from his mother's womb ; the 'holiness' of the child of even one believing parent, introduced as an obvious and well-known fact on which to build the argument against separating from unbelieving spouses; St. Peter's words at Pentecost, 'the promise is to you and to your children';-all such plain indications of the Child's position in the Covenant of Grace, are in line with those taught by Christ's word, gesture and deed, on the memorable occasion detailed in the Gospel narrative. Nor must it be forgotten that the Lord's healing work when upon earth, so expressly conditioned by the faith of the recipients, extended to the Syrophenician woman's daughter, the lunatic son, the nobleman's son, and the centurion's slave ( $\pi \alpha i s)$, on the ground of a faith not possessed by the one healed, but by those claiming intimate relationship, parental or quasi-parental.

Here is the point at which to apply the argumentum a silentio. Abraham received circumcision, as a sign of the faith which he had yet being uncircumcised; he is bidden to administer the rite to the infant Isaac, incapable of faith, but within the Covenant through the faith of his father. Without an explicit command to the contrary, it was impossible for the Christian Jew to imagine the postponement of the N.T. Covenant rite; and, it is said, the converted Jew finds such a postponement incomprehensible to-day.

Will this explanation justify the language of the address and the thanksgiving prayer after baptism in the B.C.P. where 'regencration' is claimed as a past act? The Reformers took refu $e$ in Calvinistic theories little acceptảble to-day. It is fair to say that the use of the word 'regenerate' in the Office, being devotional and undogmatic, must rest for its interpretation upon the Catechism and the Articles, and ultimately upon the Holy Scriptures. Faith and repentance are essential to the benefits of Baptism; the presentation of a child, of Christian parentage or guardianship, is a 'charitable work' resting upon the capacity of a child for Covenant relationship with God, and depending upon such training as shall be instrumental in transforming the rite from a charitable work on the part of the believing parent, into the sign and seal of a realized death unto sin and life unto righteousness on the part of the child.

It is interesting to note that the sanction of this view of the Sacrament in the famous Gorham Case, which drove Manning from a Church where he deemed the Sacrament to be undervalued, drove Mozley to an inquiry into the Scriptural and historical. meaning of Holy, Baptism, which resulted in his classical work endorsing the view above given. 
In the Irish B.C.P. the language of the Public Baptism of Infants is not altered, but in the Preface reference is made to the desire of some for alteration and the principle that devotional language should be interpreted by more formal statements of doctrine is enunciated in the following clause: 'No Minister of this Church is required to hold or teach any doctrine which has not been clearly determined by the Articles of Religion.'

The Revised B.C.P. of the Reformcd Spanish Church (1889), adapted from the Anglican, Mozarabic, and Gallican Liturgies, has changed 'to regenerate this Infant' into 'admit to the Sacrament of Regeneration and of the Remission of Sins.'

\section{The Effect of Infant Baptism.}

The following are the main views:-

(1) A complete change of nature takes place, the soul being restnred to the innocency of Adam before the fall; sin is not only pardoned, but rooted out. Concupiscence remaining after baptism is not to be called sin on this theory.

(2) There is, besides pardon of sin, the implantation of a new nature, the old remaining to be overcome: thus concupiscence after Baptism is sin.

(3) Sin is remitted and a germ of grace implanted in the soul, but without any change of nature. The blessings on this view are: (1) pardon; (2) aid of the Holy Spirit; (3) a contingent promise of everlasting life. This view involves the idea that pardon can be granted without renovation.

(4) Baptism admits merely to the privileges of the Church, and legeneration denotes a change of external status only, not of heart. The effects, therefore, vary in importance, according to the definition of 'privileges of the Church,' but the theory tends to regard Baptism as hardly more than the dedication of the child to God.

(5) Regeneration is predicated of the baptized only hypothetically-God's promises are visibly signed and sealed, but man's side of the Covenant, repentance and faith, must be carried out to render the grace of Baptism effective. The Gorham Judgment sanctioned this view of Baptism, as at least a permissible interpretation of the Articles and Formularies of the Church of England.

The following is the view of Dr. H. C. G. Moule, Bishop of Durham:-

'Christian Baptism is an ordinance of the New Covenant. It is an ordinance of entrance into Covenant. It initiates the 
receiver of it into the new, better, and everlasting Covenant. It does this after the manner of a rite. It does it formallycermonially. It gives new birth, new life, forgiveness, the Spirit, grace and glory. But it gives as a deed gives-not as an electric wire gives. It gives a title. It conveys to the right recipient such possession as now after conveyance only demands his actual entering on and using to be complete.

'There are legal documents called escrows. These are deeds of conveyance which speak in the present tense, and do a present act of gift and transfer, but they carry with them a condition to be fulfilled before the effect is actualized. Till that condition is fulfilled the present giving does not become actual possession. The receiver of the title-deed does not actually enter on the property given in it. $\mathrm{He}$ has it in title, but he has it not yet in act and use. He has something at once. He received a beneficial title, right and pledge, the possession of which conceivably at once entitles him to special care, attention, and privileges.

'So Baptism, at once and literally, in the sense of title, makes an infant a member of the Church-a member of Christ, the child of God, and an inheritor of the Kingdom of Heaven. In the sense of title, he is at once regenerate. He receives at once in that respect the acceptance of an adopted child of God in Christ, and the new life, which is wrought in man by the Holy Ghost. But in the ordinary law of God's working revealed in His Word, these precious things, in their actual possession, await the humble claim of repentance and faith. So the infant who in Sacramental title is born again, still needs to be born again. He is baptismally regenerated, but he needs subsequently to be actually regenerated by Faith and Repentance.'

\section{Regeneration.}

The Greek word literally equivalent to 'regeneration' ( $\pi a \lambda \iota \gamma$ $\gamma\left(v \varepsilon \sigma^{\prime} a\right)$ occurs only twice in the New Testament, Matt. xix. 28 , and Titus iii. 5 ; the former relating to the renewal of the earth, the latter to the renewal of the believer.

There are, however, other cognate expressions in Holy Scrip ture, which relate to the same thing, as $\gamma^{\prime \prime} v^{\prime} \eta \theta_{\eta} \hat{\eta} \mu^{\prime \prime} \omega \theta \epsilon v$ (" begotten from above') in John iii. 3, and 'á' $\alpha \gamma \in \gamma \in v^{\prime} v^{\prime} \mu_{\mu} \epsilon^{\prime}$ ' o ('born again ') in 1 Pet. i. 23. Cf. also John i. 13; 1 John v. 1.

Regeneration denotes in Scripture both an external status and an internal change. This externa! status enables St. Paul to address all the members of the Churches to which he wrote as 'saints' (Rom. i. 7, etc.); cf. also the argument in 1 Cor. vii. 14. The internal change is described as the new birth and entry upon a new life (John iii. 3-8; Col. ii. 12, 13;. 


\section{Ancient Baptismal Services.}

There are three distinct services in the Sarum Manual: 'The Order of making a Catechumen,' 'The Blessing of the Font,' and 'The Rite of Baptism.' The following ceremonies were connected with these Services:-

(1) The Order of making a Catechumen.

a. Preliminary reception with the sign of the Cross.

$b$. The touching the lips with consecrated salt, the emblem of wisdom and purification.

c. The ' exorcism' or adjuration of Satan to give up all attack on the child, now to be dedicated to God.

$d$. The touching the child's ears and nostrils with saliva, with the use of the word 'Ephphatha.'

$\boldsymbol{e}$. The leading the child into the Church, addressing him by name, and bidding him 'enter into the Temple of God.'

(2) The Blessing of the Font.

$a$. The Prayer for the Sanctification of the water.

$b$. The pouring oil into the water, as 'a conjunction of the water of Baptism and the anointing with the Spirit.'

(3) The Rite of Baptism.

$a$. The first anointing of the child after the vow of renunciation.

$b$. The Baptism with the second anointing and putting on the Chrism (or white garment).

c. The placing of a lighted taper, emblematic of the light of life, in the child's hand.

\section{The Reformed Baptismal office.}

1549. The Service was formed from:-

(1) The three ancient Baptismal Offices in the Sarum Manual, which were unified, re-arranged, and simplified.

(2) Parts (especially the hortatory portions) of the Consultatio of Hermann, as found in the Baptismal Book of Luther. It retained the Exorcism, Anointing, and Chrism, with a separate Service for Blessing the Font, at the renewal of the water at least once a month. The Prayers at the commencement were in a more detailed form than those now in use.

1552. The Blessing of the Font, the Exorcism, Anointing, and Chrism were abolished; and the declaration of the Regeneration of the child was inserted. 


\section{The Principles of the Service.}

(1) It regards Baptism as the normal means of entry into the Christian covenant.

(2) It recognizes both God's part in the free gift of Salvation, and Man's part in the acceptance of the gift, by repantance and faith.

10. Defects alleged in 1661.

(1) The obligation to baptize the children of unbaptized or unclean and ungodly parents.

(2) The pronouncement of the declaration of regeneration ovcr all, whether they be the children of Christians or not. The weakness of the two above objections is the impossibility. of judging the spiritual condition of parents.

(3) The requirement of Sponsors in all cases, and the putting the interrogatories to others than the parents. 


\section{A TABLE COMPARING THE ORDER OF PUBLIC BAPTISM OF INFANTS, 1662, WITH THE ORDER OF PUBLIC BAPTISM, 1549.}

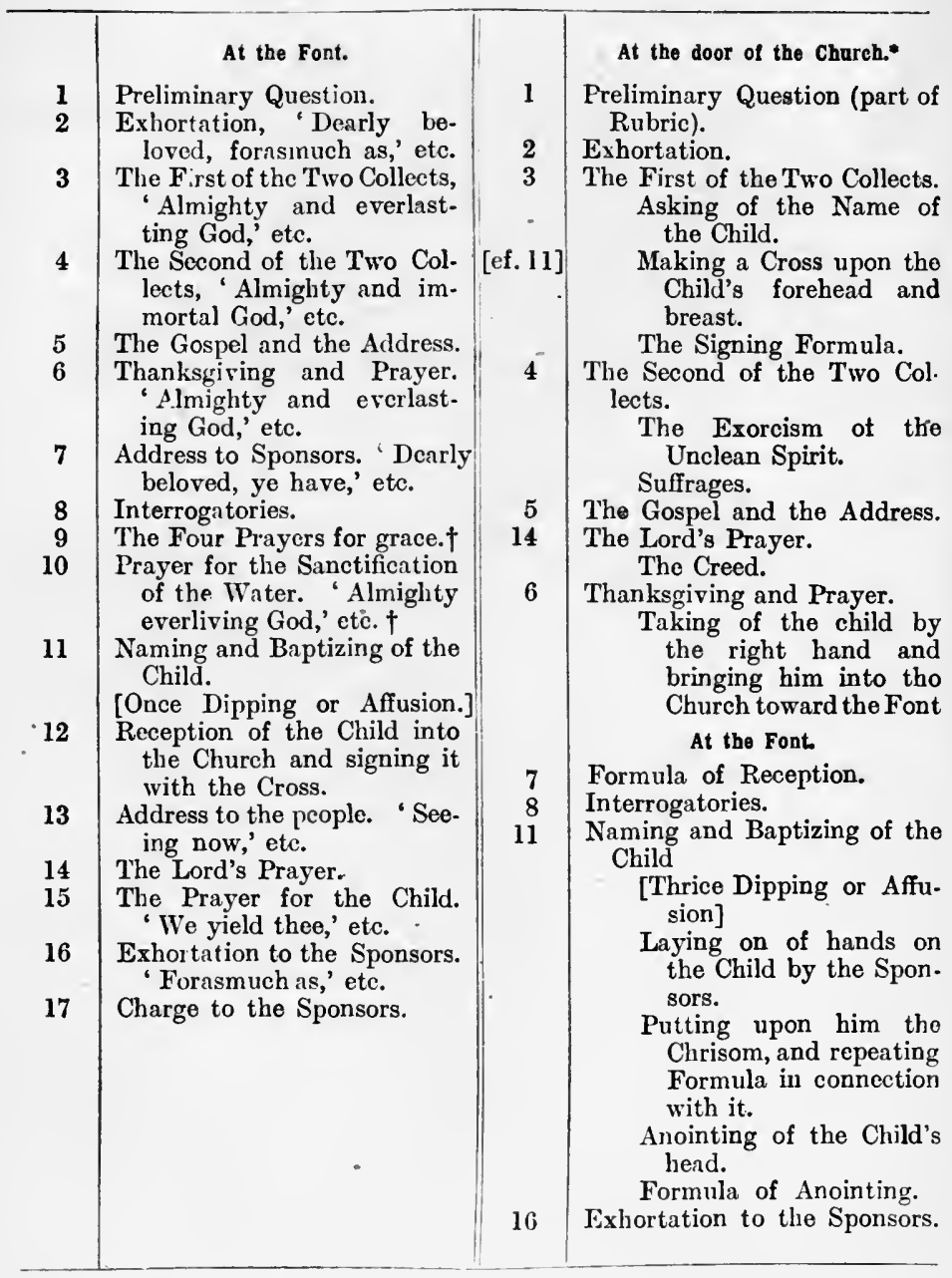

* The indented varts are peculiar to 1549 .

+ In the Form if Consecration of the Font 1549, at the end of the Office for Private Baptism. 
Special features of the 1549 Service contrasted with that of 1552.

1519. (1) There was a separate service, usually held monthly, for consecrating the water.

(2) The consecrated water was kept in the Font and used as occasion required.

(3) The Baptismal Service was held partly at the Church door.

(4) There was an exorcism of Satan; trine immersion or affusion; the putting on of the Chrisom or white vesture; and the Chrism, ${ }^{*}$ or anointing with oil.

1552. One immersion or affusion ordered; the above remaining ceremonies being discontinued.

\section{ANALYSIS AND HISTORICAL NOTES.}

[The date is 1549, unless otherwise stated.]

\section{Ante-Baptism.}

1. The question whether the child has been baptized. 1662 .

[Prior to 1662 this question was in an opening rubric.]

2. Exhortation to the congregation in behalf of the child.

3. The two Collects for spiritual benefits. The first altered 1552 and 1662.

4. The Gospel, (Great Bible, 1549; A.V., 1662), and Address upon it. Altered 1552.

5. Thanksgiving and Prayer for spiritual blessing.

\section{Baptism.}

\section{The Baptismal Vows.}

(1) Address to the Sponsors. Altered 1662.

(2) Interrogatories. Altered 1552, 1662.

2. The Administration of Baptism.

(1) The Four Petitions for grace in behalf of the child. Altered 1552 and placed here.

(2) Prayer for the sanctification of the water, and for the

* Chrism is used for :-

(1) A sacred ointment, consecrated by a bishop, employed in the unreformed Churches in baptism confirmation, ordination, and coronation, the consecration of ehurehes, altar stones, and ehalices.

(2) The baptismal vesture; a white garment formerly given to the newly baptized as a symbol of the new robe of righteousness : in this sense commonly spelt chrisom.

In the Roman Church tho 'sacred o ntment' consists of a mixture of oil and balsam, and in the Eastern Chureh of oil, wine, and various ointments. In the former the chrism is consccrated by the Bishop on Maunly Thursday; though its preparation is commenced on the Monday in Holy IVeek. 
benediction of the child. Altered and placed here 1552 ; altered again 1662.

(3) Naming and baptizing of the child. Altered 1552, 1662.

[The manner of baptizing was altered 1552, but not the formula.]

14) Reception into the Church, and the sign of the Cross, 1552 .

[Prior to 1662 the sign of the Cross was made before the words of the reception were spoken.]

\section{Post-Baptism.}

1. Address to the People reciting the benefits of Baptism. 1552.

2. The Lord's Prayer. 1552.

3. The Prayer in behalf of the Child. 1552.

4. Exhortation to the Sponsors.

5. Charge to the Sponsors concerning Confirmation. 1662.

[Prior to 1662 this charge was embodied in a closing rubric.]

The Title.

\section{EXPOSITION.}

1549. Of the administration of Public Baptism, to be used in the Church.

1552. 'Of' and 'Public' omitted. 'Ministration' for ' administration.'

1662. 'Of Infants' after 'Baptism' added.

\section{1st Rubric.}

1549. Commenced thus: 'It appeareth by ancient writers, that the Sacrament of Baptism in the old time, was not commonly ministered but at two times in the year, at Easter and Whitsuntide; * at which times ['time,' 1552] it was openly ministered in the presence of all the Congregation: which custom (now being grown out of use,) although it cannot for many considerations be well restored again; yet it is thought good to follow the same as near as conveniently may be.'

1662. This portion of the Rubric was removed, and it now begins: 'The people are to be admonished,' etc.

1549. 'This rubric ended thus: 'Children ought at all times to be Baptized, either at the Church or else at home.'

1552. Altered to 'Children may at all times be baptized at home.'

1662. 'Upon any other day' substituted for ' at all tires' (' at home' omitted).

* Epiphany was added in the East and in some Western Churehes. 
2nd Rubric. 1662.

There is very early evidence of the institution of sponsors: that of Tertullian, c. 150-220 ; Fourth Council of Carthage, 398 ; St. Augustine (fidejussores). The number has varied; the Sarum Manual allowed ordinarily two persons, viz. one man and one woman, never more than three. The rule in the present Rubric agrees with the Synod of Worcester, 1240, by which the number required is three. The Eastern and Latin Churches to-day require one sponsor, but allow two. Canon xxix forbids parents to act as sponsors to their own children. This prohibition was altered by the Convocation of Canterbury 1865, but the alteration has not been sanctioned by the Crown. Various titles have been given to sponsors significant of the position they hold and the duties to which they are pledged. They are called :-

(1) Sponsors, as responding for the baptized.

(2) Sureties, as giving security that the baptized shall be ' virtuously brought up to lead a godly and a Christian life.'

13) Godparents, as. undertaking parental responsibilities in regard to the things of God.

Godparents were, in ancient times, called 'Gossips,' from 'God' and ' sib,' i.e. 'relations in God,' the old word 'sib' meaning 'kindred.'

3rd Rubric.

3549. And then the Godfathers . . must be ready at the Church door, either immediately afore the last Canticle at Matins, or else immediately afore the last Canticle at Evensong, etc.

1552. And then the Godfathers ... must be ready at the Font, either immediately after the last lesson at Morning Prayer, or else immediately after the last Lesson at Fvening Prayer, etc.

The Baptism is directed to be after the last Lesson, appropriately following the Gospel message, and preceding the public confession of Faith.

\section{4th Rubric.}

1549. And then standing there, the Priest shall ask whether the children be Baptized or no. If they answer, No, then shall the Priest say thus.

1662. And the Priest coming to the Font, (which is then to be filled with pure water,) and standing there shall say.

Direction is here given for the Font to be filled with water. Anciently it was filled on the Saturday before Easter Day, the 
Saturday before Whit-Sunday, and on other special occasions, and the water was never changed until it was unfit for use.*

In 1549 it was ordered, in the Rubric at the end of the Service for the Private Baptism of Infants, that 'the water in the Font shall be changed every month once at the least.'

The Question whether the child has been baptized.

It is found in the older Offices. It implies that the Sacrament of Baptism ought not to be repeated.

Exhortation to the Congregation. 1549. Based on Herm. Con.

\section{Analysis.}

I. Opening Statement concerning-

(1) The fact of original sin.

(2) Our Lord's declaration to Nicodemus of the need of Regeneration.

II. A Call to prayer for supernatural gifts, viz. :

(1) Baptism with the Holy Ghost.

(2) Reception into Christ's holy Church.

(3) Living membership.

Prayer for Spiritual Benefits (No. 1). 1549.

This is similar to a form, attributed to Luther, found in Hermann's 'Consultatio.'

1549. Almighty and everlasting God, which of thy justice didst destroy by floods of water the whole world for sin, except eight persons, whom of thy mercy (the same time) thou didst save in the Ark; And when thou didst drown in the Red Sea wicked king Pharaoh, with all his army, yet (at the same time) thou didst lead thy people the children of Israel safely through the midst thereof; whereby thou didst figure the washing of thy holy baptism; and by the baptism of thy well-beloved Son Jesus Christ, thou didst sanctify the flood Jordan, and all other waters, to this mystical washing away of sin; We beseech thee (for thy infinite mercies) that thou wilt mercifully look upon these children, and sanctify them with thy holy Ghost; that by this wholesome laver of regeneration, whatsoever sln Is in them may be washed clean away; that they, being delivered from thy wrath, may be received into the ark of Christ's Church, and so saved from perishing; and being fervent in spirit, stedfast in faith, joyful through hope, rooted in charity, may ever serve thee; And

* The water was not changed, because of efficacy being supposed to reside in the 'holy water.' 
finally attain to everlasting life, with all thy holy and chosen people. This grant us, we beseech thee, for Jesus Christ's sake, our Lord. Amen.

1552. Altered to nearly its present form.

\section{Analysis."}

I. The Address, in which mention is made of :

(1) Two Types, viz.

i. The Ark, a type of salvation in Christ's Churen.

ii. 'The Passage of the Red Sea, a type of Baptism.

(2) The Baptism of the Saviour, setting water apart for its baptismal use.

II. A Petition for blessings, viz. :-

(1) Sanctification.

(2) Security.

(3) Perseverance.

After this Prayer in 1549 there was the following rubric :-

Here shall the Priest ask what shall be the name of the child; and when the Godfathers and Godmothers have told the name, then he shall make a cross upon the child's forehead and breast, saying,

This was the formula of consignation.

$N$. receive the sign of the holy Cross, both in thy forehead, and in thy breast, in token that thou shalt not be ashamed to confess thy faith in Christ crucified, and manfully to fight under his banner against sin, the world, and the devil, and to continue his faithful soldier and servant unto thy life's end. Amen.

Then came the following rubric :-

And this he shall do and say to as many children as be present to be Baptized, one after another.

Prayer for Spiritual Benefits (No. 2). 1549. Sar. Man.

There was a similar Prayer in Herm. Con.*

\section{Analysis.}

I. Address, especially emphasizing the immortality of God, as leading up to petitions for everlasting blessings.

II. Prayer on behalf of the infant for :

(1) Remission of his sins by spiritual regeneration,

(2) His reception by God according to promise, with a view to $(a)$ the everlasting benediction of heavenly washing, and (b) entry into the eternal kingdom.

- Dowden considers that Justus Jonas rather than Hermann is the person to whom the origin of this prayer is to be traeed ("Further Studies in the Prayer Book,' pp. 48, 49). 
The words ' may receive remission of his sins by spiritual regeneration' must not be limited to the washing away of the sin which the child inherits from Adam, but refer to sin generally. If the reference were to original sin, the phrase would not be 'of his sins' but 'of sin.'.

Spiritual regeneration means being 'born again,' or from above, by the operation of the Holy Spirit. It is a real change of nature. But the new birth does not necessarily begin with Baptism; it may precede or follow that which seals it.

After this Prayer in. 1549 there was the following rubric :-

Then let the Priest, looking upon the children, say.

Then came the form of exorcism, viz. :

I command thee, unclean spirit, in the name of the Father, of the Son, and of the holy Ghost, that thou come out, and depart from these infants, whom our Lord Jesus Christ hath vouchsafed to call to his holy Baptism, to be made members of his body, and of his holy congregation. Therefore, thou cursed spirit, remember thy sentence, remember thy judgment, remember the day to be at hand, wherein thou shalt burn in fire everlasting, prepared for thee and thy Angels. And presume not hereafter to exercise any tyranny toward these infants, whom Christ hath bought with his precious bloud, and by this his holy Baptism, calleth to be of his flock.

This was omitted at Bucer's suggestion in 1552 .

After the Exorcism in 1549 came-

Then shall the Priest say-

The Lord be with you.

The People. And with thy spirit.

This also was omitted in 1552 .

The Passage of Scripture. Mark x. 13-16. Great Bible, 1549. A.V., 1662.

The passage in the Sar. Man. was from Matt. xix. 13-15.

The Eastern. Offices had. two passages: Rom. vi. 3-12 and Matt. xxviii. 16-20.

Our Reformers wisely selected Mark x. 13-16, which has a bearing upon the question of the bringing of infants to God in Baptism, a practice violently opposed by the Anabaptists throughout Europe.

In the American Prayer Book the following Rubric is inserted before the Gospel :

Then the Minister shall say as followeth, or else shall pass immediately to the questions addressed to the Sponsors. But note that in every church the 
intermediate parts of the Service shall be used, once at least in every month (if there be a baptism), for the better instructing of the people in the grounds of Infant Baptism.

Address on the Passage. 1549. - Founded on Herm. 'Con.'

1552. The words at the end of this Address, 1549, viz.

'the Prayer which the Lord himself taught. And in declaration of our faith, let us also recite the articles contained in our Creed,' were omitted.

1604. The opening word 'Beloved' was substituted for 'Friends.'

After the Address in 1549 there was the following:-

Here the Minister, with the Godfathers, Godmothers, and people present, shall say,

Our Father, etc.

And then shall say openly,

I believe in God the Father Almighty, \&c.

The Priest shall add also this Prayer,

Almighty and everlasting God, etc.

Thanksgiving and Prayer for Spiritual Blessing. 1549. Herm. Con.

1549. Increase and confirm this faith.

1552. Increase this knowledge, and confirm this faith.

1549. The introductory service at the Church door ended here, and the priest was then directed to 'take one of the children by the right hand, the other being brought after him,' and when he came into the Church toward the font, to say, "The Lord vouchsafe to receive you into his holy household, and to keep and govern you alway in the same, that you may have everlasting life. Amen.'

1552. This was omitted, doubtless as obscuring the reception of the duly baptized into Christ's holy Church.

Address to the Sponsors. 1549. Based on Herm. 'Con.'

1662. 'Dearly beloved' for 'Well-beloved friends.'

1662. The words 'to lay his hands upon them and bless them,' omitted, 'to sanctify him with the Holy Ghost,' until he came of age' etc., added.

I demand therefore. 1662.

In the previous Books of Common Prayer there was here a rubric : 
1549. Then shall the Priest demand of the child (which shall be first Baptized) these questions following: first naming the child, and saying.

1552. Then shall the Priest demand of the Godfathers and Godmothers these questions following.

\section{The Interrogatories.}

The Vow of Renunciation. 1549. Sar. Man.

1549. In this vow three questions were asked, viz. : 'Dost thou forsake the devil,' etc.? 'Dost thou forsake the vain pomp,' etc.? 'Dost thou forsake the carnal desires of the flesh,' etc.? And the answer to each was, 'I forsake them.'

1552. The threefold question became one, and the answer was, 'I forsake them all.'

1662. Altered to its present form.

The Vow of Belief. Enlarged from Sar. Man. 1549.

1549. In this vow three questions were likewise asked, one for each main division of the Creed, and the answer to each was, 'I believe.'

1552. The threefold question became one. The answer was, as it now stands, 'All this I stedfastly believe.'

1549 contained also these questions :-

Minister. What dost thou desire?

Answer. Baptism.

Minister. Wilt thou be baptized?

Answer. I will.

1552. Altered to its present form.

The Vow of Obedience. Sar. Man. 1662.

In the Amcrican Prayer Book it is stated, that 'the questions are to be considered as addressed to the Sponsors generally, and the answers to be made accordingly.'

\section{The Four Petitions.}

1st Petition.

1549. O merciful God, grant that the old Adam, in them that shall be baptized in this fountain, may be so buried, that the new man may be raised up again. Amen.

1552. Altered to its present form, and placed here.

2nd Petition. 1549. Placed here 1552.

3rd Petition. 
1549. Grant to all them which at this fountain forsake the devil and all his works; that they may have power and strength to have vietory, and to triumph against him, the world, and the flesh. Amen.

1552. Altered to its present form, and placed here.

4th Petition. 1549. Placed here 1552.

In 1549 these petitions were placed in the Special Service for the Consecration of the Water at the end of the Order for the Private Baptism of Infants. There were also four others which eame between the present third and fourth, and which ran as follows :-

Whosoever shall confess thee, 0 Lord: recognize him also in thy kingdom. Amen.

Grant that all sin and vice here may be so extinct : that they may never have power to reign in thy servants. Amen.

Grant that whosoever here shall begin to be of thy flock : may evermore continue in the same. Amen.

Grant that all they which for thy sake in this life do deny and forsake themselves: may win and purchase thee, (0 Lord) which art everlasting treasure. Amen.

\section{Prayer for the Sanctification of the Water. 1549.}

This Prayer was also taken from the Form of Consecration of the Water in the Font, to which reference has been made.

1549. And grant that all thy servants which shall be Baptized in this water, prepared for the ministration of thy holy Sacrament, may receive the fulness of thy grace.

1552. And grant that all thy servants which shall be baptized in this water, may receive the fuiness of thy grace.

1662. Sanctify this water to the mystical washing away of sin; and grant that this Child, now to be baptized therein, may receive the fulness of thy grace.

In the 1549 Form of Consecration there was also another prayer for the sanctification of the water. It commenced the Service, and ran thus :-

O most merciful God our Saviour Jesu Christ, who hast ordained the element of water for the regeneration of thy faithful people, upon whom, being baptized in the river of Jordan, the holy Ghost came down in likeness of a dove; Send down, we beseech thee, the same thy holy Spirit to assist us, and to be present at this our invocation of thy holy name. Sanctify + this fountain of baptism, thou that art the sanctifier of all things, that by the power of thy word, all those that shall be baptized therein may be 
spiritually regenerated, and made the clildren of everlasting adoption. Amen.

Sanctify this water to the mystisal washing a way of sin. Sanctification of an inanimate object, such as water, can only mean setting it apart for a sacred purpose, and using it as a symbol.* The change is in the use and purpose of the thing consecrated, and not in itself.

Elect children. This may mean either :-

(1) Those who are admitted into the covenant of grace, and called to enjoy Christian privileges; or

(2) Those who are predestined to eternal life.

The clause in which these words occur is capable of being regarded either in an Arminian or Calvinistic sense, and clearly cannot be quoted as an argument either for or against indefectible grace.

This Prayer of Consecration is in keeping with the Prayer of Consecration in the Communion Service.

The naming of the child at Baptism corresponds with the practice of the Jews, who named their children at circumcision.

\section{Rubric before the Baptismal Formula.}

1549. Directed the priest to 'dip the child in the water thrice. First, dipping the right side; Second, the left side; The third time dipping the face toward the font.' If the child was weak, affusion was allowed.

1552. Trine immersion was abolished.

1662. The rubric directs that the Pricst shall dip the child in the water, if he may well endure it, but if the sponsors certify that the child is weak, it shall suffice to pour water upon it.

From consideration of climate and convenience, the affusion of water has become practically universal. The Greek word $\beta a \pi i_{\zeta} \omega$ at least includes affusion (see Mark vii. 3, 4).

The Baptismal Formula. 1549.

In the name. Baptism is not merely in, but into (eis) the Name. $\dagger$ The phrase does not mean only involing the Name, or the sanction of the great Name, but more even than this. It significs into the power and influence of the Holy Trinity, into fuith in the Three Persons of the Godlead, and the duties and privileges consequent on that faith, above all into the family of the

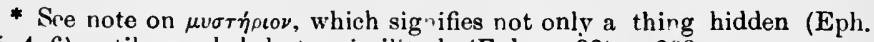
iii. 4-6) until revealed, but a similitude (Eph. v. 32$)$ p. 289.

$\dagger$ For this use of $\epsilon i s$, see $\epsilon l s \tau \delta \nu N \omega \nu \sigma \hat{\eta} \nu$, to follow Moses, as a leader (1 Cor. x. 2). 
Father, the redeeming power of the Son, and the fellowship of the Holy Ghost.

The 'Name' of God is, as so often in Holy Scripture, used for God Himself, as including all that we know of Him, His Being and His attributes.

The Reception into the Church, and the Sign of the Cross. 1552.

This is the formal welcome, on the part of the congregation, of the baptized child into the Church. The incut rubric, 1662, was taken from the rubric formerly at the head of the invitation to prayer after baptism.

1549. The Child was to be signed with the sign of the Crcss upon his forehead and breast at the Church door, before the exorci $\mathrm{m}$.

The consignation with the sign of the cross was a frequent practice in the Early Church. 'Thou art to be signed this day, on thy forehead with the sign of the passion and the cross' (Augustine). Gradually the use became more extended, being adopted at the consecration of the elements, Ordinations, dedications, admission of catechumens, consecration of the water, exorcism, unction before Baptism, and unction at Confirmation. The practice was very largely curtailed in 1519 , and confined to this single instance in 1552 .

The Puritans strongly opposed the retention of the cross in Baptism, and in 1604, Canon 30 was drawn up to answer their objections. It contains a carefully reasoned explanation, based upon ancient authority and the fitness of things.

The following extracts deserve specially to be noticed:-

(1) It must be confessed that in process of time the sign of the cross was greatly abused in the Church of Rome, especially after that corruption of Popery had once possessed it. But the abuse of a thing does not take away the lawful use of it.

(2) That the sign of the cross used in Baptism is no part of the substance of the Sacrament.

(3) That the infant baptized is, by virtue of Baptism, before it be signed with the sign of the cross, received into the congregation of Christ's flock, as a perfect member thereof, and not by any power ascribed unto the sign of the cross.

(4) So that for the very remembrance of the cross, which is very precious to all them that rightly believe in Jesus Christ, and in other respects mentioned, the Church of England hath still retained the sign of it in Baptism; following therein the primitive and Apostolic 
Churches, and accounting it a lawful outward ceremony and honourable badge whereby the infant is dedicated to the service of Him that died upon the cross.

The American Prayer Book allows the sign of the cross to be omitted if those who present the infant shall desire it, " although the Church knows no worthy cause of scruple concerning the same.'

1549. The Rubric after the Baptism ran :

Then the Godfathers and Godmothers shall take and lay their hands upon the child, and the Minister shall put upon him his white vesture, commonly called the Chrism.

The Minister then said,

Take this white vesture for a token of the innocency which, by God's grace, in this holy sacrament of baptism is given unto thee; and for a sign whereby thou art admonished, so long as thou livest, to give thyself to innocency of living, that, after this transitory life, thou mayest be a partaker of the life everlasting. Amen.

There was another rubric which directed that: Then the Priest shall anoint the infant upon the head. The prayer was:

Almighty God, the Father of our Lord Jesus Christ, who hath regenerated thee by water and the holy Ghost, and hath given unto thee remission of all thy sins; he vouchsafe to anoint thee with the unction of his holy Spirit, and bring thee to the inheritance of everlasting life. Amen.

\section{Invitation to Prayer. 1552.}

Seeing now that this child is regenerate. (See pp. 373, 5.)

The Lord's Prayer. 1552.

It seems to be a general rule that where the note of thanksgiving occurs, the Doxology is added to the Lord's Prayer ; but its suppression here constitutes a marked exception, which is hardly met by the suggestion that it is due to the Thanksgiving which immediately follows.

The Prayer in behalf of the Child. We yield. 1552.

1604. 'The residue of thy holy Church' was substituted for 'the residue of thy holy congregation.'

\section{Analysis.}

L Thanksgiving for :

Regeneration, adoption, membership. 


\section{Prayer for :}

Death unto sin, Resurrection, Everlasting Inheritance. The words of the prayer are taken directly from Rom. vi. 3-6.

With the residue of thy holy Church. Compare similar inclusion in the Prayer for the Church Militant ("that with them we may be,' etc.) and the Prayer in the Burial Office ("that we with all those that are departed,' etc.). Note that on all these occasions the faith of those so included is definitely specified, so that there is no doubt about their inheriting everlasting life. The Prayer is that we with them, not they with us, may be blessed. (See Dowden, 'Work and Witness,' April, 1909, pp. 46, 47.)

\section{The Rubric before the Exhortation to the Sponsors.}

1549. When there are many to be Baptized, this order of demanding, Baptizing, putting on the Chrism, and anointing, shall be used severally with every child; Those that be Baptized departing from the font, and remaining in some convenient place within the Church, until all be Baptized. At the last end, the Priest calling the Godfathers and Godmothers together, shall say this short exhortation following.

1552. At the last end, the Priest calling the Godfathers and Godmothers together, shall say this short exhortation following.

1662. Altered to its present form.

In the Sarum Use the corresponding instructions were :-

(1) That the parents were to keep the children from fire, and water, and other perils to the age of seven years.

(2) That they were either to teach it, or see that it was taught the Paternoster, Ave Maria, and Credo.

(3) That it was to be confirmed in all godly haste.

(4) That the mother was to bring the Chrism back to the Church at her Purification. (Cf. 1549, rubric at end of Office.)

(5) That they were to wash their hands before they left the Church.

Post-Baptismal Address. 1549.

\section{Analysis.}

Injunction to the Sponsors:-

(1) To teach the child its baptismal vow.

(2) To furnish needful instruction (publio and private).

(3) To provide a godly upbringing, conformable to the symbolical connexion between Baptism and our Lord's Death and Resurrection. 
Charge to the Sponsors concerning Confirmation. 1662.

Previous to 1662 this charge was in the form of a rubric.

The Minister shall command that the Chrisms be brought to the Church, and delivered to the Priests after the accustomed manner, at the Purification of the mother of every Child; And that the Children be brought to the Bishop to be confirmed of him, so soon as they can say in their vulgar tongue the articles of the faith, the Lord's prayer, and the ten commandments; and be further instructed in the Catechism, set forth for that purpose, accordingly as it is there expressed.

And so let the congregation depart in the name of the Lord.

Note, that if the number of children to be Baptized, and multitude of people present be so great that they cannot conveniently stand at the church door, then let them stand within the Church, in some convenient place, nigh unto the Church door; And there all things be said and done, appointed to be said and done, at the Church door.

1552. The Minister shall command that the children be brought to the Bishop to be confirmed of him, etc.

1662. This rubric was changed to an address with a specified form of words.

The Final Rubrics. 1662.

They are printed, not in italics as usual, but in the same type as the main body of the Service.

The 1st Rubric, respecting the salvation of the baptized children, is taken from a work entitled, 'A Necessary Doctrine and Erudition,' 1543. From 1549 until 1662 the same phraseology is used in the rubric immediately preceding Confirmation, to reassure any parents who might be in doubt as to the heavenly status of a child dying unconfirmed, and without having received Holy Communion.

The 2nd Rubric, respecting the sign of the cross, was added in 1662, referring to the 30 th Canon of 1604 . 


\section{THE MINISTRATION OF PRIVATE BAPTISM OF CHILDREN IN HOUSES}

THIs Service is drawn largely from the Sarum Manual and Hermann's 'Consultation,' and through the latter from earlier Lutheran Baptismal Offices.

\section{TABLE}

Comparing 'The Ministration of Private Baptism of ChilDREN IN Houses,' 1662, WITH ' OF THEM that BE BAPTIZED in Private Houses in Time of Necessity,' 1549.

\section{2.}

I. Baptism of Children in the House.

1. Tho Lord's Prayer.

2. Collects at Minister's discretion from the Form of Public Baptism.

3. Naming the Child.

4. Pouring water upon it.

5. Formula of Baptism.

6. Thanksgivirg and Prayer: 'We yield theo hearty,' etc.

II. Reception into the Church.

7. Certificates and Inquiries, respecting the due Baptizing of the Infant.

8. The Gospel, St. Mark x. 13-16, and Address upon it.

9. The Lord's Prayer.

10. Thanksgiving and Prayer: -Almighty and everlasting God,' etc.

11. Interrogatories.

12. Reception of the Child into the Church, signing it with the sign of the Cross.

13. Address to the People: "Seeing now.'

14. Prayer for grace for the child: 'We yield thee most hearty,' etc.

15. Exhortation to the Sponsors : 'Forasmuch as,' etc.

16. Hypothetical Formula of Baptism.

- This is very similar to the-Prayer for sanctiflcation of the Water in the I'ublic Baptism of Infants, 1662.
1549.

I. Baptism in the House.

1. Calling upon God for His grace, and saying the Lord's Prayer.

3. Naming of the Child.

4. Dipping of him in the water, or pouring water upon him.

5. Formula of Baptism.

II. Reception into the Church.

7. Inquiries and Certificates, respecting the due Baptizing of the Child.

8. The Gospel, Mark x. 13-16, and Address upon it.

9. The Lord's Prayer and the Creed (said by Minister and Sponsors).

11. Interrogatories.

Putting on the Chrism, and the Formula.

10. Thanksgiving and Prayer: 'Almighty and everlasting God,' etc.

15. Address to the Sponsors : 'Forasmuch as,' etc.

16. Hypothetical Formula of Baptism.

III. Form of Consecration of Font.

Order to change the water once every month.

Prayer for Sanctification of the W'ater : 'O most merciful God,' etc.

Several Prayers for Grace: 'O merciful God.' etc.

Mutual Salutation: "The Lord be,' etc.

Prayer for Grace for the Child : "Almighty everliving God." * 


\section{The Title.}

1549. Of them that be Baptized in Private Houses in time of necessity.

1604. There was added the words, 'By the Minister of the Parish or any other lawful Minister, that can be procured.'

1662. The Ministration of Private Baptism of Children in Houses.

Though the title describes the Service as for the Ministration of 'Private Baptism of Children in Houses,' it also contains a Service for their reception in Church, should they survive.

\section{Preliminary Rubrics.-1st Rubric.}

1549. The Pastors and Curates shall oft admonish the people, that they defer not the Baptism of infants any longer than the Sunday, or other holy-day next after the child be born, unless upon a great and reasonable cause declared to the Curate, and by him approved.

1662. The Curates of every Parish shall often admonish the people, that they defer not the Baptism of their Children longer than the first or second Sunday next after their birth, or other holy-day falling between, unless upon a great and reasonable cause, to be approved by the Curate.

\section{2nd Rubric.}

1549. And also they shall warn them, that without great cause and necessity, they baptize not children at home in their houses; and when great need shall compel them so to do, that then they minister ['it,' 1552] on this fashion.

1604. And also they, etc., . . . and necessity they procure not their children to be baptized at home in their houses, And [altered to 'But,' 1662] when great need, etc., so to do, then Baptism shall be administered on this fashion.

3rd Rubric.

1549. First, let them that be present call upon God for his grace, and say the Lord's Prayer, if the time will suffer. And then one of them shall name the child, and dip him in the water, or pour water upon him, saying these words.

This rubric directly authorized Baptism by the laity in cases of great necessity; a practice which had been permitted for many centuries. The Sarum Manual not only sanctioned it, but enjoined that each parish 
priest should often, on the Sunday, set forth to his parishioners the form of baptizing, in order that, if need be, they might know how to baptize infants. The English formula which they were to be instructed to use was: 'I christen thee, N., in the name of the Father, and of the Son, and of the Holy Ghost. Amen.' But in Elizabeth's reign no inconsiderable opposition arose, and a Canon was drawn up by Convocation in 1575, prohibiting it. Elizabeth, however, would not give her sanction to it. But in 1604, at the request of the Puritan party, the rubric was so altered as to make it appear that Lay Baptism was no longer legal.* It ran as follows :-

1604. First, let the lawful Minister, and them that be present, call upon God for his grace, and say the Lord's Prayer, if time will suffer. And then the child being named by some one that is present, the said lawful Minister shall dip it in water, or pour water upon it, saying these words.

This was again altered in the Revision of

1662. First, let the Minister of the Parish (or, in his absence, any other lawful Minister that can be procured) with them that are present call upon God, and say the Lord's Prayer, and so many of the Collects appointed to be said before in the Form of Public Baptism, as the time and present exigence will suffer. And then, the Child being named by some one that is present, the Minister shall pour water, saying these words upon it.

In his absence, any other lawful Minister, etc.-'The very widest possible latitude of interpretation is allowed to this phrase, which may be taken to include a layman, or even the midwife, or any other woman present at the birth of the child. Lay Baptism has been considered valid in the Church of England from the remotest times, and it is only discouraged, not forbidden, by our present vernacular rubrics (Maskell's 'Mon. Rit.,' 2nd Ed. I. ccliii.)' (F. E. Warren).

The rubrics of 1549, 1552, and 1559 did not require Baptism

- The rule respecting Lay Baptism now seems to be, that while it is irregular, it is valid. Hence the Judicial Committee of the Privy Council, July 2, 1842, ruled, in Escott $v$. Mastin, that, in the Church of England, Lay Baptism, though not encouraged, is not disallowed. On May 31, 1844, the Arches Court, in the case of Titchmarsh \%. Chapman, pronounced that Baptism rightly administered even by one in heresy and schism was ralid. 
to be administered by a clergyman, but in 1604 they were modified to exclude Lay Baptism.

The directions as to conditional re-Baptism make clear that this regulation (1662) does not invalidate Lay Baptism Fieri non debet, factum valet.

This third rubric also leaves to the discretion of the Minister the choice of Prayers and the number to be used. The following, however, would seem the best, except when through extreme urgency the number must be reduced:-

The Lord's Prayer.

'Almighty and everlasting God.'

'Almighty and immortal God.'

'Almighty and everlasting God, heavenly Father.'

The Prayer of Consecration.

The Formula.

N., I baptize thee, etc.

The Thanksgiving Prayer. 1662.

We yield thee hearty thanks.

The former portion of this Prayer is the same as in the preceding Service; but from the nature of the case the latter part had to be altered in case the child's illness proved fatal.

As the Service ends here somewhat abruptly, it seems appropriate to close with one of the usual Blessings.

\section{THE SERVICE FOR THE RECEPTION OF THE CHILD (SHOULD HE SURVIVE) INTO THE CHURCH.}

From time immemorial the Church has directed that children baptized at home through severe illness should, subsequently, if they recover, be received into the Church. The object of this was:-

1. That there may be a public recognition and certification that the child has been duly baptized.

2. That the sponsors may undertake their obligations.

The Opening Rubric.

1549. And let them not doubt ... to the intent the Priest may examine and try, whether the child be lawfully Baptized or no. And if those that bring any Child to the Church do answe that he is already Baptized; then shall the Priest examine them further.

1604. And let them not doubt ... to the intent that if the Priest or Minister [' the Minister,' 1662] of the same Parish did himself Baptize that child, the Congregation may be certified of the true form of Baptism, by him 
privately before used : Or if the child were baptized by any other lawful Minister, that then the Minister of the Parish where the child was born or Christened, shall examine and try whether the child be lawfully baptized, Or no. In which case, if those that bring any child to the Church, do answer that the same child is aiready baptized; then shall the Minister examine them further, saying.

1662. And let them not doubt ... privately before used : In which case he shall say thus.

The Certification if performed by the Minister present.

I certify you, that according to the due and prescribed order, etc.

The Rubric following.

1662. But ['Or,' 1604] if the child were baptized by any other lawful Minister . . examine them further, saying.

This was the latter part of the 1604 rubric.

\section{inquiries.}

[1]. By whom was this child baptized ?* 1549. Herm. 'Con.'

[2]. Who was present when the [' this' substituted in 1604 for 'the'] child was baptized? 1549. Herm. 'Con.'

And because some things, Essential to this Sacrament, may happen to be omitted through fear or haste in such times of extremity; therefore I demand further of you. 1604.

[3]. With what matter was the child baptized ? 1549.

N.B.-Until 1604 before 'what matter' were the words 'what thing or.'

[4]. With what words was the child baptized? 1549.

In 1549 there were two other inquiries. One after the second question, viz.: "Whether they called upon God for grace and succour in that necessity?' (omitted in 1604), and another after the Pourth, viz.: "Whether they think the Child to be lawfully and perfectly Baptized?' (omitted in 1662).

The Rubric after the Inquiries. 1549. Sar. Man.

The Certification if Baptism performed by another Minister. 1549. Herm. Con.

I certify you that in this case all is well done, and according unto due order, etc. Before 1604, instead of the words 'all is well done' were the words 'ye have done well.'

* The exact wording in 1549 was 'By whom the Child was Baptized?' 
Laver of Regeneration. This corresponds to the expression in Titus iii. 5. 'The washing of regeneration.' The word 'laver,' from the Latin, lavo, 'I wash,' is a vessel containing water for washing. The vessel itself is figuratively used for its purpose, i.e. washing. Cf. 'This cup is the New Testament,' etc. (Luke xxii. 20).

The Gospel, Mark x. 13-16. 1549.

The Address upon it. 1549.

In 1662 the word 'brief' was added before 'exhortation' in the rubric.

Will give unto him the blessing of eternal life. Prior to 1604 it was ' hath given unto him'; and 'make him' was 'made him.'

The Lord's Prayer. 1549.

From 1549 to 1604 there was the following rubric before the Lord's Prayer, 'Here the Minister with the Godfathers and Godmothers shall say.' This was omitted in 1662.

The Thanksgiving Prayer. 1549.

Almighty and everlasting God, heavenly Father, we give thee humble thanks, etc.

Increase this knowledge and confirm this faith. The Apostles once asked the Lord to increase their faith (Luke xvii. 5), and $\mathrm{He}$ replied by showing them that the only sense in which faith can increase is by the conscious exercise of it by its possessor. Confirm this faith, i.e. by providential guidance and spiritual experience.

Prior to 1662 this Prayer came immediately before the Exhortation to the Sponsors.

\section{Rubric before the Interrogatories.}

1549. Then shall they say the Creed; and then the Priest shall demand the name of the child, etc.

1552. Then shall the Priest demand the name of the child, etc.

The Interrogatories. 1549.

The Reception of the Child. 1662 .

The Short Address to the Congregation. 1662.

The Prayer for the Child. 1662.

The Exhortation to the Sponsors. 1549. Infants.

In the Prayer Book of 1549, after the Interrogatories addressed to the sponsors, the Minister was directed to "put the white vesture, commonly called the Chrism, upon the child, saying,'

Take this white vesture for a token of the innocency which, by God's grace, in the holy sacrament of Baptism, is given unto thee, and for a sign whereby thou art admonished, so long as 
thou shalt live, to give thyself to innocency of living; that, after this transitory life, thou mayest be partaker of the life everlasting. Amen.

This investiture of the Chrism was omitted in 1552.

The Rubric before the Conditional Formula of Baptism.

1549. But if they which bring the infants to the Church, do make an uncertain answer to the Priest's questions and say that they cannot tell what they thought, did, or said, in that great fear and trouble of mind : (as oftentimes it chanceth,) then let the Priest Baptize him in form above written, concerning public Baptism, saving that at the dipping of the child in the Font, he shall use this form of words.

1604. But if they which bring the infants to the Church do make such uncertain answers to the Priest's questions, as that it cannot appear that the child was baptized with water, In the Name of the Father, and of the Son, and of the holy Ghost (which are essential parts of Baptism), then let the Priest baptize it in form above written, concerning Public Baptism; saving, etc.

1662. The words 'before appointed for Public Baptism of infants' were substituted for 'above written, concerning Public Baptism.'

The Conditional Formula of Baptism. 1549. Sar. Man.

Conditional Baptism should, of course, never be used hastily but only when, after careful inquiry, it is feared that the child or person has either never been baptized or not properly baptized, that is to say, when the essentials of Baptism, viz. water and the words of institution, were not rightly used.

The earliest mention of a conditional Baptism is in the Statutes of St. Boniface, Archbishop of Mentz, c. 745. 


\section{T'HE MINISTRATION OF BAPTISM TO SUCH AS ARE OF RIPER YEARS, AND ABLE TO ANSWER FOR THEMSELVES}

THIs Office was added at the last revision in 1662, being drawn up by a Committee of Convocation, of three members, of whom Dr. George Griffith, Bishop of St. Asaph, was the chief. The reasons for its introduction are stated in the Preface to the Prayer Book, where it is described as a Service which, although not so necessary when the former Book was compiled, 'yet by the growth of Anabaptism, through the licentiousness of the late times crept in amongst us [the allusion here being to the general neglect of the ordinances of the Church during the Rebellion], is now become necessary, and may be always useful for the Baptizing of Natives in our Plantations, and others converted to the Faith.'

The Service is based upon that for the Baptism of Infants adapted to the case of adults.

The chief points of difference are the following:-

1. The first Exhortation, "Dearly beloved, forasmuch as all men,' etc., recognizes the washing of actual as well as original sin.

2. The Gospel is taken from our Saviour's discourse with Nicodemus (John iii. 1-8) concerning the necessity of the new birth, and supplies the place of Mark x. 13-16.

3. The Exhortation, founded on John iii. 1-8, quotes our Lord's words in Mark xvi. 16, and those of St. Peter in Acts ii. 37-40, and 1 Pet. iii. 21 on the subject of Baptism.

4. The demands (i.e. the questions) are made to the candidates themselves and not to the Godparents, who are spoken of not as 'sureties' but 'witnesses.'

5. The Priest takes each person to be baptized by his right hand and places him conveniently by the font.

6. The Priest is to dip the candidate in the water, or pour water upon him.

7. The Thanksgiving 'We yield (give) thee humble thanks' 
comes after the Lord's Prayer (i.e. after the Baptism, as well as after the address founded on the Gospel, i.e. before the Baptism).

8. The Thanksgiving after the Lord's Prayer used in the Baptism of Infants is omitted altogether.

9. The Addiess to the Godparents ('Forasmuch as this child,' etc.) is altered to suit the case of adults.

10. The Clcsing Exhortation to the newly baptized, 'And as for you, who have now,' which bids them walk answerable to their Christian calling, etc., takes the place of "Ye are to take care that this child.'

The rubrics at the commencement of the service.

These direct not only examination of the candidate but that :

(1) 'Timely notice shall be given to the Bishop, or whom he shall appoint for that purpose, a week before at the least,' to secure due instruction in 'the Principles of the Christian Religion.'

The American rubric runs: 'Timely notices shall be given to the Minister, that so due care may be taken,' etc.

(2) 'They may be exhorted to prepare themselves with prayers and fasting for the receiving of this holy Sacrament.'

Prayer and fasting. The word 'fasting,' together with ' the Table of Days of Fasting or Abstinence,' was added in 1662: it is the only place in the B.C.P. where it is directly enjoined. The discovery, however, that the word 'fasting' has been interpolated into the sacred text in Matt. xvii. 21 ; Mark ix. 29 ; Acts x. 30 ; and 1 Cor. vii. 5, tends to rob this combination of prayer and fasting of much of its scriptural sanction; while the absence of any definition of fasting throughout the B.C.P. leaves the manner of its observance to be determined by the bodily and spiritual circumstances of the candidate for the solemn rite of Holy Baptism.

In the first of the closing rubrics Confirmation is ordered to follow as soon as conveniently may be.

The Closing Rubrics. In the first rubric the declaration of the expediency of Confirmation following speedily upon Adult Baptism, with a view to Holy Communion, forms a clear commentary upon the meaning of the words in the Title 'able to answer for themselves.' This does not mean ability to read or repeat the answers to the questions, but, as in the address to the Godparents in the Public Baptism of Infants, capacity to appreciate the instruction upon the fundamentals of the faith, contained in the Catechism. The addition, in 1662 , to the closing rubric of the Confirmation Office, 'or be 
ready and desirous to be confirmed,' renders it unnecessary for one who has been baptized as an adult to wait for Confirmation before communicating.

In the second rubric the Minister is given discretionary power to decide whether a child brought to be baptized is or is not old enough to answer for himself. The not infrequent presentation of a child oid enough to appreciate the difference between right and wrong, yet not old enough to be deemed spiritually responsible, creates a difficulty for which the B.C.P. makes no provision. On the opus operatum theory of the Sacraments this would be no difficulty, but in view of the general tenour of the Holy Scripture and the Prayer Book itself, it would seem to be wise to defer the Baptism of a child approaching years of discretion, except in case of sickness.

This rubric is carelessly worded. Starting with a reference to the Baptism of children who are not infants, yet too young to answer for themselves, it uses the word 'child' and the adult word 'person' at the close. This was doubtless due to the intention to make provision for the Baptism of an adult in danger, a case not otherwise considered in the B.C.P. 


\title{
A CATECHISM
}

\author{
That is to say, \\ An Instruction to be learned of every \\ person, before he be brought to be confirmed \\ by the Bishop.
}

\section{INTRODUCTORY NOTES.}

IN the English Church prior to 1549 there was no form of religious instruction in dialogue for children or adults.* There was, however, a short explanation of the Lord's Prayer and the Creed which was used in the Medirval Church. But this provision was meagre and unsystematic, and the people knew little about even the essential doctrines of the faith, as is evidenced by the Injunctions issued during the reign of Henry VIII in the years 1536 and 1538 .

The Catechism in its original form did not deal with the Sacraments. It was probably composed by Dean Nowell, although it has been attributed to Poynet, Bishop of Rochester, and Goodrich, Bishop of Ely. The Catechism in the Consultatio may have aided the compilers, here as elsewhere. The part dealing with the Sacraments was composed in response to a request made by the Puritans, and added in 1604 ; it is supposed to have been the work of Dr. Overall, Dean of St. Paul's, afterwards Bishop of Norwich.

Until 1662 the Catechism was inserted in the Order of Confirmation, with the intention that the Bishop should put the questions to the children at the time of Confirmation.

The title of the combined Service was in 1549: 'Confirmation, wherein is contained a Catechism for Children.' In 1604 it was altered into 'The Order of Confirmation, or laying on of hands upon children baptized, and able to render an account of their faith according to the Catechism following.'

After the title there followed several rubrics explaining the purpose of Confirmation. These rubrics were entirely altered

* The first Catechism in English was a translation of one in Herm. Con., 1547. 
in 1662, and in an abridged form converted into an opening address placed at the commencement of the Confirmation Service. In 1604 there was printed at the end of the rubrics the present title of the Catechism, with the single substitution of 'person' for ' child.'

The word 'Catechism' is derived from $\kappa a \tau \eta \chi \chi^{\prime} \omega$, ' ' to sound in the ear, to resound, to instruct by word of mouth ' (see Luke i. 4 ; Acts xviii. 25 ; Matt. xxviii. 19, 20 ; Rom. ii. 18 ; l Cor. xiv. 19), and is therefore specially applicable to instruction by question and answer.

In the Early Church a Catechist was attached to cvery congregation, whose office it was to instruct the Catechumen, i.e. candidate for Holy Baptism, in the first principles of the oracles of God.

In the Church Catechism there are twenty-five questions and answers, and they contain a summary of all those cardinal points of faith and duty which a child 'ought to know and believe to lis soul's health.'

Canon 59 orders catechetical instruction on every Sunday and Holy Day, under pain of 'reproof, suspension, and eventual excommunication.'

\section{Analysis.}

\section{Exposition of the Baptismal Covenant.}

II. The Creed and its Exposition.

III. The Ten Commandments and their Explanation.

IV. The Lord's Prayer and its Explanation.

V. The Doctrine of the Sacraments as to :-

1. Their outward visible signs.

2. Their inward spiritual grace.

3. Their requirements.

\section{EXPOSITION OF THE BAPTISMAL COVENANT.}

The first section contains four questions referring to : (1) The name received; (2) the privileges bestowed; (3) the obligations incurred; and (4) the ratification made.

N. or M.

It is generally supposed that $\mathrm{N}$. stands for Nomen (name), and that M. is a printer's contraction of NN., for Nomina (names) (cf. MSS.).

Godfathers and Godmothers (see Baptismal Service, p. 381).

Sponsorship belongs to the discipline of the Church, and not to the essence of Baptism.

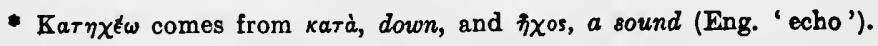


Wherein I was made, i.e. provisionally, or sacramentally. This answer must be read with the answer to the question: 'What is required of persons to be baptized?' Ars.: 'Repentance, etc., and faith, etc.,' promised by their sureties, "which promise, when they come of age, themselves are bound to perform.'

A member oi Christ, i.e. of Christ's mystical Body, the Church in its highest sense (1 Cor. xii. 13, 27 ; Col. i. 18 ; cf. John xv. 1-6). "We are very members incorporate in His mystical Body, which is the blessed company of all faithful people' (Communion Service).

The chlld of God, not merely in the general sense of creation, but in the special sense of adoption (Gal. iii. 26 ; iv. 5 ; cf. Heb. ii. 11).

An inheritor of the kingdom of heaven, i.e. of the present kingdom of grace, and the future kingdom of glory (Rom. viii. 17 ; Gal. iii. 29).

They did promise, etc.

1549. First that I should forsake the devil, etc.

1662. The word 'renounce' was substituted for 'forsake.'

Promise and vow: promise before your fellow-men, vow before God. The three vows here are those of Renunciation, Faith, Obedience.

Renounce is a better word than 'forsake,' as we cannot in this life, through the weakness of our mortal nature, entirely forsake sin; but we can abjure, refuse allegiance to, break off connexion with and proclaim war against it. (Cf. Questions put to Godparents in the Office for Public Baptism.)

All his works, such as pride (1 Tim. iii. 6), presumption, envy, hatred, malice, lying and slandering (John viii. 44 and cf. 1 John iii. 8).

The pomps. 'Pomps' is from $\pi \circ \mu \pi \eta$, a procession, and means ostentatious display, grandeur, empty glory.

Vanity means emptiness, hollowness, and unreality.

Wicked world, i.e. the unregenerate, uninfluenced by the fear of God.

The sinful lusts of the flesh. These are the appetites of the body, unlawfully or unduly indulged in, leading to gluttony, drunkenness, sloth, and unchastity.

All the Articles, i.e. the items or separate clauses of the Creed.

By God's help so I will corresponds to 'I do' in the Confirmation Service.

Called me to this state, etc., i.e. invited me by grace to a condition 


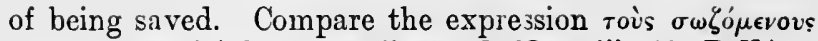
'present participle) (Acts ii. 47, R.V.; xiii. 48, R.V.).

\section{THE CREED AND ITS EXPOSITION.}

1549. Question. Rchearse the Articles of thy belief.

1662. Catechist. Rehearse, etc.

It contains twelve articles, and the words ' $I$ believe' belong to each of them and to every part or single truth contained in them. In the Creed we use the first person singular, not the plural: as in 'The Confession,' 'The Thanksgiving,' etc., because belief must be essentially personal.

\section{Analysis.}

The objects of Belief are:-

1. God the Father,

2. God the Son,

3. Gol the Holy Ghost,

4. The Church and its privileges present and future.

\section{Expository Paraphrase.}

I believe, i.e. accept with all the personal responsibility attaching to a belief in the fact of the existence of God the Father, Almighty Maker of heaven and earth, i.e. of the whole universe.

And I believe in Jesus (Matt. i. 21) Christ; anointed (Acts x. 38) to be Prophet (Luke iv. 18; Acts iii. 22), Priest (Heb. vii. 21), and King (John xviii. 37), His only and eternally begotten Son our Lord, to whom the Father hath delegated all authority during the present economy (Matt. xvii. 5; 1 Cor. xv. 24), Who was conceived by the Holy Ghost (through a secret and inexplicable operation superseding all known natural laws (Matt. i. 20 ; Luke i. 35), Born of the Virgin Mary (Luke ii. 5-7), Suffered under Pontius Pilate, the Roman Governor of Judæa, Was crucified (thus enduring the cruel and ignominious Roman method of putting criminals to death), dead, and buried, He descended into Hell, i.e. Hades, the place of departed spirits, where wicked and righteous in their different abodes alike await the day of judgment (Luke xvi. 23 ; cf. xvi. 22 and xxiii. 43); The third day he rose agaln from the dead, having lain in the tomb (according to our days of the week) the latter part of Friday, the whole of Saturday and the beginning of Sunday; Ho ascended Into heaven, as God and Man, after remaining forty days upon the earth, And sitteth at the right hand of God, the place of highest honour and greatest majesty and glory as our Intercessor (Heb. i. 3 ; vii. 25 ; 1 John ii. 1 ; From thence 
he shall come to judge the quick, i.e. those who shall be alive at His coming, and the dead.

I believe in the Holy Ghost, the Third Person of the Blessed Trinity who, as the Paraclete, applies the redemptive blessings which Christ has procured (John xiv. 26) ; The holy Catholic (i.e. general and universal) Church, which embraces in the widest aspect all the baptized, but in a stricter sense is limited to those who form 'the blessed company of all faithful people'; The Communion of Saints * with (1) God, the Father, Son, and Holy Ghost ( 1 John i. 3,$6 ; 1$ Cor. i. $9 ; 2$ Cor. xiii. 14) ; (2) with each other in prayer and praise and holy converse; (3) and the departed saints in looking forward to the same glorious hope of the appearing of Christ. The Forgiveness of sins, $\uparrow$ granted by God through Christ's meritorious Cross and Passion to those who truly repent and confess their sins (Rom. iii. 25; John i. 9); The Resurrection of the body, $f$ both of the just and the unjust; And the Life everlasting, which for the righteous will be a life of unspeakable happiness, and for the wicked the reverse (John v. 28, 29). Amen, I truly assent to all the foregoing articles.

Notes on the Summary of the Belief.

The Hoiy Ghost, who sanctifieth me by putting good desires into our hearts and giving us grace to carry those desires into good effect. The work of sanctification is progressive.

The elect people of God, i.e. those persons chosen out of the world to be adopted into His family (John xv. 19).

\section{THE TEN COMMANDMENTS AND THEIR EXPLANA- TION.}

The Commandments, or the Decalogue, 'The ten words'.(see Exod. xxxiv. 28 (marg.); and ef. Matt. xix. 18; xxii. $37-40$; Luke $x .27$ ).

1552. The same which God spake in the $x x$. Chapter of Exodus, etc. (vers. 2-17). The version of the Commandments here given is from Cranmer's Bible, called also 'The Great Bible' (1539).

* The saints are members of one family through their union with Christ (Eph. iii. 15); as such, they have a common fellowship with each other, are bound together by common ties, are animated by the same desires, hopes, and aspirations, join together in common acts of worship, and mutually enjoy spiritual convcrse.

$\dagger$ In Acts ii. 38 and xxii. 16, remission of sin is connected with Baptism; but in both instances it is clear that this Sacrament is the sign and seal of a forgiveness granted to faith and repentance.

‡ See Note p. 478. 
Ten Commandments. They are not numbered where recorded (Exod. xx. and Deut. v.), but in Exod. xxxiv. 28 and Deut. iv. 13 they are specified as ten.*

A useful rule of interpreting the Commandments is that:

(1) When any duty is enjoined, the contrary sin is forbidden.

(2) When any sin is forbidden, the contrary duty is enjoined.

The first lour Commandments relate to our duty toward God, and the last six to our duty towards men. In the first four Commandments we are taught :-

(1) To acknowledge God, and God alone, as God.

(2) To avoid idolatry, and the use of images in worshipping God who, as a Spirit, is to be worshipped in spirit and truth.

(3) To honour His Holy Name and Word.

(4) To consecrate one day in seven.

First Commandment. 1549.

But me, A.V. 'Before me,' i.e. 'in my sight,' ' in my very presence,' suggesting the idea that any request to another power as in any sense Divine is flagrant insult to the all-seeing Jehovah.

\section{The Prohibition :-}

(1) Against direct apostasy, i.c. the sin of having or acknowledging any other God.

(2) Against indirect apostasy, i.e. the sin of ascribing all things to fate or chance.

(3) Against virtual apostasy, i.e. the sin of supremely setting the heart upon wealth, pleasure, or any object, aim or desire.

\section{The Implied Duty :-}

(1) To believe in Him, i.e. to trust Him.

(2) To fear Him as a Being of infinite holiness and power.

(3) To love Him with all our heart, with all our mind; with all our soul, and with all our strength.

The Second Commandment. First part 1549; Second part, commencing 'For I the Lord thy God,' added 1552.

\section{The Prohibition :-}

(1) Against direct idolatry, i.e. the sin of making any visible representation of God for the purpose of worship.

* In some ancient writers the commandments are divided three for the first table and seven for the second-the first and second commandments being united into one, and the tenth commandment divided. 
(2) Against indirect idolatry, i.e. the sin of harbouring unworthy conceptions of God.

\section{The Implied Duty :-}

(1) To worship Him in Spirit and in truth (John iv. 23, 24), as He has been pleased to reveal Himself to us in His Word.

(2) To give Him thanks for all temporal and spiritual blessings (cf. Rom. i. $21 ; 1$ Tim. iv. 3).

(3) To put my whole trust in Him, under all the circumstances and conditions of life.

(4) To call upon Him in public and private prayer.

The Third Commandment. First part 1549 ; Second part, commencing 'For the Lord will not,' added 1552.

In vain, i.e. without a proper purpose or for a wrong purpose.

Name of God stands for God Himself or for anything involving His honour.

The Prohibition :-

(1) Against perjury, i.e. the sin of using the Name of God in support of falsehood.

(2) Against profane swearing, i.e. the sin of using God's Name to give point to our angry feelings towards our fellow-men, or in consequence of our misfortunes.

(3) Against blaspheming, i.e. the sin of speaking against God through anger at His dealings with us.

(4) Against rash vows, i.e. the sin of appealing to God's Name in making promises without sufficient or serious forcthought.

(5) Against all irreverence concerning God, and levity and thoughtlessness in regard to holy things.

\section{The Implied Duty :-}

To honour His Holy Name and His Word, i.e. to regard His Name with becoming reverence and awe, as sacred beyond thought, and accept implicitly the revelations which $\mathrm{He}$ has made concerning His Divine will.

The Fourth Commandment. First clause 1549. The rest, commencing from 'Six days shalt thou labour,' added 1552.

Remember implies the earlier statute (cf. Gen. ii. 2, 3 ; Exod. xvi. 23-30; and ancient Babylonian usage). The observance of the sabbath was designed :-

(1) To recall God's rest after the work of Creation.

(2) To commemorate the deliverance of Isracl from Egypt (Deut. v. 15).

(3) To be a sign of perpetual covenant between God and 
the children of Israel (Exod. xxxi. 16, 17 ; Ezek. xx. 12).

(4) To make merciful provision for the recreation of man and beast (Exod. xxiii. 12).

(5) To furnish a type of the heavenly sabbath (Heb. iv. 9).

(6) To be a day in which especially to delight in God (Isa. lviii. 13, 14).

The Underiying Teaching; "To serve Him truly all the days of my life,' as all our days are to be consecrated to God : the sabbath day being specially for rest, worship, holy meditation, and works of mercy and charity; and the remaining six for the strict and conscientious discharge of our earthly duties as service done unto God and with an eye to His glory.

Old Testament Observance of the Sabbath.

It was not kept as a fast, but as a day of rest from all worldly occupations. Desecration of the day was punished with stoning (Exod. xxxi. 14, 15 ; Num. xv. 32-36).

\section{Christian Observance of the Sabbath.}

The alteration of the day was evidently made in Apostolic times, as we read that the Apostles met together on the first day of the week for breaking bread and joining in holy worship (Acts xx. 7 ; 1 Cor. xvi. 1, 2 ; cf. Rev. i. 10). This change was suggested by the fact that the Lord rose from the dead and the Holy Spirit was outpoured on the first day of the week. The command requires the observance of one day in seven, not specifying any particular one.

The Second Division of the Commandments has reference to our duty towards our neighbours (i.e. all men with whom we have to deal), and is summed up in the words, "To love him as myself, and to do to all men, as I would they should do unto me.'

The Fifth Commandment (cf. Eph. vi. 2, 3).

The Duty actuaily named :- to honour parents.*

To love, honour and succour my father and mother.

The Impiied Duty :-to submit to all divinely appointed authority.

(1) To honour and obey the King, and all that are put in authority under him (1 Pet. i. 17).

- We honour our parents (1) by obeying their direct commands (Col. iii. 20) and indirect wishes (Luke ii. 51); (2) by treating them with respect both in manner and word (Deut. xxvii. 16; Exod. xxi. 15, 17; if. 1 Kings ii. 19). 
(2) To submit myself to all my governors, teachers, spiritual pastors (Heb. xiii. 17) and masters.

(3) To order myself lowly and reverently to all my betters (Lev. xix. 32 ; Rom. xii. 10;1 Pet. v. 5).

1549. To honour and obey the King, and his Ministers.

1662. To honour and obey the King, and all that are put in authority under him.

The Sixth Commandment deals with the security of the person.

The Direct Prohibition :-

Not to deprive our fellow-man of life wilfully.

The Indirect Prohibition (Matt. v. 21, 22) :-

(1) To hurt nobody by word nor deed. . . .

(2) To bear no malice nor hatred in our heart, and in fact to avoid all vindictive passions (Eph. iv. 26, 31).

The Implied Duty :-

(1) To cultivate a loving and forgiving spirit (Matt. vii. 14 ; Eph. iv. 32).

(2) To pray for and relieve the wants of our enemies (Matt. v. 44 ; Rom. xii. 20).

(3) To contribute to the necessities of those in need (1 John iii. 17).

(4) To be merciful, even as our Father in heaven is merciful (Luke vi. 36).

The Seventh Commandment upholds the sanctity of family life.

The Direet Prohibition:-

Not to destroy marital relationship 'instituted by God in the time of man's innocency.'

The Indirect Prohibition:-

Not to gratify sensual desires.

The Implied Duty :-

To keep my body in temperance, soberness, and chastity. Matt. v. 27-30, which inculcates purity of thought, should be read as showing the true meaning of this command.

The Eighth Commandment sanctions the possession of property. The Direct Prohibition :-

To keep my hands from picking (i.e. pilfering and petty theft) and stealing.

The Indirect Prohibition :-

To keep from robbery, cheating, and trickery in business, and gambling.

The Impiied Duty :-

To be true and just in all my dealings, usin all honest means to get a livelihood (Eph. iv. 28 ; cf. 1 Tim. v. 8). 
The Ninth Commandment defends character and reputation.

The Direct Prohibition :-

Not to give false evidence against our neighbour, especially in the public Courts.

The Indirect Prohibition :-

(1) To keep my tongue from evil speaking, lying, and slandering; incladin; equivocation exaggeration, and suppression of the truth.

The Implied Duty :-

(1) To keep silence when we cannot speak good of any one, except when silence would be itself a sin (Prov. x. 19; Jas. i. 26).

(2) To avoid uncharitable judgments, and to find no pleasure in detecting the failings of others (Matt. vii. 1).

The Tenth Commandment searches the thoughts and intents of the heart (cf. Rom. vii. 7) and enjoins contentment.

The Direct Prohibition :-

Against covetousness (Luke xii. 15; Eph. v. 3, 5; Col. iii. 5 ; 1 Tim. vi. 10).

Not to covet nor desire other men's goods, in such a way as to wish to deprive them of their possessions, nor to feel envious or discontented.

The Indirect Prohibition :-

Against any immoderate desire and a grasping disposition.

The Implied Duty :-

(1) To learn and labour truly to get mine own living, and,

(2) To do my duty in that state of life into which it shall please (not 'has pleased') God to call me.

1549. But learn and labour truly, etc.

1662. But to learn, etc.

\section{THE LORD'S PRAYER AND ITS EXPLANATION.}

The Question introducing the Lord's Prayer.

1662. 'Catechist' was put above the question.

1549. My good son.

1552. My good child.

\section{The Lord's Prayer.}

Our Lord gave this prayer not merely as a form ('When ye pray say,' Luke xi. 2), but also as a pattern ('After this manner pray ye,' Matt. vi. 9) by which we are to frame our prayers. In the versions given by the two Evangelists there are some variations. Both these differ again from the version in the Prayer Book. The Doxology is not given by St. Luke, and the R.V omits it in St. Matthew's Gospel : it is a liturgical addition. 
In the early days of Christianity this Prayer was concealed from the outside world and reserved as 'the Prayer of the Faith: ful.' As Christianity spread it was recited in the public Services ; and in the Prayer Book is used at least once in every Service.

\section{Expository Analysis}

I. Address, showing :-

(I) Our Redemptive Restoration to Sonship ('Our Father').

(2) Our Brotherhood (' Our Father').

(3) God's Supremacy over the Universe ('In heaven ').

\section{Petitions.}

Their number seven, the covenant number.

1. First Three for God's Glory.

(1) The Hallowing of His Name,

(2) The Coming of His Kingdom,

(3) The Fulfilment of His Will.

2. The Fourth for our Daily, Bodily Needs.

This shows that God is willing and ready to provide for our temporal wants. But while there are three petitions for our spirltual needs, there is only on $\theta$ for our bodlly requirements.

3. The Last Three for our Spiritual Needs.

(1) Forgiveness.

It was the only new petition added by our Lord, the others existing in Jewish devotions. It is also the only one to which a condition is attached (Matt. vi. 14, 15).

(2) Guidance.

For 'Lead us not' the King's Book had 'Let us not be led.' This latter rendering is the more correct. The passage is so translated in the Bishops' Book, 1537.

(3) Deliverance.

\section{Doxology.}

Compare 1 Chron. xxix. 11, 'Thine, 0 Lord, is the greatness, and the power, and the glory ... thine is the kingdom.'

\section{EXPOSITION.}

Our. The use of the plural pronoun rebukes selfish exclusiveness in prayer.

Father. In this invocation we are not bidden to employ some term expressive of the might or majesty of Jehovah, but a parental term, bespeaking the tenderness and love 
of God, and inspiring us with confidence. He is our Father not only by creation, but also by redemption, having given us His only Son to die for us, and bestowed upon us the power to become the sons of God. 'He made us, and is our Father by creation; He preserves us, and is our Father by His providential care; He has in mercy taken us into His family, and is therefore our Father by adoption' (Maldonatus).

In heaven. In one sense God is omnipresent: $\mathrm{He}$ fills heaven and earth. But in another sense heaven is especially His dwelling place - ' the Father's house'-for there His presence is more fully manifested and His glory more fully revealed. The words 'in heaven' are to remind us of the majesty of Him whom. we address.

The Explanation of the Address : .I desire my Lord God our heavenly Father, who is the giver of all goodness.

Hallowed be thy Name. The Name of God is used as an equivalent to God Himself, and here, therefore, it embraces His Being and His Attributes. It stands for all that $\mathrm{He}$ has been pleased to reveal respecting Himself. To hallow God's Name is to treat everything that belongs to Him, His Word, His Sanctuary, and the Sacraments instituted by His Son, with reverence.

Explanation: To send his grace unto me, and to all people; that we may worship him as we ought to do.

Thy kingdom come. The kingdom of God is the spiritual sphere in which His rule is acknowledged. The mission of Christ was to reveal to the world its true character, to exemplify its principles, and to open it to all believers. The duty of the Church in both its corporate and individual capacity is to complete the work which Christ began. In this petition, consequently, we pray in the first instance that His kingdom may come into our hearts, that we may become its loyal subjects, and that the gospel of His kingdom may be spread throughout the world. In the next instance we pray that God will hasten the time when our Saviour shall return and 'the kingdoms of this world shall become the kingdoms of our Lord and of His Christ' (Rev. xi. 15 ; cf. xxii. 20).

Explanation: That we may serve him as we ought to do. Thy will be done in earth, as it is in heaven.

Matt. vi. 10, 'In earth as it is in heaven.'

Luke xi. 2, 'As in heaven, so in earth.' Some MSS. omit this phrase in St. Luke.

We pray here that God's revealed will may be studied, 
loved and obeyed on earth as it is in heaven; i.e. as by the angels whose wills are voluntarily conformed to God's will.

Explanation: That we may obey him as we ought to do. Give us this day our dally bread.

Our Lord bids us to pray for the daily necessities of life, not for superabundance, or needless luxuries, or accumulated supplies.

It has been thought by some that this petition refers also to spiritual needs.

Our daily bread (

The Greek word 'ं $\pi$ เov́rıs thus translated 'daily,' is not found anywhere save in the Lord's Prayer (Matt. vi. 11 ; Luke xi. 3). Its meaning, therefore, cannot be decided by general usage, and has occasioned difficulty.* The A.V. 'daily' is retained in the text of R.V. with the marginal note, 'Gr. for the coming day.' But the Greek is not 'for the coming day,' but, on this derivation, 'the coming bread.' Moreover, the plain meaning of 'the coming day' is 'to-morrow,' and to pray for the bread for 'to-morrow' is curiously inconsistent with the thrice-given advice following 'to take no heed' (Matt. vi. 25, 28, 31). 'Jerome states that the 'Gospel of the Hebrews' had the Hebrew word for "to-morrow' here. Some early Fathers translate 'coming,' finding in the 'coming bread' an allusion to spiritual bread. + This is ruled out by the tenour of the whole prayer: there is little or no significance in 'give us this day the bread which is to come.'

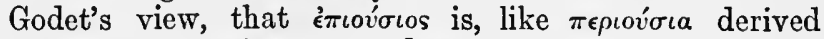
from ovvia = existence, and signifies 'sufficient,' as contrasted with 'superfluous' ( $\pi$ ep to be desired. Liddell and Scott give this same rendering, but derive the word from ${ }^{\prime} \pi \epsilon \iota \mu \iota=$ to go (or come) to. The Vulg. ' Panem supersubstantialem,' literal rendering

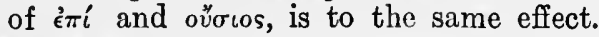

The Explanation: That he will send us all things that be needful both for our souls and bodies. The reference to 'souls' as well as 'bodies' is anticipatory of the following petitions.

And forgive us our trespasses, etc.

Matt. vi. 12, 'And forgive us our debts (rà ó $\phi \epsilon \iota \lambda \eta \mu a ́ \tau a)$

- Vide Grimm, 'Greek-English Lexicon of the New Testament,' revised by J. H. Thayer.

+ Vide G. F. Maclear, 'A Class-Book of the Catechism,' etc. (J892), p. 132. 
as we forgive ['as we also have forgiven,' R.V.] our debtors.'

Luke xi. 4, 'And forgive us our sins (áraptias)' (we are justified in so praying), ' for we [' we ourselves,' R.V.] also forgive every one that is indebted to us.'

'The word 'trespass' ( $\pi \alpha \rho \alpha \tau \omega \dot{\mu} \mu \alpha \tau u)$ is used in Matt. vi. 14, 15. The three ideas of sin suggested by these words are robbing God, missing the mark, and going astray.

This is the only conditional petition; we are solemnly taught that God's forgiveness knows no limits but those imposed by our own unwillingness to forgive.

Our forgiving others is not the cause, however, but the condition of our being forgiven by God (Mark xi. 25, 26; cf. Matt. xviii. 21-35 ; Eph. iv. 32). This is the only petition upon which our Lord comments (Matt. vi. 14, 15).

The Explanation : And that he will be merciful unto us, and forgive us our sins.

And lead ('bring,' R.V.) us not into temptation.

There are two senses in which the word 'temptation' ( $\pi \epsilon \iota \rho a \sigma \mu o ́ s)$ is used, viz. :-

(1) In a good sense, as when God is said to put men to the proof for their spiritual benefit (Gen. xxii. 1,2 ; Deut. viii. 2 ; xiii. 3 ; Job i. $8-12$; ii. $1-7 ; 2$ Cor. xii. 7 ).

(2) In a bad sense, as when Satan puts men to the test seeking their seduction and ruin (1 Thess. iii. 5). The petition, therefore, may mean :-

(1) Suffer us not to be led into positions of temptation, where we may be solicited to do evil and fall, but rather deliver us from the evil one who tempts us.

(2) Allow us not to be tempted beyond our power, as a punishment for our sins.

(3) Lead us not into trials, even when necessary for discipline, without Thy presence going with us and Thy grace being given to us (1 Cor. x. 13).

(4) Keep us from presumptuously running into temptation.

The Explanation : It will please him to save and defend us in all dangers ghostly and bodily.

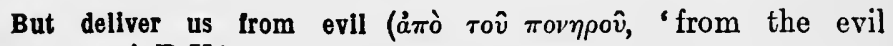
one,' R.V.).

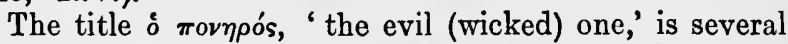
times applied to the tempter (Matt. xiii. 19; John xvii. 15 ; Eph. vi. 16; 1 John iii. 12 ; v. 18); but it is 
possible that the phrase is neuter, and may be rendered impersonally as in A.V.

This and the former clause are closely allied, and the conjunction 'but' which connects them together may mean either 'but if thou dost, then,' or 'nay rather.'

In this petition we pray that we may not be overcome by 'Satan's arts, snares, and powers'; but that in all our conflicts with evil God will keep us from falling into $\sin$.

The last two clauses (perhaps better regarded as one) form a fitting conclusion to the prayer, and lead the mind to think of the future kingdom of glory where it can alone be perfectly realized.

The Explanation : That he will keep us from all sin and wickedness, and from our ghostly enemy, and from everlasting death.

[The phrase 'everlasting death,' as well as that of 'eternal death,' is not found in Scripture, but has been formed as the opposite to 'everlasting life.']

Amen, a Hebrew word implying strong assent.. It denotes our confidence that our petitions are accepted, and that the answer is certain.

The Explanation: And this I trust he will do of his mercy and goodness, through our Lord Jesus Christ. And therefore I say, Amen, So be it.

\section{THE DOCTRINE OF THE SACRAMENTS.}

The second part of the Catechism was added after the Hampton Court Conference of 1604 , in response to a request made by the Puritans for some explanation of the Sacraments. At the Savoy Conference (1661) the Puritans, though they suggested additions, found no fault with the doctrine, as the following remark will show: "In the general we observe that the doctrine of the Sacraments which was added upon the Conference at Hampton Court, is much more fully and particularly delivered than the other parts of the Catechism, in short, answers fitted to the memories of children.'*

The word 'Sacrament' is nowhere found in the Scriptures, but it is supposed to have been adopted into the language of the Church from the 'Sacramentum' of the Romans, the oath taken by the soldiers whereby they bound themselves to obey their commander. Hence the 'Sacramentum' came to signify

* Vide Cardwell, 'History of England,' p. 23 (Oxford, 1841), quoted by Blakeney, 
a solemn engagement or ceremony which binds or imposes obligation. With this thought in view, the term 'Sacrament' was used in connexion with Baptism and the Lord's Supper, because at the former believers were enlisted as soldiers and servants of Christ, and at the latter they renewed and ratified their obligations. The two Sacraments thus symbolize our entry into the Christian life, and our sustenance therein. It is a mistake to describe them as extending the work of Christ. They are rather a channel by which the spiritual benefits of Christ's death and Passion are conveyed.

\section{The Analysis.}

I. The Sacraments generally.
1. Number.
2. Nature.
3. Parts.

II. The Sacrament of Baptism.
1. The outward sign.
2. The inward spiritual grace.
3. The requirements.
4. Infant Baptism.

\section{The Sacrament of the Lord's Supper.}
1. The objects.
2. The outward part or sign.
3. The inward part.
4. The benefits.
5. The requirements.

Q. How many Sacraments hath Christ ordained in his Church ? $A$. Two only, as generally necessary to salvation, that is to say, Baptism, and the Supper of the Lord.

These are the only two Sacraments that are mentioned in the New Testament as ordained by Christ. The Romish Church adds the following five, viz.: Confirmation, Penance, Orders, Matrimony, and Extreme Unction. But Penance and Extreme Unction are not even ordinances of the Church, having arisen from 'the corrupt following of the Apostles' ; Orders and Matrimony are only 'states of life allowed in the Scriptures;' and Confirmation was not 'ordained of Christ' (vide Art. XXV).

Although the Church of Rome insists upon seven Sacraments, we cannot find any mention of this number in the writings of the Fathers. 'Peter Lombard is said to have first devised it in the twelfth century, and from him it was adopted generally by the Schoolmen. It was laid down with authority in a decree 
to the Armenians, sent from the Council of Florence, 1439, which runs only in the name of Pope Eugenius. It was then confirmed by the Provincial Council of Lens, otherwise called the Council. of Paris, 1528 A.D. ; after that, by the Council of Trent 1547 A.D. It finally stands as part of the Creed of Pope Pius IV.' *

The expression, 'as generally necessary to salvation,' does not mean that they are universally, and In all cases absolutely necessary (for then none could be saved without receiving them); but that as a general rule (allowing for exceptions, e.g. the thief on the cross) they are requisite. This interpretation harmonizes with the following words in the Second Exhortation in the Office of Adult Baptism: "Whereby ye may pereeive the great necessity of this Sacrament, where It may be had ' ; and also with the rubric in the Communion of the Sick, 'But if any by reason of extremity of sickness,' etc.

As applicable to all sorts and conditions of men, they are markedly distinguished from all the other five so-called Sacraments.

Q. What meanest thou by this word Sacrament?

A. I mean an outward and visible sign of an inward and spirigiven unto us, ordained by Christ himself, tual grace, as $\left\{\begin{array}{l}\text { a means whereby we receive the same } \\ \text { [viz. the inward spiritual grace], and } \\ \text { a pledge to assure us thereof. }\end{array}\right.$

The meaning of this answer largely depends upon the punctuation.

In accordance with the Prayer Book as now printed, the frrst comma comes after the words 'given unto us.' If this be the right punctuation, it sigrifies that it is not the sign but the grace which is 'given unto us,' implying that grace is absolutely tied to the Sacrament. But according to the original and authoritative editions of the Prayer Book, the first comma comes after the word 'grace.' $\uparrow$ The interpretation then would be that it

*Vide 'Exposition of tho XXXIX Articles,' 8th edit., Harold Browne, p. 500 .

† "“'The true text" (i.e. the comma af ter the word 'grace') is uniformly found not only in the Annexed Book, and in all tho 'Sealed Books,' but the same reading is found in every Prayer Book which has the slightest pretension to an official eharacter, as in the earliest text, viz. the Letters Patent of King James, as given in both editions of Rymer's 'Fœdera'; the two editions of 1603 (O.S.), which were the earliest printed containing this part of the Catechism; in 'the Durham Book' of 1619, now in Bishop Cosin's Library, marked 'D. iii. 5 '; in 'Sancroft's Prayer-Book,' now in the Bodleian (dated 1634), which was used by the Committee for preparing the Revision of 1661 ; also in tho Black Letter Book of 1636 
is not the grace, but only the sign, that is given unto us. This is proved to be the correct punctuation by Dean Durel's contemporary Latin version: signum gratice quod datur.

Given unto us. These underlined words exclude the idea that the Lord's Supper is a sacrifce, i.e. a thing given by man to God. A Sacrament is essentially a thing given by God to man.

A 'pledge' surpasses a 'sign' in that it furnishes the further thought of security that the promise will be kept. In the Bible we find that God has in various ages condescended to use material things as signs and pledges; e.g. the rainbow, Gen. ix. 12-17; circumcision, Gen. xvii. 9-14; cf. Rom. iv. 11 ; the shadow on Ahaz's dial, 2 Kings xx. 8-11; and even as means, e.g. the brazen serpent, Num. xxi. 8,9 ; the clay and the washing, John ix. 6,7 ; cf. also Mark vii. $32-35$.

Q. How many parts are there in a Sacrament?

$A$. Two; the outward visible sign; and the inward spiritual grace.

It is important to lay stress upon the two parts in a Sacrament ; for the doctrine of Transubstantiation, i.e. that the bread and wine are converted into the actual body and blood of Christ, or any conception which involves a localized objective presence in the consecrated elements, reduces the two parts to one, for it 'overthroweth the nature of a Sacrament' (Art. XXVIII).

The outward visible sign. This is sometimes called the 'matter and the form,' and sometimes 'the element.'

The inward spiritual grace, i.e. the spiritual benefits which we receive through God's favour resting upon us, such as remission of sins in Baptism, and redemption in Holy Communion.

There is no virtue or efficacy in the consecrated elements themselves, except as regarded in connexion with their Sacramental use. Faith and a right disposition of heart on the part of the recipient are the essential means by which blessing is received. Q. What is the outward visible sign or form in Baptism ? $A$. Water: wherein the person is baptized

In the Name of the Father, and of the Son, and of the Holy Ghost.

Water is an emblem of cleansing and purification. Ablutions

(photo-zincographed by Government), in which Convocation 'marked up' all their alterations in 1661. It is found also in the MS. annexed to the Irish Act of Uniformity (17 \& 18 Car. II, c. 6, Ireland); in the Scotch Liturgy of 1637; and in the Manx translation made by Bishop Phillips in 1610.' 'The Statutory Prayer Book,' by J. T. Tomlinson and Dr. C. H. H. Wright, Editors' Preface, pp. vii., viii. 
were familiar to all nations from the earliest times for cercmonial purification. Amonr the Jews similar lustrations were used (Gen. xxxv. 2; Exod. xix. 10; 2 Chron. iv. 6). At a later time these 'divers washings' (Heb. ix. 10) were multiplied, and the baptizing of proselytes became an established practice, so that John the Baptist introduced no new custom when he preached a baptism of repentance. Our Lord, to fulfil all righteousness, accepted baptism at his hands (Matt.iii. 15), and directed His own disciples to baptize (John iii. 22 ; iv. 1,2 ).*

$Q$. What is the inward and spiritual grace?

A. A death unto sin, and a new birth unto righteousness: for being by nature born in sin (Ps. li. 5; Rom. v. 12), and the children of wrath (Eph. ii 3), we are herehy (i.e. by this spiritual change) made the children of grace.

The children of grace is a phrase which does not orcur in Scripture. It means that baptized persons are brought under Divine favour, and are recipients of spiritual blessing. 'Hereby' (hac ratione in Durel) should be carefully contrasted with the 'wherein' of the second answer in the Catechis n.

$Q$. What is required of persons to be baptized?

A. Repentance, whereby they forsalie sin; and faith, whereby they stedfastly believe the promises of God, made to them in that Sacriment.

'Repentance and faith' are necessary for a due reception of Baptism (Luke xxiv. 47 ; Mark xvi. 16).

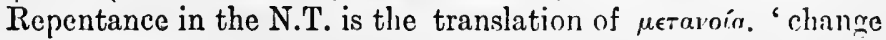
of mind,' ' mind' being used in its fullest sense. including the will and emotions as well as the reason-in fact, the whole man. The English phrase 'to change the mind' is used in a similarly inclusive sense, connoting both the conviction that the former course is wrong, and the resultant intention to enter upon a new one. Such a change necessarily involves (1) altering of mind, (2) sorrow for error discovered, (3) purpose to amend, each alike indispensable for 'repentance to salvation' (2 Cor. vii. 8-11; contrast the sorrow of Peter and Judas).

Faith is personal trust in a personal being. Faith in God is attained by acceptance of the revelation of Himself given in the Holy Scriptures and in the Universe (Heb. xi. 6; cf. Acts xiv. 17 ; xvii. 27 ; Rom. i. 20). Heb. xi. 1 (see R.V.) rather describes the value of faith than defines it. $\dagger$

* For questions concerning the manner and matt er of Baptism, see Introduction to Baptismal Office, pp. $370 \mathrm{ff}$.

$\dagger$ The Gospel according to St. John, though written avowedly to produce

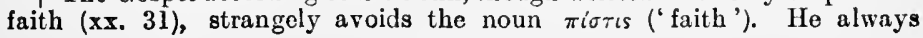


'The promises of God made to us' in Baptism, are :-

(1) The forgiveness of sins (Acts ii. 38; xxii. 16).

(2) The quickening and renewing power of the Holy Spirit (John iii. 5-8; Tit. iii. 5).

(3) Everlasting life (Mark xvi. 16).*

Q. Why then are Infants baptized, when by reason of their tender age they cannot perform them?

$A$. Because they promise them both (i.e. repentance and faith) by their sureties; which promise, when they come to age (i.e. the age of understanding or discretion), themselves are bound to perform.

1604. Yes; they do perform them by their Sureties, who promise and vow them both in their names; which when they come to age, themselves are bound to perform.

1662. Altered to its present form.

The arguments for Infant Baptism are: (1) the analogy of circumcision under the Old Covenant; $(2)$ inference from the teaching of our Lord; (3) the Apostolic practice of baptizing 'households' ; (4) the custom of the Primitive Church; and (5) the propriety of the case (see Office of Baptism, p. 371).

$Q$. Why was the Sacrament of the Lord's Supper ordained?

$A$. For the continual remembrance (Luke xxii. $19 ; 1$ Cor. xi.

$24,25)$

(1) of the sacrifice of the death of Christ, and

(2) of the benefits which we receive thereby.

In remembrance of means simply 'in memory of,' i.e. it is the remembrance of a finished sacrifice, and in no sense can it be said to perpetuate or re-present it. The Holy Communion is not a memorial sacrifice but a memorial service.

The sacriffee of the death. Genitive of quality, or more correctly, of apposition. The phrase means 'the sacrifice which consisted in the death' (Matt. xvi. 21 ; John iii. 14, 15; x. 11, 15 ; Heb. ix. 26).

1604. And the benefits.

1662. And of the benefits.

The addition of the preposition 'of' prevents any misapprehension of the grammatical structure and meaning of the sentence Q. What is the outward part or sign of the Lord's Supper ?

employs the verb, $\pi \iota \sigma \tau \epsilon \dot{v} \epsilon \iota \nu$ with the preposition $\epsilon^{\prime} \nu$, for what we term ' having faith,' distinguishing it from 'having bare assent,' for which he uses the same verb without the preposition (contrast $v v .30$ and 31 of John viii. R.V.).

- The elosing part of ch. xvi. of St. Mark's Gospel in which ver. 16 occurs is marked in the R.V. as of somewhat doubtful authority, not being fourd in 'the two oldest Greek Manuseripts and some other authorities.' 
A. Bread and wine, which the Lord hath commanded to be received.

In all four accounts of the Institution of the Lord's Supper both the bread and wine are expressly mentioned as being taken and received by those present. Hence there is no justification for withholding the cup from the laity, the prastice of the Church of Rome.

Q. What is the inward part, or thing signified?

$A$. The body and blood of Christ, which are verily and indeed taken and received by the faithful in the Lord's Supper.

The Body and Blood of Christ are taken and received 'only after an heavenly and spiritual manner' (Art. XXVIII). Christ is present by the Spirit whom He has sent to apply to 'His people the blessings of redemption, secured by His atoning Sacrifice. Hence to take and receive the Body and Blood of Christ, is to receive the grace and benefits procured by the offering up of His Body once given and His Blood once shed for $\sin .^{*}$

In order to prevent misinterpretation the Irish B.C.P. adds the following $Q$. and $A$.

Q. After what manner are the Body and Blood of Christ taken and received in the Lord's Supper?

$A$. Only after a heavenly and spiritual manner; and the mean whereby they are taken and received is Faith.

By the use of the ipsissima verba of Article XXVIII, the Irish Book has avoided a!l suspirion of doctrinal modification.

These blessings arc only received 'by the faithful,' and the means by which they are received is Faith. 'Thus in the words of delivery of the Bread, in the Communion Scrvice, the Minister says, "Take and eat this in remembrance that Christ died for thee, and feed on Him in thy heart by faith with thanksgiving.' Hence 'the wicked and such as be void of a lively faith,' though they receive the elements of the Sacrament, 'yet in no wise are they partakers of Christ' (see Art. XXIX).

Q. What are the benefits whereof we are partakers thereby? $\boldsymbol{A}$. The strengthening and refreshing of our souls by the body and blood of Christ, as our bodies are by the bread and wine.

The actual benefits are :-

(1) The assurance of forgiveness and reconciliation.

(2) Union with Christ.

(3) Fellowship with His mystical Body the Church.

(4) Pledge of His return: ' till $\mathrm{He}$ come.'

(5) Anticipation of future happiness.

* For examination of later theories respecting this $Q$. and $A$. see p. 276. 
The appropriation of these benefits constitutes 'the strengthening and refreshing of our souls.'

$Q$. What is required of them who come to the Lord's Supper?

$A$. To examine themselves (1 Cor. xi. 28-31)

whether they $\left\{\begin{array}{l}\text { repent them truly of their former sins, } \\ \text { - stedfastly purposing to lead a now life ; } \\ \text { have a lively faith in God's mercy through Christ, } \\ \text { with a thinkful remembrance of His death; and } \\ \text { be in charity with all men. }\end{array}\right.$

The subjects of this examination are stated in the answer to be three in number: (1) repentance, including amendment; (2) faith leading to gratitude; and (3) love.

\section{Rubrics at the End of the Catechism.}

First Rubric until 1662 stood at the end of the Office for Confirmation.

1549. The Curate of every Parish, once in six weeks at the least, upon warning by him given, shall upon some Sunday or holy day, half an hour before Evensong, openly in the Church instruct and examine so many Children of his Parish sent unto him, as the time will serve, and, as he shall think convenient, in some part of the Catechism.

1552. The Curate of every Parish, or some other at his appointment, shall diligently upon Sundays and holy-days, half an hour before Evensong, openly in the Church instruct and examine so many Children of his parish sent unto him as the time will serve, and as he, etc.

1662. The Curate of every Parish shall diligently upon Sundays and Holy days, after the Second Lesson at Evening Prayer, openly in the Church, etc.

The almost universal institution of Sunday schools has somewhat, but not entirely, fulfilled the spirit of this requirement.

\section{Second Rubric.}

1549. At the end of the Confirmation Service.

1604. Placed in its present position.

\section{Third Rubric.}

1549. So soon as the Children can say in their mother tongue the articles of the faith, the Lord's prayer, the ten Commandments, and can also answer to such questions of this short Catechism, as the Bishop, (or such as he shall appoint) shall by his discretion appose [examine] them in ; then shall they be brought to the Bishop by ore that shall be his godfather, or godmother, that every child may have a witness of his Confirmation. 
1662. So soon as Children are come to a competent age, and can say, in their Mother tongue, the Creed, the Lord's Prayer, and the ten Commandments; and also can answer to the other questions of this short Catechism; they shall be brought to the Bishop. And every one shall have a.Godfather, or a Godmother, as a witness of their Confirmation.

Fourth Rubric (first part).

1549. It stood at the end of the Office for Confirmation.

1549. And whensoever the Bishop shall give knowledge for children to be brought afore him to any convenient place, for their Confirmation; then shall the Curate of every Parish either bring, or send in writing, the numes of all those children of his Parish, which can say the Articles of their faith, the Lord's prayer, and the x. Commandments, and also how many of them can answer to the other questions contained in this Catechism.

1662. And whensoever the Bishop shall give knowledge for Children to be brought unto him for their Confirmation, the Curate of every Parish shall either bring, or send in writing, with his hand subscribed thereunto, the names of all such persons with his Parish, as he shall think fit to be presented to the Bishop to be confirmed.

1662. Placed in its present position.

Fourth Rubric (second part).

1549. And the Bishop shall confirm them on this wise.

1662. And, if the Bishop approve of them, he shall confirm them in manner following. 


\section{THE ORDER OF CONFIRMATION}

\section{A HISTORY OF CONFIRMATION.*}

Few Services in the Prayer Book indicate more clearly the Evangelical orig nality of the Reformers. A study of the strange history of the Confirmation rite reveals in a marked degree the extraordinary tendency of the human mind to depart from the simplicity of spiritual religion. This history may be divided into four sections.

1. The germ of our Confirmation Service was the action of the Apostles in Acts viii. 15-17 and xix. 6, from which we gather that there was in the Apostolic Church an ordinance, or ceremony, or service which consisted in (1) the laying on of hands, (2) by a distinctively Apostolic personage, (3) on the heads of those who had been previously baptized, (4) with prayer for the reception of the Holy Ghost. Heb. vi. 2 appears to indicate that this rite was to take its place amongst the permanent institutions of the Church, and in the opinion of John Calvin is ample proof of the Apostolic origin of the rite of Confirmation.

2. Two or three centuries later the rite of Confirmation was firmly established in the post-Apostolic Church of three continents. Tertullian in his Treatise on Baptism, Cyprian in his Letter to Jubaianus, Jerome in his Treatise against the Luciferians, and Augustine in his work on the Trinity, all speak of the practice of Confirmation, of which the outstanding features were the imposition of hands, the invocation of the Holy Ghost, and prayer.

3. The way to the third stage, the Mediæval, was prepared by an idea which originated at some unknown but certainly very early date that Confirmation was the chrisma mentioned in 1 John ii. 20, 27, and the 'Seal' in 2 Cor. i. 21,22 and Eph. i. 13 ; and in consequence the ritual act of anointing with consecrated oil was introduced, to signify the sacerdotal seal upon the baptized as the outward and visible sign of the invisible anointing of the Holy Ghost. $\dagger$ The Occidental mind,

* Sce Dyson Hague on Confirmation (Elliot Stock).

$\uparrow$ This was unquestionably developed in the days of Tertullian; and in the age of Cyprian, say 250 A.D., was described as a sacrament (72 rrd Epistle). 
prone to literalize the metaphorical conceptions of the Oriental soon transformed this rite into an elaborate ceremony which tended to obscure the original idea of Confirmation altogether. With the increasing supernatural powers with which mystic Mediævalism invested the Bishop and the Priest, the Bishop claimed, as God's vicegerent, to have the power of imparting the Holy Ghost both to the oil by consecration and to the confirmee by the manual act.*

4. When the compilers of the first and second Prayer Books had to face the reconstruction of the Confirmation Service, they were confronted by the fact that the Anglo-Roman Service was little more than what John Wycliffe had declared in the "Trialogus' to be a piece of pompous mummery. $\dagger$ They saw that it was not a Confirmation Service in the proper sense of the word. Instead of the laying-on of hands with prayer and the profession of faith on the part of a carefully instructed candidate, there was naught but a pontifical ceremony performed upon little children, and consisting in signings of the cross, anointings, and other ritual acts. But of our modern Church idea of Confirmation as a solemn public profession of faith and a solemn layingon of hands of the Bishop with prayer, there was not a trace. +

The work of the Reformers, then, was not only destructive but constructive. They determined to revert, as in other Offices, to the practice of the Apostles and the primitive Church, and completely abandoned the Mediæval theory that grace was conferred by Episcopal manual obsignation without regard to the ratification and confirmation of their baptismal vows by the candidates,§ maling the public personal profession of faith a salient feature of the rite. Thus they laid down as a fundamental principle of the Church of England Confirmation Service, that none hereafter shall be confirmed but such as can say in their mother tongue the Articles of the Faith, and shall answer such questions of the Catechism as the Bishop shall 'appose them in,' in order that children come to years of discretion may themselves of their own consent openly before the Church confess their faith and promise by the grace of God to observe and keep their confession.

* See Foye's 'Romish Rites,' pp. 143-150, and the Roman Pontifical, 3rd part-on the Benediction of the Oils. The language is almost incredible.

$\dagger$ Tho student must remember that there was no difference essentially in the Service in the Roman Chureh and the Service in the Angliean, for the Anglican was Roman until 1549-1552.

$\ddagger$ See Dyson Hague's 'The Protestantism of the Prayer Book,' p. 96, and tho authorities there quoted, espeeially Bp. Jewel (Parker Soc. ii. 1126).

$\S$ See 'Tridentine Catechism' ii. 3-20.

II Some have recently asserted that not until 1662 did the Church of 
The Service of 1549 is the basis of our present Conf mation Service, rendered more perfect in 1552, and completed in 1662 . The litu gical Reformation of 1549 swept away the essential featuses of the Anglo-Roman Service of Confi: mation, acco ding to which the substance of the Service consisted in the anointing with oil ; according to the teaching of the Chu ch of England, the substance of the Service consists in the laying-on of hands by the Bishop on those who have not only been baptized, but have received spiritual preparation rendering them competent to receive the rite.*

The word 'Hereafter' (' none hereafter should be confirmed, but such,' etc.) emphasizes tlis important depaiture from Mediævalism. For many centuries the Confizmation Service was characterized by ignorance on the part of those who received, and those who witnessed, for the whole Service was in Latin; of incompetence, as previous instruction was impossible when the majoity of the recipients were either infants or at least very young children. Since that time, the characteristics of the Confirmation Service of the Church of England have been intelligence, for the Service is now in English, and is spiritual and simple ; and of competency, for no one can be confilmed now in the Church of England unless he has come to a competent age, has been thoroughly instructed, and is spiritually fit to be presented for Confirmation. $\dagger$

\section{CHANGES MADE BY THE REFORMERS.}

\section{The chrism and the sign of the cross were no longer to be} used.

England oblige a candidato to eonfirm or ratify the Baptismal vows, but in 1549 the Rubrie explicitly declared the necessity of such a confession of faith, though tho form was not added to the Service until the last revision

* See Gasquet's 'Edw. VI B.C,P.,' p. 228.

† For fuller details of the historieal aspect of the subject, see Kurtz's 'Chureh History,' 1-119; Robertson's 'History of the Christian Chureh, 1-233; Bungener's 'History of the Couneil of Trent,' p. 163; and the able artiele by Dean Plumptre in Smith's 'Dietionary of Christian Antiquities,' 1-425. The statement of Daniel in his work on the Prayer Book, that in the Medirval English Chureh the rite was not administered in the ease of ehildren till they had reached seren years of age, needs eosrection. As a matter of fact, Confirmation in the Roman Servieo (and therefore, of eourse, in the English Church) was in theory a Service primarily for infants, and it was on account of the Bishops not being able to visit every part of the diocese at once that the Dioceses of Woreester and Chiehes. ter, for examplo, enacted that the Confirmation should take place within one year, Exeter within three years, Sarum within five years. The pressure of Protestantism began to be felt at the time of the Council of Trent, and so it was declared that it may be advisablo to delay Confirmation till the ehild was seven, and even twelve. ('Trent Catechism', ii. 3-17.) 
2. The rite was not to be administered until the baptized had come to years of discretion.

3. The Bishop was to lay his hands on each candidate instead of merely extending his hands towards all who were piesented for Confirmation.

Before 1662 the Catechism was included in the Order for Confirmation.

The Church of England directs us to view this ordinance as :-

1. The occasion on which the candidate confirms and ratifies the promises made for him at Baptism.

2. The means of being confirmed and strengthered by the Holy Ghost the Comforter.

\section{POINTS TO BE BORNE IN MIND RESPECTING CONFIRMATION.}

\section{Why is Confirmation not a Sacrament?}

It is not a rite ordained by Christ, or even by the Apostles.

\section{What are its two sides?}

(1) A public avowal on the part of the candidate that he will be true to the Baptismal pledge.

(2) A solemn calling down of blessing from God, whose good will is signified by the laying-on of the Bishop's hands.

\section{How far is it right to associate the rite of Confirmation with} Acts viii. 14-17 ?

(1) Only with much caution, because-

(i The gifts received by laying-on of the Apostles' hands were extraordinary gifts (miracies, prophecy) which have long ceased.

(ii) Spiritual gifts are bestowed according to the measure of the recipient's faith and of Christ's bestowal (Rom. xii. 6, etc. ; 1 Cor. xii. 4, etc.).

(2) However, it is right to follow the example of the Apostles in laying-on of hands as an appropriate manner in which to invoke God's b'essing. 


\section{A TABLE COMPARING 'THE ORDER OF CONFIRMATION,' 1662, WITH 'CONFIRMATION,' 1549.}

1662.

The Order of Confirmation, or laying-on of hands upon those that are baptized and come to years of discretion.

1. The Preface: "To the end that.'

2. The Ratification of Baptismal Vows: 'Do ye,' etc.

3. The Suffrages : ' Our help is.'

4. Prayer for Spiritual Gifts and Graces : 'Almighty and everliving God, who hast vouch. safed.'

$5 a$. Imposition of hands.

5b. Prayer : 'Defend, O Lord.'

6. The Mutual Salutation : "The Lord be.'

7*. The Lord's Prayer.

8. The Collect: "Almighty and everliving God, who makest.'

9. Prayer for sanctification and protection: ' $\mathrm{O}$ Almighty Lord.'

10. Benediction.
1549.

Confirmation, wherein is contained a Catechism for chiidren.

1. Rubrics commencing, 'To the end that.'**

$$
\text { A Catechism, }
$$

That is to say,

An Instruction to be learncd of every child, before he be brought to be confirmed of the Bishop.

The Catechism, ending with the Dosire.

The Bishop examining tho Candidates.

\section{Confirmation.}

3. The Suffrages : 'Our help is.'

6. The Mutual Salutation : 'The Lord bo.'

4. Prayer for Spiritual Gifts and Graces : "Almighty and everliving.'

The Prayer that God may sign: 'Sign them (O Lord).'

The Act and Formula :

(a) Of signing on the forehend with the sign of the cross.

5 . (b) Of imposition of hands.

cb. Versicles: "Tho Peace of the Lord abide with you.' $\dagger$

8. Tho Collect.

10. The Benediction.

- From thesc rubrics, 'The Preface' - To the end that,' was abridged.

+ This was sald by the Bishop, not to ench child severally, but to all after he hul laid his hands on every clild one aftcr another.'

\section{ANALYSIS AND HISTORICAL NOTES.}

Preliminary Rubric. 1662

I. Preface, or Address to the Congregation. 1662 Abridged from rubrics of 1549 . 
II. The Candidates' Ratification of their Baptismal vows.

1. The Solemn Stipulation, or Vow. 1662. Adapted from Herm. 'Con.'

2. The Versicles, or Acts of Praise.

First, second, third and fou!th Versicles. 1549.

Fifth and sixth Versicles. 1552.

3. Prayer of Invocation. 1549, altered slightly 1552.

Almighty and everliving God, who hast vouchsafed, etc.

III. Confirmation of the Candidates by the Bishop.

Prayer, with the laying-on of hands by the Bishop. 1552.

Defend, 0 Lord, etc.

IV. Concluding Portion of the Service.

1. The Lord be with you. 1662.

2. The Lord's Prayer. 1662.

3. A Prayer for the Exercise of God's Providence and Grace towards the Confirmed. 1549.

Almighty and everliving God, who makest us.

4. A Prayer for the Preservation of Body and Soul. 1662.

5. Benediction. 1549. Sar. Man.

Closing Rubric 1549, altered 1552 and 1662. Sar. Man.

\section{EXPOSITION.}

The Title.

1549. " Confirmation.

1604. Confirmation, or laying on of hands.

1662. The Order of Confirmation, or laying on of hands upon those that are baptized and come to years of discretion.

The first mention of the word 'confirm' in connexion with the rite occurs in Ambrose's De Mysteriis which appeared about 402, A.D.

Laying on of hands, used in the O.T. both for blessing and ordination (Gen. xlviii. 14 ; Num. xxvii. 18-20).

In the N.T. our Lord laid hands on little children when He blessed them, and on sick folk to heal them (Matt. xix. 13; Mark v. 23, vi. 5). The Apostles laid hands on newly baptized persons (Acts viii. 17 ; xix.6). Laying on of hands is mentioned as one 'of the principles of the doctrine of Christ' (Heb. vi. 2). By the A postles' laying on of hands extraordinary gifts of the Holy Spirit were bestowed (Acts xix. 6 ; cf. 1 Cor. xii. 10). At Confirmation we look to receive the ordinary gifts of the Spirit (Gal. v. 22, 23). For laying on of hands in ordination, see p. 512. 
The Preface. 1662. Abridged from the rubrics preceding the Catechism, 1549.

'The office of Baptism in the primitive Gallican Church began with an Address' (Cornford).

In the American P.B. the Preface is optional, and the congregation are directed to stand until the Lord's Prayer.

\section{STRUCTURAL DISPLAY.}

To the end that Confirmation may be ministered to the more edifying of such as shall receive it, the Church hath thought good to order,

That none hereafter shall be Confirmed,

but such as can say

[ments ;

the Creed, the Lord's Prayer, and the ten Commandand can also answer to such other questions,

as in the short Catechism are contained;

Which Order is very convenient to be observed; to the end

$$
\begin{aligned}
& \text { that }\left\{\begin{array}{r}
\text { children }\left\{\begin{array}{r}
\text { being now come to the years of discretion, and } \\
\text { having learned what their Godfathers and God- } \\
\text { mothers promised for them in Baptism, }
\end{array}\right. \\
\text { they may themselves, with their own mouth and consent }
\end{array}\right. \\
& \text { openly before the Church } \\
& \text { ratify and confirm the same; and also promise } \\
& \text { that } \begin{array}{c}
\text { by the grace of God } \\
\text { they will evermore endeavour themselves } \\
\text { faithfully to observe such things, } \\
\text { as they }\left\{\begin{array}{l}
\text { by their own confession, } \\
\text { have assented unto. }
\end{array}\right.
\end{array}
\end{aligned}
$$

None hereafter shall be confirmed, etc. 'The two most important changes in the rite of Confirmation made in 1549 were (1) the order for the delay of the administration of the rite till the children had "come to the years of discretion" and had received catechetica. instruction ; and (2) the abolishing of the anointing with chrism. In both these particulars our Reformers had been ant:cipated by the German Reformers; and in Archbishop Hermann's books both features are emphasized, and reasons assigned for the changes' (Dowden's 'Further Studies in the Prayer Book,' p. 265).

In the Greek Church the Priest used oil consecrated by the Bishop to confirm infants immediately after baptizing them. In the Roman Catholic Church children are confirmed, by the Bishop at a very early age, seven and upwards.

Having learned. "The idea of Confirmation being preceded by catechetical instruction is common to both (i.e. our own and 
the Lutheran form). In the Mediæval Church in England Confirmation soon after infant Baptism was enjoined under penalties. The Constitutions of the Diocese of Worcester in 1290 directed that fathers and mothers should be warned that, if the opportunity of a Bishop being in the neighbourhood is not taken advantage of for the Confirmation of their children within the space of one year from their birth, they will be suspended from entering the church. A few years later a Synod at Chichester also made one year the permissible limit. The Synod of Exeter in 1287 extended the time to three years. At Durham, at an earlier date, it was ordained, perhaps on account of the great cxtent of the diocese, that the penalty should not fall upon the parents till seven years after the birth of the child '* (Dowden's 'Workmanship of the Prayer Book,' pp. 33, 34).

What their Godfathers and Godmothers promised. 'The present service is not quite appropriate to occasions when adults form some proportion of the candidates, and many of the candidates have never had sponsors, and no promises on their bchall were made at their Baptism. In order to overcome this difficulty the Scotch Episcopal Church at the last revision of the Code of Canons (1890) gave permission to the Bishop to substitute a suitable address and to modify the question "Do ye here in the presence of God," etc. ? In the American Church the reading of the Preface may be (by a permissive rubric) omitted, and the words, "which your Godfathers and Godmothers then undertook for you" for "which ye then undertook, or your sponsors then undertook for you"' (see Dowden's 'Workmanship of the Prayer Book,' pp. 36, 37).

The Solemn Stipulation or Vow. 1662. Adapted from Herm. Con. Do ye here, etc. ?

For the reference to Godfathers and Godmothers, see Baptismal Office, p. 381.

Do ye here... renew the solemn promise, etc.? This question brings into distinct prominence the side of Confirmation, namely the open profession of faith and of obedience, which is ignored in the Mediæval Service.

The Versicles, or Acts of Praise. (Ps. cxxiv. 8 ; cxiii. 2 ; cii. 1.) First, second, third, fourth Versicles. 1549. Sar. Man.

Fifth and sixth. 1552.

Prayer of Invocation. Almighty and everliving God, who hast vouchsafed, etc.

*Wilkins' 'Concilia,' tom. i. pp. 576, 667, 668; tom. ii. p. 132. 
It may also be called a prayer for the diffusion upon the candidates of the manifold graces of the Holy Spirit.

1549. Send down from heaven, we beseech thee, ( 0 Lord) upon them thy holy Ghost the comforter, with the manifold gifts of grace.

1552. Strengthen them, we beseech thee, (O Lord) with the holy Ghost the comforter, and daily increase in them thy manifold gifts of grace.

To regenerate... and hast given unto them forgiveness of all their sins. The addition in 1662 of the solemn stipulation or vow upon the part of the candidates themselves justify the presumptive use of this definite assertion.

Manifold gifts (septiformem spiritum). The gifts enumerated are taken from Isa. xi. 2, a seventh being added, 'the spirit of true godliness' to carry out the thought (contained in Zech. iii. 9 ; Rav. i. 4 ; iv. 5) of 'the seven spirits,' i.e. the sevenfold manifestation of the Spirit, seven being the symbol of perfection. It is noteworthy that the Reformers do not translate the Latin phrase septiformem spiritum, but designedly change it into ' manifold gifts,' there being no scriptural justification for the idea of the sevenfoldness of the Spirit, meaning seven separate gifts of grace proceeding from Him. (1) The Spirit of wisdom and understanding (intellectus), (2) the Spirit of knowledge (scientice) and godliness (pietatis), (3) the Spirit of counsel and strength (fortitudinis), (4) the Spirit of the fear of the Lord;-this is the order of the gifts of the Spirit in the Sarum Use. The order in the Prayer Book, in Gel. Sac., and in the Vulgate, and in both A.V. and R.V. is 1, 3,2,4. In some of the English Pontificals the order is the same, and also in the Pontifical of Cologne, as indicated in Archbishop Hermann's 'Enchiridion Christiæ Institutionis' (1538) (Dowden's 'Further Studies in the Prayer Book,' p. 270).

Sometimes the gift was bestowed before Baptism (Acts ix. $18 ; x .44$ ) and sometimes immediately after Baptism (Acts xix. 6). The chief reference inthese passages seems to be to the extraordinary gift of the Spirit. In pressing the analogy on the bestowal of extraordinary gifts by the laying on of hands by the Apostles and the bestowal of ordinary gifts at Confirmation in our day, considerable caution needs to be exercised.

The following summary is worthy of quotation :-

' Wisdom, to choose the one thing needful.

Understanding, to know how to obtain it.

Counsel, the habit of asking guidance of God.

Strength, to follow where He shall lead us. 
Knowledge, that we may learn to know God.

Godliness, that knowing Him, we may grow like Him.

Holy fear, meaning reverence and adoration' (Canon Norris's 'Manual of Rel. Inst. on P.B.,' ii. 77).

In the Prayer Book of 1549 here came the following Prayer, etc. :-

Sign them (0 Lord) and mark them to be Thine for ever, by the virtue of thy holy cross and passion. Confirm and strength* them with the inward unction of thy holy Ghost, mercifully unto everlasting life. Amen.

Then the Bishop shall cross them in the forehead, and lay his hand upon their head, saying,

N. I sign thee with the sign of the cross, and lay my hand upon thee, In the name of the Father, and of the Son, and of the Holy Ghost. Amen.

And thus shall he do to every child, one after another; And when he hath laid his hard upon every child, then shall he say,

The peace of the Lord abide with you.

Answer. And with thy spirit.

All this was omitted in 1552.

The Signing with the Cross. "As this was retained in the Service of Baptism, it would seem that the omission here can hardly have been due to regarding the use of this ceremony as essentially objectionable. But there is one difference between the two signings. In the Baptismal Service the significance of the signing was explained; at Confirmation (though it might have been) it was not explained as a matter of fact. And the spirit of the Reformation was hostile to unexplained symbolism. At any rate, in the Cologne Reform we tind the same features as in the Second Book of Edward VI. : the cross was retained at Baptism ; it was omitted at Confirmation' (Dowden's 'Further Studies in the Prayer Book,' 271).

In Herm. Con. the anointing was, in effect, said to be superfluous and without the authority of primitive antiquity. "In Confirmation,' writes Hermann, 'the symbol of the imposition of hands shall suffice in this rite, as it sufficed for the Aposties and the more ancient Fathers' (fol. lxxxii. verso).

Rubric respecting the Laying on of hands.

1552. Then the Bishop shall lay his hand upon every child severally, saying.

1662. Then all of them in order kneeling before the Bishop,

* Evidently a printer's error for 'strengthen.' 
he shall lay his hand upon the head of every one severally, saying.

Every one. The alteration was made in view of the fact that many confirmees were no longer children (see 'The Preface,' 4th paragraph).

Severally. From Sac. Gel. and other early writers it appears to have been a custom to raise the hands over all the candidates at once.

In 1549 the use of Chrism, which had been adopted for many centuries, was omitted. Chrism was the use of oil consecrated by the Bishop, and employed to symbolize the communication of the grace of the Holy Spirit. In the Scottish Episcopal Church the signing by the Bishop with the sign of the cross is permissive.

Prayer with the Laying on of Hands. 1552.

Defend, 0 Lord, etc.

In 1662 the words in brackets ['or this thy servant'] were added; unnecessarily, for the age does not modify the paternal relationship of God.

Daily increase. The word 'daily,' which occurs here and in other parts of this Service, 'brings out clearly a thought which may be very helpful in meeting the difficulties which sometimes beset those recently confirmed, who are disappointed in finding that they do not at once experience in their struggle against temptation such an access of spiritual strength as they had hoped for' (Dowden's 'Further Studies in the Prayer Book,' p. 275).

The Mutual Salutation. 1549 ; placed here 1662.

In 1549 the form was, 'The peace of the Lord abide with you,' the ordinary form having been used earlier in the Service.

The Rubric preceding 'Let us Pray.'

1552. Then shall the Bishop say.

1662. And (all kneeling down) the Bishop shall say.

The Lord's Prayer without Doxology. 1662.

The Doxology is omitted because it precedes prayer and not thanksgiving. It is somewhat strange that the Confirmation Service contains no thanksgiving.

A Prayer for the Exercise of God's Providence, etc.

Almighty everliving God, which makest, etc. 1549.

This Prayer was adapted from a Collect in the Order of Confirma ion in Herm. Con. A few slight verbal alterations bave since been made, including the substitution of 'servants' for 'children.' 
The Last Collect. 1662.

'This is a Prayer for the preservation of body and soul, and is one of the dismissal Collects appointed in 1519 to be said after the Uffertory when there is no Communion.

The Benediction. Sar. Man.

Frecerling liubric.

1519. Bless the children.

16iv2. Bless them.*

Follo'ving Ru'ric.

1549. And there shall none be admitted to the holy Communion until such time as be be contirmed.

1552. And there shall none be admitted to the holy Communion. until such time as he can say the Catechism, and be confirmed.

1662. And there shall none be admitted to the boly Communion, until such time as he be confirmed, or be ready and desirous to be confirned.

The rule prescribed in the Sar. Man. was that no one should be admitted to communicate, save when dying, except he had been confirmed or had been reasonably hindered from receiving Confirmation.

This rubric has received increased attention of late, as bearing upon the relation of the Church of England to other Reformed Communions, and upon the question of 'Occasional Conformity.'

It is to be noted, therefore, that :-

(1) The rubric does not contemplate admission to Holy Communion of unconfirmed members of the Church of England, save when Confirmation is desired and purposed, and opportunity only is wanting.

(2) The rubric, nevertheless, teaches by plain implication that the rite, as such, is not essential to fitness for partaking of Holy Communion.

(3) The rubric, even in its unqualified form of 1552 , certainly did not contemplate the exclusion of Members of Churches not subject to the ecclesiastical ordinances of the Church of England, and the well-known advice of Cosin, counselling Communion with the Reformed Churches of the Continent, illustrates the way in which strangers to the Church of England would be welcomed by the Caroline divines.

In addition to the foregoing rubric there were in 1549,1552 , 1559, and 1604 three other rubrics. In 1662 these were removed, with the Catechism to which they relate, to a separate place.

* In the American Prayer Book two addit:ons have been made, viz., a form for presenting the candidates similar to that at the Ordination and

- Lesson (Acts viii. 14-17). 


\section{THE FORM OF SOLEMNIZATION OF MATRIMONY}

\section{INTRODUCTION.}

From very remote times marriage has been regarded as a religious undertaking, and, not only among the Jews, but also umong heathen nations, its solemnization was generally accompanied by some form of ritual. This aspect is brought into great prominence in the New Testament. Our Lord Himself shows that it was a Divine institution ' in the time of man's innocency' (Matt. xix. 4-6), and, by the use of the word 'bridegroom 'to express His relation to believers (Matt. xxv. 6), elevates matrimony to the position of a type and symbol. St. Paul follows the Lord in both respects, speaking of the marriage of Christians as a marrying 'in the Lord' ( 1 Cor. vii. 39), and emphasizing its symbolic applicability to the union between Christ and His Church (Eph.v. 22-24). Hence, from Apostolic times marriage has been regarded not only as a civil contract, but as a religious rite; and there is distinct evidence that from the early days of Christianity marriage was performed with ecclesiastical ceremonies and by ecclesiastical persons.

Owing to the festivities usually associated with weddings they were, as early as the fourth century, discouraged during Lent. In the eleventh century further restrictions were made from the same cause; no marriage could take place between Advent and the octave of the Epiphany; between Septuagesima Sunday and the octave of Easter; during the fourteen days prior to the Feast of John the Baptist; on Ember days, or vigils. Since the Reformation there have been no such restrictions in the Church of England.

The Church of Rome regards marriage as a 'Sacrament,' her authority being the Vulgate rendering of Eph. v. 32, Sacramentum hoc magnum est; A.V. 'This is a great mystery.' *

Originally the Parish Church of either of the persons to be married was the only place where the marriage could be solem-

- For the meaning of the word 'niystery' in the New Testament, see Communion Service, pp 271, 289. 
nized. But now marriages can take place in Nonconformist places of worship licensed for the purpose, and a civil marriage can be performed at a Registrar's office.

No person under twenty-one can be legally married without the consent of the parents or guardians; no male can be married under the age of fourteen, and no female under the age of twelve.

To secure publicity, the Act 6 \& 7 Will. IV, c. 85,1836 , fixed the hours of marriage between 8 a.m. and noon, but in 1886 the time was extended to 3 p.m. (49 \& 50 Vict. c. 14).

According to Statute, no person can be lawfully married unless by licence,* or after the publication of banns. $\dagger$

A licence must be obtained from the Master of the Facultics, the Vicar-General of the Province of Canterbury, or from any Surrogate. But by 4 Geo. IV, c. 76 , it is enacted that 'in order to avoid fraud and collusion in obtaining licences for marriage, before any such licence be granted, one of the parties shall make an affidavit, an oath, that there is no legal impediment to the intended marriage ; and also that one of such parties hath made a usual place of abode for the space of fifteen days immediately preceding the issue of the licence, in the parish of the Church in which the marriage is to be solemnized.' A licence is valid for three months after the date of issue.

Special licences can be issued by the Archbishop of Canterbury which are not subject to these restrictions.

If parties are married by banns, $\ddagger$ these must be previously published three Sundays in the Church of the parish in which they reside; or, if they are dwelling in different parishes, they must be published in both Churches, and the marriage must take place in one of them. A certificate that the banns were properly published must be given to the officiating clergyman before the service. The banns need not be published on the same three Sundays in both parishes. If omitted by mistake on any Sunday, they may be published the next Sunday, three consecutive Sundays not being essential ; and the banns hold good for three months after the last date of publication.

The laws regarding the solemnization of marriage are very strict: any clergyman infringing them is liable to be suspended for three years.

* It is singular that no mention of marriage by licence is foumd in the rubrics of the Marriage Service.

t The word "banns" is derived from the Latin word bannum, an edict or proclamation. The old phrase was 'interrogare banna,' hence we -still speak of 'asking banns.'

¥ When the ceremony is performed in a Registrar's office, the Banns of Marriage must have been kept on the wall of the office for a space of time covering three Sundays ( $6 \& 7$ Will. IV, c. 85$)$. 
ANALYSIS WITH HISTORICAL NOTES.

[The date is 1549 , except where otherwise stated].

Directions respecting the Publication of Banns, altered 1662.

I. The Marriage Service Proper, performed in the body of the Church.

1. The Charges.

(1) To the Congregation.

Dearly beloved, etc.; slightly altered 1662 .

(2) To the Bride and Bridegroom.

I require and charge you, etc.; slightly altered 1662 .

2. The Marriage.

(1) The Espousals or Mutual Promise (Stipulation).

Wilt thou have, etc. ?

(2) The Betrothal.

Who giveth this woman, etc. ?

I N. take thee N., etc.

(3) The placing of the Wedding-Ring.

With this ring, etc.; altered 1662 .

(4) Prayer for a Blessing on the Bride and Bridegroom, altered 1662 .

0 eternal God, etc.

(5) The Joining of Hands.

3. The Pronouneement.

Forasmuch as, etc.

4. The Benedietion.

II. The Post-Matrimonial Service.

1. Psaim cxxviii. or lxvii., while going to the Lord's Table.

2. Lesser Litany.

3. Lord's Prayer.

4. Versieles and Responses.

5. Three Prayers for the Bride and Bridegroom.

(1) Prayer for Divine Blessing.

0 God of Abraham; etc.; altered 1552.

(2) Prayer for Fruitfulness.

0 Merciful Lord, etc.

(3) Prayer for Holy Married Life ; altered 1662.

O God, who by Thy mighty power, etc.

6. The Benedietory Prayer for Grace.

7. Scriptural Address, altered 1662. Quotations from A.V.

Rubric respecting receiving the Lord's Supper after Marriage; altered 1662 . 


\section{EXPOSITION.}

The greatcr part of the Service is taken from the Sarum Manunl, but use has also been made of Hermann's 'Consultatio.'

The Opening Rubric. 1549, altered 1662. Sar. Man.

1549. The Banns were to be "asked three several Sundays or holy-days, in the service time,' etc.

1662. They ' must be published in the Church three several Sundays, or Holy-days, in the time of Divine Service, immediately betore the Sentences for the offertory.'

In the reign of George II, however, a statute was passed (1753) directing that "the Banns shall be published upon three Sundays preceding the solemnization of marriage during the time of Morning Service, or in the Evening Service, if there be no Morning Service, in such Church or Chapel on any of those Sundays, Immediately after the Second Lesson.' Hence the rubric in our present Prayer Book has been altered to the words of the Act.

It has been held by some judges* that this Act did not annul the rubric of 1662 , but left it untouched, and only provided for contingencies. If this be the right interpretation of the statute, then, when there is a Morning Service, and the Ante-Communion Service is read, the proper place for the Banns to be published is still Immediately after the Nicene Creed. See Marriage Acts, 26 Geo. II, c. 33 ; s. 1 (1753) ; 4 Geo. IV, c. 76 (1823); also p. 307.

The form of words for the publication of banns was drawn up by Bishop Cosin, and inserted in 1662 .

\section{THE MARRIAGE SERVICE PROPER.}

1st Rubric before the Address. 1549. Sar. Man. 2nd Rubric before the Address.

1549. At the day appointed for solemnization of Matrimony, the persons to be married shall come into the body of the Church, with their friends and neighbours. Sar. Man. ; Herm. 'Con.'

1662. And there standing together, the man on the right hand, and the woman on the left, etc. Sar. Man.

In the Sarum Manual the direction was that 'the man and woman should be placed before the door of the Church (ante ostium ecclesice) before God and the priest and the pcople, the man at the right of the woman, and the woman at the left of the man.' It was here that the first part of the Service was performed, the Priest being vested in surplice and white stole, with an attendant minister bearing the book and the holy water.

- Lord Mansfield and Baron Alderson, in Reg. v. Benson, 1856. 
Address to the Congregation (see Gen. ii. 18; Matt. xix. 6 ; John ii. 1-11; Eph. v. 22, 23). 1549, slightly altered 1662.

The first sentence, 'Dearly beloved . . . in holy matrimony' and the last, 'Therefore if any man ... hold his peace' were derived from the Sar. Man. The rest was probably suggested by Herm. 'Con.'

Mystical union, i.e. spiritual union (see Eph. v. 22, 23, 32).

The three 'causes for which matrimony was ordained' have been modified in the Irish B.C.P., omitted in the American B.C.P.

Any just cause. 'The following are the lawful impediments :-

(1) Existing marriage.

(2) Bodily or mental defect.

(3) Tender age, i.e. below fourteen years in the case of a boy, below twelve years in the case of a girl.

(4) Dissent of parents or guardians if either party be under twenty-one years of age.

(5) Relationship within the prohibited degrees of consanguinity and affinity.

Charge to the Bride and Bridegroom.

1549. I require and charge you, etc. York Man. (in English); Sar. Man. similar.

The Rubric dealing with the case of some impediment to the Marriage being alleged. Expanded from Sar. Man.

- This is a very difficult rubric, and does not seem ever to have received a judicial interpretation. On the one hand, it appears to stop the marriage only in case the objector submits to " be bound, and sufficient sureties with him, to the parties; or else put in a caution ... to prove his allegation." On the other hand, the mere fact of a real inpediment, alleged by any apparently trustworthy person, seems to put it out of the power of the clergyman to proceed with the marriage, whether the objector offers security or not, until legal investigation has taken place' (Blunt's 'Annot. P.B.', 1885, p. 451).

Espousals, or Mutual Consent. Sar. (in English) and York Manual very similar. M. Wilt thou have, etc. ?

The ' $M$.' representing the name of the man, is a corruption of the old printing. In old editions ' $N$.' is used for both parties, the first letter of the word nomen.

Wilt thou obey him? In the York Man. it ran "Wilt thou be buxom to him.' The older meaning of the word 'buxom' is 'obedient,' 'submissive.'

The Espousals were 'a formal and religious recognition of what is now termed an engagement, and took place sometimes 
months, sometimes years, before the marriage itself' (Blunt's

' Dict.'). The custom still survives in parts of Europe.

The ceremonies were:-

(1) The verbal expression of free consent.

(2) The presentation of gifts arra or sponsalia.

(3) Giving and receiving of a ring.

(4) A kiss.

(5) Joining of hands.

(6) Settling a dowry in writing (Blunt's 'Dict.').

The Betrothal. Sar., York, and Hereford Man. similar (in Enalish). Who giveth this woman, etc.?

Rubric slightly altered and transposed, 1662, Sar. Man.

According to God's holy ordinance. In Sar. Man, 'If holy chyrche it woll ordeyne.'

I plight thee my troth, i.e. 'I pledge thee my word, or my honour.'

The rubric between these two pledges was inserted 1549; made more explicit 1662. Sar. Man. similar.

The Rubric respecting the giving of the Ring. Sar. Man.; similar Herm. Con.

1549. The man was directed to give unto the woman beside the ring 'other tokens of spousage, as gold or silver, laying the same upon the book.'

1552. 'Other tokens of spousage,' etc., was omittcd, and the man was directed to lay the ring 'upon the book, with the accustomed duty to the Priest and Clerk.'

1662. In the last clause between the words 'And the man' and ' taught by the Priest,' etc., was added 'holding the ring there, and.'

The use of the ring-the token of the marriage covenant-is of unknown antiquity. In Germany rings were, and are still, interchanged between Bride and Bridegroom.

The Wedding-Ring. 1549, altered 1552. Sar. Man. (partly English, partly Latin).

1549. With this ring I thee wed; this gold and silver I thee glve.

1552. The words 'This gold and silver I thee give' were omitted.

With my body I thee worshlp means ' I will render thee service and show thee honour' (see Gen. xxiv. 53, 67); cf. phrase 'your Worship,' as addressed to magistrates.

A most elaborate Service was provided in the Sarum Manual for the blessing of the ring, during which it was sprinkled with holy water, and signed with the sign of the cross. The man 
was instructed to place the ring on the thumb of the bride, saying, 'In the Name of the Father'; then upon the second finger, saying, 'and of the Son'; and then upon the third finger, saying, 'and of the Holy Spirit'; and then upon the fourth finger, saying, 'Amen.' ('And there let him leave the ring.') It was an old belief that a particular vein proceeded from the fourth finger to the heart, the supposed seat of the affections. This was so stated in the Sarum rubric. The form of the ring, being without ends, singests the duty of constancy. The gold, of which the ring is invariably composed, being usually free from alloy,* is an emblem of purity.

The Rubric before the Prayer for Blessing. 1549.

The words 'they shall both kneel down' were inserted 1662.

The Prayer for Blessing. 1549, altered 1552. Compiled from two prayers in Sar. Man. used in the blessing of the ring.

' O Eternal God, Creator,' etc. After the words 'as Isaac and Rebecca' there was the following parenthetical clause : (" after bracelets and Jewels of gold given of the one to the other for tokens of their matrimony'). It is to be noted that Isaac and Rebecca are cliosen as the Old Testament types of constancy, their history being free from any trace of polygamy.

Joining of Hands, with the preceding Rubric. 1549. Herm. 'Con.'

This rite is not to be found in any pre-Reformation manuals (see Dowden's ' Workmanship of the Prayer Book,' p. 38).

The Pronouncement, with the preceding Rubric. 1549. Herm. Con.'

The Rubric before the Blessing. 1549.

The Blessing, Slightly altered 1552. Sar. Man.

1549. God the Father bless you.+ God the Son keep you. God the holy Ghost lighten your understanding The Lord mercifully with his favour look upon you. and so fill you with all spiritual benediction and grace, that you may have remission of your sins in this life, and in the world to come life everlasting. Amen.

\section{THE POST-MATRIMONIAL SERVICE.}

\section{The Rubric before Psalm cxxviii.}

1549. Then shall they go into the quire, and the Minister or Clerks shall say, etc.

1552. Then the Ministers, or Clerks, going to the Lord's Table, shall say, etc.

- The best gold ordinarily used is 18 carat, wedding-ring gold is 22 carat. 
1662. 'Ministers' altered to 'Minister.'

Psalm cxxviii., Beati omnes (as in Psalter), describes the domestic and national blessings attendant upon holy home life.

Psalm lxvii., Deus miscreatur (as in Psalter), connects temporal and spiritual blessings with praise of God.

\section{The Rubric before the Lesser Litany.}

1549. The psalm ended, and the man and woman kneeling alore the altar.

1552. Afore the Lord's table.

1662. Before the Lord's Table.

The Lesser Litany. 1549. Sar. Man.

The Lord's Prayer. 1549. Sar. Man. The absence of the Doxology denotes that the prayers which follow are of the nature of supplication, not of thanksgiving. Until 1662 only the last clause, 'But deliver us from evil,' was said by the people.*

The Versicles and Responses. 1549. (Ps. lxxxvi. 2; xx. 1, 2 ; lxi. 3 ; cii. 1.)

Prayer for Divine Blessing. 1549, slightly altered 1552. Sar. Man. O God of Abraham, etc.

1519. And as thou didst send thy angel Raphael to Thobie and Sara, the daughter of Raguel, etc. $\dagger$

1552. For this clause was substituted the following: 'And as thou didst send thy blessing upon Abraham and Sara,' etc.

Prayer for Fruitfulness. 1519, altered 1552. Sar. Man. 0 Merciful Lord, and heavenly Father, etc.

1549. That they may see their childer's ['children's,' 1552] children, unto the third and fourth generation, unto thy praise and honour.

1662. That they may see their children Christianly and virtuously brought up, to thy praise and honour.

Prayer for Holy Married Life. 1549, altered 1662. Sar. Miss., Nuptial Mass.

1549. After 'loving and amiable' 'to her husband as Rachael, wise as Rebecca, faithful and obedient as Sara.'

* There is no rubrical direction cven now that it shall be said by all prosent. The custom may have arise because of the similarity of this part of the Service to the portion of Morning and Evening Priayer following the Ap satles' Creed, and where the Lord's Prayer is direeted to be silil by 'minister, clerlis and people.' It may also have arisen from the hibitual teaderey of the enngregition to repent the Lord's Prayer after the minister whenever and whe ever it is recited, except in the one instance of its first occurrence in the Communion Service.

+ Tobit iii. 7 . 
1662. Altered to 'faithful and obedient to her husband.'

Benedictory Prayer for Grace. 1549. Sar. Man. similar.

In 1549 the words ' sanctify and bless you' were printed thus:

- sanctify and + bless you.'

Rubric before the Address.

1549. Then shall be said, after the Gospel, a sermon, wherein ordinarily (so oft as there is any marriage) the office of man and wife shall be declared, according to holy scripture. Or if there be no sermon, the Minister shall read this that followeth.

1552. Then shall begin the Communion. And after the Gospel, shall be said a Sermon, etc.

1662. After which, if there be no Sermon declaring the duties of man and wife, the Minister shall read as followeth.

The Scriptural Address. 1549. A.V. 1662.

Eph. v. 25-33a ; Col. iii. 19; 1 Pet. iii. 7 ; Eph. v. 22-24; Col. iii. 18 ; 1 Pet. iii. 1-6.

\section{Closing Rubric.}

1549. The new married persons (the same day of their marriage) must receive the holy Communion.

1662. It is convenient that the new married persons should receive the holy Communion at the time of their marriage, or at the first opportunity after their marriage.

It will be observed that the rubric of 1662 no longer makes the reception of the Holy Communion compulsory on the part of the bride and bridegroom on the day of their marriage, but merely states that it is ' convenient,' i.e. ' appropriate' that they should communicate that day or as soon after as possible.

The desuetude into which the custom of communicating has generally fallen leaves the Service without any proper conclusion. In the Irish B.C.P. some concluding prayers are added; in the American Book only the Marriage Service Proper is retained, which has its own concluding Benediction. 


\section{ORDER FOR THE VISITATION OF THE SICK}

\section{INTRODUCTION.}

Provisions here made for ministering to the sick and dying are based upon the direction of the Apostle St. James; 'Is any sick among you,' etc., and primitive practice * (Jas. v. 14, 15; cf. Mark vi. 13; xvi. 18; Luke x. 8, 9).

This Office, however, is of a set and formal character, and is not intended for general or promiscuous use. For the duty incumbent on Ministers to visit the sick, see Matt. xxv. 36 ; Luke $\times$. 8, 9 ; also fifth question in the Ordering of Deacons, fourth question in the Ordering of Priests, and the 67th Canon. $\dagger$

The Service, excepting the Exhortations, is drawn with much correction and simplification from the Order for the Visitation of the Sick, the Service of 'Extreme Unction,' and 'the Commendation of the Soul' in the Sar. Man. The following three points in which our Service differs from that of the Sar. Man. deserve special notice :-

1. The omission of the formal procession of the Priest and the Clergy to the house of the sick, saying the seven Penitential Psalms.

2. The disuse of 'sacred images' and of Extreme Unction.

3. The addition, at the end of the Service, of four prayers for special cases.

* 'In the middle of the third century, when the persecutions were most violent. St. Cyprian returned to his city, Carthage; plague was devastating it and the streets were crowded with the sick and dying; he at once organized a nursing staff to attend without distinction of creed in the case of the poor people' (Bernard Reynolds).

$\dagger$ "When any person is dangerously sick in any parish, the Minister or Curate, having knowledge thereof, shall resort unto him or her (if the disease be not known, or probably suspected to be infectious), to instruct and comfort them in their distress, according to the Order of the Communion Book, if he be not a preacher; or if he be a preacher, then as he shall think most needful and convenient' (Canon IXVIII. 1603). 


\section{ANALYSIS WITH HISTORICAL NOTES.*}

['The date is 1519 , except where otherwise stated.]

\section{THE INTRODUCTORY PORTION.}

(N.B.-This portion forms both a little Service in itself, and also a fit prelude to the Communion Office.)

1. The Salutation of Peace.

2. The Deprecation, called 'The Antiphon' in Sar. Man.

Remember not.

The Answer: 'Spare us,' added 1662.

3. The Lesser Litany.

4. The Lord's Praycr.

5. The Versicles and Responses.

O Lord, save thy servant.

6. A Prayer for Support under Affiction.

() Lord, look down.

7. A Prayer for the Sanctifying of A filction. Altered 1552 and 1662. Hear us, Almighty and most merciful-God.

\section{THE CENTRAL PORTION.}

1. Exhortation (first part).

Dearly beloved, know this.

2. Exhortation (second part), 1662, quotation from A.V.

3. Interrogatory Rehearsal of the Creed by the Minister.

Dost thou believe in God the Father.

4. Answer of the slck person, 1662 .

All this I stedfastly believe.

5. Temporal and Spiritual Preparation in view of Death.

1 st rubric. Subject: Forgiveness, Making amends, Will, etc. Altered 1662 .

2nd rubric. Altered 1552.

3rd rubric. Liberality to the poor. Altered 1662.

4 th rubric. Confession in the case of troubled con. sciences. Altered 1552 and 1662, with a suggested form of Absolution.

6. A Prayer for Mercy and Renewing Grace. Altered 1662. 0 most merciful Gor.

7. Psalm Ixxi. In te, Domine, speravi. As in Psalter.

8. An EJaculatory Prayer to the Redeemer.

- Tho following is a useful nnd suggestivo division:-

I. The Suppliention to depreanto ovil (1. 1-3).

II. 'The Prayers to petition for gool (1. 4-7).

1II. Tho Exhortalion (I1. I to the Absolution).

IV. The Consolation (he Absolution to the Benediction). 


\section{First Form of Benediction.}

The Almighty Lo d, who is a strong tower.

10. Second Form of Benediction. 1662.

Unto God's mercy and protection.

\section{THE CONCLUDING PORTION. 1662.}

\section{Four Prayers for Special Cases :-}

(1) For a Sick Child.

(2) For a Sick Person, when there appeareth small hope of recovery.

(3) For a Sick Person at the point of departure.

(4) For Persons troubled in mind or in conscience.

\section{EXPOSITION.}

The Title, in Sar. Man. Ordo ad Visitandum Infirmum.

1549. The Order for the Visitation of the Sick, and the Communion of the same.

1552. The second half omitted, the Communion of the Sick being separated from the Visitation.

The Prellminary Rubric.

1549. The Priest entering into the sick person's house, shall say.

1662. Altered to its present form by the addition of the direction to give notice of a sick case to the Minister of the Parish in accordance with the direction in Jas. v. 14.

In the Sar. Man. it was directed that the seven Penitential Psalms were to be sung by the Priest on his way to the sick person's house.

The Salutation of Peace. (Sce Luke x. 5.)

1549. Peace be in this house, etc.

1662. Peace be to this house, etc.

The Rubric after the Salutitlon.

1549. When he cometh into the sick man's presence, he shall say this Palm.

Between this rubric and the Deprecation (called an

' anthem'), there was the following:

Domine. exaudi. Ps. cxliii.

'The Gloria Patri.

With this anthem.

1552. When he cometh ... he shall say, kneeling down.

In the Sar. Man., the following histrionic ceremony took place:- 
1. The Priest presented to the eyes of the sick the crucifix.

2. He sprinkled him and his bed with holy water, saying the antiphon 'Asperges.'

3. The sick person had to make confession, and learn what penance to perform.

4. The Priest prayed that all their benedictions and sprinklings of holy water, all his own knockings of the breast, contritions, confessions, fastings, alms, vigils, prayers, pilgrimages, all his good works, all injuries borne for God's sake, the Saviour's passions, the Virgin's merits, the merits of the Saints, all the prayers of the Catholic Church, might be effectual for the remission of his sins, the increase of his merits, and the obtaining of eternal rewards.

5. The sick person was directed to kiss the crucifix; there were allusions to the granting of indulgences; there was the ceremony of Extreme Unction, and various practices connected therewith (see Dyson Hague's 'Protestantism of the Prayer Book,' pp. 99, 100).

The Deprecation. 1549. Sar. Man. the answer added 1662. (Cf. Tobit iii. 3 ; Baruch iii. 5 ; Joel ii. 17.)

This was originally an 'Anthem' 0 ' respond to Ps. cxliii.

The Lesser Litany. 1549. Sar. Man.

In 1662 the introductory words 'Let us pray' were added. The Lesser Litany is placed here with special appropriateness, as such was the cry of the sick to our Lord (Matt. ix. 27 ; xvii. 15 ; xx. 30, 31).

The Lord's Prayer. 1549. Sar. Man.

1549. The people only repeated the last clause, ' But deliver us from evil. Amen.'

1662. The practice was dropped.

The Versicles. 1549. Sar. Man. (See Ps. Ixxxvi. 2 ; Ps. xx. 1, 2 ; Ps. Ixxxix. 22, 23 ; Ps lxi. 3 ; Prov. xviii. 10 ; Ps. cii. 1.) 1549. In the last the words stood 'my prayer' and ' $m y$ cry.'

1552. ' $M y$ ' in both cases was altered into 'our,' in accordance with the example set us in the Lord's Prayer.

The Prayer for Support under Affliction. 1549. Sar. Man.*

* In the Sar. Man. there were nine Collects used; two only have been retained in B.C.P. 
In the Sarum Office, this prayer concluded, 'And send an angel of peace who may guard him to that home in perpetual peace.'

A Prayer for the Sanctifying of Affliction. 1549 ; altered 1552 and 1662. Cf. Sar. Man.

1549. Visit him, O Lord, as thou didst visit Peter's-wife's mother and the captain's servant. And as thou preservedst Thobie * and Sara by thy angel from danger : So restore unto this sick person his former health (if it be thy will,) or else give him grace so to take thy correction, that after this painful life ended, he may dwell with thee in life everlasting.

1552. Visit him, O Lord, as thou didst Peter's wife's mother and the captain's servant. So visit and restore unto this sick person, etc.

1662. Sanctify, we beseech thee, this thy fatherly correction to him ... through Jesus Christ our Lord.

Exhortation (first part); 1549 Sar. Man. ; emphasizing :-

1. That all our bodily conditions are in God's hands.

2. That therefore sickness is God's visitation.

3. That whatever be its design, if borne in a Christian manner in good part, will lead to spiritual benefit.

Rubric preceding Exhortation (second part).

1549. If the person visited be very sick, then the Curate may end his exhortation at this place.

1662. The words 'or else proceed' were added.

Exhortation (second part). 1549, 1662 quotations from A.V. (see Heb. xii. 6-10 ; Rom. viii. 17, 18 ; 2 Tim. ii. 11, 12 ; Col. i. 11).

1549. These words, good brother, are God's words, and written.

1662. 'These words, good brother, are written.

1549. Therefore I shall shortly rehearse the Articles of our faith.

1662. 'Shortly' was omitted.

St. Paul saith. St. Paul's authorship of the Epistle to the Hebrews is a matter of much dispute, his name not being mentioned in the sacred text.

\section{Analysis.}

I. Reasons for taking Chastisement in good part.

1. Chastisement is an instrument of love, a sign of sonship, and a means of partaking of the Father's holiness.

* Thobie, or (Tobias) and Sara were two persons spoken of in Tobit iii. 17. The story connected with them is highly fanciful. 
2. The comfort of being made like unto Christ who passed through suffering to glory.

II. Duties during an Illness.

1. The exercise of patience.

2. Self-examination.

Rubric respecting the Interrogatory Rehearsal of the Creed.

The Creed. 1549. Sar Man.

1549. Dost thou believe in God the Father Almighty, etc. And so forth as it is in Baptism.

1662. Printed in full.

In the Sar. Man., if the sick man were laicus vel simpliciter literatus, then he was examined in the words of the Apostles' Creed : otherwise the Priest was to set before him 'fourteen Articles of Christian faith of which the first seven belong to the mystery of the Holy Trinity, and the last seven to the humanity of Christ,' following generally the Athanasian Creed, and concluding with the words, "This is the Catholic Faith, which unless thou firmly and faithfully believe as Holy Mother Church believeth, thou canst not be saved.'

The Answer. All this I stedfastly believe. 1662.

\section{Rubrics respecting Temporal and Spiritual Preparation in View of Death.}

There have been considerable changes in these rubrics.

First Rubric, respecting forgiveness, making amends, making of will by the sick man. (See Luke xix. 5 ; xxiv. 34 ; Acts vii. 60.)

1549. Then shall the Minister examine whether be be in charity with all the world.

1662. Then shall the Minister examine whether he repent him truly of his sins, and be in charity with all the world.

1549. He make amends to his uttermost power.

1552. He make amends to the uttermost of his power.

1549. Let him then make his will.

1662. Let him then be admonished to make his will.

1549. (But men must be oft admonished that they set an order for their temporal goods and lands, when they be in health.)

This sentence came immediately after 'Let him then make his will.'

1604. This sentence (but not in parentheses) was placed at the end of the rubric.

1662. But men should often be put in remembrance to take order for the settling of their temporal estates, whilst they are in health, 
There was in 1549 an in-cut note in this rubric which was removed in 1604 and ran as follows: "This may be done before the Minister begin his Prayers, as he shall see cause.' In an old Canon the Priest is ordered after he hath prayed for the sick 'to speak comfortably and mildly to him, exhorting him to place all his hopein God, and to bear his scourging patiently; to believe it is designed for his purifying and amendment, and also to confess his sins, and promise reformation if God grant him life, and that he engage to do acts of penance for his faults ; also that he dispose of his estate while his reason and senses remain entire; that he break off his iniquities by almsdeeds; that he forgive all that have offended him; that he hold a right Faith and Belief, and never despair of God's mercy (Concil. Nannetens, cap 4, ap, Binium. tom. 3, p. 2, pag. 131).'*

To make his will. Wills were originally (till 1857) registered in ecclesiastical courts, and in yet older days people were forbidden to make their wills except in the presence of the parish priest.

\section{Second Rubric.}

1552. The in-cut note in first rubric of 1549 , slightly altered was printed as a second rubric.

This meant that the instruction given in the first might precede the whole Service, so as not to disturb the Service.

Third Rubric, respecting liberality to the poor.

1549. The Minister may not forget, nor omit to move the sick person, (and that most earnestly) to liberality toward the poor.

1662. The Minister shall not omit earnestly to move such sick persons as are of ability, to be liberal to the poor.

Fourth Rubric, respecting Confession in the case of a troubled conscience, followed by a suggested form of Absolution.

1549. Here shall the sick person make a special confession, if he feel his conscience troubled with any weighty matter. After which confession, the Pricst shall absolve him after this form ; and the same form of absolution shall be used in all private confessions.

1552. 'After this form' was altered to 'after this sort,' and the words, 'and the same form,' etc., were omitted.

1662. 'A special confession' was alte ed to 'a special confession of his sins,' and the words 's hall make' altered to the less imperative 'shall be moved to make,' and 'if he humbly and heartily desire it' (ahsolution), were added.

* J. H. Blunt, 'The Annotated Book of Common Prayer' (1885), p. 463. 
After which confession. The confession is recognized as abnormal, and the following points deserve special notice, viz. that :-

1. It is to be made voluntarily: ' moved to make.'

2. It is expressly a special confession dependent upon special trouble.

3. Its connexion with any form of absolution is optional on the part of the sick person.

Other allusions to confession will be found in the second Exhortation in the Communion Service, ${ }^{*}$ in the 113th Canon, and in the Homily on Repentance.

The Church of Rome accounts private confession of mortal sin to be necessary to salvation, and thereby departs from the teaching and practice of the first twelve hundred years. Not until the year 1215 (Lateran Council) was confession of all adults made obligatory at least once a year.

The words of Hooker $\dagger$ are well worth quoting in the direction given to the sick man to confess :-

'If peace with God do not follow the pains we have taken in seeking after it, if we continue disquieted, and not delivered from anguish, mistrusting whether we do be sufficient; it argueth that our sore doth exceed the power of our own skill, and that the wisdom of the pastor must bind up those parts, which being bruised are not able to be secured of themselves.'

'Public confession they (i.e. the Fathers) thought necessary [in the case of grievous offences] by - way of discipline, not private, as in the nature of a sacrament, necessary. The ancient confession was made openly in the hearing of a public assembly of Ministers.'

Absolution. 1549. Sar. Man.; Herm. Con. (see John xx. 23). It also occurred in the Order of Communion, 1548.

The personal form, 'I absolve thee' (Ego te absolvo), was not in use till the twelfth or thirteenth century. $\ddagger$ This statement has been questioned, and it is said that "An indicative Absolution is found in Egbert's Pontifical, a tenth-century MS. copy of an eighth-century English Service Book (Surt. Soc., xxvii. p. 124), and in an eighth-century French Service Book (Codex Gellonensis) published by Martène, 'De Antiq. Eccles. Rit.,' 1788, i. 283) (F. E. Warren).

I absolve thee must be understood to mean "I declare and pronounce unto thee God's absolving grace.' 'The office of the minister in absolution is to present in the name of God a remission

* See pp. 321, 2.

† See c. Polity,' Bk. VI., ch. iv., 6 and 16.

‡ See Bingham's 'Christian Antiquities' (1878), p. 1,094. 
of sins as a gift to the penitent, which he himself must take up, either then or thereafter, by his own personal or individual faith in Christ' (C. Hole).

If a minister be ' $a$ preacher' he need not in instructing the sick use this Office, and therefore may never be requested to say this absolution. (For further information on absolution, see Daily Service and Holy Communion, pp. 95-7, 322, 327).

In the 'Order for the Visitation of the Sick,' the Puritans desired a greater liberty in the prayer as well as in the exhortation ; and that the form of the Absolution be declarative and conditional, as 'I pronounce thee absolved,' instead of ' $I$ absolve thee,' and 'If I pronounce thee absolved,' instead of ' I absolve thee,' and 'If thou dost truly repent and believe'; and that it may only be recommended to the Minister to be used or omitted as he shall see occasion. The answer given was: 'The giving of absolution must not depend upon the minister's pleasure, but on the sick man's penitence. The form is closer to St. John xx. than the amendment' (Procter and Frere's 'A New History of the Book of Common Prayer;' p. 186).

Prayer for Mercy and Renewing Grace. Sac. Gel.; Sar. Man.

In the pre-Reformation Service Books it was entitled 'The Reconciliation of a Dying Penitent,' and was the original form of absolution to be pronounced over dying penitents.

1549. As shall be seen to thee.

1662. As shall seem to thee.

1549. Impute not unto him his former sins, but take him to "' unto,' 1552] thy favour.

1662. Impute not unto him his former sins, but strengthen him with thy blessed Spirit; and when thou art pleased to take him hence, take him unto thy favour.

\section{Rubric before Psalm.}

1549. Then the Minister shall say this Psalm.

1604. 'Priest' was substituted for 'Minister.'

1662. 'Minister' was restored.

Psalm Ixxi. In te, Domine, speravi. 1549. As in Psalter. Sar. Man. commencing the Office of Extreme Unction.

An Ejaculatory Prayer to the Redeemer. 'The Antiphon. 1549. Sar. Man. This is the only Antiphon left in the B.C.P. in its ancient position (after a Psalm), except the Gloria.

First Form of Benediction. 1549.

Second Form of Benediction. 1662. Ancient Gallican and Anglican Missals. It is an expansion of Num. vi. 24-26. 
The Four concluding Prayers. 1662.

These are a substitution for the lengthy litany to the Saints which closed the Visitation Office in the Sar. Man.

The American Prayer Book has two Prayers and a Thanksgiving in addition. The 67 th Canon orders the ringing of the passing bell at the time of the sick person's expected departure from life.

In 1549 there was at the end of this service (i.e. after the first Benediction) the following :-

If the sick person desires to be anointed, then shall the Priest anoint him upon the forehead or breast only, making the sign of the cross, saying thus,

As with this visible oil thy body outwardly is anointed, so our heavenly Father, almighty God, grant of his infinite goodness that thy soul inwardly may be anointed with the holy Ghost, who is the Spirit of all strength, comfort, relief, and gladness. And vouchsafe for his great mercy (if it be his blessed will) to restore unto thee thy bodily health, and strength, to serve him; and send thee release of all thy pains, troubles, and diseases, both in body and mind. And howsoever his goodness (by his divine and unsearchable providence) shall dispose of thee ; we, his unworthy ministers and servants, humbly beseech the eternal majesty to do with thee according to the multitude of his innumerable mercies, and to pardon thee all thy sins, and offences committed by all thy bodily senses, passions, and carnal affections: who also vouchsafe mercifully to grant unto thee ghostly strength, by his holy Spirit, to withstand and overcome all temptations and assaults of thine adversary, that in no wise he prevail against thee : but that thou mayest have perfect victory and triumph against the devil, sin, and deaih ; through Christ our Lord; who by his death hatl overcome the prince of death; and with the Father and the holy Ghost evermore liveth and reigneth, God, world without end. Amen.

Usque quo Domine? Psalm xiii.

How long wilt thou forget me, \&c.

Glory be to the Father, \&c.

As it was in the beginning, \&c.

The Greek Church anoints with oil, together with the Priest's prayer for the sick, hoping thereby to obtain recovery from sickness as well as forgiveness of sins.

The Church of Rome has departed widely from the primitive practice, and having found that the unction seemed to produce no effect in healing the sick, has instituted a new thing, for which 
the passage of St. James (the only one in Scripture which can conceivably bear upon the subject) supplies no authority at all, for she never uses unction when there seems any hope or prospect of recovery, but, on the contrary, orders it to be applied only to those "who lie in such imminent danger as to seem to stand at the point of death.'

The Service of Unction left in 1549 was short and simple, markedly different in character from the old Service, and implied no sacramental character. The Reformers, in the first Prayer Book, no doubt left the Unction rather as an indulgence to such men as might, in the infancy of the Reformation, be uneasy without it. It was discontinued in 1552 by the advice of Bucer. The following description of the old Service will show what a step in advance was even the Anointing Service of 1549. "The service of the sick included the recommendation of the soul in the article of death. The rubric directed that when dissolution was seen to be imminent, the clergy were to be apprised of it by the loud beating of a board, upon which signal they were to be hurried to the scene. This Service consisted mainly of a Litany, which after the invocation of the saints, appealed to a long list of saints to intercede for the dying one. The Service was entirely in Latin, and there were no directions such as those in the Office of Matrimony, for the occasional employment of the mother tongue; yet it is incredible that custom did not establish some use of it' (C. Hole).

Upon the forehead or breast only. "In the old Service the anointing was of various parts of the body, first the hands and feet, then in dorso inter limbos maris, vel umbilicum mulieris, all " for the purification of the mind and body, and defence against the darts of unclean spirits." Communion then followed. "The anointing of St. James contemplated recovery ; Extreme Unction, death' (C. Hole).

The common-sense argument for the discontinuance of the practice of Extreme Unction is the fact that the miraculous powers for which those who first were bid to adopt it are no longer possessed by any in the Church. 


\section{THE COMMUNION OF THE SICK}

\section{HISTORICAL INTRODUCTION.}

Though there is no provision made in Holy Scripture for the case of any one unable to be present at Holy Communion, the right to share in the 'Sacrament of Unity' has been recognized from very early times. Justin records the practice of sending a portion of the bread and wine to the absent by the deacons. The simplicity with which this was done may be seen from Euscbius, who tells us that a boy was used to carry the elements, and from Jerome, who mentions a wicker basket and glass for carrying them. Though devoid of scriptural sanction, this attempt to assure absent ones of their fellowship in the mystical body of Christ would command the sympathy of all, were it not for the danger that has been shown to lurk in even so well-intentioned a departure from scriptural precedent. Apart from doctrinal error, the custom of sending some of the bread to distant churches as a mark of fellowship, soon showed that the only safety lay in scrupulous adherence to Holy Scripture.

With the doctrinal degradation of the Sacrament, this practice lost its early meaning; now it tended to mean that the sick must not pass away without the supposed spiritual benefits of literal feeding on Christ's Body. This notion of a Viaticum, or provision for the road from this life to the next, associated administration to the sick with the imminence of death.* Naturally, the dogma of Transubstantiation, with its corollary of Concomitance, claiming that ' whole Christ, Body, Soul, and Divinity;' was in every least portion of the bread and wine, resulted in administration in one kind, to the sick as well as to the whole. Moreover it was no longer a simple carrying of the consecrated bread to the sick; a

* It has been claimed that the 13th Canon of the Council of Nicæa (488) ordered all men to receive the Viaticum, but such a claim is a perversion of the merciful provision that the Sacrament should be administered to those who had been excommunicated, if death were imminent, to restore them to fellowship before they passed away. It had nothing whatever to do with the dying, as such, but only with the excommunicated who were near death. Cf. Meyrick, Art. Viaticum in Protestant Dictionary. 
procession, with a lighted candle and a ringing bell as the minimum requirements, heralded the approach of the priest carrying ' Christ.'

Meanwhile the needs of the sick had become the least important reason for reservation of the consecrated elements; the actual Presence of ' Christ upon the Altar' suggested the value, not unreasonably if the dogma be once accepted, of reservation for the purpose of adoration.

\section{FIRST PRAYER BOOK.}

In 1549 an effort was made to conserve the primitive custom of reservation with such safeguards as should effectually prevent superstitious misuse of the reserved elements. The opening Rubric included these words:-

'And if the same day there be a celebration of the Holy Communion in the Church, then shall the Priest reserve (at the opon Communion) so much of the Sacrament of the body and blood, as shall serve the sick person, and so many as shall Communicate with him (if there be any). And so soon as he conveniently may, after the open Communion ended in the Church, shall go and minister the same, first to those that are appointed to communicate with the sick (if there be any), and last of all to the sick person himself. But before the Curato distribute the holy Communion, the appointed general confession must be made in the name of the Com. municants, the Curate adding the Absolution, with the comfortable sentences of Scripture following in the open Communion. And after the communion ended, the Collect, Almighty and everliving God, we most heartily thank thee, etc.'

The following were the safeguards against superstition :-

(1) Such reservation was only to be made if there were a Communion in the Church on the same day; the reservation could last but an hour or so at most.

(2) Reservation was to be in both kinds.

(3) The presence of others, though not compulsory, was contemplated.

(4) There was to be a preparatory service.*

(5) A Royal Injunction of 1549 ordered " that going to the sick with the sacrament the Minister have not with him either light or bells.'

In addition to this provision for the sick on days when there was a Communion in the Church, the 1549 B.C.P. contained a special Office for other times, consisting of :-

* The mediæval regulations for administration to the sick were : 'Let the priest ask him if he recognizes the body and blood of our Lord Jesus Christ, thus saying: Brotber, dost thou believe that the Sacrament which is handled (tractatur) on the Altar is the true Body and Blood of our Lord Jesus Christ ? Let the sick answer : I believe. Then let him be communicated.' A prayer and Psalm civ. followed. 
Rubric concerning notice, etc.

Psalm cxvii., with Gloria.

Lesser Litany, ' without any more repetition.'

The Lord be with you, etc.

The Collect.

The Epistle.

The Gospel.

The Lord be with you, etc.

Lift up your hearts, etc., "unto the end of the Canon.

Rubric prescribing order of administration, and urging the presence of others to communicate with the sick.

Rubric permitting reservation at such private communion, if there be other sick desiring to communicate on the same day.

Rubric declaring that any who are reasonably debarred from reception, if they are repentant, believing, and thankful, do 'eat and drink the body and blood of our Saviour Christ.'

Rubric prescribing a shortening of the Visitation Service, if it be at once followed by the Communion.

Rubric still further shortening the Visitation Service, 'if the sick desire to be anointed.'

\section{THE SECOND PRAYER BOOK.}

In 1552 the well-meant effort to restore the primitive simplicity of reservation was abandoned, for two good reasons. In the first place, it was impossible to dissociate reservation from superstitious error; in the second place, the custom lacked scriptural sanction. The great alterations in the Communion Office necessitated also the abandonment of the 1549 directions, e.g., there was now no 'Canon.' The 1552 provisions were exceedingly brief :-

Rubric concerning notice, etc.

The Collect.

The Epistle.

The Gospel.

Rubric regulating the order of administration.

Rubric declaring that the repentant and grateful believer partakes of Christ, though he be debarred from receiving the elements.

Rubric shortening Visitation Office, when accompanied by Communion.

Rubric permitting the Minister to communicate with the sick man alone, in case of infectious disease, 'upon special request of the diseased.'

The paucity of these regulations, and especially the absence of any instructions as to the part of the regular Communion Office to be used, have been taken to prove that the 1552 Office did not abandon reservation. The following is the latest statement of this contention*:-

' In 1552 the directions for reservation and for celebrating in the sick man's house were alike omitted : the Collect, Epistle, and Gospcl were retained, with a Rubric authorizing the Curate to "minister" the Holy Communion, provided there were a good number to receive the Communion with the sick person. Thus

* Frere, New History of B.C.P., p. 628. 
the Sacrament might be reserved, but no method was prescribed, the Curate was to carry it to the sick man, but he was not suffciently instructed what service he was to use in administering it.'

The utter untenableness of this theory may be easily seen :-

1. The directions for reserving and celebrating were not ' alike omitted,' for, besides the retention of the Collect, Epistle, and Gospel, which were not ordered to be used in administration of the reserved Sacrament under the 1549 B.C.P., there were definite directions for celebrating in the sick man's house, though the word ' celebrate' was altered to ' minister.'

2. The Rubric did not merely authorize the Curate to minister, but laid down the conditions under which such ministration was to take place, and that in the very words of 1549 for celebration, only altering the word ' celebrate' to ' minister ;' and adding the prescription of 'a good number' to communicate with the sick man. There was to be 'a convenient place in the sick man's house, where the Curate may conveniently minister'; he must have ' all things necessary for the same.' The theory, therefore, demands that these requirements, made in the very words of 1549 , meant one thing in 1549 , and quite another in 1552 . What could be the need of such requirements, and what "convenient place' or other 'things necessary' could there be, in order to adıninister the reserved elements to the sick man?

3. The basis of the theory consists of two things : the alteration of the specific word 'celebrate' to the general word ' minister,' and the absence of directions as to what part of the ordinary Communion Office should be used in ' celebrating.' The abolition of reservation rendered unnecessary the distinctive use of the word ' minister' for delivery of the elements to the communicants, and even in 1549 the distinction was not observed, for the whole Office, including consecration, is termed 'ministration' three times in the fourth Rubric of the ordinary Communion Office. So little did the Revisers mark any difference between the two words at the last revision, that they used both words: " that the Curate may reverently minister, he shall there celebrate.' S.L. made no alteration in the 1552 use of ' minister,' though it did make other alterations in the Rubric, proving that the wording was under consideration. As regards the absence of directions for a shortened form of service, supplied in 1662, that by no means proves that there were no directions as to what service to use. The whole service, with a special Collect, Epistle and Gospel, is prescribed, with whatever latitude might be dictated by the condition of the sick communicant.

4. It is most instructive that the only historical support claimed for the theory is contained in a foot-note citing, not quoting, 
Calvin, Epistle 361 (Aug. 12, 1561) ; Hill, Communicant Instructed (1617), pp. 36, 37. As neither writer makes any reference to the 1552 B.C.P., it is to be presumed that the dates of their writings constitute the supposed historical support of the theory. Apart from the fact that Calvin's opinion of the merits or demerits of Reservation has not the slightest bearing upon the 1552 B.C.P., and the further fact that even an English writer's opinion is not an interpretation of the 1552 directions, unless he states or suggests that it is intended as such, the actual words of the two writers will demonstrate how much, or rather how little, support the theory gains from their words.

Calvin says (tr. from the original Latin) :-

'Why I do not think the Supper is to be denied to the sick, many and serious reasons urge me. Meanwhile $I$ perceive how readily it has slipped into many abuses, which should be prudently and carefully met. For if there is no communion (communicatio), it is a grievous distortion of the institution of Christ. There ought therefore to be some assemblage, of relatives, members of the household, and neighbours, that there may be distribution according to Christ's command: next, let the action be con. joined with an explanation of the mystery : and nothing should be different from the common practice (ratione) of the Church. Moreover, to carry (it) about (deferre) hither and thither is very perilous. Also this is difficult to avoid, lest superstition may urge some, ambition and vain ostentation others, to ask for it. Therefore there would be need of judgment and discrimination, that it should not be given to any but those whose life is in great danger. That bread should be brought from the temple as if sacred is preposterous : that it should be carried in procession indeed, is no way tolerable.'

If words mean anything Calvin finds no good word to say for reservation.

R. Hill, D.D., in a work called The Pathway to Piety, published in London, Eighth Edition 1629, devoted one of his four sections to $A$ Communicant Instructed, the form of instruction being by question and answer. The first question upon Communion of the Sick is: "You have given many good instructions concerning this Sacrament: tell me, I pray you, is it lawfull, to prevent (sic) it privately ?' The answer details the early custom of administering to repentant excommunicated sick folk. The next question asks: "Did there any harm come of this order? Answ. Verie much : First, that if any were deadly sicke, the Eucharist must needs be administred to him : Secondly, that in Poperie, everie Parish Priest must bring to everie one of yeeres, ready to die, this breaden 'god in a box, with bell, booke and crosse ; and if any departed without receiving this journall, he was not to $b_{3}$ interred in Christian buriall : if he did receive it, he must needs, in the end, goe to Heaven.' The third question is: 'Doe all reformed Churches us 3 this order, privately to administer this holy Communion? Answ. Some doe not,' ten reasons being given for not privately administering, including (the ninth reason), "Other meanes of comfort may bee used, as well as this ; as comfort from the promises of the Gospell, and our ingrafting into Christ.' The fourth question on this topic is : 'Doe you well thinke, that a Minister may not administer this Sacrament to a sicke, or condemned man privately, 
if hee desire it?' The answer allows the practice, on the three grounds that the Minister cannot deprive a man of "the confirmation of his faith and seale of his salvation,' that the concession to the excommunicate of old should not be refused to the faithful to-day, and that such privato Communion is a testimony to the oneness of the recipient with the Church. The fifth and last question is : 'Are there no caveats to be given about this doctrine? Answ. Yos: 1. That it bee sparingly used. 2. To such only as desire it. 3. That they be taught, that it is not of necessitie. 4. That some words cf exhortation goe with it. 5. That no pompe bee used in carrying the Communion. 6. That the Minister know, it is not desired in superstition. 7. That it bee done to such as cannot come. 8. That the partie have a convenient company with him. 9. That if it may be done, the partio then receive it privately, when other doe so, in the Congregation. 10. That in the administration, the institution of Christ be observed, and all be done in remembrance of Christ's death.'

Hill, therefore, after defending at length the abandonment of any administration to the sick, justifies the retention of that practice, with ten caveats, the fifth of which denounces pomp in carrying the Communion. This is no more an exposition of the prescription of the 1552 B.C.P. than a modern treatise upon reservation would be an exposition of the 1662 B.C.P. Further, while its two last answers justify administration to the sick, the two preceding ones justify the abandonment of any Communion of the sick, so that the B.C.P. regulations cannot possibly be under consideration.

\section{THE LAST REVISION.}

In the 1662 B.C.P. there, is a provision for shortening the Office when used in the sick man's house, the regulations of 1552 being practically unaltered in other respects. The Rubric in the ordinary Communion Office, directing the consumption of surplus bread and wine immediately after the Blessing, rendered reservation impossible. In 1885 the Upper Houses of both Convocations declared 'that the practice of Reservation is contrary to the wise and carefully revised order of the Church of England as expressed in the Book of Common Prayer .... ro Reservation for any purpose is consistent with the rule of the Church of England.' In 1900 the question was argued before the two Archbishops, who expressed an unequivocal condemnation of Reservation, as not lawful in the Church of England.

The excuse for considerable disregard of the B.C.P. in this matter, is the supposed hardship inflicted upon a sick man in extremis, who might be robbed of the comfort and privilege of communicating through lack of time for consecration. It is ignored that a different kind of provision was made for such cases so early as 1549, namely, that the clergy should exhort to regular attendance so that deat h could not find a man negligent in regard 
to this ordinance of Christ; and that a sick man desirous of communicating, but prevented by any cause, should be plainly told that to be deprived of the consecrated elements is not to be deprived of feeding upon Christ's Body and Blood. Continuous reservation for the sick, which alone would meet the emergency contemplated in this excuse, was not permitted even in 1549 , from the desire to avoid anything like the suggestion that physical reception of the elements could control the eternal destiny of a dying man. The B.C.Y., therefore, designedly refuses to recognize any such excuse for reservation.

Other reasons are put forward, concerning the opinions of the minister rather than the need of the sick man.

1. The prescription of ' a convenient place' and of ' all things necessary' is alleged as a good reason for not consecrating in the sick man's house. If indeed a stone altar, and elaborate vestments, were requisite according to the B.C.P., it would be difficult to find a hotise where consecration could ever take place, and impossible where it could be done in an emergency. But no such demands are contemplated by the Rubrics; the bare thought that the simplest home of the poor could be unsuitable for the fulfilment of the Lord's Institution, is perilously inconsistent with the teaching of Him who 'became poor.'

2. The exigencies of a self-imposed rule of fasting before reception is a more frequent reason for disregarding the B.C.P., which, however, was framed for the benefit of Christ's people, and not to suit the private practices of individual men, even ministers.

3. Not infrequently the real reason for defying the B.C.P. is the desire to keep the Reserved Sacrament in the Church, for the purposes of prayer and adoration. It is needless to say that the B.C.P., which included safeguards against any such practices even when it allowed reservation for the sick, affords no countenance to such reasons when, as now, it forbids reservation altogether.

Finally, it should be added that the jus liturgicum, by which it is assumed that power resides in the episcopacy to set aside the requirements of the Church of England, and under which the practice of reservation has received episcopal sanction with certain safeguards, is a figment of the imagination. The Church of England includes bishops amongst its ministers, all of whom are bound equally by the Rubrics of the Church, save where those Rubrics themselves credit the 'Ordinary' with special power to interpret specific rules, concerning which there may be dispute. No such power is granted in regard to Reservation. 


\section{ANALYSIS AND HISTORICAL NOTES.}

Title, 1549.

Preliminary Rubric, 1549 ; much altered, 1552 ; two clauses added, 1662.

The Collect, 1549 .

The Epistle, 1549 ; A.V., 1662.

The Gospel, 1549 ; A.V., 1662.

Rubric prescribing abbreviated Service, 1662.

Rubric prescribing order of reception, 1549.

Rubric containing comfort for those unable to communicate, 1549.

Rubric shortening Visitation Office when followed by Communion, 1549 ; altered, 1552.

Rubric permitting the Minister to communicate with sick man only, in certain cases, 1552.

\section{EXPOSITION.}

Title, 1549 .

The word 'Communion' was chosen from the first, to express the return to the primitive conception of the sick man's right to share in the "Sacrament of Unity,' as part of the Mystical Body of Christ.

Preliminary Rubric, 1549 ; much altered, 1552 : two clauses added, 1662.

The Rubric comprices three directions:-

i. To the Curate to exhort parishioners to the frequent reception of the Holy Communion in the Church.

This direction has remained unaltered, save verbally, since 1549 .

ii. To the sick person to give notice of wish to communicate, and of the number who will communicate with him.

1549. Over night, or else early in the morning.

1662. Timely notice.

1549. "Nany' to communicate with the sick.

1552. As in 1549, with a clause in the next direction specifying 'a good number.'

1662. Three, or two at the least.

Here came, in 1549 , the provision for communicating the sick directly from the Church : see Historical Introduction, p. 459. iii. To the Curate, regarding the Service.

1549. But if the day be not appointed for the open Communion in the Church, then (upon convenient warning given) the Curate shall come and visit the sick person afore noon. And having a convenient place in the sick man's house

$\therefore \quad$ (where he may reverently celebrate) with all things necessary 
for the same, and not being otherwise letted with the public service, or any other just impediment, he shall there celebrate the holy Communion after such form and sort as hereafter is appointed.

1552. And having a convenient place in the sick man's house, where the Curate may reverently minister, and a good number to receive with the sick person, with all things necessary for the same, he shall there minister the holy Communion.

1662. And having a convenient place in the sick man's house, with all things necessary so prepared, that the Curate may reverently minister, he shall there celebrate the holy Communion, beginning with the Collect, Epistle, and Gospel, here following.

For an examination of the supposition that the 1552. Rubric did not refer to 'celebrating' in the sick man's house, see Introduction, pp. 460-63.

The omission, since 1552, of the words 'afore noon,' and 'not being otherwise letted with the public service, or any other just impediment,' is important as marking the disappearance of any suggestion in B.C.P. that late celebrations are undesirable, or that fasting Communion is desirable.

The Collect, 1549.

The Epistle, 1549; A.V., 1662.

The Gospel, 1549 ; A.V., 1662.

The American B.C.P. permits the substitution of the Collect, Epistle, and Gospel for the Day, when the Office is used for aged and bed-ridden folk, etc.

Rubric prescribing abbreviated Service, 1662.

In 1549 (seee Introduction, p. 460), a shortened form of Service was prescribed, ending with the direction " unto the end of the Canon.' This was the only place where the word 'Canon' was retained, to disappear finally in 1552 , when the prayers forming the Canon were separated. The Canon, in the 1549 B.C.P., would include what are now the Prayer for the Church Wilitant. the Prayer of Consecration, the First alternative Thanksgiving after reception, and the Lord's Prayer. The name 'Anaphora" was also given to this part of the Communion Service, including the Sursum Corda and Ter-Sanctus.

In 1552, the word 'Canon' became meaningless, and no directions were given for shortening the Service, save the shortened special Epistle and Gospel.

In 1662 the present Rubric was inserted, directing the use of 
the whole Office after the Third Exhortation, preceded by the special Collect, Epistle, and Gospel.

The American B.C.P. specifies a still more brief Service, in cases of contagious sickress.

Rubric prescribing order of reception, 1549.

The last clause, mentioning the sick person as the last to receive, was omitted from 1552 to 1662 , but the omission can have had no meaning, seeing that the minister is directed to receive first, and then to deliver to those appointed to communicate with the sick. The words ' if there be any ' were inserted in 1549, with a direction to the sick man always to try to get some to communicate with him, a 'singular great comfort' to himself, and 'a great token of charity' on their part.

Here another Rubric permitted, in 1549, the reservation of consecrated elements at a private celebration, if there were other sick to be communicated the same day.

Rubric containing comfort for those unable to communicate, 1549.

The doctrinal import of this Rubric is partly contained in a comparatively ancient direction, quoting the famous words of Augustine, In Joann. xxv. 22: Crede et manducasti: 'Believe and thou hast eaten.' The translation of the form is (Maskell, Mon. Rit. i. p. 89): 'Unless there is probable fear of vomiting or other irreverence, in which case the priest may say to the sick man :-Brother, in this case true faith and a good will are suffcient for thee: only believe, and thou hast eaten.'

The 1549 Rubric goes much further than this, however. It specifies conditions which may prevent communicating, and delineates the attitude of faith which constitutes feeding on the Body and Blood of Christ.

i. The possible justifiable hindrances are :-

(a) Extremity of sickness.

(b) Lack of giving notice in time.

(c) Lack of others to communicate with the sick (added in 1552).

(d) Other just impediment.

It will be noticed that the hindrances of the B.C.P. are more in number, and wider in kind, than those specified in the form translated from Maskell, which only dwells upon possible irreverence to the elements.

ii. The attitude of faith is :-

(a) True repentance.

(b) Belief in Christ's vicarious death upon the Cross.

(c) Belief in personal redemption by that blood-shedding.

(d) Earnest remembrance of the benefits of Christ's death.

(e) Hearty thanksgiving for those benefits. 
The justification of the teaching that such an attitude of spirit is a feeding on the body and blood of Christ, is to be found in a comparison of John vi. 47 and 53, where the possession of everlasting life is predicated alike of him who believes on Christ, and him who eats His flesh and drinks His blood. The Rubric certainly does not justify abstention from the Lord's Table, but it does certainly imply the truth that, whether at the Lord's Table or not, the on'y possible feeding on Christ's body and blood is that which results from faith in Him.

Rubric shortening Visitation Office when followed by Communion, 1549 ; altered 1552.

In 1549 , besides the direction to use another part of the Visitation Office than that ordered since 1552, a Rubric followed stating that ' if the sick desire to be anointed, then shall the Priest use the appointed prayer without any Psalm. For the Anointing of the Sick, sce Visitation of the Sick, pp. 456, 7.

Rubric permitting the Minister to communicate with the sick man only, in certain cases, 1552.

In 1549 the possibility of there being none to communicate with the sick man was contemplated, without any refusal to permit such solitary communion. This was no longer allowed from 1552 onwards, and the special case of contagious sickness, which might justly deter others from communicating with the sick man, was provided for in this Rubric. The permission was given, however, only ' upon special request of the diseased,' and 'lack of company to receive with him' was specified as a 'just impediment' to reception of the elements. The quaint adverb 'alonely' was used for 'only' until 1662- 


\section{THE ORDER FOR THE BURIAL OF. THE DEAD}

\section{INTRODUCTION.}

From very early ages religious ceremonies were performed at the Burial of the Dead, not only by the Jews, but also by heathen nations. Many of the latter, notably the Greeks and Romans, burned the bodies of their dead, and placed their ashes in urns.

The first Christians buried their dead in the open fields or in caves by the roadside, where the funeral urns of the heathen were also deposited.

As churches were multiplied, pieces of ground at some distance from, but subsequently contiguous to, the sacred edifices were consecrated for the interment of the dead. These wero

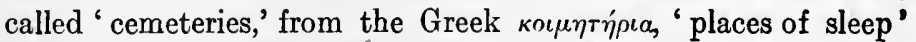
-resting-places of those who sleep in Jesus. Constantine was the first who was buried in a church; but it was not until the monks obtained the right as a means of profit for their establishments, that interments in churches became general.*

The Service which was held at the burial of Christians in early days was, naturally, of a primitive character. It merely comprised hymns and psalmody expressive of joy and hope, together with informal prayers and some commemoration of the departed. But in process of time it crystallized into a more definite form, and in the fifth century the celebration of the Holy Communion came to form part of it. By degrees, this Service, originally designed for the comfort of the living, was changed into an elaborate system of Masses for the dead.

The Medireval Service Books directed various ceremonies to be performed at the Burial of the Dead. The following are those

* 'Abraham buried Sarah at Machpelah, 1800 (?) B.c., Gen. xxiii. Places of burial were consecrated under pope Calixtus I. in 210 A.D. (Eusebius). 'The Greeks had their burial-places at a distance from their towns; the Romans near the highways; hence the necessity for inscriptions. The first Christian burial place, it is said, was instituted in 596 ; burial in cities, 742 ; in consecrated places, $750:$ in churchyards, 758. Many of the early Christians are buried in the catacombs at Rome' (Hayden's 'Dictionary,' Vincent, 1906, art. 'Burials'). 
ordered in the Sarum Use :-The rite began with the 'Commendatio Animarum, i.e. the commendation of the soul of the departed to God, which was said at the house. The corpse was then taken to the church, where the Nass, called also the Requiem,* was said for the soul of the departed, and prayers were offered for the pardon of the dead man's sins. The Priest then censed the body three times, and after the last time sprinkled it with holy water. It was then borne to the grave, where a requiem was chanted, and more prayers offered, not only for the dead person, but also for the benediction and sanctification of the grave, which was then sprinkled with holy water and censed. The Priest then placed an absolution on the breast of the corpse and pronounced one likewise. Then as the corpse was being deposited in the grave the latter was again sprinkled, earth being placed on the body in the form of a cross, and the body itself censed and sprinkled. Afterwards, while the body was being covered with earth, the Priest said, 'I commend thy soul to God the Father Almighty, earth to earth, ashes to ashes, dust to dust, in the name...., etc.

The Service in 1549 differed very greatly from that in the preReformation Manuals. While parts of the old Uses were retained, a great deal was rejected, much was added, and the whole Service entirely rearranged. It was now framed, not mainly for the benefit of the dead, but for the edification and comfort of the living. There was no service at the house, no incense, no holy water, no requiem, no signing of the cross, no Mass.

-There was, however, a prayer for the soul of the departed, and a celebration of the Holy Communion. The latter, as has been observed, had been introduced at an early date; its object was to give the friends of the departed an opportunity of testifying to their belief 'that the Communion of Saints extended beyond the grave.'

In 1552 the Prayer for the Dead, the celebration of the Holy Communion, and certain other portions of the Service were omitted, while the remainder was considerably altered and rearranged.

In 1662 different Psalms were chosen, and their position with that of the Lesson was changed.

The Greeks have separate Offices for Laics, for Monks, for Priests, and for Infants.

- The parish minister is compelled by Statute to use the. present

* So called from the beginning of the Introit or Officium: 'Requiem atcrnam dona eis, Domine, el lux prrpetua luceat eis' (Sar. Miss., col. 860). 
Service, if required, over all who die in his parish, with the exception of those who are excluded by the opening rubric. The penalty for refusal is immediate suspension.

By the Burial Laws Amendment Act, 1880 (43 \& 44 Vict. c. 41 , s. 9), chiefly taken from the laws of the Church, where a person is entitle 1 to be buried in any churchyard or graveyard, any person responsible for the burial may give a 'notice of burial' to the incumbent or clergyman that the burial will be without the Church Service. The burial may be either with or without any religious service, if professedly Christian and orderly, as the person responsible for the burial may think fit.

Any clergyman may, with the consent of the representatives of the dead and of the bishop, substitute a form of Service wholly scriptural. He may also read, in the case of those excluded by the opening rubric (of the Burial Service), a short service consisting of prayers from the Prayer Book and portions of Holy Scripture approved by the Ordinary (see B. Whitehead, 'Church Law,' 4th ed., art. 'Burial').

A layman may, by request, conduct a burial if he use a Service of a 'Christian and orderly character.'

\section{- $\quad$ ANALYSIS AND HISTORICAL NOTES.}

[The date is 1549, except where otherwise stated.]

\section{Opening Rubrics.}

No. 1. Limiting the use of the Office. 1662.

No. 2. Directing where to be held. Altered in 1662 .

I. The Service in Chureh.

1. The Sentences, or the Anthem of Hope and Resignation. 1549, Great Bible: 1662, A.V.

2. The Psalms, as in Psalter, 1662 : Dixi, Custodiam, Psalm xxxix. ; Domine, refugium, Psalm xc.

3. The Lesson. 1 Cor. xv. 20. 1549, Great Bible; 1662, A.V.

[N.B.-The Psalms and the Lesson were allowed in 1549 to precede or follow the actual burial.]

\section{The Service at the Grave.}

1. Anthem of Lament and Supplieation. In 1549 the Scripture quotation was from the Great Bible; in 1662 from A.V.

2. The Committal. Altered 1552. The Rubric altered 1552 .

3. Anthem of Assurance and Consolation. I heard a voice, etc. 1549 Great Bible. 1662, independent translation. 


\section{The Concluding Part.}

The Rubric altered, 1662.

1. The Lesser Litany, or Suffrages.

2. The Lord's Prayer.

3. Prayer for the Speedy Coming of God's Kingdom and the Complete Happiness of God's Church. Composed in 1552.

4. The Collect, adapted from Burial Communion Office; hence the name. 1552.

5. The Grace, 1662, there being no Communion Office to follow.

Table comparing 'The ORder for the Burial of the Dead' and 'The Communion Office,' 1549, 'with 'The Order for the Burial of the Dead,' 1662.

1662.

The Order for the Burial of the Dead.

At the entrance of the Churchyard, either going into the Church or towards the grave.

1. The Sentences.

$$
\text { In the Church. }
$$

2. Psalm xxxix., or xc.

3. The Lesson, 1 Cor. $x v .20$. At the Grave.

4. Opening Anthem: 'Man that is born,' etc.

5. Committal Words.

6. Closing Anthern: 'I heard a voice.'

7. Lesser Litany.

8. The Lord's Prayer.

Prayer for the Complete Happiness of God's Church.

9. lst Clause: "Almighty God, with whom,' etc.

10. 2nd Clause : "We give theo hearty,' etc.

11. Remaining Clauses : 'Beseeching Thee,' etc.

The Collect.

12. Ist Part: 'O Merciful God, the Father,' etc.

13. 2nd Part: 'Come, ye blessed,' etc.

14. The Grace.

\section{9.}

The Order for the Burial of the Dead.

At the Church stile, or going either into the Church or towards the grave.

1. The Sentences.

\section{At the Grave.}

4. Opening Anthem : 'Man that is born,' etc.

5. Committal Words.

6. Closing Anthem : 'I heard a voice.'

Prayer for Complete Happiness, etc., No. 1.

lst Part: 'We commend,' etc.

13. 2nd Part: 'Come, ye blessed children,' etc.

10. Prayer for Complete Happiness, etc., No. 2. 'Almighty God, we give thee.'

2. Psalm cxvi., Psalm cxxxix., Psalm cxlvi.

3. 1 Cor. xv. 20.

7. Lesser Litany.

8. The Lord's Prayer. Suffrages.

9. Prayer for Complete Happincss, etc., No. 3. 'O Lord. with whom do live.' eto. 


\section{THE SERVICE.}

Opening Rubrics.

These limitations of the use of the Office were inserted in 1662. The removal in $\mathbf{1 5 5 2}$ of all prayers for 'the faithful departed' made such limitations unimportant, the $\mathrm{n} \geqslant \mathrm{w}$ Office being mainly, as far as the prayers were concerned, for use by the mourners, and the spiritual condition of the deceased being only by implication charitably assumed, in accordance with other Services in B.C.P. Nevertheless, the trend of the Office is such as to render it most unsuitable for the burial of those notoriously separate from Christ.

1. The First Rubric prohibits the use of this Office in regard to three classes of persons, viz. the unbaptized, suicides, and the excommunicate. The same were excluded from Christian Burial by the Ancient Ecclesiastical canons.

(1) The Unbaptized those who have not been baptized either at all, or whose Baptism is invalid by reason of the proper matter and the proper words not having been used. It is regarded as valid if performed properly by a layman. Baptism is taken for granted in a Christian country unless there is proof to the contrary. It may well be that the growth of Anabaptism, entailing the unbaptized condition of considerable numbers, instigated the insertion of this limitation. Yet the guarded .. words of the closing rubric of the Baptismal Office, predicating the safety of children who die baptized without pronouncing upon the case of infants not baptized, would suggest that the Church of England is not to be accused of condemning innocent children for the neglect or opinions of their parents. The restoration of Holy Baptism, both infant and adult, to its true position as a Clristian rite instead of a mere custom, would do much to invest this rubric with an intelligible meaning, and to make the use of this Service over the unbaptized, as Archbishop Longley termed it, ' an anomalous and irregular proceeding.' Meanwhile it is to be feared that this regulation, though it does indeed impress parents with the necessity of Baptism, emphasizes its importance with a view to burial with Church of England rites rather than entry into Christ's Kingdom. The case of those unbaptized through unwillingness to belong to Christ offers no difficulty. Canon 68, 1604, only mentioned the 'greater excommunication' as justifying refusal to bury, any refusal on other grounds entailing suspension for three months.

(2) 'The Excommunicate' were those whom the 60th Canon described as being under 'the greater excommunication'-a spiritual punishment formerly inflicted for some 'grievous and 
notorious crime not repented of.' It consisted of being expelled from the communion of the Church, and deprived of its privileges. The enforcement of discipline by excommunication had been so abused by Popes, Prelates, and Priests, that even in 1549 it had fallen into disuse, the words of the opening address in the Commination Office expressing a desire for its restoration in its primitive form, but the desire has never been realized. The difficulty and even the impossibility of avoiding such distinction between acts of $\sin$ as would obscure God's attitude towards sin of every kind; the absence of any guarantee that man, either individually or collectively, is wise and 'indifferent' enough to exercise dis. ciplinary power without tyranny; and the above-mentioned misuse of the power, rendering the laity as a whole absolutely intolerant of it; - these and other like causes have prevented any restoration of the practice. Discipline is now purely a legal matter, to be dealt with in Court. In recent history a clergyman has wrongfully attempted to pronounce and enforce excommunication of one who had married his deceased wife's sister; but the Courts have proved that the individual clergyman has no such right of discipline. Under the circumstances, there is little likelihood of any problem arising in regard to the use of the Burial Service over excommunicate persons.

(3) The Suicides, here referred to, are they who have destroyed themselves with a full knowledge of what they were doing, and in whose case the jury at the coroner's inquest has returned a verdict of felo-de-se. It does not include those who have laid violent hands upon themselves in temporary or permanent mental derangement. Till comparatively recently it was the barbarous practice to bury suicides at cross-roads, the corpse having been thrust through with a stake; still later the law was severe, burial only being allowed at night, without any religious service, and all property reverting to the Crown. The gencral feeling that it is wanton cruelty thus to penalize the living for the desperate deed of the dead has put an end to these laws, but the difficulty is thrust upon the Minister with regard to Christian burial. That difficulty is minimized by the fact above noted, that our Reformed Office is composed for the mourners, with the careful exclusion in 1552 of prayers for the deceased, and, further, the charitable hope which is entertained in other Services will often dictate the course to be followed in the use of this.

2. The Second Rubric directed where the Service is to be held. The Priest and Clerks are to meet the corpse 'at the entrance of the Churchyard,' 1662 ('at the Church stile' 1549, etc.), and go 
' before it either into the Church or towards the grave.' The latter alternative was ordered on sanitary grounds.

The Anthem of Hope and Resignation.

(1) I am the Resurrection, etc. (John xi. 25, 26). 1549, Great Bible ; 1662, A.V. Sar. Brev., Vigil of the Dead.

(2) I know that my Redeemer liveth, etc. (Job xix. 25-27). 1549, Great Bible ; 1662, A.V. Sar. Brev., Vigil of the Dead.

The word 'Redeemer' (Heb. Goel) should be more correctly renered 'Vindicator.' See R.V. mary.

The old Service Books contained only these two sentences; the former was sung as an Antiphon, the latter as a Respond.

(3) We brought nothing, ctc. (1 Tim. vi. 7 ; Job i. 21).

\section{The Psalms.}

1549. Dilexi, quoniam. Psalm cxvi.

Domine, probasti. Psalm cxxxix.

Lauda, anima mea. Psalm cxlvi.

Note.-These Psalms were to be said 'in the church, either before or after the burial of the corpse.'

1552. The Psalms omitted.

1662. The present Psalms (xxxix. and xc.) appointed to be read in the church before the burial.

Psalm xxxix., Dixi, Custodiam (Psalter Version).

This Psalm is ascribed to David upon Joab's reproach for his grief for Absalom's death. It may be described as a prayer of one who, while feeling the vanity of a.l earthly things, finds hope in God. This Psalm is more suitable than the following one at the Burial of a young person.

ANALYSIS.

VERS.

I. The Psalmist's soliloquy respecting the bridling of his tongue

II. The expressions of his emotions which could no longer be restrained

(1) He asks to know the direction of his life.

(2) He expostulates on the brevity, the uncertainty, and the frailty and the vanity of life.

(3) He declares that the foundation of all his hope is in God. III. Prayer (interspersed with humble acknowledgements) that God's chastening hand may be removed, and his life prolonged

Psa'm xc., Domine, Refugium (Psalter Version).

The traditional view is that it was written towards the close of the wanderings in the wilderness by Moses, who had watched one generation of Israel after another dying for their faithless nuumuing. Many moderu commentators, however, think that 
it was composed at the time of the Exile by some gifted poet to express what he conceived to be Moses' feeling.

This Psalm (see ver. 10) is the more appropriate one to be used at the funeral of an aged person.

ANaLysis.

VERS.

I. The Psalmist's meditation on God's eternity, man's transitory existence, and the Divine indignation . . 1-11

II. Prayers suggested by the subjects of his meditation.

(1) For wisdom to value life and use it for God's honour and glory . • . . . . . . •

(2) For mercy and comfort after days of adversity : . 13-15

(3) For the prospering of the work of God's servants . . 16,17

The Lesson (1 Cor. xv. 20).

1549. The Lesson was read in the church after the Psalms, ' either before or after the burial.'

1552. It was read by the graveside after the anthem, 'I beard a voice,' etc.

1662. Placed in its present position.

. In the Sar. Man. (in the Mass for the Dead) part of this Epistle was directed to be read. In Herm. Con., 1 Cor. xv. 20-28 was ordered to be read and explained after the funeral. Alternatives were provided in 1 Cor. xv. 50-58; Phil. iii. 20, 21 ; Rom. vi. 8-11 (Dowden's 'Workmanship'' etc., pp. 39, 40).

The Scotch Episcopal Church, by a Canon of the year 1890 , ordained that with 'the sanction of the Bishop another Lesson may be substituted for that in the Book of Common Prayer.'

In the Diocese of Edinburgh permission has been given under this provision to use 1 Thess.iv. 13-18 (the Epistle in 1549 of the Burial Service), or Rev. vii. $9 \mathrm{ff}$. to the end of the chapter; Mark x. 13-16 has been sanctioned permissively for the burial of a child.

The doctrine of the Resurrection has been more fully expounded in this Epistle than in any other part of the Bible, the majestic diction in which the argument is clothed (stately music heard in the stillness of night rather than an argument) justifies its use for the comfort of man in the presence of deat?.

ANaLysis of I CoRINThIANS $\mathrm{x} v$. 20-59.

The Resurrection of the Body.

I. The Fact, proved from :-

VERS

(1) The historical resurrection of the 'Firstfruits' (1-20a) with Whom the believer is in vital union

The postponement of the believer's resurrection is in agreement with the revealed course of Christ's triumph * . . . . . . . .

* 'Then shall the Son also Himself be subject,' etc. (v. 28). All hostile 
(2) The testimony of Christians :-

VERS.

i. Martyrs (?) *

29

ii. St. Paul's own living martyrdom . . . 30-32

Warning against the real sources of unbelief $\quad 33,34$

I. The Mode, taught by :-

(1) God's Method in Nature, life through death . . 35-38a

(2) God's Power in Nature, variety in the universe . 38b-41 Application of (1) and (2) . . . . . 42, 43

(3) God's Promise of the New Body, revealed in :-

forces having been finally destroyed in the overthrow of 'the last enemy'. by the resurrection of the body, the Son will resign the restored Kingdom into the Father's hands, voluntarily subjecting Himself (this is the refexive foree of the second aorist passive) to Him. This passage was regarded as the Arian stronghold in Holy Seripture, and many attempts have been made to find an orthodox explanation of the subjection of the Son. The use of the Name 'the Son,' expressive of the eternal relation within the Godhead, excludes the very numerons efforts to explain it of the Manhood of Christ, and thus to bring the passage into line with the words of the Athanasian Creed; 'inferior to the Father as touching His Manhood.' To interpret the subjection as equivalent to a mere resignation of the Mediatorial priestly office, is virtually to ignore the word 'subject,' and, moreover, it is not that office which is resigned but the Kingdom (v. 24). It is wiser to recognize that there is a sense in which from eternity a relative

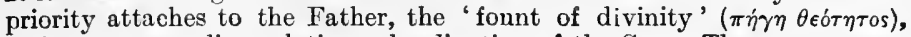
and a corresponding relative subordination of the Son. The very names, 'Father,' 'Son,' 'Word,' given to reveal the essential relationship of the First and Second Persons of the Blessed Trinity, intimate some such subordination; the seeming contradiction of their substantial equality being due to the impossibility of any adequate representation of that transcendental celationship in himan langnage. The dispensational subordination of the Spirit to the Son, taught by Christ Himself in John xvi. 7, 13, 14, may serve to remind us that subordination by no means implies inequality. St. Paul's words, therefore, teach the truth that after the final victory, complete in the resurrection, the Son will resume that relationship which He had with the Father before the world began (John xvii. 5).

" 'Else what shall they do which are baptized for the dead ?' (v. 29).

The meaning of this obscure sentence turns upon the answer given to the following questions:-

1. Is ' baptized' to be taken literally, or figuratively as in Luke xii. 50)?

2. Is the preposition ( $\dot{v} \pi t \rho)$, translated 'for' in A.V., to be rendered 'over,' or ' for,' ' on behalf of,' or ' concerning,' ' in the matter of,' as in 2 Thess. ii. 1: (A.V. 'we beseech you, brethren, by the coming of our Lord Jesus Christ').

3. Is the word 'dead' (literally 'corpses') to be interpreted of the dead generally, of dead bodies of particular people, e.g. unbaptized dead or martyred dead, or of the graves of the dead, or of death itself ?

The following are some of the chief interpretations:-

1. The baptism of living people in the place of the unbaptized dead.

2. Baptism into the place of the martyred dead, i.e. to fill up the ranks.

3. Baptism for the resurrection of the dead, i.e. in hope of the resurrec; tion.

4. Figurative baptism, i.e. martyrdom (as in Mark x. 38; Luke xii. 50). 
i. The different natures of the First and Second VERS. Adams* .

ii. The need of a new body for the new conditions of life

A song of triumph, and

An appeal for constancy in expectant service.

The Anthem of Lament and Supplication. 1549. Sar. Brev. First Paragraph Job xiv. 1, 2 (1549, Great Bible ; 1662, A.V.), taken from Sar. Brev., Office of the Dead; second, third, and fourth, are free translations of an Antiphon sung after the Nunc dimittis at Compline during a part of Lent. They date from the ninth century. The use of this anthem at Burials is borrowed from Herm. Con.

Before the Reformation, Psalms cxiv. and xxv. were sung on the way to the grave, the Antiphon being 'May the Angels carry thee to Paradise ; may the martyrs receive thee into their assembly, and bring thee unto the city of the heavenly Jerusalem.'

\section{The Rubric before the Committal.}

1549. Then the Priest casting earth upon the Corpse shall say.

1552. Then, while the earth shall be cast upon the body, by some standing by, the Priest shall say.

The Sar. Man. had a similar Rubric to that of 1552 .

The Casting of Earth upon the Corpse.

The practice of casting earth upon the body is a retention, in

* 'A natural body . . a s spiritual body' (v. 44). Both adjectives are misleading. The word translated 'natural' is $\psi v \chi \chi^{\circ} \kappa$ s$^{\prime}$, 'belonging

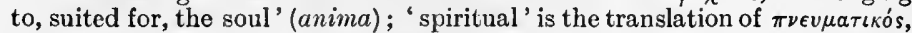
'belonging to, suited for, the spirit,' not ' composed of spirit,' 'ghostly.' The tripartite division of man into body, soul, and spirit, is taught expressly in 1 Thess. v. 23 ; the contrast between the soul, $\psi v \chi \eta^{\prime}$, and the spirit, $\pi \nu \epsilon \hat{v} \mu a$, is also brought out in Rom. viii. 16 ; 1 Cor. ii. II ; xiv. 14 . The

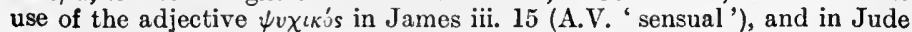
19 ('sensual, having not the Spirit'), is in line with St. Paul's teaching. The very frequent use of the word $\psi v \chi \eta^{\prime}$ for 'life,' and for 'soul ' in contrast with the body, in the rest of the N.T., and in the LXX, marks an ambiguity which is removed by St. Paul's psychology. Here, at all events, the $\psi v \chi \eta$ means that part of man's nature which he shares with all animal life, however man may differ from animals in degree; the $\pi \nu \epsilon \hat{v} \mu a$ is that part of man which is capable of entering into relations, even communion, with God Himself. St. Paul's argument therefore is that as we have been endowed with a body which serves the purposes of the $\psi v \chi \eta$, so we shall be endowed with a body answering to the $\pi v^{\prime} \epsilon \hat{v} \mu a$. "If there is a natural body, there is also a spiritual body' (R.V.): that is, it is unreasonable to think that God will ignore the need of a body for the spirit, when he has provided one for the lower faeulty, the soul. 'To St. Paul the common Greck conception of a bodiless existence, as a 'shade,' is as unreasonable as it is undesirable (c/. 2 Cor. v. I-4). 
its most simple form, of an old ceremony which followed a long series of Psalms and Collects and a form of hallowing the grave ; the earth directed to be cast in the form of a cross. The custom of casting earth three times upon the body was one adopted by the Romans.*

The Words of Committal. 1549, altered 1552. (See Gen. iii. 19; Eccles. xii. 7 ; Phil. iii. 21.)

In 1549 they took the form of a Commendation: "I commend thy soul to God the Father almighty, and thy body to the ground; earth to earth, ashes to ashes, dust to dust ; in sure and certain hope,' etc.

Our vile body, better ' the body of our humiliation.'

There was a similar (though shorter) form of Commendation in the Sarum Manual. 'I commend thy soul to God the Father, Omnipotent, earth to earth, ashes to ashes, dust to dust, in the name of the Father and of the Son, and of the Holy Spirit.'

In the American Liturgy the form is: "Forasmuch as it has pleased Almighty God in His wise providence to take out of this world the soul of our deceased brother, we therefore commit his body to the ground ; earth to earth, ashes to ashes, dust to dust ; looking for the general resurrection of the last day, and the life of the world to come, through our Lord Jesus Christ, at whose second coming in glorious majesty to judge the world, the earth and the sea shall give up their dead; and the corruptible bodres of those who sleep in Him shall be changed, and made like unto His own glorious body, according to the mighty working whereby $\mathrm{He}$ is able to subdue all things unto Himself.'

In sure and certain hope of the resurrection to eternal life.

In 1549 the word 'resurrection' had nc article: I commend thy soul. . . in sure and certain hope of resurrection.' This suggested a definiteness in regard to the state of the deceased, which was corrected in 1662 . No one can pronounce so definitely upon another's state.

This same use of the article occurs in the Committal to be used at sea.

The American Prayer Book (see above) has made the pronouncement still more clearly general.

Anthem of Assurance and Condolation. Rev. xiv. 13. Sar. Miss. (The Vigils of the Dead). 1549, Great Bible; 1662, independent translation.

The Lesser Litany. 1549. Sar. Man.

* See Horace, Odes, Lib. I. xxviii. 35. 36: Licebit injecto ter pulvere curras. 
The Lord's Prayer, without Doxology. 1549. Sar. Man. 1549. The priest said the Lord's Prayer up to the last petition, 'but deliver us from evil,' which was said by the people. In 1662 this practice was changed, as in the Litany, Matrimony, Visitation of the Sick, Churching of Women, and Commination Service. In 1549 these Versicles followed :

Priest. Enter not (O Lord) into judgment with thy servant.

Answer. For in thy sight no living creature shall be justified.

Priest. From the gates of hell.

Answer. Deliver their souls, O Lord.

Priest. I believe to see the goodness of the Lord. Answer. In the land of the living.

Priest. O Lord, gracious y hear my prayer.

Answer. And let my cry come unto thee.

A Prayer for the speedy Coming of God's Kingdom. 1552. The first clause of this prayer is found in 1549, from Sar. Man. Portions of two other prayers in the Sar. Man. are also incorporated.

The following clause, which occurs in this Prayer in the American Prayer Book, is a corrective to Prayers for the Dead : "We give Thee hearty thanks for the good examples of all these Thy servants, who, having finished their course in faith, do now rest from their labours.'

We with all those that are departed.

1549. This prayer was wholly for the deceased; in the Collect the phrase occurs, "both we and this our brother departed,' etc.

The words 'we and this our brother' include the latter in our prayer. The change of ' and ' to 'with' is very significant, and the omission of the mention in 1662 of the words 'this our brother' remove all ambiguity. The faithful dead are remembered, but the prayer is that we may share their assured destiny. (For a similar alteration of language see 'Prayer for the Church Militant.')

\section{The Collect. 1552.}

'This prayer is mainly composed from two prayers of 1549 ; the one being the 'Collect' in the Communion Office at Burials ; the other the Prayer after the Versicles, the first clause of which, as above stated, had been incorporated in the preceding prayer.

As our hope is this our brother doth. The word 'as 'originally de- 
noted a certainty which is largely lost to-day. This explains the objection raised by the Presbyterians in 1661 to such phrases. The reply was, 'It is better to be charitable and hope the best, than rashly to condemn.' The American Liturgy omits this clause.

In the Prayer Book of 1549 bere followed the Office of Holy Communion.

The Grace. 1662.

The omission of the Communion Service in 1552 left the Burial Office without any proper conclusion. Nevertheless the 'Grace' was not inserted till the last revision.

The Burial Communion Office. 1549.

At the close of the Burial Service in 1549 was printed a Psalm (xlii.), a Collect (incorporated with a few minor alterations in the Burial Office proper from 1552, and still called 'The Collect '), an Epistle (1 Thess. iv. 13-18), and a Gospel (John vi. 53, 54). This was arranged to take the place of the Mass at Burial, one of the most common and popular features of the unreformed religion. It is easy to understand that it was almost impossible to issue a Burial .Office without this familiar accompaniment, but, with the growing recognition of the fact that the Holy Communion is neither prayer nor sacrifice, and the rea!ization that Prayers for the Dead are without scriptural support, it was equally impossible to retain the Service in any form in 1552 .

\section{PRAYERS FOR THE DEAD.}

There is no passage in the Old or the New Testament which enjoins, sanctions, or recommends prayers for the dead, believing or unbelieving. The righteous enter 'Paradise' at death, and 'are in joy and felicity' (Phil. i. 21-23); they are, therefore, in no want of our prayers or intercessions. If the unrighteous can be helped by our prayers, it is incredible that the many directions for prayer in the Bible should contain no reference whatever to this all-important matter.

It has been argued that after the Captivity prayers for the dead were publicly offered by the Jews; but there is no allusion in Jewish works, written between 160 B.C. and 200 A.D., to prayers for the dead, save 2 Macc. xii. 43-45. On the contrary, these Jewish writings set forth death as the end of man's probation and the fixed permanent state of the dead, even prior to the resurrection.

In regard to the foregoing solitary reference from 2 Macc., it is well to recollect that though the epitomist of 2 Macc. (which 
as we have it, is merely an epitome)* believed no doubt in prayer for the dead, as he lived some time between 140 and 50 B.c., when the Jews in Egypt were schismatics with a priesthood, a temple, and sacrifices of their own, his opinion is of no weight in any question of religious practice, much less in regard to synagogue worship in Palestine in the time of our Lord.

It has been further argued that the passage in 1 Cor. iii. 12-15 : ' he himself shall be saved, yet so as by fire,' suggests the existence of a purgatory, and by implication the value of prayers for the faithful departed. But the 'fire' here spoken of expressly refers to the severe test to which the work, not the worker will be subjected.

Moreover, St. Paul's words in 2 Tim. i. 18, 'The Lord grant unto him (Onesiphorus) that he may find mercy of the Lord in that day,' have been adduced as an instance of prayers for the dead. There is, however, nothing whatever in the Epistle to prove, or even suggest, that Onesiphorus was dead at the time the Apostle wrote.

In the " Form of Intercession with Almighty God on behalf of Her Majesty's Naval and Military Forces now in South Africa" (1900) there was introduced (Form V.) the petition "For all those who have fallen in the true faith of Thy Holy Name, that they may enter into the rest which Thou hast prepared for those who believe in Thee; Hear us, good Lord.' Again, in the special ' Form of Service in Commemoration of Her late Majesty Queen Victoria of blessed and glorious memory' (1901), was inserted, 'May the Lord, of His mercy, grant to us, with all the faithful departed, rest and peace.'

In the special 'Form of Service (No. 3) in Commemoration of His late Majesty, King Edward VII of blessed and glorious memory' (1910), a like petition was inserted.

In the first of these three forms definite prayer for the dead and for the believing dead is re-introduced into the Church of England. The two remaining forms, by the use of the preposition ' with,' are verbally more in accordance with the Prayer Book, but they are capable of being misunderstood and misused. Such Services being devoid of Statutory authority, have no bearing upon the doctrinal position of the Church of England.

There are traces of prayers for the dead growing out of the commemoration of the dead in early times. The Apostolic Fathers contain no allusion to prayers for the dead. Tertullian and Epiphanius refer to such prayers in their day. By the time of Augustine some form of such prayers was evidently used, for in his 'Confessions' he gives us the prayer which he 
himself used for his deceased mother Monica. But that Augustine was by no means clear as to the benefits accruing to the dead from such prayers, is proved by his curious attempt to describe such supposed benefits in his Enchiridion ad Laurent., c. 110 : ' thanksgivings for such as were very good, propitiations for such as were not very bad; but as for such as were very evil, although they were no helps of the dead, yet were they some kind of consolation for the living.' It is instructive and pertinent to note that departure from the sanction of Holy Writ leads to such a feeble conclusion.

The Greek and Oriental Churches, though they did not believe in purgatory, yet used prayers for the dead.

The Prayer Book of 1549, as above frequently noted, contained such prayers, which were carefully eliminated in 1552. The Homily on Prayer (third part) speaks against the practice.*

* See Dr. C. H. H. Wright's 'Intermediate State and Prayers for the Dead,' 1909; also art. on 'Prayers for the Dead' in 'A Protestant Dietionary.' 


\section{THE THANKSGIVING OF WOMEN AF'IER CHILD-BIRTH,}

Commonly called.

\section{THE CHURCHING OF WOMEN.}

The practice of 'Churching' of Women can be traced to the early days of the Christian Church. It is referred to in the 17th Constitution of the Emperor Leo (c. 460), and in the correspondence between St. Gregory and St. Augustine as to the customs to be observed in the English Church (c. 601).* An office of Churching is found in all Western rituals, and in that of the Patriarchate of Constantinople. The form in the Prayer Book is adapted from Sar. Man. Though this Scrvice in its main features is similar to that of the Mediæval Church, there is no allusion to the intercession of the Virgin Mary, and no sprinkling with holy water, etc., as in the Sarum Use.

\section{ANALYSIS WITH HISTORICAL NOTES.}

[The date is 1549, except where otherwise stated.1

I. The Service of Thanksgiving.

1. Address to the Woman, calling upon her to give thanks Altered 1552.

2. The Psalms of Thanksgiving.

(1) Ps. cxvi. Dilexi quoniam. Nearly as in Psalter. 1662 ; or

(2) Ps. cxxvii. Nisi Dominus. As in Psalter. 1662.

II. The Service of Prayer.

1. The Lesser Litany.

2. The Lord's Prayer.

3. The Preces and Responses.

O Lord, save this woman thy servant, etc.

4. Prayer that the woman may lead a holy life. Altered 1662.

O Almighty Gud, etc.

$$
\text { * Bedr, 'H. E.,' I. xxv.і. } 8 .
$$




\section{The Title.}

1549. The Order of the Purification of Women.

Ordo ad Purificandam Mulierem post Partum, ante Ostium Ecclesice. Sar. Man.

1552. Altered to its present form.

The Title 'The Churching of Women' is a survival of the Mediæval idea of purification and restoration to Church rites. The change of Title was probably necessary from the fact that the Church of England does not regard the Office as the means of, or as a ceremony for removing, any defilement caused through child-birth. It is misleading to regard the change as 'intended to make Thanksgiving preponderate over Purification,' for nothing is said about purification in the Service. It is simply a Thanksgiving Service. It is, however, possible that the use of such a Service arose partly from the ancient custom of the Jewish Church, which ordered the Jewish mother to present herself in the temple forty days after the birth of a male child, and eighty days after the birth of a female child (Lev. xii. ; Luke ii. 22-24). But more especially the Service was drawn up from an instinctive feeling of the piety and appropriateness of such a public recognition of God's providential care (Ps. cxvi. 17-19; Heb. ii.12).

\section{Opening Rubric.}

1549. The woman shall come into the church, and there shall kneel down in some convenient place, nigh unto the quire door; and the priest standing by her shall say these words or such like, as the case shall require.

1552. The woman ... convenient place, nigh unto the place where the table standeth, etc.

1662. The woman, at the usual time after her delivery, shall come into the Church decently apparelled, and there shall kneel down in some convenient place, as hath been accustomed, or as the Ordinary shall direct: And then the Priest shall say unto her.

Before 1519 the Office was said at the Church door to symbolize by the woman's position during the Churching that she was being re-admitted to Church privileges.*

At the usual time. This is a perfectly indefinite expression. It is a common custom for a woman to be churched the first time she appears in public. In the Greek Church the fortieth day is appointed as the time for performing this Office. In the West the time has never been strictly determined.

* It was direeted in the Sar. Man. that at the close of the Service the Priest should take her by the hand, and lead her into tie Church, saying, ' Enter into the Temple of God, that thou mayest have eternal life.' 
Decently apparelled. In the Middle Ages a woman was enjoined to wear a veil or 'kerchief,' and so late as the reign of James I a woman was cxcommunicated for refusing to comply with the custom of wearing a veil.*

There were no such directions in 1549 or 1552, and Cosin's desire for a specified apparel was disregarded in 1662 (see Blakeney, 'Common Prayer,' p. 505).

This Office would appear originally to have been said before Mass. The elosing lubric contemplates the possibility of its preceding the Holy Communion. From Articles of Enquiry made by different Bishops in the seventeenth century, it appears that the proper time for using the Office was then thought to be just before the Communion Service.

Address to the Woman, calling upon her to give Thanks. 1549, altered 1552 .

1549. Between the words 'give you safe deliverance' and ' and hath preserved' were the words 'and your child baptism.'

1552. These words were omitted.

The Rubric before the Psalm. 1662.

The iubric in the Sar. Man. directed the choral use of the Psalm, but the present rubric orders it to be said by the Priest.

The Psalm.

1549. Levavi oculos. Psalm cxxi.

1662. Dilexi quoniam. Psalm cxvi. nearly as in Psalter, 1652.

Psalm cxvi. has reference to perils escaped. In this Service the first clause of the 4 th verse has been put into the past tense ; while vers. $13-15$ are omitted, as only applicable to the other sex.

Psalm exxvii. Nisi Dominus, as in Psalter; added 1662 as an alternative:

Psalm exvi, being one of thanksgiving for deliverance from danger and sorrow by God's mercy, is applicable to any case of deliverance ; while Psalm cxxvii., being a thanksgiving for domestic blessing, especially the blessing of ehildren, is inappropriate, if the infant has died.

N.B.-In the Sar. Man. the two Psalms given were cxxi. and exxviii. The American Prayer Book has instead of Psalms, 'a hymn' drawn from Psalm exvi.

The Rubric before the Lesser Litany. Added 1662.

- Gibson's Codex juris cclesiastici Anglicani, lib. 18, cap. 12, p. 15. 
The Lesser Litany. 1549. Sar. Man.

The Lord's Prayer. Sar. Man.

1549. Without Doxology, and last clause only said by the people.

1662. Doxology added to emphasize the tone of thanksgiving.

Preces and Responses. 1519. Sar. Man.

In the American Book the suffrages are shortened.

Prayer that the Woman may lead a Holy Life.

1519. O Almighty God, which hast delivered this woman thy servant from the great pain and peril of childbirth ; Grant, we beseech thee, most merciful Father, that she through thy help may both faithfully live, and walk in her vocation, according to thy will, in this life present; and also may be partaker of everlasting glory in the life to come; through Jesus Christ our Lord. Amen.

1662. O Almighty God, we give thee humble thanks for that thou hast vouchsafed to deliver this woman, etc., and walk according to thy will, in this life present, etc.

It is remarkable that though in 1552 the title was altered to 'The Thanksgiving of Women after Child-birth,' etc., it contained no words of thanksgiving until 1662 .

The following is the prayer offered in the Roman Ritual:

' O Almighty and eternal God, who through the child-birth of the blessed Virgin Mary hast turned the pains of the faithful in child-birth to joy, look favourably upon this Thy servant joyfully coming to the holy temple to render thanks, and grant that after this life, by the merits and intercessions of the same blessed Virgin, she may deserve to come with her offspring, to the joys of eternal blessedness through,' etc.

The Closing Rubric. Sar. Man.

1549. The woman that is purified, must offer her Chrism, and other accustomed offerings. And if there be a Communion, it is convenient that she receive the holy Communion.

1552. The woman that cometh to give her thanks, must offer accustomed offerings ; and if there be a Communion, it is convenient that she receive the holy Communion.

Her Chrism. This was the white garment which was put by the mother upon her child at its Baptism, and took its name from the chrism, or ointment, with which the child was anointed 
at the time of its Baptism. The woman, formerly, was required to bring the Chrism for the use of the Church unless the infant died and was buried in it.

Accustomed offerings. The offerings are not to be regarded as fees but as voluntary gifts. The American Prayer Book directs that these shall be applied by the Minister and Churchwardens to the relief of distressed women in child-bed. In our Church what is offered becomes, like Easter Offerings, the private property of the Clergyman.

The Service ends abruptly. The Irish Prayer Book has removed this defect by the addition of a closing portion. 


\title{
A COMMINATION,
}

\author{
OR
}

Denouncing Of God's Anger And Judgments Against Sinners,

With certain Prayers, to be Used

on the Frrst Day of Lient, and at other times,

aS THE Ordinary Shall appoint. 1662.

Title.

1549. The First Day of Lent, commonly called Ash-Wednesday.

1552. A Commination against Sinners, with certain Prayers, to be used divers times in the year.

The Scottish Liturgy, 1637, added after ' in the year' the words 'and especially on the first day of Lent, commonly called, Ash-wednesday.'

The alteration in title was made in accordance with a suggestion of Bucer, who wished the Service to be used at least four times a year.

1662. The present title was adopted.

Commination; i.e. warning or threatening (comminari, to threaten).

In the Medirval Church there was a kind of Commination Service called 'the Form of the Greater Excommunication' or 'General Sentence.' The whole character of this Service was very severe and contained a long declaration of general curses. It was used on Advent Sunday, the First Sunday in Lent, Trinity Sunday, and the First Sunday after the Assumption (August 15). On these occasions there were blessing and distribution of ashes, anthems, signing of the cross with ashes on the foreheads of the people, with solemn warning, 'Remember, 0 man, that thou art ashes, and unto ashes shalt thou return.'

The present Service which is entirely of a supplicatory character, even the Psalms being said kneeling, was drawn up by the Reformers, and is a memorial of the solemn public penitence which had become so distinct a feature in the discipline of the 
Church. It is an adaptation of a Service in the pre-Reformation Church between Prime and Mass on Ash-Wednesday. Archbishop Grindal, in the reign of Elizabeth, directed the Service to be used four times a year, "on Ash-Wednesday, on one of the three Sundays next before Easter, one of the two Sundays next before the Feast of Pentecost, and one of the two Sundays next before the Feast of the Birth of our Lord.' Prior to 1662 the Prayer Book ended with the Commination Service, the Psalter and the Ordinal being separate volumes.

There is no Office in the Greek Prayer Book corresponding to our Commination Service; however, the Greek Church enjoins private confessions and has a special Office for the administration of the Rite.

\section{ANALYSIS WITH HISTORICAL NOTES.}

[The date is 1549 , except where otherwise stated.]

\section{The Commination.}

1. Address to the Congregation.

2. The Sentences of God's cursing.*

First. Independent translation of Deut. xxvii. 15, shortened 1662.

Second. Deut. xxvii. 16; Prov. xx. 20 ; altered 1662 to A.V.

Third. Deut xxvii. 17, altered 1662 to A.V.

Fourth. Deut. xxvii. 18.

Fith. Deut. xxvii. 19, altered 1662 to A.V.

Sixth. Deut. xxvii. 24.

Seventh. Independent translation of Lev. xx. 10.

Eighth. Independent translation of Deut. xxvii. 25, altered 1662 .

Ninth. Jer. xvii. 5.

Tenth. Matt. xxv. 41 ; 1 Cor. vi. 9, 10 ; Gal. v. 19, 20,21 ; Ps. xv. 3 ; altered 1662.

3. The Application and Exhortation. Quotations altered 1662.

\section{The Supplication.}

1. Psalm li. Miserere mei, Deus 1549. As in Psalter.

2. Lesser Litany.

3. Lord's Prayer.

4. Preces and Responses.

O Lord, save thy servants.

5. A Prayer for Absolution.

0 Lord, we beseech thee, etc.

- The references were printed after the words in 1604. And in the Srotch Liturgy 'Prezijyter' was used instead of 'Minister.' 
6. A Prayer for Pardon.

O most mighty God, and merciful Father

7. A Prayer for Conversion and Restoration.

Turn thou us.

8. Benediction (in form of prayer). 1662. Num. vi. 24, 26.

\section{EXPOSITION.}

The Opening Rubric.

1549. After Matins [Morning Prayer, 1552] ended, the people being called together by the ringing of a bell, and assembled in the Church, the English Litany shall be said after the accustomed manner; which ended, the Priest shall go into the pulpit, and say thus.

1662. After Morning Prayer, the Litany ended according to the accustomed manner, the Priest shall, in the reading-Pew or Pulpit, say.

Thus the present iubric, contrary to that of 1549 , assumes that the congregation will remain in church after Morning Prayer to join in this Service.

The Reading-Pew, which by its mention here obtained rubrical recognition, is the reading-desk at the top of the nave, which faced the congregation, to be found in nearly every $c$ hurch well into the second quarter of the nineteenth century.

Address to the Congregation. 1549. Slight verbal alterations in 1552,1604 , and 1662 .

On the subject of 'the godly discipline' formerly exercised in the Church, the following extract from St. Basil (370) is interesting: "The first year they (i.e. the penitents *) are to weep before the gate of the church ; the second year to be admitted to hearing; the third year to genuflexions, or repentance properly so called; and the fourth year to stand with the faithful at prayers without partaking of the oblation.'

Penance is the humiliation or punishment undergone by persons professing penitence, as a token of security for subsequent good behaviour and a means of their reconciliation and re-admission into the Church. The offender was frequently enjoined to do a public penance in the Parish Church, bareheaded and barefooted in a white sheet, and to make open confession of his crime in prescribed form of words. For minor offences, the penance was to be made before the minister, churchwardens, or some of the parishioners. In some cases, however, a money commu-

- 'The penitents were divided into four classes, viz. flentes (the mourners) audientes (the hearers), substrati (the kneelers), and consistentes (the co. standers) " (Daniel). 
tatiou of penance was alluwed. It is hardly necessary to be added that the Reformers did not contemplate the restoration of the puerilities and worse which had usurped the place of the simple primitive penance (see p. 321).

\section{The Sentences of Cursing.}

First. 1549. Between 'nolten image' and 'to worship it' stood the words 'an abomination to the Lord, the work of the hands of the craftsmen, and putting it in a secret place.'

1662. The words were omitted.

Tenth. 1549. Between 'adulterers' (advouterers, 1549) and 'slanderers' were 'the covetous persons, the worshippers of images.'

1662. 'The worshippers of images' omitted.

The sentences of God's curses on impenitent sinners were most prohably suggested by those in "The Greater Excommunication,' and they are pronounced against themselves. There is no method apparently adopted in these ten denunciations. Bucer thought they ought to be arranged in the order of the Decalogue. The use of these curses is designed as a protest against the way in which men are apt to make light of $\sin$ (whether they be professed Antinomians or not).

The Application and Exhortation. 1549. Quotations altered in 1662 .

The following is Bishop Barry's useful analysis of it:

'1. Declaration of the sure and searching character of God's Judgment falling suddenly on the wilfully blind and impenitent, and vainly deprecated in remorse, when the hour of repentance has passed away.' ('Now seeing . . . which is prepared for the devil and his angels.')

'2. A call to timely penitence, while the day of salvation lasts, enforced by the most gracious promises of forgiveness from the Old Testament prophecy.' ('Therefore, brethren, take we heed betime . . . I have no pleasure in the death of him that dieth, saith the Lord God. Turn you then, and you shall live.'

-3. The Gospel call to faith in Jesus Christ, our Advocate, as ready to receive and willing to pardon, calling us to take His yoke upon us and find rest, promising us a place on His right hand and His llessing at the Great Day.' ('Although we have sinned, yet have we an Advocate' to the end of the Exhortation.)

Ps. li. Miserere mei, Deus. $\Lambda \mathrm{s}$ in Psalter. Sar. Miss 
Analysis.

I. The Pleadings of the Penitent . . - . - Ps li.

1. For Forgiveness and Purification . . . 1-7

2. For Restoration, Renewal, Return to God's favour and to the joy and freedom invo!red in it .

II. The Holy Resolves of the Restored Penitent. $\quad$ - 13-17

III. Entreaty - of the Restored and Grateful Penitent . . 18,19

N.B.-The omission of vers. 18,19 , or at least some adaptation of them to Christian times, would seem advisable.

During the services on Ash-Wednesday all the seven penitential Psalms are used.

The Lesser Litany. 1549. Sar. Miss.

The Lord's Prayer. 1549. Sar. Miss.

The response of th2 last clause was by the people until 1662 .

Preces and Responses. 1549. Sar. Miss.

Prayer for Absolution. 1549. Sar. Miss.; Sac. Gal.

A Prayer for Pardon. 1549.

0 most mighty God, etc.

1549. Receive and comfort us.

1559. Comfort [N.B. the words 'receive and' were inadvertently omitted by the printer].

1604. Receive and comfort us.

The first part of the prayer is taken from 'Benedictio Cinerum' (the Blessing of the Ashes) in the Sar. Miss.; and the remainder, 'spare us,' etc., is founded on one of the collects preceding the 'Benedictio.'

In this praye: we have the breathing of profound conviction of sin and desire for pardon, but is less detailed than the other Confessions in the Prayer Book. (Lam. v. 21; Joel ii. 12, 13, 17.)

A Prayer for Conversion and Restoration. 1549, with borrowings from ancient forms. 'Turn thou us.' The first part corresponds to the Lection (Joel ii.), and the latter to the antiphons in the Service 'for the Blessing of the Ashes' in the Sar. Miss. In 1549 the Service ended here.

Through the merits, etc. These words were added in 1662 .

Benedietion in the form of prayer. 1662. Num. vi. 24, 26 (the Aaronic blessing), ver. 25 omitted apparently by the inadvertence of the printer. 


\section{FORMS OF PRAYER TO BE USED AT SEA. I 662}

\section{INTRODUCTION.}

Especial mention is made of the addition of these Forms in 'The Preface.' They do not form a complete Service in themselves, but are merely additional Prayers and Thanksgivings to meet the emergencies which beset the seafaring life, and to be introduced as occasion requires into the Morning or Evening Prayer, which the Rubric directs shall daily be used at sea in his Majesty's Navy.

They are stated to have been composed by Robert Sanderson, Bishop of Lincoln (ob. 1663), and were examined and revised at the request of Convocation by Stern, Bishop of Carlisle, in 1661 .

It is possible that they were suggested by a little book which was published by the Long Parliament in 1664 for the use of sailors, which was intended as a Supplement to "The Directory of Public Worship.' It was called 'A Supply of Prayer for the Ships that want Ministers to pray with them.' In its preface the reason of the work is thus stated: "Whereas there are thousands of ships which have not ministers with them to guide them in prayer, and therefore either use the old form of Common Prayer, or no prayer at all; the former whereof for many weighty reasons hath been abolished, and the latter is likely to make them rather heathens than Christians : therefore to avoid these inconveniences, it has been thought fit to frame some prayers agreeing with the Directory established by Parliament.'

In cases of Burial at Sea the Rubric orders that the office for the Burial of the Dead may be used, but in the Form of Committal, the words "We therefore commit his body to the ground, earth to earth, ashes to ashes, dust to dust,' are changed into 'We therefore commit his body to the deep, to be turned into corruption.' The passage also 'In sure and certain hope of the Resurrection to eternal life,' is altered to 'Looking for the Resurrection of the body (when the Sea shall give up her dead) and the life of the world to come.' 
In the 'Articles of War,' the following order appears : ' Officers are to cause Public Worship according to the Liturgy of the Church of England to be solemnly performed in their ships, and take care that prayers and preaching by the Chaplains be performed diligently, and that the Lord's Day be observed.'

These 'Forms of Prayer to be used at Sea' are retained in the American Prayer Book, with the necessary changes of expressions, such as 'Ships of War for his Majesty's Navy,' etc. 'They are also, with certain omissions, found in the Irish B.C.P.

\section{ANALYSIS WITH BRIEF COMMENTS.}

\section{Morning and Evening Prayer.}

1. The same as appointed in the Book of Common Prayer.

2. Additional Prayers.

(1) For Daily use.

(2) To be used in Storms at Sea.

(3) To be said before a Fight at Sea.

II Short Prayers for Single Persons, who cannot meet to join in Prayer with others by reason of the Fight, or Storm.

1. General Prayers : three ejaculatory petitions.

2. Special Prayers with respect to the Enemy : five appeals for God's help.

3. Short Prayers in respect of a Storm : appeals to Omnipotence, including the Lesser Litany and the Lord's Prayer.*

\section{Service in Imminent Danger.}

'When there shall be imminent danger, as many as can be spared from necessary service in the Ship shall be called together, and make an humble Confession of their sin to God: In v: hich every one ought seriously to reflect upon those particular sins of which his conscience shall accuse him.'

1. The Confession as in the Communion Service.

2. The Absolution as in the Communion Service.

IV. Thanksgiving after a Sto:m.

1. Jubilate Deo. Psalm lxvi., as in Psalter.

2. Confitemini Domino. Ps. cvii., as in Psalter.

3. Collects of Thanksgiving.

4. An Hymn of Praise and Thanksgiving after a dangerous Tempest. 'This is a combination of several verses (some adapted) from different Psalms.

5. The Grace. 2 Cor. xiii. 14.

* For use of Doxology, see pp. $98,390$. 
496 FORMS OF PRAYER TO BE USED AT SEA

V. Service after Victory or Deliverance.

1. A Psalm or Hymn of Praise and Thanksgiving after Victory. Compiled from Psalms, as above.

2. Te Deum.

3. The Collect.

4. The Grace.

VI. Service at the Burial of their Dead at Sea. The regular Office with a special form of Committal. 


\section{THE FORM AND MANNER OF MAKING, ORDAINING, AND CON- SECRATING BISHOPS, PRIESTS, AND DEACONS,}

\section{ACCORDING TO THE ORDER OF THE CHURCH OF ENGLAND}

1662. The word 'ordaining' and the clause 'according to the Order of the Church of England' were added.

'Consecrating' refers to Bishops; 'ordaining' to Priests ; and 'making' to Deacons.

\section{THE HISTORY OF THE ENGLISH ORDINAL.}

The 1549 B.C.P. contained no Ordinal ; it was drawn up in the following year by six Bishops, and six other learned men, appointed for the purpose.* It was mainly an original composition, but followed the lines of the older Pontificals. Of these latter many types have come down to us. In the early Church Ordinations consisted chiefly of prayer and the laying on of hands of the Bishops or Presbyters. There were certain minor orders in connexion with which there was no laying on of hands, and for them the custom of delivering to the candidate something connected with his office seems to have come into use. For instance, in the African Church of the fourth century the subdeacon received an empty chalice and paten, it being his duty to keep them clean, while the doorkeeper received the keys of the church, etc. Afterwards this custom obtained in the case of the major orders. In the sixth century the Bishops received

* ' In November, 1549, was passed an Act (3 \& 4 Ed. VI. c. 12), ordering the sole use of such an Ordination Service as should be devised by six Bishops and six divines to be appointed by the King, and should he set forth under the Great Seal before April 1, 1550. Parliament rose January 31, 1550. On February 2, 1550, the Council ordered twclve Bishops and leaıned men to devise a new Ordination book, and on February 28 it was brought to the Council signed by eleven of the twelre, Bishop Heath declining. The names of the rest are unrecorded' (Holc's 'Manuai of the Book of Common Prayer,' p. 27). 
a pastoral staff and a ring; in the seventh (Council of Toledo, 633 ), bishop, priest, and deacon, all received appropriate vesture. Later, Orders came to be looked upon as a 'sacrament,' and the custom sprang up of giving to the Priest at his Ordination a paten and chalice, with bread and wine, as the 'matter' of the Sacrament, the form being the words, which of course are not taken from Scripture, 'Receive power to offer sacrifice to God, and to celebrate Masses for the living and for the dead in the name of the Lord.'

It was some such sort of Pontifical, probably that in use at Sarum, which Archbishop Cranmer and his eleven colleagues had before them as they began their work in 1550. In the Ordering of Deacons the old ceremony of investing with a stole was omitted. The candidate was to wear a plain alb, and the Deacon who read the Gospel a tunicle. In the Ordination of Priests an alb was to be worn by the candidate, and the ceremony of delivering the paten and chalice was continued; but the investing with the chasuble, the anointing of the hands, and the blessing of the vestments, were omitted. At the Consecration of a Bishop copes were to be worn both by the candidate and the consecrating bishops, and pastoral staves carried. The new Ordinal satisfied no one, least of all the Reformation party; and in 1551, a commission was appointed to revise it. In the revised form mention was omitted both of alb and tunicle: so also was the delivery of the chalice and paten to the Priest; so also the use of the cope and pastoral staff in the Consecration of Bishops. These customs were comparatively modern, dating from 800 to 1000 A.D. One much older custom was discontinued, that of laying the Bible on the new Bishop's neck, at the moment of Ordination, a custom at least as old as the fourth Council of Carthage (398). This revised Ordinal was made part of the Prayer Book in 1552, and stood unchanged both in 1559 (except for some slight variations of language) and in 1604. In the last revision, 1662 , some changes were made :-

(1) The age of deacons was raised from twenty-one to twentythree:

(2) in the Litany 'pastors and ministers of the Church' was changed to 'priests and deacons':

(3) in the fifth question to candidates for the diaconate tle words 'to baptize' were limited by the phrase 'in the absence of the priest':

(4) a new 'Epistle' (Eph. iv. 7) was inserted in the place of the old alternatives (Acts xx. 17; 1 Tim. iii.), and Matt. ix. 36 became the 'Gospel' instead of Matt. xxviii. 17 : 
(5) a second translation of the Veni Creator was added:

(6) to the words ' receive the Holy Ghost' was added 'for the Office and Work of a Priest in the Church of God now committed unto thee by the imposition of our hands':

(7) the Consecration of Bishops was ordered to take place on some Sunday or holy-day:

(8) a special Collect and alternative 'Epistle' and two alternative 'Gospels' were added :

(9) the directions as to the vesture of the bishop-elect were given here for the first time:

(10) the sentence of consecration was changed, the old form ' Take the Holy Ghost, and remember that thou stir up the grace of God, which is in thee by imposition of hands.' giving place to the present.

Since 1662 there has been no further change. It will be noticed that from the beginning our Reformers retained all that is essential to the rite, and practically all that is really ancient, simply removing, in the interests of simplicity and truth, the accretions of the Middle Ages.

\section{DIFFERENCES BETWEEN THE ORDINAL IN SAR. MISS. AND THE B.C.P.}

- In the Roman Use :-

(a) The Bishop celebrates the Mass, vested in amice, alb, cincture, cross, dalmatic, maniple, stole, and chasuble; then the candidates, bearing a folded chasuble on the left arm, and holding in the right hand a candle and a cloth, advance toward his throne. After an address to the people on their right to be consulted* with regard to the character of those to be admitted to the regimen of the altar, he addresses the candidates on the duties of a priest, 'It is the duty of a priest to offer sacrifice, to bless, to rule, to preach; and to baptize.'

(b) After prayer follows the ceremony of the laying-on of hands. The mitred Bishop, with the clergy present, lay their hands on the head of each one to be ordained, without saying any words at all (nihil dicens). After this comes prayer for the benediction of the Holy Spirit, and the infusion of sacerdotal grace.

(c) The Bishop next crosses the stole over the cardidate's breast, and puts on him a chasuble, with the words: Accipe vestem sacerdotalem, 'Receive the sncerdotal vestment.'

(d) A prayer follows in which it is implored that the newly-

- This is an interesting recognition of the seriptural right of the whole Chureh to select its minist $y$, cf. Acts vi. 3 , and the use of the word $\chi \in$ tcotové $\omega$ in Acts xiv. 23 (mistranslated 'ordicined' in A.V., R.V. ‘ ajpointed'). 
ordained priest may transform, by an immediate benediction, the bread and wine into the Body and Blood of God's Son, after which the hands of the priest are anointed with oil.

(e) Last comes the crowning ceremony of all, without which any ordination in the teaching of Rome is invalid, the tradition of the instruments, and the priest-making words. A chalice with wine and water, and a paten with an unconsecrated 'host,' are given to the candidate by the Bishop, with the sealing words : 'Receive power to offer sacrifice to God, and to celebrate Mass, both for the living and for the dead, in the name of the Lord. Amen.' (Accipe potestatem offerre sacrificium Deo, missasque celebrare, tam pro vivis, quam pro defunctis. In nomine Domini. Amen.) This is the matter and form of a proper and valid ordination, the res sacramenti $\mathrm{b}$ ing the making of a priest, and the signum et forma sacramenti being the 'tradition of the instruments,' the authoritative words, and the accompanying ceremonies.*

The contrast between this service and the Ordinal of the Church of England is fundamental.

Not only is the form (signum sacramenti) altogether at variance with the Roman practice, but the whole ceremony is subversive of, and a protest against, the Roman doctrine as to the purport of the service (res sacramenti).

In the First Ordinal, of 1550 , a tradition of the instruments is indeed retained, but it is not the 'tradition of the instruments' of the Roman Pontifical.

'The Bishop shall deliver to every one of them the Bible in the one hand, and the chalice and cup with the Bread in the other hand, and say, Take thou authority to preach the Word of God, and to minister the holy sacraments.'

Here the Bib.e is given first; afterwards authority is given to administer the sacraments, not to 'offer sacrifice.'

In 1552 the Ordination Service is practically the same as that of 1550 , but, in accordance with the Church's intention to remove all things that could be 'mis-taken' to countenance superstition, all tradition of the Holy Communion instruments was omitted, the Bible only being delivered to the ordained. (Abbreviated from Dyson Hague's 'Protestantism of the Prayer Book,' pp. 146-149.)

'The Preface to this Service does not touch upon the subject of its revision in any way whatever, and we are led to gather the reason and object of its reform from interial evidence alone. We may represent the reason as briefly this: under the old worship the priest was a sacrificer, and the ceremonies of his 
ordination were almost as though he was to be made priest for the mass alone. The mass had in 1549 been changed into a communion, and the ritual which had hitherto been used in ordaining the priest was become altogether untenable.' (Hole, 'Manual of the Book of Common Prayer,' p. 30.)

The first mention of anointing is in the 4 th Council of Carthage, in which the rites of Ordination are described ; nor was it practised even in Rome in the time of Nicholas I in the ninth century, who remarks that 'Neither priest nor deacons are anointed at their Ordination.' As to the delivery of the vessels, and the accompanying form, Morinus proves that there is no trace of such a ceremony in any ritual for a thousand years after Christ. Yet the Council of Florence declares that the matter or visible sign of priesthood is the delivery of a chalice with wine in it, and that the form is the above. The form "Receive ye the Holy Ghost'-though there is nothing objectionable in these words, as used in our Ordinal, when properly received-is also rovel in its use, not being found in any of the Ordinals for 1200. (Condensed from Blakeney's 'The Book of Common Prayer,' 3rd ed., pp. 633, 634.)

\section{THE CHRISTIAN MINISTRY.}

- The preface to the Ordinal, probably written by Cranmer himself, claims that ' it is evident unto all men, diligently reading holy Scripture, and ancient Authors, that from the Apostles' time there hath been these Orders of Ministers in Christ's Church; Bishops, Priests, and Deacons.' It will be thus seen that the ministry of the Church of England expressly connects itself with the ministry of the New Testament and the Primitive Church. It is necessary therefore to summarize the history and development of the ministry in the Early Church.

As regards the method of Ordination, it is impossible to speak with dogmatic certainty. For example, there is no trace of any ordination of the Apostles, and an 'ordination' which St. Paul and Barnabas underwent at Antioch was plainly conferred in view of a special ministry, and not ministry in general, which both had been fulfilling for some years. However, the instances recorded are sufficient to explain how the example of the Apostles could fairly be claimed for Ordination by laying on of hands with prayer: Acts vi. $6 ; 1$ Tim. iv. $14 ;$ v. 22 ; 2 Tim. i. 6.

So far as the threefold ministry is concerned, it is noteworthy that the Ordinal does not speak of 'ordining,' but of ' consecrating' bishops, the identity of 'bishops' and 'presbyters' in the N.T. being generally recognized. The three names are all 
Scriptural, but the N.T. lists of ministries, 1 Cor. xii. 28, and Eph. iv. 11, do not contain any of them, the systematic arrangement of the ministry in a threefold order being obviously a later development.*

Deacons. The seven who were ordained (Acts vi. 6) to relieve the Apostles are not called 'deacons' except in the paginal and capitular headings of A.V. Indeed, the abstract noun 'diaconate' is used twice in the passage, but of 'the daily ministration,' and of 'the ministry of the word,' showing that to call the seven 'deacons' is an anachronism.

They are spoken of as 'the seven' (Acts xxi. 8), so that their office was obviously unique. They did not all confine themselves to the relief work to which they were appointed; St. Stephen and St. Philip were both Evangelists. Later on others, who received the name 'deacons' (Phil. i. 1 ; 1 Tim. ii. 8 ff.) were appointed to do unspecified ministerial work. In later days the deacon of a particular Church, or Bishop, is found to be a personage of some importance, corresponding perhaps to

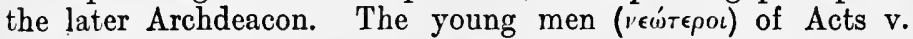
6-10 have been conjectured to correspond to our deacons

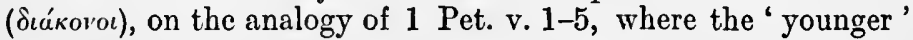
are placed in contrast with the 'elders.'-The 'deacon' of the Pastoral Epistles was obviously an inferior order of minister, the Bishop being the superior, and St. Paul's language suggests that a deacon might expect to be promoted (1 Tim. iii. 13).

Priests, or Presbyters. $\dagger$ The two words are etymologically one, and mean 'elder,' from the Greek $\pi \rho \epsilon \sigma \beta \dot{v} \tau \epsilon \rho o s$. We are definitely told that elders were 'appointed' ( $\chi є \iota$ ротог' $\omega$, A.V. 'ordained,' R.V. 'appointed') by Barnabas and Paul in Acts xiv. 23. They are mentioned in connexion with several Churches : Acts xv. 6 ; xx. 17 ; xxi. 18 ; cf. 1 Tim. v. 22.

Presbyters and Bishops. The word 'bishop' ('ंлí $\sigma \kappa o \pi \circ)$ means 'overseer.' In the N.T. nowhere are bishops and presbyters mentioned together. In Phil. i. 1 and in 1 Tim. iii. 1-8, bishops and deacons are mentioned, and not presbyters, where the omission cannot be intended to exclude them. In Acts xx. 17 presbyters are mentioned, and later on in the same chaptcr (ver. 28) are called 'bishops,' R.V. (A.V. 'overseers '). In Titus i. 5-8 Titus is bidden to ordain 'elders,' and St. Paul proceeds to guide him in his choice by describing the qualifications of 'bishops.' In 1 Pet. v. 1-3 St. Peter commits to the

* For further information, sce p. 507.

† For the meaning of the word 'priest' in the B.C.P. see pp. 515 ff. 
presbyters the oversight (episcopacy*) of the flock. From this it is perfectly clear that in the N.T. bishops and presbyters do not represent distinct orders. The most that can be said is that to some presbyters, perhaps to all, there was given the office of superintendence; some presbyters, if not all, were bishops. There were in N.T. times some exercising higher functions, viz. the Apostles themselves, Apostolic men like Barnabas and Silas, and delegates of an Apostle, like Timothy and Titus. This is practically the New Testament position, but in the sub-Apostolic age the Episcopal office, more as we understand it, came into being. Either the Christian communities modelled their ministry upon heathen institutions (Hatch), or Episcopacy sprang from below, the Bishop being primus inter pares of the Presbyters (Lightfoot), or it came from above, the Bishops being the successors of the Apostles (Gore), or, possibly, it arose from the union of these two latter ideas. Bishop Lightfoot's view seems to accord best with the history of the Early Church.

The attitude of the Church of England as a whole towards non-episcopal Churches has varied considerably under conflicting circumstances, but the general trend is clear. In its formularies, while it carefully expresses its belief in apostolic sanction of episcopacy, cf. Preface to Ordinal, it as carefully avoids any definition of Church which might 'unchurch.' the non-episcopal reformed communions on the Continent and in Scotland, cf. Article XIX. With this conservative yet inclusive position agree the acts and words of authoritative exponents of the teaching of the Church of England. Hooker (Eccles. Pol., III. vi. 16) says: 'Although I see that certain Reformed Churches-the Scottish especially and French-have not that which best agreeth with the Sacred Scripture-I mean the government that is by bishops, inasmuch as both those Churches are fallen under a different kind of regimen; which to remedy it is for the one altogether too late, and too soon for the other during the present affliction and trouble; this their defect and imperfection I had rather lament in such case than exagitate, considering that men, oftentimes without any fault of their own, may be driven to want that kind of polity or regimen which is best, and to content themselves with that which either the irremediable error of former times or the necessity of the present hath cast upon them.' Consistently with this attitude refugees of the Eglise Réformée found countenance in England as early as 1550, and the crypt of our Metropolitan Cathedral has been and is still used for divine

- The phrase, 'taking the ovcrsight' (R.V. 'exercising the oversight'), is omitted by Westcott and Hort. 
worship by that Church. Nor was this merely the policy of a section of the Church, however large. Cosin and Overall, whose known opinions have been calculated to win them the accusation of overstating rather than understating the case for episcopacy, were under no doubt as to the ecclesiastical validity of the Reformed Churches. Cosin bids an anxious inquirer, travelling in France, communicate with the Eglise Réformée and not the Roman Church; Overall was willing to admit to an English benefice one who had been ordained by the Presbytery at Leyden.

\section{THE PREFACE}

\section{REVIEW OF ITS CONTENTS.}

This, which was appended to the Ordinal in 1550, was almost certainly written by Cranmer himself. It deals with the following subjects :-

(1) The Three Orders dating from the Apostolic Time.

(2) The Age of Admission to the Three Orders. The old Canon law demands that the Priest shall bethirty, but permits twentyfive. The Deacon was to be at least twenty-four. The Bishop in the Apostolic Constitutions must be fifty, but quite soon it was reduced to thirty. The Roman Church, according to the Council of Trent, demands twenty-five and twenty-three for Priest and Deacon respectively; the Greek Church, thirty and twenty-five. In our first English Ordinal twenty-one was prescribed for the Deacon-it is still the rule in the American and Scottish Churches-and twenty-five for the Priest. By the canons of 1604 the present ages of twenty-four and twenty-three were fixed. Since then there has been no change, save that by an Act of Parliament of George III the Archbishop of Canterbury may grant a special licence to a person under twenty-thre? for Ordination as Deacon. The licence may only be granted on account of extraordinary ability or some other sufficient reason, and no exception is permitted in the age of the candidate for the priesthood.*

(3) Character and Qualifications. The modern Bishop's examination is based on a very ancient practice. It was the business of the Bishop to discover whether the candidate was of the canonical age, of sufficient knowledge, and of virtuous conversation. 'Virtuous conversation' involved not only careiul

* 'But an Act of Parliament in 1804 (44 Geo. III. c. 43) enforcing the rule without naming any exception might make the legal value of such a dispensation doubtful ' (Bishop Barry's 'Teacher's Praycr Book,' p. 453). 
inquiry into character, but the concurrence of the laity. The old requirements still hold good: a baptismal certificate, and sometimes a bir h $h$ certificate, are needed to prove age: 'Letters Testimonial' from competent clergy are required ; and a document called Si Quis has to be read in the Church of the parish in which the candidate is resident, in order to give the laity an opportunity of objection. A similar opportunity is given at the Ordination Service itself ; the inte'lectual test is, of course, the examination conducted by the Bishop's Chaplains.

(4) Time and Place. Ordination is to take place in Church, and on a Sunday or a holy-day, 'at the times appointed in the Canon.' These appointed times are referred to as the Ember days, in connexion with the occasional prayers to be used in the daily office. They are called in the Calendar the 'Ember days at the four Seasons.' They were originally arranged as Fast days in connexion with the four seasons, but by decree of the Council of Placentia in 1095 it was arranged that Ordination should take place on the Sundays following them. The Ember days are the Wednesday, Friday, and Saturday after the First Sunday in Lent, after Whitsunday, after September 14 (formally observed as Holy Cross Day), and after December 13 (the Feast of Saint Lucy). 
506 THE FORM AND MANNER OF MAKING, ORDAINING.

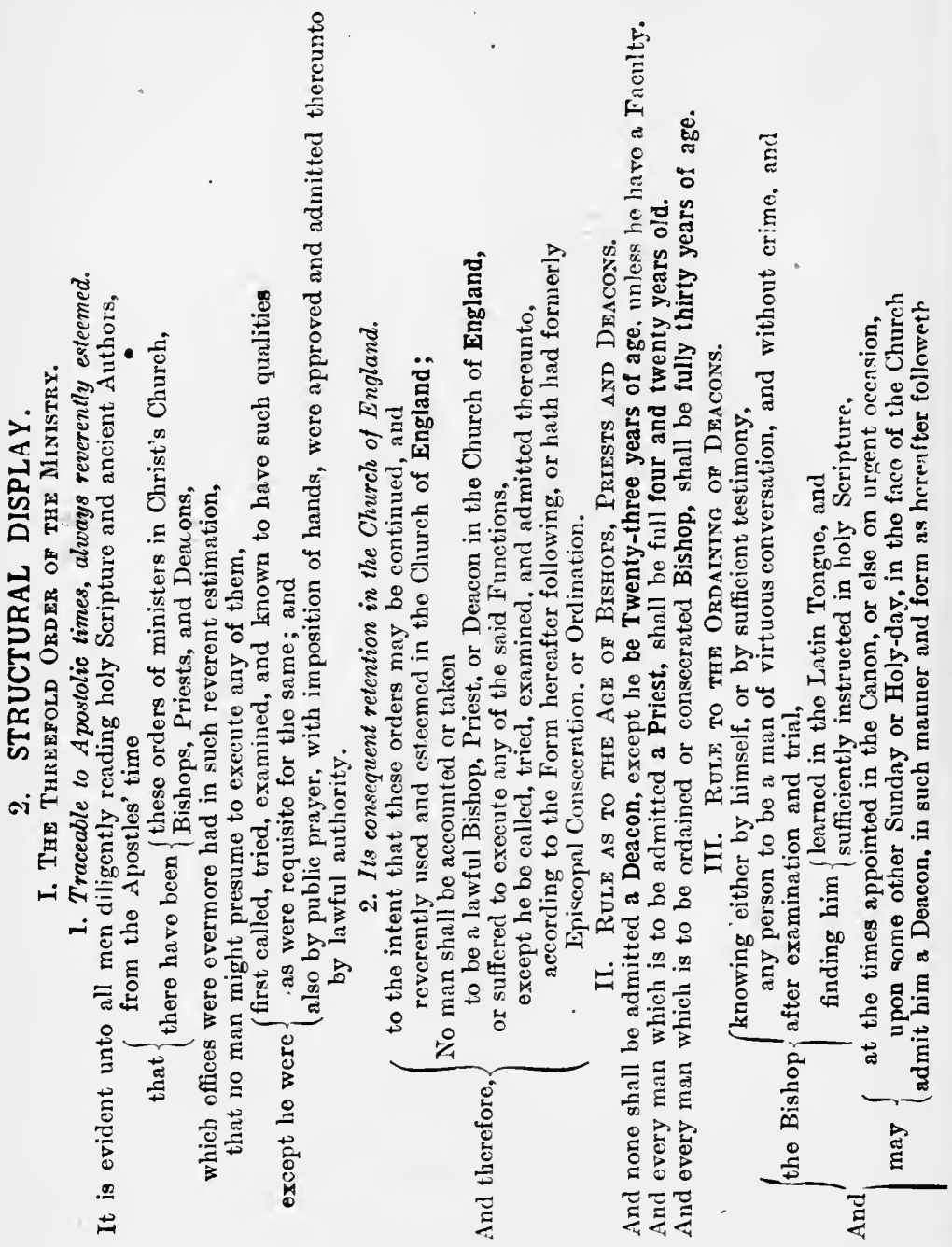

3. EXPOSITION OF PREFACE.

1st Paragraph.

1552. It is requisite that no man (not being at this present Bishop, Priest, nor Deacon) shall execute any of them except he be called, tried, examined, and admitted, aecording to the form hereafter following. 
1662. No man shall be accounted or taken to be a lawful Bishop, Priest, or Deacon in the Church of England, or suffered to execute any of the said Functions, except he be called, tried, examined, and admitted thereunto, according to the Form hereafter following, or hath had formoriy Episcopal Consecration, or Ordination.

\section{Bishops, Pricsts, and Deacons.}

The testimony to the existence of Episcopal rule from the second century onwards, is clear and decisive, ef. Epistles of Ignatius, c. 110-120: 'Ad Philad.' 8. 10 ; 'Ad Trall.' 3. 7 ; 'Ad Eph.' 4.5 ; etc. Irenaeus, c. 180, dwells upon the succession of the Bishops from the Apostles, as the great guarantee of the identity of the existing doctrine of the Church with that of the Apostles themselves: 'Adv. Hær.' iii. 2, 3 ; iv. 26, 33 . Moreover, Tertullian, $c$. 200, speaks of St. John as the founder of the Episcopal succession in the Churches of Asia : 'Adv. Marc.' iv. 5 ; and of Priests and Deacons baptizing only with the authority of the Bishops ('De Bapt.' c. xvii.) These three writers plainly considered Episcopacy to be a normal accompaniment of continuous Church life in the fullest sense. (See 'Prayer Book Commentary for Teachers and Students,' p. 174.)

In the Church of Rome there are seven orders, divided into two groups, viz. :-

1st. The Greater Orders, ordines majores: Priest, Deacon, and Sub-deacon, the Bishop ranking as a superior Priest.

2nd. The Minor Orders, ordines minores.

1. Porter, 'ostiarius,' $\pi i \lambda \omega \rho$ ós. His duty is to open and close the church doors, to prevent the entry of unbelievers, and guard the approach to the Altar at the time of Mass. He also talics care that the division of the sexes is observed in church time, and keeps order.

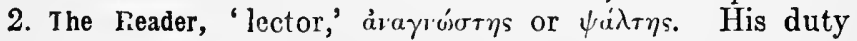
is to read the Lessons, to guard the Church books, and bless the bread and new fiuits. He also has charge of the saclisty.

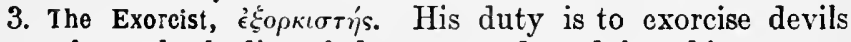
from the bodies of the possessed, and for this purpose he is provided with a book of exorcisms when ordained. He also warns non-communicants to give place to those who are approaching the Altar, and funishes water for the celebrant.

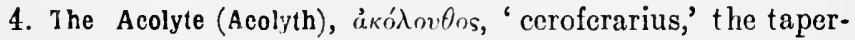
bearer, who lights the Church lamps, and furnishes the celebrant with the cruets of wine at Mass. 


\section{2nd Paragraph.}

1552. And none shall be admitted a Deacon, except he be xxi. years of age at the least. And every man which is to be admitted a Priest, shall be full xxiii. years old.

1662. And none... except he be Twenty-three years of age, unless he have a Faculty. And every ... Priest, shall be full four and twenty years old.

In 1662 the Preface was altered to correspond with Canon $\mathrm{xxx}$ of 1604 .

In the early Church the general rule was, that neither Bishops nor Priests might be ordained under thirty years of age, nor Deacons under twenty-five. That these were the ages fixed both by Civil and Canon Law may be seen from Justinian's 'Novellæ Constitutiones' (123, c. 14), the Councils of Agde A.D. 506 (c. 16), Carthage (third) A.D. 397 (c. 4), Constantinople ' in Trullo ' A.D. 629 (c. 14), Toledo (fourth) A.D. 693 (c. 19) But the ages of Ordination have varied considerably at different times, except in the case of Bishops. (See 'Prayer Book Commentary,' p. 181.)

\section{3rd Paragraph.}

1552. And the Bishop knowing, ... may upon a Sunday or Holyday, in the face of the Church admit him a Deacon, in such manner and form as hereafter followeth.

1662. And the Bishop knowing, ... may at the times appointed in the Canon, or else on urgent occasion, upon some other Sunday or Holyday, in the face of the Church admit him a Deacon, etc.

\section{The Canon.}

The words ' may at the times appointed in the Canon, or else on urgent occasion' were added in 1662 . The 31st canon lays it down 'that no Deacons or Ministers be ordained and made, but only upon the Sundays immediately following Jejunia quatuor temporum, commonly called the Ember Weeks, appoirited in arcient time for prayers and fasting.'

'It would appear, however, that the Ember Seasons werc established first and independe tly, and that the solemnity previously attaching to them caused them to be selected as periods for Ordinations. No trace of the connexion can be found before the time of Pope Gelasius (492-6), who in a letter to the Bishops of Southern Italy fixes those times for the Ordination of Presbyters and Deacons (Ep. ix. c. 11 in P.L. lix. 52).' (Hule's 'Manual of the Book of Common Prayer,' p. 137.) 


\section{THE FORM AND MANNER OF MAKING OF DEACONS}

\section{ANALYSIS AND HISTORICAL NOTES.}

(The date is 1552 unless otherwise stated.)

\section{Introductory Part.}

1. Morning Prayer.

2. Sermon.

3. Presentation by the Archdeacon and final 'Si Quis.'

4. Litany with special suffrage.

5. Commendation of the Candidate to the Prayers of the Congregation.

II. Holy Communion and Ordination.

1. Communion Office to end of the Epistle.

(1) The Collect, altered 1662.

(2) The Epistle, 1 Tim. iii. 8-13 or Acts vi. 2-7.

2. The Examination of the Candidates and Address respecting the Deacons' duties, altered 1662.

3. The Ordination of the Candidates.

(1) Imposition of Hands.

(2) First Formula of Ordination.

Giving the authority to execute the office ot Deacon.

(3) Delivery of the New Testament.

(4) Second Formula of Ordination.

Giving the authority to read and preach the Gospel in the Church of God.

4. Continuation of the Communion Office.

From the Gospel, Luke xii. 35-38 (1662), to Gloria in Excelsis.

III. Concluding Part.

1. Prayer for the newly ordained Deacons. 1662.

'Almighty God, giver of all good things.'

2. The Collect, 'Prevent us, O Lord.' 1662.

3. Benediction (printed in full 1662). 


\section{EXPOSITION.}

The Title. In 1662 the word 'making' was substituted for 'ordering.'

\section{Preliminary Rubrics.}

1st Rubric. In 1662 some slight verbal changes were made. 2nd Rubric.

1552. After the exhortation ended, the Arch-deacon or his Deputy shall present such as come to the Bishop to be admitted, saying these words.

1662. First, the Arch-deacon or his Deputy shall present unto the Bishop (sitting in his chair, near to the holy Table) such as desire to be ordained Deacons; (each of them being decently habited) saying these words.

Archdeacon. A very old office in the Church, first heard of at the Council of Carthage, 398.

\section{Presentation by the Archdeacon and final 'Si Quis.'}

In the second rubric after 'Brethren, if there,' etc., in 1662 'Clergy' was substituted for 'Clerks,' and 'sing or say' for 'say or sing,' and 'with the Prayers, as followeth' for 'as followeth with the Prayers.'

The Litany. 16th Suffrage, Sar. Pont. The Litany in Sar. Pont. was different from that in B.C.P.

1552. That it may please thee, to keep Edward the Sixth, thy servant, our King and Governor (tenth Suffrage). 1662. That it may please thee to keep and strengthen in the true worshipping of thee, in righteousness and holiness of life, thy servant Charles, our most gracious King and Governor.

1552. All Bishops, Pastors and Ministers of the Church (thirteenth Suffrage).

1662. 'Priests and Deacons' substituted for 'Pastors and Ministers of the Church.'

1552. That it may please thee to bless these men, and send thy grace upon them, that they may duly execute the office now to be committed unto them, to the edifying of thy Church, and to thy honour, praise and glory (fourteenth Suffrage).

1662. This special Suffrage was verbally altered.

Rubric before the Collect 'Almighty God, who,' etc.

1552. This rubric with some slight difference stood after the Collect.

The Collect before the Epistle. Sar. Pont. (greatly altered). 
The Eplstle.

1552. 1 Tim. iii. 8-16, 'Great Bible.'

1662. 1 Tim. iii. 8-13, A.V.

This passage points out the moral standard to which Deacons and their families ought to conform.

The Alternative Epistle. Acts vi. 2- 'Great Bible' 1552, A.V. 1662. This passage describes the election and ordination of 'the seven.'

[The Oath of the King's Sovereignty* (1552 called 'The Oath of the King's Supremacy'). 1662. Much curtailed. It was altered in form by $1 \mathrm{Wm}$. \& Mary c. $8 . \dagger$

The present form of clerical subscription is printed from an Act of 1865, amending the provisions of the Acts of Uniformity. It requires assent to the Thirty-nine Articles, and to the Book of Common Prayer, and of the Ordering of Bishops, Priests and Deacons. It runs as follows:- 'I believe the doctrine of the Church of England as therein set forth to be agreeable to the Word of God, and in Public Prayer and the administration of the Sacraments, I will use the Form in the said Book prescribed and none other, except so far as shall be ordered by lawful authority.' This oath is now taken before the Service.]

The Examination of the Candidates.

The seven questions deal with (1) the inward calling by the Holy Spirit, (2) the outward calling by the Church, (3) faith in Holy Scripture, (4) the ministry of the same, (5) specified Diaconal duties, (6) consistency of daily life, (7) loyalty to ecclesiastical superiors. This examination takes the place of the statement of the Sarum Pontifical that the Deacon must minister at the Altar, read, Baptize and preach.

1662. In the fifth question the words "in the absence of the Priest to Baptize' were substituted for 'to Baptize' 1552 , and a few other minor changes made.

\section{Rubric before the Ordination.}

1662. The words 'humbly kneeling before him' were added.

Note that in the admission to the order of Deacons the laying on of hands is by the Bishop alone.

- For the text of these, see pp. 591, 2.

$\uparrow$ The order form xiv. Caroli II runs : 'I-A.B. Do hereby declare my unfeigned assent and consent to all and everything contained and prescribed in and by the Book instituted, the Book of Common Prayer.

† Manus autem impositio non sicut baptismus repeti non potest. Quid est enim aliud nisi oratio super hominem? (Augustine, De Bapt., c Donat. iii. § 21). 
The laying on of hands in Ordination* expresses the bestowal of two quite distinct gifts :-

1. Ministerial Authority conferred by the Church through its appointed delegate or delegates.

2. Ministerial Grace, conferred by God, and depending upon the reality of the divine calling of the ordinand. The dependence is taught in 1 Tim. iv. 14, and 2 Tim. i. 6 (whether both refer to the same occasion or not). $\dagger$

First Charge, or Formula of Ordination. 1552. Sar. Pont. somewhat similar.

This gives the authority to execute the office of a Deacon.

The Rubric before the Second Formula of Ordination. 1552.

The delivery of the New Testament to the Candidate seems to be peculiar to the English Service.

\section{Second Charge, or Formula of Ordination.}

1552. Take .... if thou be thereunto ordinarily commanded.

1662. Take . . . if thou be thereto licensed by the Bishop himself.

This gives the authority to read, and conditionally to preach the Gospel in the Church of God. Until the Reformation the stole was placed over the left shoulder of the candidate, with the words 'Receive the stole of immortality.'

Rubric before the Gospel. 1552.

In 1662, 'the Gospel' was substituted for 'the Gospel of that day.'

The Gospel. Luke xii. 35-38. 1662.

1552. 'The Gospel of that day' was for the Sunday or holy day on which the Ordination was held.

The Rubrles before the Special Collects. 1552.

The first rubric directs that "the Bishop proceed in the Communion,' and 'all that are Ordered ' are to 'receive the Holy Communion the same day with the Bishop.'

Prayer for God's special grace upon the newly ordained. 1552. Sar. Pont. somewhat similar.

There was a similar Collect in the Pontifical of Egbert.

Prayer for direction and success in all our undertakings. 1662.

- The laying-on of hands upon ministers was not confined to Ordinationcf. Aots xiii. 3, where appointment to a special work, and not to the minis, terial office, was accompanied by the rite.

$\uparrow$ The mechanical theory of a bestowal of grace without regard to the spiritual condition of the candidate, is as contrary to the Holy Scriptures in this connexion as in the case of the Sacraments. 


\section{Benediction.}

1552. Appointed by a former rubric to be said, but not printed.

1662. Printed in full.

\section{Final Rubric.}

1662. 'For the space of a whole year' was substituted for

'For the space of a whole year at the least.'

1662. The concluding words of the Rubric, beginning with

'at the times appointed in the Canon,' were added. 


\section{THE FORM AND MANNER OF ORDER- ING OF PRIESTS}

THE TABLE COMPARING 'THE FORM OF ORDERING PRIESTS,' 1552, WITH 'THE FORM AND MANNER OF ORDERING OF PRIESTS,' 1662

\begin{tabular}{|c|c|c|c|}
\hline & 1662. & & 1552. \\
\hline $\begin{array}{c}1 \\
2 \\
3 \\
4 \\
5 \\
5 \\
5 a \\
5 b \\
5 c \\
6 \\
7 \\
8 \\
9 \\
10\end{array}$ & $\begin{array}{l}\text { The Morning Prayer. } \\
\text { The Sermon. } \\
\text { The Presentation of the Can- } \\
\text { didates. } \\
\text { The Litany and Suffrages. } \\
\text { The Ante-Communion Service, } \\
\text { ending with the Gospel. } \\
\text { Special Collect. } \\
\text { The Epistle, Eph. iv. } \\
\text { The Gospel, Matt. ix. or John x. } \\
\text { [The Oath] } \\
\text { The Bishop's Address. } \\
\text { The Examination of the Can- } \\
\text { didates. } \\
\text { The Bishop's Prayer for the } \\
\text { Candidates. } \\
\text { The Silent Prayer of the Con- } \\
\text { gregation. } \\
\text { The Veni Creator. } \\
\text { (a) lst Version. } \\
\text { (b) 2nd Version. } \\
\text { Thanksgiving followed by } \\
\text { Prayer. } \\
\text { The Ordination of the Can- } \\
\text { didates. } \\
\text { The Remainder of the Com- } \\
\text { munion Service. } \\
\text { Prayer for the newly-made } \\
\text { Priests. } \\
\text { The Collect 'Prevent us.' } \\
\text { The Benediction. }\end{array}$ & $\begin{array}{r}6 \\
7 \\
8 \\
9 \\
12 \\
13 \\
14 \\
16\end{array}$ & $\begin{array}{l}\text { The Exhortation. } \\
\text { The Ante-Communion Service } \\
\text { ending with the Gospel. } \\
\text { The Epistle, Acts xx. 17-35; } \\
\text { or I Tim. jii. l-end. } \\
\text { The Gospel, Matt. xxviii.; or } \\
\text { John x. l-16; or John xx. } \\
\text { 19-23. } \\
\text { The Veni Creator (2nd Ver- } \\
\text { sion). } \\
\text { The Presentation of the Can- } \\
\text { didates having plain Albs. } \\
\text { The Collect, being a prayer } \\
\text { for the Candidates. } \\
\text { [The Administration of } \\
\text { the Oath concerning the } \\
\text { King's Supremacy.] } \\
\text { The Bishop's Address. } \\
\text { The Examination of the Can- } \\
\text { didates. } \\
\text { The Bishop's Prayer for the } \\
\text { Candidates. } \\
\text { The Silent Prayer of the Con- } \\
\text { gregation. } \\
\text { The Ordination of the Candi. } \\
\text { dates. } \\
\text { The Remainder of the Com- } \\
\text { munion Service. } \\
\text { Prayer for the newly-made } \\
\text { Priests. } \\
\text { The Benediction (not printed } \\
\text { in full). } \\
\text { N.B. The last Rubric implies } \\
\text { that the Litany is said in } \\
\text { this Office, but does not state } \\
\text { the place where it is to be } \\
\text { used. }\end{array}$ \\
\hline
\end{tabular}




\section{Excursus on the Use of the Word 'Priest' in B.C.P.}

Despite the ambiguity of the word 'priest,' etymologically meaning 'elder,' but in common use 'sacerdos,' 'offerer of sacrifices,' it might have been thought that the significant changes in the Ordinal, and the careful removal of all mention of sacerdotal functions and appliances, such as 'sacrifice' and 'altar,' would have effectually disposed of anything uncertain in the Anglican use of the word. However, claims are still put forward for associating a sacerdotal idea with the word in B.C.P.

1. It is contended that the Preface to the Ordinal, with its appeal to the fact that the three Orders have been in the Church 'from the Apostles' time,' and its declared intention to continue them in the Church of England, is confessedly, to be used for the making of just such bishops, priests, and deacons, as had always been made ... the same powers conferred, the same functions executed' (Treatise on the Bull Ap. Cur. S.P.C.K., p. 38).

The fallacy in this reasoning becomes clear when account is taken of what was the status of the priesthood 'from the Apostles' time.' There is no uncertain sound in Holy Scripture; the Greek is free from the ambiguity of the English tongue, and it is universally admitted that the word for an offerer of sacrifices is never used of the Christian ministry. Nor is this evidence so negative as that bare statement may seem to be. The word iepev́s, Heb. cohen, A.V. 'priest,' is common in the N.T. It is used of Christ, Ep. Heb. passim: of the Jewish priesthood whenever mentioned: and of the whole mystical 'Body of Christ.' On the other hand, though there are two lists of N.T. ministerial functions, 1 Cor. xii. 28, Eph. iv. 11, though the three Pastoral Epistles are mainly devoted to ministerial duties, and though numberless references occur throughout the Acts and Epistles, that word is never used of the ministry. That eloquent silence is not broken but intensified by the fact that in Rom. xv. 16: ' that I should be the minister ( $\lambda \epsilon \iota \tau o v \rho \gamma o ́ v)$ of Jesus Christ to the Gentiles, ministering

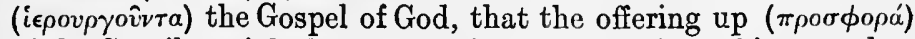
of the Gentiles might be acceptable': St. Paul draws his metaphor from sacrificial terms, yet, in describing his office, refrains from

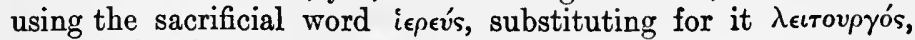
which is free from any possible misunderstanding.

The sub-apostolic period is equally decisive : "it is only toward the end of the second century that sacerdotal terms begin to be regularly applied to the clergy,' Gore: Church and Ministry, p. 196. It might fairly be contended that this statement falls short of the truth: for when terms capable of a sacerdotal 
construction became common, 'Presbyter' was still the recognized designation, and all other namescould only be understood metaphorically. As Lightfoot points out (Commenay on Philippians, p. 244), 'The very absence fo a word for a sacrificing priest as distinct from a presbyter, an absence in French and German, as well as in English, demonstrates that in the original establishment of the Christian Ministry in those countries, the sacerdotal idea was imported, and not orignal.' Be the period before the introduction of that idea but a few years, there is an acknowledged break, and the continuity of the priesthood 'from the Apostles' time' is not a continuity of sacerdotalism, but of ministry. What our Reformers meant by the continuity may be gathered from the following passage from Fulke's Defence of the English Translations (1583), p. 251 : 'we may lawfully wish that both Chrysostom and other ancient writers had kept that distinction of terms, which the Apostles and Evangelists did so precisely observe.'

2. The use of the word sacerdos in Latin Versions of B.C.P. has not infrequently been cited. Those who are acquainted with the history of such versions, and their worthlessness as translations (see Blakeney, pp. $182 \mathrm{ff}$.), were surprised to find in the reply of the late Archbishops to the Pope's condemnation of Anglican Orders (p. 27) the following: "Nor indeed do we avoid the term sacerdos and its correlatives, either in the Latin edition of " the Book of Common Prayer, or of the Ministry of the Sacraments as administered in the Church," published in 1560, in the reign of Elizabeth, nor in other documents written in Latin.' But Lathbury says (History of Prayer Book, p. 61): 'the book of 1560 . by no means gives an accurate view of the Book of common Prayer of this reign,' and Strype tells us that it was rejected at, Cambridge as 'the Pope's dreggs.' As for the 'other documents' the use of sacerdos in Art. XXXI describes the 'priest' who offers Mass, while in the title of the next Article, asserting the right of clergy to marry, seeing that the Article begins to enumerate episcopi, presbyteri, et diaconi, if any pressure is placed upon the word as here used, deacons are sacerdotes! The fact is that the Latin use in such places is worthless for the argument.

3. A more weighty argument is tendered in the same Archbishops' reply, in a sentence immediately following the above quotation: "That this (use of sacerdos in Latin B.C.P.) was not done without intention appears from the fact that in our translations of the Bible published in the sixteenth century the word iepeús is rendered by 'priest' (the word which is always used in the Anglican Ordinal, and very often in the Communion 
Office and elsewhere), while $\pi \rho \epsilon \sigma \beta \dot{v} \tau \epsilon \rho o s$ is translated "elder." This confusion of usage, due simply to the absence of a word for

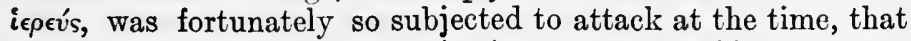
we are not at a loss for authoritative answers to this argument. The Roman Communion roundly abused the English Church for

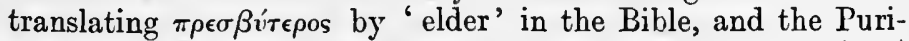
tans found fault with the retention in B.C.P. of the word 'priest.' Two typical replies, one to either objection, will suffice. Fulke, Defence of the English Translations, carries the war into the opponent's camp, saying: ' you corruptly translate sacerdos and presbyter always, as though they were all one, a priest, as though the Holy Ghost had made that distinction in vain, or that there were no difference between the Priesthood of the New Testament and the Old.' Whitgift replies to the Puritan Cartwright, on the other side : "the very word itself ("priest"), as it is used in our English tongue, soundeth the word presbyter. As heretofore use hath made it to be taken for a sacrificer, so will use now alter that signification, and make it to be taken for a minister of the Gospel.'* The Scripture translation, therefore, is defended on the ground that sacerdos must be distinguished from 'presbyter' in the N.T., the B.C.P. retention of 'priest' is defended on the ground of its etymological meaning. Whitgift's hope of rescuing the word 'priest' has been falsified, but what he took it to mean is clear enough.

4. A further effort to retain some notion of sacerdotium in connection with the N.T. priesthood has obtained much recognition of late, and that by many who are confessedly opposed to sacerdotalism. The argument is that since all the redeemed are

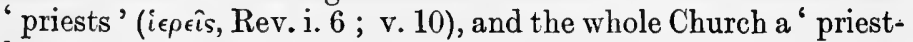

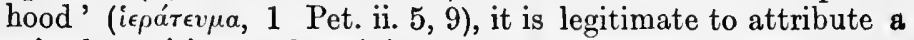
priestly position to the ministry, as representing the priesthood of the Church. This reasoning is attractive, and finds a double welcome as both reconciling the absence of sacerdotalism in B.C.P. with the early use of sacerdotal terms, and also seeming to provide a via media, a flag of truce held out to the warring conceptions claiming exclusive right to exist in the Church of England. Moreover it is built in part upon genuine scholarship, which has

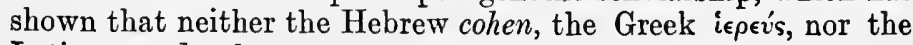
Latin sacerdos, has any necessary etymological connection with sacerdotalism in its modern sense. Historical support, too, is not wanting; such terms as are now under consideration were freely used in the third century, without any such connotation as is now supposed to be inseparable from them. So widespread a teaching,

* These quotations aro taken from Dimock : Doctrine of Sacerdotium, pp. $77 \mathrm{ff}$., where this point is fully considered. 
uttered in the sacred name of charity, and claiming scholarly and historical support, needs a careful examination.

(1) The following words of Lightfoot (Commentary on Philipp., p. 264) constitute a serious gravamen against all such theories: "It might have been better if the later Christian vocabulary had conformed to the silence of the Apostolic writers, so that the possibility of confusion would have been avoided.' In other words the possibility of interpreting the early use of sacerdotal phraseology in a sound sense, far from justifying the reintroduction of such terms, condemns it as unnecessary, unscriptural, and fraught with perilous confusion of thought.

(2) Such confusion may obscure divisions: it cannot heal them. 'All cats are grey in the dark,' but unanimity purchased at the expense of light is not unity. The differences are not verbal, but real, and the attempt to assert agreement by using the same terms with a different connotation is as futile as it is dishonest. The belief that a 'representative priest' offers sacerdotal sacrifices in the full sense of the words, cannot be reconciled with the behef that the supposed 'representative priest' is only such for the purpose of representing the priestly laity in spiritual sacrifices. For the latter directly negates the conclusions of the former ; following Holy Scripture, it claims that the only priestly work left is one which excludes sacrifice so far as atonement is inherent in the word. It knows only 'spiritual sacrifices' (1 Pet. ii. 5), and those as defined in Holy Scripture, viz. selfsacrifice for others (Phil. iv. 18 ; Heb. xiii. 16), and self-dedication to God (Rom. xii. 1).

(3) Most important of all, even if this idea of a 'representative priesthood' attaching to the N.T. ministry were calculated to bridge the gulf marking 'our unhappy divisions,' it still remains to ask whether the idea is true. Can any one represent another in 'spiritual sacrifices'? Can a man deny himself by proxy, and procure a delegate to whom to resign his duty of self-dedication to God? To ask the question is to answer it. The priestly office of a man is just that kernel of his whole relationship to God which is by its very nature untransmissible.

(4) Finally, the whole argument rests upon the fallacy that the functions of the ministry, as such, are of a higher spiritual order than the functions of the laity. Where is this to be found in Holy Scripture? Two quotations to show the shifts to which they are driven, who attempt to make this distinction in this connection, will sufficiently expose the barrenness of the position. Dimock, whose teacling is to be dissociated from the general idea of a representative priesthood, nevertheless endeavours to save some rags and tatter's of the sacerdotalism he has so ably torn to 
pieces (Christian Doctrine of Sacerdotium, note on p. 54). Citing Waterland and Patrick, who shared his desire, with all scholars, that not words but things should be considered, he ventures upon this statement: "To prevent misunderstanding, it may be well to add that it is not intended at all to deny that there is what may be called a certain official nearness pertaining to those who are ministers of Christ and stewards of the mysteries of God ... only a functional nearness (or rather, officium). It has strictly nothing to do, as the nearness of the sacerdotium of the O.T. had, with the matter of access.' ' Homer nods' : experience tells us that official nearness, functional nearness, is non-existent. Is the celebrant at Holy Communion in any sense nearer to Christ than the recipient? Is the reader of the Absolution nearer than the hearer? He may be nearer, and he may be further off ; and the difference does not depend upon his function. The other quotation is from Central Churchmanship, by the Bishop of Sodor and Man, pp. 72, 73, where the representative idea is expressly upheld : "If the Church be a priestly body-which no one deniesthen the clergy, as its accredited representatives, must hold a priestly office.' Note in passing that on the same argument, and far more directly, the people's warden holds a priestly office, if all representatives of a priestly body are thereby invested with priestly functions. The Bishop proceeds to eliminate erroneous notions of this priestly office. It is not' a sacerdotal order distinct and separate from the sacerdotalism of the whole Church.' It is not 'to mediate between the soul and God.' Grace is not 'in any way conditioned' by the office. Bishop Lightfoot is quoted with approbation as saying that the priestly functions and privileges of the Christian people were never regarded as being transferred or even delegated to these officers.' This representative priesthood is held, the author avers, "without infringing upon any of the rights and privileges which belong to the priestly laity.' After all these safeguards the question arises : 'Then in what sense are they priests? In the sense that they are chosen to be in the order of public worship and pastoral work the representatives of the priesthood of the entire Church.' An example is given: "The priest, therefore, offers prayers as the spokesman of the whole body of worshippers.' So that it comes to this, that the 'spiritual sacrifices' of the 'holy priesthood' are representatively offered by what may only too easily be the mechanical discharge of ecclesiasticalfunctions, and, in spite of the impossibility of delegating the priesthood, it is delegated after all! Worse remains : when a deacon, or a layman, is the " spokes man,' he is either a priest or he is not. If he is, then at any rate representative priesthood has nothing to do with the second order 
of the ministry as such, and ' priest ' in B.C.P. means ' presbyter' and nothing else. If he is not, then on such occasions the priestly office of the laity is suspended for the nonce, and prayers are offered which lack this important accompaniment! Is not this a reductio ad absurdum? It is with gratitude that the absence of any such notion from Holy Scripture is once more emphasized. If there were any real fundamental value in any such conception of the Christian ministry, would the Apostles have carefully refrained from the use of the word which would have established the truth? Nay, if the priesthood of the whole Church were of such fundamental importance, would all reference to it be confined to two references in one Epistle, to a passage in Isaiah lxi. 6, and two songs of the redeemed in the Apocalypse?. Not by such theories is that due proportion of the teaching of Holy Scripture observed, without which there is no security from dangerous error.

The Revisers did not so defend the use of the word 'priest.' To them, in spite of the ambiguous conceptions which had accumulated around it, it was the only word which could at the same time adequately express the presbyter of the N.T., and differentiate the second order of the ministry. It is unfortunate that. under whatever pretext any should have tried to go behind this, the historical explanation of the Prayer Book usage.

\section{ANALYSIS AND HISTORICAL NOTES.}

I. Introduction.

(The date is 1552 unless otherwise stated.)

1. Morning Prayer, 1662. Exhortation, 1552.

2. Sermon, 1662 .

3. Presentation by Archdeacon, Bishop's Address, and Final Si Quis. Placed here 1662.

4. Commendation of the Candidates to the Congregation, 1662.

5. Litany, with special Suffrage (slightly altered, 1662).

II. Holy Communion and Ordination.

1. Communion Offee to the end of the Gospel.

(1) The Collect (placed here 1662).

(2) The Epistle, Eph. iv. 7-13, 1662.

(3) The Gospel, Matt. ix. 36-38, 1662 ; or John x. $1-16,1552$; A.V. 1662.

2. Exhortation to the People. Altered 1662.

3. Examination of the Candidates. (Eight questions.)

4. Bishop's Prayer of Blessing. Altered 1662.

5. Silent Prayer.

6. Veni Creator; 1st Version, 1662 ; 2nd Version (1552). altered and placed here 1662 .

7. Thanksgiving and Prayer. 
8. Ordination.

(1) Imposition of hands.

(2) 1st formula, altered 1662.

Giving authority to ex. cute the Office of Priest.

'Receive the Holy Ghcst.'

(3) Delivery of the Bible.

(4) 2nd formula, altered 1662

'Take thou authority to preach the Word of God. and to minister the holy Sacraments.'

9. Remainder of the Communion Office, from the Nicene Creed. ending with the Gloria in Excelsis.

\section{Conclusion.}

1. Prayer for the newly made Priests, altered 1662.

2. The Collect: 'Prevent us'; 1662.

3. The Benediction; printed in full 1662 .

\section{The Title.}

\section{EXPOSITION.}

1552. The Form of Ordering of Priests.

1662. The Form and Manner of Ordering of Priests.

Preliminary Rubrics. 1662 ; the second, Sar. Pont.

The Presentation, Address, and Si Quis. 1552; cf. Old Pontificals; placed here 1662.

The Three Rubrics which follow, 1552 ; placed here 1662.

The 2nd, Sac. Gel. ; York Pont.

The 3rd was in 1552: "When the Exhortation is ended, then shall follow the Communion. And for the Epistle shall be read out of the twentieth chapter of the Acts of the Apostles as followeth.'

It was with this rubric that the Service then began.

The Collect. 1552; placed here 1662.

The Epistle.

1552. Acts xx. 17-35, or Tim. iii. 1-16.

1662. Eph. iv. 7-13.

The Epistles of 1552 were transferred (1662) to the Service for the Consecration of Bishops.

The Gospel. 1662 ; in 1552 the former alternative was Matt. xxviii. 18-20, the latter alternative was as in 1662 . A.V. substituted for ' Great Bible,' 1662.

In 1552 after the Gospel came : The Veni Creator, The Presentation of Candidates, The Collect, The Bishop's Address to the People.

The Administration of the Oath. (See Order of Deacons.)

The Bishop's Address to the Candidates. Slightly altered 1662.

1552. 'messengers, watchmen, pastors and stewards of the Lord'; 'pastors' omitted 1662 


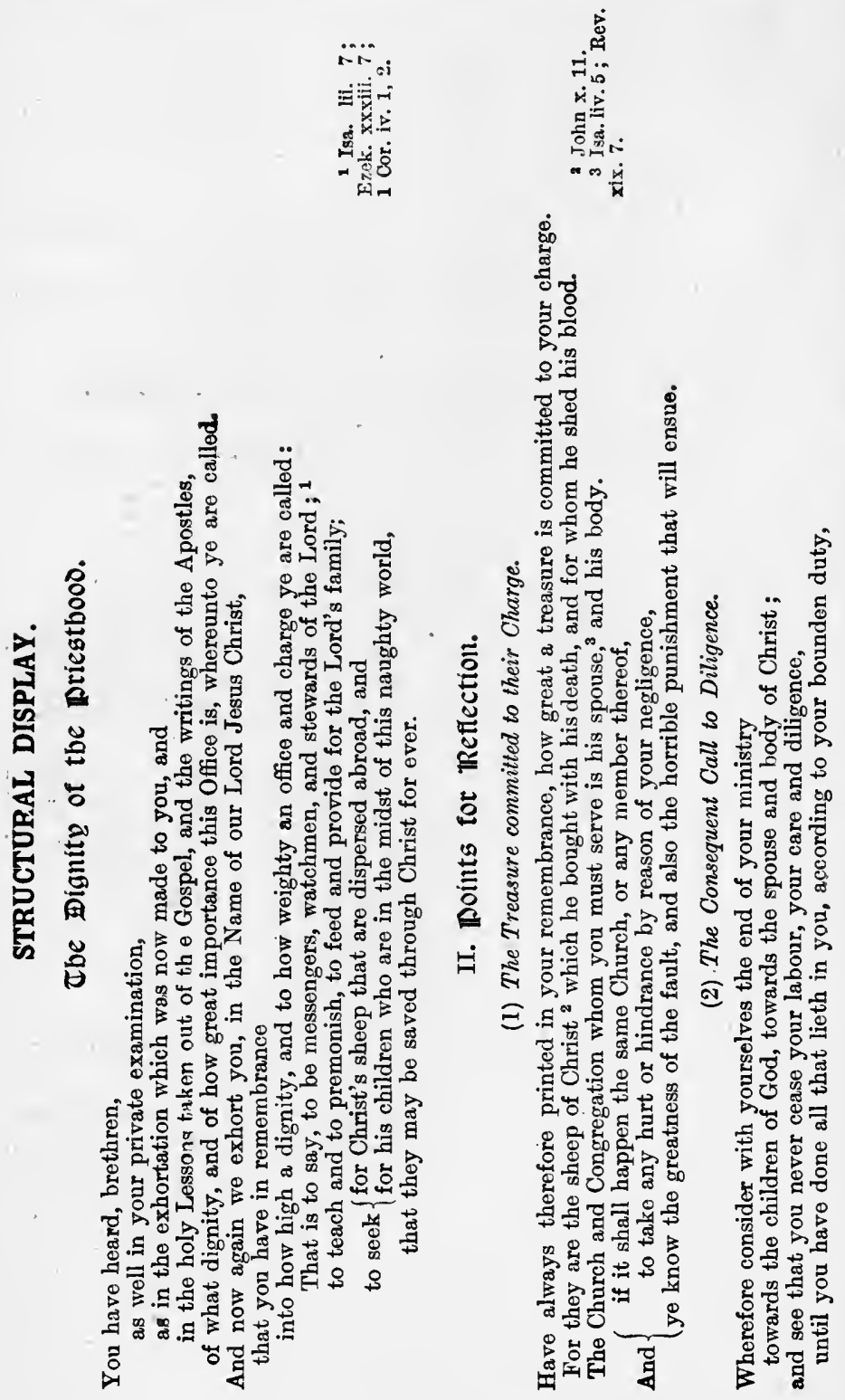



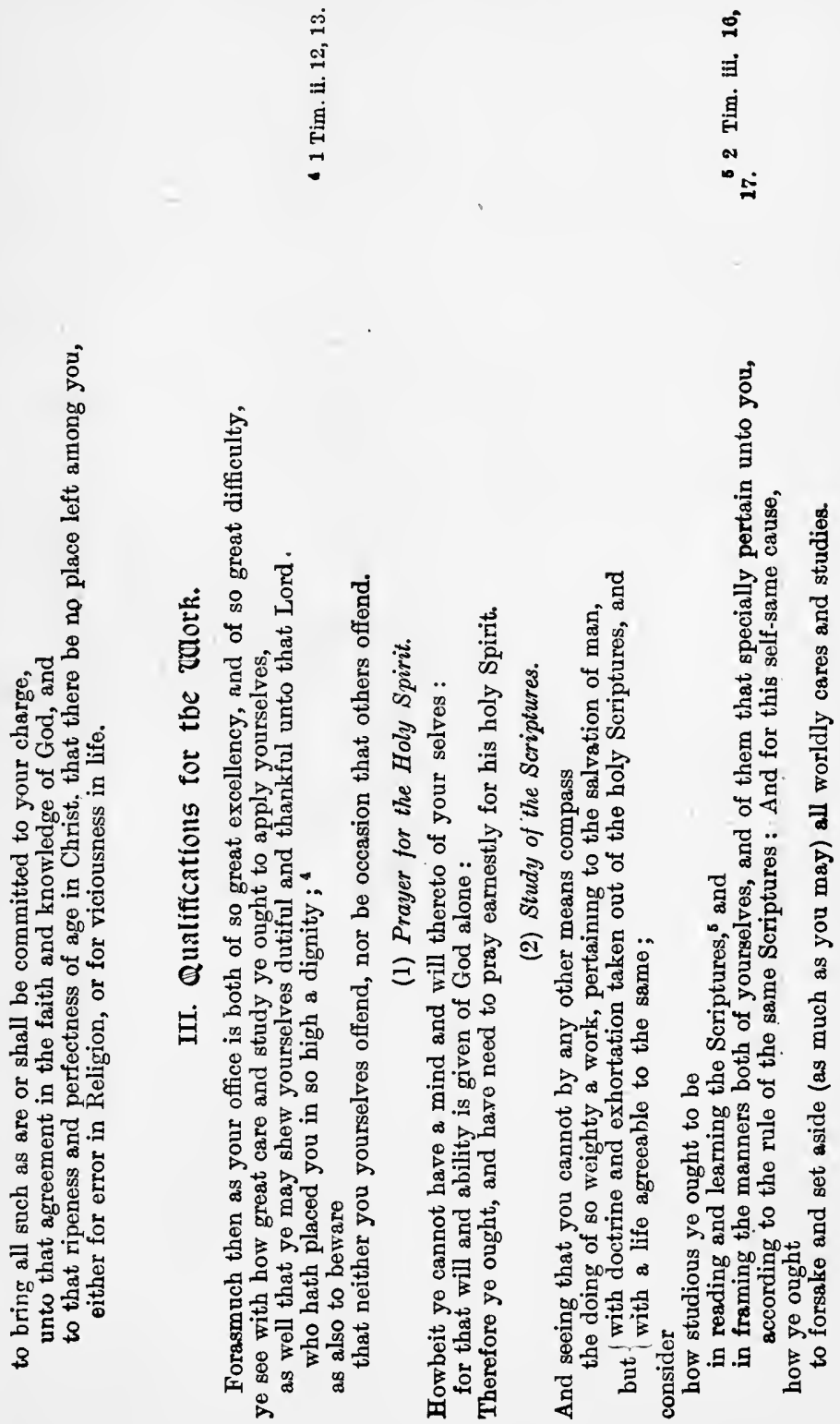
$\stackrel{+}{\dot{3}}$

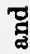

$\stackrel{9}{8}$

i a

$\because$ 曹

$\stackrel{4}{\$}$

¿

을

욜

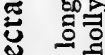

品

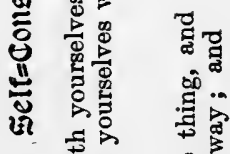

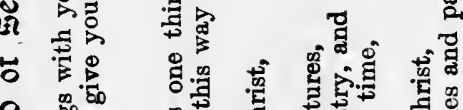

8 范。

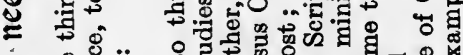

¿

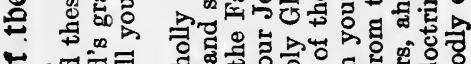

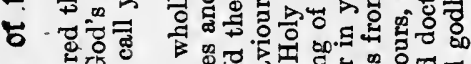

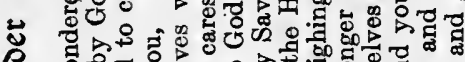

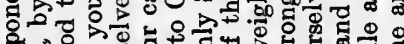

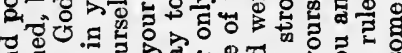

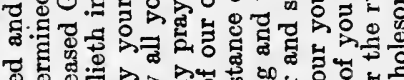
诃

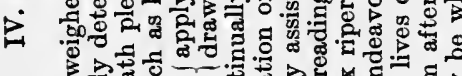

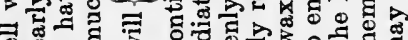

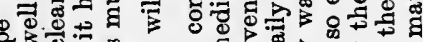

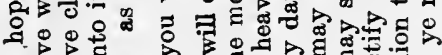

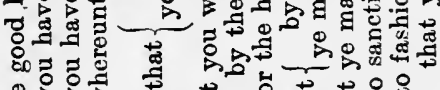

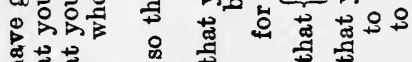

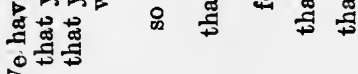

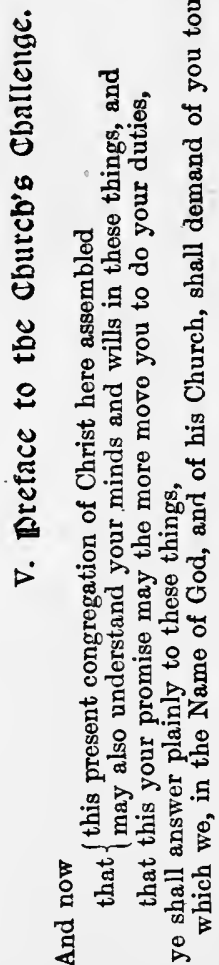


The Public Examination.

There is a short form of Examination in an Ordinal of the eleventh century: the last Interrogatory is similar to one in Sar. Pont.

1552. 'The Ministry of Priesthood,' in 1st Interrogatory.

1662. The Order and Ministry, etc.

The Bishop questions the Candidates as to :-

(1) Their inward call,

(2) Their belief in the sufficiency of Scripture.

(3) Their faichful fulfilment of duty.

(4) Resistance to heresy, and warning against evil.

(5) Prayer and the study of Scripture.

(6) Consistency of life.

(7) Furtherance of unity among all Christians.

(8) Canonical obedience.

\section{Rubric before the Bishop's Prayer of Blessing.}

The words 'standing up' were added 1662.

The Bishop's Prayer of Blessing. Sar. Pont. similar.

1552. Almighty God ... begun in you, until the time he shall come at the latter day to judge the quick and dead.

1662. Almighty God ... begun in you, through Jesus Christ our Lord. Amen.

Rubries before Veni, Creator Spiritus. 1st 1552; 2nd 1662, Sar. Pont.

Veni, Creator Spiritus. 1st Version, 1662 ; 2nd Version, 1552, modernized and placed here 1662 .

The shorter (first) version is taken from Cosin's Private Devotions, which appeared in 1627. It has been wrongly ascribed to Dryden (1631-1701). The authorship of the Latin hymn is unknown. It has been ascribed to Ambrose or Rhabanus Maurus, a ninth-century Abbot, and even to Charlemagne. It occurs first in the Pontifical of Loisson, which dates from the eleventh century. It is sometimes used in the early Breviaries as a hymn for Whit-Sunday at Tierce. The Latin version is :-

Veni, Creator Spiritus,

Mentes Tuorum visita:

Imple superna gratia

Quæ Tu creasti pectora.

Qui Paracletus diceris,

Donum Dei altissimi;

Fons vivus, ignis, caritas,

Et spiritalis unctio. 
Tu septiformis munere,

Dextræ DEI Tu digitus :

$\mathrm{Tu}$ rite promissum Patris,

Sermone ditans guttura.

Accende lumen sensihis,

Infunde amorem cordibus:

Infirma nostri corperis

Virtute firmans perpetim.

Hostem repellas longius,

Pacemque dones protinus:

Ductore sic Te prævio

Vitemus omne noxium.

Per te sciamus da Patrem,

Noscamus atque Filium :

Te utriusque SpIRITuM

Credamus omni tempore.

Sit laus Patri cum Filio,

Sancto simul Parachito:

Nobisque mittat Filius

Charisma Sancti SpIRITus. Amen.

Prayer. 1552. Sar. Pont. (1st part).

The Imposition of Hands.

The First Formula of Ordaining down to 'they are retained.' John xx. 22, 23. Sar. Pont. lst part.

The words 'for the Office and Work of a Priest in the Church of God now committed unto thee by the Imposition of ou c hands' were inserted 1662.

Receive ye the Holy Ghost, etc. This formula consists of a prayer, an address, and a charge. 'The Bishop, by speaking these words, doth not take upon him to give the Holy Spirit, no more than he doth to remit sins, when he pronounceth the remission of sins; but by speaking these words of Christ . . . he doth show the principal duty of a minister, and assureth him of the assistance of God's Holy Spirit, if he labour in the same accordingly.' * (See also pp. 96, 322, n.) The words 'Receive ye the Ho'y Ghost,' do not occur in any Ordinal prior to 1200 A.D.

The Rubric before the Second Formula of Ordination.

1549. The Bishop shall deliver to every one of them the Bible in the one hand, and the chalice or cup with the bread, in the other hand and say.

* 'Works of Whitgift,' p. 489, vol. i. P.S. 
1552. The Bishop shall deliver to every one of them the Bible in his hand, saying.

1662. The Bishop shall deliver to every one of them kneoling the Bible into his hand, saying.

The Second Formula of Ordination.

1552. Take thou .... in this congregation, where thou shalt be so appointed.

1662. Take thou .... in the Congregation, where thou shalt be lawfuly appointed thereunto.

' The Commission, hitherto, was limited to the single diocese in which the Priest was ordained, but now was made general throughout the Church, in whatsoever part he was lawfully called to minister' (Blunt).

The Medirval formula was, "Receive thou power to offer sacrifices to God, and to celebrate Masses for the living and the dead.'

'The Church of Rome, in making her priests, says nothing about preaching. The Church of England, in making her priests, says nothing about sacrificing' (Dyson Hague).

In the Roman 'Sacrament' of Holy Orders the inward and spiritual grace is the sacrificial and sacerdotal character conferred.

The Roman benediction is, "The Blessing of God Almighty the $\mathrm{Fa}+$ ther, the $\mathrm{S}+$ on, and the Holy + Ghost descend upon you; that you may be blessed in the priestly order, and offer propitiatory sacrifices for the sins and offences of the people to Almighty God, to whom be honour and glory for evermore R. Amen.'

The Rubric after the Second Formula. Sar. Pont.

1552. When this is donfe the Congregation shall sing the Creed, and also they shall go to the Communion, etc.

1662. When this is done the Nicene Creed shall be sung or said, and the Bishop shall after that go on in the Service of the Communion, etc.

Prayer for the Newly Ordained.

The words 'receive the same as thy most holy word, and the mean of our salvation' were changed in 1662 to ' receive what they shall deliver out of thy most holy Word, ar agreeable to the same, as the means of our salvation.'

The Final Prayer. 1662.

The Benediction. Printed in full 1662; Sar. Pont.

The Final Rubric.

1552. And if the Orders of Deacon and Priesthood be given 
both upon one day, then shall all things at the holy Communion be used as they are appointed at the ordering of Priests; saving that for the Epistle the whole third chapter of the first to Timothy shall be read as it is set out before in the Order of Priests. And immediately after the Epistle, the Deacons shall be ordered. And it shall suffice, the Litany to be said once.

1662. Altered to its present form.

It gives direction for the Order of the Service when an Ordination takes place of Deacons and Priests together.

The two Services are to be dovetailed together as follows :-Morning Prayer, Sermon, Presentation of Deacons, then Priests, the Litany, the Ante-Communion Service, the special Collects for Deacons and Priests, and the Epistle, Eph. iv. 7-13. The Deacons are then examined and Ordained, after which the Gospel (any of those contained in the two Offices) is read. After this the Priests are examined and Ordained, and the remainder of the Service is as contained in the Ordering of Priests. 


\section{THE FORM OF ORDAINING OR CON- SECRATING OF AN ARCH-BISHOP, OR BISHOP;}

Which is always to be performed upon some Sunday or Holy-Day.

ThIs form differs somewhat from the preceding two. In the consecration of Bishops at least three Bishops must take part; the Archbishop of the province in which the new Bishop is to serve must be assisted by at least two other Bishops. Different Bishops must read the Epistle and Gospel, and the Bishopclect must be presented by two Bishops. These directions are evidently intended to secure valid Episcopal Consecration. Thus it will be noted that a Priest or Presbyter is ordained by a Bishop and Presbyters; whilst a Bishop is consecrated by an Archbishop or his deputy and at least two Bishops.

The Ordinal of 1550 discontinued the old custom of the unction of head and hands, and the delivering of the ring and mitre, but retained the delivery to the Bishop of pastoral staff, the wearing of the cope, and the laying of the Bible upon the head; these, however, were dropped in 1552.

\section{ANALYSIS AND HISTORICAL NOTES.}

(The date is 1552 unless otherwise stated.)

I. Introduction.

1. Morning Prayer. 1662.

2. Ante-Communion Service ending with Nicene Creed.

(1) The Collect, being a Prayer for Bishops. 1662.

(2) The Epistle, being either 1 Tim. iii. 1-6. [(1662). (Great Bible, 1552; A.V., 1662,) or Acts xx. 17-35.

(3) The Gospel, being either John xxi. 15-17, (Great Bible, 1552 ; A.V., 1662), or John xx. 19-23 (1662), or Matt. xxviii. 18-20 (1662). The alternative Gospel in 1552 was John x. 1-16.

3. Sermon. 1662.

4. Presentation of the Bishop-elect, altered 1662.

5. Reading of the Sovereign's mandate.

6. Oath of obedience to the Archbishop.

7. Invitation to pray for the Bishop-elect.

8. Litany with special Suffrage. 
II. Ordination.

1. Prayer for the Bishop-elect.

2. Preface to Interrogatories. Altered 1662.

3. Interrogatories (seventh added 1662).

4. Prayer for the Bishop-elect to fulfil his promises.

5. Putting on by the Bishop-elect of the Episcopal habit.

6. The Veni Creator. 1st version, $1662 ; 2$ nd version, altered 1662.

7. Suffrages.

8. Prayer for Bishop-elect. Altered 1662.

9. Ordination of the Bishop-elect.

(1) Imposition of hands.

(2) Formula of Ordaining. Altered 1662.

(3) Delivery of the Bible.

(4) Exhortation to newly consecrated Bishop.

III. Conclusion.

1. Communion Service from the offertory sentences ending with the Gloria in excelsis.

2. Prayer for the new-made Bishop.

3. The Prayer 'Prevent us.' 1662.

4. The Benediction, printed in full 1662 .

The Order of the 1552 Service in regard to the earlier part differed from that of 1662 :-

1. Ante-Communion Service ending with the Nicene Creed.

2. Epistle, 1 Tim. iii. 1-6.

3. Gospel, John xxi. 15-17 or John x. 1-16.

4. Presentation of the Bishop-elect.

5. Reading of the King's Mandate.

6. Oath of Supremacy.

7. Oath of Obedience to the Archbishop.

8. Litany.

9. Invitation to pray for the Bishop-elect.

\section{EXPOSITION.}

The Title. Sar. Pont.

1662. 'ordaining or' adcied and the direction 'which is always,' etc.

The Rubric before the Collect. 1662.

In 1552 the simple instruction was 'At the Communion.'

The Collect. 1662 ; adapted from tha for St. Peter's Day.

The Rubric before the Epistle, requiring 'another Bishop' to read it, 1662. 
The Epistle.

1552. 1 Tim. iii. 1-6 (old Pontifical), 'Great Bible.'

1662. 1 Tim. iii. 1-6, A.V., or Acts xx. 17-35.

The Rubric before the Gospel. 1662. Directing 'another Bishop' to read it.

The Gospel.

1552. John xxi. $15-17$ or x. 1-16, 'Great Bible.'

1662. John xxi. 15-17, A.V., or xx. 19-23, or Matt. xxviii. 18-20.

The Rubric before the Presentation.

The words 'vested with his Rochet,' and 'the Archbishop sitting in his Chair near the holy Table,' were added in 1662.

In 1550 the following rubric occurs : 'After the Gospel and Credo ended, first the elected Bishop, having upon him a surplice and a cope, shall be presented by two Bishops (being also in surplices and copes, and having their Pastoral staves in their hands) unto the Archbishop,' etc. Up to the end of the sermon it is the usual custom for the Bishop-elect to wear the academic gown. The rochet is a long vestment of white lawn or linen, with full sleeves fastened at the wrist. Before the Reformation it was the usual dress of Bishops.

The Presentation of the Bishop-elect.

In 1662, 'Ordained and' was inserted before 'Consecrated.'

The Reading of the Sovereign's Mandate.

The rubric respecting this verbally altered 1662. Sar. Pont.

The Oath of Obedience to the Archbishop. Sar. Pont.

.... and His holy Gospel.

1550. So help me, God, and all the holy Evangelists.

1552. So help me God, through Jesus Christ.

1662. So help me God, through Jesus Christ.

The rubric (1552) following directs the omission of this Oath at the Consecration of an Archbishop.

A declaration of deference to the See of Canterbury is customarily made here by Archbishops-elect.

Invitation to pray for the Bishop-elect. 1552 ; Old Pontificals.

Rubric concerning the Litany. Verbally altered 1662.

Special Litany Suffrage. 1552; Old Pontificals.

Prayer for the Bishop-elect to fulfil efficiently the Office of a Bishop.

In 1552 the rubric preceding it was 'Concluding the Litany in the end with this Prayer.' 
Brief Preface to Interrogatories. 1552 ; Sar. Pont.

1662. Some slight verbal changes were made, the chief one being 'government in the Church of Christ' being substituted for 'the government of the congregation of Christ.'

Questions to the Bishop-elect.

(1) His sense of both inward and outward call.

(2) His belief in the sufficiency of Holy Scripture.

(3) His faithful study of the same Scripture.

(4) His readiness, personally and through others, to banish erroneous doctrine.

(5) His godliness of life.

(6) His exercise of discipline on behalf of unity.

(7) His care in ordaining others.

(8) His mercifulness towards the destitute.

Rubric after Interrogatories.

In place of the present preceding rubric in 1552 was simply 'The Archbishop.'

Prayer for the Bishop-elect. 1552.

Rubric before the Veni, Creator Spiritus.

1552. Then shall be sung or said, Come, Holy Ghost, \&c., as it is set out in the order of Priests.

1662. Then shall the Bishop Elect put on the rest of the Episcopal habit; and, kneeling down [Veni, Creator Spiritus], shall besung or said over him, the Archbishop beginning, and the Bishops, with others that are present, answering by Verses, as followeth.

Rest of the Episcopal habit, i.e. the black satin chimere or upper robe, cut down the middle, etc.

The Veni, Creator Spiritus. 1st version, 1662; 2nd version 1552 ; altered 1662 .

The Suffrage. 1552.

Prayer for Bishop-elect.

'Almighty God, and most merciful Father.'

The major alterations in 1662 were-

(1) 'Making perfect his Church' substituted for 'making perfect of his congregation.'

(2) 'Not to destruction, but to salvation' substituted for 'not to destroy, but to save.'

The Rubric before the Formula of Consecration. 1552 ; Sar. Pont. 
The words 'kneeling before them upon his knees' inserted 1662.

The Formula of Consecration. Exeter Pont.

1552. Take the Holy Ghost, and remember that thou stir up the grace of God, which is in thee, by imposition of hands ; for God hath not given us the spirit of fear, but of power, and love, and of soberness.

1662. Receive the Holy Ghost, for the office and work of a Bishop in the Church of God, now committed unto thee by the Imposition of our hands : In the name of the Father, and of the Son, and of the Holy Ghost. Amen.

'And remember,' etc. (see 2 Tim. i. 6, 7).

The Rubric before the Exhortation. 1552. Slight verbal alterations 1662 .

1550. Then the Archbishop shall lay the Bible upon his neck, saying, 'Give heed unto reading,' etc.

The Exhortation. 1552.

1550. Before the words ' Be to the flock of Christ a shepherd,' etc., there was this rubric: 'Then shall the Archbishop put into his hand the Pastoral Staff, saying.'

The Rubries after the Exhortation. 1552; very slightly altered 1662.

Prayer for newly-made Bishop. 1552; adaptation from Benediction in Sar. Pont.

The Prayer 'Prevent us.' 1662.

The Benediction. 1552; printed in full 1662.*

* In 1552 the following note was appended:-

\section{THE PRICES OF THIS BOOK.}

This Bcok is to be sold by the imprinter in quires for two shillings and six pence, and not above. Bound in parchment or forell, for three shillings and iij pence, and not above. And bound in leather, in paper boards or clasps, for four shillings, and not above. And at tho next impression, the imprinter leaving out the form of making and consecrating of Archbishops, Bishops, Priests, and Deacons, shall sell the said book in quires for two shillings, and not above. And bound in forell, for two shillings and eight pence, and not above. And bound in leather, in pasteboards or clasps, for three shillings and four pence, and not above. 


\section{FORMS OF PRAYER WITH THANKSGIVING TO ALMIGHTY GOD ;}

For use in all Churches and Chapels within this Realm, every Year, upon the Anniversary of the Day of Accession of the Reigning Sovereign, or upon such other Day as shall be appointed by Authority.

Certain special Services have from time to time been promulgated for use in connexion with important events of State. Until 1859 there were four such services, annexed to the Book of Common Prayer, and issued at the commencement of each reign by the authority of a royal proclamation.* Their history may be summarized as follows :-

1576. A Service for use on the Accession day of Elizabeth was published.

1578. The same Service was set forth by royal authority.

1626. A new form was issued.

1640. The new form was sanctioned by Convocation.

$1685,1704,1715,1728$. Slight changes were made.

1901. Considerable changes were made, under the superintendence, it is believed, of Archdeacon Sinclair.

Three other days were also observed and the Authority for the Services rested upon Acts of Parliament. November 5 was kept in remembrance of the failure of the Gunpowder Treason Plot in which Robert Catesby and Guy Fawkes were chief conspirators. This Service was arranged immediately after the Pot, in James I's reign. In Charles II's reign two other days with special Services were added, viz., January 30, in memory of the execution of Charles I, and May 29, in memory of the restoration of Charles II. The observance of the days depended upon Acts of Parliament, but the Services depended for their authority upon Convocation and the Crown. The Services have been slightly altered from time to time, James II altering the Service for May 29 in order to include himself, and William III adding to the Commemoration of the Gunpowder Plot a

* There is no Act of Parliament enjoining the observance of days of Accession; they have been observed with special prajers in ercry reign since the Reformation. 
remembrance of his own landing. These three special Services were removed from the Prayer Book by royal warrant in 1859 .

All these Services, together with the Accession Service, were constructed on much the same model. The Daily Office was modified by special opening sentences, by the substitution of a composite Psalm for the Venite, by arranging proper Psalms and Lessons, by adding suffrages and collects, and by ordering, in the Communion Office, special Collect, Epistle and Gospel.

Perhaps the greatest contribution to the wealth of our Liturgy that these Services contain is the prayer for Unity which was added in 1715, authorship unknown.

Three forms are now given, the first and second being adaptations of Morning Prayer and the Communion Service, the third a service to be used on the same day apart from either. The following are the chief alterations:-

1.

(1) The special sentences and composite Psalm are omitted.

(2) Two alternative Proper Lessons are given, Proverbs viii. 1-17 and Rev. xxi. 22-xxii. 4.

(3) The Suffrages are slightly altered.

(4) A new Collect is substituted for the old ind longer first Collect.

(5) In the following Prayer some few changes are made.

(6) A second is added kneeling.

(7) The Collect for Unity follows here, the old second Collect being omitted.

2.

(1) The Collect ' $O$ God, who providest' is substituted for the very long Collect in the old form.

(2) The Epistle and Gospel are as in the old form, but all other special arrangements are omitted.

(3) A rubric is added that, if this day falls on a Sunday or other Holy day, the Service is to be the Communion Service in its ordinary form with the addition, after the Collect for the day, of the special Collect, ' O God, who providest.'

3.

(1) The Te Deum, divided into three sections.

(2) Lesser Litany and Lord's Prayer.

(3) Suffrages, including the two omitted from the old Service in the new first form.

(4) The three Collects, one now and two adapted.

(5) The Prayer for Unity.

(6) The Collect from the end of the Cummunion Service.

(7) The Blessing. 


\section{SUBJECT-INDEX TO THE ARTICLES}

\begin{tabular}{|c|c|c|c|}
\hline \multicolumn{2}{|c|}{ ARTICLE } & \multicolumn{2}{|r|}{$\triangle R T I C L E$} \\
\hline Adoration of the Elemen & nts. $\quad 28$ & Invocation of Saints & - $\quad 22$ \\
\hline Apocrypha, its uses . & 6 & Justification by Faith . & \\
\hline scension. - . & . 4 & Justification and Works. & 12 , \\
\hline tonement $\cdot$. & $2,18,31$ & Last Judgment . . & \\
\hline uthority of Princes & - $\quad 37$ & Liberality enjoined & \\
\hline uthority, Papal . & - $\quad 37$ & Light of Nature insufficien & \\
\hline uthority of Seripture . & . $6,8,20,21$ & Lord's Supper . 25 , & $28-$ \\
\hline aorit $y_{0}$ of Chureh & - 20,34 & lass-Sacrifice . & \\
\hline hority of Councils. & - 21 & Military Service. . & \\
\hline $\mathrm{sm} \cdot \therefore \cdot \cdot$ & $\therefore \quad 16,25,27$ & Ministerial Authority & \\
\hline ommunion in Both $\mathrm{Ki}$ & inds $\quad 30$ & Ministerial Call . & \\
\hline .T. and N.' & 6 & Ministers, Deposition of . & - \\
\hline 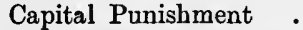 & 37 & try, effect of Unwortl & \\
\hline & $7,20,34$ & stry and Marriage. & . \\
\hline inless & . 15 & n justifiable & \\
\hline ent into $\mathrm{Hel}$ & & relation to N.T. & \\
\hline inity . . & & ar binding & \\
\hline acrifice & 31 & dward, validit & \\
\hline S Resurrection & 4 & 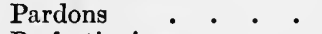 & \\
\hline ments. & & & \\
\hline thority & 20,34 & hip in Vernacu & \\
\hline efined & & nd Scripts & \\
\hline ure . & & ns with the Hos & \\
\hline & & of the Holy $\mathrm{C}$ & Ghost \\
\hline & & iptural. & \\
\hline & 19 & rship & 2 \\
\hline Goods & 38 & ed Repentance & \\
\hline & & tion . . . & \\
\hline ture. & 2. & & $25-2$ \\
\hline & & wrongly so-c & \\
\hline ture & & Way of & \\
\hline & & & \\
\hline Christ & 28,29 & & \\
\hline of the Will & & vation & \\
\hline odhead, The . . & & ptism . & \\
\hline Vorks . & $10,12,13$ & . & \\
\hline pirit . & . $\quad 5,16$ & versality & \\
\hline & - 35 & against the Holy Ghos & \\
\hline & & n, works & \\
\hline & & & \\
\hline Bentiam & 2 & antiation. & \\
\hline & & & \\
\hline
\end{tabular}




\section{ARTICLES}

Agreed Upon

By The Archbishops and Bishops of Both Provinces, And The Whole Clergy

\section{In The}

Convocation Holden At London In The Year 1562,

For The Avoiding Of Diversities Of Opinions, And For The Establishing Of Consent Touching True Religion.

freprinted by his majesty's Commanoment, With His Royal Declaration Prefixed Thereunto. 


\title{
HIS MAJESTY'S DECLARATION
}

This was drawn up by Laud in 1628 to disarm opposition to his Arminian policy, and his ignoring of Parliament or any Authority save that of the King.

\section{HIS MAJESTY'S DECLARATION.}

\author{
ANALysis.
}

Paragraphs.

No. 1. I. Its Justiffeation.

II. Its Contents.

1. Commands respecting:-

No. 2. (1) Reprinting the Articles, and Publication of Declaration.

No. 3. (2) Method of Settling Differences.

No. 4. (3) Leave to Convocation to discuss but not alter Articles.

No. 5. 2. Expression of Satisfaction that, despite difference of opinion, the clergy agree with the Articles, and have no intention of departing from their teaching.

No. 6. 3. Direction to discontinue further speculation, and to submit to the Articles honestly interpreted.

No. 7. 4. Penal Enactment in the case of:-

(1) Affixing any new sense to any Article, and controversy in the Universities or Colleges.

(2) Preaching or printing anything against what has been established in Convocation with the Royal Assent 


\section{ARTICLES OF RELIGION}

\section{HISTORICAL INTRODUCTION.}

Two periods of Church history have been specially marked by the composition of formularies of faith, the fourth and fifth centuries, and the sixteenth. The periods differed, and the formularies produced differ accordingly. In the earlier period the Church was suddenly brought face to face with the rapid rise of successive heresies. Imperial Rome had just become Christian, and, with a large influx of scarcely half-converted pagans, if the faith was to be preserved, the Church must provide itself with watchwords which could not be misunderstood. These are enshrined in what are called the three Creeds of undivided Christendom, two of them at least being expansions of earlier and simpler statements of the faith.

In the sixteenth century, on the other hand, the crisis was of another kind. The New Learning had begotten new ideals of spiritual and intellectual freedom which made the old ecclesiastical tyrannies as intolerable as they were. now seen to be unscriptural. It was, therefore, pre-eminently needful to restate the Christian position in a way which would bring back the simplicity of the Gospel age. The makers of the various Continental sets of Articles, as well as of our own, would have failed in their task if they had not exposed and condemned the errors of their day in clear and cogent language. The Articles were not intended to supersede but to supplement the old credal statements with carefully reasoned explanations of their meaning and implications.

The following Continental Formularies contributed, either directly or indirectly, to our present XXXIX Articles :-

\section{The Schwabach Articles.}

In the year 1529, under the auspices of the Elector John of Saxony, a series of seventeen articles was drawn up at the Convent of Schwabach, to lay down the conditions of membership of a reforming league, and, if possible, to reconcile Lutherans and 
Zwinglians. They were based on a similar test which had been presented to the Zwinglians without success a few days before at Marburg. Their main importance is due to the fact that they in turn became the basis of the much more important 'Confession of Aingsburg.'

\section{Confession of Augsburg.}

Melancthon was deputed by the Elector to remodel and extend the Schwabach test. He sent his revision to Luther, who returned it to him for final correction. The work was barely finished when the Emperor Charles V. expressed his willingness to receive the Reformers' defence. Melancthon made a German copy of the original Latin, and it was submitted to the Emperor over the signatures of the Elector John and the other Protestant princes (1530). The Confession consisted of 28 Articles, in two parts, twenty-one being doctrinal and seven dealing with ecclesiastical abuses. The doctrinal Articles are Lutheran in position, and conclude with the statement that there is nothing in their doctrine which is fundamentally divergent, either from Scripture or from the teaching of the primitive Church. The second section, dealing with ecclesiastical abuses, discusses Communion in both kinds, the marriage of Priests, private masses, confession, fasts and feasts, monastic vows, and the civil power of Bishops. Our thirteen Articles of 1538 were based upon the Augsburg Confession, which consequently influenced the forty-two articles of 1553. After much discussion at Augsburg, a confutation was drawn up by the Roman party; and, finally, after a little wavering, the Emperor decided against the reforming princes.

\section{Confession of Würtemberg.}

This was drawn up in 1552 for the State of Würtemberg, and was a shorter form of a document drawn up by the Saxon Churches to be presented to the Council of Trent, called Repetitio Confessionis Augustance (Augsburg). It consisted of thirty-five articles, and was used by Archbishop Parker in the preparation of the Articles of 1563 .

\section{The Decrees of the Council of Trent.}

The Council of Trent was Rome's reply to the Reformers' demand for a general Council. It was composed only of those who were loyal to the Roman position, and commenced to sit in 1545. It sat until 1547 and then, after an interval of four years, again in 1551. After some bricf sessions it was again suspended until 1562, and its decrees were finally confirmed by a Bull of Pope Pius IV in 1564. Thus Rome was confirming and stereo- 
typing her doctrine, at the same time that the Reformers of England and the Continent were giving formal expression to theirs.

\section{ENGLISH FORMULARIES:}

\section{The Ten Articles of 1536.}

Apparently these Articles were drawn up by a Committee of the moderate Divines of each party under the presidency of the King himself, and were subscribed by eighteen bishops and many other ecclesiastics. The doctrinal tone of them is transitional. They avoided and qualified Lutheranism, excluded Anabaptist teaching, and were as sympathetic as possible with the old learning. Five of them were doctrinal, dealing with the grounds of faith, the Sacraments of baptism, penance, and the altar, and the doctrine of justification. Five dealt with ' laudable' ceremonies used in the Church, images, the honouring of saints, prayers to saints, and purgatory. These latter articles are characteristic; they partly cling to the position of the old learning, they partly draw away from it. Although these Articles were virtually superseded within a year by the Bishops' Book, yet much of the contents was contained in that Book; and, seeing that the latter never received royal sanction, the Ten Articles remained legally in force until the publication of the King's Book.

\section{- 2. The Institution of a Christian Man.}

This compilation of 1537 was called, because it never received Royal Authority, the Bishops' Book. It was prepared at Lambeth, Cranmer presiding; it was published in the name of the two Archbishops and all the Bishops, and with the King's consent, but lacked the authority of the King, Parliament and Convocation. It contained an exposition of the Apostles' Creed, of the seven Sacraments, of the ten Commandments, of the Paternoster and Ave Maria, together with two Articles from the Ten, those on justification and purgatory. The book was devotional and popular, and constituted a distinct step in the direction of reform.

\section{The Thirteen Articles.}

These Articles came into being in 1538, as the result of an embassy to England from the Lutherans. They appear to have been drawn up by Cranmer, largely on the basis of the Augsburg Confession. They were never sanctioned or published, and have been only recently brought to light. They are the historical connecting link between our Articles and the Augsburg Confession. It may have been that the period of reaction which set in with Gardiner's rise to influence (1539 to 1543 ), prevented the publica- 
tion of these Articles. They have an interesting historical bearing upon the process of Cranmer's reforming work, and the share in that work due to Continental influence.

\section{The Law of the Six Articles.}

This law was carried, in 1539, both by Parliament and the Southern Convocation, through the influence of Gardiner. It was so hostile to the Reformation that it came to be known as "The Whip with Six Strings.' It enforced Transubstantiation, Communion in one kind, clerical celibacy, monastic vows, private masses, and auricular confession.

\section{The Necessary Doctrine and Erudition for any Christian Man.}

This was better known as 'The King's Book.' It was a retrograde revision of the Bishops' Book, much less favourable to the Reformers and enjoying the approval of Convocation and the support of a Royal mandate. It was the last publication of the kind during the reign of Henry VIII, dating from 1543.

\section{The Forty-two Articles.}

After the death of Henry VIII, Cranmer drew up in 1549 a set of Articles to be used as a proof of orthodoxy in licensing clergy to preach and teach. In 1551 he was commanded to draw up a ' Book of Articles of Religion for the preserving and maintaining peace and unity in this Church, that, being finished, they might be set forth by public authority.' This he did, probably using the 1549 series as a basis. In 1552 these Articles, which had. been revised and approved by other bishops, were laid before the Council. They were forty-two in number, the Article on Holy Communion being broken up into four parts. In the next year, 1553, after further revision, they were issued under the authority of a Royal mandate. Whether they also received the authority of Convocation or not is impossible to prove, because the records of Convocation perished in the Great Fire of London. All existing copies, however, claim to have been ratified at the last Synod of London, and though there is no mention of the fact in the Royal Letter requiring subscription, it is probable that they did possess the sanction of Convocation. They owed much to the Confession of Augsburg, through the thirteen Articles of 1538, Articles I, II, XXIII, XXVI, XXVII and XXXIII coming almost verbally from that Confession.

They are the basis of our present Articles, and it will be convenient to notice the difference between the two series.

i. Seven whole Articles are now omitted :- 
(1) Grace.

(2) Blasphemy against the Holy Ghost.

(3) The Moral Law (now part of Article VII).

(4) The Resurrection.

(5) The Souls of the departed.

(6) The Teaching of the Millenarii.

(7) Universalism.

ii. Two parts of Articles are also omitted :-

(1) A Clause on Christ preaching in Hades.

(2) In the Holy Communion Article on the Bodily Presence of Christ.

iii. Four Articles have been added :-

(1) On the Holy Ghost (V).

(2) Good Works (XII).

(3) The Wicked at the Lord's Supper (XXIX).

(4) Communion in both kinds (XXX).

iv. Two parts of Articles have been added :-

(1) The Catalogue of Canonical Books (VI).

(2) The reference to Second Book of Homilies (XXXV).

Note.-There was drawn up at the same time as the Forty-two Articles, and practically by the same hands, a document called Reformatio Legum Ecclesiasticarum. It was intended that it should be sanctioned by Parliament, and imposed by authority, but Edward VI died before this proposal could be carried out. It was a kind of draft code of Reformed Canon Law, to supplement the Articles.

\section{The Eleven Articles.}

Soon after the accession of Elizabeth, in April, 1561, the two Archbishops, with the bishops, issued a series of Articles as a temporary expedient. These Articles avoided many matters of controversy, but were clearly intended to remedy the Marian reaction. They were to be accepted by the clergy upon admission to their benefices, and to be publicly professed twice a year.

\section{The Thirty-eight Articles.}

In this episcopal revision in 1563 of the Forty-two Articles the Confession of Würtemberg was largely used. Four Articles were omitted, four new ones inserted, and seventeen revised. Convocation struck out three more, dealing with Anabaptist theories no longer important, and sent the Thirty-nine to the Queen for her approval. The Queen returned them with two important alterations; Article XXIX, dealing with unworthy reception of the Holy Communion, was struck out, and the first clause of 
Article XX, "The Church hath power to decree rites or ceremonies and authority in controversies of faith,' was inserted. The much-canvassed responsibility for these changes rests in part, at least, with the Queen herself. These Articles, thus reduced to thirty-eight, were to be made binding upon the clergy. They received the royal authority, and were enforced by the ecclesiastical authority of the episcopate.

\section{The Thirty-nine Articles.}

The XXXVIII Articles were finally revised in 1571 and a compromise effected, by which the first clause of Article XX was accepted, and Article XXIX was reinstated. The Queen's authority was granted, and the Articles thus sanctioned have been unaltered ever since.

NotE.-Two serious attempts at alteration have been made.

In 1595 Archbishop Whitgift drew up the Lambeth Articles in order to give the doctrine of the Church of England a closer approximation to Calvinism, but the Queen intervened and nothing more was done. The Puritans failed to secure their incorporation in the XXXIX Articles at the Hampton Court Conference, 1604, but they were included in the Irish Articles of 1615 .

In 1643 the Westminster Assembly amended the first fifteen Articles, but were ordered by Parliament to abandon the revision.

\section{The History of Subscription.}

In 1553 subscription to the Forty-two Articles was intended, but not enforced owing to the death of the King. In 1563 no attempt was made to enforce general subscription. In 1571 the Act required subscription to all the Articles which " concern confession of the true Christian faith, and the dnctrine of the Sacrament,' from all clergy, from all future ordinands, and from all beneficed clergy at the time of their institution. This was the only such Act until 1865, and it is curious to notice that it enforced subscription to the 1563 edition (without Article XXIX or the first clause of Article XX), and that it was not concerned with the Articles which deal with discipline. In practice, however, the Church has demanded subscription to all the revised Articles. In 1583, Whitgift jssued a form of subscription in three Articles which were inserted in the Canon 36 of 1604 . The Uniformity Act of 1662 demanded assent to the P. B., but did not deal directly with the Articles. In 1689 the Comprehension Bill attempted to get rid of subscription altogether, but failed in the Commons. Similar attempts have been made since. In 1865 it was felt that the forms of subscription in use were unnecessarily 
complicated, and an Act was passed to give effect to a simpler form. That at present in use was compiled, and Canon 36 was amended accordingly. At the Universities of Oxford and Cambridge subscription in the case of all degrees except those in divinity was abolished in 1871 . It had first been introduced at Oxford by a Puritan Chancellor at Matriculation to exclude Roman Catholic Students.

\section{EXPOSITION.*}

I The Triune God . . . . . . I I-V

II The Rule of Faith $\quad \cdot \quad \cdot \quad \cdot \quad \cdot \quad \cdot$ VI-VIII

III Sin and Salvation $\quad . \quad . \quad . \quad$. IX-XVIII

IV Church; Ministry and Sacraments . . XIX-XXXVI

V Citizenship . . . . . XXXVII-XXXIX

\section{ARTICLE I. \\ Of Faith in the Holy Trinity. \\ De Fide in Sacro-sanctam Trinitatem.}

There is but one living and true God, 1 everlasting, without body, parts, or passions ${ }^{2}$; of infinite power, wisdom, and goodness ${ }^{3}$; the Maker, and Preserver of all things both visible and invisible. ${ }^{4}$ And in unity of this Godhead there be three Persons, of one substance, power, and eternity; the Father, the Son, and the Holy Ghost. ${ }^{5}$
Unus est virus et verus Deus, æternus, ineorporeus, impartibilis, impassibilis, immensæ potentiæ, sapientix, ac bonitatis; Creator et Conservator omnium, tum visibilium, tum invisibilium. Et in unitate hujus divinæ naturæ, tres sunt Personæ, ejusdem essentiæ, potentiæ, ac æternitatis ! Pater, Filius, ot Spiritus Sanctius.

1 Deut. vi. 4 ; Isa. xliv. 6, 8 ; 1 Cor. viii. 6.

2 Num. xxiii. 19 ; John iv. 24.

3 Ps. exlv. 9; cxlvii. 5; Matt. xix. 26 ; Luke xviii. 19; Rom. xi. 33.

4 Gen. i. 1 ; Col. i. 16, 17.

5 Gen. i. 26 ; Matt. xxviii. 19; John x. 30.

1553.* Aug. Con., through the Thirteen Articles of 1538.

Errors condemned.

In the first part:-

Atheism, Tritheism, Pantheism, Polytheism, Anthropomorphism. In the second part:-

Arianism, Sabellianism, Macedonianism, Socinianism (akin to some errors of the Anabaptists).

* 1553 stands for the Forty-two Articles;

1563 for the Thirty-eight Articles;

1571 for the Thirty-nine Articles;

Aug. Con. for the Confession of Augsburg, 1530;

Wür. Con. for the Würtemberg Confession, 15.52.

The date of the Article is 1553 unless otherwise stated. 


\section{ARTICLE II.}

Of the Word or Son of God, which was made very Man.

THE Son, which is the Word of the Father, 1 begotten from everlasting of the Father, ${ }^{2}$ the very and eternal God, ${ }^{3}$ and of one substance with the Father, ${ }^{4}$ took Man's nature in the womb of the blessed Virgin, of her substance 5 : so that two whole and perfect Natures, that is to say, the Godhead and Manhood, were joined together in one Person, never to be divided, 6 whereof is one Christ, very God, and very Man $^{7}$; who truly suffered, was crucified, dead and buried, to reconcile his Father to us, ${ }^{8}$ and to be a sacrifice not only for original guilt, but also for all actual sins of men.”
De Verbo, sive Filio Dei, qui verus Homo factus est.

Frurus, qui est Verbum Patris, ab æterno a Patro genitus, verus et aternus Deus, ac Patri consubstantialis, in utero beatro Virginis, ex iilius substantiâ naturam $h u$ manam assumpsit: ita ut dux naturæ, divina et humana, integre atque perfecte in unitate personæ fuerint inseparabiliter conjunctæ, ex quibus est unus Christus, verus Deus et verus homo; qui vere passus est, crucifixus, mortuus, et sepultus, ut Patrem nobis reconciliaret, essetque hostia, non tantum pro culpa originis, verum etiam pro omnibus actualibus hominum peccatis.

\section{John i. 1, 14.}

2 John i. 18.

3 Col. ii. 9 ; Heb. i. 8.

4 John x. 30.

5 Matt. i. 18; Luke i. 31.

- Matt. i. 23; John i. 14; Acts i. 11 ; Rev. i. 17, 18.

7 Matt. xvi. 16; Acts ii. 36; 1 Tim. ii. 5.

B Rom. v. 10; Col. i. 20 ; Eph. ii. 16.

- Rom. v. 18; John i. 29; I Pet. iii. 18; Col. i. 20, 21.

1st Clause. 1553; altered 1563, Aug. Con.

2nd Clause. 1563. The clause, 'begotten from everlasting with the Father' added; Wür. Con.

\section{Errors condemned.}

In the part referring to the Incarnation:-

Arianism, Apollinarianism, Nestorianism, Eutychianism.

In the part referring to the Propitiatory Sacrifice: Socinianism, and all teaching which ignores the necessity of God being reconciled to us.

\section{ARTICLE III.}

Of the going down of Christ into Hell.'

As Christ died for us, and was buried, so also is it to be belicved that he went down into Hell. ${ }^{1}$
De Descensu Christi ad Inferos.

Quemadmodum Christus pro nobis mortuus est, et sepultus, ita est etiam credendus ad Inferos descendisse.

1 Acts ii. 27; Luke xxiii. 43; Eph. iv. 9; 1 Pet iii. 19, 20. 
1553. One clause omitted 1563: 'Fo the body lay in the sepulchre unti. the Resurrection; but His ghost, departing from Him, was with the ghosts that were in prison, or in hell, and did preach to the same as the plac of St. Peter doth testify.'

Errors condemn $d$.

Apollinarianism, and all teaching denying the perfect manhood of Christ.

\section{ARTICLE IV.}

Of the Resurrection of Christ.

CHrist did truly riso again from death, and took again his body, with flesh, bones, and all things appertaining to the perfection of Man's nature 1; wherewith he ascended into Heaven, and there sitteth, until he return to judge all men at the last day. ${ }^{2}$
De Resurrectione Christi.

Chrisros vere a mortuis resurrexit, suumque corpus, cum carne, ossibus, omnibusque ad integritatem humanæ naturæ pertinentibus, recepit; cum quibus in Coelun. ascendit, ibique residet, quoad extremo die, ad judicandos homines reversurus sit.

1 John xx. 16, 27; xxi. 13; Luke xxiv. 39, 40.

Acts iii. 21 ; xvii. 31 ; 2 Cor. v. 10.

1553. Cf. language of Reformatio Legum Ecclesiasticorum. Latin title: 1553 Resurrectio Christi, altered 1571 to De Resurrectione Christi.

Error condemned.

The denial of the reality of our Lord's Resurrection.

\section{ARTICLE V.}

\section{Of the Holy Ghost.}

THe Holy Ghost, proeceding from the Father and the Son, ${ }^{1}$ is of one substance, majesty, and glory, with the Father and the Son, very and eternal God. ${ }^{2}$

\section{De Spiritu Sanclo.}

SpIritus Sanctus, a Patre et Filio procedens, ejusdem est eum Patro et Filio essentiæ, majestatis, et gloriæ, verus ac æternus Dous.

1 Matt. x. 20 ; Gal. iv. 6 ; John xiv. 26.

2 Acts v. 3, 5 ; 1 Cor. vi. 19.

1563. Wür. Con.; almost verbatim.

Errors condemned.

Arianism, Macedonianism. 


\section{ARTICLE VI.}

Of the Sufficiency of the Iloly Scriptures for salvation.

HoLy Scripture containeth all things necessnry to salvation ${ }^{1}$ : so that whatsocver is not read therein, nor may be proved thereby, is not to be required of any man, that it should be bclieved as an article of the Faith, or be thought requisite or necessary * to salvation. ${ }^{2}$ In the name of the holy Scripture we do understand those Canonical Books of the Old and New Testament, of whose authority was never any doubt in the Church.
De divinis Scripturis, quod sufficiant ad salutem.

SCrIPTURa sacra continet omnia quæ ad salutem sunt necessaria, ita ut quicquid in ea nec legitur, neque inde probari potest, non sit a quoquam exigendum, ut tanquam articulus fidei credatur, aut ad salutis necessitatem requiri putetur.

Sacræ Scripturæ nomine, eos Canonicos libros Veteris et Novi Testamenti intelligimus, de quorum auctoritate in Ecclesia nunquam dubitatum est.

1 Deut. iv. 2; 2 Tim. iii. 15-17; Rev. xxii. 18, 19.

2 Mark vii. 13 ; Tit. i. 14.

* The edition of 1571 reads 'requisito necessary'; the earlicr MS. requisite as necessary.'

Of the Names and Number of the Canonical Books.

\footnotetext{
Gencsis,

Erodus,

Leviticus,

N'umbers,

Dcutcronomy,

Joshua,

Judges,

Ruth,

The First Book of Samucl,

The Sicond Book of Samucl,

The First Book of Kings,

The Sccond Book of Kings,

The First Book of Chronicles,

The Sccond Book of Chronicles,

The First Book of Esdras,

The Sccond Book of Esdras,

This Book of Esther,

Tic Book of .Jo',

The Psilms.

The Prorcrbs,

E:clcsiastcs, or Preacher,

Cantira, or Songs of Solomon,

Four Prophrts the grcatcr,

Tuelec l'rop'icts the lcss.
}

De Nominibus et Numero Librorum sacra Canonica Scriplura Veteris T'cstamenti.

Genesis,

Exodus,

Leviticus,

Numeri,

Deuteronium,

Josuæ,

Judicum,

Ruth,

Prior liber Samuelis,

Secundus liber Samuelis,

Prior liber Regum,

Secundus liber Regum,

Prior liber Paralipomenon,

Sccundus liber Paralipomenon,

Primus liber Esdræ,

Sccundus liber Esdræ,

Liber Hester,

Liber Job,

Psalmi,

Proverbia,

Eeclesiastes, vel Concionator,

Cantica Solomonis,

IV. Prophetæ Majores,

XII. I'rophetæ Mlinores, 
And the other Books (as Hierome saith) the Chureh doth read for example of life and instruction of manners; but yet doth it not apply them to establish any doetrine. Such are these following :

The Third Book of Esdras,

The Fourth Book of Esdras,

The Book of Tobias,

The Book of Judith,

The rest of the Book of Esther,

The Book of Wisdom,

Jesus the Son of Sirach,

Baruch the Prophet,

The Song of the Three Children,

The Story of Susanna,

Of $B \mathrm{Cl}$ and the Dragon,

The Prayer of Manasses,

The First Book of Maccabees.

The Seeond Book of Maccabees.

All the Books of the New Testa. ment, as they are eommonly re. ceived, we do receivo, and aceount them Canonical.
Alios autem libros (ut ait Hieronymus) legit quidem Ecelesia ad exempla vitæ et formandos mores : illos tamen ad dogmata eonfirmand non adhibet; -ut sunt:

Tertius liber Esdræ,

Quartus liber Esdræ,

Liber 'Tobix,

Liber Judith,

Reliquum libri Hester,

Liber Sapientiz,

Liber Jesu filii Sirach,

Baruch Propheta,

Canticum Trium Puerorum,

Historia Susanna,

De Bel et Dracone,

Oratio Manassis,

Prior liber Maccabæorum,

Sccundus liber Maecabæorum.

Novi Testamenti omnes libros, ut vulgo reepti sunt, recipimus, et habemus pro Canonicis.

1st Clause. 1553; altered 1563.

2nd Clause. 1563. Wür. Con.

1553. Although it be sometime received of the faithful, as godly, and profitable for an order and comeliness; yet no man ought to be constrained to believe, as an article of faith, or repute it requisite to the necessity of salvation. 1563. 'In the name of the Holy Scripture' to end, added.

Errors condemned.

(1) The decree of the Council of Trent, of 1546, declared that 'the truth is contained in the written books and in the unwritten traditions, which having been received by the Apostles, either from the mouth of Christ Himself or from the dictates of the Holy Spirit, were handed down even to us.'

(2) Some of the Swiss Reformers and their followers laid undue stress upon the witness of the individual conscience, and of subjective feeling.

\section{ARTICLE VII.}

Of the rild Testument.

Tile Old Testament is not eon. trary to the New : for both in tho
De V'etcri Testamento.

Testauentum Vetus Novo contrarium non est: quandoquidem 
Old and New Testament, overlasting life is offered to Mankind by Christ, 1 who is the only Mediator between God and Man, being both God and Man. Wherefore they are not to be heard, which feign that the old Fathers did look only for transitory promises. ${ }^{2}$ Although the Law given from God by Moses, as touching Ceremonies and Rites, do not bind Christian men, nor the Civil precepts thereof ought of necessity to bo received in any commonwealth; yet notwithstanding no Christian man whatsoever is free from the obedience of the Commandments which are called Moral. ${ }^{8}$ tam in Veteri, quam in Novo, per Christum, qui unicus est Mediator Dei et hominum, Deus et homo, reterna vita humano generi cst proposita. Quaro male sentiunt, qui veteres tantum in promissiones temporarias sperasse confingunt. Quanquam lex a Deo data per Mosen, quoad Cæremonias et Ritus, Christianos non astringat, neque Civilia ejus præcepta in aliqua republica necessario recipi debeant; nibilominus tamen $a b$ obedientia mandatorum, quæ Moralia vocantur, nullus quantumvis Christianus est solutus.

1 Matt. v. 17, 18 ; Luke xxiv. 44 ; Rom. iii. 21 ; Gal. iii. 24 ; ef. Heb. viii. 5 .

2 11eb. xi. 13.

S Matt. v. 17-20; Rom. iii. 31.

1553. The title was 'The Old Testament is not to be refused.' 1563. Nltered to its present form.

1563. 'Although the Law' to the end added, being transferred from the Ninctcenth Article of 1553.

Error condemned.

Antinomian doctrine, which denied the obligation of the Moral Law.

\section{ARTICLE VIII.}

Of the Three Creeds.

The Three Creeds, ${ }^{1}$ Niccne Creed, Athanasius's Creed, and that which is commonly called the Apostles' Creed, ought thoroughly to be receired and believed: for they may be proved by most certain warrants of holy Scripture.
De Tribus Symbolis.

Symbola tria, Nicanum, Athanasii, et quod vulgo Apostolorum appellatur, omnino recipienda sunt et credenda : nam firmissimis Scrip. turarum testimoniis probari possunt.

1 Supposed references to Creeds in N.T.: Rom. vi. 17 ; 1 Tim. vi. 20; 2 Tim. i. 13, 14 ; Jude 3. Supposed quotations from Creeds : 1 Cor. viii. 6 ; 1 Cor. xv. 3, 4; 1 '́lim. iii. 16.

Errors condemncd.

The disposi ion of several Reforming bodies, notably the Anabaptists, to belitt e the ancient Catholic standards of belief. 


\section{ARTICIE IX.}

Of Original or Birth-sin.

Orianal $\operatorname{Sin}$ standeth not in the following of Adam, as the Pelugians do vainly talk; but it is the fault and corruption of the Nature of every man, that naturally is ingendered of the offspring of $\operatorname{Adam}^{1}$; whereby man is very far gone from original righteousness, and is of his own nature inclined to evil, so that the flesh lusteth always contrary to the spirit ${ }^{2}$; and therefore in every person born into this world, it deserveth God's wrath and damnation. ${ }^{3}$ And this infection of nature doth remain, yea in them that are regenerated ${ }^{4}$; wheroby the lust of the flesh, called in the Greek, phronema sarkos, which some do expound the wisdom, some sensuality, some the affection, some the desire, of the flesh, is not subject to the Law of God.5 And although there is no condemnation for them that believe and are baptized, yet the Apostle doth confess, that concupiscence and lust hath of itself the nature of sin. ${ }^{6}$

\section{De Peccato Originali.}

Peccatum originis non est, ut fabulantur Pelagiani, in imitatione Adami situm; sed est vitium et depravatio naturæ cujuslibet hominis ex Adamo naturaliter propagati; qua fit, ut ab originali justitia quam longissime distet, ad malum sua natura propendeat, et caro semper adversus spiritum concupiscat; unde in unoquoque nascentium, iram Dei atque damnationem meretur. Manct etiam in renatis hæc naturæ depravatio: qua fit, ut affectus carnis, Græce $\phi \rho o ́ v \eta \mu a$ бapкòs, quod alii sapientiam, alii sensum, alii affectum, alii studium carnis interpretantur, legi Dei non subjiciatur. Et quanquam renatis et credentibus nulla propter Christum est condemnatio, peccati tamen in sese rationem habere concupiscentiam, fatetur A postolus.

1 Ps. li. 5 ; John iii. 6; Rom. v. 14, 17-19.

2 Rom. vii. 22, 23 ; Gal. v. 17.

Eph. ii. 3.

4 John i. 8.

5 Rom. viii. 5, 7.

- Rom. viii. 1; Mark xvi. 16; Rom. vii. 7, 8; Col. iii. 5.

1553. Based upon Aug. Con., through the Thirteen Articles. Error condemned.

Some Anabaptists adopted the teaching of Pelagius, of the fifth century, and its inadequate view of sin:-

(1) That the sin of Adam hurt only himself and not mankind.

(2) That new-born infants are in the same state as Adam was before the Fall.

(3) That man can be sinless, and keep Gorl's commandments, if he will. 


\section{ARTICLE $\mathrm{X}$.}

Of Free-Will.

THe condition of Man after the fall of Adam is such, that he cannot turn and prepare himself, by his own natural strength and good works, to faith, and calling upor God: Wherefore we have no power to do good works pleasant and acceptable to God, ${ }^{1}$ without the grace of God by Christ preventing us, $^{2}$ that we may have a good will, and working with us, when we have that good will. ${ }^{3}$
De Libero Arbitrio.

EA est hominis post lapsum Adæ conditio, ut sese, naturalibus suis viribus ot bonis operibus, ad fidem et invocationem Dei convertere ac proparare non possit. Quare absque gratia Dei, quæ per Chris. tum est, nos præveniente ut velimus, et co-operante dum volumus, ad pictatis opera facienda, qux Den grata sunt, et accepta, nihil valemus.

1 John vi. 44; Rom. viii. 26 ; Eph. ii. 8.

2 Phil. ii. 13.

3 Cor. xv. 10.

1553 ; altered 1563 and 1571. 1st part similar to Wür. Con. ; 2nd part taken from Augustine's treatise De Grata et Libero Arbitrio, xvii.

1563. 'The condition of Man-upon God' added.

1553. Working in us.

1571. Working with us.

Errors condemned.

(1) Hyper-Calvinism, which left no room for free will.

(2) Extreme Arminianism, which under-estimated the necessity of grace.

\section{ARTICLE XI.}

Of the Justification of Man.

$W \mathrm{E}$ are accounted righteous before God, only for the merit of our Lord and Saviour Jesus Christ, by Faith, and not for our own works or deservings: 1 Wherefore, that we are justified by Faith only is a most wholesome Doctrine, and very full of comfort, as more largely is expressed in the Homily of Justification.
De Hominis Justificatione.

TanTuM propter meritum Domini ac Servatoris nostri Jesu Christi, per fidem, non propter opera et merita nostra, justi coram Deo reputamur. Quare sola fide nos justificari, doctrina est saluberrima, ac consolationis plenissima, ut in Homilia do Justificatione hominis fusius explicatur.

1 Rom. iii. 20, 22, 24, 30; v. 18 ; Gal. ii. 16.

1553 ; altered 1563 . 1st part, Wür. Con.

1553. Justification by only faith in Jesus Christ in the sense as is declared in the Homily of Justification, is a most certain and wholesome doctrine for Christian men. 
1563. Wherefore, that we are justified by Faith only ... Homily of Justification.

Errors condemned.

(1) Justifying righteousness is not imputed righteousness, but infused, or inherent, righteousness.

(2) It is not faith, but faith together with good works, which is necessary for justification.

\section{ARTICLE XII.}

\section{Of Good Works.}

ALbeIr that Good Works, which are the fruite of Faitl, and follow after Justification, 1 eannot put away our sins, and endure the severity of God's Judgment ${ }^{2}$; yet are they pleasing and aeceptable to God in Christ, ${ }^{3}$ and do spring out neeessarily of a true and lively Faith; insomueh that by them a lively Faith may be as evidently known as a tree discerned by the fruit. ${ }^{4}$

\section{De Bonis Operibus.}

BoNa opera, quæ sunt fructus Fidei, et Justifieatos sequuntur, quanquam peceata nostra expiare, et divini judieii severitatem ferre non possunt; Deo tamen grata sunt, et aceepta in Christo, atque ex vera et viva fide neeessario profluunt; ut plane ex illis æque fides viva eognosei possit, atque arbor ex fructu judicari.

1 Eph. ii. 10 ; Jas. ii. 17, 18, 26.

${ }^{2}$ Luke xvii. 10 ; Rom. iii. 20.

3 Matt. xvi. 27; 1 Pet. ii. 5.

4 Matt. xii. 33 ; John xv. 1, 2.

1563. Wür. Con.

Error condemned.

Solifidianism, which denied the necessity of good works.

\section{ARTICLF XIII.}

Of Works before Justification.

Works done before the grace of Christ, and the Inspiration of his Spirit, are not pleasant to God, for. asmueh as thcy spring not of faith in Jesus Christ, 1 neither do they make men meet to receive graee, or as the Sehool-authors say, deserve grace of eongruity ${ }^{2}$ : yea rather, for that they are not done as God hath willed and commanded them to be done, we doubt not but they have the nature of sin. ${ }^{3}$

\section{De Operibus ante Justificationem.}

OpEra quæ fiunt ante gratiam Christi, et Spiritus ejus afflatum, eum ex fide Jesu Christi non prodeant, minime Deo grata sunt; neque gratiam, ut multi vocant, do eongruo merentur: immo eum non sint faeta ut Deus illa fieri voluit et præcepit, peecati rationem habero non dubitamus.

1 Rom. viii. 7, 8; ix. 31, 32; Hcb. xi. 6; John xv. 5.

2 Rom. iv. 2 ; 'Tit. iii. 5.

S Rom. xiv. 23. 
1553. In an early draft the first clause opened with the words: 'Works that are done before Justification.'

\section{Error condemned.}

A doctrine of the 'School Authors,' that men can do certain acts in their unaided strength, which, because of the congruity or harmony between such acts and the will of God, have such a measure of goodness in them as can attract God's grace.

The Council of Trent passed the following Canon: 'If any one shall say that all works that are done before justification, in whatever way they are done, are truly sins, or deserve the hatred of God, or that the more earnestly any one strive to dispose limself to grace, the more gravely he sins; let him be anathema.'

\section{ARTICLE XIV.}

Of Works of Supererogation.

Vol.ONTARY Works besides, over and above, God's Commandments, which they call Works of Supererogation, cannot be taught without arrogancy and impiety ${ }^{1}$; for by them men do declare, that they do not only render unto God as much as they are bound to do, but that they do more for his sake, than of bounden duty is required : whereas Christ saith plainly, When ye have done all that are commanded to you, say, We are unprofitable servants. ${ }^{2}$
De Operibus Supererogationis.

Opera, qua Supererogationis appellant, non possunt sine arrogantia et impietate prædicari ; nam illis declarant homines, non tantum so Deo reddere quæ tenentur, sed plus in ejus gratiam facere quam deberent: cum aperte Christus dicat : Cum feceritis omnia quæcunque pracepta sunt vobis, dicite, Servi inutiles sumus.

1 Matt. v. 48 ; Luke x. 27 ; Jas. iii. $2 ; 1$ John i. 8.

2 Luke xvii. 10.

Error condemned.

That good deeds may be done over and beyond what is necessary, and that such good deeds, e.g. of Christ and His Saints, form a reserve fund, which the Pope dispenses in the form of Pardons and Indulgences. This teaching claimed to be based upon Matt. xix. $11,12,20,21$; 1 Cor. vii. 25.

\section{ARTICLE XV.}

Of Christ alone willout Sin.

Cunist in the truth of our nature was made like unto us in all things, sin only except, from which he was clearly void, both in his flesh,
De Christo, qui solus est sine Peccato.

Curistus, in nostræ naturie veritate, per omnia similis factus est nobis, excepto peccato, a quo prorsus erat immunis, tum in carne, 
and in bis spirit. He came to be the Lamb without spot, who, by sacrifice of himself once made, should take away the sins of the world, and sin, as Saint John saith, was not in him.1 But all we the rest, although baptized, and born again in Christ, yet offend in many things; and if we say we have no sin, wo deceive ourselves, and tho truth is not in us. ${ }^{2}$ tum in spiritu. Venit ut agnus absque macula, qui mundi peccata per immolationem sui semel factam tolleret; et peccatum, ut inquit Johannes, in eo non erat. Sed nos reliqui, etiam baptizati et in Christo regenerati, in multis tamen offendimus omnes; et si dixerimus, quod peceatum non habemus, nos ipsos seducimus, ot veritas in nobis non est.

1 Heb. ii. 14,15 ; 1 John iii. 5 ; 2 Cor. v. $21 ; 1$ John ii. 2.

2 Jas. iii. 2 ; 1 John i. 10.

\section{Errors condemncd.}

(1) Any teaching denying the sinlessness of Christ.

(2) Any teaching exaggerating the merits of saints, martyrs, etc.

(3) Any teaching implying sinless perfection.

\section{ARTICLE XVI.}

\section{Of Sin after Baptism.}

Not every deadly sin willingly com mitted after Baptism is sin against the Holy Ghost, and unpardonable. ${ }^{1}$ Wherefore the grant of repentance $s$ not to be denied to such as fall nto sin after Baptism. ${ }^{2}$ After wo havo received the Holy Ghost, we may depart from grace given, and fall into sin; and by tho grace of God we may arise again, and amend our lives. And therefore they are o be condemned, which say, they an no more sin as long as they live ere, or deny the place of forgiveness to such as truly repent. ${ }^{3}$

\section{De Pcccalo post Baptismum.}

NoN omne pcecatum mortale post Baptismum voluntarie perpetratum est peccatum in Spiritum Sanctum, et irremissibilo. Proindo lapsis a Baptismo in peccata locus ponitentix non est negandus. Post acceptum Spiritum Sanctum, possumus a gratia data recedere, atque peccare; denuoquo per gratiam Dei resurgere, ac resipiscere. Ideoque illi damnandi sunt, qui se, quamdiu hic vivant, amplius non posse peccare affirmant, aut vere resipiscentibus veniæ locum denegant.

1 Matt. xii. 31, 32 ; 1 John v. 17 ; cf. Heb. vi. 4-6.

Acts viii. 22, 23.

31 Cor. v. 5; 2 Cor. ii. 10; Gal. vi. 1; Jas. v. 19, 20.

553. Tit'e: De Peccato in Spiritum Sanctum. 563. De Lapsus post Baptismum.

In 1553 there was another Article entitled 'Blasphemy against the Holy Ghost ':- 'Blasphemy against the Holy Ghost is when a man of malice and stubbornmess of mind, doth rail upon the truth of God's Word manifestly perceived, and, being enemy thereunto, persecuteth the same. And because such be guilty of God's curse, they entangle themselves with a most grievous and heinous crime, whereupon this kind of sin is called and affirmed of the Lord unpardonable.' This was omitted in 1563. 


\section{Errors condemned.}

(1) The Montanists and Novatians who held that every wilful sin committed after Baptism is unpardonable.

(2) Those who claimed sinlessness after regeneration.

\section{ARTICLE XVII.}

\section{Of Predestination and Election.}

Predestination to Life is the everlasting purpose of God, whereby (before the foundations of the world were laid) he hath constantly decreed by his counsel secret to us, to deliver from curse and damnation those whom ho hath chosen in Christ out of mankind, and to bring them by Christ to everlasting salvation, as vessels made to honour. Wherefore they, which be endued with so excellent a benefit of God, be called according to God's purpose by his Spirit working in due season : they through Grace obey the calling: they be justified freely: they be made sons of God by adoption : they be made like the image of his only-begotten Son Jesus Christ : they walk religiously in good works : and at length, by God's mercy, they attain to everlasting felicity. 1

As the godly consideration of Predestination and our Election in Christ, is full of sweet, pleasant, and unspeakable comfort to godly persons, and such as feel in them. selves the working of the Spirit of Christ, mortifying the works of the flesh and thcir earthly members, and drawing up their mind to high and heavenly things; as well because it doth greatly establish and confirm their faith of eternal Salvation to be enjoyed through Christ, as beeause it doth fervently kindle their love towards God ${ }^{2}$ : So, for curions and earnal persons lacking the Spirit of Christ, to have continually before their eyes the sentence of Corl's Predestination, is a most dangerous downfall; whereby the Devil doth thrust them

\section{De Prodestinatione et Electione.}

Prementinatio ad vitam est æternum Dei propositum, quo, ante jacta mundi fundamenta, suo consilio, nobis quidem oceulto, constanter decrevit, eos, quos in Christo elegit ex hominum genere, a maledicto et exitio liberare, atque, ut vasa in honorem efficta, per Christum ad æeternam salutem adducere. Unde, qui tam præclaro Dei beneficio sunt donati, illi Spiritu ejus, opportuno temporo operante, secundum propositum ejus vocantur: vocationi per gratiam parent: justiticantur gratis : adoptantur in filios Dei : unigeniti ojus Jesu Christi imagini efficiuntur conformes : in bonis operibus sancte ambulant: et demum, ex Dei misericordia, pertingunt ad sempiternam felicitatem.

Quemadmodum Prredestinationis et Electionis nostra in Cliristo pia consideratio, dulcis, suavis, et ineffabilis consolationis plena est vere piis, et his qui sentiunt in se vim Spiritus Christi, facta carnis et membra, quæ adhuc sunt super terram, mortifieantem, animumque ad colestia et superna rajientein; tum quia fidem nustram de reterna salute consequenda per ('hristum plurimum stabilit atque confirmat, tum quia amorem nostrum in Deum vehementer aecendit: Ita hominibus curiosis, carnalibus, et Spiritu Christi destitutis, ob oculos perpetuo versari Prædestinationis Dei sententiam, perniciosissinum est priecipitium; unde illos Diabolus protrudit vel in desperationem, vel in æque perniciosam impurissima vitw securitatem.

1 Rom. viii. 28-3n; Eph. i. 3 5; ii. 1 ; 1 Pet. i. 2.

2 Rom. viii. 33-3j. 
either into desperation, or into wrctchlessness of most unclean living, no less perilous than desperation.

Furthermore, we must receivo God's promises in such wise, as they be generally set forth to us in holy Scripture : and, in our doings, that Will of God is to be followed, which we have expressly declared uuto us in the Word of God. ${ }^{3}$
Proinde, promissiones divinas sie amplecti oportet, ut nobis in sacris litcris generaliter proposita sunt; ct Dei voluntas in nostris actionihus ea sequenda est, quam in verbo Dei habemus diserte revelatam.

s Mark xvi. 15; John iii. 16; 1 Tim. ii. 4 ; 2 Pet. iii. 9.

1553 ; altered 1563.

1553. Furthermore, although the decrees of Predestination are unknown to us, yet we must receive.

1563. Furthermore we must receive.

Errors condemned.

(1) Hyper-Calvinism, which weakens human responsibility, is incompatible with Divine justice, and restricts the offer of salvation.

(2) Arminianism, which fails to recognize the true place of Divine Sovereignty in salvation.

\section{ARTICLE XVIII.}

Of obtaining eternal Salvation only by the Name of Christ.

THey also are to be had accursed that presume to say, That every man shall be saved by the Law or Sect which he professeth, so that be be diligent to frame his life according to that Law, and the light of Nature. 1 For holy Scripture doth set out unto us only the Name of Jesus Christ, whereby men must be saved. ${ }^{2}$

1 John iii. 18, 19, 36 ; xii. 48 .

2 Acts iv. 12.
De speranda aterna Salute tantum in Nomine Christi.

SuNT et illi anathematizandi, qui dicere audent unumquemque in Lege aut Sccta quam profitetur, esse servandum, modo juxta illam, et lumen naturæ, accurate vixerit: cum sacræ liter $\circledast$ tantum Jesu Christi nomen prædicent, in quo salvos fieri homines oporteat.

1553 ; altered 1563,1571 .

1553. Title: Tantum in nomine Christi speranda est coterna salus. 1571. De Speranda asterna Salute tantum i乞 Nomine Christi. 1553. They are to be had accursed and abhorred.

1563. 'And abhorred' omitted.

Error condemned.

The Latitudinarianism which regards all creeds and communions alike, provided men live accordingly, and consequently makes true faith a matter of indifference. 


\section{ARTICLE XIX.}

\section{Of the Church.}

The visible Church of Christ is a congregation of faithful men, in the which the pure Worel of God is preached, and the Sacraments be duly ministered according to Christ's ordinance, in all those things that of necessity are requisite to the same.

As the Church of Jerusalem, Alexandria, and Antioch, have erred; so also the Church of Rome hath erred, not only in their living and manner of Ceremonies, but also in matters of Faith.

\section{De Ecclesia.}

EcclesIa Christi visibilis est cœtus fidelium, in quo Verbum Dei purum prædicatur, et Sacramenta, quoad ea quæ necessario exigantur, juxta Christi institutum recte administrantur.

Sicut crravit Ecclesia Hieroso. lymitana, Alexandrina, et Antiochena; ita et erravit Ecclcsia Romana, non solum quoad agenda et Cæremoniarum ritus, verum in iis etiam quæ credenda sunt.

1553. Cf. Aug. Con.: "The Church is a congregation of the Saints, in which the Gospel is rightly taught, and the sacraments are rightly administered.'

\section{Errors condemned.}

(1) The Ecclesiasticism which unchurches non-episcopal Christian congregations, such as the Reformed Churches of France and Germany.

(2) The Roman view that attributes Infallibility to a Church.

\section{ARTICLE XX.}

\section{Of the Authority of the Church.}

THE Church hath power to decree Rites or Cercmonies, and authority in Controversies of Faith ${ }^{1}$; And yet it is not lawful for the Church to ordain any thing that is contrary to God's Word written, neither may it so expound one place of Scripture, that it be repugnant to another. ${ }^{2}$ Wherefore, although the Cliurch be a witness and a keeper of holy $\mathrm{W}^{\mathrm{r} i t}{ }^{3}{ }^{3}$ yet, as it ought not to decree anything against the same, so besides the same ought it not to enforce any thing to be believed for nccessity of Salvation.

\section{De Ecclesia Auctoritate.}

HABET Ecclesia Ritus sive Cæremonias statuendi jus, et in fidei controversiis auctoritatem; quamvis Ecclesiø non licet quidquam instituere, quod Verbo Dei scripto adversetur, nec unum Scripturæ locum sio exponere potest, ut alteri contradicat. Quare, licet Ecclesia sit divinorum librorum testis et conservatrix, attamen ut adversus eos nihil decernere, ita præter illos nihil credendum de necessitate salutis debet obtrudere.

1 Acts xv. 28, 29.

2 Rom. xii. 6 ; 1 Cor. ii. 13 ; I Pet. iv. 11 ; 2 Pet. i. 20.

3 Rom. iii. 2 ; 1 Tim. iii. 15. 
1553 ; altered 1563 ; cf. Wür. Con.

1553. The Article began: 'It is not lawful for the Church', etc. 1563. 'The Church hath power . . . and yet,' added in Latin version.*

Errors condemned.

(1) The Puritanism which disregarded the legitimate authority of the Church.

(2) Medicevalism, which dangerously exaggerated the authority of the Church.

\section{ARTICLE XXI.}

Of the Authority of General Councils.

General Councils may not be gathered together without the commandment and will of Princes. And when they be gathered together, forasmuch as they bo an assembly of men, whereof all be not governed with the Spirit and Word of God, they may err, and sometimes have erred, even in things pertaining unto God. Wherefore things ordained by them as necessary to salvation have neither strength nor authority, unless it may be declared that they be taken out of holy Scripture. ${ }^{1}$

1 Isa. viii. 20; John xvii. 17 ; Rev. xxii. 18.

\section{De Auctoritate Conciliorum Genera. lium.}

Generalia Concilia sine jussu et voluntate principum congregari non possunt : et ubi convenerint,quir ex hominibus constant, qui non omnes Spiritu et Verbo Dei reguntur,-et errare possunt, et interdum errarunt, etiam in his quæ ad Deum pertinent. Ideoquo quæ ab illis constituuntur, ut ad salutcm necessaria, neque robur habent neque auctoritatem, nisi ostendi possint e sacris literis esse desumpta.

1553. Sometimes have erred, not only in worldly matters but also in things, etc.

$\left.\begin{array}{l}1563 \\ 1571\end{array}\right\}$ 'not only in worldly matters' omitted.

Errors condemned.

(1) The papal claim to the sole right of summoning councils.

(2) The infallibility of Councils.

(3) The claim of Councils to override or go beyond Holy Scripture.

* The date of this clause is not clear. It was wanting in Parker's MS. of 1562, in the English Version of 1563, and the English MS. signed by the Bishops. It was, however, in the first Latin version of 1563, the English Version of 1571, and in the copy made by a notary from the MS. signed for the Queen in 1562 . This copy was obtained by Laud, who was accused of interpolating the clause. Some consider Queen Elizabcth to be respon. sible for its inscrtion. 


\section{ARTICLE XXII.}

\section{Of Purgatory.*}

The Romish Doctrine concerning Purgatory, I Parclons, ${ }^{2}$ Worshipping and Adoration as well of Images, as of Reliques, ${ }^{3}$ and also invocation of Saints, ${ }^{*}$ is a fond thing vainly invented, and grounded upon no warranty of Scripture, but rather repugnant to the Word of God.

\section{De Purgatorio.}

Doctrna Romanensium de Pur. gatorio, de Indulgentiis, de Veneratione et Adoratione tum imaginum, tum reliquiarum, necnon de Inrocatione Sanctorum, rcs est futilis, inaniter conficta, et nullis Scripturarum testimoniis innititur : immo Verbo Dei contradicit.

1 Luke xxiii. 43 ; 2 Cor. v. 8 ; Rev. xiv. 13.

2 Mark ii. 7.

2 Kings xviii. 4; 1 John v. 21.

4 Acts x. 26 ; xiv. 15 ; Rev. xxii. 8, 9.

1553. 'The Doctrine of School Authors' (Scholasticorum doctrina).

1563. 'The Romish Doctrine' (Doctrina Romanensium).

N.B. (1) In 1563 pernitiose which stood before contradicit was omitted.

(2) In the Article as originally drafted there were the words De precatione pro defunctis.

\section{Errors condemned.}

Certain specific dogmas and practices notoriously inconsistent with Holy Scripture, and, therefore, by Article XXI, beyond the legislative province of any Church.

\section{ARTICLE XXIII.}

\section{Of Ministering in the Congregation.}

IT is not lawful for any man to take upon him the office of publick preaching, or ministering the Sacraments in the Congregation, before he be lawfully called, and sent to execute the same.1 And those we ought to judge lawfully called and sent, which be chosen and called to this work by men who have publick authority given unto them in the Congregation, to call and send Ministers into the Lord's vineyard.

1 John xx. 21 ; Acts vi. 6 ; 1 Tim. iv. 14 ; v. 22 ; Tit. i. 5.
De Ministrando in Ecclesia.

NoN licet cuiquam sumere sibi munus publice prædicandi, aut administrandi Sacramenta in Ecclesia, nisi prius fuerit ad hæc obeunda legitime vocatus et missus. Atque illos legitime vocatos et missos existimare debemus, qui per homines, quibus potestas vo. candi ministros, atque mittendi in vineam Domini, publice concessa est in Ecclesia, co-optati fuerint et adsciti in hoc opus.

* The notion that the coudemnation of 'The Romish Doctrine concerning Purgatory, Pardons,' does not extend to those conceptions themselves, but only to the Roman presentation of them, is rendered untenable by the fact that at the time of the compilation of the Articles there were no other current presentations of these unscriptural ideas save such as emanated from Rome. 
1553. Founded on Aug. Con., 14th Article; cf. Article X. of the Articles of 1538.

Errors condemned.

(1) The supposed individual right to preach and minister the Sacraments independently of the Church as a whole.

(2) The supposed right of ecclesiastical authorities to ordain independently of the 'congregation' as a whole.*

\section{ARTICLE XXIV.}

Of speaking in the Congregation in such a Tongue as the People undcr. standeth.

IT is a thing plainly repugnant to the Word of God, and the custom of the Primitive Church, to have publick Prayer in the Church, or to minister the Sacraments, in a tongue not understanded of the Pcople. 1 De loquendi in Ecclesia Lingua
quam Populus intelligit.

Linada Populo non intellecta, publicas in Ecclesia preces peragere, aut Sacramenta administrare, Verbo Dei, et Primitivæ Ecclesiæ consuetudini, plane repugnat.

11 Cor. xiv. 16-19.

1553. Title: 'Men must speak in the congregation in such tongue as the people understandeth. It is most seemly and most agreeable to the Word of God that in the congregation nothing be openly read or spoken in a tongue unknown to the people, the which thing St. Paul did forbid except some were present that should declare the same.'

\section{Error condemned.}

The compulsory use of the Latin Liturgy, enforced by an anathema at the Council of Trent against those who said that the Mass ought to be celebrated only in the vulgar tongue.

\section{ARTICLE XXV.}

Of the Sacraments.

SACRAMENTS ordained of Christ be not only badges or tokcns of Christian men's profession, but rather they be certain sure witnesses, and effectual signs of grace, and God's good will towards us, by ths which bo doth work invisibly in

\section{De Sacramentis.}

SaCramenta a Christo instituta non tantum sunt notæe professionis Christianorum, sed certa quædam potius testimonia, et efficacia signa gratiæ, atque bonæ in nos voluntatis Dei, per quæ invisibiliter ipse in nos opcratur, nostramque fidom in

* The Si Qurs is a relic of the larger authority cummitted to the congregation in Holy Scripture and the Primitive Church. 
us, and doth not only quicken, but also strengthen and confirm our Faith in him.1

There are two Sacraments ordained of Christ our Lord in the Gospel, that is to say, Baptism, and the Supper of the Lord.

Those five commonly called Sacra. ments, that is to say, Confirmation, Penance, Orders, Matrimony, and Extreme Unction, are not to be counted for Sacraments of the Cospel, being such as have grown partly of the corrupt following of the A postles, partly are states of life allowed in the Scriptures; but yet have not like nature of Sacraments with Baptism, and the Lord's Supper, for that they havo not any visible sign or ceremony ordained of God.

The Sacraments were not ordained of Christ to be gazed upon, or to be carried about, but that we should duly usc them. And in such only as worthily receive the samo they have a wholesome effect or operation: but they that receive them unworthily purchase to themselves damnation, as Saint Paul saith. ${ }^{2}$ se non solum excitat, verum etiam confirmat.

Duo a Christo Domino nostro in Evangelio instituta sunt Sacramenta, scilicet Baptismus, et Cœna Domini.

Quinque illa vulgo nominata Sacramenta, scilicet, Confirmatio, Pœnitentia, Ordo, Matrimonium, et Extrema Unctio, pro Sacramentis Evangelicis habenda non sunt, ut quæ partim a prava Apostolorum imitatione profluxerunt, partim vitæ status sunt in Scripturis quidem probati; sed Sacramentorum eandem cum Baptismo et Cœna Domini rationem non habent, ut quæ signum aliquod visibile, seu crere. moniam a Deo institutem, non ha. beant.

Sacramenta non in hoc instituta sunb a Christo ut spectarentur, aut circumferrentur, sed ut rite illis uteremur; et in is duntaxat qui digne percipiunt, salutarem habent effectum; qui vero indigne percipiunt, damnationem (ut inquit Paulus). sibi ipsis acquirunt.

1 Rom. vi. 3-5; Tit. iii. 5 ; 1 Pet. iii. 21 ; 1 Cor. x. 16.

1 Cor. xi. 17-30.

1553 ; altered 1563, 1571. Aug. Con., cf. Thirteen Articles (Art. IX.).

1563. The Lord's Supper in which sort neither is Penance, for that it hath no visible sign or ceremony ordained of God.

Errors condemned.

(1) Low views of the Sacraments, often styled Zwinglianism.

(2) The Roman view of Sacraments which placed other rites on the same level with the two instituted by Christ.

(3) The Roman custom of adding to the Sacraments practices which changed their scriptural intention from use to display.

(4) The notion that any benefit could accrue save to worthy recipients, 


\section{ARTICLE XXVI.}

Of the Unworthiness of the Ministers, which hinders not the effect of the Sacrament.

Althodgh in the visible Church the evil be ever mingled with the good, and sometimes the evil have chief authority in the Ministration of the Word and Sacraments, yet forasmuch as they do not the same in their own name, but in Christ's, and do minister by his commission and authority, wo may uso their Ministry, both in hearing the Word of God, and in receiving of the Sacraments. Neither is the effect of C'hrist's ordinance taken away by their wickedness, nor the grace of God's gifts diminished, from such as by faith and rightly do receive the Sacraments ninistered unto them; which bo effectual, because of Christ's institution and promise, although they be ministered by evil men. ${ }^{1}$

Neverthcless, it appertaincth to the discipline of the Church, that enquiry be made of evil Ministers, and that they bo accused by those that have knowledge of their offences; and finally being found guilty, by just judgment be deposecl. ${ }^{2}$

\section{De Vi Institutionum divinarum, quod cam non tollat Malitia: Ministrorun.}

QUAMvis in Ecclesia visibili boni ct mali semper sunt admixti, atque interdum ministerio Verbi et Sacra. mentorum administrationi præsint ; tamen, cum non suo, sed Christi nomine agant, ejusque mandato et auctoritate ministrent, illorum ministerio uti licet, cum in Verbo. Dei audiendo, tum in Sacramentis percipiendis. Neque per illorum. malitiam effectus institutorum Christi tollitur, aut gratia donorum Dei minuitur, quoad eos qui fido et rite sibi oblata percipiunt; quæ propter institutionem Christi et promissionem, efficacia sunt, licet per malos administrentur.

Ad Ecclesiæ tamen disciplinam pertinet, ut in malos ministros inquiratur, accusenturque ab his, qui eorum flagitia noverint; atque tandem justo convicti judicio, deponantur.

1 Matt. xxiii. 2,3 ; cf. Phil. i. 18 ; 1 Cor. iii. 7 ; 2 Cor. iv. 5 , 7.

21 Tim. v. 20, 22 .

1553. Aug. Con., through the Thirteen Articles.

1553. Title: 'The Wickedness of the Minister doth not take away the effectual operation of God's Ordinance.'

\section{Errors condemned.}

(1) The doctrine of the Donatists, revived by Wycliffe and held by some at the Reformation, that the unholy lives of the clergy render their ministry ineffectual.

(2) The Roman doctrine of 'intention,' by implication.

(3) The subterfuges by which gross ministerial unfitness was often condoned on the plea of the sacrosanct condition of an ordained priest. 


\section{ARTICLE XXVII.}

\section{Of Baptism.}

BAptis is not only a sign of profession, and mark of difference, whereby Christian men aro discerned from others that be not christened, but it is also a sign of Regeneration or New Birth, whereby as by an instrument, they that receive Baptism rightly are grafted into the Church 1; the promises of forgiveness of sin, ${ }^{2}$ and of our adoption to be the sons of God by the Holy Ghost, are visibly signed and sealed; Faith is confirmed, and Grace increased by virtue of prayer unto God. ${ }^{3}$

The Baptism of young children is in any wise to be retained in the Church, as most agreeable with the institution of Christ.

\section{De Baptismo.}

Baptismus non est tantum professionis signum, ac discriminis nota, qua C'hristiani a non Christianis disccrnantur, sed etiam est signum Regencrationis, per quod, tanquam per instrumentum, recte Baptismum suscipicntes Ecclesiæ inseruntur; promissiones de remissione peccatorum, atque adoptione nostra in filios Dei per Spiritum Sanctum, visibiliter obsignantur ; fides confirmatur, et vi divinæ invocationis gratia augetur.

Baptismus parvulorum omnino in Ecclesia retinendus est, ut qui cum Christi institutione optime congruat.

1 John iii. 5 ; Rom. vi. 3 ; 1 Cor. vi. 11 ; 2 Cor. v. 17 ; Gal. iii. 27 ; Tit. iii. 5.

2 Acts ii. 38 ; xxii. 16.

- Mark x. 13-16 ; Acts ii. 39 ; 1 Cor. vii. 14.

1553. The custom of the Church to christen young children to be commended and in any wise to be retained in the Church.

1563. The Baptism of young children is in any wise, etc.

1553 Signum Regenerationis translated 'sign and seal your new birth.'

1563, 1571. 'And seal ' omitted, though obsignatur was rendered 'signed and sealed.'

1563. 'By the Holy Ghost' first inserted, though per Spiritum Sanctum occurs in the Latin Article, 1553.

Errors condemned.

(1) Theories called $Z$ winglian, which reduced the Sacrament from a sign of regeneration to merely a distinguishing sign or mark of Christian profession.

(2) The ex opere operato theory, by which a spiritual change is supposed to be wrought, independently of receiving Baptism 'rightly,' i.e. with Faith to be 'confirmed,' and Grace to be 'increased,' 'by virtue of prayer unto God.'

(3) The teaching that Infant Baptism is incongruous with Christ's institution. 


\section{ARTICLE XXVIII.}

\section{Of the Lord's Supper.}

The Supper of the Lord is not only a sign of the love that Christians ought to have among themselves one to another; but rather is a Sacrament of our Redemption by Christ's death : insomuch that to such as rightly, worthily, and with faith, receive the same, the Bread which we break is a partaking of the Body of Christ ; and likewise the Cup of Blessing is a partaking of the Blood of Christ. 1

Transubstantiation (or the change of the substanee of Bread and Wine) in the Supper of the Lord, cannot be proved by holy Writ; but is repugnant to the plain words of Scripture, ${ }^{2}$ overthroweth the nature of a Sacrament, and hath given occasion to many superstitions.

The Body of Christ is given, taken, and eaten, in the Supper, only after an heavenly and spiritual manner. And the mean whereby the Tio:ly of Christ is received and eaten in the Supper is Faith.

The Sacrament of the Lord's Supper was not by Christ's ordiuance reserved, carried about, lifted up, or worshipped.

\section{De Cona Domini.}

Cana Domini non est tantum signum mutuæ benevolentiæ Chris. tianorum inter sese; verum potius est Sacramentum nostræ per mortem Christi redemptionis; atque adco rite, digne, et cum fide sumentibus, panis, quem frangimus, est communicatio corporis Christi ; similiter poculum benedietionis est communicatio sanguinis Christi.

Panis et Vini Transubstantiatio in Eucharistia ex sacris literis probari non potest; sed apertis Scrip. turæ verbis alversatur, Saeramenti naturam evertit, et multarum superstitionum dedit occasionem.

Corpus Christi datur, accipitur, et manducatur, in Coona, tantum colesti et spirituali ratione. Modium autem, quo corpus Christi accipitur et manducatur in Cona, fires $\theta: t$.

Sacramentum Eucharistiæo ex i) titutione Christi non servabatur, circu... erebstur, elevabatur, neo adorabatur.

1 Matt. xxvi. 28; 1 Cor. x. 16 ; cf. John vi. 48-55, 63.

21 Cor. xi. 26; Acts iii. 21.

1553. 'Overthroweth the nature of a Sacrament' added in 1563

'I orasmuch as the truth of man's nature requireth, that the body of one and the self-same man can not be at one time in divers places, but must needs be in some one certain place: therefore the body of Christ can not be present at one time in many and diverse places. And because (as the Holy Scripture doth teach) Christ was taken up into heaven, and there shall continue unto the end of the world, a faithful man ought not to believe, or openly to confess the real and bodily presence (as they term it) of Christ's flesh and blood, in the Sacrament of the Lord's Supper.' Omitted in 1563.

Errors condemned.

(1) The teaching called Zwinglianism, which asserted the Lord's Supper to be a bare commemoration of the death of Christ. 
(2) The Roman doctrine of Transubstantiation, viz. that after consecration the elements become the Body and Blood of Christ.

(3) Any doctrine involving literal giving, taking, and eating the Boady of Christ in the Supper.

4) The teaching which assumed that the Body of Christ could ke received apart from faith.

(5) The practices of Reservation, Processions of the Host, Elevation and Adoration, which have no scriptural sanction.

\section{ARTICLE XXIX.}

Of the Wicked which eat not the Body of Christ in the use of the Lord's Supper.

Tine Wicked, and such as be void of a lively faith, although they do carnally and visibly press with their teeth, as Saint Augustine saith, the Sacrament of the Body and Blood of Christ, yet in no wise are they partakcrs of Christ : but rather, to thcir condemnation, do eat and drink the sign or Sacrament of so great a thing. 1
De Manducatione Corporis Christi, et impios illud non manducare.

INIPL, et fide viva destituti, licet carnaliter et visibilitcr, ut Augustinus loquitur, corporis et sanguinis Christi Sacramontum den. tibus promant, nullo tamen modo Christi participes efficiuntur : sed potius tantæ rei Sacramentum, seu symbolum, ad judicium sibi manducant et bibunt.

11 Cor. xi. 27-30 ; cf. John vi. 56, 57 ; Heb. iii. 14.

1571 : composed and passed by the Upper House of Convocation in 1562 ; but struck out then by the Lower House, or, more probably, by the Queen; restored in 1571 .

\section{Error condemned.}

The implication of the Roman and Lutheran doctrines of a Real Corporal Presence, viz. that the Body and Blood of Christ are received by every participant, without regard to his spiritual condition.

\section{ARTICLE XXX.}

$$
\text { of both kinds. }
$$

Tire Cup of the Lord is not to be denied to the Lay-people: for both the parts of the Lord's Sacrament, by Christ's ordinance and commandment, ${ }^{1}$ ought to be min. istered to all Christian men alike.

\section{De utraque Spccie.}

Callx Domini laicis non est denegandus: utraque enim pars Dominici Sacramenti, ex Christi institutione et præcepto, omnibus Christianis ex equo administrari debet.

1 Matt. xxvi. 27 ; Mark xiv. 23 ; 1 Cor. xi. 26, 28.

Errors condernned.

(I) The Roman practice of withholding the cup from the laity, and, indeed, from all save the celebrant.

(2) The Roman doctrine of concomitance. 


\section{ARTICLE XXXI.}

Of the one Oblation of Christ finished upon the Cross.

THE Offering of Christ once made is that perfect redemption, propitiation, and satisfaction, for all the sins of the whole world, both original and actual ; and there is none other satisfaction for sin, but that alone. 1 Wherefore the sacrifices of Masses, in the which it was commonly said, that the Priest did offer Christ for the quick and the dead, to have remission of pain or guilt, were blasphemous fables, and dangerous deceits.
De unica Christi Oblatione in Cruce perfecta.

Oblatio Christi semel faeta, perfecta est rodemptio, propitiatio, et satisfactio pro omnibus peccatis totius mundi, tam originalibus quam actualibus: neque præter illam unicam est ulla alia pro peccatis expiatio. Unde Mlissarum saerificia, quibus vulgo dicebatur sacerdotem offerre Christum, in remissionem pœnæ aut culpæ, pro vivis et defunctis, blasphema figmenta sunt, et perniciosæ impos. turæ.

1 Heb. vï. 27 ix. 26 ; x. 10, 14, 25, 26; 1 Pet. iii. 18 ; 1 John ii. 2.

1553. Forged fables.

1563. 'Blasphemous fables,' the Latin word blasphema being : prefixed to figmenta.

Error condemned.

The Roman idea of any offering for sin in the Mass, and any. other suggested offering for sin save that of Christ "once made.."

The Roman teaching that there is an offering for sin in the Mass, which blasphemously and dangerously derogates from the perfect sacrifice of Christ.

\section{ARTICLE XXXII.}

Of the Marriage of Priests.

Bishors, Priests, ând Deacons, are not commanded by God's Law, either to vow the estate of single life, or to abstain from marriago: therefore it is lawful for them, as for all other Christian men, to marry at their own discretion, as they shall judge the same to serve better to godliness. 1

\section{De Conjugio Sacerdotum.}

EPISCOPIS, Presbyteris, et Diaconis nullo mandato divino præceptum est, ut aut cœlibatum voveant, aut a matrimonio abstineant. Licet igitur etiam illis, ut cæteris omnibus Christianis, ubi hoc ad pietatem magis facero judicaverint, pro suo arbitratu matrimonium contrahere.

1 Matt. viii. 14; 1 Cor. ix. 5; 1 Tim. iii. 2, 4, 12; Tit. i. 6 ; cf. Heb. xiii. 4; 1 Cor. vii. 2; alleged contra texts: Matt. xix. 10-12; 1 Cor. vii. 7 .

1553. Title: "The state of single life is commanded to no man by the Word of God,' altered in 1563.

'Bishops, Priests, and Deacons are not commanded to vow the state of single life without marriage, neither by God's law are they compelled to abstain from matrimony,' altered in 1563 . 
Errors condemned.

(1) The requirement $(c .1050)$ that Priests at their ordination should give a promise of celibacy, and the binding of the Bishops by oath not to ordain married men.

(2) The statement in the Six Articles of Henry VIII, 1539, that 'Priests may not marry by the Law of God.'

\section{ARTICLE XXXIII.}

Of Excommunicate Persons, how they are to be avoided.

That person which by open denunciation of the Church is rightly cut off from the unity of the Church, and excommunicated, ought to be taken of the whole multitude of the faithful, as an Heathen and Publi. can, 1 until he be openly reconciled by penancs, and received into the Church by a Judge that hath authority thereunto. ${ }^{2}$

1 Matt. xviii. 16, 17 ; 1 Cor. $\nabla_{.} 2-5$; 1 Tim. i. 19, 20 ; ef. Rom. xvi. 17 ; 2 Thess. iii. 6 .

2 Cor. ii. 5-11.

Error condemned.

The Anomian idea that no authority is vested in the Church to excommunicate.

\section{ARTICLE XXXIV.}

Of the Traditions of the Church.

IT is not necessary that Traditions and Ceremonies be in all places one, and utterly like: for at all times they have been divers, and may be changed according to the divorsitios of countries, times, and men's mauners, so that nothing be ordained against God's IVord. Whosoever through his private judgmont, willingly and purposely, doth openly break the traditions and ceremonies of the Church, which be not repugnant to the Word of God, and bo ordained and approved by common authority, ought to be rebuked openly, (that others may fear to do the like,) as he that offendeth against the common order of the Church and hurteth the author. ity of the Magistrate, and woundeth the consciences of the weak brethren.

\section{De Traditionibus Ecclesiasticis.}

Tradiriones atque Cæremonias easdem non omnino necessarium est esse ubique, aut prorsus consimiles: nam et variæ semper fuerunt, et mutari possunt, pro regionum, temporum, et morum diversitate, modo nihil contra Verbum Dei instituatur. Traditiones et cæremonias Ecclesiasticas, quæ cum Verbo Dei non pugnant, et sunt auctoritate publica institutx atque probatæ, quisquis privato consilio volens, et data opera, publice violaverit, is, ut qui peccat in publicum ordinem Ecclesiæ, quique lædit auctoritatem Magistratus, et qui infirmorum fratrum conscientias vulnerat, publice, ut cæteri timeant, arguendus est. 
Every particular or national Church hath authority to ordain, change, and abolish, ceremonies or rites of the Church, ordained only by man's authority, so that all things be done to edifying. 1
Quælibet Ecclesia particularis sive nationalis auctoritatem habet instituendi, mutandi, aut abrogandi cærcmonias aut ritus Ecclesiasticos, humana tantum auctoritato institutos, modo omnia ad ædificationem fiant.

11 Cor. xiv. 40 ; Heb. xiii. 17 ; cf. Rom. xiv. 13, 17-19; 1 Cor. viii. 12 ; 1 Cor. xi. 16; 1 Thess. v. 14; 1 Pet. ii. 13.

1553; altered 1563; derived from the Thirteen Articles.

1563. 'Times' inserted between 'countries' and ' and men's manners.' 2nd paragraph added.

\section{Errors condemned.}

(1) The Roman insistence on uniformity of doctrine, ceremonial, and discipline.

(2) The claim to individual liberty, amounting to licence respecting regulations for due order in public worship, etc.

(3) The Roman refusal to recognize the rights of National Churches.

\section{ARTICLE XXXV.}

\section{Of the Homilies.}

THE second Book of Homilies, the several titles whereof we have joined under this Article, doth contain a godly and wholesome Doctrine, and necessary for these times, as doth the former Book of Homilies, which were set forth in the time of Edward the Sixth; and therefore we judge them to be read in Churches by the Ministers, diligently and distinctly, that they may be understanded of the people.*

\section{Of the Names of the Homilies.}

1. Of the right Use of the Church.

2. Against peril of Idolatry.

3. Of repairing and keeping clean of Churches.

4. Of good Works : first of Fasting.

5. Against Gluttony and Drunken. ness.

6. Against Excess of Apparel.

7. Of Prayer.

8. Of the Place and Time of Prayer.

9. That Common Prayers and Sacraments ought to be ministered in a known Tongue.

10. Of the reverent Estimation of God's Word.

* The American Church adds the following note to this Article: 'This Article is received in this Church so far as it declares the Book of Homilies to be an explication of Christian doctrine and instructive in piety and
11. Of Alms-doing.
12. Of the Nativity of Christ.
13. Of the Passion of Christ.
14. Of the Resurrection of Christ.
15. Of the worthy receiving of the
Sacrament of the Body and
Blood of Christ.
16. Of the Gifts of the Holy Ghost.

17. For the Rogation-days.

18. Of the State of Matrimony.

19. Of Repentance.

20. Against Idleness.

21. Against Rebellion. 
1563. An appendix to the previous Article.

1571. Introduced as a separate Article, with its present title. Error condemned.

The Mediæval custom of leaving the laity without instruction. Homilies were necessary through the inability of the ministry generally to expound the Holy Scriptures themselves.

\section{ARTICLE XXXVI.}

\section{Of Consecration of Bishops and} Ministers.

THE Book of Consccration of Archbishops and Bishops, and Ordering of Priests and Deacons, lately set forth in the time of Edward the Sixth, and confirmed at the same time by authority of Parliament, doth contain all things necessary to such Consecration and Ordering: neither hath it any thing, that of itself is superstitious and ungodly. And therefore who. soever are consecrated or ordered according to the Rites of that Book, since the second year of the forenamed King Edward unto this time, or hereafter shall be con. secrated or ordered according to the same Ritcs; we decree all such to be rightly, orderly, and lawfully consecrated and ordered.

\section{De Episcoporum et Ministrorum Consecratione.}

Libelios de Consecratione Archicpiscoporum et Episcoporum, et de Ordinatione Presbyterorum et Diaconorum, editus nuper temporibus Edvardi VI, et auctoritate Parliamenti, illis ipsis temporibus confirmatus, omnia ad ejusmodi consecrationem et ordinationem necessaria continet: et nihil habet, quod ex se sit aut superstitiosum aut impium. Itaque quicunque justa ritus illius Libri consecrati aut ordinati sunt, ab anno secundo prædicti regis $E d$ vardi usque ad hoc tempus, aut in posterum juxta eosdem ritus con. sccrabuntur, aut ordinabuntur, rito atque ordine, atque legitime statuimusesse et fore, consecratos et ordinatos.

1 John xx. 22, 23; 1 Tim. iv. 14; 2 Tim. i. 6.

1553. Of the Book of Prayers and Ceremonies of the Church of England.

The book which was of very late time given to the Church of England by the King's authority and the Parliament, containing the manner and form of praying and ministering the Sacraments in the Church of England, likewise also the book of ordering ministers of the Church, set forth by the aforesaid authority, are Godly and in no point repugnant to the wholesome doctrine of the Gospel, but agreeable thereunto, furthering and beautifying the same not a little, and therefore of all faithful ministers of the Church of England, and chiefly of the ministers of the Word, they ought to be received and allowed with all readiness of mind and thanksgiving, and to be commended to the people of God.

morals. But all references to the constitution and laws of England are considered as inapplicable to the circumstances of the Church; which also suspends the order for the reading of said Homilies in churchesuntil a revision of them may be conveniently made for the clearing of them, as well from obsolcto worcls a: $d$ phrases as from local references.' 
1563. The present title and Article substituted.

Errors condemned.

(1) The Roman objection to the Ordinal, especially to the absence of the traditio instrumentorum, and of the bestowal of the power to offer up sacrifice.

(2) The Puritan objection to certain alleged superstitious forms and phrases, especially the words 'Receive the Holy Ghost,' etc.

\section{ARTICLE XXXVII. \\ Of the Civil Magistrates.}

THE Quecn's Majesty hath the chief power in this Realm of England, and other her Dominions, unto whom the chief Government of all Estates of this Realm, whether they be Ecclesiastical or Civil, in all causes doth appertain, and is not, nor ought to be, subject to any foreign Jurisdiction.

Where we attribute to the Queen's Majesty the chief government, by which Titles we understand the minds of some slanderous folks to be offended; we give not to our Princes the ministering either of God's Word, or of the Sacraments, the which thing the Injunctions also lately set forth by Elizabeth our Queen, do most plainly testify; but that only prerogative, which we see to have been given always to all godly Princes in holy Scriptures by God himself ; that is, that they should rule all states and degrees committed to their charge by God, whether they be Ecclesiasti. cal or Temporal, and restrain with the civil sword the stubborn and evil-doers. ${ }^{1}$

The Bishop of Rome hath no jurisdiction in this Realm of England.

The Laws of the Realm may punish Christian men with death, for heinous and grievous offences. ${ }^{2}$

It is lawful for Christian men, at the commandment of the Magis. trate, to wear weapons, and servo in the wars. ${ }^{3}$

11 Kings xiii. 4; 2 Chron. xxvi. 16-21; Acts iv. 19; 1 Pet. ii. 13, 14 ; cf. Matt. xxii. 21 ; Acts xxv. 1; Rom. xiii. 1-7 ; Tit. iii. 1.

2 Gen. ix. 6; Exod. xxi. 12, 15, I6; Rom. xiii. 1-4. ' ${ }^{3}$ Luko iii. 14.

* Hard wick inserts ' jure 'bcfore 'summam.' Cardwell omits the word It is not found in the Parker MS. or in Day's edition of 1571 . 
1553. The King of England is supreme head in earth, next under Christ, of the Church of England and Ireland.

The Bishop of Rome hath 10 jurisdiction in this realm of England.

The civil magistrate is ordained and allowed of God: wherefore we must obey him, not only for fear of punishment, but also for conscience' sake.

The civil laws may punish Christian men with death for heinous and grievous offences.

It is lawful for Christians, at the commandment of the magistrate, to wear weapons, and to serve in lawful wars.

1563. Altered to its present form.

Errors condemned.

(1) The Roman theory of the supremacy of the Pope.

(2) The Erastian theory: the supremacy of the Civil Power.

(3) The Puritan theory: the denial of the right of the State to a share in the control of the Church's affairs.

\section{ARTICLE XXXVIII.}

\section{Of Christian men's Goods, which are not common.}

The Riches and Goods of Christians are not common, as touching the right, title, and possession of the same, as certain Anabaptists do falsely boast. 1 Notwithstanding, every man ought, of such things as he possesseth, liberally to give alms to the poor, according to his ability. ${ }^{2}$

\section{De illicita Bonorum Communicatione.}

Facultates et bona Christianorum non sunt communia, quoad jus et possessionem; ut quidam Anabaptistæ falso jactant. Debet tamen quisque, de his quæ possidet, pro facultatum ratione, pauperibus eleemosynas benigne distribuere.

1 Acts ii. 44, 45 ; v. 5 ; cf. Eph. iv. 28.

Matt. vi. 1 ; xxv. 40, 45; Rom. xii. 13 ; 1 Tim. vi. 17, 18 ; 1 Pot. จ. $9 ; 1$ John iii. 17.

\section{Error condemned.}

The Communistic teaching of the Anabaptist zealots.

\section{ARTICLE XXXIX.}

Of a Christian man's Oath.

As we confess that vain and rash $S$ wearing is forbidden Christian men by our Lord Jesus Christ, and James Lis Apostle, ${ }^{1}$ so we judge that ('hristian Religion doth not prohibit, but that a man may swear when

\section{De Jurejurando.}

QUEMaDModUM juramentum vanum et temerarium a Domino nostro Jesu Christo, et Apostolo ejus $J a c o b o$, Christianis hominibus interdictum esse fatemur; ita Christianorum Religionem minime pro.

\footnotetext{
1 Lev. xix. 12 ; ef. Jer. iv. 2.
} 
the Magistrate requireth, in a cause of faith and charity, so it be done according to the Prophet's teaching, in justice, judgment, and truth." hibere censemus, quin jubente magistratu, in causa fidei ot chari. tatis, jurare liceat, modo id fiat juxta Prophetæo doctrinam, in justitia, in judicio, et veritate.

2 Lev. v. 1 ; Deut. vi. 13 ; Matt. xxvi. 57-64; 2 Gor. i. 18, 23 ; xi. 31; Phil i. 8.

Error condemned.

The refusal of the Anabaptists (and subsequently the Quakers) to take oaths through a misinterpretation of Matt. v. 33-37, and Jas. v. 12. 


\section{A TABIE OF KINDRED AND AFFINITY}

\section{Wherein Whosoever Are Related Are Forbidden In Scrip- ture ANd OUr Laws To Marry Together. 1563.}

This Table is based upon Leviticus xviii. 6-18.* Every degree forbidden in the Table is either expressly, or by implication and fair inference, forbidden in Scripture (Matt. xix. 4-9, xxii. 24 ; cf. Tobit iii. 7);-except Nos. 17 and 18 in either Table, concerning which there is difference of opinion.

The political law of the Jews connected with inheritance allows, and even to a certain extent enjoins, marriage with a deceased husband's brother.

The recent Act of Parliament (7 Edw. 7. c. 47) allows marriage with a deceased wife's sister.

The conflict of the new Act with the former Law of the Church as here expressed was partly provided for by a clause in the Act expressly excluding interference with ecclesiastical custom. However, dispute speedily arose, taking the form of exclusion of a communicant who had married his deceased wife's sister from Holy Communion. The courts have pronounced this action to be illegal, and the decision of the Honse of Lords on Appeal is an endorsement of that judgment.

* The interpretation. of Lev. xviii. 18 has led to a great deal of discussion in its bearing upon social polity and canon law. If the marginal rendering of $A . V$. be adopted which takes the words in an idiomatic sense ('Neither shalt thou take one wife to another'), the text may be considered as a prohibition of polygamy, or, circumseribing the liberty of polygamy (permitted, see Exod. xxi. 7-11; Deut. xxi. 15-17) by the application of the law of charity and good taste. Accepting the words in their natural sense, as is done both in the main text of the A.V. ("Neither shalt thou take a wife to her sister '), and in the R.V. ("And thou shalt not take a woman to her sister, to be a rival to her'), the statute forbids an imitation of Jacob in marrying two sisters, and may be understood to mean 'Thou shalt not marry the sister of thy present wife, to vex her in her lifetime; although thou mayest take her sister in her deeease.' As touching upon the much vexed question of the marriage of a deceased wife's sister, it is important to remember that the law of the levirate (i.e. the husband's brother) was laid down in Deut. xxv. 5, and the substance of it quoted by the Sadducees in their entrapping question put to our Lord respeeting the Resurrection (Matt. xxii. 23-33, and parallel pasgages). 
There are three principles which govern the Table:-

(1) That what is said of man is to be understood equally of woman.

(2) That all marriages are forbidden within the third degree of relationship inclusive, and none outside that degree.

(3) That the prohibition of marriage extends not only to relation by consanguinity, but to relation by affinity.

Degrees of relationship are reckoned between two persons in the following manner. Each of the two persons reckons the number of generations from the common ancestor, and then the numbers are added together, and if the sum total is three or less the parties come within the prohibited degrees.

1st. Ex. An uncle and a niece.

The uncle is one generation from the common ancestor (i.e. his father), and the niece two generations (i.e. from her grandfather). As the sum total does not exceed three they cannot marry.

2nd Ex. Two first cousins.

Both are two generations removed from the common ancestor. As the sum total is therefore four, they may marry.

There is some doubt as to the physiological wisdom of such a union, which suggests a real weakness in the above principle.

The 99th Canon of 1603 gives the following directions respecting this Table and the penalties of its infringement:-

'No person shall marry within the degrees prohibited by the laws of God, and expressed in a Table set forth by authority in the year of our Lord 1563. And all marriages so made and contracted shall be judged incestuous and unlawful, and consequently shall be dissolved as void from the beginning, and the parties so married shall by course of law be separated. And the aforesaid Table shall be in every Church publicly set up and fixed at the charge of the parish.'

Until the fifteenth century the Church held the precepts of Leviticus xviii. to be moral, and, therefore, not to be modified or reversed. Since that time the Church of Rome has in practice held that a very close kindred of affinity is no necessary bar to marriage ; such unions, however, need special dispensations.

From the sixth to the fifteenth century the number of forbidden degrees was much enlarged, but the degrees thus added, when beyond the restrictions of Holy Scripture. were frequen.ly overridden. Such forbidden degrees included the relationships created by sponsorship, e.g. a godfather could not marry his goddaughter. 


\section{SOME DOCUMENTS, PUBLICATIONS, ETC., OF THE REIGN OF HENRY VIII.}

1. Controversial Publications. (See also Appendix E, 'Books for Further Study.')

1511. 'Encomium Moriæ' ('Praise of Folly'), by Erasmus.

A satire on the Schoolmen, Scholastic theology, the preaching of the friars, the worldliness of popes, cardinals, and on the ignorance shown by the priests-written in the form of an oration delivered by Folly to an imaginary audience composed of all sorts and conditions of men.

1516. Greek Text of the New Testament (1st edition, many subsequent editions), by Erasmus.

A free Latin version by Erasmus was written with the Greek - satiric notes $v$. papal claims, clerical immorality, adoration of relics, etc., were appended to special passages-these notes were supplemented by striking paraphrases in the later editions.

1520. 'Appeal to the Christian Nobility of Germany' (published in August), 'The Babylonian Captivity' (published in October), by Luther.

Two famous controversial manifestoes-English versions of the above-produced a marked effect in England.

1521. 'Assertio Septem Sacramentorum' ('Defence of the Seven Sacraments'), by Henry VIII.

An attack on Luther's teaching-based on the Fathers and other primary authorities-gained for Henry from Leo $\mathrm{X}$ the flattering title 'Fidei Defensor' ('Defonder of the Faith'), which was re-conferred by Parliament, 1544.

1522 (also throughout period 1516-1536). 'Colloquia' ("The Colloquics '), by Erasmus.

A collection of reminiscences and observations-a brilliant expose of the ignorance and vice prevalent among numbers of the clergy.

1521. 'Diatribe de Libero Arbitrio,' by Erasmus.

An attack on Luther's theology written owing to repeated requests by Archbishop Warham, Bishop Fisher, Sir Thomas More, etc., that he should try to expose and silence Lutherwritten also to be a declaration and proof for Clement VII that Erasmus was no heretic. 
1525. Luther replied: 'De Servo Arbitrio.'

1526. 'Hyperaspistes Diatribe adversus servum Arbitrium Martini Lutheri' by Erasmus.

1526. English Version of the New Testament (1st edition), by Tyndale.

Based on Erasmus' Greek Testament and his Latin translation, the Vulgate, the German Version by Luther-progenitor of the Authorised Version (1611).

1528. 'The Obedience of a Christian Man,' by 'Tyndale.

A refutation of the eharge that the Reformers eneouraged insubordination against the civil power-it was the first English book to set forth definitely (l) the supremo authority of the Holy Seriptures in the Church, (2) the supreme authority of the King in the State, two fundamental principles of the English Reformation.

1528. 'The Supplication of the Beggars' (a pamphlet), by Șimon Fish (of Oxford and Gray's Inn).

A humorous pamphlet purporting to be a petition by beggars who complained of the eompetition of the begging friars-denuneiation of the monks and clergy in general-provoked a reply by More, 'The Supplication of Poor Souls in Purgatory'-much interestcd Henry VIII.

1529. 'A Dialogue of Sir Thomas More' (with an imaginary student tainted with heresy).

Written at the request of Tunstall, Bishop of London (translated to Durham, 1530) that More should write a formal defenee of the Church against 'the pestilent sect of Luther and Tyndale'-an able defence of the Papal position, of image worship, veneration of saints and relies, miraeles, pilgrimages-bitter criticism of Tyndale's Version of the N.T.- violent attack upon Luther and his followers-contention that the eivil power is bound to use every means to suppress heresy-provoked a bitter reply by Tyndale, 'An answer unto Sir Thomas More's Dialogue' (1531).

1530. 'The Practice of Prelates,' by Tyndale.

An unsparing attack upon the Papal hierarchy, upon the whole of Wolsey's administration, and a denunciation of the divorco proceedings.

1535. 'De Vera Obedientia Oratio,' by Stephen Gardiner.

A renunciation, prompted by expediency, of the Papal claim to universal jurisdiction-three ehief ententions: (I) inferiority of human tradition to the divine precepts, (2) repudiation of Papal claim to jurisdiction over other Churches, (3) elaim that kings, princes and Christian magistrates are entitled to supremacy over their national Churches-much circulated abroad by Cromwell. and greatly pleased Bucer at Strassburg and the Swiss Reformers.

\section{The Divorce from Catherine of Aragon.}

1525. Bitter disappointment of Henry at the realization that he never would obtain by Catherine a male heir to 
the throne-desire to be free to re-marry-strained rela tions due to Catherine's resentment at Henry's cooing attachment to Spain.

1526. Infatuation for Anne Boleyn, who is ambitious to be Queen Consort, prompts the King to consider the possibility of a removal of the opposing difficulties.

1527, 1528. Fruitless embassies, Wolsey to obtain French intervention, Knight to Clement VII, Gardiner and Edward Fox to Clement VII-despatch of Cardinal Campeggio as Papal Legate to England to try with Wolsey the divorce case (Papal device to gain time).

1529-1532. Suggestion by Cranmer to his Cambridge friends Gardiner and Fox at Waltham that the verdict of the European Universities should be obtained-royal interview granted to him-proceedings under 'Præmunire' against Wolsey (d. 1530). by the King-despatch of Cranmer with three others to the chief Furopean Universities-death of Archbishop Warham, 1532-secret marriage of Henry to Anne Boleyn, January, 1533.

1533. Cranmer appointed by Henry to See of Canterbury (January) - confirmatory Papal Bull granted (February) by Clement VII after strong pressure by Henry VIIIconsecration of Cranmer in Westminster Abbey (March)the necessary fees were paid by the eager King-special session of the Archbishop's Court opened under presidency of Cranmer at Dunstable (Catherine's residence near, but she refused to attend the Court, May).

On May 23 Cranmer pronounced the verdict of the Court to be that the marriage of Henry to Catherine in 1509 was null and void from the beginning, because the Pope had no authority to permit a man to marry his deceased brother's wife, and in particular since the previous marriage had been consummated.

1533. On May 28 Cranmer officially declarcd that the King's recent marriage to Anne Boleyn was valid, and on June 1 (Whit Sunday) he crowned Anne Boleyn in Westminster Abbey.

Henry thereby flouted Papal Dispensations, and proclaimed his resolve to defy Papal suzerainty.

\section{Statute of Supremacy.}

Parliament by pronouncing therein "That the King, our Sovereign Lord, his heirs and successors, shall be taken, accepted, and reputed, the Only Suprome Head on Earth of the Church of England,' cxpressed Henry's open defiance of Papal suzerainty and England's political breach with the Papacy. 
1534. Statute of Succession.

In defiance of a Bull from Clement VII ordering the King to desert Anne Boleyn and to return to Catherinc of Aragon, Par. liament was instructed to pass this Statute, which confirmed the Divorce and the legality of the King's -marriage to Anne Boleyn, and named as heir to the throne, failing male issue, the infant daughter (afterwards Queen Elizabeth) of Anne. Princess Mary (afterwards Queen Mary) was thereby excluded from the succes. sion.

N.B.-The Statute was altered several times to suit the new circumstances connected with Henry's subsequent marriages. The succession was finally decided, according to the terms of the Will drawn up by the King's instructions shortly before his death.

\section{The Political Breach with the Papacy.}

The political breach with the Papacy accomplished by Henry VIII was but the climax to several national protests against Papal interference with England's temporal affairs. For example, the Statute of Provisors, 1350, was a protest against repeated usurpation of patronage; the Statute of Præmunire, 13531393, forbade under severe penalties appeals to Papal law-courts or the purchase of Papal Bulls. Nationa resentment had become specially bitter against the constant demands for subsidies that were used to promote on the Continent Papal political ventures sometimes even inimical to England.

The position of the Great Continental Powers was favourable to Henry's project. The rivalry between Francis I and Charles $\mathrm{V}$ had removed immediate danger of a coalition of France with Spain against England. The former was suffering from the humiliation of a recent defeat by Charles V, and Germany was passing through a religious and political crisis that overshadowed Charles' victory over Francis.

The Parliament by means of which Henry VIII declared himself and not the Pope to be "The Only Supreme Head on Earth of the Church of England,' sat session after session from November 3, 1529, to A pril 4, 1536, in other words, nearly seven years, an exceptionally long life for a Tudor Parliament. It was not dissolved until the political breach with the Papacy was complete, and has often been called 'The Reformation Parliament.'

\section{Anti-Papal Measures.}

\section{Those Affecting Directly the Clergy :-}

1529. Commons attack the spiritual courts, which they accused of levying exorbitant fines re probates-clergy attacked for avarice, pluralities, nou-residence, for devoting 
their time to grazing farms, breweries, tanneries, etc.Statutes to check these practices.

1531. Clergy pronounced by Parliament to be liable to penalties under Statute of Præmunire for having accepted Wolsey's jurisdiction as Papal Legate-about $£ 100,000$ paid by Canterbury Convocation and more than $£ 18,000$ by York Convocation to the King for royal pardonproceedings under Præmunire stayed on condition that the clergy acknowledge Henry to be 'The Only Protector, Sole and Sovereign Lord, and ... Supreme Head of the Church and Clergy of England.'

1532. Statute limiting 'Benefit of the Clergy' to those possessing Orders not under that of Sub-Deacon.

Minor clergy beneath the rank of Sub-Dcacon accused of ' a crime or of a civil offence could no longer claim the privilgge of trial by the Church courts.

1532. The Submission of the Clergy (surrender by Convocation to the $\mathrm{King}$ ).

Clergy promised no more to publish or enforee through Convocations any canons, constitutions, unless by royal liconcethe existing canons to be submitted to a commission of thirtytwo, sixteen for each House of Parliament, who shall abrogate any canon deemed by them to be subversive of the laws of the realm.

1534. Statute for the Submission of the Clergy and Restraint of Appeals.

This made legally binding the terms of the 'Submission'further provisions : the King's writ required for the convoning of Convocation, instead of appeals to the Papal courts, final appeal to be made from tho Archbishops' courts to tho King in Chancery.

\section{Those Affecting the King :-}

1533. The Restraint of Appeals (24 Hen. VIII, cap. 12).

Assertions of the Sovereign's ancient 'plenary, wholc, and entire power, pre-eminenee, authority . . . to render and yield justice,' and that English Church 'always hath been reputed . . . both for knowledge, integrity and sufficieney of number' ... to be ' sufficient of itself, without the intermeddling of any exterior person or persons, to declare and determine all sueh doubts, and to administer all such offices and duties, as to their room-spiritual doth appertain . . -statement that several English kings, e.g. Edward I, Edward III, Richard II, Henry IV, had, through Parliament, ' made sundry ordinances, laws, statutes, and provisions for the entire and sure eonservation of the prerogatives, liberties, and pre-eminences of the said Imperial Crown of this realm, and of the jurisdiction spiritual and temporal of the same, to keep it from the annoyanee as well of the See of Rome, as from the authority of other foreign potentates...'-reference to the 'sundry incon- 
veniences and dangers' and the 'great delay and let' to the true and speedy determination of justice that had arisen 'by reason of appeals sued out of this realm to the See of Rome '-declaration that henceforth all law cases determinable by spiritual jurisdiction (e.g. suits re matrimony, divorces, tithes, etc.) should be 'heard, examined, discussed ... and definitely adjudged and determined within the King's jurisdiction and authority, and not elsewhere,' despite any foreign inhibitions, summons, interdictions, excommunications, etc., from the See of Rome; and further, that only decisions pronounced in the King's courts should 'be firmly observed and obeyed'-instruction that 'all the spiritual prelates, pastors, ministers and curates' within the realm shall 'minister, execute, and do' ... the sacraments and divine services ' unto all the subjects of the same,' notwithstanding any in: terdict or excommunication from the See of Rome or inhibition by any foreign prince; fines and imprisonment for a year for each breach of the same-the penalties and forfeitures under the Statutes of Provisors and Præmunire decreed against any who shall henceforth 'attempt, purchase, or procure' from the See of Rome or from any other foreign court any form of appeal, inhibition, judicial decision, excommunication, etc. - all judicial appeals to be tried within the realm-a final appeal may be made from the Court of either Archbishop to the Upper House of Convocation, in suits relating to the King.

N.B.- Under the terms of the Statute for the Submission of the Clergy and Restraint of Appeals, 1534 (25 Hen. VIII, cap. 19), a final appeal might be made to the King's Court of Chancery.

'A just Statute that was necessary for the welfare of England.'

1534. The Supremacy Act (26 Hen. VIII, cap. 1).

Preliminary statement that the Clergy of the realm have already expressed formally, through the Convocations of Canterbury and York, their recognition of the King as Supreme Head of the Church of England - statutory declaration, "That the King, our Sovereign Lord, his heirs and successors, kings of this realm, shall be taken, accepted and reputed the Only Supreme Head in Earth of the Church of England, called Anglicana Ecclesia; and shall have and enjoy ... as well the title and style thereof, as all honours, dignities, pre-eminences, jurisdictions, privileges . . to the said dignity of Supreme Head of the same Church belonging and appertaining '-this Statute further bestowed on the King, his heirs and successors, full power and authority 'to visit, repress, redress, reform ... all such errors, heresies, abuses, ... that ought or may lawfully be formed, repressed, redressed . . . ' in so far as such repressive measures should promote the 'pleasure of Almighty God,' the increase of virtue, and 'the conservation of the peace, unity, an 1 tranquillity of this realm,' and notwithstanding a breach thereby of any foreign custom, law, or prohibition.

\section{Those Affecting the Pope.}

1532. The Conditional Restraint of Annates (strengthened by Eccles. Appoint. Act, 1534) (23 Hen. VIII, cap. 20).

Protest that the realm had long been imporerished by " the great and inestimable sums of money' that constantly were extructed therefrom by successive Popes, specially in payment of 
Annates, otherwise called First-fruits, by newly appointed Archbishops, many of whom had been thereby 'utterly undone and impoverished ' - assurance that this protest has not been prompted by unfaithfulness to God or to Holy Church, but simply by the King's sense of duty before Almighty God to preserve the realmstatutory declaration " that the unlawful payments of Annates, or First-fruits, and all manner contributions for the same, for any arahbishopric or bishopric, or for any Bulls hereafter to be obtained from the Court of Rome . . . shall from henceforth cease, and no such hereafter to be paid . . o other or otherwise than hereafter in this present Act is declared '; forfeiture of goods and of episcopal estates to the King the penalty for breaches of this Statute-powers granted to the Archbishops to consecrate in England any nominated Bishop despite probable Papal refusal to grant the customary Bulls, and declaration that every prelate so consecrated shall be duly enthroned, and shall 'be accepted, taken, reputed, used, and obeyed as an Archbishop or Bishop of the dignity, see, or place whcreunto he so shall be named, presented, and consecrated 'henceforth the payment for a Bull for an archbishopric or bishopric to amount to 5 per cent. of the annual income attaching to the see-expression of desire to settle this question by friendly arrangement with the Pope and Curia instead of by formal Statute-warning that should the Papacy proclaim an Interdict or Excommunication as a reprisal, the clergy will be authorized and commanded to continue their ministrations notwithstanding, and that the Bishops will be forbidden to execute the Interdict. . . .

N.B.-On 9th July, 1534, the King issued Royal Letters Patent, ratified and confirmed this conditional Statute, and gave it his Royal Assent. (See also the next Statute.)

\section{The Ecclesiastical Appointments Act. The Absolute} Restraint of Annates, Election of Bishops, and Letters Missive Act (25 Hen. VIII, oap. 20).

Summary of the Conditional Annates Statute and statement that the Pope, though informed of its provisions, had ignored it-benceforth, no nominated Prelate or Abbot shall seek Papal confirmation nor shall pay First-fruits to the Pope, but shall be elected by cathedral or monastic bodies only on the King's nomination, or shall be appointed by Royal Letters Patent-consecration, according to the custom of the Church, to follow promptly, and to confer full spir tual privileges, even without a Bull or other Papal sanction-every Prelate elect to render homage to the reigning sovereign-every Prelate thus nominated, elccted, granted the temporalities by the sovereign, and duly consecrated, shall be deemed in the fullest sense entitled to the "possessions, profits, spiritual and temporal' belonging to the See, and 'shall be obeyed in all manner of things,' saving only the violation of "the prerogative royal of the Crown and the laws and customs of this realm'-penalties attaching to 'Provisors' and 'Præmunire' decreed against the members of any cathedral or monastic body who shall fail to elect within twenty days from the receipt of the licence the King's nomince.

N.B.-This Statute still regulates in the main tho appointment of Prelates to English Sees 
1534. Act forbidding Papal Dispensations and the Payment of Peter's Pence (25 Hen. VIII, cap. 21).

Preliminary petition by Parliament against the intolerable Papal exactions, assertion that the realm is subject only to laws made therein, and that King and Parliament have the power to dispense with or to alter the laws of the realm-the payment of Peter's Pence and other Papal impositions 'shall from henceforth clearly surcease, and never more be levied, taken, received, nor paid to any person or persons in any manner of wise'-no person henceforth, whether English monarch or subject, shall apply to the Pope or to any Papal representative for ' licences, dispensations, compositions, faculties, grants, rescripts ... .; but such, the fees for which shall not exceed £4, shall be granted by the Archbishop of Canterbury after royal confirmation (when required), the more valuable to be confirmed by the Great Seal, and the fees to be divided between the King, the Archbishop, and the Lord Chancellor - the offspring of marriages thus licensed to be deemed legitimatepermission granted to the Archbishop to appoint a Clerk to write and register the licences, dispensations, etc.- to avoid future exorbitant charges, a fixed scale of fees to be assessed and registered by authority - a licence unjustly refused by an Archbishop may be granted by Royal Writ-repudiation of a possible interpretation of the Statute as a token that the King, the nobility, or the people intend ' to decline or vary from the congregation of Christ's Church in any things concerning the very articles of the Catholic Faith of Christendom, or in any other things declared by Holy Scripture and the Word of God, necessary for salvation '-the visitation of 'exempt' monasteries and colleges to be by Royal Commission-no man henceforth to attend a Council, etc., for religion held abroadpenalties attaching to 'Provisors' and 'Præmunire' decreed against any person who shall henceforth apply to Rome for any dispensation or licence, but dispensations, licences, etc., obtained from Rome before 12th March, 1533, shall remain valid, subject to the laws of the realm-the King may, if he wills, annul or revise this Statute.

\section{The First Act of Succession (25 Hen. VIII, cap. 22).}

Petition by Parliament that the succession to the Throne may be fixed by Statute, so that the political disturbances, the evils of a possible war, and the opportunity for Papal intrigue may be avoided - the official declaration by Thomas Cranmer, Archbishop of Canterbury, confirmed, and the King's marriage with Catherine pronounced by $\mathrm{P}$ arliament and adjudged to be "against the laws of Almighty God,' and to be 'accepted, reputed, and taken of no. value nor effect, but utterly void and annulled'-Catherine to be styled henceforth and reputed 'only Dowager to Prince Arthur, and not Queen of this realm '-the marriage to Queen Anne to be deemed, in accordance with the 'just judgment' of Thomas Cranmer, the Clergy of both Convocations, and the chief Italian and French Universities (names quoted), to be 'accepted, approved, ratified for good and consonant to the laws of Almighty God'marriages within the decrees forbidden by the Church no longer to be permitted; all such marriages already contracted are null and void, the parties to be separated, the offispring not to be deemed legitimate; no appeal from this decision and enactment may bo 
addressed to the Court of Rome-all the offspring of the marriage of Queen Anne to the King to be deemed 'inheritable' and to inherit the 'dignities, honours, pre-eminences, prerogatives' of the blood royal; the succession to the throne assigned to male issue of the Queen in hereditary order, and failing male issue to the 'Lady Elizabeth, now Princess, and to the heirs of her body lawfully begotten,' or to the other female issue of the Queen in hereditary order-this Statute to be proclaimed throughout England before 1st May 'next coming' (1534)-any person or persons who shall write and print or do anything to produce and circulate anything defamatory against the Crown and the Royal Marriage, or who shall proceed against the Crown, to be adjudged high traitors, to forfeit their property and goods, and they and their heirs to be attainted; such offenders may not claim the privilege of sanctuary-in the event of a minority being caused by the death of the King, the successor till age of eighteen (male-sirteen female) shall remain under the governance of the Queen assisted by such counsellors as shall have been appointed by royal authority; any attempt to disturb this arrangement to involve high treason-all the peers spiritual and temporal and other subjects shall, when required, 'make a corporal oath' in the presence of the King or of his heirs or of some other authorized representative, to "truly, firmly and constantly . . . fulfil, maintain, defend and keep . . . the whole effects and contents' of this Statute; refusal to take this oath to involve high treason.

N.B.-This Statute was promulgated shortly after the issue, March, 1534, by Clement VII of a Bull declaring the marriage with Catherine valid, repudiating the divorce proceedings and ordering Henry to receive again Catherine. It tacitly excluded from the Succession the Princess Mary, daughter of Catherine, who had already been deprived of the title Princess. The refusal of Sir Thomas More and Bishop bisher and others to take the oath caused theiv committal to the Tower. In 1534 this Statute was modified by a new Statute (28 Hen. VIII, cap. 7), which settled the Crown on the issue of Jane Seymour, and which decreed that failing issue by her or by any other lawful wife of the King, the Succession should be decided according to the King's pleasure. Accordingly Henry made careful provision for the Succession in the terms of his Will, The first Statue was strengthened by the Statute of Treasons (26 Hen. VIII, cap. 13), 1534, which pronounced guilty of bigh treason any person or persons who should maliciously wish or attempt bodily harm to the King or Quecn, or to their heirs, who should try to deprive them of their title, or slanderously accuse the king of heresy. Such deeds were classed with treasonably keeping the King's castles, ordnancc, artillery, etc.

\section{Formal Resolutions v. Papal Supremacy by Houses of Convocation and by the Universities.}

Despatch of a Royal Breve, March, 1534, to Canterbury Convocation instructing the members of the two Houses to examine the evidence and pronounce a formal answer to the question "Whether the Roman Pontiff has any greater authority in this kingdom of England given him by God in Holy Scripture than any other foreign Bishop'?-answer in November, 34 denied it, 4 affirmed it, 1 remained doubtful; instructions by Archbishop Cranmer that 
henceforth in all official documents the Archbishop should be styled 'Metropolitan' and not 'Legate of the Apostnlic See.' *

Official pronouncement by York Convocation, June, 1534, 'That the Bishop of Rome has no greater authority in the kingdom of England, in the Holy Scriptures, than any other foreign Bishop.' $†$

Similar pronouncements were made the same year by the Universities of Oxford and Cambridge. $\ddagger$

N.B. - These Resolutions were strengthened 1537 by the Statute 'for extinguishing the Authority of the Bishop of Rome' (28 Hen. VIII, cap. 10).

1536. Repudiation by Canterbury Convocation of Papal Claim to Supreme Authority to summon General Councils.

'We think that neithcr the Bishop of Rome, nor any one prince, of what estate, degree, or pre-eminence soever he be, may by his own authority call, indict, or summon any General Council, without the express consent, assent, and agrcement of the residue of Christian princes. ... $\S$

N.B.-This was the reply to the citation to Henry VIII sent by Paul III to attend the General Council that he proposed to hold at Mantua in 1537.

1536. The First Royal Injunctions of Henry VIII.\|

All Clergy having the cure of souls to faithfully keep and observe ... ' all and singular laws and statutes of this realm made for the abolishing and extirpation of the Bishop of Rome's pretensed and usurped power and jurisdiction within this realm, and for the establishment and confirmation of the King's authority and jurisdiction within the same, as of the Supreme Head of the Church of England '-every Sunday for ensuing three months and twice each quarter thereafter, to declare in their sermons ' that the Bishop of Rome's usurped power and jurisdiction... was of most just causes taken away and abolished - - the Clergy to explain in the course of their sermons the 'Ten Articles,' especially the abrogation of 'certain superfluous holy days '-Clergy " not to set forth nor to extol any images, relics, or miracles for any superstition or lucre,' nor allure the people to the pilgrimage of any saint, otherwise han permitted in the Articles (Ten Articles) lately put forth by royal authority ... 'seeing all goodness, health and grace ought to be both asked and looked for only of God ...'-Clergy in heir ser-

- Cant. Convocat.: 'An Romanus Pontifex habeat aliquam majorem iurisdictionem collatam sibi a Deo S. Scriptura in hoc regno Angliae, quam alius quivis externus episcopus.' Wilkins, III, 769.

† York Convoc.: 'Quod Episcopus Romanus in Sacris Scripturis non habit aliquam maiorem iurisdictionem in regno Angliae quam quivis externus episcopus.' Wilkins, III, 782.

$\mp$ Cambridge: 'Determinatio adv. Suprematum Papae' (Cant. wording), Oxford: 'Protestatio Universitatis Oxon. quod Romanus Episcopus non habet maiorem aliquam jurisdictionem . . ' (practically the York word. ing). Wilkins, III, 771, 772, 775, 776.

$\S$ See Wilkins, Concilia, III, 803, 808 (the whole pronouncement is interesting).

II Issued shortly after the 'Ten Articles' by Thomas Cromwell in his capacity as Vicar-General-the first Tudor Injunctions. Gee and Hardy, p. 269. 
mons, etc., diligently to admonish "the fathers and mothers, masters and governors of youth' to teach, or cause to be taught, their children and servants their ' Pater-noster, the Articles of ouv Faith, and the Ten Commandments in their mother tongue,' and to spare no pains to secure that the youth shall know these by heart and understand them-parents, guardians, masters, to 'bestow their children and servants . . .' either to learning, or to some other honest exercise, occupation, or husbandry, and the Clergy to use every means to promote this-Clergy 'diligently to provide that Sacrament and sacramentals be duly and reverently ministered in their parishes,' and to provide efficient substitutes to minister $v$ he 1 ever they themselves shall be absent by permission-Clergy $n$ )t 'to haunt or resort, save when necessary, to any taverns or alehouses,' not to give themselves to drinking or riot, nor to card-playing, bct to devote their spare time to the study of the Holy Scriptures ... and always to have in mind "that they ought to excel all other in purity of life, and should be example to all other to live well and Christianly'-all non-residentiary beneficed Clergy receiving therefrom more than $£ 20$ (more than $£ 200$ in modern money) per annum to devote not less than one-fortieth part to the poor; and Clergy whose annual income is $\mathfrak{f 1 0 0}$ (more than $\mathfrak{£ 1 , 0 0 0}$ in modern moncy) or more shall support at Oxford or Cambridge an Exhibitioner for every $£ 100$ of income received-Clergy whose Churches or parish buildings are out of repair to devote a fifth of their annual income to make good the dilapidations.

\section{The Second Royal Injunctions of Henry VIII.*}

Confirmation of the Injunctions issued 1536-Clergy to provide before Easter, 1539, " one book of the whole Bible of the largest volume, in English, $\dagger$ and the same set up in some convenient place within the said Church that you have cure of . . -Clergy not to discourage, but rather to 'provoke, stir, and exhort every person to read the same, as that which is the very lively Word of God'; at same time Clergy to admonish against "all contention and altercation therein '-every Sunday and holy-day, the Clergy plainly to recite and to explain to their parishioners a sentence in English from the Pater-noster or from the Creed, so that in time the parishioners may know these by heart and understand them, so also the 'Ten Commandments'; every Lenten season the people to be examined whether they know by heart in English the "Articles of our Faith and the Pater-noster' - at least once a quarter the Clergy to preach a simple sermon declaring " the very Gospel of Christ,' and exhorting 'to the works of charity, mercy, and faith, specially prescribed and commanded in Scripture,' and to warn the parishioners not to trust for salvation and blessing to pilgrimages, offerings to relics, telling of beads, etc.-images to which offerings are made to be taken down without delay, henceforth no candle, taper, etc., to be set before any image or picture ; only " the light before the Sacrament of the altar, and the light about the Sepulchre' may be retained-Clergy to give instruction re the use and abuse of images - non-resident Clergy to provide efficient Curates to minis-

* Issued by Thomas Cromwell in his capacity as Vicar-General.

$\uparrow$ Doubtful if ' Great Bible' hcre specifically required, since not published lill 1539-probably 'Matthew's Bible' (1537). Gee and Hardy, p. 275. 
ter in their stead, and only the duly licenzed preachers to be allowed to preach sermons-Clergy who have hitherto extolled pilgrimages, the cult of feigned relics or images publicly to repudiate this teaching as contrary to Scripture-every Parson in charge of a Church to keep for each Church 'one book or register, wherein ye shall write the day and year of every wedding, christening, and burying made within your Parish for your time'; for these Registers the Parish to provide "one sure coffer with two locks and keys; the entries in the Registers to be duly made every Sunday in the presence of the Churchwardens-Clergy to read in public once a quarter the two Scries of Injunctions-Tithe to be promptly paid, and the Clergy who neglect their duties to be reported to 'their Ordinaries' and other superiors' hands '-Clergy forbidden to alter the date on manner of observance of any authorised fast or festival-the regulas Suffrages of the Litany never to be omitted, but rather the introductory invocation of saints to be curtailed-the First Injunctions (1536) to be fully observed on pain of deprivation or other necessary compulsion.

\section{The Dissolution of the Monasteries.}

\section{Some Previous Dissolutions :-}

1378-13S2. Suppression by William of Wykeham, with Papal sanction (Bulls), of several monasteries in order to provide endowments for his dual foundation ('St. Mary's College of Winchester') of a college in Oxford and a school in Winchester-college ('New') opened 1386 ; school, 1394.

1439-1441. Suppression by Henry VI, with Papal and Parliamentary sanction, of several French priories (English territory in France) in order to provide endowments for his dual foundation ('King's College of Our Lady ... .) of a college and school in Eton and of a college in Cambridge-chatter of foundation of the school, 1440 ; of King's, Camb., 1441.

1497. Conversion, with Papal sanction, of the declining nunnery of St. Rhadegund, Camb., by John Alcock, Bishop of Ely, into Jesus College.

1524-1528. Suppression by Wolsey, under the terms of a Bull granted by Clement VII, of the monastery of St Ftideswide, $0 x f o r d$, in order to build on the site a great college to be called 'Cardinal College'--suppression, 1525, of 29 small monasteries in order to provide endowments for the college and also for the projected school in Ipswich.

N.B. - The fall of Wolsey, 1529, prevented the completion of this scheme. In 1546 the king devoted some of the endowment to found the college under the name 'Henry VIII College.'

1534. Suppression by Henry VIII of the 7 houses belonging to the 'Observantes' (a reformed Order of Franciscan Friars). 


\section{Process of the Disso'ution.}

1535. Royal Commission granted to Thomas Cromwell to conduct a general Visitation of the monasteries, the universities, the cathedral, collegiate and parish churches.

\section{5-1539. Progress of the Visitation.}

Despatch by Layton and Ligi of a series of unfavourable reports ("Comperta') respecting the spiritual and moral condition of many monasteries, and containing also inventories of the property and treasure belonging to these Houses.

1536. Act for the Dissolution of the Lesser Monasteries (27 Hen. VIII, cap. 28).

Rcasons given, the suppression of vice, the desirability of filling up 'divers and great solemn monasteries . . . destitute of such full numbers of religious persons as they ought and may keep,' the application to better uses of the confiscated property p,nd treasure, the necessity that 'unthrifty religious persons, should be compelled to reform their lives.

'His Majesty to have and enjoy to him and to his heirs for ever' all Houses the annual revenue of which did not exceed $£ 200$ (equivalent to about $£ 2,000$, modern reckoning) per annum, and all Houses that within a year previous to the Act had either been surrendered or suppressed-provision "to live honestly and virtuously' in secular life to be made for those who shall refuse to be transferred to the greater monasteries.

1537-1540. Suppression of the Greater Monasteries.

Surrender to the King of about 188 Houses, suppression by Act of Attainder (charges of treasonable complicity in the 'Pilgrimage of Grace,' 1536) of 12 Houses (including the famous Glastonbury, Jervaulx, Reading, Woburn Abbeys), and confiscation of 43 ' Commandries' of the Knights of St. John of Jerusalem, and suppression of a number of Houses that had been granted in 1536 licences to continue.

1539. Act for the Dissolution of the Greater Monasteries (31 Hen. VIII, cap. 13).

Preliminary statement that the abbots, abbesses and other ecclesiastical governors and governesses of 'divers and sundry' Houses had surrendered them voluntarily to the King since 4th February, 27 Hen. VIII (1535)-declaration that the King, his heirs and successors for ever shall ' have, hold, possess, and enjoy' the property, the revenues, the advowsons and all other ecclesiastical, manorial and judicial rights and privileges appertaining to all the Houses, colleges, hospitals, etc., suppressed or surrendered since 4th February, 27 Hen. VIII ; and the entire possession, rights, and privileges of Houses that hereafter shall be suppressed or surren. dered 'shall be vested, deemed, and adjudged by authority of this present Parliament' in the King, his heirs and successors for everall monastic lands, rents, reversions, advowsons, patronages, etc., to be "in the order, survey, and governance . . . of the King's Court of Augmentations of the revenues of his Crown, and of the 
chancellor, officers, and ministers of the same'-leases made by monastic governors within a year of the dissolution of the respective Houses, and leases made by monastic governors of Houses that should hereafter be suppressed or surrendered, to be void-concessions granted in certain special cases-leases allowed and enrolled in the Court of Augmentations to stand and to be valid-purchasers by royal authority of monastic lands, advowsons, etc., and the heirs of the purchasers may have and enjoy the same-confirmation of the King's claim to whatever monastic possessions have been purchased or obtained in exchange by the Crown since 4th February (1535)-continuing the privilege enjoyed by the governors of Houses, the King and his heirs and every person or persons and their heirs to whom monastic property has been granted, shall be free from the obligation to pay tithe on monastic property-monastic premises hitherto exempt from episcopal visitation to be henceforth ' within the jurisdiction and visitation of the Ordinary or Ordinaries ' in whose diocese they be situated-special exemption granted to the Duke of Norfolk's monastery at Sibton, Suffolk. and to Lord Cobham's college and chantry at Cobham, Kent.

1540-1542. Foundation with part of the confiscated revenues of the following six new Sees: Westminster (re-absorbed into London, 1550), Bristol, Chester, Gloucester, Oxfo:d, Peterborough.

\section{Literary Efforts towards Doctrinal Reform. (See also App. E.)}

1534. Marshall's Primer ('A Prymer in Englysshe'), Rev. Edit. 1535.

Chief contents :-English versions of the Hour Services-an exposition of Psalm li.-a harmony of the Gospel narratives of the Passion-a summary of doctrinal instruction consisting of explanations of the vow at Holy Baptism, the Creed, and the Commandments written in the form of a dialogue between a father and his son-to the Rev. Edit. 1535, the omitted 'Dirge' (Dirige-Mattins of the Dead) and 'Commendations' were added, but accompanied with warnings $v$. prayers for the dead, and with expositions of the selected Psalms and Lessons-though denounced by Convocation, the Primer widely circulated 1534-1539-Cranmer transferred verbatim parts of it to the treatise 'The Institution of a Christian Man.'

William Marshall, c. 1535. . . Printer, translator-zealous disciple of the Reformers-in favour of the Divorce of Catherinebesides the Primer, prepared for publication several controversial books, e.g. English version of 'Defensorium Pacis,' a fourteenth century treatise written in Padua $v$. the temporal power of the Pope.

\section{The Ten Articles ("The Articles of our Faith'*).}

The first English Confession of Faith, the first authorized formulary of the Church of England-basis of 'Forty-two Articles' (pub.

* MS. evidence for the title is conflicting - the Articles were published by Berthelet, 1556, under the following title : 'Articles devised by the King's Highness Majesty to stablish Christian Quietness and Unity among us, and to avoid contentious opinions : which Articles be also approved by the Con. 
1553) and of 'Thirty-nine Articles' (pub. 1563 and 1571)-the draft attributed to Edward Fox, Bishop of Hereford (draft probably submitted for revision to Henry VIII and Cranmer), who apparently derived much help from the 'Confession of Augsburg, 1530'-an attempt to set forth a via media between Reformation and Papal Doctrine, to preserve thereby the unity of the Church of England, and to provide a safeguard against religious disruption-published by Royal Authority (Preface in the name of Henry VIII), signed by Thomas Cromwell, the Prelates and several Clergy of the Lower House.

Two Divisions-Articles I-V re Doctrine; Articles VI-X re Ceremonies* - the Rule of Faith that all bishops and preachers must teach to the people and 'most constantly bclieve and defend,' declarep to be "comprehended in the whole body and canon of the Bible and also in the Creed and Symbols' $\dagger-e x p o u n d e d$ according to the plain meaning of the words and according to the interpretations accepted by the approved doctors of the Church-all doctrine must be " utterly refused and condemned 'that had been anathematized by the Councils of Nicæa, Constantinople, Ephesus, Chalcedon, etc.-instead of Seven Sacraments the three following were defined and explained; Tise Sacrament of Baptism, of Penance, of the Altar $\$-a$ modified doctrine re Presence in the Elements (not full Transubstantiation) !! $\longrightarrow$ re Ceremonies, the people to be taught "how they ought and may use' images; that the saints were to be honoured, not with the honour due only to God, but because 'they be known the elect persons of Christ .... because they already do reign in glory with Christ' ; the people further to be taught that though God alone can remit sins through Christ's mediation, "it is very laudable to pray to saints in heaven everlastingly living' (a suggested form of prayer to a saint is given); the Saints' Days as recently revised to be observedEucharistic vestments to be worn-explanations of several ceremonies and customs, e.g. Holy Water, candles on Candlemas Day, ashes on Ash Wednesday, palms on Palm Sunday, etc.; these not to be condemned and cast away, but to be used and continued as

sent and Determination of the whole Clergy of this Realm.' For Text see 'Formularies of Faith Under Henry VIII,' Oxford, 1825 ; Collier, ' Eccles. Hist. of Great Britain, ${ }^{2}$ vol. iv, pp. 343-359. Fuller, 'Eccles Hist.,' vol. iii, book $\nabla$, pp. 141-159.

* Division I re the things ' commanded expressly by God . . . necessary to our salvation'; Division II, re the things ' as have been of a long continuance-prudently instituted and used in tle Church of our realm . . . although they be not expressly commanded of God, nor necessary to our salvation' (Preface).

† These are specified, viz. 'The Apostles', Nicene, Athanasian Crccds.'

$\ddagger$ For summaries of these Articles, cf. Dixon, 'Hist. of the Church of England,' vol. i, pp. 416-418.

!I Doctrine re Presence in the Elements. 'Under the form and figure of Bread and Wine... is verily, substantially, and really contained and comprehended the very selfsame Body and Blood of our Saviour Jesus Christ. . . . And that under the same form and figure of Bread and Wine, the very selfsame Body and Blood of Christ is corporally, rcally, and in very substance, exhibited, distributed, and received of all them which receive the said Sacrament.' N.B. From the latter part of Article IV several sentences have been incorporated into one of the exhortations in the present Communion Office. 
things good and laudable ...'-since 'due ordcr of charity requircd' and the opinion of 'divers ancient doctors' was in favour of prayers for the souls departed, Bishops and preachers were to teach ' that no man ought to be grieved with the continuance of the same.' At the same time the abuscs connected with the means of Purgatory, ๑.g. the efficacy ' of the pardons of the Bishop of Rome,' must be clearly put a.vay.

1537. 'The Institution of a Christian Man'* (" The Bishop's Book').

A second and expanded Confession of Faith to meet the wants of students and preachers, and intended to be an eirenicon for conservative Churchmen who thought the 'Ten Articles' too sweopingcompiled by a Commission of Bishops $\dagger$ and other divines convened by Cranmer apparently by Cromwell's instructions; Cranmer and Fox and Stokesley and Tunstall took the lead in the compilationwas arranged in the following divisions: The Creed, the Seven Sacraments, the Ten Commandments, the Pater-noster, the Ave Maria, Justification, Purgatory. The 'Ten Articles' were incorporated-written entirely in English and conciliatory in tonereceived the signatures of the archbishops, the diocesans, and twentyfive divines, but was not passed either by Convocation or Parliament-was intended chiefly to prepare the way for a permanent treatise ; betrays haste in preparation, and never received full Royal authorization.

\section{$A P P E N D I X \quad B$}

\section{THE OATH OF 'THE KING'S SOVEREIGNTY}

1552. 'I from henceforth shall utterly renounce, refuse, relinquish, and forsake the Bishop of Rome, and his authority, power, and jurisdiction. And I shall never consent, nor agree, that the Bishop of Rome shall practise, exercise, or have, any manner of authority, jurisdiction, or power, within this Realm, or any other the King's dominions, but shall resist the same at all times to the uttermost of my power. And I from henceforth will accept, ropute, and take, the King's Majesty to be the only

* The commissioners described the book as "A plain and sincere doctrine concerning the whole sum of all those things which appertain unto the profession of a Christian man.'

$\dagger$ See Strype, Memorials of Cranmer, I. xiii. 
supreme Head in earth of the Church of England: And to my cunning, wit, and uttermost of my power, without guile, fraud, or any undue mean, I will observe, keep, maintain, and defend the whole effects and contents of all and singular Acts and Statutes made, and to be made within this Realm, in derogation, extirpation, a'd extinguishment of the Bishop of Rome and his authority, and all other Acts and Statutes made or to be made in confirmation, and corroboration of the King's power of the supreme Head in earth, of the Church of England. And this I will do against all manner of persons, of what estate, dignity, or degree, or condition they be, and in no wise do nor attempt nor to my power suffer to be done or attempted, directly or indirectly, any thing or things, privily or apertly, to the let, hindrance, damage, or derogation thereof, or any part thereof, by any manner of means, or for any manner of pretence. And in case any oath be made or hath been made by me to any person or persons, in maintenance, defence, or favour of the Bishop of Rome, or his authority, jurisdiction, or power, I repute the same as vain and annihilate. So help me God through Jesus Christ.'

1662. ' I, A. B., do utterly testify and declare in my conscience, That the King's Highness is the only Supreme Governor of this Realm, and of all other His Highness's Dominions and countries, as well in all Spiritual or Ecclesiastical things or causes, as Temporal: And that no foreign Prince, Person, Prelate, State, or Potentate hath, or ought to have, any jurisdiction, power, superiority, preeminence or authority Ecclesiastical or spiritual within this Realm. And therefore I do utterly renounce and forsake all foreign jurisdictions, powers, superiorities, and authorities: and do promise, That from henceforth I shall bear faith and true allegiance to the King's Highness, his Heirs and lawful Successors, and to my power shall assist and defend all jurisdictions, privileges, preeminences and authorities granted, or belonging to the King's Highness, his Heirs and Successors, or united and annexed to the Imperial Crown of this Realm. So help me God, and the Contents of this Book.'

The Oath of Supremacy is no longer required by law, but Art. XXXVII, Of the Civil Magistrates, is binding upon the Clergy, as are also Canons 1, The King's Supremacy over the Church of England, in Causes Ecclesiastical, to be maintained, and 2, Impugners of the King's Supremacy censured.

The modern Oath of Allegiance is : ' I, M. N. . . . do swear that I will be faithful and bear true allegiance to his Majesty, King George V, his heirs and successors according to law. So help me God.' 


\section{$A P P E N D I X \quad C$}

\section{SERVICE-BOOKS IN REFORMATION TIMES}

I. The Service-Books for the Holy Communion, called, in their combined form, the Missal, or Mass Book, first known about the eighth century. The Missal roughly corresponds to our Holy Communion with Collects, Epistles, and Gospels. (See pp. 2, 3.)

It was an expansion of the Sacramentary, and contained things to be daily said in the Mass.

1. The Mass-Book for the Celebrant.

It contained the 'Ordinarium,' the 'Canon,' etc., and the lections and devotions proper to the season.

2. The Epistle-Book for the Sub-deacon.

3. The Gospel-Book for the Deacon.

4. The Books for the Choir.

(1) The Gradual, or Grail.

It was formcrly called Antiphonarium Missæ, or Cantatoium, and contained everything that was sung antiphonally-

(2) Troper for the Choir.

It contained the more recent musical additions to the Services.

II. The Service-Books for the Divine Service or Canonlcal Hours,* forming the 'Breviary' corresponding to our Morning and Evening Prayer, Litany (also found in the Processional), and Psalter. It contained the Hour Services for the year, arranged under four heads, the Psalter, the 'Proper of Time,' the 'Common of Saints,' and the 'Proper of Saints.'

The following parts of the Breviary are often found separate:-

1. The Liturgical Psalter, containing the Psalms and Canticles.

2. The Legend, ' readings,' containing, with portions of Scripture and Homilies, patristic extracts and many legends of saints.

(1) The Lectionarius, properly a book of Scripture lessons only.

(2) Sermologus and Homiliarius, supplying patristic sermons, and expositions. - The Book of the Day Hours' service was formorly called Diurnale.
693 
(3) Passionarius, describing the sufferings of Martyrs.

(4) Bibllotheca, the Bible.

3. The Antiphonal, Antiphonary, containing the musical part of the Service, and often including :

(1) The Hymnal, Hynarium,

(2) The Passionale,

(3) The Collectar, Collectarium, for the principal off ciant, containing short texts from Scripture and the Collects.

In addition to the above books there were:

The Consuetudinary, or a book of Directions which showed how the Services in the above were to be conducted.

In process of time the Missal was incorporated with the Breviary, and subsequently with the Pie or Perpetual Kalendar, when the whole book was called the Directorium. The Pit corresponds in measure to our Kalendar and other Tables.

\section{The Service-Books of the Occasional Services.}

1. The Manual, Liber mxnualis, or manuale, known on the Continent as the Pastoral, Liber pastoralis. It contained the Services performed by the priest, such as Baptism, Matrimony, Services for the Sick, etc.

2. The Pontifical, Pontificale, Liber Pontificalis, containing the Offices belonging to Eiscopal ministrations, such as Ordination Services, Consecration of places and people, Episcopal Benediction, etc.

IV. The Service-Books used in various Processions, called the Processional.

V. The Service-Books for Private Devotional Use.

1. The Psalter with an appendix containing Canticles, Creeds, Lord's Prayer, Gloria in Excelsis, etc.

2. The Horm, or Primer.

Books of this kind furnished for the laity a simple unchanging form of hour services, and, if they desired it, several alternative forms, as well as their own private prayers to be said at home and in Church.

N.B.-(1) In the Early Church the Service of Divine Worship and more especially the Eucharistic Service came to be called the Liturgy among the Eastern Greek-spealking Christians.

In the West the corresponding term was the Mass.

(2) These Service-Books in their combined and varied forms were from the eleventh century called ' Uses' in England. Those of Salisbury, York, Hereford, Bangor and Lincoln were the most important, and are referred to in the Preface to the Book of Common Prayer. 
(3) The Portifo ium was a portion of the Breviary; the name assumed many forms in popular use, such as Portifory, Portuary, Porthors, Portous, Portuis, Portass. In the Mediæval Church in England it was the name given to an office-book containing the offices of the canonical hours.

(4) The Canonical Hours were as follows:-Nocturns, afterwards ccmbined with Lauds, or Matins, said at break of day; Prime, 6 a.m.; Tierce, 9 a.m. ; Sext, noon; Nones, 3 p.m.; Vespers, 6 p.m.; Compline, before retiring to rest.

N.B.-For further Information respecting Services, see pp. 228-233. 


\section{APPENDIX D CLASSIFIED LISTS *}

\section{No. 1. THEOLOGICAL TERMS.}

Communicatio Idiomatum. The result of the perfect union of the two natures in the Person of Christ. By it the properties of either nature may be predicated of the Person of Christ.

Homoousros. The watchword of the orthodox in the Arian controversy, denoting identity of nature, as distinguished from Homoiousios, denoting similarity, and from Heter-ousios, denoting difference. The substantive, however, homoioma, tr. 'similitude' or'likeness' in A.V., does not thus distinguish between identity and likeness; cf. Rom. v. 14, vi. 5, viii. 3 ; Phil. ii. 7.

Humanitarian. See under 'Unitarian.'

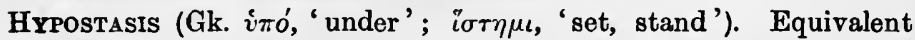
to Latin Substantia, that which is the reality, the substance of a thing, cf. Heb. xi. I : 'faith is the substance of things hoped for';

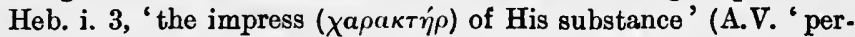
son'). Here the word is equivalent to ovoi'(1, but later postNicene technical language used it for the Latin persona, a curious instance of a contradictory use of the same word, and a conclusive proof of the inadequacy of any human thought to conceive, and language to express, the Being of God.

Locos ( $\lambda$ óyos, 'word,' 'reason '). The double meaning of the Greek word, combining the 'expression of reason,' and also 'reason' itsclf, makes its use by St. John for the Second Person of the Holy Trinity a blend of the Jewish MI mra, the 'Word of God' of the O.T., with the Logos, 'Creative Reason,' of Plato and the Stoics, with, of course, the new revelation of the personality of the Logos. Monarchia ( $\mu$ ó$^{\prime} o \mathrm{~s}$, 'alone'; à $\rho \chi \epsilon \iota$ ', 'rule'). Monarchia was a primitive term for Christian monotheism. To those who held unitarian views of the Godhead, assuming that thereby they defended the Divine Unity, Tertullian applied the term 'Monarchians.'

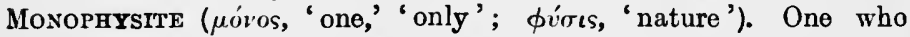
follows Eutyches in maintaining that there is but one nature in

- The words in these Lists, togrther with other instances of their occurrence in the text, are ontered in the Index. 
the Lord Jesus Christ, the human and divine being merged into one. This error was a reaction from that of Nestorianism, which taught two Persons as well as two Natures in Christ. It was condemned at Chalcedon 451, but still persists in the Monophysite Churches of the East.

Monotheism ( $\mu$ óvos, 'one,' 'only'; $\theta$ cós, 'God '). Belief in the unity of the Godhead. Distinguished from :-

(1) Polytheism-belief in many gods.

(2) Tritheism-belief in the separate deity of Father, Son, and Holy Ghost.

(3) Pantheism-belief (in various forms) that God and His Creation are one.

(4) Henotheism-a modern name for the ancient belief that each tribe or nation has but one god, but that one different from those of other nations.

Monotheltee ( $\mu$ óvos, 'one,' 'only'; $\theta \dot{\epsilon} \lambda \epsilon \iota v$, 'to will'). One who holds that the Lord Jesus Christ had but one will, a Divine Will controlling both His Divine and human actions. Condemned at Constantinople 680.

Ousra (ov'oía, 'essence,' 'being'). That which makes a thing to be what it is, indistinguishable from Hypostasis, 'Substance,' in N.T., and ante-Nicene use.

Patripassian (Lat. pater, 'father'; passus, 'having suffered'). A name applied to certain early speculative theologians, whose zeal for the unity of the Godhead 'confounded the Persons,' so that the logical deduction from their teaching was that the Father suffercd on the Cross.

PerRoN (Lat. persona, 'an actor's mask,' thence 'a character,' thence 'a person' in the modern sense). This word has been borrowed as a technical term for the three Subsistences in the Godhead, revealed in Holy Scripture. As such it is incapable of definition.

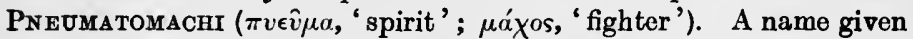
to those who denied with Macedonius (Cent. IV) the divine personality of the Holy Spirit. Condemned by Council of Constantinople 381 .

Substance (Lat. sub, 'under'; stare, 'stand'). See 'Hypostasis.' Theandric ( $\theta \epsilon o ́ s$, 'God'; àví $\rho$, 'man'), i.e. existing by the union of the divine and human natures; specifically used of the "Theandric operation,' the co-operation of the two wills and two natures of Christ, the one indivisible Person, perfect God and perfect man. See 'Communicatro Idomatum.'

Theopaschite ( $\theta \epsilon o ́ s$, 'God'; $\pi \dot{a} \sigma \chi \epsilon i$ ', 'to suffer'). The name given to a Monophysite sect of the sixth century, which bclieved Christ to have suffered in His divine nature.

Tuzотокоs ( $\theta$ єós, 'God'; riktєı, ' bring forth'). A title of the 
Blessed Virgin Mary, definitively accepted by the Council of Chalce. don, 451, against Nestorianism. The term was also adopted at Ephesus and Chalcedon as safeguardirg the Divinity of Christ.

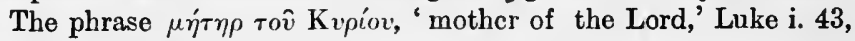
is the Scriptural term.

Trinity (Lat. trini, 'three'). Tertullian used the late word trinitas, ' a triad,' to describe the Trinity, the three Persons in the One God.

Unitarian (Lat. unus, 'one'). A name given to one who denies the deity of the Lord Jesus Christ. Sometimes called 'Humanitarian.' Unitarianism varies from vaguest deism to an exalted conception of the Lord Jcsus, often scarcely distinguished from Trinitarianism.

\section{No. 2. HERESIES AND SECTS.}

AnabaptisM (Gk. àvù $\beta a \pi \tau i \zeta(\omega$, 'baptize again'). The re-baptism of those baptizcd as infants was only one feature of the anabaptist creed, which arose in the sixteenth century; extreme socialistic, evch anarchical, tenets in regard to Church and State distinguished its adherents from the later advoeates of adult baptism, now called 'Baptists.'

ApolinNarianism (Apollinaris, Bishop of Laodicea, 362). Three distinct heresies are connected with Apollinaris :-

(1) Christ's body came into being by the conversion of the substance of the Godhead into the substance of flesh.

(2) In the Incarnation these two substances were blended.

(3) Our Lord had no human soul, its place being taken by the Divine Nature.

The last named is that generally known as Apollinarianism. Condemned by a Synod at Rome, 373 .

Arianism (Arius, a Presbyter of Alexandria in 319). Influenced by Paul of Samosata, Arius taught that there was a time when the Son did not exist, and that He differs from other created beings in degrec only and not in kind. His views were, to a large extent, a reaction from Sabellianism. The Council of Nicæa, 325, condemned his views, and excommunicated him.

The name Arianism was applied to various shades of heretical teaching, all alike in denying identity of substance in the Father and the Son. The name 'Semi-Arianism' was attached to the less crude views, according to which like but not identical substance

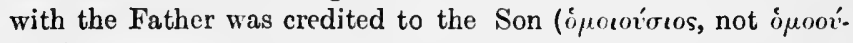
$\sigma(0)$ ).

ARtemonitism (Artemon or Artemas, early in third century). Denicd the Divinity of Christ and of the Holy Spirit; admitted the superior moral excellence of Christ, due to a measure of the Divine imparted to Him after His birtl.

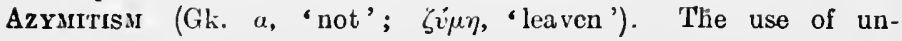


leavened bread in the Holy Communion. Generally applied by the Greek Church to members of the Roman or Armenian Communion. The antithetical term used by R.C.'s is 'Fermentarianism' or 'Prozymitism.'

Ebron. It is an open question whether the Ebionites derived their origin from an individual of this name, or from the word Ebyon, 'Poor.'- The latter is asserted by Ignatius and Origen; the former by Tertullian, who refers to the refutation of Ebion's teaching in the Epistle to the Galatians and the Gospel of St. John. The Ebionites were strong Judaizers; they held inadequate views of the Person of the Lord.

Eutyches, c. 440 ; a presbyter of Constantinople. An opponent of Nestorius $(q . v$.$) , he erred in a contrary direction, asserted that in$ the Person of Christ was but one Nature, hence the term 'monophysite.' After having appeared before the 'Robber Synod' at Ephesus, 449, he was condemned by the Council of Chalcedon

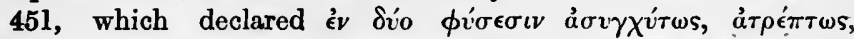

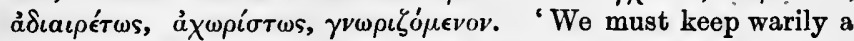
middle course, shunning both that distraction of persons wherein Nestorius went awry, and also the confusion of natures which deceived Eutyches.' Hooker, 'Ecc. Pol.,' V. lii.

Maokdonids, c. 360, the Arian Bishop of Constantinople, deposed by the Arian Council of that city in 360. During his exile he elaborated opinions hostile to Catholic belief in the personality and divinity of the Holy Spirit.

Nestorios, c. 428, Patriarch of Constantinople, declared that the title $\theta$ єотоко was inapplicable to the Virgin Mary, since God could not be born of a human creature. The word had been used to exprcss the orthodox doctrine of the two Natures in the one Person of Christ. He was condemned and deposed by Council of Constantinople 431.

Noetus, a Presbyter of Smyrna, denied the distinction of Persons in the Godhead, and declared that the Father suffered on the Cross as a necessary result of the 'passibility' of the Divine Naturo itself.

Padl of Samosata, c. 260. Bishop of Antioch, a man of lax opinions, and said to be of still looser morals. Theodoret states that he adopted the views of Artemon in order to ingratiate himself with Zenobia, Queen of Palmyra. He forms a link between Artemon and Arius, and is credited with denial of the Trinity, and the true divinity of Christ, though maintaining the Virgin Birth. Condemned and deposed by Council of Antioch, 270.

Pelagrans. Followers of Pelagius, the Briton of the 5th cent., whose denial of original sin and the nceessity of prevenient grace was refuted by Augustine. 
Praxeas, c. 200. Maintained only one Divine Person in the Godhead, yet acknowledged a Divine Nature in Christ, while in some way distinguishing Jesus from the Christ.

SABELLIUs, c. 220, a presbyter of Ptolemais, in or near Upper Egypt, developed the crroneous teaching of Praxeas and Noetus (q.v.), asserting that the Godhead consisted of but one Person only, from Whom the Son and the Spirit emanated, the former charged with the work of redemption, the latter with that of quickening the Church. Since this theory would infer that the Father suffered on the Cross, those who held it are spoken of as Patripassians. Sabellianism stands at the opposite pole from Arianism.

Theodotus. Two heretics bore this name; 'the Tanner' and 'the Banker.' The former flourished c. 190; charged with apostasy during a time of persecution, his defence was that he had denied not God but man : his views were similar to those of Cerinthus. The latter perpetuated his namesake's errors.

VALENTINUS, $c$. 150, a presbyter of Alexandria, originator of a Gnostic sect, holding a most complicated system of speculative philosophy. He was among the first to attempt to combine Judaism and Christianity with Oriental philosophy.

\section{No. 3. LITURGICAL AND ECCLESIASTICAL TERMS.}

\section{(1) Services and Ceremonies.}

Ablutions. The ceremonial washing of the ressels at Holy Communion.

Asperaes (Lat. aspergere, 'sprinkle'). A rite of the R.C. Church, during which altar, clergy, and congregation are sprinkled with holy water. It is performed with a kind of brush-the 'aspersorium ' or 'aspergillum.'

Beatification. The act by which a deceased person is declared one of the 'blessed,' and therefore a proper subject of a certain degree of public religious honour, the power to confer which is now an exclusive prerogative of the Pope. It is usually the second step towards canonization and cannot take place till fifty years after death.

Candlemas Day. February 2. A festival of the Roman Church, commemorating the Presentation of Christ in the Temple. On the strength of the reference in St. Luke ii. 32, candles are carried in procession, and those to be used in the coming year are consecrated.

Coimmemorations. A short service in memory of the departed. The name is also given to the prayers for the dead in the Mass.

Excomis (Lat. encomium, 'eulogy'). Festivals, commemorating the consecration of churches.

Exoncism. The expulsion of the demon from one possessed, still part of the ritual of Baptism in the Greek and Roman Churches. 
FerLLL (Lat. feria, 'holiday'-the original application of the word has been reversed: no explanation is forthcoming). Strictly, any day of the week but Saturday or Sunday. Denotes any day which is not a festival.

Hoosel (A.S. huslian, 'to administer the Lord's Supper '). The bread in the Holy Communion (archaic).

Lammas (A.S. 'Hläf Masse,' 'Loaf Mass'). An old English Harvest Festival, celebrated on August 1. Bread was then presented at the Mass as a thankoffering.

LAVABO. In the Ritual of the Mass, the act of washing the hands of the Celebrant. The priest recites Psalm xxvi. 6, commencing with the word lavabo.

Low Mass. The Mass as said plain, by the priest without a choir. Mass (Lat. missa, 'sent'; from ite, missa est, 'go, the congregation is sent away'). The name of the Holy Communion, retained as a well-known title in the Prayer Book of 1549, but expunged in 1552.

Mrssa Sicca. A Mass without consecration or communion.

OCTave (Lat. octava, 'eighth'). The extension of a Festival up to and including the eighth day.

Pentecostals. Offerings made at Whitsuntide ('Whitsun-farthings') to the clergy of a parish.

Presanctified (Lat. pre, 'before'). The 'Mass of the Presanctified' is celebrated on Good Friday, with a wafer consecrated the day before.

Trental (Fr. trente, 'thirty'). A series of thirty Masses for the dead.

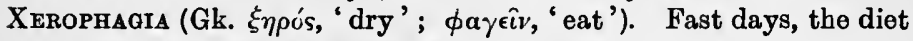
being restricted to bread, salt and herbs.

YUle (A.S. Geol, 'December'). Christmas.

\section{(2) Things used in Church Services.}

Ampolla (Ampholla, Amphora, $\dot{\alpha} \mu \phi i$, 'on both sides'; фoptés, 'a bearer'). A cruet, holding the wine and the water for Sacramental use. Also the receptacle for the oil at a Coronation.

ANTEPENDIUM (Lat. ante, 'before'; pendere, 'hang'). The silk or velvet frontal which hangs from a prayer desk, or from the sermon desk in the pulpit.

AsPERGILlum (Lat. aspergere, 'sprinkle '). 1. The brush, or other instrument, by which holy water is sprinkled. 2. A stoup for holy water.

AUMBRy or AMbry (Lat. aumarium, 'chest'). A recess in the wall of a church near the Holy Table, designed to receive the sacred vessels.

Boat. The vessel containing incensc placed in the 'thurible.'

BoGIA (Fr. bougie, 'candle'). A candlc carricd in procession. 
BURse (Lat. bursa, 'purse'). The case, usually of carboard covered with silk, in which are placed the linen cloths used at the Celebra. tion of Holy Communion.

Crenser. A ressel in which incense is burned.

Chatice (Lat. calix, 'cup'). The cup at Holy Communion.

Chalice Vetr. The Chalice Veil is the silken covering of the vessels before the offertory ; while the Pall is a square piece of linen, used to cover the sacred vessels, at the close of the administration of Holy Communion.

Chirismal or Chrismatory. The vessel in which the chrism, or 'holy oil,' was contained.

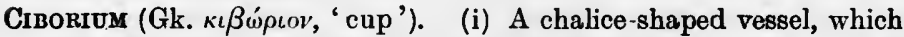
contains the Host-bread in communicating the people. (ii) $\mathrm{A}$ canopy, above the high altar, in a Roman Catholic church.

Corporal (Lat. corpus, 'body'). A linen cloth, spread on the Holy Table, on which are placed the sacramental vessels.

Cruets. Glass vessels contain:ing wine and water.

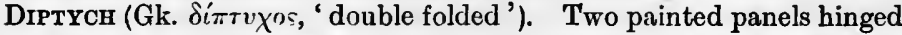
together; also tablets, on which were inscribed the names of those to be commemorated at the Holy Communion, later known as the ' bead-roll.'

Dossel or Dossal (Lat. dorsalis, 'pertaining to the back'). Hangings of embroidered cloth or silk, covering the wall behind the Communion Table.

Fanow (Fr. fanon, 'pendant,' ' banner'). A napkin, used by officiating priest at Mass; also, an alternative term for 'Maniple' (q.v.); also the band of silk hanging from a mitre.

Flagon (Lat. flascus, 'flask'). The covered vessel, in which sacramental wine is brought to the Holy Table.

Frontal. Hangings often used to cover the front of the Holy Table.

Gremial (Lat. gremium, 'bosom'). A square of silk, placed on the knees of a Bishop, to protect his robes from the consecrated oil.

LABARUM. Originally the imperial Roman standard; later, used of a banner borne in a religious procession.

Monstrance (Lat. monstrare, 'show'). A vessel, in which the consecrated wafer is exhibited for adoration.

Mundatory (Lat. mundus, 'clean'). See 'Purificator.'

Navicula (Lat. navis, 'ship'). Same as 'Thurible,' q.v.

Paschal Candle. In Roman ritual, a candle 'blessed' by the Priest on Easter-Eve, and set at the north side of the Sanctuary until Ascension Day. It was sometimes broken into fragments, which were given to the poor for funeral purposes, and then known as 'poor lights.' 
Paten (Lat. patina, 'a shallow dish '). A small silver plate on which the bread is placed at the time of Holy Communion.

Pax. A tablet engraved or painted with the representation of some Christian symbol or story. Formerly at Mass, it was kissed by the celebrant, assistants, and worshippers. It superseded the 'Kiss of Peace ' (1 Cor. xvi. 20). Hence, sometimes called 'Osculatory.'

Pede Cloth. The mat on the floor before the Holy Table.

Poмe (Lat. pomum, 'apple '). A globular, or apple-shaped, vessel filled with hot water, at which the Mass priest eould warm his fingers while celebrating.

Purificator (Lat. purificare, 'make elean'). A small linen eloth used for cleansing the Chalice at Holy Communion.

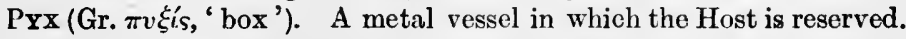
It was known also as the arca or turris, and, in the Greek Church, Artophorion.

Sanctos Bell. A bell rung at the Sanetus, in preparation for the elevation of the Host.

Super Frontal. The cover of the Holy Table hanging over the frontal.

TabernacLe. A receptacle, usually placed upon the 'altar' in a R.C. Church, in which is placed the Pyx (q.v.), containing the reserved host.

Thurible (Lat. thuribulum, 'ecnser'). The bearer of the censer is called 'Thurifer.'

(3) Vestments.

AlB (Lat. albus, 'white'). A vestment of white linen, fitting closele to the body and reaching to the ground. It is worn under the copy or chasuble and is 'apparelled' with square pieces of embroidered work. In the Greek Church i is known as the Stoicharion.

AlmUCE or Amys. A furred hood with long ends hanging down the front; worn in church as a protection against cold.

AMIcE (Lat. amictus, 'mantle '). An oblong piece of embroidered linen, secured round the neek and falling over the shoulders over the alb.

APParel. Decorative patches of lace or silk worn upon the wrists and skirt of the alb, or upon the outcr part of the amice.

BrReTta (Lat. birrus, 'hood'). An ecelesiastical head-dress, square. with three intersceting ridges.

Cassock (Fr. casaque, 'jacket' or 'jerkin'). A long black garment, worn under the surplice.

Chasuble (Lat. casula, 'a hut'). The outermost of the Mass vest. ments, without sleeves, and riehly urnamented, bearing a Y Cross, back and front, in the Transalpine West, a T Cross, on the front only, being the Italian form. In the Greek Chureh it is known 
as the Phelonion. Reference to the Greek of 2 Tim. iv. 13 will indicate the non-ecclesiastical origin of this garment. It is essentially the sacrificial vestment, and in 1549 B.C.P. it is called the 'Vestment.'

Chimere (also spelt Simar, Spanish zamarro, 'sheepskin,' hence any ' loose gown'). The episcopal robe of black satin, to which, for convenience, the lawn sleeves are attached; see p. $5 \leqslant 2$.

CnNoture (Fr. ceinture, Lat. cinctura, ' girdle'). A girdle worn round the cassock.

COPE (Lat. cappa, 'cape '). Strictly a processional or choral vestment. The former is of rich material fastened over the breast by an embossed or jewelled clasp, called a 'morse.'

Cotra (Lat. cotta, 'coat'). A short surplice trimmed with lace.

Dalmatic (Lat. dalmaticus, "pertaining to Dalmatia'). First appears (in non-ecclesiastical use) in second century as the "tunic of the Dalmatians,' whence the name; Mediæval vestment for the deacon, worn over the alb.

MaNiple (Lat. manipulus, 'handful'). One of the Mass vestments, originally a handkerchief, now a narrow silken strip, worn upon the left wrist of the celebrant.

ORPHREY (Lat. aurum Phrygium, 'Phrygian gold'). An ornamental band of embroidered work found on vestments, frontals, etc. The orphrey on a Bishop's mitre is technically called the auriphrygia.

Pallium (Lat. pallium, 'coverlet'). A vestment which, under the name of the 'Pall,' is constantly met with in early English Church history; of wool, as indicating the pastoral office; it consists of a narrow band like a ring, passing round the shoulders, with two short vertical pieces falling respectively down breast and back. . . . By the seventh or eighth century it came to be regarded as a sign of acknowledgment of papal supremacy. Though no longer worn by Anglican archbishops, it forms part of the heraldic insignia of the Archbishops of Canterbury, Armagh and Dublin.

ROcHET (Ital. rochetto, 'mantle'). A linen vestment worn by Bishops, under the Chimere.

SCARF (properly ecarp; A.S. sceorp, 'robe'). A broad band of black silk worn over the shoulders, the 'Tippet' of Canons 58 and 74. Stole (Lat. stola, 'robe'). A strip of silk, worn yokewise over the shouldcrs, the ends hanging down in front; often coloured according to the ecclesiastical season. The scarf is often misnamed 'stolo' in Anglican use, and the confusion lias led almost to the disappearance of the true scarf.

Tunicle. Somewhat like the Dalmatic (q.v.), worn by the sub-deacon.

Vhistment (Lat. restimentum, 'vesture'). Etymologically a yy garment, but largely confined to ecclesiastical dress. It ha; been the technical term for the Chasuble (q.v.). 


\section{(4) Hebrew Terms.}

Alleluia (Heb. Hallelu-Jah, 'praise ye Jehovah'). An ascription of praise; the Grcek form found in N.T. only in Rev. xix. 1, 3.

AMen (Heb. Amen, 'firm, faithful'). (1) Adopts as one's own what has just been said; Num. v. 22. (2) Confirms one's own prayers; Rom. xv. 33. (3) Gives solemnity to an affirmation; John iii. 3. (4) A divine name; Rev. iii. 14.

Cherdan (Heb. K'rubhh, pl. strictly cherubim). An order of angelie beings.

Hosanna (Heb. Hoshiah-na, 'save us'). A plea for salvation in the form of praise.

SabaOth (Heb. 'armies,' 'hosts'). The heavenly hosts.

SeraphIN (Heb. strictly Seraphim, 'burning ones'). An order of heavenly beings, cf. Is. vi. 2.

No. 4. FAMOUS LITURGIOLOGISTS, ETC.

Ambrose. Born at Trèves, 340-397. Elected Bishop of Milan by popular acclamation, while as yet unbaptized and unordained. He became one of the most effective defenders of the Faith against Arianism; 'Ambrosian Ritual' bears his name.

augustine of Canterbury. Died 604. Sent to Kent by Pope Gregory in 597. Grafted Roman practices upon the native Christian stock ; first Archbishop of Canterbury, 600.

Augustine of Hippo. Born in Numidia, 354-430. In 395 became Bishop of Hippo. Prolific writer against heresies of the Donatists and Pelagians.

BASIL. Born at Cresarea, 329-379. By profession a teacher of rhetoric, having studied at Constantinople and Athens with his friend Gregory Nazianzen; when about thirty entered the monastio life, and in 370 became Bishop of Cæsarea. Determined opponent of Arianism, and a prolific writer of Commentaries, etc.

BAXTER, RichaRD, 1615-1691. Ordained in 1638, seven years later became Chaplain to Cromwell's troops. On the Restoration was appointed Chaplain to Charles II, but seceded from the Church of England on the passing of the Act of Uniformity, 1662. A volum. inous author, 'The Saints' Everlasting Rest,' 'A Call to the Unconverted,' etc.

Bede, The ' Venerable.' Born at Wearmouth 670 ; died at Jarrow 735. Chiefly famous as the author of an ecclesiastical history of the English people.

Bucer, Martin. Born in Alsace 1491; died at Cambridge 1551. Colleague of Luther in the Reformation movement, and, coming to England at Cranmer's invitation, became Professor of Divinity at Cambridge. 
Bullinger, Henry. Born in Switzerland 1504; died 1575. An ardent Reformer, friend and successor of Zwinglius, and influential in the formation of reformed Confessions of Faith.

Calvin, John. Born in Picardy 1509; died 1564. One of the strongest formative influences in the Reformation movement. When only twenty-seven he published his famous 'Institutes,' and at Geneva, later, developed the system of Church government associated with his name.

Cirnysostom, 347-407. Presbyter of Antioch, and afterwards Patriarch of Constantinople, 398-404. An eloquent preacher-hence his name, 'Golden Mouth,' and a commentator on Holy Scripture.

Clement (of Alexandria), 150-220. Head of the Catechetical school at Alexandria, and a voluminous writer.

Clement (of Rome). Died c. 100. Prominent amongst the Christians in Rome in the sub-Apostolic period through his Epistle to the Corinthians.

Cosin, 1594-1672. Dean of Peterboro' in 1640, and Bishop of Durham twenty years later. A keen Royalist, and sympathetio with the ecclesiastical outlook of Laud. Author of various liturgical writings.

Cranmer, Thomas, 1489-1556. Archbishop of Canterbury 1533, and thenceforward increasingly a supporter of the Reformation movement. Married the niece of Osiander. The English Prayer Book owes much to him. Martyred at Oxford.

GaRDINER, c. 1485-1555. Bishop of Winchester 1531; a staunch ally of Henry VIII in his domestic and ccclesiastical difficulties. In the reign of Edward VI he opposed the reforming views of Cranmer, was deprived and imprisoned, but was reinstated on the accession of Mary.

Gelasius. Pope 492-496. The reputed compiler of a Sacramentary, from which some twenty-seven Collects in B.C.P. are taken.

Gregory the Great. Pope 596-604. Credited with much liturgical work, especially the Sacramentary, which was largely used in B.C.P.

GrTNDaL, 1519-1583. Bishop of London 1559; translated to Canterbury 1575. Sympathized strongly with Puritan ideals, which led to his suspension by Elizabeth from 1577 to 1582 .

Gunnina. Bishop 1662. Author of the Prayer for 'All sorts and conditions of Men.'

Hermans. Died 1552. Archbishop, and Elector of Cologne, 15181547. Influenced by Luther he issued in $\mathbf{1 5 4 5}$ a new service book for use in his diocese, based on one by Luther himself, under the title of 'A simple and religious Consultation by what means a Christian Reformation may be begun,' an English v.rsion of which was published in London. To this book our Prayer Buok owes muoh. 
HrLsey. Bishop of Rochester 1539. Author of a Primer utilized by the Reformers in their work upon the English Prayer Book.

HOOPER. Born 1495; martyred 1555. Under the influence of Zwinglius became a Reformer. Appointed Bishop of Gloucester 1550 ; his scruples as to taking the canonical oath, and wearing the episcopal habit, led to his temporary imprisonment. He was again imprisoned under Mary, condemned for heresy, and burned at Gloucester.

Jewel, 1522-1571. The friend of Peter Martyr, he retired to Frankfort on the accession of Mary, returning to England at her death, and became Bishop of Salisbury. A prominent figure at the Westminster Conference 1559. He is best known as the author of 'The Apology.'

LASCO, 1499-1560. A prominent Pole, leader in the Reformation movement on the Continent. Visited England at Cranmer's invitation, and there acted as overseer of the Church of Foreign Protestants in Austin Friars. On the accession of Mary he returned to Holland.

LATIMER, 1485-1555. Bishop of Worcester. In early days ' as obstinate a Papist as any in England,' but later taught the reformed doctrines by Bilney. A preacher of power and fervour, he did much for the cause of the Reformation. Martyred at Oxford.

LAUD, 1573-1645. Successively Bishop of St. David's and London, and Archbishop of Canterbury. An ardent supporter of the monarohy. As a subverter of the laws, the enemy of the Parliament and of the Protestant religion, he was impeached by the Commons and beheaded. He was a zealous opponent of Calvinism and Presbyterianism, and his drastic policy was supported and enforced by the Court of High Commission and the Star Chamber.

Leo the Great. Pope 440-461. The reputed author of a Sacramentary, MS. of which was discovered in the Library of Verona in 1735-the oldest Sacramentary known. Fivo of our Collects are derived from this source.

LUTher, 1483-1546. Entered the monastic life at Erfurt 1505. Visited Rome in 1510. On Octobcr 31, 1517, he nailed to the church door at Wittenberg his famous 'Theses,' and three years later was excommunicated. In 1521 he made his famous defence before the Diet at Worms, and was proscribed. The Elector of Saxony concealed him for nearly a year, the time being spent by Luther on a translation of the New Testament, the whole Bible being published in 1534 .

Nowell, 1507-1602. Dean of St. Paul's. Author of a Catechism approved by Convocation in 1572 .

Overall. Regius Professor of Divinity at Cambridge 1596. Strenuous opponent of Calvinistic views, supposed to be author of the 
concluding portion of the Catechism, dealing with the Sacrament (see p. 403), which was, however, largely drawn from Nowell.

Peter Martyr, 1500-1562. In early life an Augustinian, he for some years cherished Reformation principles, and in 1542 came under the notice of the Inquisition and escaped to Zurich. Became colleague of Bucer at Strasburg, and later, at Cranmer's invitation, lecturer in N.T. at Oxford till Mary's accession, when he returned to Strasburg.

Pollanus. A Flemish clergyman who in 1552 was ministering to a Walloon congregation in Somersetshire. The Liturgy used by these people was translated by Pollanus and was known as 'The Strasburg Liturgy.' It is a moot point whether this was published in time to influence the 1552 B.C.P.

Quianonez. A Spanish Cardinal, who, at the request of Pope Clement VII, drow up in 1535 a revised Breviary. Its motto was 'Search the Srriptures' and throughout it gave marked prominence to Scripture. Its life was a short one, the book being suppressed forty years later. Traces of its language are to be found in the Preface to our Book of Common Prayer.

ReYNoLDS. Bishop of Norwich 1662. Author of the General Thanks giving. A leader of the Puritans who accepted office in the Church of England at the Restoration.

RidLey, 1500-1555. Bishop of London 1550. Three years' residence on the Continent convinced him of the Scriptural character of the Reformers' teaching, of which he became a learned and powerful exponent. Shared with Cranmer the work of preparing the Articles. Burned at Oxford.

SANDrRSON, 1587-1663. Regius Professor of Divinity at Oxford in 1646, and subsequently Bishop of Lincoln. During the Commonwealth he compiled a Liturgy for the use of those clergy who clung to the old forms.

Whitgift, JohN, 1530-1604. Lady Margaret Professor of Divinity at Cambridge in 1563; Bishop of Worcester 1577; Archbishop of Canterbury 1583. A determined opponent of the Puritan party, he yet so strongly held Calvinistic views as to be concerned in the drawing up of the so-called Lambeth Articles of 1596. 


\section{APPENDIX E}

\section{LIST OF BOOKS FOR FURTHER STUDY*}

Absolntion. See under Conf ssion.

Act of Uniformity (1662), Parliamentary History of. Swalnson, C. A., 1875.

Acts of Uniformity, Text of.

2 and 3 Edward VI. 5 and 6 Edward VI. Stutes at Large.

1 Elizabeth, C. 2.

13 and 14 Car. II.

Statutes at Large, and Cornford, James,

An Act for the Amendment Book of Common Prayer with His. of the Act of Uniformity, torical Notes, 1906.

35 and 36 Victoria.

Anabaptist Errors. Rogers, Thomas, An Exposition of the Thirty-Nins Articles, with introduction by J.J. S. Peroune, 1854 (see Index).

Antiquities of the Church.

Bingham, J., The Antiquities of the Christian Church, 1856.

Smith, W., and Chectham, Samuel, The Dictionary of Christian Antiquities, 1875.

Apostles' Creed. See under Creeds.

Apostolical Constitutions.

Article in Smith and Cheetham's Dictionary of Christian Antiquities. Ante-Niccne Library, vol. xvii. (Translation of Text).

Apostolical Succession. Soe also under The Church.

Aitken, W. Hay M. H., A postolical Succession, 1903.

Gore, Charles, The Ministry of the Christian Church, 1889.

Haddan, $\dot{A}$. W., A postolical Succession in the Church of England, 1869.

Hatch, Edw., The Organization of the Early Christian Churches, Bamp. ton Lectures, 1880.

Lindsay, Thomas M., The Church and Ministry in the Early Centuries, 1902.

Moberly, R. C., Ministerial Priesthood (Tractarian), 1897.

Wordsworth, John, The Ministry of Grace (Tractarian), 1001.

Articles of 1552, 1553, 1563, 1571, Text of.

Hardwick, C., A History of the Articles of Religion, 1884. (See Appendix, which contains also tho 104 Articles drawn up for Ireland.)

Articles, The Thirty-Nine.

Boultbee, T. P., $A$ Commentary on the 39 Articles, 1871.

Browne, F. Harold, Exposition of the 39 Articles, 1887.

Gibson, E. C. S., The 39 Articles, 1898.

Maclear, G. F., and Williams, W. W., An Introduction to the Articles of Religion of the Church of England, 1899.

Smith, J. Hamblin, Exposition of the 39 Articles.

Tait, Arthur J., Lecture Outlines on the 39 Articles, 1910.

- As the history of the Reformation is inseparably connected with that of the B.C.P. works on the former have been Included. The list is not exhaustive, but represcutative, and practically useful works, covering a suffieiently wide field for ordinary purposes, are glven. By its aid refercnce can easily be made to a still wider range of literature. The date given is in nearly all cases that of the latest or best edition of the work named. 
Athanasian Creed. See under Creeds.

Atonement. Remensnyder, J. B., The Atonement and Modern Thought

Baptism. Philadelphia, 1905.

Goode, W., The Doctrine of Infant Baptism, 1864.

Mozley, J. B., Review of the Baptismal Controversy, 1883.

Stone, D., Holy Baptism (Tractarian), 1899.

Wall, W., History of Infant Baptism, 1862.

Bibliography (Historical and Liturgical).

Political History of England, (Hunt and Poole), v-vii, 1907, eto.

Cambridge Modern History, II, The Reformation, 1903.

Central Society of Sacred Study, 1907-1911, Leaflet 46a; History, pp. 16-23; Liturgiology, pp. 23-25.

Biographies. See also under Non-Conformity, and Non-Jurors.

\section{Archbishops of Canterbury.}

Hook, W. F., Lives of, 1868.

\section{Calvin.}

Walker, Williston, Life of, in Heroes of the Reformation Series, 1906.

\section{Compilers of Liturgies.}

Downes, Samuel, Lives of, prefixed to Anthony Sparrow's Rationale, 1722.

Cranmer.

Cox, John Edmund, Life of, Parker Society P'ublications.

Jenkyns, H., see Preface to The Remains of Thomas Cranmer, 1833.

Pollard, A. F., Life of, 1904.

Strype, John, Memorials of, 1896.

\section{Elizabeth, Queen.}

Camden, William, History of, 1719.

Creighton, Mandell, Life of, 1899.

\section{Erasmus.}

Capey, Ernest F. H., Erasmus, 1902 (contains a valuable list of his works). Drummond, R. B., Life and Writings, 1877.

Emerton, J. Ephraim, in H.R. Series, 1899.

Froude, J. A., Life and Letters of, 1901.

Strype, John, Life of, 1821.

\section{Grindal.}

Parker Society, Arindal's Remains, 1850.

Hooker.

Walton, Isaac, Life of, in Hooker's Works, 1868.

\section{Hooper.}

Nevinson, Later Writings of Bp. Hooper, with Biographical Sketch, 1852.

Ryle, J. C., Bishops and Clergy of other Days, 1868.

Knox.

Cowan, Henry, Life of, in H.R. Series, 1898.

Latimer.

Carlyle, A. J., Life of, in H.R. Series, 1899.

Demaus, Robert, $A$ Biography of, 1881.

Parker Society, Latimer's Remains, 1845.

Land.

Bell, Archbishop Laud and Priestly Government, 1905.

Heylyn, Peter, Life of, 1719.

Simpkinson, C. H., Life and Times of, 1894.

Luther.

Jacobs, Henry E., Life of, in H.R. Series, 1898.

Köstlin, Julius, Life of, 1898.

Melanchthon.

Richards, Jamee W., Life of, in H.R. Series, 1898. 
Oxford Reformers (John Colet, Erasmus, and Thomas More).

Seebohm, Frederick, History of their Fellow Work, 1887.

Popes, The.

Ranke, L. von, History of, 1866.

Creighton, M., History of the Papacy, 1882-94.

Grisar, History of, Authoriz ?d English Translation, 1911 (in progress).

Tyndale, William.

Demsus, Robert, Life of, 1871.

\section{Wycliffe.}

Carrick, J. C., Wycliffe and Lollards, 1908.

Loserth, John, Wiclif and Hus, tr. by M. J. Evans, 1884.

\section{Zwingle.}

Jackson, Samuel Macauley, Life of, 1898.

Consult Smith and Wace, Dictionary of Christian Biography, Dictionary of National Biography, and Wordsworth's Ecclesiastical Biography, Edn. 4, 1853.

Book of Common Prayer, Aids to Study of the Editions of the Prayer BookFacsimiles, published by William Pickering, 1844.

The Two Liturgies, in Parker Society Publications, 1844.

The Elizabethan Prayer Book, P. S. Publications, 1847.

Statutory Prayer Book, 1962, J. T. Tomlinson, and C. H. H. Wright.

Bailey, Henry Ives, The Liturgy compared with the Bible, 189 .

Cardwell, Edw., History of Conferences about the Prayer Book, 1842. Documentary Annals of the English Prayer Book, 1840.

Dimock, R. N., Vox Liturgice Anglicance, 1897.

Dowden, J., Workmanship of the Prayer Book, 1902.

Further Studies in the Prayer Book, 1908.

Drury, T. W., How we got our Prayer Book, 1901.

Principles of the B.C.P., 1909.

Two Studies in the B.C.P., 1901.

Gee, H., Elizabethan Prayer Book, 1902.

Girdlestone, R. B., Hard Words in the Prayer Book, 1908.

Green, J., A Concordance to the Liturgy, 1851.

Hague, Dyson, Protestantism of the Prayer Book, 1893.

Harford and Stevenson, The Prayer Book Dictionary, 1912.

Joynt, R. C., Liturgy and Life.

Procter, F., A History of the B.C.P., 1870.

Pullan, L., German Precedents, 1874.

Tomlinson, J. T., The Prayer Book, Articles, and Homilies, 1897.

See slso under Liturgies.

Book of Common Prayer, Notes and Commentaries.

Allen, A. J. C., Notes on the Preface to the Prayer Book, 1899.

Barry, Alfred, The Teacher's Prayer Book, 1900.

Blunt, J. H., Annotated Book of Common Prayer (Tractarian), 1903.

Blakeney, R. P., The B.C.P., its History and Interpretation, 1870.

Campion, W. M., and W. J. Beamont, The Prayer Book Interleaved, 1868.

Cornford, James, The Book of Common Prayer with Historical Notes, 1906.

Daniel, Evan, The Prayer Book, its History, Language, and Contents, 1909.

Hole, Charles, A Manual of the Book of Common Prayer, 1903.

Humphry, W. G., A History and Explanatory Treatise on the B.C.P., 1881.

Procter, F., and W. H. Frere, A New History of the B.C.P., with a Rationale of its Offices (Tractarian), 1910.

Reynolds, Handbook to the Book of Common Prayer (Trartarian), 1904.

S.P.C.K., Prayer-Book Commentary, Revised by F. G. Warren, 1910.

Tomlinson, J. T., Tracts on Ritual.

Book of Common Prayer, Revision (Abortive) of 1689.

Cardwell, E., Book of B.C.P., ch. ix. (Abortive Revision).

The Proposals of the Commissioners are in a Blue Book of 1854. 
A Return to the House of Commons was ordered to be printed They are also printed and published separately.

Book of Common Prayer, Works on.

For a uscful descriptive list of such Works, see C. Hole's Manual of the B.C.P., 1903.

Calendar, The Ecclesiastical.

Article in The I'rayer-Book Dirtionary, 1912.

Butcher, Samuel, The Ecclesiastical Calendar: its Theory and Con struction, 1877.

Dowden, J., The Church Year and Calendar, 1910.

Cumbridge, Annals of, Cooper, Charles M., 1842-1908, 5 vols.

Canon L3w. See also under Ecclesiastical Law.

Maitland, F. W., Roman Canon Law in the C. of E., 1898.

Mylne, R. S., The Canon Law, 1912.

Ogle, A., Canon La'o in Mediceval England, 1912.

Richter and Friedberg, Corpus Juris Canonici, 1879.

Sinclair, W. M., The English Church and the Canon Law, 1894.

S.P.C.K., The Constitutions and Canons Ecclesiastical (made in the year 1603 and amended 1865), 1906.

Walcott, M. E. C., The Constitutions and Canons Eccl., referred to their original source, 1874.

Catechism, The.

Dimock, Nathaniel, Disputed Punctuation of, 1903.

Maclear, G. F., A Class Book of the, 1868.

Norris, Archd. J. P., The Catechism and the Prayer Book, 1842.

Catechism of 1552. Parker Society Publication, The Tuo Liturgies, 1844.

Catechism, Nowell's (Parker Society Publications), 1853.

Catechism, The Shorter, published by T. \& T. Clark.

Carruthers, Wm., a facsimile of lst Edn., with historical account and bibliography, 1897.

Catholic Faith.

Thomas, W. H. Griffith, The Catholic Faith, 1911.

Westcott, B. F., Historic Faith, 1883.

Church, The. See also under History: Greek, Gallic, Latin; Infallibility.

Allen, A. V. G., Christian Institutions, 1898.

Field, R., Of the Church, 1601-10.

Lightfoot, J. B., Excursus in Commentary on Philippians, 188.

Rainy, Robert, The Ancient Catholic Church, 1902.

Collects.

Wordsworth, Chr., Theophilus Anglicanus, 1879.

Bright, W., Ancient Collects, 1862.

Goulburn, E. M., The Collects of the Day, 1883.

Communion, Evening.

Hughes-Games, Joshua, Evening Communion, 1894.

Liddon, H. P., Evening Communion, 1876 . Publislied by the E.C.U.

Reports of Convocation on the Subject.

Communion, Hoiy. See under Lord's Supper.

Communion, Fasting.

Kingdon, H. 'T', Fasting Communion, 1875.

The Protestant Dictionary, see article under that title.

Puller, F. W., The Fast before Communion (Tractarian), 1903.

Confession.

Drury, T. W., Absolution and Confession, 1903.

Lea, H. C., Auricular Confession, 1896.

Report of the Fulham Round Table Conference, 1901.

Confessions of Faith.

Schaff, Philip, Protestant Confessions, 1884.

Conflrmation.

Chase, F. H., Confirmation in the Apostolic Age, 1909.

Hague, Dyson, Confirmation, 1912.

Hall, A. C. A., Confirmation (Tractarian), 189 ?.

Fastings, James, Encyclopcedia of Religion and Ethics, see article on Confirmation, 1908. (Contains a comprehonsive historical review of the subiect.)'

Wright, J. C Confirmation, Engligh Church Jan!zals 1910. 


\section{Conrocation.}

Fellows, T. H., Convocation, its Origin, Progress and Authrity, 1852.

Lathbury, T., History of, 1853.

Peace, R. R., Law of Convocation, 1851.

Whitehead, Benj., in Halsbury's Laws of England, Art. Convocation.

Chronicle of Convocation (Canterbury), 1847 in progress. National Society.

York Journal of Convocation, 1861 in progress. National Society.

Councils. See also under Trent.

Bright, W., Canons of the First Four General Councils, etc., with notes, 1882.

Bose, W. P. Du, The Ecumenical Councils, 1897.

Haddan, A. W., and Stubbs, W., C. and Eccl. Documents, 1871.

Hardouin, P., Concilia, 11 vols., 1715.

Hefele, C. J., History of the Christian Councils, translated and edited by H. N. Oxenham, 1876.

Labbeus, P., Sacrorum Conciliorum nova et amplissima collectio, fol., 1759, in progress.

Landon, E. H., A Mantial of Councils of the Holy Catholic Church, 1893.

Nicolas, N. Harris, Chronology of History, 1838. (Contains an enumeration of 1604 Councils, with alphabetical list.)

Wilkins, D., Concilia Magnoe Britannice et Hibernia, 1851-53.

Creeds. See also under Theology.

Schaff, Philip, Creeds of the Evangelical Protestant Churches, 1884.

Curtis, W. A., A History of Creeds and Confessions of Faith in Christendom and beyond, 1911. (Gives full text of the ancient Creeds. Contains much valuable information; its tone, however, is rationalistic.)

Gibson, G. C. S., The Three Creeds, 1908.

Swainson, C., The Nicene and the Apostolic Creeds, 1875.

Turner, C. H., The History and Use of Creeds and Anathemas, 1906

Apostles'.

Goodwin, Harvey, The Fountation of the Creed, 1889.

McGiffert, A. C., The A postles' Creed, Its Origin, Purpose, etc., 1902.

Pearson, John, An Exposition of the Creed (ed. Sinker), 1899.

Swete, H. B., The Apostles' Creed in relation to Primitive Christianity.

\section{Athanasian.}

Taylor, R. O. P., The Athanasian Creed in the 20th Century, 1911. N.B.-See Works referred to, pp. 125-135.

Lias, J. J., Nicene Creed, 1897.

Nicene.

Swainson, C. A., The Nicene and Apostolic Creeds, 1875.

Dead, Prayers for the.

Drury, T. W., Prayers for the Dead, 1909.

Luckock, H. M., Prayers for the Dead, 1886.

Wright, C. H. H., The Intermediate State and Prayers for the Dead, 1900.

Dictionaries.

Blunt, J. H., Dictionary of Doctrinal and Historical Theology (Trac tarin), 1872.

Bumpus, John S., A Dictionary of Ecclesiastical Terms.

Harford, G., and Stevenson, M., The Prayer-Book Dictionary, 1912.

Hook, W. F., A Church Dictionary, 1887.

Lee, Fred. G., A Glossary of Liturgical and Ecclesiastical Terms, 1877.

M. T. (Moore, Thomas), Dictionary of the English Church, 1881.

Didaché.

Wright, C. H. H., and Neil, Charles, The Protestant Dictionary, 1904.

Romestin, H. De, The Teaching of the Tuelve Apostles, 1885.

Schaff, Philip, The Oldest Church Manual called 'The Teaching of the A postles,' 1887.

Spence-Jones, H. D. M., The Teaching of the Tuelve A postles, 1885.

Translation of, in Ancient and Modern Library of Theol. Lit., The Ap. Fathers, Part II, p. 171.

Directory, The.

$A$ Directory for the Public Worship of God throughout the three Kingdoms of England, Scotland, and Ireland, 1644.

The Westminster D.. edited bv T. Leishman. 1901. 
Divine Service, The Principles of. Freeman, P., 1855-62.

Documents. See also under State Papers ; Articles.

Political History of England, ed. by Wm. Hunt and R. C. Poole, 1905, etc., vols. v-viii.

Burnet, Gilbert, History of the Reformation, ed. Nicholas Pocock, 1865. (Contains valuable records, 1320-1713, of which an Index is furnished, vol. vii. pp. 251-280.)

Cardwell, E., Documentary Annals of the Reformed Church of England, Iniunctions, Declarations, Orders, etc. (1546-1716), 1839.

Gardiner, S. R., Constitutional Documents (1625-60), 1906.

Gee, H., and Hardy, W. J., Documents Illustrative of English Church History, 1896.

Hamilton, W. D., The Chronicle of Wriothesley, 1878.

Kidd, J., Documents Illustrative of the Continental Reformation, 1911.

Lewis, J., The Reformation Settlement, being a Summary of the Public Acts and Official Documents relating to the Law and Ritual of England from A.D. 1509 to $1666-1885$.

Lloyd, C., Formularies of the Faith put forth by Authority, 1856.

Maskell, W., Monumenta Ritualia Ecclesice Anglicanoe, 1847.

Parker Society Publications. (Contain a valuable series of liturgical texts of Reformation:period, besides other writings illustrative of the history. Consult In lex.)

Pocock, N., Records of Reformation, 1870.

Prothero, G. W., Statutes and Documents (1558-1625), 1906.

Sparrow, Bp., A Collection of Articles and other Public Records of the Church of England (Reprint), 1846.

State Papers, Eleven Volumes of selected (Record Commissioners, 1830-1852).

Letters and Papers, Foreign and Domestic, ed. by J. S. Brewer (p. 32), 1862-76.

Strype, J., Ecclesiastical Memorials, 1822.

Stubbs, W., Registrum Sacrum Anglicanum, 1897.

Fcclesiastical Law.

Burn, Ecclesiastical Laws, ed. by Robert Phillimore, 1877.

Cripps, A. C., Law relating to the Church and the Clergy, 1886.

Godolphin, Repertorium Canonicum, 1687.

Makower, F., Constitutional History of the Church of England, 1895.

Miller, Henry, A Ciuide to Ecclesiastical Law, 1907.

Phillimore, R., Ecclesiastical Law, 1895.

Steer, John, Parish Lau, 1899.

Stephens, A. J., Ecclesiastical Statutes, with useful notes, 1846.

Whitehead, Benj., Church Lau, 1911. (Being a concise Dict. of Statutes, Canons, Regulations, and decided cases affecting the clergy.)

Eucharist. See under Lord's Supper.

Evangelical Movement. See also under History : Church of England.

Balleine, G. R., A History of the Evangelical Party in the Church of England, 1908.

Evening Communion.

Games, Hughes, Evening Communion, 1878.

Tomlinson, J. T., Review of Canon Knox-Little's Answer to Archdeacon Farrar, 1894. See also The Chronicle of Convocation of Canterbury, Report No. 276.

Fathers, The.

Blunt, J. J., The Early Fathers, 1875.

Harrison, J., Whose are the Fathers, 1837.

Lightfoot, J. B., The A postolic Fathers, ed. by J. R. Harmer, 1891.

Migne's Patrologia Latina, vols. liii., Ixxii., Ixxiv., Ixxviii.

Oudini Dissertationes, 1722. (Gives an account of each early writer, and an analysis of his work.)

Pusey, E. B., Library of the Fathers anterior to the division of the East and West.(Translations).

Suiceri Thesaurus Eccles., 1746. (Answers as a complete index to the Greek Fathers.)

Whitby, Dan., Diss. de Scripturarum Interpretatione, 1714. (Quotes the conflioting opinions of the Fathers.) 
First Six Centuries.

Palmer, J. R., The Case against the Proposed Appeal to the First Six Cen. turies, 1905.

Hampton Court Conference. Cardwell, E., Conferences, ch.iv., 1841. (Includes a report of Barlow's 'Sum and Substance of the Conference at Hampton Court.')

Heresies and Sects.

Blunt, J. H., Dictionary of Sects, Heresies, Ecclesiastical Parties, and Schools of Religious Thought, 1874.

Browne, L. Harold, Exposition of the Thirty-Nine Articles, 1887. (See. Index under Heresies and Sects.)

Gwatkin, H. M., Studies of Arianism, 1882.

Hastings, Encyclopcedia of Religion and Ethics, 1908.

Smith, W., and Wace, H., A Dictionary of Christian Biography, etc:, Sects, etc., 1877-87. One-volume edition, 1912.

Eistory, Ecclesiastical.

Britain.

Hutton, William Holden, $A$ Short History of the Church of Great Bmitain, 1899.

\section{Church of England.}

Abbey, C. J., and Overton, J. H., The English Church in the 18th Century, 1878.

Dixon, R. W., History of the C. of E., 1529-1570, 1893.

Fuller, Thomas, Church History of Britain, ed. Brewer, 1845.

Hole, Charles, A Manual of English Church History, 1910.

Makower, F., Constitutional History of the Church of England (English Translation), 1895.

Patterson, W. M., A History of the C. of E., 1909.

Perry, G. G., Student's English Church History, 1861-64.

Plummer, A., English Church History, 1904-5.

Stephens, W. R. W., and Hunt, W., $A$ History of the English Church. (A.D. 597-1900, vol. vii.), 1899-1906.

Wake, W., The State of the Church, etc., 1703.

N.B.-Froude's History of England, Hallam's Constitutional History. of England, and Green's History of the English People contain a good deal of information respecting the Church of England. A General Index to the Historical and Biographical Works of John Strype, is an invaluable referenee book.

Gairdner, James, Henry VIII to Queen Mary, 1904.

Frere, W. H., Elizabeth to Charles I, 1904.

Hutton, W. H., Charles I to Anne, 1904.

\section{Early Church History.}

Bartlet, J. Vernon, The Apostolic Age, 1900.

Greek Ecclesiastical Historians, published by Bagster, 1845, and afterwards by Bohn.

Gwatkin, H. M., Early Church History to A.D. 313, 1909.

Waterman, Lucius, A postolic and Post-A postolic Ages, 1899.

The Christian Church.

Milman, H. H., Early Christianity, 1883.

Robertson, J. C., History of the Christian Church, 1858-73.

Schaff, Philip, History of the Christian Church, 1886-94.

The Gallic Church.

Scott, J., The Christian Church in Gaul, 1911.

The Greek and Eastern Churches.

Adeney, W. F., The Greek and Eastern Churches, 1898.

Neale, J. M., History of the Holy Easiern Church, 1850.

Stanloy, A. P., Lectures on the History of the Eastern Church, 1884.

The Latin Church.

Milman, H. H., History of Latin Christianity, 1864. 
Holy Spirit.

Moule, H. C. G., Veni Creator, 1890.

Swote, H. B., The Holy Ghost in N.T., 1900.

Homilies.

History of the Doctrine of the Procession of the H.S., 1876.

S.P.C.K. Edition, 1908.

Tomlinson, J. T., The Prayer Book, Articles and Homilies, 1897.

Hour Services, The.

Breviary Offices from Lauds to Compline inclusive, translated from the Sarum Book, and supplemented from Tallican and Monastic Uses. Edited by the Members of St. Margaret's Sisterhood, East Grinstead (Tractarian), 1874.

Infallibility. Salmon, George, Infallibility of the Church, 1890.

Jesuits, The.

Griesinger, Theodor, A Complete History of their. Open and Secret Pro. ceedings from the Foundation of the Order to the present time. Translated by J. A. Scott, 1883.

Walsh, Walter, The Jesuits in Great Britain, 1903.

Justiflcation by Faith. Consult books on 'The Articles.'

Lessons, Revised Table of. Blenkinsop, R. B. C. L., Historical and Com. prehensive Sketch of the Revised Table of Lessons, 1872.

Lincoln Judgment Case, The.

Roscoe's spec. ed. of The Lincoln Case in the Law Reports (1892), A.c. 662.

Tomlinson, J. T., The Historical Grounds of the Lambeth Judgment, 1892.

Litany. Karslake, W. H., A Manual of the Litany, 1878.

Liturgies.

Bray, T., Bibliotheca (gives a list of the chief liturgies of all ages), 1707.

Cabrol, Le Rme Dom., Introduction aux Ettudes Liturgiques (Paris), 1907.

Daniel, H. A., Codex liturgicus, 1851. (Gives the liturgies of the Papal, Lutheran, Oriental, and Reformed Churches, with valuable notes.)

Hall, Peter, Reliquice Liturgica, and Fragmenta Liturgica, 1847-8. (Contains 12 Liturgies, including the Middelburg, Saxon, Scotch, and American.)

Hammond, C. E., Ancient Liturgies, 1878.

L'Estrange, Hamon, Alliance of Divine Offices, 1846. (Exhibits all the Engli s $\mathrm{h} \mathrm{Ch}$. Liturgies, with various readings and running commentary.)

Warren, F. E., article on Liturgies in The Encyclopodia Britannica.

Catalogue of Liturgies, Liturgical and Sacramental Works, classified with alphabetical index of Authors and Subjects, compiled by C. J. Steward, 11, King William Street, West Strand, W.C.

Anglican, see also under B.C.P.

Burbidge, E., Liturgies and Offices of the Church, 1885.

Palmer, W., Origines Liturgica, 1845.

\section{Continental.}

A Simple and Religious Consultation, by Hermann (Von Wield), Archbishop of Cologne.

Calvin, Directo:y (1545).

Daye's English Edition of Hermann's Consillation, 1548.

Pullain, Liturgia Sacra * * per Valerendum Pollanum, 1556. Sometimes called 'the Strasburg Liturgy.'

Greek and Oriental.

Bjerring, N., Offices of the Oriental Church, 1885.

Brightman, F. E., Eastern Liturgies, 1896.

Littledale, R. F., Offices from Service Books of the Holy Eastern Churches, Translations, 1863, 1867.

Renaudotii, E., Liturgiarum Orientalium Collectio, 1847. (Contains fifty Liturgies, with dissertations and notes.)

Swainson, C. A., Greek Liturgies, 1884.

Warren, F. E., The Liturgy and Ritual of the Ante-Nicene Church, 1897. (A brief outline with original text.)

Scrapion's Prayer Book. An Egyptian Pontifical (dated probably c. 350-356, translated from the edition of Dr. G. Wobbermin, with Introduction, Notes and Indices, by John Wordsworth, 1910. 
Liturgy and Ritual of the Ante-Nicene Church, by F. E. Warren, 1881.

Liturgy of the English Book of the 'A postolic Constitutions' (The), com. monly called The Clementine Liturgy, translated into English, with Introduction and Notes, by R. H. Creswell, 1900.

The Liturgies, by T. Brett (contains Translations of the Clementine, and the Liturgies of St. James, St. Mark, St. Chrysostom, Basil, etc.), 1838.

The Liturgies of SS. Mark, James, etc. Texts and Translations by J. M. Neale, and R. F. Littledale, 1869.

The Anle-Nicene Library, vol. xxiv., contains several ancient Liturgies, 1870.

Irish.

The Book of Common Prayer according to the use of the Church of Ireland, etc. Published by the Association for Promoting Christian Knowledge, Dublin, 1874.

Latin.

Muratori, L. A., Liturgia Romana Vetus (Venice), 1748.

Quignon, F., Breviarium Romanum, ed. J. W. Legg, 1888.

The Roman Breviary, translated by John, Marquess of Bute, 1908.

The 2nd Recension of the Quignon Breviary, translated by J. Wickham Legg, 1908, in Henry Bradshaw Society Publication.

Scottish.

Sprott, G. W., Scottish Episcopal Liturgies of the reign of James V1, 1875.

The Book of Common Order of the Church of Scotland, commonly known as John Knox's Liturgy, with Historical Introduction and illustrative notes, 1901 .

The Episcopal Book of 1637 reprinted for the Church Services Society, by Dr. J. Cooper, 1871 , (?) 1904.

The Ordinal in Wodrow Miscellany, 1842.

Liturgies compared.

Cardwell, E., The Two Liturgies of Edivard VI compared, 1838.

Keeling, W., Liturgice Britannice, 1851. (The text of the various editions of the B.C.P. arranged in parallel columns.)

Liturgice Americano, 1895.

Maskell, W., The Ancient Liturgies of the Church of England according to the Uses of Sarum, Bangor, York, Hereford, and the Modern Roman Liturgy arranged in parallel columns (Pickering), 1844.

The First Prayer Book of Edward VI, compared with the successive revisions of the B.C.P., also a concordance to the rubrics in the

Lollards. several editions, 1883, by James Parker.

Poole, R. Lane, Wycliffe and Movements for Reform, 1886.

Lord's Supper. See also under Evening Communion.

Cranmer, The Lord's Supper, with an Introduction by H. Wace, 1907.

Doctrine of the Holy Communion and its Expression in Ritual, Fulham Conference, 1900.

Dimock, N., Doctrine of the Lord's Supper, 1910.

Doctrine of the Sacraments, 1908.

Notes on the Round Table Conference of the Holy Communion and its Expression in Ritual, 1901.

Drury, T. W., The Elevation in the Eucharist, 1907.

Goode, W., The Nature of Christ's Presence in the Eucharist, 1856. A Supplement to the above, 1858.

Harrison, John, An Answer to Dr. Pusey's Challenge respecting the Doctrine of the Real Presence, 1871.

Meyrick, F., Doctrine of the C.E. on the Holy Communion, 1908.

Moule, H. C. G., Ridley on the Lord's Supper, 1895.

Newbolt, W. C. E., The Sacrament of the Altar (Tractarian), 1903.

Perowne, J. J. S., Doctrine of the Lord's Supper, 1898.

Ridley, On the Lo d's Supper (Parker Society Publications), 1845.

Scudamore, W. E., Notitia Eucharistica, 1876.

Stone, D., History of the Doctrine of the Holy Eucharist (Tractarian), 1909.

Thomas, W. H. Griffitb, Sacrament of Redemption, 1905. 
Tomlinson, J. T., The Great Parliamentary Debate of 1548, 1894.

Watcrland, D., The Doctrine of the Eucharist, 1896.

Martyrology.

Catley, S. R. and J. Townsend, Acts and Memorials of John Foxe, 1841.

Foxe, John, Martyrologia, 1848.

Foxe, Book of Martyrs, by Milner, with Essays by C. H. H. Wright, 1908.

Ministry, Christian. See also under Apostolical Succession.

Blunt, A. W., Studies in the A postolic Christianity, 1909.

Jacob, G. A., The Ecclesiastical Polity of the N.T., 1884.

Lefroy, Wm., The Christian Ministry; its Origin, Constitution, Nature, and Work, 1890.

Lightfoot, J. B., The Christian Ministry, Excursus in his Commentary

Monasteries. on the Philippians, 1883.

Suppression of the Monasteries, Camden Society.

Hole, Charles, Manual of English Church History, pp. 154, 152.

Non-Conformity.

Burrage, Champlin, The Early English Dissentcrs in the Light of Recent Research, 1550-1641 ; vol. i., History and Criticism; vol. ii., Illus. trative Documents, 1912.

Curteis, G. H., Dissent in relation to the E.C., 1872.

Dale, R W., History of English Congregationalism, 1897.

Non-Jurors.

Price, Thomas, History of Non-Conformity, 1840.

Lathbury, T., History of the Non-Jurors, 1845.

Macaulay, T. B., History of England, vol. ii., 1895.

Ordinal. See also Ministry.

Brightman, F.G., What Objections have been made to the English Orders, 1896.

S.P.C.K., Ordination Problems, 1909.

Oxford, Annals of.

Wood, Anthony, Athence (1500-1695), 1848.

Oxford Movement.

Browne, E. G. K., Annals of the Tractarian Movement from 1842 to 1860. (R.C.), 1861 .

Church, R. W., The Oxford Movement, Twelve Years (1833-1845), 1891.

Hall, S., A Short History of the Oxford Movement, 1906.

Liddon, H. P., Life of Dr. Pusey, 1893-97.

Minutes of Evidence taken before the Royal Commission on Ecclesiastical Discipline : Archbishop of Canterbury's Evidence, vol. ii. pp. 340-374.

Patten, S., Development of English Thought, 1899.

Preston, W., Anti-Ritualism. Revised Edit. by Charles Neil, pp. 89$111,1910$.

The New Schaff-Herzog Encyclopadia, article on Ritualism, 1908.

Walsh, Walter, Secret History of the Oxford Movement, 1897.

Parliamentary Debate of 1548.

Tomlinson, J.'T., The Great Parliamentary Debate of 1548 on the Lord's Supper, 1894.

Polemical Books.

Bertram (Ratram), De Corpore et Sanguine Domini, translated by W. F. Taylor, 1880.

Cartwright, Thomas, Reply to Whitgift against the Admonition of Par. liament, 1573.

Erasmus.

Enchiridion Militis Christiani (1503).

English translation published by Methuen \& Co., 1905.

Encomium Morioe (1510).

Translated into Finglish by J. Wilson, 1668, and appeared in Blackic's English School Texts, edited by W. N. D. Rouse, 1905.

Colloquia (1522). (All the familiar Colloquies translated into Eng. lish by N. Bailey, 1725, and re-edited with notes by E. Johnson, 1878 ) 
Fish, Simon, A Supplication for the Beggars, English Scholars' Library, 1880 .

(Printed in Foxe's Martyrology.)

Gardiner, S., De Vera Obedientia, 153 , tr. 1553.

Hooker, Richard, The Laws of Ecclesiastical Polity, 1909.

Institution of a Christian Man, The (1537).

(Reprinted in Formularies of Faith, 1856.)

Jewell, Bp. John, A pology for the Church of England (1563); and The Defence of the A pology (1567). Parker Society Publications.

More, Sir Thomas, Utopia (1516), Opera 1556, and English Works con. taining Supplication of Souls (1557).

Myroure (The) of Oure Lady (1450), ed. by J. T. Blunt, 1873.

Practice of Papistical Prelates, The. Translated by William Tyndale, 1530 , ed. by Foxe in Tyndale's works, fol. 1573.

Wandsworth Presbytery, Admonition to Parliament emanating from the, 1572 .

Prayers for the Ships of this Kingdom, A Supply of, c. 1645.

Primers.

Three Primers put forth in the reign of Henry VIII, ed. by Edward Burton, 1834.

Primer, 1553. Parker Society Publications.

Primers, Sarum, York, Rome, ed. by Hoskins, S. E., 1901.

The Prymer, ed. by Littlehales, 1891.

Hilsey's Primer, ed. by Hensderson, 1824 .

Puritans and Puritanism.

Brook, Benjamin, Lives of the Puritans, 1813.

Frere, IV. H., and Douglas, Puritan Manifestoes, 1907.

Gardiner, S. R., The Constitutional Documents of the Puritan Revolution $(1625$ to 1660$)$.

Heywood, James, Cambridge University Transactions during the Puritan Controversy, 1854.

Knowles, J. D., Memoir of Roger Williams (Boston), 1834. (Contains many valuable documents.)

Marsden, J. B., Early Puritans, 1850 ; Later Puritans, 1852.

Neal, Daniel, History of the Puritans, 1732-38 (1822).

Nichol, J., Series of Standard Puritan Divines, 1861. See art. The Puritan Preaching and Puritan Literature, by James McCosh, in vol. i. of Charnock's works.

Paget, Franois, Introduction to the Fifth Book of Hooker's Ecclesiastical Psalms. Polity, 1907.

Alexander, W., The Witness of the Psalms to Christ and Christianity, 1890.

Barry, Alfred, A Commentary upon the Psalter, in the Teacher's Prayer Book, 1900.

Holmes, Edward M., A Handbook to the Pralms, Prayer Book Version, 1893. (Contains a useful table giving Author, Probable date, Purpose and Occasion, Historical Reference Subject.)

Kirkpatrick, A. F., The Book of the Psalms, 1897-1901. (Published in the Cambridge Bible for Schools, etc., Series.)

Reformation.

Perowne, J. J. Stewart, The Book of Psalms, 1886.

Continental.

Kidd, J., The Continental Reformation, 1902.

Lin Isa , T. M., History of the Reformation, vol. i. and part of vol. ii, 1906-7.

Schaff, Philip, History of the Reformation, 1883.

English.

Boultbee, T. P., A History of the Church of England Pre-Reformation Period, 1871.

Burnet, G., History of the Reformation, ed. Pocock, 1865.

Central Society of Sacred Study, 1907-1911, p. 19.

Gee, H., The Reformation Period, 1909.

Hardwick, C., History of the Christian Church: Reformation, 1874.

Heylyn, Peter, Ecclesia Restaurata, ed. James C. Robertson, 1849. 
Lindsay, T. M., A History of the Reformation, 1907.

MacColl, Malcolm, The Reformation Setllement (Tractarian), 1901.

Perry, G. G., History of the Reformation in England, 1886.

Poole, R. Lane, Wycliffe and Movements for Reform, 1889.

Strype, John, Annals of the Reformation, 1824.

Wace, H., and C. A. Buchh - im, Principles of the Reformation, 189 ô.

Walsh, Walter, England's Fight with the Papacy, 1912.

\section{Scottish.}

Calderwood, D., True History of the Church of Scotland, from the brginning of the Reformation to the end of the reign of James VI, 1680.

Cook, Geo., Reformation in Scotland, 1819.

Knox, John, History of the Reformation of Religion in the realms of Scotland, 1573.

Mitchell, A. F., The Scottish Reformation, 1900.

Reformation, The Counter-.

Ritual.

Pennington, A. R., The Counter-Reformation in Europe (1.558-1648), 1899

Ward, A. W., The Counter-Reformation, 1889.

Dimock, N., Ritual : Its Use and Misuse, 1010.

Meyrick, F., Ritual and Ritualism, 1903.

Tomlinson, J. T., Collected Tracts on Ritual.

\section{Sacramentaries.}

Gallicas, ed. Neale and Faber, 1855.

Gelasian, ed. Wilson, 1894.

Gregorian, ed. Warren, 1883 (Leofric Missal ?).

Leonine, ed. Feltoe, 1896.

Sacraments, The. See also under Baptism and Lord's Supp:r.

Diggle, J. W., The Ministry of the Word and Sacraments, 1903.

Franey, J. S., Mr. Dibdin's speech on Res'rva'ion, at the hearing before the Archbishops of Canterbury and York, at Lambeth, July, 1899, and some of the Evidence, with Notcs and Appendices, 1899.

Goode, W., Doctrine of the C.E. on the Two Sacraments, 1864.

Sarum Use, The. Frere, W. H., Use of Sarum, Cambridge, 1898 and 1902.

Sarum Use, its Various Portions.

Breviary, Cambridge, 1879-86.

Procter and Wordsworth, Breviarium ad Usum insignis Ecclesios Sarum. With facsimiles, 1879. (For its translation, see Hour S rvices.)

Missal, Burntisland, 1861-83.

Pearson, A. H., The Sarum Misaal done into English, 1884.

Processional.

Ed. Henderson, Leeds, 1882.

Wordsworth, C., Salisbury Processions, 1901.

Gradual and Antiphonal, Plainsong Society, 1895.

Psalter, The Psalter, or Seven Ordinary Hours of Prayer, according to the Use of Sarum, ed. J. D. [Chambers], 1852.

\section{Service Books.}

Surtees Society Publications, 1835 to present time.

Swete, H. Barclay, Church Services and Service Books, before the Reformation. With facsimile MS., 1896.

\section{State Papers.}

Gairdner, James, Letters and Papers foreign and domestic of the reign of Henry VIII, arranged and catalogued by J. S. Brewer, 1862, etc.

\section{Statutes of the Realm.}

Amos, Andrew, Statutes of the Reformation Parliament in the reign of Henry VIII, 1859.

Chitty, Eccl. Statutes, by Lily and Whitehead, 1894.

Law, James Thomas, Ecclesiastical Statutes at Large, 1847.

Statutes at Large of the Realm.

Synods.

Stephens, A. J., Ecclesiastical Statutes, $18 \pm 6$.

Cardwell, E., Synodalia from 1547-1717, 1842.

To Deum, The. Wordsworth, John, The T.D. : its structure, etc., 1002. 
Tractarianism. See Oxford Movement.

Trent, Council of.

Buckley, T. A. Canons and Decrees of the Council of Trent, 1851.

Catechism of the Council of Trent, 1852.

History of the Council of Trent, 1852.

Froude, J. A., Council of Trent, The, 1896.

Waterworth, J., Canons and Decrees of the Council of Trent. Translated Virgin Birth. (R.C.), 1848.

Orr, James, The Virgin Birth of Christ, 1907.

Westminster Assembly, The.

Beveridge, W., A Short History of the Westminster Assembly, 1904.

Hetherington, W. M., History of the Westminster Assembly of Divines, ed. 1878 .

Westminster Confession. Published by T. T. Clark.

Worship.

Atkinson, Wm., The Church (on the wide-spread error of substituting worship for religion), 1854 .

Chambers, J. D., Divine Worship in England in the $X I I I, X I V$, and $X I X$ Centuries, $1877,1886$.

Duchesne, L., Christian Worship : its Origin and Evolution. Translated from the Third French Edition by M. L. McClure, 2nd English Edition Revised, with considerable additions by the Author, 1910. (A Study of the Latin Liturgy up to the time of Charlemagne.) (Roman Catholic.)

Jurieu, P., Critical History of Worsh ip from Adam to Christ, with an account of all the Idolatries of Ancient Pagans, 1705.

Meyrick, F., Scriptural and Catholic Worship, 1911.

Wordsworth. John, Ministry of Grace (Tractarian), 1901 


\section{$A P P E N D I X \quad F$}

\section{A CHRONOLOGICAL TABLE FOR PRAYER BOOK STUDY}

\section{ARRANGED ALPHABETICALLY ACCORDING TO SUBJECTS.}

\section{Acts of Uniformity.}

1st Act of Uniformity (2 \& 3 Edward VI, c. 1) • . 1549 2nd Act of Uniformity (5 \& 6 Edward VI, c. 3) . . 1552 3rd Act of Uniformity (1 Eliz. c. 2) . . . . 1559 'Advertisements' enforcing Uniformity (in print May). 1566 4th Act of Uniformity (13 \& 14 Car. II, c. 4) . . 1662 Act of Uniformity Amendment Act (35 \& 36 Vict. c. 35) 1872

Archbishops of Canterbury.

(Reformation and Prayer-Book Period.)

Thomas Cranmer . 1533 Richard Bancroft • 1604

Reginald Pole . . 1556 George Abbot . . 1611

Matthew Parker . . 1559 William Laud . . 1633

Edmund Grindal $\quad 1576$ [See vacant $15 \mathrm{yrs}$.] .

John Whitgift . 1583 / William Juxon . . 1660

Articles.

The Ten Articles, borrowed chiefly from the Confession of Augsburg . . . . . . . . 1536

The Thirteen Articles, the substance of them afterwards, embodied in the Forty-two Articles . . . 1538

The Six Articles, The Act of the . $\quad$. $\quad . \quad 1539$ Amended . . . . 1542, 1543

Repealed, Christmas Eve . . . 1547

The Forty-two Articles, the Augsburg Confession used in their drafting . . . . . . . 1553

The Eleven Articles, to be accepted by the clergy; (legalized for the Church of Ireland 1566) . . 1561 
The Thirty-eight Articles, a revision of the Forty-two Articles-the Würtemberg Confession used . . 1563 The Thirty-nine Articles . . . . . . 1571

The Lambeth Articles, incorporated with the Irish Articles in 1615 .

The Thirty-mine Articles confirmed and subscribed by Convocation, and declared to be agreeable to the Word of God - $\cdot$ - $\cdot$. One hundred and four Articles drawn up for Ireland by Archbishop Ussher . . . . . . 1614 Adoption by the Irish Church of the English Articles .- 1635 The Thirty-nine Articles ordered to be removed from the obligatory course of study at Oxford . . 1871

\section{Bible Translations and Versions.}

Wycliffe's Versions from the Vulgate.

First Complete Edition

(Revised Edition by Purvey.)

Erasmus' Greek Testament with Latin Translation.

First Edition

Luther's Translation of the Bible

(Many subsequent Editions.)

Tyndale's New Testament. First Edition . . 1525, 1526

First Revised Edition . . . . . . . 1534

Coverdale's Bible . . . . . . . . 1535,1536

Matthew's Bible . . . . . . . . . . 1537

Taverner's Bible. $\quad . \quad$. $\quad . \quad$. $\quad . \quad$. $\quad .1539$

New Edition of Matthew's, called 'The Great Bible,' published under the patronage of Cranmer.

Revised Edition with Preface by Cranmer, hence often

called 'Cranmer's Bible': ordered to be placed in every Church as the 'Authorized Version'

English Bible and Erasmus' Paraphrase: ordered to be set up in Churches . . . . . 1547

'The Geneva Bible' ('Breeches Bible '). Rèvised Edition

[1576]

The Bishops' Bible ('Treacle Bible') :

The Bishops Bible ('Treacle 1568

'The Douai Version' for English-speaking Roman Catholics-

New Testament, at Rheims .

Old Testament, at Douai Authorized Version of the Bible . Authorized Jewish-English Version . 1582 Revised Bible-

New Testament

- 1609

. 1611

$1851-61$ 


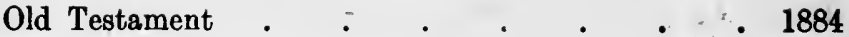

Apocrypha . $\quad . \quad$. $\quad . \quad$. $\quad$ • . 1895

Breviary.

Roman Breviary ascribed to Pope Gelasius I (Bp. c. 492)-

Revised by Cardinal Quignonez by direction of

Clement VII

1535

Revised again by order of Pope Pius V $\quad$ • $\quad .1568$

Restored by Clement VIII . . . . . 1602

Revised by order of Urban VIII . . . . . 1631

First used in England by Romanists . . c c 1750 Sarum Breviary . $\quad . \quad$. . . . . . c. 1085

Revised . . . . . . . . . . . .

Revised again . . . . . $\quad . \quad . \quad .1531$

Revised again and adopted in Prov. of Canterbury . 1541 Mozarabic Breviary . . . . . . c. 1500

Canons and Homilies.

Canon Law-

Introduced into England . . . . c. 1154

Abolished . . . . . . . 1533

Teaching of it at English Universities prohibited . 1536 1st Book of Homilics . . . . . . . 1547 2nd Book of Homilies. $. \quad . \quad . \quad . \quad . \quad .1563$ The Canons of 1571,1575 , and 1584 .

The Canons of 1603, received Royal Assent. . . 1604 Canon of Laud (unauthorized) . . . . . 1640 Canons of 1604, altered . . . . 1865 and 1888 Canon accepting Clergy Discipline Act . . . 1892

Committees and Conferences, etc.

Committees appointed to revise Service Books . . 1543 Prayer Book Committee (?) . . . . . . 1547 Great Parliamentary Debate . . . . . 1548 Committee of Revision appointed . . . . . . 1551 Advisory Committee appointed to consider a new form of

Church Service to be submitted to the Queen (?) * 1558 Hampton Court Conference $\dagger$. . . . . 1604 Committee for a proposed revision . . . . 1641 Westminster Assembly appointed. (Sat until 1645) • 1643 Savoy Conference $\ddagger$. $\quad . \quad$. $\quad . \quad$. . . 1661 Commission to revise Prayer Books . . . . 1689 First Lambeth Conference . . . . . . . 1867

- See Note, No. 3, p. $636 . \quad †$ See Note, No. 4, p. 636.

$\ddagger$ See Note, No. 5, p. G37. 
Ritual Commission appointed . . . . 1867

Royal Commission respecting Ceremonial . . . 1905

The King's Letter of Business authorizing Convocation to consider certain recommendations of the Report of the Royal Commission on Ecclesiastical Discipline. Issued November 10

First Pan-Anglican Conference

Continental Service Books and Formularies.

Luther published his first attempts at liturgical reform . 1523 Schwabach Articles . . . . . . . . 1529

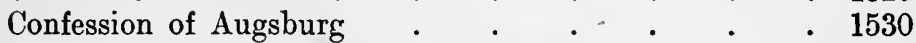
Kirchen-Ordnung (Church Ordinances) drawn up by

Osiander for Brandenburg, Nuremberg . . 1533 Quignon's Breviary . . . . . . . . 1535

A revised form . $. \quad . \quad . \quad . \quad . \quad . \quad 1537$

A papal rescript decreed that there was no longer any reason for allowing it to be printed

1558 Hermann's 'Consultatio,' compiled by Melancthon and Bucer . . . . . . . . 1543

A Latin Translation appeared . . . . . 1545 Rendered into English . . . . . . . 1547

A Second Edition of this English Edition . . 1548

A reply entitled Antididagma (Counter-Teaching) issued by the Chapter of Cologne; and Hermann, Archbishop of Cologne, excommunicated . . and deprived for the use of the Reformed Church at Strassburg . . . . . . .

It was written in French and afterwards published in Latin.

An Order of Service published in Latin by Valerandus Pollanus (Pullain), Pastor of the Refugees settled at Glastonbury .

1546

1547

Calvin's Directory for the use of the Reformed Church
at Strassburg .

Würtemberg Confession

Knox's Book of Common Order

This was an abridgement of Calvin's Form of

Service, printed . $\quad . \quad$. 1641 and 1643

Councils.

[The first four General Councils were accepted as authoritative by the Act of Supremacy, 1559, $\S 36$ (now repealed)].

Nicæa, condemned Heresy of Arius- $\ddot{\lambda} \lambda \hat{\theta} \hat{\omega} s$ (truly God) 325 Laodicea, condemned praying to Angels, and fixed the

canon of Scripture ....$\quad$. 
Constantinople (1), condemned heresy of Arius, Apollinarius, Macedonius- $\tau \epsilon \lambda \epsilon i \omega s$ (perfectly man).

Carth age (3), local, enumerated the Books of the Scriptures Ephesus, condemned the heresy of Nestorius-ádıaı

(indivisibly God-man)
Chalcedon, condemned the heresy of Eutyches-ai $v \gamma \gamma \chi^{\dot{v}-}$ $\tau \omega s$ (distinctly God and man) . . . .

Constantinople (2)

Constantinople (3), condemned Monothelites, including Pope Honorius .

Trullan, held at Constantinople, confirmed the canon of Scripture

Frankfort, held under Charlemagne, condemned use of images . . . . . . .

Florence, defined Purgatory
Nicra (2), sanctioned the adoration of images, and declared elements in the Eucharist to be the very Body and Blood of Christ

Lateran (4), decreed Transubstantiation, Auricular Confession and the execution of heretics .

[There were four other Lateran Councils he'd at Rome $1122,1139,1179,1516]$

Councils in 15th Century Summoned to Reform Church Abuses.

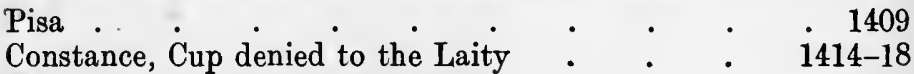

Basle, continued at Florence 1439 . $\quad$. $\quad$. 1431

Council of Trent.

There were virtually three Councils of Trent:-

1st, summoned by Paul III

(at Trent in the Tyrol and at Bologna) . 1545-1547

2nd, summoned by Julius III (at Trent) • 1551-1553

3rd, summoned by Pius IV (at Trent) . . 1562-1563

Its Canons were issued in 1564.

Early English Church History.

Introduction of Christianity into Britain by Refugees from

Gallic persecution . . . . . . c. 177

Martyrdom of St. Alban $\quad . \quad+\quad . \quad+\quad . \quad$. c. 305

British Bishops attended the Councils of Arles 314, Sar-

dica 343 , and Ariminum 359. 
The Gallican Liturgy and Ritual introduced by the Bishops brought over by Germanus . . . . c. 447

Voyage of St. Columba the Celtic monk, from Ireland to Iona, where he evangelized the Picts in North Britain . . . . . . . . . 563

Mission of Augustine to the Saxons . . . $\quad . \quad 597$

Ethelbert and his people converted to Christianity . c. 597 Augustine consecrated first Archbishop of Canterbury 598 (601) Abortive Conference between Augustine and representatives of the British Church at Augustine's Oak, Aug, near the Severn

The King of Northumbria invites St. Aidan from Iona to evangelize his kingdom . . . . . 635

Aidan fixes his See at Lindisfarne $\quad . \quad$. $\quad . \quad 635$

The Roman (Western) Church wins the day in the controversy at Synod of Whitby between Roman and Celtic traditions

Enthronement of Theodore as Archbishop of Canterbury

Divine Worship began to be conducted in the Latin tongue, to the exclusion of the native Saxon. Early in 7 th cent. Completion of the evangelization of the Saxon Heptarchy c. 685 The British Church in Wales, according to Bede, still independent of Canterbury. . . .

731

N.B.-It was so until the twelfth century.

Death at Jarrow of the Venerable Bede, the Historian 735

Destruction of many Churches and Monasteries by the Danes $856-871$

Revival and reformation by Dunstan (Abbot of Glastonbury) of the English monastic system a c. 943-958 Appointment of Dunstan to be Archbishop of Canterbury Homage from William I demanded by Pope Gregory VII 960 Issue by William I of the 'Consuetudines,' which defined the relationship of the English Church to the Papacy 1075

1076

Definition by the Constitutions of Clarendon of the relation: ship between the ecclesiastical and civil courts . The freedom of the Church set forth in the clauses of Magna Charta . . . . . . .

Edward VI.* Legislative Enactments.

Royal Visitation of the Church for removing images, asserting the Royal Supr macy, and compelling the use of the English tongue in the Church Service.

Repeal of the Six Articles and Henry's Act forbidding the English Translation of the Bible

For the Legislative Enactments of Henry VIII, sec App. A, pp. 576-591. 
An Act providing that the laity should communicate in both kinds with the priest

A Commission appointed to reform the offices of the Church

which added an Office of Communion in both

kinds to the Mass on Easter, April 16 . .

1st Act of Uniformity. a b ill positive $\cdot$. .

the Marriage of Priests

An Order issued that all the old Service books be destroyed 1550

An Act for persons to be appointed to prepare a New Ordinal 1550

An Act passed enabling the King to nominate 32 persons to

revise the ecclesiastical laws . . . . 1550

2nd Act of Uniformity . . . . . . 1552

Mary. Legislative Enactments.

Repeal of 25 Henry VIII, c. 19, Act of submission of clergy,

which had fettered Convocation. . . .

1553

An Act forbidding the Marriage of the Clergy . . 1553

Repeal of all laws enacted against the supremacy of the See

[of Rome], since 20th year of Henry VIII . .

An Act reviving the statutes of the later Plantagenets against the Lollards repealed by Henry . .

Royal Proclamation $v$. the importation, buying, selling, or keeping of the writings of the leading Reformers, and the retention of any part of the English Prayer Book of Edward VI

Injunction issued, arming the Visitors with Royal authority

to traverse the parishes of England to see that recent

legislation on changes of religion was carried out.

Order of Cardinal Pole to destroy English Bibles and books

containing heretical opinions . . . .

1554

1554

1555

Elizabeth. Legislative Enactments. (See also under Injunctions.)

The Act of Supremacy, an Act for restoring to the Crown its ancient jurisdiction over the Ecclesiastical and Spiritual, and abolishing foreign powers repugnant to the same

An Act for abolishing the anti-Lollards revived by Mary

The Act of Uniformity Act for the Ministers of the Church to be of sound 1559 1559 religion, requiring the Church Ministers to subscribe to the XXXIX Articles . . . . .

A Proclamation against the despisers of the order prescribed in B.C.P. 
Proclamation $v$. harbouring "Jesuit Seminary men, Massing Priests"

An Act making it treason to proselytise to the Roman Church; perverts to be deemed traitors; heavy fines against those who refused to attend their Parish Church The Act $v$. Jesuits and Seminary Priests. Jesuits to leave Engiand within forty days from a set date ; students in Seminaries abroad to return to England

1581

1581

1585

The Act $v$. Popish Recusants. This forbade the above to remove more than five miles from their usual place of abode.

Proclamation that Jesuits and Secular Priests must leave England within thirty days from a set date . .

InJUNCTIONS, ETC.

Royal Injunctions issued, instructing the clergy in respect of their duties.

Injunctions issued by Cromwell, as the King's VicarGeneral, directing the setting up of a Bible in every Church, and making provision for the teaching of the Creed, the Lord's Prayer, and the Ten Commandments in English

Royal Injunctions issued with the Articles of Enquiry for the Royal Visitation, requiring a copy of the Paraphrases of Erasmus in English upon the Gospels to be set up and studied by the clergy

The Edwardine Injunctions issued, adapting 1547 Injunctions to the B.C.P. of 1549 , and abolishing the Sunday Procession before High Mass.

The Injunctions of Elizabeth, dealing with the Royal Supremacy and the vestments. . . .

The so-called 'Interpretations of the Injunctions,' of unknown authorship, dates from about . Tominson,
(For an account of this document, see Tomling C. A. Tract, 413.)

The Advertisements issued, giving authoritative orders respecting vestments.

Papal Secular Power, Limitation of the.* Wilfrid, Bp. of York, imprisoned for appealing to the Pope William the Conqueror refused to receive any Papal Legate except by the King's request . . 1076-78

* For further instanees, see Walter Walsh's England's Fight with the Papacy. 
The Constitutions of Clareudon in Henry 1I's reign limited the Pope's power of intervening in English temporal affairs . . . . . . .

The Magna Charta re-affirmed the anti-Papal provisions of the Constitutions of Clarendon

1215

Parliament protested against Papal exactions, and refused to allow the legate to carry away the money he had collected

1307

The Statute of Provisors denied the right of the Pope to fill vacant livings . . . . . . .

The Statute of Præmunire made it treasonable to appeal to the Pope against English judges . . .

Act for Restraint of Appeals

1351

1353

1533

Act of Submission of the Clergy, who recognized Henry as sole and supreme lord, also Supreme Head of the Church of England

The two Convocations affirmed "That the Roman bishop has not in the Holy Scriptures any greater jurisdiction given him by God in this kingdom than any other loreign Bishop'.

1534

Popes of the Reformation Period.

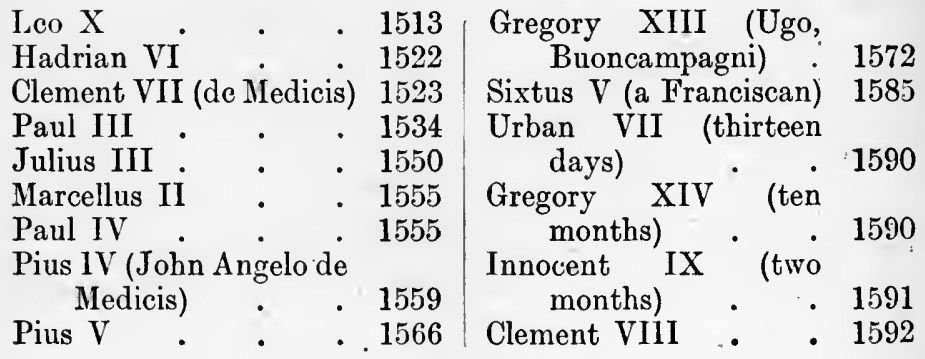

Prayer Book.

1st Prayer Book of Edward VI.*

Submitted to Parliament December . . . 1548

Enacted by First Act of Uniformity, January 22 . 1549

'The Second Year of the Reign of King Edward the Sixth'

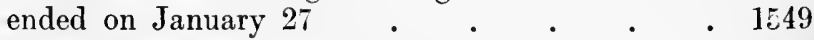

Came into legal use on Whit Sunday, June 9 - "

Latin translation by Aless . . . . • 1551

2nd Prayer Book of Edward VI. $\dagger$

Enacted by 2nd Act of Uniformity, April 14 . 1552

* See Note, No. 1, p. $635 . \quad †$ See Note, No. 2, p. 635. 
First Printed, August .

Use made compulsory on and from All Saints' Day

Suppressed by Mary, December 20

1553

Prayer Book of Elizabeth.*

(i.e. the Second B.C.P. restored with three specified alterations.)

Enacted by Act of Uniformity, May 8 . . . 1559

Printed May 15 (?)

Use made compulsory, June 24, the Nativity of

John the Baptist

Translation made into Latin (loose and unauthorized) 1560 Prayer Book of James $I$. $\dagger$

Authorized by Letters Patent, February 9 . . 1604

First circulated, March

Came into use "Within such times as the Bishops shall think good to limit'.

Attempted Revision

Suppressed by the Long Parliament, the Directory for Public Worship being ordered to be used in its stead

Prayer Book of Charles II. $\ddagger$

Royal Letters to Convocation to revise Prayer Book, October

Carried out by Convocation from November 21 to December 20

Submitted to Parliament and approved, and annexed to the Act

Passed the Lords, April 9, received Royal Assent, May 19

Use made compulsory, August 24 .

Approved by Irish Convocation, November 11 . ,

Standard copies certified under Seal, January 5 . 1663

Embodied in Irish Act of Uniformity, June 18 (17

\& 18 Car. II. c. 6) . . . . . . 1666

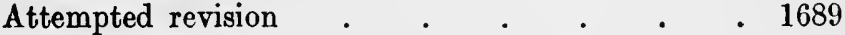

The Prayer Book first translated into Welsh . . 1567

The Prayer Book first translated into Irish . • . 1608

The Scotch Prayer Book, prepared by Archbp. Laud and others

The American Prayer Book-

First Edition

Second Edition

- See Note, No. 3, p. $636 . \quad \dagger$ See Note, No. 4, p. 636. 
Revised Prayer Book according to the Use ot the Church of Ireland .

Prayer Book-Recent Changes.

Provision by 4 Geo. IV c. 76 for publication of Banns of Marriage directly after the Second Lesson when necessary (see page 307) . . • • 1824 Subscription and the Oath at Ordination . . . 1865

The new oath therein enjoined was that of $21 \&$ 22 Vict. c. 48.

This was altered by the Clerical Subscription Act, $28 \& 29$ Vict. c. 122 .

Relinquishment of Holy Orders allowed in certain cases Act of Uniformity Amendment Act (35 \& 36 Vict. c. 35), allowing a shortened Service for Daily Prayer, and a- separation of Services, etc.

New Lectionary Act, $34 \& 35$ Vict. c. 37 . Optional from January 1,1872 , and compulsory from January 1

The Burial Law Amendment Act $(4 \dot{3} \& 4 \dot{4}$ Vict. c. 41 , sec. 13)

1880

The minister may, at the request of the representatives of the deceased, use another Form of Service consisting of Prayers taken only from the Prayer Book or the Bible and approved by the Ordinary.

Act authorizing extension of time of Marriage to 3 p.m. 1886

Prayer Book-Other Events.

English Psalter . . . . . . . . . 1ن34

English Epistles and Gospels •. . . . . 1538

English Litany. First used in St. Paul's Cathedral in.

Procession, St. Luke's Day

1545

The Order of the Communion in English, an addition

to the Latin Mass for the use of the people . . 1548

Cranmer's Catechism . . . . . . . ' 1548

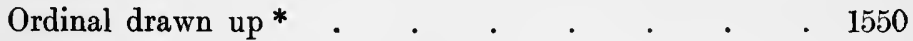

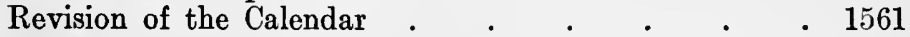

Nowell's Catechism, sanctioned by Convocation . . 1563

Rectification of the Calendar: eleven days struck out of

September . . . . . . . 1752

Forms of Prayer for-

'The Gunpowder Treason' (Nov. 5) . . . 160 E

This was revised in 1662 , and 1689 .

'Martyrdom of Charles' (Jan. 30), altered, 1685 . 166๘

* Sec Note, No. 6, p. 637. 
'The Restoration' (May 2?).

This was altered in $168 \mathrm{j}$.

These Services discontinued.

Revised Lectionary, optional • • • • 1859

"

eompulsory .

1872

- 1879

Primers.

Marshall's Primer-

'A Goodly Prymer in English' . . . . 1534

Re-printed by Marshall. . . . . . 1535

Hilsey's Prymer, ealled 'A Manual of Prayers, or the

Prymer in English' . . . . . . 1539

The King's Primer, containing the Litany of 1544 . 1545

Primitive Christian Public Worship, Description of and Reference to.

Epistle of St. Clement of Rome . . c. 96

The Didaché (Teaching of the Twelve Apostles) * $90-120$ (?)

Pliny's Letter to Trajan . . . . . . . c. 112

Justin Martyr, 1st Apology. . . . . . . c. 148

2nd Apology . . . . . . c. 150

Several passages in Tertullian . . . . c. 197-207

Canons of Hippolytus. . . . . . . . 250 (?)

(Containing directions and formulas for the Liturgy and other rites.)

Cateehetical Lectures given by St. Cyril (?) .

(Being comments on the Liturgy.)

The Prayers of Serapion, Bishop of Thmuis (North Africa) . . . . . . . c. 350

'Peregrinationes ad Loea Sancta' by St. Silvia of Aquitaine $c .385$

(Being a Pilgrim's account of services held in Jerusalem.)

The Apostolic Constitutions.

(Containing the 'Liturgy of St. Clement.')

The 'Testament of our Lord' . . . . 250-380 (?)

(Containing the essential parts of the Liturgy, the

Baptismal and Ordination Serviees.)

Reformation Period.

The Title 'Defender of the Faith' bestowed by Pope

Leo X upon Henry VIII . . . . . 1521

The Royal Supremacy imposed on the Clergy by Henry 1531

Papal Supremaey abolished . . . . . 1534

Dissolution of the smaller Monasteries and Nunneries . 1536 
Suppression of the greater Monasteries.

Order of the Jesuits formally established, September 271540

Arrival of Peter Martyr in England, 1547-appointed Reg.

Prof. Div, Oxon.

1548

Communion in both kinds sanctioned . . . . 1548

Compline sung in English in the Royal Chapel . . 1548

Arrival of Martin Bucer in England--appointed Reg.

Prof. Div. Cantab. . . . . . . 1549

Mass set up October 5. Protests by Cranmer . . 1553

Cardinal Pole enters London (November 24) . . 1554

Official Absolution of the nation by Cardinal Pole in

presence of Philip and Mary and both Houses

of Parliament at the Royal Palace, St. Andrew's

Day, November 30

High Mass in St. Paul's, Sunday, December 2

Stephen Gardiner the Preacher (text Rom. xiii. 11).

Martyrdom of Ridley and Latimer (October 16) . . 1555

Martyrdom of Cranmer, March 21 . . . . 1556

Excommunication of Elizabeth by Pius V (Bull ' Regnans

in Excelsis'), May . . . . . . 1570

Sentence of Deposition promulgated against Elizabeth

by Sixtus V . . . . . . . 1588

Romish Errors

Worship of Images permitted at 2nd Council of Nicæa.

Transubstantiation proclaimed to be a necessary Article

of Faith at 4th Lateran Council. . . . 1215

Auricular Confession made compulsory. . . . 1215

Denial of Cup to the Laity decreed at the Council of

Constance . . . . . . . 1414

Doctrine of Intention enunciated by Eugenius . . 1547

Definition of Papal Doct ine and Discipline published

in Canons of Trent. Pius IV added to the Nicene

Creed (325) 12 novel doctrines.

1564

The Immaculate Conception declared to be an Article of

the Faith, by Pope Pius IX

Vatican decreed Pe"sonal Infallibility of the Pope, and

denounced modern philosophical systems and ideas $1869-70$

The Infallibility of the Pope proclaimed by the Vatican Council

1870

Sacramentaries, Nominal Authors.

Pope Leo I (The Great)

Pope Gelasius I .

Pope Gregory I (the Great) 
Sovereigns of the Prayer Book Period.

Henry VIII • • 1509 |James I . . . 1603 Edward VI . . 1547 Charles I . . 1625 Mary I . . . 1553 (The Commonwealth) . 1649 Elizabeth . . . 1558 Charles II . . . 1660

\section{Special Days instituted and appointed.}

Rogation Days, by Mamertus, Bishop of Vienne . . c. 460 Ember Days

\section{UsEs.}

Egbert's Pontifical

Sarum Use drawn up by Osmond

[Some consider that Richard Poore, Bp. of Salisbury, compiled it at the beginning of the thirteenth century.]

Abandonment of the 'Use of St. Paul' Adoption of Reformed Sarum Use by the Convocation

of Canterbury . . . . . . . . 1542

Hereford Use (revised under Bp. Trillett, 1344-1361),

1085

Lincoln, York, Exeter, Bangor, Aberdeen Uses.

Revised Breviary of Cardinal Quignonez . . .

\section{NOTES.}

No. 1. The Committee who drew up ihe B.C.P., 1549.

Archbishop Cranmer, Bishop Ridley of Rochester, Holbeach of Lincoln, Thirlby of Westminster, and Goodrich of Ely ; Doctors May, Dean of St. Paul's, Haynes, Dean of Exeter, Robertson (afterwards Dean of Durham), and Redman, Master of Trinity College, Cambridge, who took part at Chertsey in Ferrar's Consecration to the see of St. David's, were probably among the number of Bishops and divines assembled at Windsor for 'the reformation of the service of the Church,' and 'a uniform order of prayer,' Dr. Fuller, in his Church History, adds tl:e names of Bishops Skip of Hereford and Day of Chichester, with Doctors Cox and Taylor. This body is sometimes called the Windsor Commission. When the work was finished probably there had been a consultation of the Bishops with a definite aeeeptance and subseription of a formal document (see Somerset's letter to Pole enclosing a copy of the Book of Common Prayer, June 4, 1549).

No. 2. The Commission who conducted the Revision of the B.C.I., 1552.

No records remain to show us in what manner or by whom this revision was ultimately made. It has been suggested by Dr. Cardwell ( $T$ wo Liturgies 
of $E d w . V I$, xvii. n.) that the Convocation delegated its authority to a Commission appointed by tho King, and this Commission was the same with that which had set forth the Ordinal of 1550 , consisting of 'six Prelates, and six other men of this Realm, learned in God's law, by the King's Majesty to be appointed and assigned;' but of which only the name of Bishop Heath of Worcester is recorded. Archdeacon Freeman considers it to be 'all but certain that it was the Ordinal Commission which conducted the Revision of 1552,' especially because the Ordinal was affixed to the Act of Parliament by which the revised book was legalized.

\section{No. 3. The Advisory Committee of 1553-9.}

The Committeo consisted of the following persons :-

Matthew Parker, subsequently Archbishop of Canterbury.

Edmund Grindal, subsequently Bishop of London, Archbishop of York, and Archbishop of Canterbury.

James Pilkington, subsequently Bishop of Durham.

Richard Cox, subsequently Bishop of Ely.

William May, appointed Archbishop of York, but died before consecration.

William Bill, subsequently Dean of Westminster.

Sir Thomas Smith, quondam Dean of Carlisle.

David Whitehead.

Edwin Sandys, subsequently Bishop of Worcester, and Archbishop of York.

Edmund Guest, subsequently Bishop of Rochester, and of Salisbury

The last two were summoned to attend upon the Committee after its first appointment. Doubt has been expressed whether this proposed Committeo ever sat.

\section{No. 4. The Hampton Court Conference.}

The Church was represented by :-

Whitgift, Archbishop of Canterbury.

Bancroft, Bishop of London.

Matthew, Bishop of Durham.

Bilson, Bishop of Winchester.

Babington, Bishop of Worcester.

Rudd, Bishop of St. David's.

Watson, Bishop of Chichester.

Robinson, Bishop of Carlisle.

Dove, Bishop of Peterborough.

James Montague, Dean of the Chapel.

Ravis, Dean of Christ Church.

Edes, Dean of Worcester.

Andrewes, Dean of Westminster.

Overall, Dean of St. Paul's.

Barlow, Dean of Chester, the Chroniclęr of the Conference.

Bridges, Dean of Salisbury.

Dean of Windsor.

Dr. Field, Chaplain to James.

Dr. King [Archdeacon of Nottingham]. 
On the side of the Puritans the deputies were :-

1. Dr. Reynolds (known by his contemporaries as Rainolds), President of Corpus.

2. Dr. Sparkes, from Oxford.

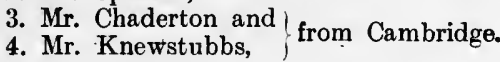

No. 5. The Savoy Conference.

The Commission consisted of the following :-

\section{Episcopal Divines.}

Frewen, Archbishop of York. Sheldon, Bi.hop of London. Cosin, Bishop of Durham.

Warner, Bishop of Rochester. King, Bishop of Chichester. Henchm $:$ n, Bishop of Sarum. Morley, Bishop of Worcester. Sanderson, Bishop of Lincoln. Laney, Bishop of Peterborough. Walton, Bishop of Chester. Sterne, Bishop of Carlisle. Gauden, Bishop of Exeter.

\section{Presbiterian Divines.}

Reynolds, Bishop of Norwich. Dr. Tuckney, Master of St. John's College, Cambridge.

Dr. Conant, Reg. Prof. Div., Oxford.

Dr. Spurstow.

Dr. Wallis, Sav. Prof. Geom., Oxford.

Dr. Manton.

Mr. Calamy.

Mr. Baxter.

Mr. Jackson.

Mr. Case.

Mr. Clarke.

Mr: Newcomen.
Condjutors.

Dr. Earle, Dean of Westminster.

Dr. Heylin.

Dr. Hacket.

Dr. Barwick.

Dr. Gunning.

Dr. Pearson, afterwards Bishop of Chester.

Dr. Pierce.

Dr. Sparrow, afterwards Bishop of Norwich.

Mr. Thorndike.

\section{CoAdjutors.}

Dr. Horton.

Dr. Jacomb.

Dr. Bates.

Dr. Cooper.

Dr. Lightfoot.

Dr. Collins.

Mr. Wood ridge.

Mr. Rawlins in.

Mr. Drake.

No. 6. The Publication of the Edwardine Ordinal.

By the Statute $3 \& 4$ Edw. VI, c. '2 (January 31, 1550) the King was empowered to appoint 'six prelates and six other men of this realm, learned in God's law, to complete the liturgical reform by the preparation of a new Ordinal, and whatever should be devised for that purpose by the most number of them, and set forth under the Great Scal of England before the 8th day of April, should be lawfully exercised and used, and none other.' On February 2 an order of the Council was made appointing the commissioners, but there is no list of names recorded in the Council Book. Probably the work of preparation was already done, and some think that it had been experimentally used at an Ordination held by Cranmer and Ridley at St. Paul's before the end of 1549. (See Strype's Cranmer, 191, and Procter and Frere's $A$ New History of the B.C.P., pp. 60, 61.)

The following remarks of Tomlinson in The Prayer Book Articles and Homilies are important as throwing light upon Article XXXVI : "The 
Ordinal did not exist at all in the "First" Prayer Book of Edward, nor did it come into being till long after the close of the third year of Edward VI. On January $31 \mathrm{st}, 1550$, i.e. in the beginning of the fourth year of Edward VI, was the Act (3 and 4 Edw. VI, cap. xii.) passed.'

By the 2nd Act of Uniformity (1552), i.e. 5 \& $6 \mathrm{Edw}$. VI, cap. 1, both the revised books were 'annexed" to the statute which, after enacting the second B.C.P., went on, " adding also a formeand manner of making and consecrating of archbishops, bishops, priests, and deacons to be of like force, auctoritie, and value, as the same like foresaid book entitled The Boke of Common Prayer, was before" ; the penalties of the former Act, 2 and 3 Edward VI, cap. i., being made applicable to "also the said form of making archbishops, \&e., thereunto annexed." 


\section{APPENDIX G}

\section{DISTINCTIVE FEATURES OF 'ГHE IRISH PRAYER BOOK}

\section{The Preamble and Declaration.}

In 1869 the 'Irish Church Act' was passed, and the Church of Ireland became disestablished on January 1, 1871. In the preceding year a General Convention of clerical and lay representatives met and adopted a Preamble and Declaration which is prefixed to the Statutes of the Church of Ireland. "The Archbishops and Bishops of this Ancient, Catholic and Apostolic Church of Ireland together with the Representatives of the Clergy and Laity of the same' then solemnly declared:-

I.

1. The Church of Ireland doth, as heretofore, accept and unfeignedly believe all the Canonical Scriptures of the Old and New Testament, as given by inspiration of God, and containing all things necessary to salvation; and doth continue to profess the faith of Christ as professed by the Primitive Church.

2. The Church of Ireland will continue to minister the Doctrine, and Sacraments, and the Discipline of Christ, as the Lord hath commanded; and will maintain inviolate the Three Orders of Bishops, Priests or Presbyters, and Deacons in the Sacred Ministry.

3. The Church of Ireland, as a reformed and Protestant Church, doth hereby reaffirm its constant witness against all those innovations in doctrine and worship, whereby the Primitive Faith hath been from time to time defaced or overlaid, and which at the Reformation this Church did disown and reject.

II.

The Church of Ireland doth receive and approve The Book of the Articles of Religion, commonly called the Thirty-nine Articles, received and approved by the Archbishops and Bishops and the rest of the Clergy of Ireland in the Synod holden in Dublin, A.D. 1634; also, The Book of Common Prayer and Administration of the Sacraments, and other Rites and Ceremonies of the Church, according to the use of the Church of Ireland; and the Form and Manner of Making, Ordaining, and Consecrating of Bishops, Priests, and Deacons, as approved and adopted by the Synod holden in Dublin, A.D. 
1662, and hitherto in use in this Church. And this Church will continue to use the same, subject to such alterations only as may be made therein from time to time by the lawful authority of the Church.

III.

The Church of Ireland will maintain Communion with the sister Church of England, and with all other Christian Churches agreeing in the principles of this Declaration; and will set forward, so far as in it lieth, quietness, peace, and love, among all Christian people.

IV.

The Church of Ireland, deriving its authority from Christ, Who is the Head over all things to the Church, doth declare that a General Synod of the Church of Ireland, consisting of the Archbishops and Bishops, and of Representatives of the Clergy and Laity, shall have chief legislative power therein, and such administrative power as may be necessary for the Church, and consistent with its Episcopal Constitution.

Whenever a candidate presents himself for Ordination, or a Clergymain is licensed or instituted, he has to declare solemnly that he 'approves and agrees to' this Declaration.

\section{The Revisers' Preface.}

The Prayer Book was provisionally accepted as it stood, but preparations were made for its Revision, which was debated and carried out by the General Synod of the Church. A fundamental principle of the Revision was that no change should be made unless supported by a two-thirds majority of each order present and voting at the Synod. The House of Bishops had a power of veto over any changes. In 1877 the B.C.P. ' according to the use of the Church of Ireland ' was issued, and is the only Service Book lawfully used in that Church. All the Clergy declare that " they will use the form in the said Book prescribed, and none other, except so far as shall be allowed by the lawful authority of the Church.'

A New Preface, adopted in 1877, and incorporated in the B.C.P., gives authoritative reasons for the results of the Revision. This Preface reveals the principles which guided the Revisers :-

- As concerning the Holy Communion, some of our brethren were at first earnest that we should remove from the Prayer Book certain expressions, which they thought might seem to lend some pretext for the teaching of doctrine, concerning the Presence of Christ in that Sacrament, repugnant to that set forth in the Articles of Religion, wherein it is expressly declared that the Body of Christ is given, taken, and eaten in the Supper only after an heavenly and spiritual manner, and that the mean whereby it is therein received and eaten is Faith; but upon a full and impartial review, we have not found in the Formularies any just warrant for such teaching, and therefore, in this behalf, we have made no other change than to add to the Catechism one question, with an answer taken out of the Twenty. eighth of the said Articles.' 
- As for the error of those who have taught that Christ has given Himself or His Body and Blood in this Sacrament, to be reserved, lifted up, carried about or worshipped, under the Veils of Brcad and Wine, we have already in the Canons prohibited such acts and gestures as might be grounded on it, or lead thereto; and it is sufficiently implied in the Note at the End of the Communion Office (and we now afresh declare) that the posture of kneeling prescribed to all communicants is not appointed for any purpose of such adoration; but only for a signification of our humble and grateful acknowledgenaent of the Benefits of Christ, which are in the Lord's Supper given to all worthy receivers, and for the avoiding of such profanation and disorder as might ensue if some such reverent and uniform posture were not enjoined.'

' In the Formularies relating to Baptism we have made no substantial change, though some have desired to alter or omit certain expressions touching which diversities of ninion have prevailed among faithful members of our Church. At the same time, we desire fully to recognize the liberty of expounding these Formularies hitherto allowed by the general practice of the Church. And as concerning those points whereupon such liberty has been allowed, we hereby further declare that no Minister of this Church is required to hold or teach any doctrine which has not been clearly determined by the Articles of Religion.'

The Preface mentions three other changes. (1) The Special Absolution in the Office for the Visitation of the Sick has been removed. It had been the cause of offence to many, and as it was unknown to the Primitive Church, as there was no ground for its retention, and as its removal made no change in the doctrine of the Church, its place is taken by the form of Absolution in the Communion Office. (2) The Rubric directing the use of the Athanasian Creed has been removed, but the Church retains its witness to the truth of the Articles of the Christian Faith therein contained. (3) The Lectionary follows generally that of the Church of England, but all the lessons from the Apocrypha are removed, and their place is taken by Lessons from the Canonical Scriptures.

No change has been made in the formula for the Ordination of Priests-

- For, upon a full review of our Formularies, we deem it plain and here declare that, save in the matter of Ecclesiastical censures, no power or authority is by thein ascribed to the Church or to any of its Ministers, in respect of forgiveness of sins after Baptism, other than that of declaring and pronouncing, on God's part, remission of sins to all that are truly penitent, to the quieting of their conscience, and the removal of all doubt and scruple; 'nor is it anywhere in our Formularies taught, or implied, that confession to or absolution by a Priest are any conditions of God's pardon; but, on the contrary, it is fully taught that all Christians who sincerely repent, and unfeignedly believe the Gospel, may draw nigh, as worthy communicants to the Lord's Table, without any such confession or absolution; which comfortable doctrine of God's free forgiveness of sin is also more largcly set forth in the Homily of Repentance and in that of the Salvation of Mankind.' 


\section{The Changes Made.}

Tho
Prefaces. The three Prefaces are entitled 'The Preface Prefixed at the Revision of 1662'; 'The Original Preface (1549), altered in 1552 and 1662, concerning the Service of the Church'; and 'Concerning Ceremonies (1549).' The three Rubrics at the close of the Second Preface are omitted.

Psalter and Lectionary.
Calendar, etc.
Morning and Evening Prayer.
'The Order how the Psalter is appointed to be read 'is omitted, and, in ' the Order how Holy Scripture is appointed to be read,' it is commanded that special lessons approved by the Ordinary must be taken from the Canonical Scriptures.

The Note on Proper Psalms and Lessons is transferred to the end. In the Lessons Proper for Holy Days the title 'Annunciation of our Lady' is changed into 'Annunciation of the B.V.M.'

A short introduction on the Dominical or Sunday Letters precedes the Calendar, which omits mention of all the Black Letter Saints' Days, and substitutes for the passages from the Apocrypha, Lessons from the Canonical Scriptures. All the Book of Revelation is appointed to be read. At the end of the Table of Vigils and Feasts, authority is given to 'the Archbishops and Bishops to appoint Days of Humiliation and Days of Thanksgiving, to be observed by the Church of Ireland ; and to prescribe Special Services for the same.'

A new Note is added on the Golden Numbers, and the General Tables for finding the Dominical or Sunday Letter, etc., are omitted.

The words ' to be said and used' are omitted from the note before the Ornaments Rubric, which finds no place in the Irish B.C.P. Instead of the Rubric there is a series of directions for the conduct of public worship, and an additional note gives the Ordinary power to consent to the service being ' read or sung in the Irish or any other language that is better understood by the people.'

The Rubric gives permission for the Lessons to be read by ' a fit person appointed by the Minister.' Psalm cxlviii may be sung as an alternative to the 'Te Deum 'or 'Benedicite.' The reference to the Athanasian Creed is removed from the Rubric before the Apostles' Creed, and a new Rubric is added after the Invitation 'Let us pray.' This Rubric runs 'When the Litany is said, the Minister may omit the Lord's Prayer and the three Versicles preceding it.' 'A Prayer for the Chief Governour or Governours of Ireland' has been added, and directions are given for its use in the Litany.

In the Order for Evening Prayer an alternative Thira Collect for 'Grace and Protection' is provided by the insertion of the second prayer at the close of the B.C.P. Communion Office. 
The Athanasian Creed is simply prefaced by the words 'The Athanasian Creed (commonly called) of St. Athanasius.'

New Rubrics are added to the Litany, giving directions or Litany. its use as a separate Service, and providing for special prayer being offered for individuals.

New Prayers have been added for Unity, for a sick person Prayers and (a summary of two collects in the Visitation of the Sick), for the ThanksRogation Days, New Year's Day, Christian Missions, the General Synod, and for use in Colleges and Schools. The Prayer to be used in the time of any common Plague or Sickness has been modified.

A Rubric has been added to the General Thanksgiving, "Which may be said of the whole Congregation after the Minister,' and a new Thanksgiving after Recovery from Sickness has been inserted.

Alternative Collects, Epistles and Gospels are appointed for Collects, ete. Easter and Christmas Days which may be used 'if there be two celebrations of the Holy Communion in any Church' on those days ; * 1 Cor. v. 6-8 takes the place of 1 John v. 4-10 (which contains text of the three Heavenly Witnesses), as the Epistle for the First Sunday after Easter.

The second and third Rubrics before the Service are combined, Holy Conand abbreviated. The new Rubric rcads: 'If the Minister shall have knowledge or reasonable ground to believe that any person who is living in open and notorious sin intends to come to the Holy Communion, so that scandal would thereby arise, he shall privately admonish him not to presume to come to the Lord's Table till the cause of offence shall have been removed; and in every such case the Minister shall have regard to the Canons relating thereto.' The reference is to the Canons of 1877.

In the Rubric referring to the position of the Holy Table the words 'where Morning and Evening Prayer are accustomed to be said' are omitted, and a New Rubric provides that 'The

- The alternative Collect for Christmas Day-taken from the Sarum Use- ' Collect for the Eve of Christmas,' is : 'O God, who makest us glad with the yearly remembrance of the birth of thy only Son Jesus Christ, grant that, as we joyfully receive him for our Redeemer, so we may with sure confidence behold him when he shall come to be our Judge; Who liveth and reigneth with Thee and the Holy Ghost, one God world without end.' The Epistle, Titus ii. 11-14; The Gospel, St. Matthew i. 18-25.

Alternative Colleet for Easter Day-taken from the Sarum Breviary- $O$ God, who for our redemption didst give thine only-begotten Son to the death of the Cross, and by his glorious resurrection hast delivered us from the power of our enemy; Grant us so to die daily from sin, that we may evermore live with him in the joy of his resurrection; through the same Christ our Jord.' The Epistle, Hebrews xiii. 20, 21 ; The Gospel, St. Mark xvi. 1-8. 
Minister shall say the Service following in a distinct and audible voice.'

The Rubric following the Commandments permits the omission of the Prayer for the King, if 'he has been prayed for in any service used along with this office,' and in the Rubric preceding the Nicene Creed, after the announcement of the Gospel, there is interpolated 'Here may be said or sung Glory be to Thee, 0 Lord. And, after the Gospel ended, Thanks be to Thee, O Lord, or Hallelujah.' A comma has been inserted in the Nicene Creed after 'the Lord,' and before ' and Giver of Life.'

In the Rubric after the Creed the words ' and Briefs, Citations and Excommunications read ' are omitted, and for the last clause are substituted the words 'or enjoined by the General Synod of the Church of Ireland, or permitted by the Ordinary of the place.' The provision to read a Homily instead of a Sermon is omitted. In the Offertory sentences the two from the Book of Tobit are omitted.

In the Rubric following the sentences the allusion to a ' decent bason' is omitted, and the addition is made 'But, subject to the control of the Ordinary, Alms may be collected at other times during the Divine Service, with or without the use of the Offertory Sentences; provided that when the Holy Communion is celebrated, a collection shall be made as here directed.'

The Rubric after the Prayer for the Church Militant reads: - When the Minister giveth warning for the celebration of the Holy Communion he may read this Exhortation following, or such part of it as he thinketh most convenient.'

In the Rubric before the Exhortation these words have been interpolated: "those who do not intend to communicate having had opportunity to withdraw,' and a new Rubric is added, 'Note -This Exhortation may be omitted at the discretion of the Minister, the consent of the Ordinary having been first obtained : provided that it shall be read once in the month at least, and on all great Festivals.' In the Exhortation 'damnation' is altered to 'judgment,' and the words are omitted 'we kindle God's wrath against us; we provoke him to plague us with divers diseases, and sundry kinds of death.'

In the Rubric before the Prayer of Consecration the Priest is ordered to 'stand at the North side of the Table.' The Rubric directs that 'all stand up' when the Gloria in Excelsis is said or sung. A new collect is provided by adapting the prayer from the Burial Service: 'Almighty God, with whom do live the spirits of them that depart hence in the Lord, we humbly beseech thee that it may please thee, of thy gracious goodness, shortly to accomplish the number of thine elect, and 
to hasten thy kingdom; that we, with all those that are departed in the true faith of thy holy Name, may have our perfect consummation and bliss, both in body and soul, in thy eternal and everlasting glory; through Jesus Christ our Lord.' 'l'he first of the three Collects at the end of the Ordering of Priests is also inserted among those at the close of the Communion Office.

The following Collect is provided for use (optional), when the Prayer for the Church Militant is not read : "Almighty God, we humbly beseech thee to accept the offerings which we have presented unto thee, and mercifully to receive our supplications and prayers; and grant that those things which we have faithfully asked according to thy will, may effectually be obtained, to the relief of our necessity, and to the setting forth of thy glory ; through Jesus Christ our Lord.'

The first Rubric after the Office reads: 'Upon Sundays and Holy-days (if there be no Communion) all shall be said as appointed up to the Prayer (for the whole State of Christ's Church Militant here in earth); which prayer may in such case be said, or omitted, at the discretion of the Minister; and then shall foilow one or more of the Collects ; concluding with the Blessing.'

The number required to be present for the Celebration of the Lord's Supper is 'three (or two at the least).' The following new Rubrics are added :-

' On occasions sanctioned by the Ordinary, this Office may begin with the Collect, Epistle, and Gospel.'

All Ministers shall exhort their people to communicate frequently. And every Parishioner shall from time to time be exhorted to contribute regularly of his substance to the maintenance of the worship of God, according as God shall prosper him.'

'And when by reason of numbers, it is inconvenient to address to each communicant separately, the words appointed to be said on delivering the Bread and the Cup, the words may, with the consent of the Ordinary, be said once to as many as shall together kneel for receiving the Communion at the Holy Table; provided that the words shall be said separately to any Communicant so desiring it.'

In the fifth Rubric the words 'the Bread shall be such as is usual to be eaten' are substituted for 'it shall suffice that the Bread be such, etc.'

The second, seventh and eighth Rubrics after the Communion Office are omitted in the Irish B.C.P.

A new Rubric reads: 'Parents may be Sponsors for their own Public children. When three Sponsors cannot be found, two shall of Infants. suffice; and if two cannot be found, one shall suffice.' 
Baptisms may take place after the Third Collect; as well as after the Second Lesson. The Rubric following the request to Name this Child reads:- "And then, naming it after them, he shall dip it in the water discreetly and warily, if they shall desire it, and he shail be certified that the child may well endure it ; otherwise it shall suffice to pour water upon it, saying always.'

Instead of a simple reference to the Thirtieth Canon of 1604, the following note concludes the Office: "Whereas the sign of the Cross is by this Office appointed to be used in Baptism according to the ancient and laudable custom of the Church, it is not thereby intended to add any new rite to the Sacrament as a part of it, or necessary to it; or that the using that sign is any virtue or efficacy of itself; but only to remind all Christians of the Death and Cross of Christ, which is their hope and their glory; and to put them in mind of their obligation to bear the Cross in such manner as God shall think fit to lay upon them, and to become conformable to Christ in his sufferings; as more largely is expressed in the Thirtieth Canon of the Church of England, which Canon is printed by the direction of the General Synod at the end of the Canons of the Church of Ireland.'

Private

Baptism.

The First Rubric reads "The Curates of every Parish shall often admonish the people that they defer not the Baptism of their Children longer than the third or fourth Sunday next after their birth, or other Holy-day falling between, unless upon a great and reasonable excuse.'

In the Office for the reception of privately baptized Children into the Church, before the Gospel the following Rubric is inserted '... after having certified the Congregation of the form of baptism, whether by himself or another Minister, he shall proceed and say.'

The Lord's Prayer is omitted between the brief Exhortation and the Collect. At the close of the Office, a Rubric gives directions for conducting the Service of Baptism and the Reception of a Child into the Church at the same time.

Catechism. The following new question and answer are inserted :-

Question: After what manner are the Body and Blood of Christ taken and received in the Lord's Supper?

Answer: Only after a heavenly and spiritual manner; and the mean whereby they are taken and received is Faith.

The first Rubric after the Catechism reads: "The Curate of every Parish shall diligently, at such times as he shall think convenient, instruct and examine the children of his Parish in this Catechism; and upon Sundays and Holy-days, after the second Lesson at Evening Prayer, or at such other time as may be convenient, he may, with the approval of the Ordinary, 
openly in the Church instruct and examine as many of such children as he shall think fit, in some part of the Catechism.'

In the Second Rubric 'Mistresses' is substituted for 'Dames.' In the third Rubric the following clause is omitted: 'And every one shall have a Godfather or a Godmother, as a Witness of their Confirmation.'

The Rubric before the final Collect reads : "And this or some Confrmaother Collect out of this Book, at his discretion.'

The Bishop is directed to stand up when giving the Blessing, and the following additions are made to the Service:

'When Confirmation is ministered only to those baptized in riper years, the Bishop shall begin the Service with this question 'Do ye here in the presence of God and of this Congregation renew the solemn vow and promise of your baptism?'

'The Bishop may address the candidates during the Service at his discretion.'

The final Rubric reads : Every person ought to present himself for Confirmation (unless prevented by some urgent reason) before he partakes of the Lord's Supper.'

Banns may be published on three following Sundays or Feast Matrimony. days after the Nicene Creed, or immediately after the Second Lesson at Morning or Evening Prayer.

The Exhortation is shortened by the omission of expressions, which are coarse to the ears of Churchmen of the present day.

The Service ends, if there be no Communion, with a Collect and the Grace.

A New Rubric states:- 'Nothing in this order prescribed visitation shall restrain the Minister or Curate from edifying and comforting of the the sick, as he shall think meet and convenient, by instruction or prayer ; but if the sick shall require it, he shall use this Office.'

The Rubric before the Absolution reads: 'Here if the sick person feel his conscience troubled with any weighty matter, he shall be moved to open his grief, after which (if he humbly and heartily desire it) the Minister shall say': (the Absolution in the Communion Office).

The Office ends with 'A Prayer for a Sick person when his sickness has been mercifully assuaged.'

The preliminary Rubric has for "which shall be three or two communion at the least " which if possible shall be two at least' and discretion of the is given to the Minister to use the Collect, Epistle and Gospel for the day.

$\Lambda$ new Rubric has been added: 'If the sick person be very weak, and necessity so require, it shall suffice to use for this ofiice the Confession, Absolution, Prayer of Consecration, Form of Delivery of the Sacrament, Lord's Prayer, and Blessing.' 
Burial.

Churching and Com. mination.

Psalms.

Ordinal.

Accession.

A new Rubric says : 'Here is to be noted, that the Office ensuing is not to be used, for any that die unbaptized, or excommunicate, or in whose case a verdict shall have been found of felo de se. But if any be brought for burial who have died unbaptized, being infants of tender age, the offspring of Christian parents, and not having been withheld from Baptism by wilful default or neglect, or being persons known or certified to the Minister to have been at the time of their death prepared for or desirous of Baptism, the Minister shall in such cases read one of the following Psalms or Lessons, or such portion of them as he shall see fit, and the four sentences at the grave, concluding with the Lord's Prayer and the Benediction at the close of the Office.'

1 Thess. iv. 13-18 is provided as an alternative Lesson.

In the Committal the words ' of his great mercy' are omitted, and in the penultimate Prayer 'We bless thy holy name for all thy servants departed this life in thy faith and fear' are substituted for "We give thee hearty thanks that it hath pleased thee to deliver this our brother out of the miseries of this sinful world.'

The words of the opening Rubric are changed from 'in some convenient place' to 'in such place and at such time'; and in the Commination Service references are given in the Address, and 'penance' is changed into 'repentance.'

The Note from the beginning of the B.C.P is in substance prefixed to the Psalter, and a Rubric is added:- ' Upon Occasions to be approved by the Ordinary other Psalms may, with his consent, be substituted for those appointed in the Psalter.' In the Rubric for ' his Deputy' (of the Archdeacon) the words 'in his absence, one appointed in his stead' are inserted, and in the Rubric of the Form of Consecrating 'the Certificate of the Bench of Bishops and of the election and fitness of the person to be consecrated' takes the place of 'the King's mandate for the Consecration.'

The Second Rubric reads : 'If this day shall happen to be a Sunday, or Holy-day the Collects of this Office shall be added to the Office of the day, and the rest of this Office shall be omitted.'

The substitute for the Venite is omitted, and the Rubric before the Thanksgiving begins 'After the' in place of 'Instead of.' The use of the Litany and the Collect following are omitted, and a new Rubric says : 'In the Communion Service, immediately before the reading of the Epistle, after the Collect of the Day, shall be used this Prayer for the King' (called in the B.C.P. 'A Collect, for God's Protection of the King against all his enemies '). The two Final Collects and the Benediction are not printed. 
The Order for Morning Service to be used on the First Sunday New on which a Minister officiates in the Church of a Cure to which offices. he has been instituted.

A form of Thanksgiving for the Blessings of Harvest.

The form for the Consecration of the Church.

The form of Consecration of a Churchyard or other Burial Ground.

A form of Prayer for the Visitation of Prisoners. This is not altogether new as it was ' treated upon by the Archbishops and Bishops, and the rest of the Clergy of Ireland and agreed upon by her Majesty's License in their Synod, holden at Dublin, in the year 1711, and amended in the Synod of said Church, holden in Dublin in the year 1875.'

Two notes precede the Articles:-

Received and approved by the Archbishops and Bishops, and the rest of the Clergy of Ireland, in the Synod holden in Dublin A.D. 1634.

Received and approved by the Archbishops and Bishops, and the Clergy and Laity of the Church of Ireland in the Synod holden in Dublin A.D. 1870.

\section{Constitutions and Canons Ecelesiastical.}

At the end of every copy of the Irish B.C.P. are found 54 Canons, and a re-print of the thirtieth of the English Canons on the lawful use of the Cross in Baptism. These Canons, and none other, have full force and effect as the Canons of the Church of Ireland. They deal with many subjects, and as the Ornaments Rubric is omitted from the Irish B.C.P., the conduct of Public Worship and the Ornaments of the Chancel and Minister are clearly prescribed.

4. Of the use of the prescribed Form of Divine Service on Sundays and Holy-days with all decency and due reverence.

On every Lord's Day, commonly called Sunday, and Holy-day appointed by the Church, unless dispensed with by the Ordinäry, the Parsons, Vicars, and Curates shall celebrate Divine Service at convenient and usual times of the day, and in such place in every Church or other suitable building provided for the purpose as the Bishop of the Diocese or Ecclesiastical Ordinary of the place shall think meet, so as the people may be most edified. All Ministers shall likewise use and observe the Orders, Rites, and Ceremonies prescribed in the Book of Common Prayer, as well in reading the Holy Scriptures and saying of Prayers as in administration of the Sacraments, without either diminishing or adding anything in the matter or form thereof, save as hereinafter provided. 
Every Archbishop and Bishop at all times of his public ministration of the Services of the Church shall use the customary Ecclesiastical Apparel of his Order. And every Presbyter and Deacon at all times of his public ministration of the Services of the Church shall wear a plain white Surplice with sleeves, and such Minister may wear Bands, and upon the Surplice the customary Scarf of plain black silk, and being a Graduate of a University he may wear the Hood pertaining to his degree. And no Minister shall wear any other Ecclesiastical vestment or ornament: Provided that any Minister shall be at liberty to wear a plain black Gown when Preaching. And if any question shall arise touching the suitableness of any vestment or ornament worn by any Minister during the public ministration of the Services of the Church, the same shall be decided by the Ordinary, subject to an appeal to the Court of the General Synod.

\section{Of the Ordering of Divine Service.}

Every Minister at all times of his public ministration of the Services of the Church shall speak in a distinct and audible voice, and so place himself that the people may conveniently hearken unto what is said, and in no case when he is offering up Public Prayer shall his back be turned to the Congregation.

And every Minister when saying the Prayer of Consecration in the Service prescribed for the administration of the Lord's Supper shall stand at the north side of the Table, by which, both here and in the Rubric of the Communion Office, is to be understood that side or end of the Table which, in Churches lying East and West, is towards the North. And if any question shall arise as to the interpretation or application of this Canon in any particular case, the same shall be decided by the Ordinary, subject to an appeal to the Court of the General Synod.

It shall be unlawful to use in any Public Office of the Church any Psalm, Hymn, or Prayer other than those prescribed in the Office itself, or ordered or permitted by the Ordinary or other lawful authority of the Church; except the words "Glory be to Thee, $O$ Lord,' at the beginning, and the words 'Thanks be to Thee, O Lord,' or 'Hallelujah,' at the end of the Gospel. But there may be used, at the discretion of the Minister, subject to the control of the Ordinary, a Hymn or Psalm so authorised, at the beginning or end of any Office, or after the third Collect in Morning or Evening Prayer; or a Prayer with or without a Hymn or Psalm so authorised, at the beginning or end of a Sermon; or an occasional Prayer at any other part of the Service directed by the Ordinary. Morning Prayer with or without 
the Litany, Evening Prayer, the Litany, and the Communion Service are to be regarded as distinct Offices.

No Minister or other person during the time of Divine Service shall make the sign of the Cross save where prescribed in the Rubric;' nor shall he bow, or do any other act of obeisance to the Lord's Table, or anything there or thereon; nor shall any bell be ruing during the time of Divine Service.

It shall be competent for the Ordinary to restrain and prohibit in the conduct of Public Worship any practice not enjoined in the Book of Common Prayer, or in any Rubric or Canon enacted by lawful authority of the Church of Ireland.

\section{Of the Communion Table.}

The Communion Table shall be a movable table of wood, and : hall have such decent covering only as the Ordinary shall approve of ; but for the administration of the Lord's Supper, it shall be covered as provided by the Rubric.

35. Of Lights at the Communion Talle, or elsewhere.

There shall not be any lighted lamps or candles on the Communion Table, or in any other part of the Church, during the celebration of the Services or the administration of the Sacraments, or any other of the Public or Common Prayers or Rites of the Church, or during Public Preaching, except when they are necessary for the purpose of giving light.

\section{Crosses on or behind the Communion Table forbidden.}

There shall not be any cross, ornamental or otherwise, on the Communion Table, or on the covering thereof, nor shall a cross be erected or depicted on the wall or other structure behind the Communion Table, in any of the Churches or other places of worship of the Church of Ireland.

37. Of the Administration of the Lord's Supper.

In the administration of the Lord's Supper, the elevation of the Paten or Cup beyond what is necessary for taking the same into the hands of the officiating Minister, the use of wine mixed with water, or of wafer bread, and all acts, words, ornaments, or ceremonies other than those that are prescribed by the Order in the Book of Common Prayer, are hereby declared to be unlawful, and are prohibited: Provided always, that nothing herein contained shall be taken to prohibit the customary act of reverence when the name of our Blessed Lord is mentioned in reciting the Nicene Creed. 


\section{Of Incense.}

No incense or any substitution therefor, or imitation thereof, shall at any time be used in any Church or Chapel, or other place in which the Public Services of the Church are celebrated.

39. Of Processions.

It shall be unlawful to carry any cross, banner, or picture through any Church or Churchyard in any religious service or ceremonial. Nor shall any procession take place therein as a Rite or Ceremony in connection with any part of such Service, unless prescribed by the Bishop, or by the Rubrics of the Book of Common Prayer.

It is clear from these Canons that the Church of Ireland has taken every possible measure to prevent the assimilation of the Communion Service to the Roman Mass. The character of its worship, the doctrine it teaches and its theological position are defined free from all ambiguity, in its B.C.P., in its Preamble and Declaration, in its Preface, and in the Canons that govern the worship, rites, and ceremonies of Irish Churchmen. 


\section{INDEX}

An asterisk placed after the number of the page indicates that the word is to be found in the Classifed Lists, Appendix D, pp. 596-608

PAGE

PAGE

\section{$\mathbf{A}$}

Ablutions. . . . 420,600*

Absolution . 95-97, 116, 327, 454

Abstinence, Days of . . $51 \mathrm{ff}$.

Accession Service . . . 57, 534

Accipe vestem sacerdotalem. $\quad 499$

'Accustomed place' . . . 77

Acolyte . . . . . 507

Acts of Uniformity. See.Uniformity.

Adoptionism . . . . 127

Adoration . . . . 366-369

Advent . . . 42, 153, 154

Advertisements of Elizabeth xxi,

Affinity. See Kindred.

xxiv, 83, 84, 80

Affusion . . . . . . 370

a $\gamma d \pi \eta$. . . . . . . . 181

Agape. . . . . . . . 219

¿́rios . . . . . . . . 191

Agnus Dei . . . . 266,346

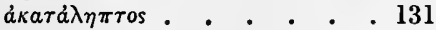

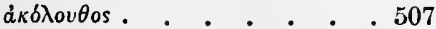

Alb . . . . 85, 498, 603*

Alleluia . . . . . $605^{*}$

All Martyrs, Festival of. See

Saints' Days.

All Souls' Day. See Saints' Days.

Alms . . . . . 312,315 Almuce, or Amys . . . .603* Alonely . . . . . . 468 Altar . . . 231, 270, 292, 575

Altars. . . . . . . . 261

Stripping of . , , . 170
Altarwise Position of Holy

Table . . . . . $\mathbf{x} \times \mathbf{v}$

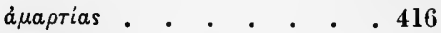

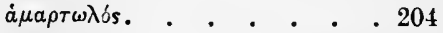

Ambrose . . . 104, 431, 605*

Amen . . . . . .95, 605*

American B.C.P. 94, 99, 106, $109,112,114,118,121,126$, $143,144,145,147,148,154$, $168,174,178,204,437,442$, $456,466,467,479,480,481$,

487,488

Amice. . . . . . $603^{*}$

Amor . . . . . . 182

Ampulla . . . . . .601*

Anabaptism . . . 400, 473, 598*

Anabaptists $17,384,543,545$,

$550,551,572,573$

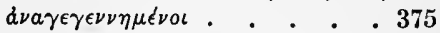

à $\alpha \mu \nu \eta \sigma \iota s$. . . . . . 216

Anaphora. . . . . . .466

Anastasius . . . . . 240

Anglicanism . . . . .xxiv

Annexed Book . . . . 6

Annunciation. See Saints' Days.

Anointing with Oil . 376,500,501

Anointing of the Sick . 456, 463

in B.C.P. of 1549 . . . 45 ;

Greek and Roman Practice. 45(;

Antependium . . . . .601*

Anthem . . . . . . . 112

Anthems, or Antiphons . . 24

Easter . . . . . . 172

Antinorilanism . . . . . 550

Anti-Papal Measures - . 579 ff. 
Antiphonary . . . . 149 n., 594

Antitype . . . . . . . 239

Apocrypha . . . . 24, 38, 103

Apollinarianism 124, 125, 127, $134,135,547,598^{*}$

Apostasy . . . . . . . 408

Apostles' Creed . 108, 109, 406

Apostolic Succession . . . xxV

Apparel . . . . . . .603*

Archbishop, Ordaining or Con-

secrating of . . 529-533

Archdeacon . . . . 502,510

Arianism $125,127,129,130$,

134, 598*

Arminianism. . . $\times x v, 552$

Artemonitism . . . . .598*

Article XXVII . . . 371,372

Article XXIX - . . 276, $280 n$.

Article XXXI . . . 278,516

Article XXXIV. . . . . xiii

Article XXXVI. . . . . 637

Articles of Religion-

Final Draft . . . . . xxi

Historical Introduction . . 539

Six, Law of the - xvi, 10,

$$
252,542,568,589
$$

Ten, the . . . . . .541,589

Eleven, the . . . . . 543

Thirteen, the . . . . . 541

Thirty-eight, the . . lxxi, 543

XXXIX, the . . Xxi, 536, 544

Forty-two, the . . xxi, 542

Irish . . . . . . 544

Lambeth . . . . xxi n., 544

Schwabach, the . . . 539

Bishops' Book . xvi, 541, 591

For literature, see App. E . 609

See also Chron. List 622, 623

Articles, XXXIX . xxi, 536, 544

Exposition. . . . . 545

His Majesty's Declaration . 538

History of Subscription. . 544

Index . . . . . . 536

'Title-pago. . . . . 537

Articles of War . . . . . 495

Ascension-Day . . 42, 176, 177

Ash Wednesday . $53,164,165$

Asperges . . . . . . .600*

Aspergillum . . . . . .601*

Athanasian Creed . . .122-136

Authorship . . . . . 124

Date . . . . . . . 125

Exposition. . . . .128-136

Special Characteristic . . 123

Summary and Analysis .126-128

Use in Services . . . . 125

Augmentation Theory 239, $242 n$. Augsburg. See Confessions.

Augustine of Canterbury . .605* Augustine of Hippo 31, 104, $218,235,237,605^{*}$

Aumbry or Ambry . . . .601* Auricular Confession . . . 542 Ave, Maria, plena gratia . . 199 Azymitism . . . . . .598*

\section{B}

Banns of Matrimony . . 307 Publication of $\quad .439,439 n$., 441 Baptism . 171, 370 ff., 407 n., 422 Conditional Formula. . . 399

Cross in. See Cross.

Formula . . . . . 388

Lay. - . $394,395,395 n$.

Matter . . . . . 370

Ointment (Chrism) . . $379 n$.

Place . . . . . . . 371

Time . . . . 371, 380

Vesture (Chrisom) . $379 \mathrm{n}$.

Views on . . . . . 374

Baptism of Adults . . . .400

Differences between it and that for Infants . . . 400

Prayer and Fasting . . . 401

Reason for the Service. . 400

Baptism of Infants, Private-

Office of 1662 compared with that of 1549 . . . . 393

Service for Reception into the Church . . . . . 396

Baptism of Infants, Public-

Analysis and Historical Notes . . . . . . 379

Arguments for . . . . 422

Consccration of Water, Form of . . . . . . 387 
Baptism of Infants, PublicExposition. . . . . 380 Introduetion . . . . 370 Offieo of 1662 compared with that of 1549 . . . 378

Puritan Objeetions . . . 389 The-1549- Eervice eompared with that of $1552 . \quad . \quad 379$

Baptismal Office-

Alleged Defects . . . . 377 Ancient Services . . . . 376

Prineiples of the Service . 377 Reformed . . . . . . 376 Vows . . . . . . 386

Baptized for the Dead. . $47 i n$. $\beta a \pi \tau i \xi \omega$. . . . 370,388 Bartholomew, Blaek . . $x_{x x}, 8$ Basil . . . . . . . . $605^{*}$ Baxter, Richard. . .xxviii, $605^{*}$ Beatifieation . . . . $.600^{*}$ Bede . . . . . .70, $605^{*}$ Bede's Death-bed Antiphon . 177 Believe, and thou hast eaten. 467

Believers' Baptism . . . . 372 Benedicite. . . . . 105, 106 Benedictio Cinerum. . . .493 Benedictus . . . . . . 106 Berengarian Controversy . . 244 Bertram's T'reatise on the Lord's BibleSupper . . . . . xviii Chained . . . . . 34 The Great. . . . . . 34 Translation $\%$ and Versions . 623 Bidding Prayer . . xxiv, 10, 309 Bishop, Ordaining or Conseerating of . . . $529-533$

Bishops, Priests, and Deaeons 507 Bishops' Book . . xvi, 541,591 Biretta . . . . . . .603* Black-lotter Days . . . 66-73 Eastern . . . . . 71 English. . . . . . 70 Freneh . . . . . . 69 Roman. . . . . . 67 Biblical . . . . . 66

Black Rubrio 265, 268, 273,

341,365

Blasphema figmenta. . 279
Blasphemy against the Holy Ghost

PAGE

Blessing -

of the Ashes. . . . . 164

of the Candles.. . . . 196

of the Palms . . . . 167

of the Waters . . . . 159

of the Wedding-ring . . 443

Boat . . . . . . . 01*

Book-

Annexed . . . . . 6

Bishops' . . xvi, 541, 591

King's . . . . . . . 542

Books, Sealed . . . . . 5

Both Kinds xvii. See Communion; Cup.

Bowing at Name of Jesus xxii $n$, $\mathrm{xxv}, 109$

Bowing to Holy Table. . xxvi Bradley and Tables for Easter 42 Bread, Saeramental. 266, 357-360 Breviary . . . xvii, 2, 593, 624 Briefs . . . . . . . . 307 Bueer, Martin . xix, 317, 384, $457,488,492,605^{*}$

Bugia . . . . . . .601* Bullinger, Henry . . . .606* Burial Communion Office . . 481 Burial Laws Amendment Aet 471 Burse . . . . . . .602* Buxom . . . . . . 442

\section{C}

Cæsarius . . . . . . . 124

Rule of. . . . . . . 104

Calendar . . . . . . 64-75

Dates when Names placed in $\mathbf{7 4}$

Holidays . . . . . . 66

Since the Reformation . . 65

Use of, in finding Dates - 75

Calendarium . . . . . . 64

Calvin. . . . 426, $462,606^{*}$

Calvinism. . . 544, 552, 557

Candlemas Day 45, 164, 196, 600*

Candles, Blessing of the . . 196

Canon, the . $99 n ., 270,466,575$

Canons, the xxiv, xxvi, $84,109,624$

Cantate 
PAG IE

Canterbury, Abps. of, during Reformation and Prayer

Book Period . . . . 622

Cassock . . . . . . .603*

Catechism-

Alleged non-Protestant

Teaching . . . . . 276

Authors of . . . . . . 404

Proposed Additions in 1887, xxxi

For Literature, see App. E. . 612

Catherine of Aragon, Divorce

from . . . . . 577

Celibacy, Clerical . . . . 542

Censer. . . . . . . $602^{*}$

Ceremonies . . . . 3, 31

Why some abolished and

some retained . . . . 27

Chalice . . . . . . $.602 *$

and Paten, Delivery of . . 493

Mixed . . . . . . 313

Veil. . . . . . $.602 *$

Chancels . . . . . 77

Chasuble . . . . 499,603*

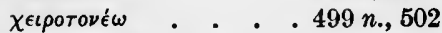

Cherubin . . . . . $.605^{*}$

Childermas Day. .... . . 157

Children of grace . . . . 421

Chimere . . . . . .604*

Chrism 169, 237, 376, 379 n., 390 391, 399, 436. See Baptism.

Chrisma . . . . 426, 427

Chrismal or Chrismatory . $.602 *$

Chrisom 171, 177, 379 n., 487.

See Baptism.

Christian Man, Institution of a xvi, 541, 591

Christian Man, Necessary Doctrine and Erudition for any 542

Christian Ministry, The . . 501

Christmas-Day . . .44, 155, 156

Sunday after . . . . 157

Chrysostom . . . . . .606*

Fasting Communion. . 219

Prayer of . . . . . 114

Churches, Non-Episcopal . . 503

Ciborium . . . . . .602*

Cincture . . . . . . .604*

Circumcision, Feast of $44,157,158$

Citations . . . . . 307

Clement of Alexandria. $606^{*}$

Clement of Rome . . . . $.606^{*}$

Clementine Liturgy. . . . 229

Clergy and People, Prayer for 114

Clerical Celibacy . . . . 542

Cohen. . . . . . 515, 517

Collect (word) . . . . . 149

Collects . . . . . . . 300

Collects, Epistles, and Gospels

149-209

Comfortable Words. . . . 327

Commandments, the . .407-412

Commemorations . . . 23, 112

$317,600^{*}$

Commendation of Soul. . . 447

Commendatio Animarum . 470

Commination, A . . .489-494

Analysis and Historical

Notes . . . . . 490

Exposition. . . . . . 491

Character of Service . . 489

Committees and Conferences, chron. list of . . . . 624

Common Prayer. . . . . 2

Communicatio Idiomatum . .596*

Communion in one Kind . . 252

Communion, Holy-

344,542

Adoration . . . 366-369

Alleged non-Protestant statcments-

in 1st Exhortation . . 270

in 3rd Exhortation . . 271

in Prayer of Humble Access . . . . . 271

in Words of Administra. tion . . . . . . 272

in first Post-Communion Collect . . . . . 272

in Black Rubric . . . 273

Benefits of . . . . . 423

Byzantine Practice . . . 233

Comparative Table . . . 281

Daily Administratir:! . . 363

Evening . . . . . . 218

Fasting. . . . . .218, 219

Frequency of Communicat-

ing . . . . 215, 363

Kneeling at . . . . 341 
Communion, Holy-

Non-communicating Attend-

ance . . . . . . . 309

Number to Communicate . 356

Order of $1548 \quad$. . . . 252

Compared with Sarum Use 256

Order of 1552 . . . 266

Receiving in Hands. . 341

Syrian Practice . . . . 232

Words of Administration . 345

For Literature, see App. E.

See also Holy Communion;

612,617

Lord's Supper.

Communion of Sick 340,451 , 458-468

Attitude of Faith . . .467

Believe, and thou hast eaten 467

Fasting. . . . . 464, 466

Communion Table . . . 266

Comprehension Bill. . . . 544

Concomitance, Doctrine of 344,

Conferences and Committees,

$$
458,566
$$

chron. list of . . . . 624

Confession-

Auricular . . . 298, 542

Auricular Secret . . . . 321

Compulsory . . . . . 246

in Communion Office . . 326

in Visitation of the Sick.453, 454

The General . . . . 95

For Literature, sec App. E. . 612

Confessions-

of Augsburg . . . 540,542

of Würtembcrg . . 540, 543

Confirmation, Order of 403,

$426-437$

Analysis and Historical Notes 430

Changes made by, the Reformers. . 428

Crossing. See Cross.

Exposition. . . . . . 431

History of Confirmation .426

Points to be borne in mind respecting . . . . . 421

For Literature, see App. E . 612

Consecration, Prayer of . . 334

Scriptural . . . . . 338
Consubstantiation . . . 369

Controversial Works in Henry

VIII's Reign . . . $576 \mathrm{ft}$.

Cope $83,85,334,498,529,604$ *

Corporal . . . . . . .602*

Corporal Presence . . 223,566

Adoration of . . . . 366

The Real 235, 249, 251, 252,

$263,265,273$

Cosin . . . 56, 154, 162, 606*

Cotta . . . . . . . .604*

Council of Trent . . 419, 250

Decrees of. . . . .540,549

For Literature, see App. E.. 621

Councils, chron. list of. . $625 \mathrm{f}$.

Counter-Reformation . . . xxv

Cranmer . xvi, xvii, xix, xx, $498,507,541,42,606 *$

Crode et Manducasti . . . 467

Credence Table. . . . 293

Creed-

Apostles' . . . 108, 109, 406

Athanasian . . . .122-136

Nicene . . . . .304-306

For Literature, see App. E. . 613

Creed of Rufinus . . . 108

Cross-

Consignation of the $383,389,392$

Creeping to the . . . . 170

in Baptism . . $\quad x \times i i n ., \times x \nabla$, xxvii, xxix

in Confirmation . . 428, 435

Invention of the. . . . 72

Gruets. . . . . . . .602*

Cup, withholding . . . . 344

Consequences of . . 344,345

Curates . . . . . . 114

Cyprian's Nursing Staff . . 447

Cyril of Jerusalem-

Catechetical Lectures . . 231

Invocation of Holy Ghost . 237

Lord's Supper . . . . 236

D

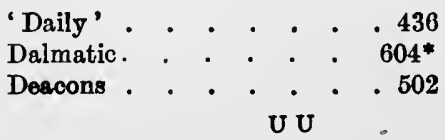


Deacons, Making of . .509-513

Analysis with Historical

Notes. . . . . 509

Exposition. . . . . . 510

The Seven. . . . 502,511

See Ordinal.

\section{Dead-}

Baptized for the . . $477 n$.

Commemoration of the 470,482

Prayers for the . $317,470,481$

Dead, Order for Burial of the

Analysis with Historical

Notes. . . . . 471

Burial Communion Office of 1549 . . . . . . 481

Introducticn . . . . . 469

The Service . . . . . 473

Deadly Sins . . . . . 141

Deceased Wife's Sister Act (7

Edw. VII, c. 47) . 574, 576

Decretals, False. . . . . 243

Deus misereatur. . . 119,120

Devotions, other . . . . 312

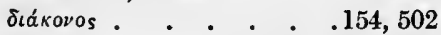

Didaché . . . xiv, 224, 225

Dies Absolutionis, Dies Crucis,

Dies Dominica Passionis 169

Dies Cinerum . . . . . 164

Dies Conce Domini, Dies Mandata, Dies Natalis Calicis,

Dies Natalis Eucharistica. 168

Diptych . . . . . .602*

Directory. . . . . . 12,494

Docetæ . . . . . . 234

Docetism . . . . . 127, 134

Doctrinal Reform, Literary

Efforts towards . . $589 \mathrm{ff}$.

Dominica in Albis . . 174, 178

Dominica vacans . . . . 187

Dominical Letter . . . 58

Donatists. . . . . . 563

Dossel or Dossal . . . .602*

Dowden . 432, 433, 434, 435,

436,444

Doxology 101, 102. See also

Lord's Prayer.

\section{$\mathbf{E}$}

Early English Church His. tory, Chron. List of Events in . . . $626 \mathrm{f}$.

Earth on Corpse, casting . . 478

East, turning to, in Creed . . 109

Easter and other Moveablc Feasts, Tables to find

$$
41,42,57-63
$$

Easter Day . . 169, 171, 172, 364

Easter Dues . . . . . . 364

Easter Even . . . . 170, 171

Easter, Monday to Thursday before . . . . 167-169

Sundays after. . . .174-176

Easter Week. . . . 173, 174

Eastward Position . 295, 296, 334

Ebion. . . . . . .599*

Ecclesiastical History Litera. ture . . . . . . 615

Ecclesiastical Terms. See Liturgical.

Ecclesiasticism

557

Edward VI, King-

Legislative Enactments . .627

Second Year of, Article

XXXVII . . . . 570

Ego Berengarius. . . 244, 247

Elect . . . . . 388, 407

Eloments, Unconsumed . . 232

Eleven Articles, the . . . 543

Elizabeth, Legislative Enact-

ments . . . . . 628

Ember Days. . . 54, 145, 505

Ember Weeks . . . 145, 508

Encomia . . . . . .600*

Epact . . . . . . . 58

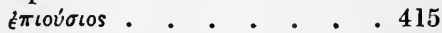

Epiphany. . . . . . 44, 158

Sundays after. . . .159-162

$\epsilon \pi i \sigma \kappa o \pi$ os . . . . . . . 502

Epistles, 300. See also Collects.

Erastianism . . . . . 572

Espousals. . . . . 442, 443

Eucharist, Children's . . . 309

Eucharistic Theories, Water-

land's Classification . .241

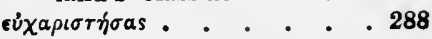




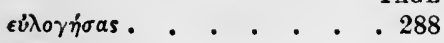

Eutyches . . . . . .599*

Eutychians . . . 127, 134, 135

Evangelistary . . . $149 n$.

Evening Prayer . . . .115-121

Evens. . . . . . 49,50

Excommunicate. . . . 473

Excommunication . . . 307

Greater . . . 489,492

Ex opero operato . . . . 564

Exoroism. . . 376, 379, 600*

Exorcist . . . . . . 507

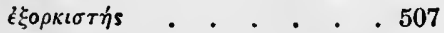

Extreme Unction - 447, 455, 457

\section{F}

Faith . . . . 421, 423, 424 Attitude of . . . 467 Justification by . . . . 251

Fanon. . . . . . .602*

Fasting, 52, 56, 219, 220. See also Communion.

Days of . . . . . 51

Fasting enjoined . . . . 401

Feasts,moveable and immoveable 40 to be observed . . . . 43

Ferial. . . . . . .601*

Fieri non debet, factum valet . 396

Filioque. . . . . 126, 132

Final Court of Appeal. . . 86

Firth, John . . . . . . 252

Flagon . . . . . . .602*

Folkestone Case. . . . . 86

Forty-two Articles, the .xxi, 542

Friday Fast, the . . . 56

Frontal . . . . . .602*

\section{G}

Gabriel and Michael $\quad 206,207$ Gardiner . . . 263, 541, 606* Gelasius . . . 149, 180, 606* $\gamma \epsilon \nu \nu \eta \theta \hat{\eta} \measuredangle \nu \omega \theta \epsilon \nu$. . . . . 375 Genuflexions . . . . . 491 Gloria in Excelsis . . 104, 353 Gloria Patri 34, 98, 99, 101, 117, 136 Godparents . . . 381, 404, 433 Golden number . . . . . 58
Good Friday. Collects . . . . 168, 170 Mediæval Customs . . . 170 Gorham Judgment, Opposite

Results from . . . . 373

Gospels. See Collects.

Gossips . . . . . . 381

Grace, Collect for . . . . 111

Gifts of . . . . . 434

Punctuation of this word in

the Catechism . . . . 41 !

Graduals . . . . . $153 n$.

Great Week . . . . . 167

Gregory the Great . . . .606*

Gregorian Calendar. . . . 42

Gremial . . . . . . $602^{*}$

Grindal . . . . . $.606^{*}$

Gunning . . . . . .606*

H

Hampton Court Conference . 544 Alterations made xxiii $n$., xxiv Demands of Puritans . xxiv $n$. Members of . . . . 636

Harvest 'Thanksgiving Sorvice, Proposed . . . . . 148

Henotheism . . . . . 597

Henry VIII, Documents and Publications of Reign of $\mathbf{5 7 6} \mathrm{ff}$. The Divorce from Catherine of Aragon . . . . 577

Heresy . . . . . . . 142 Heresies and Sects, classified list of . . . . $598 \mathrm{ff}$. Hermann. . . . . . .606* Hermann's 'Consultatio' 139, $376,393,403$ n., 435, 436, 441,478

High Court of Parliament, Prayer

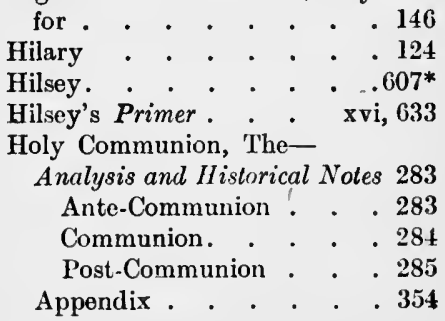


Holy Communion; The-

Early Service-Books 149 n., 593 ff.

Exposition-

Ante-Communion .: . 290

Communion. . . . : 323

Post-Communion . . . 349

Historical Introduction . : 210

For Literature, see App. E.

See also Communion; Lord's Supper.

Holy Cross Day. See Saints' Days, etc.

Holy-days

Holy Ghost, Blasphemy against the . 555

Holy Spirit, Invocation of 231, $266,335,387$

Cyril's View . . . . . 237

John Damascene's View . 241 Holy Table-

Altarwise Position . . $\mathbf{x x v}$

Bowing to . . . . . $\times x \times i$

Holy Week . . . . . 167

Homilies-

First Book of xvii, 252, 275, $308,569,624$

Second Book of . xxi, 569,624 Homoousios . . . . . .596* Honoratus . . . . . 125 Hooker on Confession . . 454 Hooper . . . . . . .607* Hosanna . . . . . . .605* Host-

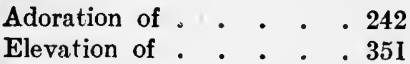

Host Bread . . . . . . 602

Hour Services . . $24593 \mathrm{ff}$.

Housel . . . . . .601*

Humanitarian . . . . .596*

Hymns . . . . . . . 112

Hymnody, Birth of . . xx, xxj

in B.C.P. . . . . . 112

Hypapante . . . . . . 195

Hypostasis . . . . 129, 596*

I

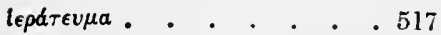

tepeús . . . . 232, 515, 516, 517

iepovproûvta.. . . . 515

Images . . . . . 252,447

Immaculate Conception $.195,196$

Immensus . . . . . . 30

Immersion . . . . 370,371

Trine . . . . 379,388

Incense . . . . . 238, 302

'Incomprehensible'. . . . 130

Indulgence Week . . . . . 167

Indulgences .. . . . . . 554

In extremis . . . . . . 463

Infant Baptism . . 371-373, 422

Injunctions, Royal--

of 1536 . $\quad . \quad . \quad .585$

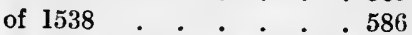

of 1547 . $\because \quad$. xvii, 82, 84, 86

See also chron. list, 628.

Innocent III. . . . . 246

Innocents' Day. See Saints'

Days.

Institution of a Christian

Man . . . . 541,591

Instruments, Tradition of the. 500

Introits . . . . . . 153

Invitatories . . . . . $\quad 24$

Invocation. See Holy Spirit.

Invocations of Saints . . . 138

Irish Articles . . . . . 544

Irish B.C.P. . . 110, 126, 147,

$148,442,488,639$

Distinctive Features ? 639-652

J

Jewel . • . . . . . .607*

Jewel's A pology . . . $\quad$ xxi, 223

John a Lasco . . . 95, 607*

John Damascene, Augmenta-

tion Theory . . . . 239

Jubilate . . . . . . 107

Judas and the Lord's Supper 320

Judicial , Committee of the ...

Privy Council . . . 86

Justification by Faith . . . 251

Justin Martyr . . . .226-228

Justus Junas • . • . 383

K

$\kappa เ \tau \sigma \gamma \gamma: \lambda \epsilon \tau \epsilon$. . . . . 221

$\kappa \alpha \tau i \chi^{\epsilon} \omega . \quad . \quad . \quad . \quad . \quad 404$

Kindred and Affinity, Table of 574 
King, Collects for the . . . 300

King's Book . . . . xri, 542 King's Primer. See Primers.

King's Sovereignty, Oath of

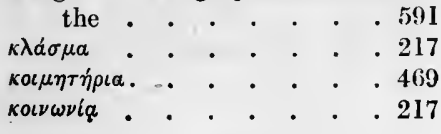

L

Labarım . . . . . .602*

Lady Day . . . . . 198

Laicus, vel simpliciter literatus 452

Lambeth Articles . . xxi $n ., 541$

Lambeth Judgment 295, 347, 361

Lammas . . . . . 72,601*

Lasco . . . . . 95, $607^{*}$

Lateran Council, Fourth . . 246

Latimer . . . . . . $.607^{*}$

Latitudinarianism . . . . 557

Laud . . . . . . . .607*

Laudianism . . . . $\quad x \times v, 265$

Lavabo . . . . . . .601*

Law Terms . . . . . . 49

Lay Baptism . 394, 395, $395 \mathrm{n}$. Puritan Objections . . . 395

Laying-on of Hands . . . 497

Lectionary, 32, 37, 103, $149 \mathrm{n}$. See Lessons.

Old . . . . . . . . 103

Revised . . . . . 37

Lector . . . . . . . 507

Legends, etc.. . . . . . . 23

Legislative Enactments, chron. list-

Edward VI . . . . 627

Elizabeth . . . . . . 628

Mary . . : . . . 629

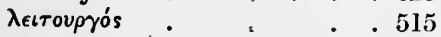

Lent . . . . 53, 164-167

Sundays in . . . 165-167

Fourth Sunday, Names of . I66

Lessons-

Daily . . 23, 36, 64, 101, 102

Proper . . . . . . 38

for Holy Days . . . . 39

for Sundays . . . . : $\quad 38$

Leo the Great . . . . .607*

Lighting of the New Fire . . 171
Lights. . . . . . . 303

Litany, the . . . . .137-143 Analysis . . . . . . I40 Expository and (ritical Notes 141 Formation of Present Litany 139 Pre-Reformation Litanies . 137

Litany to the Saints . . . 456

Literary Efforts towards Doctrinal Reform . . . $589 \mathrm{ff}$.

Liturgical and Ecclesiastieai

T'erms, classified list of $600 \mathrm{ff}$.

Hcbrew Terms . . . .605

Services and Ceremonies . 600

Things used in Church Services. . . . . .60I

Vestmonts . . . . . . 603

Liturgiologists, Famous, classi-

fied list of . . . . $605 \mathrm{ff}$.

Liturgy . . . . . . 17, 211

Liturgies, Ancient . 228, 230, 593

Logos . . . . . . .596*

Lord's Day . . . . . 44, 225

For Literature, see App. E. . 616

Lord's Prayer, the, 97, 98, 110,

$117,297,348,412-41$

Doxology, when used - 98, 110

Lord's Supper-

Account of its Institution . 212

Augmentation Theory . 239

Berengarius' View . . . 245

Bertram's View . . . . 244

Frequency of Observance . 215

Hildebrand's View . . . 244

Parliamentary Debate on xviii

Paschasius' View. . . . 242

Rabanni Mauros' Vicw . . 244

Sacrificial Meaning . . . 216

Scriptural References 211,

$220 \mathrm{ff}$.

Titles : Breaking of Bread . 287

Eueharist . . . . 287

Holy Communion . . . 287

Mass . . . . . 286

Mystcries . . . . . 289

Sacrament . . . . 288

For Literature, see App. E.

612,617

See also Communion, Holy. 
Lord's Table. . . . . . 267

Metonic Cycle . . . 4 41,42

'Loud Voice' 93, 97, 107, 109, 110

120 and passim

Low Mass . . . . .601*

Low Sunday. . . . . 174

Luther . . . . 540, 607*

Lutheranism . . . . . xx, 369

Lutherans . . . . . 541

M

Mid-Lent Sunday . . . . 166

Other Names of . . . . . 166

Millenary Petition . . . . xxii

Minister . . . . . 96, 154

Ministry, the Christian. . . 501

Missa Sicca . . . . . .601*

Missal. . . . . . xvii, xviii

Mitre. See Ring.

$\mu \nu \eta \mu \delta \sigma \nu \nu \nu \nu$. . . . . . 216

Monarchia . . . . . .596*

Macedonism . . . . . 127

Macedonius . . . . . .599*

Magnificat . . . . 117, 118

Maldonatus . . . . . .414

Maniple . . . . . . .604*

Manual . . . . . . . 2

Marcionites . . . . . . 134

Marcionitism. . . . . 134

Marriage-

Impediments to . . . . 442

Laws respecting . . . . 439

Licence. . . . . . 439

ee Matrimony.

Marshall's Primer . xvi, 589, 633

Mary, the Virgin . . . 197, 198

Mary, Legislative Enactments 629

Maskell . . . . . . . 467

Mass . . . . 270, 287, 601*

Mass of Presanctified . 170,601

Masses, Private . . 252, 542

Mass-Sacrifice . . 250, 251, 567

Matrimony, Solemnization of

Analysis and Historical

438-446

Notes . . . . . 440

Blessing of the Ring : Service in Sarum Manual . 443

Espousals . . . . 442

Exposition. . . . . 441

Holy Communion . . . 446

Introduction . . . . . 438

See Marriage.

Monasteries, Dissolution of $587 \mathrm{ff}$.

Monophysite . . . . 596 *

Monophysitism . . . . . 127

Monotheism . . . . .597*

Monothelite . . . . . .597*

Monothelitism . . . . . 127

Monstrance . . . . . .602*

Montanists . . . . . . 556

Morning Prayer-

Analysis and Historical Notes 92

Exposition. • . . . 93

Rubrics preceding . $\mathrm{xx}, 76 \mathrm{ff}$.

Morning and Evening Prayer 76-12l

Daily Use . . . . . . 25

Shortened . . . . . 9

Mothering Sunday . . . 166

Mother of the Lord . . 198

Mozarabic Liturgy . . . . xix

Mundatory . . . . . .602*

$\mu \nu \sigma \tau \dot{\eta} \rho \iota \nu . \quad . \quad . \quad$. 289,388

Mystery . . . . . . 142, 438

Mysteries. . . . . 271, 289

Mystical Body . 208, 350, 352,

$405,458,465,515$

\section{$\mathbf{N}$}

Navicula . . . . . . .602*

- Necessary Doetrine and Eru-

dition, A,' $1543 \quad$. . .392, 542

Nestorianism. . 127, 134, 135, 198

Nestorius. . . . . . .599*

$\nu \epsilon \hat{\tau} \tau \epsilon \rho \iota$. . . . . . 502

Maundy-Thursday . . . 168

Mediævalism. . . . . 559

Melancthon . . . . . 540

New Sunday. . . . . 174

Nicene Creed . . . .304-306

Memorial . . . . . 349

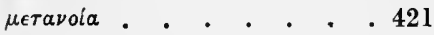

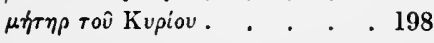

Niceta . . . . . . 104

Nocturn . . . . . 24, 595

Noetus . . . . . . .599* 
Non-Episcopal Churches . . 503

Norris, Bp. . . . . . . 434

Notices . . . . . . 306

Novatians . . . . . 556

Nowell . . . . 403, 607*

Nunc dimitlis . . . . . 119

\section{0}

Oath of the King's Sovereignty

Oblation . . . . . . . 265

Oblations. . . . 267,310,315

Obsecrations . . . . . 140

Occasional Offices . . . . 370

Octave . . . . . 173, 601*

Offering for the Departed . . 231

Offerings, Disposal of . . . 365

Offertory. . . . . . 310

See Alms; Oblation.

Officium . . . . . . . 519

Ointment, the Sacred (Chrism) $379 n$.

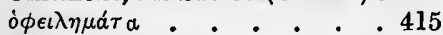

Orders, Greater . . . . 507

Minor . . . . . . 507

Ordinal, The. . . 261, 497-533

Christian Ministry, the . . 501

Differences between that in

the Sarum and the B.C.P. 499

Exposition of Preface . . 506

History of the English Ordinal.

Preface: Review of Contents 504 Structural Display of Bishop's Address to Candidate . . . 506

Ordinary . . . . . . . 291

Ordinations . . . . . . 55

Ordines majores. . . . . 507

minores. . . . . . .507

Ornaments-

Ousia . . . . . . .597*

Overall- . . . . 403,607*

Oxford Movement . . xxx, 269

For Literature, see App. E. . 618

\section{$\mathbf{P}$}

$\pi a \lambda_{\iota \gamma} \gamma^{\prime} \nu \in \sigma \iota s$.. . . . . . 375

Pallium . . . . . . .604*

Palm Sunday . . . . . 167

Palms, Blessing of the. . . 167

Pantheism . . . . . . 597

Panem supersubstantialem . . 415

$\pi a \nu \nu v \chi \delta \delta \epsilon s \quad . \quad . \quad . \quad . \quad . \quad .49$

Papal Secular Power, Limitation of the, chron. list of events . . . . . 629

Papacy, Political Breach with

the . . . . . . 579

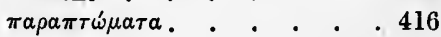

Pardons . . . .554, $560 \mathrm{n}$.

Parish Registers . . . . 587

Parker, Abp. . . . . . 5.13

Parliamentary Debate on the

Lord's Supper . . . xviii

Parson . . . . . . . 365

Pascha, $\pi \dot{\alpha} \sigma \chi \alpha$. . . . 41, 169

Pascha clausum . . . . . 174

Paschal Candlo . . . . .602*

Paschal Limits . . . . . 59

Paschasius' Theory of the Sacrament. . . . . 235,242

Passion Sunday. . . . . 166

Passion Week . . . . . 166

Pastoral Staff . . . 498, 529

Paten . . . . . . .603*

Pathway to Piety . . . . 462

Patripassian . . . . . .597*

Patripassians, Sabellians . 130

Paul, Conversion of . . . 45

Paul of Samosata . . . .599*

of the Church . . . 78,89

of the Minister . . . . 78

Ornaments Rubric . . . 78-89

Orphrey . . . . . . .604*

ópфavoús . . . . . . . . 177

O Sapientia / . . . . 72

Ostiarius . . . . . . 507

oúola . . . . . . . . 129

Pax . . . . . . . .603*

Peace, Collect for . . . . 111

Pedo Cloth . . . . . .603*

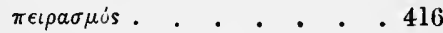

Pelagian Heresy $\cdot \quad . \quad .173,180$

Pelagians. . . . . . .599*

Pelagius . . . . . . 551

Penance . . . . 321, 491 
PAGE

Penitents, Four Classes of. $491 n$. Pentecost. . . . . . 178 Pentecostals . . . . . .601*

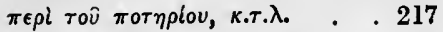

Pernoetationes . . . . 49

Person . . . . 129, 597*

Pervigilia. . . . . . 49

Peter Lombard . . . . . 418

Peter Martyr . . . . .608*

$\pi \dot{\gamma} \gamma \eta \theta \epsilon o ́ t \eta T 0 s \quad$. . . $477 n$.

Pfingsten . . . . . . 178

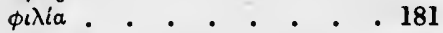

Pie, the . . . . . . . 24

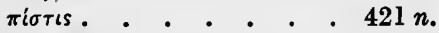

Places. . . . . . . . 112

Plague . . . . . . . 145

'Plantations, our' . . . . 17

Pliny's Letter to Trajan . . 225 $\pi \nu \Theta \hat{v \mu a} \cdot .+. \quad . \quad 478 n$. $\pi \nu \epsilon \nu \mu a \tau \iota k b s$. . . . $478 n$.

Pneumatomachi . . . .597*

Pollanus . . . . . .608*

Polytheism . . . . . 597

Pome . . . . . . .603*

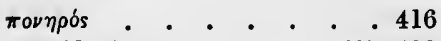

Pontificals . . . . 497, 498

Sarum Pont. . . . . 498

Yopes during Reformation and

Prayer Book Period . . 630

Porter. . . . . . . 507

Portiforium . . . . . 595

Poynet, Bp. . . . . . . 403

Praxeas . . . . . : .600*

Prayer Book-

Attempted Revisions since 1662 . . . . . . . Xxx

The Book of 1549

Character . . . xviii

Sources . . . . . xix

Committee . . . . 635

The Book of 1552-

Genesis . . . . . xix

Charactor . . . . . $\mathbf{x x}$

Commission. . . . 635

The Book of 1559 . . . $\mathrm{xx}$

Advisory Committee . 636

The Book of 1662 ' ' xxix

Direct Outoome of Bible in

English . . . . . xT
Prayer Book-

Its Discriminating Conservatism . . . . . . xiv Its Story . . . . xiii-xxxi

See also ohron. list, $630 \mathrm{ff}$.

Prayer Book Study-

List of Works for 576-591,609-621

Chronological Table for .622-637

Prayer and Fasting . . . 401

Prayer for the Dead 317, 470, 481

Prayers and Thanksgivings 144-148

Prayers . . . . . . 145

Thanksgivings . . . . 147

Prefaces, Proper . . . 329

Presanctified. . . . . .601*

Mass of . . . 170,601

Presbytor. . . . . . 516

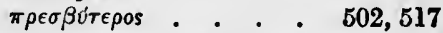

Presbyters. See Priests.

Presence, Corporal . . . 566

Priest . . . . 96,515-520

Priest, Representative . . 518

Priests or Presbyters . . . 502

Priests, Ordering of . .514-528

Analysis with Historical

Notes . . . . . 520

Bishop's Address : Structural

Display . . . . .522-524

Comparative Table . . . 514

Excursus on the use of the word 'Priest' in B.C.P.

515-520

Exposition.

$.521-528$

Priesthood, Representative . 518 Primers-

Hilsey's . . . . $x \nabla i, 633$

Marshall's . . . xvi, 589, 633

King's . . . . . . . 633

Primitive Christian Worship . 633

Primo Elizabethæ . . . . 6

Processions . . . . . . 137

тробфорd. . . . . 290,515

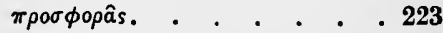

Psalms of David . . . 3,100

Psalms, Proper . . . . 38, 39

Psalter . . . . 3, 32, 33, 34

Rules concerning. . . $32 \mathrm{ff}$.

Tyndal's and Coverdale's 35,101 , 


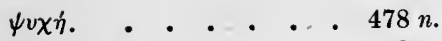
$\psi v \chi\left\llcorner\kappa b_{s} . . . . . .478 n\right.$. Purchas Judgment . . . . 295 Purgatory . . . 208, $560 n$. Purification (Candlemas) • 45, 195 Purification, Mediæval Idea of 484 Purificator -. . . . . .603* Puritans - xxvi, 88, 147, 151, $265,266-268,333,339$, $403,417,453,544,559,572$ Concessions of Convocation 266-268

Savoy Conference . ‘. 265

For Literature, see App. E. 619 Purity, Collect for . . . 297 Pusey, Quotations respecting Lord's Supper . . . . 236 Pyx . . . . . .603*

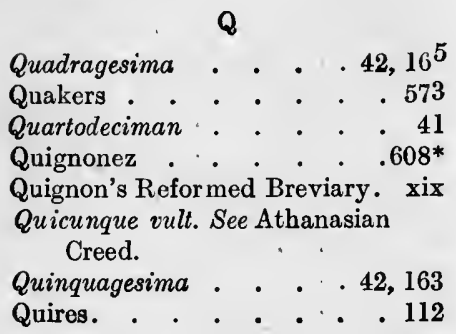

\section{$\mathbf{R}$}

Reader . . . . . . . 507

Reading-pew. . . . . . 491

Reconciliation of Dying Penitent . . . . . . 455

Reformation-

B.C.P. its Devotional Manifesto Principles . . . . . xiv Secondary Causes . . . xv For Literature, see App. E. . 619 Reformation Parliament . 579 Reformation and Prayer Book Period 633,634 Abps. of Canterbury during 622 English Sovereigns during . 635 Popes during . . . . 630
Reformatio Legum Ecclesiasticarum . . . 543,547

Refreshment Sunday, Dies Refectionis . . . . . 166

Regencration-

Baptismal . . . 373,375

Spiritual . . . . . 384

Regula Fidei. . . . . . 108

Repentance . . . . 421,424

Repetitions, Vain ‘. . . 23

Reproaches . . . . . 170

Requiem . . . . . . 470

Reservation of the Elements $361,459-463$

Responds, etc. . . . . . 23

Resurrection of the Body. . 476

Reynolds . . . 147, 608*

Ridsàale Judgment. . . . 295

Ridley .. . . . . .608*

Ring and Mitre. . . . 529

Rites .' . . . . . . 3

Ritualistic Movement . . . xxx

Rochet . . . . 531, 604*

Rogation Days . 42, 55, 137, 176

Rogation Sunday . . . 42, 176

Rogations. . . . . . 137

Romish errors . . . . . 634

Royal Family, Prayer for. . 113

Rufinus . . . . . 108

The Creed of . . . . 108

$\mathbf{S}$

Sabaoth . . . . . .605*

Sabbath . . . .44,409,410

Sabellians . . . . . . 129

Sabellius . . . . . . $600^{*}$

Sacerdos . . . 515, 516,517

Sacerdotium . . . . . . 517

Sacrament . . 280 n., 288, 417

of Unity . . . . 458, 465

Twofold Use . . . 271, 289

Sacraments, the. . . .417,418

Sacramentaries . $\quad 149,149$ n., 150

Nominal Authors. . . 634

Sacramentum. . . . 288, 289

Sacrifice . . . . . .225, 515

Association with Lord's Supper . . . . . 223,232 Unbloody . . . . 232, 238 
"S'acrifice, This our' . . 349

Application to the Lord's

Supper . . . . . . 249

Commemorative . . . 251

Sacrifices of the Mass . . . 567

Spiritual . . . . . 518

Saint . . . . . . . 191

Saints. . . . . $407 n$.

Prayer to . . . . 197

Saints' Days and Calendar

Holidays . • . . $66,7.1$

Suints' Days, etc.-

All Martyrs . . . . 179

All Saints . . . . 13, 208

Ail Souls . . . . $\therefore 203$

Annunciation . . . 45,157

Cireumcision . . $\quad 11,157,153$

Holy Cross Day . . . . 72

Holy Innocents . . . 46, 157

Purification . . . 45, 19j

St. Andrew . . . . 48, 192

St. Barnabas . . . 42, 46,201

St. Bartholomew . . . 47, 20J

St. James . . . . . 46, 201

St. Juhn Baptist. . . 46, 201

St. John Evangelist" $48,156,157$

St. Lulse . . . . . 47, 208

St. Mark . . . . . 46, 199

St. Mary Magdalene. . 66, 203

St. Matthew - . 47, 197-206

St. Matthias . . . . 46, 197

St. Michael and All Angels 47, 206

St. Paul . . . . .45, 194

St. Peter . . . . . 46, 202

St. Philip and St. James 46, 200

St.' Simon and St. Jude 47, 207

St. Stephen . . . . 48, 156

St. Thomas . . . . 48, 193

Transfiguration . . . 66,204

Sancti Michaelis in Monte

Tumba , . . . . 206

Sanctus Poll . . . . .603*

Sanders 0 . . . . . .608*

Saper 3 . . . . . . 178

Saı um Use . . . . . . xvii

Sarum Use and Communion

Office of 1518 . . . 256

Savoy Conference 17, 73, 142, 265

Savoy Conference-

Alterations made by Con-

vocation. . . . . $\operatorname{xxix} n$.

Concessions offered . $\quad$ xxviii $n$.

Members of . . . 636, 637

Puritan Demands . . 298

Puritan Objections xxvi-xxviii,

268,333

Scarf . . . . . . .604*

Schism . . . . . . . 142

Schwabach Articles, tho . 539

Scottish B.C.P. $\quad 106,114,141,146$

Scriptures, Holy-

Appeal to . . . . . 251

Authority . . . . . $\mathrm{xv}$

Reading of . . . . 37, 102

Sea, Forms of Prayer to be uscd at . . . . .494-496

Analysis with Brief Comments . . . . . 495

Introduction . . . . . 494

Scal . . . . . . .426

Sealed Books . . . . 2,6

Self-examination . . . .424

Scmi-Arians . . . . 134

Septiformum Spirilum . . .434

Septuagesima. . . . .42, 162

Seraphin . . . . . .605*

Serapion . . . . . . 231

Sermon . . . . . 307, 309

Ascription after . . . 309

Invocation before . . . 309

Service Books 2, 3, 149 n.,261, 593 ff.

Continental . . . . . 625

Services of the Church . . 18

Seven, the . . . 502,511

Sexagesima . . . . 42, 163

Shrove Sunday . . . . . 164

Sick, Communion of the .458-468

Sick, Visitation of the. .447-457

Sign . . . . . . . . 420

Signum gratice quod datur . $\quad$ 420

Sin, Threefold Idea of . . . 416

Deadly. • . . . . 141

Venial . . . . . . 141

Si Quis . . . 505, 510,561 $\mathrm{n}$.

Six Articles, the . . xvi, 252

Law of the - . 542,568,589

Socinianism . . . 545,546 
PAGE

Solemn Days, Services for . 57

Solifidianism . . . . . . 553

Sovereigns, English, during

Reformation and Prayer

Book Period . . . . 635

Spanish Church, Reformed, and

Baptism. . . . . 374

Spiritual Sacrifices . . . . 518

Sponsors . 309, 381, 390, 391,

$$
392,404,433
$$

Titles of . . . 381,400

Sponsorship . . . . 404,433

Spousage, Tokens of . . . 443

Stations . . . . . 55, 56

Stationes . . . . . 57

Stole . . . . . . . 84

Storieg, fegends, etc. • . 23

Sub-deacon . . . . . 507

Substance . . . . 129,597*

Suicides . . . . . . .474

Sunday . . . . . . . 44

Sunday Letter, Dominical 58, 59, 62

Sunday Observance. . . . 372

Super Frontal . . . . .603*

Supply of Prayer, etc., A . $\quad 494$

Surplice . . . . . . 83, 85 $\sigma \omega \zeta \delta \mu \epsilon \nu 0 s$. . . . . 406

Sweating Sickness of 1551. . 145

Symbolum . . . . . . 108

Synodals, etc. . . . . 23

\section{T}

Tabernacle . . . . .603*

Table. . . . . . . . 232

Communion . . . . . 292

Te Deum . . . . . .103-105

Ten Articles, the . . 541,589

Ter Sanctus . . . . . . 331

Tertullian, Lord's Supper . . 234

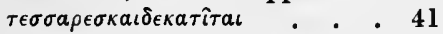

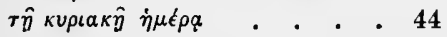

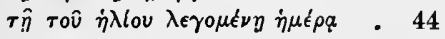

Theandrio . . . . . .597*

Theodotus . . . . . .600*

Theodosius, Code of . . . 173

Theological Terms, Classified

List of . . . . 596 ff.

Theopaschite. . . . . .597*

Theophania . . . . . 158

Theotokos . . . . . .597*

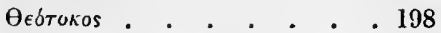

Thirteen Articles, the . . 541

Thirty-eight Articles, the .xxi, 543

Thobie . . . . . .451

Thurible . . . . . .603*

ovola. . . . . . . . 290

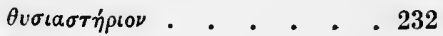

Tippet . . . . . . . 84

тойто тогеiтt. . . . . . . 216

Tractarian Movement . $\quad \mathrm{xxx}, 269$

'J'radition of the Instruments. 500

Traditions, Unwritten . . 549

Trajan, Pliny's Letter to . . 225

Transubstantiation . 252, 336, $420,458,542$

Absurdities of the Doctrine. 248

Declared to be Article of

Faith . . . . 246

Definition . . . . 238

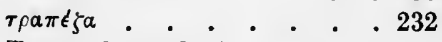

Trent, Council of. See Council.

Trental . . . . . . .601*

Tridentino Catechism 427,428, 500

Trine Immersion . . $\mathbf{3 7 9 , 3 8 8}$

Trinity . . . . . . .598*

Doctrine of . . . 127,128

Trinity Sunday . . . . 43, 170

Sundays after. . . .179-191

Trisagior . . . . . . . 191

Tritheism. . . . . . . 597

Tudor Period . . . . . 112

Tunicle . . . . 498, 604*

U

Unction . . . . . . 529

the Service of . . . . 457

Uniformity, Acts of . $\mathrm{xx}, 6,622$

lst of Edw. VI . . . . 7

2nd of Edw. VI . . . 7

2 Eliz. c. $2 \quad$. $8,80,81,85 n$.

13 \& 14 Car. II, c. 4 . 8, 544

Amondment Act . . 9, 33, 112

See also Chron. List, p. 622.

Unitarian. . . . . . .598*

Unity, Prayer for . . . 535 
PAGE

Unwritten Traditions . . . 549

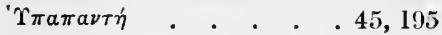

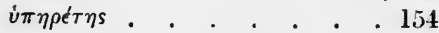

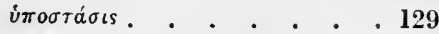

Uses, Chron. List of . . . 635
Valentinus

Veni Creator.

Venial sin

Venite

Vestment.

Vestments

- in 1549

Sacerdotal. 499

Viaticum . . . . . . . 458

Vigils, or Evens . . . 49,50

Vincentius . . . . . . 124

Voss, Gerard • . . . 124

W

Wafer Bread

Water used in Baptism-

Consecration of . . . 387

Sanctification of . . . 387 .

Waters, Blessing of the . . 159

Wedding-ring . . . . . 443

Blessing tho . . . 443, 444

Westminster Assembly. . . 544

Whip with Six Strings . 542

Whitgift. . . . 517, 544, 608*

Whit-Sunday . . . . 43, 177

Whitsun Week-

Monday in . . . . . 178

Tuesday in . . . . 179

Women, Churching of . .484-488

Analysis with Historical

Notes . . . . . 484

Worship. For Literature, see

App. E. . . . . . 621

Wren, Bp. . . . . . . 148

Würtemberg. See Confessions.

Wyolif . . . xv, 427, 563

\section{$\mathbf{X}$}

Xerophagia.. . . . . .601*

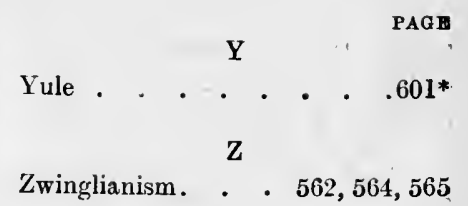

INDEX OF PASSAGES OF HOLY SCRIP'TURE

BRiefly EXaMined in this Work.

Exod. xix. 1. . . . $178 n$. xx. 3-17 . . . . $408 \mathrm{ff}$. xx. 24-26 . . . . . . 292

Lev. xii. $1-8$. . . . . 196 xviii. 18 . . . . . 574

xxiii. $15-22 . \quad . \quad . \quad . \quad 178$

Psalm xxxix. . . . . .475

xc. . . . . . . .475

Isa. xi. 2. . . . . . . 434

Iviii. 1-9 • . . . . 53

Dan. x. 13 . . . . . 206

Zech. ii. 9 . . . . . . 434

viii. 19. . . . . . 51

Mal. i. 11 . . . . . . 302

[2 Macc. xii. 43-45 . . . .481]

Matt. vi. 9 . . . . $98,412 \mathrm{ff}$.

xii. 31,32 . . . . 141

xvii. 2l . . . . . 51

xix. $28 . \quad . \quad . \quad . \quad . \quad 375$

xxvi. 26-29 . . . . 212 ff.

xxviii. 19 . . . . 370

Mark ii. 18-22 . . . . . 51

ix. $29 . \quad$. . . . 51

xiv. 22-25. . . . $212 \mathrm{ff}$.

$x v i .9-20$. . . . . 372

Luke i. 43 . . . . . . 197

i. $69 . \quad . \quad . \quad . \quad 106$

ii. 2 .

ii. 14 . . . . . 353

ix. 16 . . . . . . 213

xi.. $2 . . . \quad .412 \mathrm{ff}$.

xii. $7 . \quad . \quad . \quad . \quad . \quad 203$

xviii. $12 \quad \ldots \quad \ldots \quad \ldots \quad . \quad . \quad 56$

xxii. 19,20 . . . $212 \mathrm{ff}$ 
PAQT

John ii. 9 . . . . . . 214

iii. 30 . . . . . . . 46

vi. 47,53 . . . . . . 468

vi. 51,58 . . . . . . 344

xiv. 18. . . . . . . 177

xv. 26 . . . . . 132, 305

xx. 23 - . . . . 96, 322

xxi. $15-17$. . . . . 182

Acts ii. 42,46 . . . 215,217

vi. 6 ... .502

viii. 15 . . . . 426,429

viii. 37 . . . . . 372

x. 30 . • • . . 51

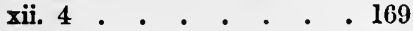

xix. 6 . . . . . . 426

xx. 7 . . . . . . 44

Rom. ii. 29 . . . . . 158

iii. 25 . . . . . . 351

xv. 4 • • • • , . 154

1 Cor. ii. 9 . . . . . . 181

iii. $12-15$. . . . . . 482

iv. $1 . . . . . .154$

vii. $5 . . . . .551$

vii. 14 . . . . . . 575

x. $14-22$. . . . $220 \mathrm{ff}$.

x. 16 . . . $213,217,287$

xi. 20

287

1 Cor. xi. 23-26. . . $212 \mathrm{ff}$. xi. 24 . • . . . . 217 xi. 26 . . . . . . 221 xi. 27 . . . . . 344 xi. $29-31$. . . . . . 325 xi. 29 . . . . . . 222,352 xiv. 16. . . . . . . 288 xv. 28 . . . . 476 n., 477 xv. 29 . . . . . $477 n$. xマ. 44 . . . . . $478 n$. xvi. 2 . . . . . . . 44 Ephes. iv. 14 . . . . . 199 Phil. iv. 7 . . . . . . 181 Col. ii. $11-13$. . . . 158,372 2 Tim. i. 8. . . . . . 482 Titus iii. 5 . . . 375,398 Heb. ix. 24 . . . . . 239 siii. 10. . . . 221,293 James ii. 10 . . . . . 141 จ. 14-16 . . . . . . 321

1 Pet. iii. 21 . . . . . 239

2 Pet. ii. 13. . . . . . 219

1 John ii. 20,27 . . . . 426 Jude 12 . . . . . . 219

Rev. i. 4. . . . . . . 434 i. 10 . . . . . . 44 хi. 1 . . . . . 292 



(1) 


(6) (1) if III) II (1) ist 1: If (y) (1) (1) 1.1. 